\title{
Language contact in a mining community
}

Citation for published version (APA):

Pecht, N. (2021). Language contact in a mining community: A Study of Variation in Personal Pronouns and Progressive Aspect in Cité Duits (1 ed.). [Doctoral Thesis, Maastricht University]. LOT. https://doi.org/10.26481/dis.20210127np

Document status and date:

Published: 27/01/2021

DOI:

10.26481/dis.20210127np

Document Version:

Publisher's PDF, also known as Version of record

\section{Please check the document version of this publication:}

- A submitted manuscript is the version of the article upon submission and before peer-review. There can be important differences between the submitted version and the official published version of record.

People interested in the research are advised to contact the author for the final version of the publication, or visit the DOI to the publisher's website.

- The final author version and the galley proof are versions of the publication after peer review.

- The final published version features the final layout of the paper including the volume, issue and page numbers.

Link to publication

\footnotetext{
General rights rights.

- You may freely distribute the URL identifying the publication in the public portal. please follow below link for the End User Agreement:

www.umlib.nl/taverne-license

Take down policy

If you believe that this document breaches copyright please contact us at:

repository@maastrichtuniversity.nl

providing details and we will investigate your claim.
}

Copyright and moral rights for the publications made accessible in the public portal are retained by the authors and/or other copyright owners and it is a condition of accessing publications that users recognise and abide by the legal requirements associated with these

- Users may download and print one copy of any publication from the public portal for the purpose of private study or research.

- You may not further distribute the material or use it for any profit-making activity or commercial gain

If the publication is distributed under the terms of Article $25 \mathrm{fa}$ of the Dutch Copyright Act, indicated by the "Taverne" license above, 


\section{LANGUAGE CONTACT IN A MINING COMMUNITY}

A STUDY OF VARIATION IN PERSONAL PRONOUNS AND PROGRESSIVE ASPECT IN CITÉ DUITS 
Published by

LOT

phone: +3120525 2461

Kloveniersburgwal 48

1012 CX Amsterdam

e-mail: lot@uva.nl

The Netherlands

http://www.lotschool.nl

Cover illustration: Photograph taken by Nantke Pecht in the C-mine of Genk, Belgium.

ISBN: 978-94-6093-367-7

DOI: https://dx.medra.org/10.48273/LOT0582

NUR: 616

Copyright @ 2021: Nantke Pecht. All rights reserved. 


\title{
LANGUAGE CONTACT IN A MINING COMMUNITY
}

\section{A Study of Variation in Personal Pronouns and Progressive Aspect in Cité Duits}

\author{
DISSERTATION \\ to obtain the degree of Doctor at Maastricht University, \\ on the authority of the Rector Magnificus, Prof. dr. Rianne M. Letschert \\ in accordance with the decision of the Board of Deans, to be defended in public \\ on Wednesday the $27^{\text {th }}$ of January 2021 at 10:00 hours
}

by

Nantke Pecht 


\title{
Supervisors:
}

Prof. dr. Leonie Cornips

Prof. dr. Peter Auer (Albert-Ludwigs-Universität Freiburg)

\author{
Assessment Committee: \\ Prof. dr. Ad Knotter (chair) \\ Prof. dr. Pieter Muysken (Radboud Universiteit Nijmegen) \\ Prof. dr. Aagje Swinnen \\ Prof. dr. Evelyn Ziegler (Universität Duisburg-Essen)
}

This dissertation is the result of an individual research project funded by the Netherlands Organisation for Scientific Research (NWO) [Research Talent Grant, PGW-15-02]. Fieldwork in 2015 was carried out under a grant from the German Academic Exchange Service (DAAD). 


\section{Acknowledgments}

Writing a dissertation felt at times like embarking on a journey to an unknown place. Many people have made this journey a pleasant experience and contributed in one way or another to the completion of this book. First and foremost, I would like to thank my supervisors Leonie Cornips and Peter Auer, for making this research project possible and for supporting me along the way, and the members of the community of Eisden-cité, for opening their doors to me and facilitating a smooth data collection. When I set out to conduct the first interviews, I was immediately welcomed and many of you supported me by expressing interest in my research, by teaching me Maaslands, or by offering a ride when there was no public transport available. My special thanks go to Angelina Chini, Jan Kohlbacher, Anica Varszak-Kos, and Pierre Meulemans - hartelijk bedankt voor de steun!

I am extremely grateful to my supervisors for all their useful suggestions and for giving me the opportunity to develop scholarly skills and explore new ideas. You were a perfect supervisory team and I learned a lot from your expertise. While Leonie as my principal supervisor encouraged me to pursue a $\mathrm{PhD}$ in the Netherlands and was always there to discuss puzzling findings and questions that arose, I greatly benefited from Peter's clear and thoughtful remarks on my transcriptions and draft chapters. Leonie, thanks for your support, also beyond linguistics! Your guidance and encouragement are appreciated beyond words. Furthermore, I want to express my gratitude to the members of the reading committee: Ad Knotter, Pieter Muysken, Aagje Swinnen, and Evelyn Ziegler. I am honored that you agreed to read and evaluate my dissertation.

My research furthermore benefited from discussions with many colleagues whom I met during extended research stays in Freiburg, Amsterdam, and Potsdam, as well as at numerous conferences. I am grateful in particular to Heike Wiese and Ulrike Freywald and my colleagues at the SFB 1287 at the University of Potsdam, where I conducted a short-term-fellowship in 2018, as well as to Christoph Schroeder for inviting me in 2019. The meetings at the SFB have always been intellectually stimulating, but also socially engaging and fun. At the FU Berlin, my appreciation goes out to Matthias Hüning and Truus De Wilde for their critical questions and literature suggestions. At the Meertens Instituut, I am indebted to Jeroen Craenenbroek, Frans Hinskens, Marjo van Koppen, Etske Ooijevaar, Gertjan Postma and Joanna Wall. My special thanks go to Hans Broekhuis for inspiring discussions over the past two years. Moreover, I would like to thank Rob Belemans for his insights into the Maaslands dialect, Rainier Grutman (Ottawa) for his thoughtful comments on the notion 'cité,' Maarten Mous (Leiden) for taking his time to discuss my work, Hans Van de Velde for his support with Belgian Dutch, and Ton van de Wijngaard for literature suggestions. Finally, I want to thank Göz Kaufmann, Marc Louden (Wisconsin) and Guido Seiler, whose classes inspired me to pursue a $\mathrm{PhD}$ in linguistics when I was a master student in Freiburg, as well as all other colleagues in the 
German Department of Linguistics in Freiburg - and Peter Auer in particular - for providing me with valuable feedback during my research stay in 2017.

This dissertation would not have been possible without the advice and kindness of many colleagues at FASoS. While I cannot name all of them here, I would like to thank in particular Ulrike Brunotte for our fruitful discussions, John Harbord for his languagerelated hints, and Charles van Leeuwen and Lauren Wagner for their wonderful course coordination. I am also indebted to two student assistants, Stella de Ree and Hannelore van Lierde, for helping me to transcribe parts of the data. Moreover, I would like to thank the editors of the volume 'Mixed Languages' (forthcoming), Maria Mazzoli and Eeva Sippola, and the editors of the IJSL-volume (2019), Leonie and Pieter, for their approval to use some sections in this dissertation. Particular recognition goes to Ton Brouwers for providing me with valuable feedback shortly before submitting this manuscript.

My $\mathrm{PhD}$ years would not have been the same without the inspiring meetings (lately online) of the Taalcultuur in Limburg team - Daan, Ilias, Jolien, Lotte, Lysbeth, Marie, Pomme, and Sara - and without my supportive office mates Iskander, Veerle, and, again, Pomme and Daan. A warm thank you goes out to Lysbeth for her constructive spirit during the many conferences and workshops we attended together (e.g. Murcia, Copenhagen, and Leeuwarden) and to Marie for our good talks during the last months when the sudden lockdown turned life inside out.

Lastly, I am incredibly fortunate to be surrounded by family and friends. To my paranymphs Artemis and Mareike: Thank you for helping me prepare for the defense and for having been there for me all these years. I realized how much I missed our shared lunches and the gezelligheid after the mandatory travel restrictions in the spring of 2020 . In Maastricht, my special thanks go out to Annet and Jos for putting my feet back on the ground, as well as for their insights and words of encouragement. Furthermore, I am thankful to Claudia for her friendship over these years, to Antonia for her thinking outside the box and for the many Sunday afternoon visits to Potsdam, to Yulia for the great conversations and walks, to Mathias for his enduring encouragement and for solving technical difficulties, to Tim for his positive attitude, to Vanessa por los barraquitos y las caminatas, as well as to Eva and Eric, Maj and Timo, and Kati and Christian - all of you made my work more pleasant and reminded me that there is a life beyond linguistics. I am grateful to my parents, my grandmother Thekla, my in-laws Ria and Jan, and Uschi for their understanding and emotional support. At this point, I also want to thank my host parents Jackie and John in Emmetsburg without whom I would not be who I am. But a double portion of gratitude goes to my mother, who taught me to take my own decisions and who has always been there for me, and to Bart-Jan for his love and patience. Your encouragement and belief in me as a person were perhaps the biggest support. 


\section{Contents}

Acknowledgments.................................................................................................. $\mathrm{V}$

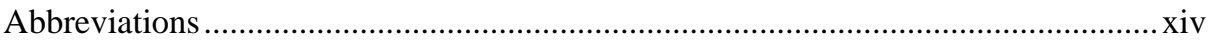

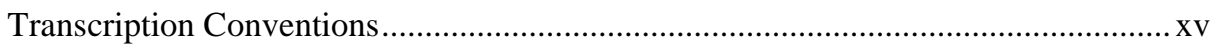

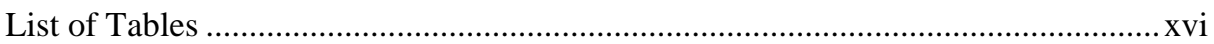

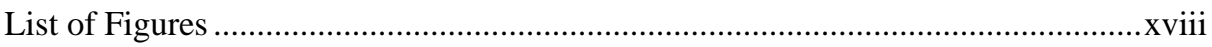

Chapter 1: Introduction................................................................................................... 1

1.1 The Research Case in a Nutshell: Research Questions and Aims ..................... 1

1.2 Belgian Limburg: Language Situation and Setting ............................................ 3

1.2.1 The Geographical Setting of Eisden ........................................................... 3

1.2.2 Historical Background of Dutch in Flanders ............................................... 4

1.2.3 Belgian Dutch: Standardization and VRT-Dutch ........................................... 6

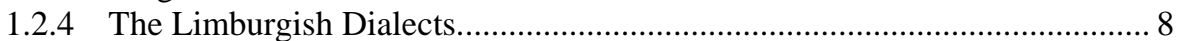

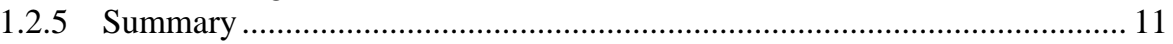

1.3 State-of-the-art: Theoretical Background ……................................................ 11

1.3.1 Sociolinguistic Approaches to Language Contact ........................................ 11

1.3.2 The Notion of Speech Community ……………....................................... 12

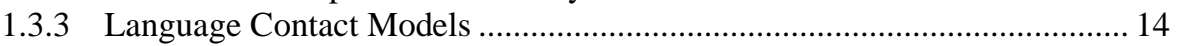

1.3.4 A Note on Previous Research ................................................................. 16

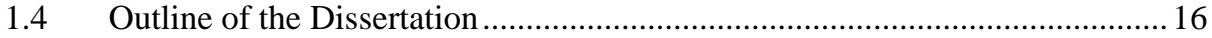

Chapter 2: Sociohistorical Context and the Emergence of Cité Duits ........ 19

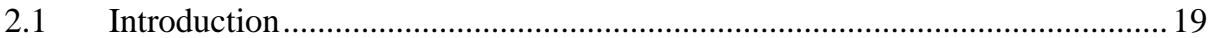

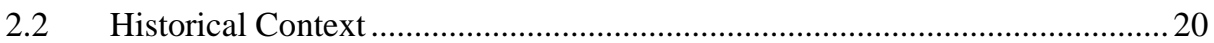

2.2.1 Mining Industry and Migration Patterns ....................................................... 21

2.2.2 Housing in Tuinwijken ('Garden Districts') .............................................. 27

2.2.3 Female Wage Labor and Gender Roles ................................................... 28

2.2.4 German in the Habsburg Empire .............................................................. 31

2.3 Sociolinguistic Conditions for the Emergence of Cité Duits ............................ 32

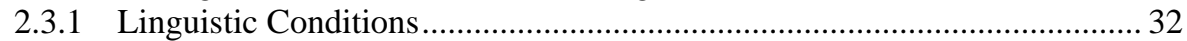

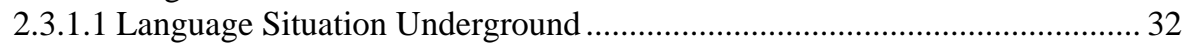

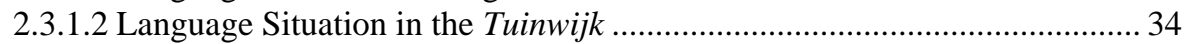

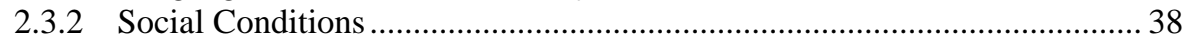




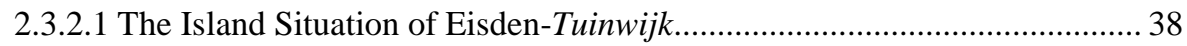

2.3.2.2 Attitudes among the Local Population....................................................... 40

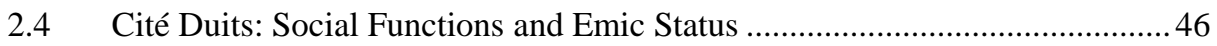

2.4.1 Social Functions of Speaking Cité Duits ............................................. 47

2.4.2 Transfer to Following Generations ...................................................... 49

2.4.3 Emic Status of Cité Duits...................................................................... 50

2.5 Where are the Female Speakers? ..................................................................52

2.6 Summary and Concluding Remarks .............................................................. 56

Chapter 3: Data and Methodology.................................................................. 59

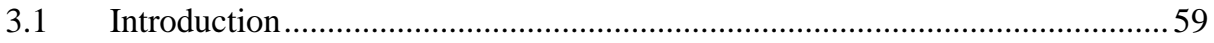

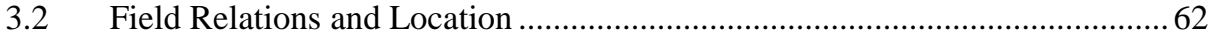

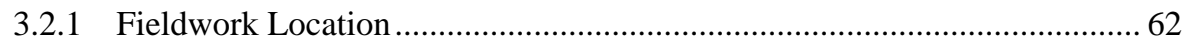

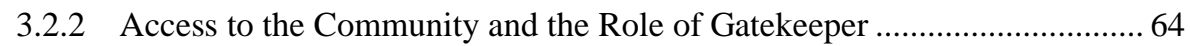

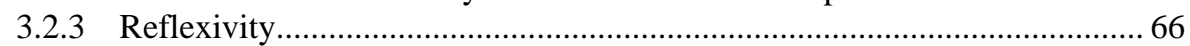

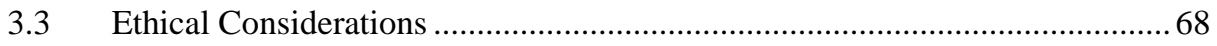

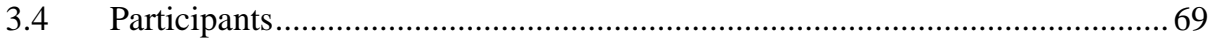

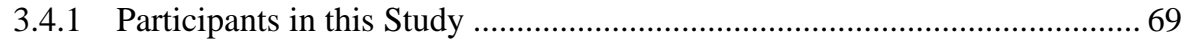

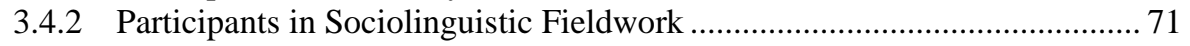

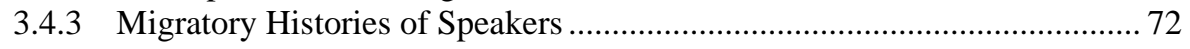

3.5 Methods of Data Collection ......................................................................... 74

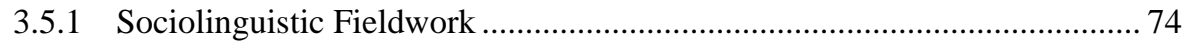

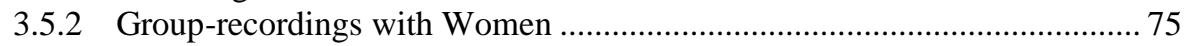

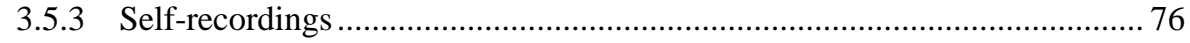

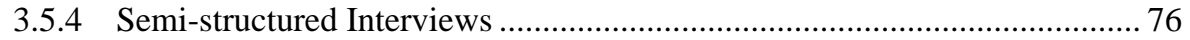

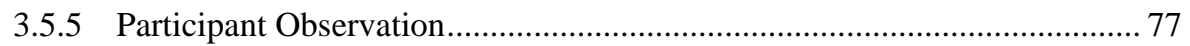

3.5.6 Written Sources and Visual Materials ........................................................ 78

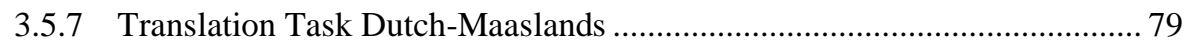

3.5.8 Evaluation of Data Collection.............................................................. 79

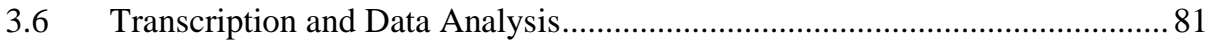

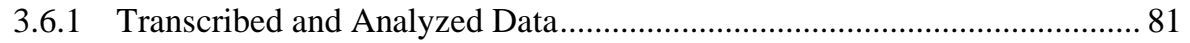

3.6.2 Transcription Conventions...................................................................... 82

3.6.3 Further Corpora and Databanks Used for Analysis ................................... 82

3.6.4 Annotation Software and Programs ......................................................... 83

3.6.5 Reflections on Linguistic Transcriptions .................................................. 87

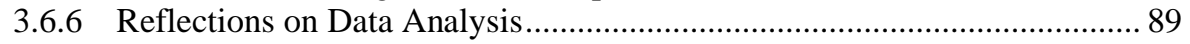

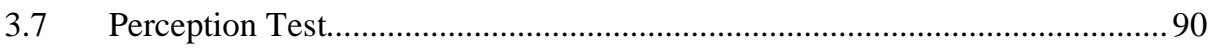




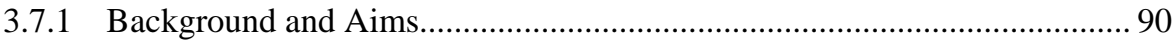

3.7.2 Test Design and Raters ......................................................................... 91

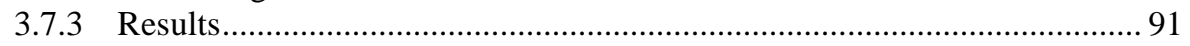

3.8 Summary and Concluding Remarks ................................................ 92

Chapter 4: Some Linguistic Features of Cité Duits.......................................... 95

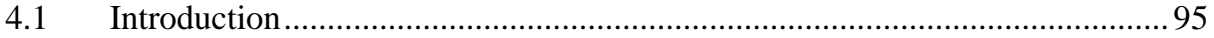

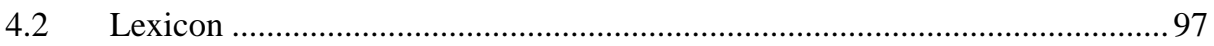

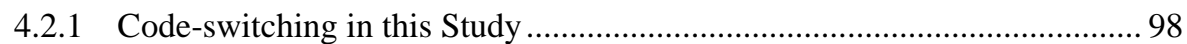

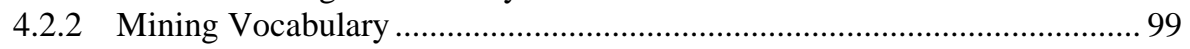

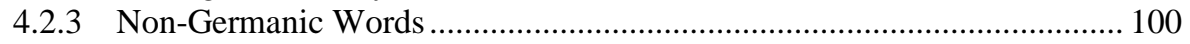

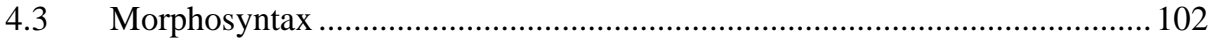

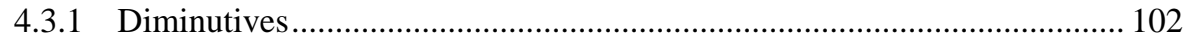

4.3.2 Plural Formation ................................................................................. 103

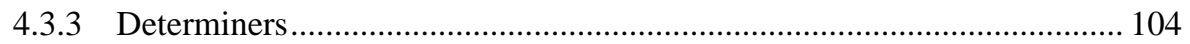

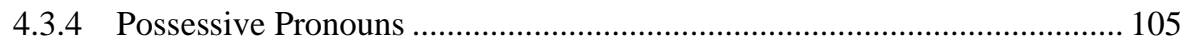

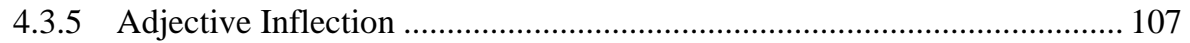

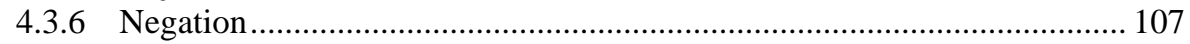

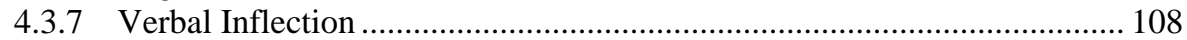

4.3.8 Participles....................................................................................... 110

4.3.9 Prepositional Phrases ............................................................................... 112

4.3.10 The Dutch Adverbial Pronoun Er and Its Variants................................... 113

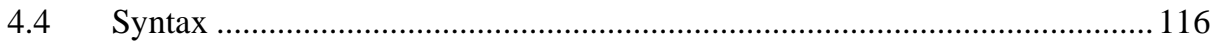

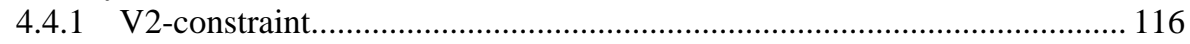

4.4.2 Weil 'Because' without Verb-final ............................................................ 118

4.4.3 Extraposition: Elements outside the Verbal Bracket .............................. 119

4.4.4 Order of Verbal Elements in the Two-verb Cluster.................................. 121

4.4.5 Passive Constructions ............................................................................ 122

4.4.6 The Infinitival Complementizers für ..zu and $u m \ldots z u$............................ 124

4.4.7 Komme 'Come' and Bleibe 'Stay' + Infinitive ........................................ 126

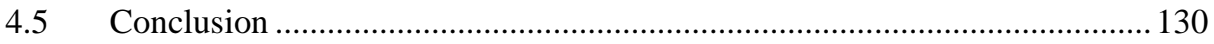

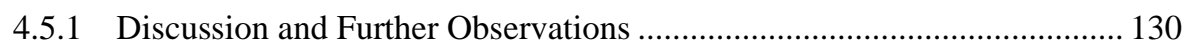

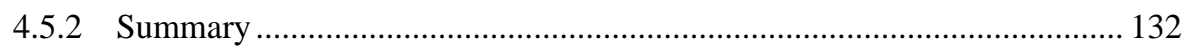

Chapter 5: Pronominal Usage in Cité Duits.............................................. 135

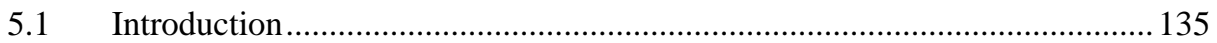

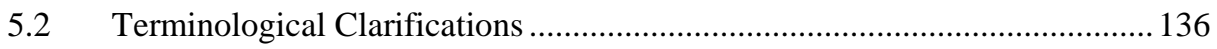

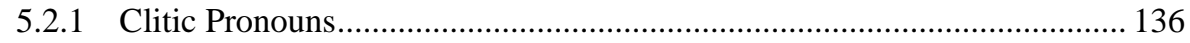

5.2.2 Weak, Strong and Demonstrative Pronouns ...................................... 138 


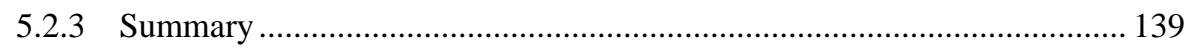

5.3 An Overview of Personal Pronouns in Cité Duits Contact Varieties ............ 140

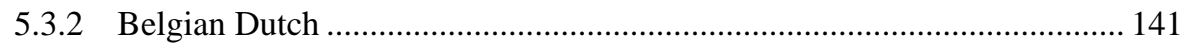

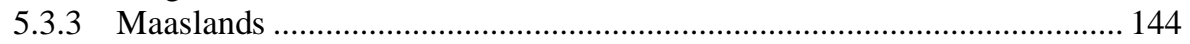

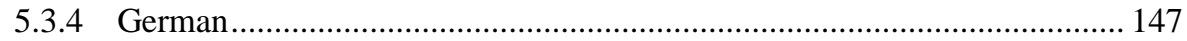

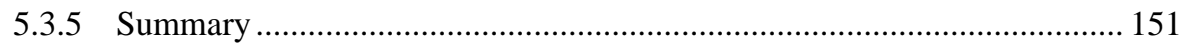

5.4 Subject Pronouns: Frequency and Phonological Properties .......................... 153

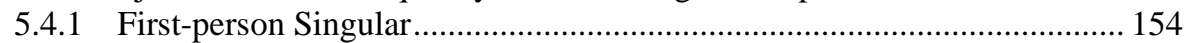

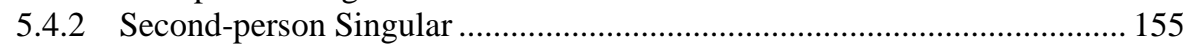

5.4.3 Third-person Singular Masculine + Human ............................................. 157

5.4.4 Third-person Singular Feminine + Human .................................................. 158

5.4.5 Third-person Singular Non-human ............................................................... 161

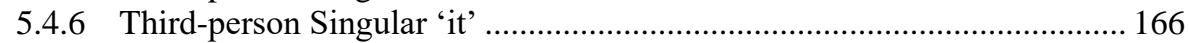

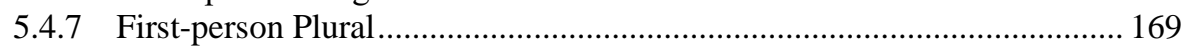

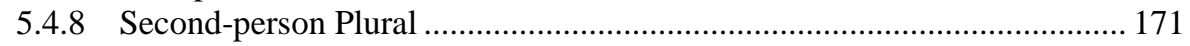

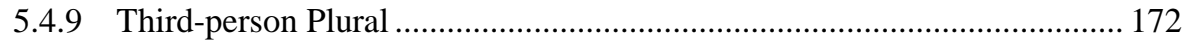

5.5 Object Pronouns: Frequency and Phonological Properties............................. 173

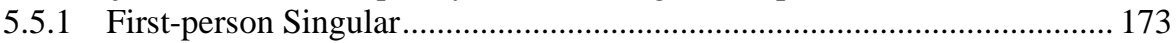

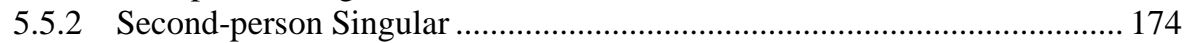

5.5.3 Third-person Singular Masculine + Human ................................................. 176

5.5.4 Third-person Singular Feminine + Human .................................................. 177

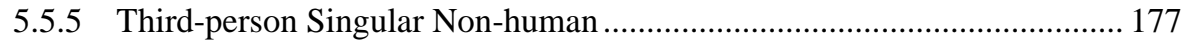

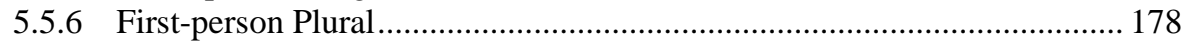

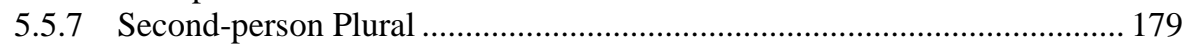

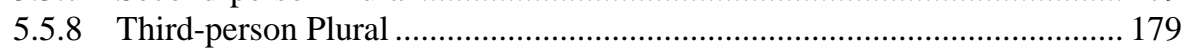

5.6 Conclusion: Distribution of Personal Pronouns in Cité Duits ........................ 180

5.6.1 Overview of Personal Pronouns............................................................. 180

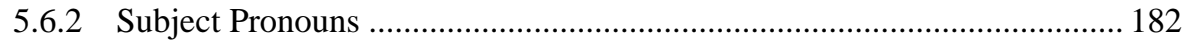

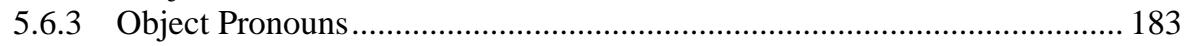

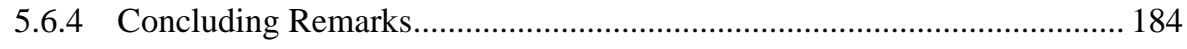

Chapter 6: Explaining Variation in Personal Pronouns .............................. 185

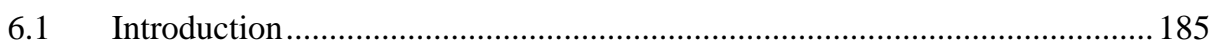

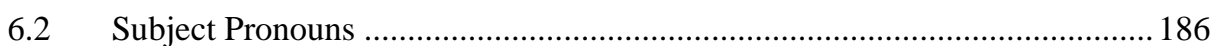

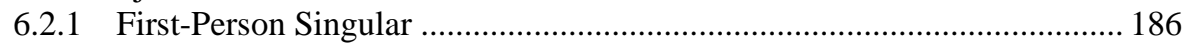

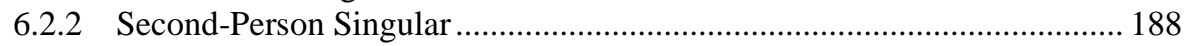

6.2.3 Third-person Singular Masculine + Human .............................................. 191

6.2.4 Third-person Singular Feminine + Human ................................................ 193

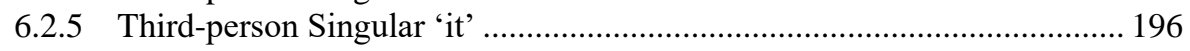




\begin{tabular}{|c|c|}
\hline 6.2 .6 & First-person Plural \\
\hline 6.2 .7 & Second-person Plural .... \\
\hline 6.2 .8 & Third-person Plural .... \\
\hline 6.2 .9 & Summary ...... \\
\hline \multicolumn{2}{|c|}{ Object Pronouns.. } \\
\hline 6.3 .1 & First-person Singular.. \\
\hline 6.3 .2 & Second-person Singular \\
\hline 6.3 .3 & Third-person Singular Masculine + Human . \\
\hline 6.3 .4 & Third-person Plural .. \\
\hline 6.3 .5 & Summary . \\
\hline \multicolumn{2}{|r|}{ The Form ma: Pronominal Clitic or Verbal Agreement Marker?.................. 208} \\
\hline 6.4 .1 & 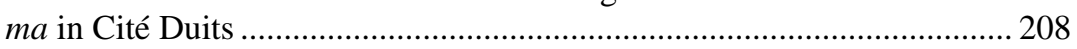 \\
\hline 6.4 .2 & Similar Developments in Other Germanic Varieties ... \\
\hline 6.4 .3 & Discussion: Clitics versus Agreement Markers ............ \\
\hline 6.4 .4 & Summary \\
\hline
\end{tabular}

6.5 Analysis and Conclusion....................................................................... 218

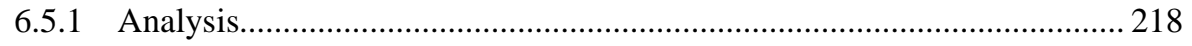

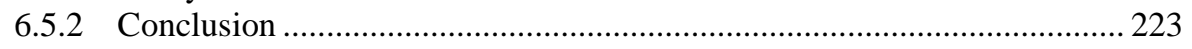

Chapter 7: Progressive Aspect in Cité Duits................................................ 227

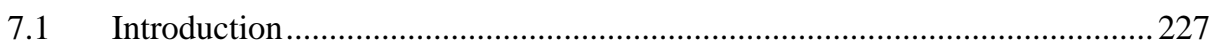

7.2 Progressive Aspect................................................................................. 229

7.2.1 Introducing Tense and Aspect .......................................................... 229

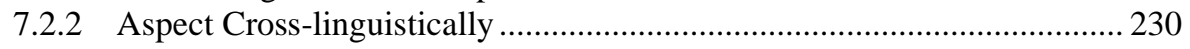

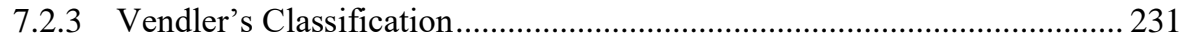

7.3 Progressive Aspect in Cité Duits Contact Varieties ..................................... 233

7.3.1 Some Contributions to the Study of Progressive Aspect in Germanic ...... 233

7.3.2 Non-marked Progressives or Implicit Use .............................................. 235

7.3.3 Aan het/Aon 't/Am-constructions ............................................................. 236

7.3.4 Posture Verb Constructions in Dutch/Maaslands ..................................... 237

7.3.5 Beim/Im-constructions in German ..................................................... 238

7.3.6 Bezig zijn te/Dabei sein zu-constructions .......................................... 239

7.3.7 Further Progressive Types .................................................................... 239

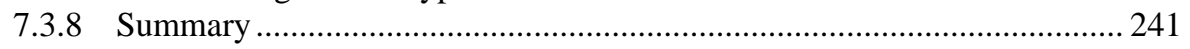

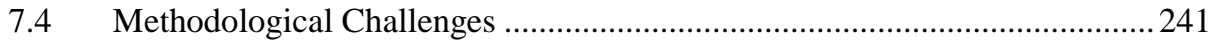

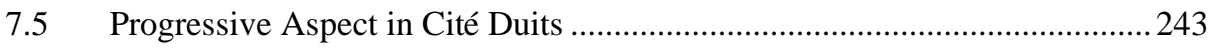

7.5.1 Frequency Distribution of Progressive Constructions ........................... 243

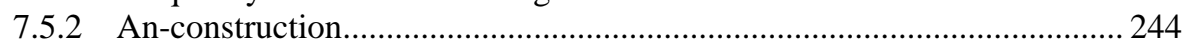




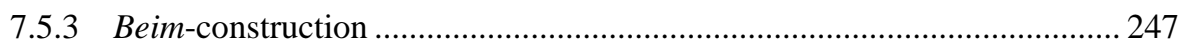

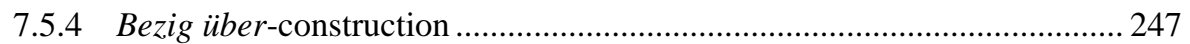

7.5.5 Posture Verb Construction with sitzen $z u$.............................................. 248

7.5.6 Non-marked Progressives .................................................................. 249

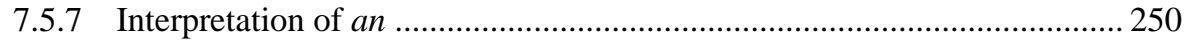

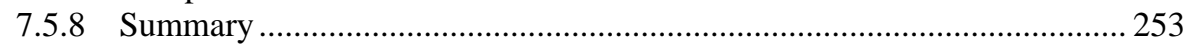

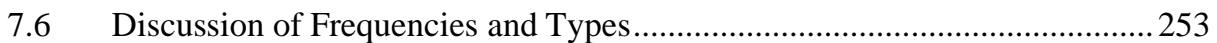

7.6.1 Frequency of Progressive Constructions in German ................................. 253

7.6.2 Frequency of Progressive Constructions in Dutch................................... 254

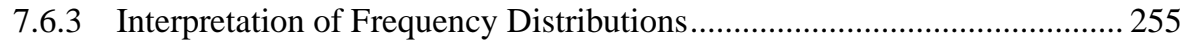

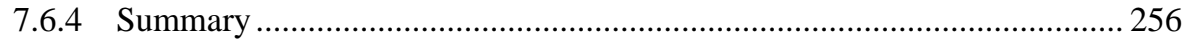

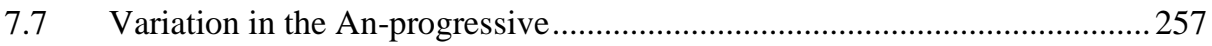

7.7.1 Corpus of Regional Varieties of German............................................... 257

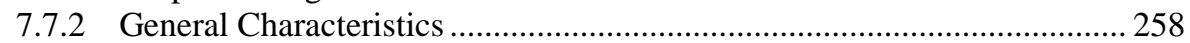

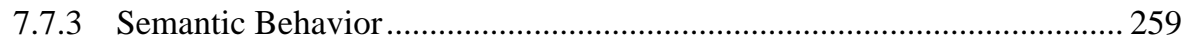

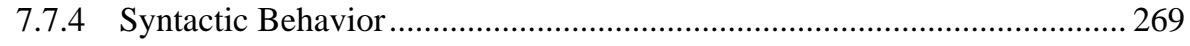

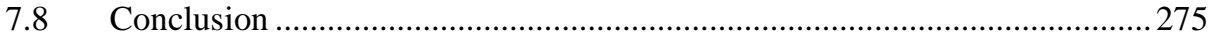

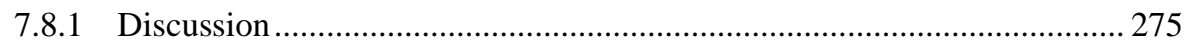

7.8.2 Summary and Concluding Remarks .................................................... 277

Chapter 8: Conclusion................................................................................. 281

8.1 Main Findings ..................................................................................... 281

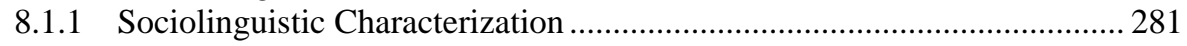

8.1.2 Linguistic Characterization ............................................................. 282

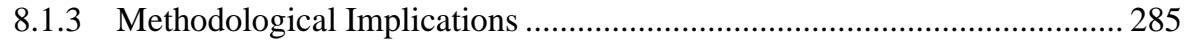

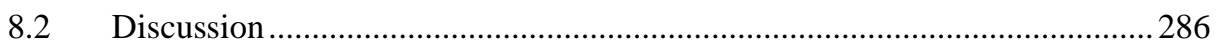

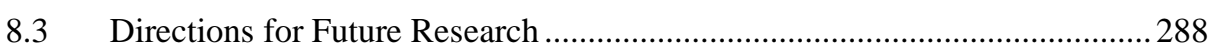

Annex ................................................................................................................ 289

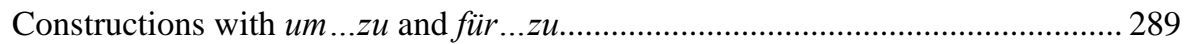

Constructions with kommen 'come' + infinitive.................................................. 292

List of Extraposed Constituents ......................................................................... 293

List of Attested Progressive Constructions in Cité Duits ................................... 297

Overview of Constructions According to Speaker .......................................... 308

List of $A m$-progressives in the German Corpus .................................................... 309

Privacy Verklaring Form ('Privacy Statement Form') .......................................... 312

Toestemmingsformulier ('Agreement Form') ................................................. 313

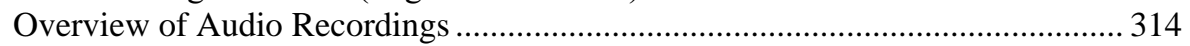

Errinerunge wie ich noch klein wa... ('Memories of when I was little') .............. 318 


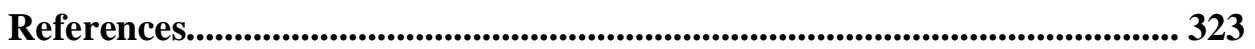

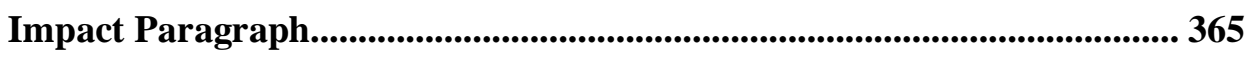

Summary in English .................................................................................................. 367

Nederlandse Samenvatting ................................................................ 371

Curriculum Vitae.................................................................................. 375 
xiv

\section{Abbreviations}

Glossing in this dissertation is based on the Leipzig Glossing Rules (Comrie et al. 2015).

* questionable or unlikely construction

1 first-person

2 second-person

3 third-person

ACC accusative

AUX auxiliary

BD Belgian Dutch

C common gender

CL clitic pronoun

COMP complementizer

COMP-S complementizer-subject order

DAT dative

DEM demonstrative

DET determiner

DIM diminutive

F feminine

G German

$\mathrm{H}$ hesitation marker

INF infinitive

MA Maaslands

M masculine

$\mathrm{MC} \quad$ main clause

$\mathrm{N}$ neuter

N- non- (e.g. non-human)

NEG negation

NP noun phrase

OBJ object

PL plural

PP prepositional phrase

PROG progressive marker

PRS present

PST past

PTCP participle

Q

SBJ subject

SG singular

$\mathrm{S}-\mathrm{V}$ subject-verb order

VP verbal particle

V-S verb-subject order 


\section{Transcription Conventions}

Transcriptions follow the Gesprächsanalytisches Transkriptionssystem 2 (GAT 2) conventions by Selting et al. (2009).

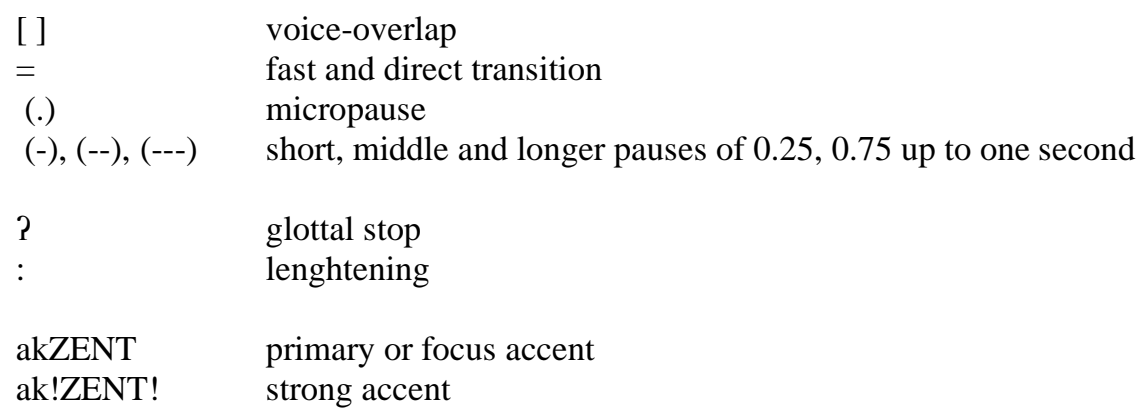

\section{Pitch movement at the end of a unit}

? raising

, slightly raising

- $\quad$ unchanged

; $\quad$ slightly dropping

. dropping

\section{Volume and speed}

$\langle\langle\mathrm{p}\rangle\rangle$

$\langle\langle\mathrm{f}\rangle\rangle$

quiet voice

$<<$ all $>>$ loud voice

$\langle\langle$ acc $\rangle\rangle$

fast voice

$<<$ len $>>$

acceleration of voice

slow voice

\section{Further conventions}
( )
(xx)
unintelligible passage without specification
(et) unintelligible passage of two syllables etc.
${ }^{\circ} \mathrm{h},{ }^{\circ} \mathrm{hh},{ }^{\circ} \mathrm{hhh}$ assumed wording
$<<$ sadly $>>$
breathing out
example of voice quality of a segment 


\section{List of Tables}

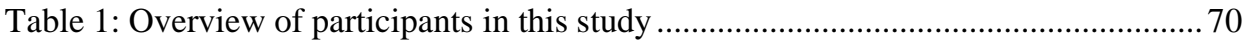

Table 2: Distribution of $e r$ and $d a$ in the Cité Duits corpus......................................... 114

Table 3: Frequency in absolute numbers and percentages of first-person singular subject pronoun forms in Cité Duits ..................................................................... 154

Table 4: Frequency in absolute numbers and percentages of second-person singular subject pronoun forms in Cité Duits.

Table 5: Frequency in absolute numbers and percentages of third-person singular masculine subject pronoun forms + human in Cité Duits ............................. 157

Table 6: Frequency in absolute numbers and percentages of third-person singular feminine subject pronoun forms + human in Cité Duits.............................................. 158

Table 7: Frequency of third-person singular subject pronoun forms non-human in Cité Duits (specific)

Table 8: Frequency in absolute numbers and percentages of third-person singular pronoun forms for 'it' in Cité Duits ............................................................................ 168

Table 9: Frequency in absolute numbers and percentages of first-person plural subject pronoun forms in Cité Duits ........................................................................ 169

Table 10: Frequency in absolute numbers and percentages of second-person plural subject pronoun forms in Cité Duits .....

Table 11: Frequency in absolute numbers and percentages of third-person plural subject pronoun forms in Cité Duits

Table 12: Frequency in absolute numbers and percentages of first-person singular object pronoun forms in Cité Duits.....

Table 13: Frequency in absolute numbers and percentages of second-person singular object pronoun forms in Cité Duits

Table 14: Frequency in absolute numbers and percentages of third-person singular masculine object pronoun forms + human in Cité Duits ................................ 176

Table 15: Frequency in absolute numbers and percentages of third-person singular feminine object pronoun forms + human in Cité Duits .................................. 177

Table 16: Frequency in absolute numbers and percentages of third-person singular object pronoun forms in Cité Duits [-hum] ........................................................... 177

Table 17: Frequency in absolute numbers and percentages of first-person plural object pronoun forms in Cité Duits

Table 18: Frequency in absolute numbers and percentages of second-person plural object pronoun forms in Cité Duits....

Table 19: Frequency in absolute numbers and percentages of third-person plural object pronoun forms in Cité Duits.....

Table 20: Second-person singular subject forms according to their position in Cité Duits

Table 21: Third-person singular masculine forms + human according to their position in Cité Duits. 
Table 22: Third-person singular masculine forms + human according to their position in the Duisburg corpus. 193

Table 23: Third-person singular feminine forms + human according to their position in Cité Duits 194

Table 24: Distribution of third-person singular forms 'it' and 'that' in the Duisburg miners' corpus 196

Table 25: First-person plural forms according to their position in Cité Duits in total numbers 197

Table 26: Third-person plural subject forms according to their position in Cité Duits. 200

Table 27: Frequency of object pronouns in percentages in Cité Duits as attested in $\S 5.5$ .

Table 28: First-person singular object forms in Cité Duits according to standard German

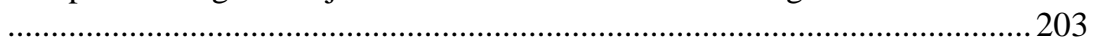

Table 29: Second-person singular object forms in Cité Duits according to standard German 204

Table 30: Third-person singular masculine object forms +human in Cité Duits according to standard German................................................................................... 206

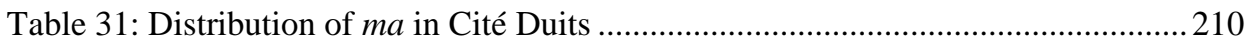

Table 32: Types of elements preceding ma in Cité Duits ..............................................211

Table 33: Low-frequency variants in Cité Duits according to speaker in absolute numbers .

Table 34: Full first-person plural forms in Cité Duits according to speaker in absolute

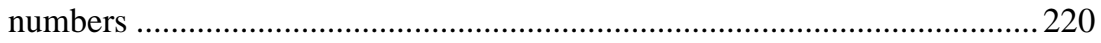

Table 35: Overview of progressive constructions in Cité Duits ....................................224

Table 36: Realization of 'an' in the an-progressive in Cité Duits .................................246

Table 37: Frequency distribution of progressive constructions in German ....................2254

Table 38: Frequency distribution of progressive constructions in Dutch ....................... 254

Table 39: Comparison of progressive constructions in percentages...............................256

Table 40: Overview of attested am-constructions in the German corpus according to

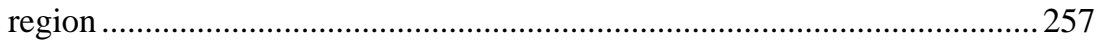

Table 41: Progressive constructions according to speaker in absolute numbers ............ 308

Table 42: Realization of progressive marker in the an-construction according to speaker

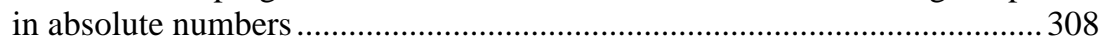




\section{List of Figures}

Figure 1: Location of Eisden (B) in the Belgian-Dutch-German border region................. 4

Figure 2: Map of today's Flanders composed of five Dutch-speaking provinces .............. 5

Figure 3: Map of the main areas where the Limburgish dialects are spoken .................... 8

Figure 4: Location of the seven Kempen mines in the Belgian province of Limburg in the

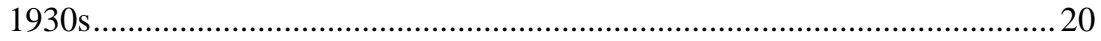

Figure 5: Percentage of non-Belgian labor force in the Kempen mines in 1930.............24

Figure 6: Development of labor force in Eisden between 1922 and 1933 ......................25

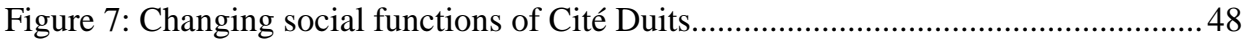

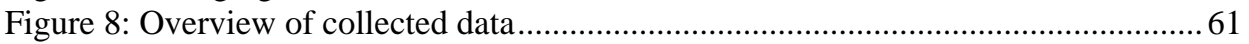

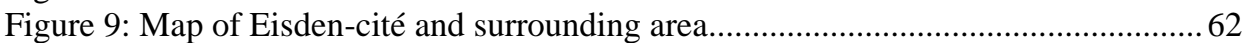

Figure 10: Overview of Cité Duits speakers who participated in sociolinguistic recordings (2012-2016) .......................................................................................... 71

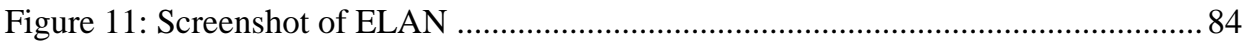

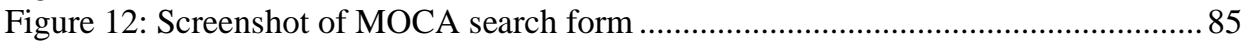

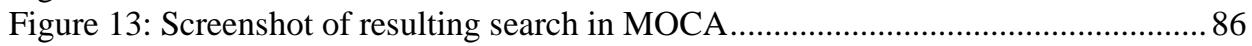

Figure 14: Screenshot of waveform view in Audacity ............................................... 87

Figure 15: Possessive pronouns in Cité Duits compared to Belgian Dutch, Maaslands, and

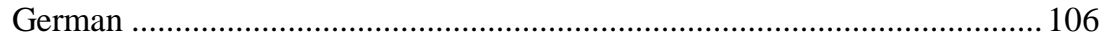

Figure 16: Inflectional paradigm of 'to be' Present Tense ............................................ 109

Figure 17: Inflectional paradigm of 'to be' Past Tense.................................................. 109

Figure 18: Main functions of Dutch $e r$ with German and Maaslands counterparts....... 114

Figure 19: Exemplification of Topological Field Model (German) .............................. 119

Figure 20: Full and weak subject and object pronouns in Belgian Dutch ..................... 142

Figure 21: Full and weak subject and object pronouns in Maaslands ........................... 145

Figure 22: Full and reduced subject and object pronouns in German ........................ 148

Figure 23: Subject pronoun forms in Belgian Dutch, Maaslands, and German (IPA) .. 152

Figure 24: Object pronoun forms in Belgian Dutch, Maaslands, and German (IPA) ... 152

Figure 25: Distribution of first-person singular subject pronoun forms in Cité Duits... 154

Figure 26: Distribution of second-person singular subject pronoun forms in Cité Duits

156

Figure 27: Distribution of third-person singular masculine subject pronoun forms + human

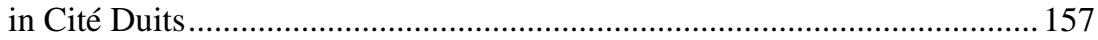

Figure 28: Distribution of third-person singular feminine subject pronoun forms + human

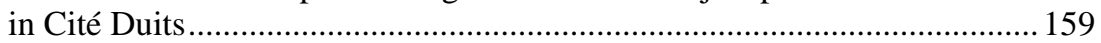

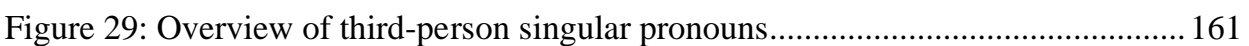

Figure 30: Overview of 'it'-functions in Dutch, German and Maaslands ...................... 167

Figure 31: Distribution of third-person singular subject pronoun forms for 'it' in Cité Duits

Figure 32: Distribution of first-person plural subject pronoun forms in Cité Duits ....... 170

Figure 33: Distribution of third-person plural subject pronoun forms in Cité Duits ..... 172 
Figure 34: Distribution of first-person singular object pronoun forms in Cité Duits .... 174 Figure 35: Distribution of second-person singular object pronoun forms in Cité Duits 175

Figure 36: Distribution of third-person singular masculine object pronoun forms + human

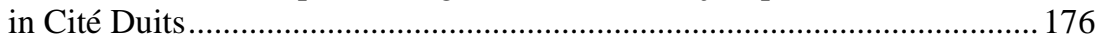

Figure 37: Distribution of third-person plural object pronoun forms in Cité Duits....... 180

Figure 38: Most frequent subject pronoun forms in Cité Duits compared to the contact varieties (IPA). 181

Figure 39: Most frequent object pronoun forms in Cité Duits compared to the contact varieties (IPA)..... 181

Figure 40: Low-frequency variants according to speaker in relation to speech share ... 219

Figure 41: Full first-person plural forms according to speaker in relation to speech share

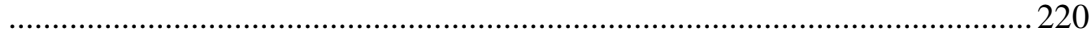

Figure 42: Paradigm of full and clitic subject and object pronouns in Cité Duits......... 224

Figure 43: Vendler's classification (Broekhuis et al. 2015a: 37) ............................... 232

Figure 44: Verbal classes according to feature bundles based on Vendler (1967) (adapted)

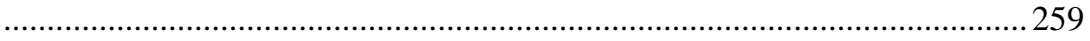

Figure 45: Distribution of verbal events in Cité Duits and in regional varieties of German in percentages ............................................................................... 260

Figure 46: Realization of progressive markers according to speaker ...........................276

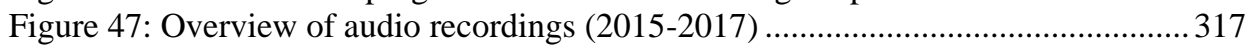




\section{Publications}

Some parts of Chapter 4 have been published in Pecht (2019), and parts of Chapters 5 and 6 will appear in Pecht (forthcoming). Furthermore, I discussed the phenomenon of extraposition in Pecht (2015), and in an unpublished script of my MA-thesis (Pecht 2014). In a similar vein, I have treated the methods of data collection and the V2-constraint in several publications (Pecht 2013; 2015; 2019). 


\section{Chapter 1: Introduction}

[L]anguage is more than a reflective tool whereby we try to make sense of our thoughts and actions. Through language use we also enter an interactional space that has been partly already shaped for us, a world in which some distinctions seem to matter more than others, a world where every choice we make is partly contingent on what happened before and contributes to the definition of what will happen next. (Duranti 1997: 5)

\subsection{The Research Case in a Nutshell: Research Questions and Aims}

While contact between speakers of different language varieties is hardly a new phenomenon (Thomason 2001; Eichinger 2016; Ptashnyk 2016b; Roberge 2010), intensified global connections and new infrastructures facilitating faster travel have changed the scope and nature of physical human mobility. Whether people travel temporarily or for longer periods, as tourists, as labor migrants or refugees, they will always take their sociocultural and linguistic knowledge along with them and share it with those they encounter. In a plethora of contexts, then, speakers of various linguistic-cultural backgrounds communicate with each other, whereby norms and practices of interaction are continuously being negotiated (Jacquemet 2005; Wang et al. 2014; Blommaert 2010; Lønsmann et al. 2017; Mortensen 2017).

This study contributes to the ongoing sociolinguistic debate on language contact of closely related language varieties. One particularly interesting case is Cité Duits, which developed among second generation immigrants in the former coalmining district of Eisden in the Belgian province of Limburg. Today this language variety is on the verge of disappearing, with fewer than a dozen speakers left. While the term cité refers to a coal miners housing district (from French cité ouvrière), Duits is the Dutch word for the German language. This label, which broadly translates as 'mining district German,' was coined by the speakers to refer to their speech. As the label suggests, speakers claim to speak a variety of German (Duits), which is remarkable because German is neither the (official) language of the area nor the home language of most speakers. The town of Eisden is part of a region where most people speak Belgian Dutch and Maaslands, whereas the speakers of Cité Duits, now all men in their eighties, grew up with different home languages, including Czech, Polish, and Italian. This in fact renders Cité Duits a quite unique case in Europe.

Although the language use of mining communities has been the focus of several studies (Mesthrie 1989; 2019; Muysken 2019; Cornips \& De Rooij 2019; Álvarez López 2019; Braber 2019; Devlin et al. 2019), Cité Duits remained a blind spot in sociolinguistics research until recently. There has been no fine-grained linguistic analysis of either Cité Duits or the language use of this particular community, which encompasses secondgeneration immigrants of European descent born and raised in Eisden in the 1930s and 1940s, as well as their children. In addition, little is known of the development of this 
'mining variety,' and it is uncertain whether women have used it at all. As a hitherto undescribed type of a variety that emerged due to intensive language contact, Cité Duits constitutes a perfect case for linguistic investigation, also because of the close similarities of the source varieties.

The aim of the present study is to unravel the language contact dynamics involved in Cité Duits. Specifically, the following research question will be explored: what are the underlying language contact dynamics in Cité Duits and which (features of) language varieties contributed to its linguistic structure? This dissertation sheds light in particular on the contact processes between colloquial spoken German, Belgian Dutch, and the Maaslands dialect, three varieties that are structurally extremely similar. Through this analysis, I aim to provide more general insights into contact between closely related varieties. Another goal of this dissertation is to enhance our understanding of variability and change in spoken language.

In order to investigate the nature of Cité Duits in a systematic fashion, I focus my analysis on two specific linguistic issues: personal pronouns and progressive aspect. From the perspective of language contact, these represent two distinct domains on the grammatical level, which allows me to look at the data from two angles (see borrowing scales by Haugen 1950; van Hout \& Muysken 1994; Thomason \& Kaufman 1988: 74-75; further Thomason 2001; Sankoff 2004). If I also touch on several other areas, such as verbal inflection and infinitival complementizers, they will benefit from more sustained analytical efforts in the future.

While the examination of personal pronouns involves both morphosyntax and phonology, progressive constructions reveal much about the syntactic and semantic characteristics of Cité Duits. Moreover, progressive aspect is interesting in particular to be considered from a cross-linguistic perspective. The linguistic means in the varieties with which Cité Duits has been in close contact differ to some extent, but they also overlap. This raises the question of how progressive aspect is marked in Cité Duits, and whether the respective constructions show particular syntactic or semantic restrictions. In contrast, personal pronouns are well-suited for an investigation at the intersection of sociolinguistics and grammatical analysis because they are highly frequent in spoken language. The behavior of pronominal forms in contexts of language contact elucidates the stability of linguistic features. Examining their frequency distribution will reveal to which degree pronominal forms are used consistently in Cite Duits, and with which language varieties these forms exhibit congruence. My analysis sets out from the premise that situations of code-switching are conducive to considerable variation when several grammatical systems exist side by side. A speaker may use a particular form from language $\mathrm{A}$ and combine it with language $\mathrm{B}$ and $\mathrm{C}$, but also vice-versa. After a process of amalgamation, however, the use of certain linguistic features is no longer optional. Generally, some features lose ground whereas others take over (Auer 1998a; 2014).

In this dissertation, I will address the following four sub-questions. (RQ1) Which social processes and linguistic environment gave rise to the emergence of Cité Duits (Chapter 2)? (RQ2) Which linguistic features are characteristic of Cité Duits (Chapter 4)? 
(RQ3) How can the pronominal paradigm be characterized and which factors account for variation (Chapters 5 and 6)? (RQ4) How is progressive aspect expressed in Cité Duits (Chapter 7)? Below I will elaborate these research questions, together with an outline of the corresponding chapters $(\S 1.4)$.

For studying the community of Eisden, I gathered different types of data (Chapter 3). Most of the data collection took place between August 2015 and November 2016. The linguistic analysis of this work is based on a six-hour audio corpus of spontaneous-like group interactions of male speakers, collected by adopting a specific method of sociolinguistic fieldwork (Labov 1972; 2001). In addition, to develop a more nuanced understanding of the linguistic resources employed within the studied community, I did group recordings with female speakers and engaged in participant observation, while I also collected written materials, took photographs of public signs, and conducted a large number of semi-structured interviews. Finally, to acquire information on Maaslands, the Limburgish dialect spoken in Eisden, I performed an oral translation task from Dutch to Maaslands.

By investigating the community of Eisden from a sociolinguistic perspective, I join an emerging approach in sociolinguistics in which language is considered as a dynamic construct that is interwoven with various cultural, historical, and social factors (Bucholtz \& Hall 2008; Coupland \& Coupland 1995; Heller 2007; Johnstone 2010; 2014; Pennycook \& Otsuji 2014; Blommaert \& Rampton 2011; Møller \& Jørgensen 2009; Eckert 2008; 2018; Wei 2011; Quist 2008; Creese \& Blackledge 2011; Mortensen 2017; Lønsmann et al. 2017). Furthermore, by providing a formal description of a set of linguistic features, this research is informed by grammatical approaches to languagedialect contact and contact languages (Sankoff 2004; Hickey 2013; Clyne 2003; Wiese 2013b; Auer 1998a; Meakins 2011; Muysken 2014; Matras 2009; Bakker \& Mous 1994).

In the remainder of this introduction, for understanding the wider historical and areal context from which this study departs, I first sketch the geographical setting of Eisden and introduce the language situation of Flanders and Belgian Limburg (§ 1.2). Next, I present the most pervasive theoretical concepts in sociolinguistics research on language contact, which serve as a backbone for this study ( $\$ 1.3$ ). I conclude this chapter by providing an outline of my research questions and of the structure of this dissertation $(\S 1.4)$.

\subsection{Belgian Limburg: Language Situation and Setting 1.2.1 The Geographical Setting of Eisden}

Geographically, the town of Eisden is situated in the Belgian province of Limburg in the Belgian-Dutch-German border area (Figure 1). 


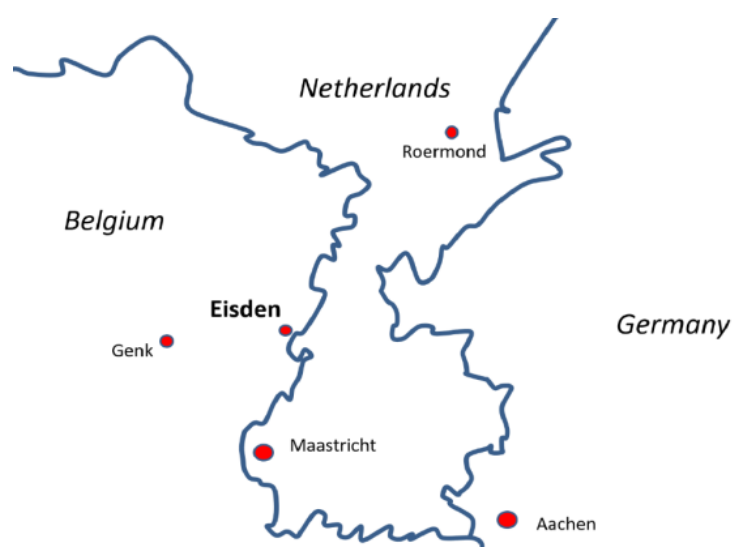

Figure 1: Location of Eisden (B) in the Belgian-Dutch-German border region

Eisden, which today is a sub-municipality of Maasmechelen of approximately 10,000 inhabitants, is located about $20 \mathrm{~km}$ east of Genk and $100 \mathrm{~km}$ east of Brussels. As visible from Figure 1, Eisden is close to the Dutch and German border, not to be confused with the homophonous Dutch town of Eijsden located $25 \mathrm{~km}$ to the south. The distance between Eisden and the German border is approximately $18 \mathrm{~km}$, and between Eisden and the Dutch city of Maastricht $15 \mathrm{~km}$. For a clearer picture of the language situation in Eisden, in particular in the 1930s when the speakers of this study grew up, I first provide a brief historical account of Dutch in Flanders, after which I sketch some recent linguistic developments and the role of local dialects.

\subsubsection{Historical Background of Dutch in Flanders}

The Belgian province of Limburg belongs to Flanders, the Dutch-speaking part of Belgium. ${ }^{1}$ Since 1963, Belgium officially has been divided into four linguistic areas: Wallonia with French in the south, Flanders with Dutch in the north, the French-Dutchspeaking capital of Brussels, and a small German-speaking part in the east (Knops \& van Hout 1988: 6; Vandekerckhove 2005: 379; Willemyns 2002: 36; 2013: 9; Marynissen \& Janssen 2013: 96; for Brussels see Treffers-Daller 2002; for the German part see Nelde \& Darquennes 2002). The majority of the Belgian population (57\%) lives in one of the

\footnotetext{
${ }^{1}$ Throughout this dissertation, I use 'Flanders' to refer to the area illustrated in Figure 2. Note that in dialect research, 'Flanders' refers more broadly to the region where the Flemish dialects are spoken, which basically comprises the western part of northern Belgium, a northern section of France, and the southwestern corner of the Netherlands (Ghyselen 2016: 37; Ghyselen \& Keymeulen 2016: 62).
} 
country's five Dutch-speaking provinces (Statbel 2019). ${ }^{2}$ As depicted in Figure 2, the province of Limburg is located in the far east of Flanders, bordering the Belgian provinces of Antwerp and Flemish-Brabant in the west.

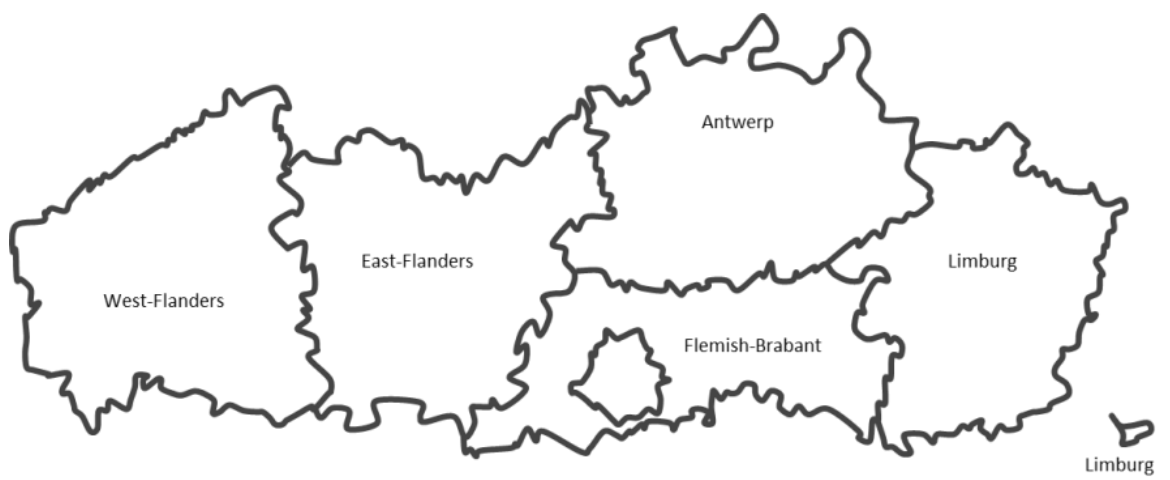

Figure 2: Map of today's Flanders composed of five Dutch-speaking provinces

Flanders, although largely Dutch-speaking, was for a long time characterized by an asymmetrical diglossic situation, ${ }^{3}$ with French serving as the official language for administration, education, and politics. Over the past centuries, language debates - which were not exclusively of a linguistic nature but closely intertwined with social and political discrepancies - caused much friction between the Flemish and the Walloons, and many Flemish developed negative feelings toward the French language (see § 2).

Historically, French began to gain prominence when Spanish troops conquered Antwerp in 1585, causing the development of Dutch as a standard language to come to a standstill in this region. Conversely, in what constitutes the Netherlands today, Dutch gradually evolved into a prestige variety during the seventeenth century. In the territories of present-day Flanders, the linguistic impact of French continued after the War of the Spanish Succession (1701-1714), when these territories transferred from the Spanish to the Austrian branch of Habsburg. ${ }^{4}$ Around 1800, public life had become almost completely Francophone. The language struggle between the Flemish and the Walloons started shortly after 1830, when Belgium achieved independence. Despite the fact that the new constitution proclaimed language freedom, it was drawn up entirely in French,

2 According to the 'Belgian Statistical Office' (Statbel 2019), approximately 6,589,000 people live in Flanders, 3,633,700 in Wallonia, 1,208,500 in Brussels and 77,500 in the German region. These numbers, of course, do not say anything about the language varieties spoken by the inhabitants.

3 The term 'diglossia' was introduced by Ferguson (1959) and describes communities in which two or more language varieties are used in different contexts. Typically, one of them is regarded as the 'high' $(\mathrm{H})$ variety (for formal uses) and the other as the 'low' $(\mathrm{L})$ variety (for informal uses).

${ }^{4}$ An attempt by Willem I (1814-1830) to reintroduce Dutch proved to be unsuccessful (see especially Vosters 2009). 
although Dutch speakers constituted the majority of the population. Because the authorities and the French-speaking bourgeoisie rejected the implementation of Dutch, many Flemish felt discriminated against.

The government's refusal to acknowledge Dutch as an official language in Flanders gave rise to the Flemish Movement, which started as a cultural organization but quickly turned into a political movement. Under pressure of its supporters, in 1898, the 'Linguistic Equality Act' (Gelijkheidswet/Loi d'Égalité) recognized Dutch as official legal language in Flanders, putting Dutch and French on equal footing. This law had a significant symbolic meaning, but it would take several years until the first language rights were implemented. Actual language use remained open to choice, which de facto meant that official documents continued to be in French only and were rarely translated (Willemyns 2013: 78-79; 2002; Grondelaers et al. 2011: 200-01; Marynissen \& Janssen 2013: 96; van de Velde 1996: 26-28). It was not until 1930 that the University of Ghent began to use Dutch as language of instruction, rather than French (van de Velde 1996: 27).

To put an end to the ongoing language conflict, Belgium adopted the territoriality principle. Following the 1932 Language Act (Taalwetgeving), separate linguistic regions were determined. ${ }^{5}$ During the first three decades, language boundaries remained subject to negotiation based on a language census held every ten years, which resulted in some districts being transferred to other provinces. For example, the Voeren (Les Fourons) exclave used to be part of the province of Liège (Wallonia), but in the early 1960s it formally became part of the province of (Belgian) Limburg. Finally, in 1962-63, Belgium defined fixed boundaries for its four linguistic regions (for a historical survey, see Willemyns 2013; Willemyns 2002; Marynissen \& Janssen 2013; Grondelaers et al. 2011: 200-01; further Rutten \& Vosters 2010).

\subsubsection{Belgian Dutch: Standardization and VRT-Dutch}

Until the introduction of Dutch as the only official language in Flanders, there was no supra-regional variety of Dutch for education or in the media. Consequently, when orthographic conventions for writing were established in 1932, Belgium adapted Netherlandic Dutch (Vandekerckhove 2005: 379-80). ${ }^{6}$ In a similar vein, radio stations and, later on, television networks actively exposed the population to the national variety of Dutch as used in the Netherlands, thereby encouraging the Flemish to take over the latter (Grondelaers et al. 2011: 201; also van de Velde 1996; Geeraerts 2001; Vandenbussche 2010). ${ }^{7}$

5 Note that the Taalwetgeving/La loi du 28 juin 1932 sur l'emploi des langues en matière administrative was already discussed in the 1920 s.

${ }^{6}$ However, it seems that certain normative traditions of written Dutch did exist in Flanders in the eighteenth and early nineteenth century (Rutten \& Vosters 2010).

${ }^{7}$ See van de Velde (1996) for an exhaustive study of spoken Dutch in Flemish radio programs (19351993). Importantly, most Flemish television channels could not be watched in the eastern province of Limburg during the first decades. As a result, many inhabitants watched German television $(\$ 2)$. 
Most speakers, however, felt uncomfortable with speaking a variety introduced from another country, and standard Dutch remained 'a rather artificial, unnatural, almost "foreign" language that is only spoken at school and in other quite formal circumstances' (Marynissen \& Janssen 2013: 95) - functioning much like 'Sunday clothes' worn for special events and taken off as quickly as possible afterward (Geeraerts 2001). Speakers perceived this "standard variety" often as too rigid and they tended to speak it only occasionally. While the Belgian and Netherlandic Dutch standard languages became linguistically quite close to each other, colloquial Belgian and Netherlandic Dutch have always exhibited considerable differences on the level of lexis, pronunciation, and grammar (Geeraerts 2001; Haeseryn 2013; Velde \& Geeraerts 2013; Marynissen \& Janssen 2013: 95; for verb clusters see De Sutter et al. 2005; for pronouns see Vandekerckhove 2004; Vandekerckhove 2005). ${ }^{9}$

Over the last decades, Flanders has developed a Flemish variant of the standard language. This spoken standard is commonly referred to as 'VRT-Dutch,' going back to the Flemish public broadcaster VRT (Vlaamse Radio- en Televisieomroep) which played a vital role in its propagation (Geeraerts 2001; Grondelaers \& Van Hout 2016). While local dialects mainly served for informal communication among speakers from the same area, VRT-Dutch became the variety spoken in contexts in which speakers avoided the dialect (Haeseryn 2013: 716). This situation has been changing in recent years, however. Dutch-speaking Belgium is currently evolving more and more from a diglossic community into a diaglossic community, marked by a broad linguistic range in between the spoken formal language and the regional dialects, often referred to as tussentaal 'in-betweenlanguage.' Instead of speaking VRT-Dutch, it appears that more and more speakers, including the media and public figures such as politicians, rather speak an 'intermediate variety,' which is gradually spreading into formal domains (e.g. Geeraerts 2001; Jaspers 2001; De Caluwe 2006; Plevoets 2008; Taeldeman 2008; Grondelaers et al. 2011; Ghyselen \& Keymeulen 2016; Ghyselen 2016; Grondelaers \& Van Hout 2016; Vandekerckhove 2009). ${ }^{10}$

${ }^{8}$ I understand the term 'standard variety' as a common variety that is codified, has overt prestige (H-variety), and preferably exhibits no geographical variation in the area in which it is employed. I refer the reader to Ammon (2004) und Auer (2011) for a thorough discussion. See Ghyselen and De Vogelaer (2018) for the theoretical importance of the variety-question.

${ }^{9}$ For an overview of features that are said to distinguish Colloquial Belgian Dutch from Standard Belgian Dutch, see Velde and Geeraerts (2013). See Haeseryn (2013: 712-13) for BelgianNetherlandic Dutch as 'pluricentric languages' (Clyne 1992), and Haeseryn (2013: 713-16) for a discussion of convergence and divergence between Belgian and Netherlandic Dutch.

${ }^{10}$ While intermediate forms of speech between the dialect and the standard are common in presentday Europe (Auer 2011: 491), linguists have paid considerable attention to tussentaal (e.g. Geeraerts 2001; Jaspers 2001; De Caluwe 2006; Plevoets 2008; Taeldeman 2008; Grondelaers et al. 2011; Ghyselen \& Keymeulen 2016; Ghyselen 2016; Grondelaers \& Van Hout 2016; Vandekerckhove 2009). Some describe the speech as 'a civilized go-as-you-please speech variety' (Marynissen \& Janssen 2013: 97), whereas others propose that tussentaal is the new endoglossic variety of Dutchspeaking Belgium (Grondelaers et al. 2011: 203-06). 
Nevertheless, the generation born prior to the 1960s is more prone to speak Belgian standard Dutch in formal contexts (see Plevoets 2008: for an in-depth study), and a local dialect in informal contexts. This also holds for the Belgian province of Limburg. 'Dialect loss,' if widespread nowadays, only started in the 1970s and is a rather recent phenomenon, which can be explained by the late standardization process of Dutch as described above (Cornips 2013: 379-80; Vandekerckhove 2009). Consequently, when the speakers of this study grew up, local dialects enjoyed a wide distribution in Belgian Limburg. In the subsequent section, I will briefly review some characteristics of Limburgish.

\subsubsection{The Limburgish Dialects}

Limburgish belongs to the South Low Frankish dialect group and is spoken in the Belgian and Dutch provinces of Limburg as well as in certain adjacent parts of Germany, as illustrated in Figure 3. In the early nineteenth century (1815-1839), Limburg was one large territory consisting of Dutch and Belgian Limburg. In 1997, the Limburgish varieties were officially recognized as a separate language in the Netherlands, while they continue to be treated as dialects in Belgium (Cornips \& Knotter 2016; Cornips 2013). ${ }^{11}$

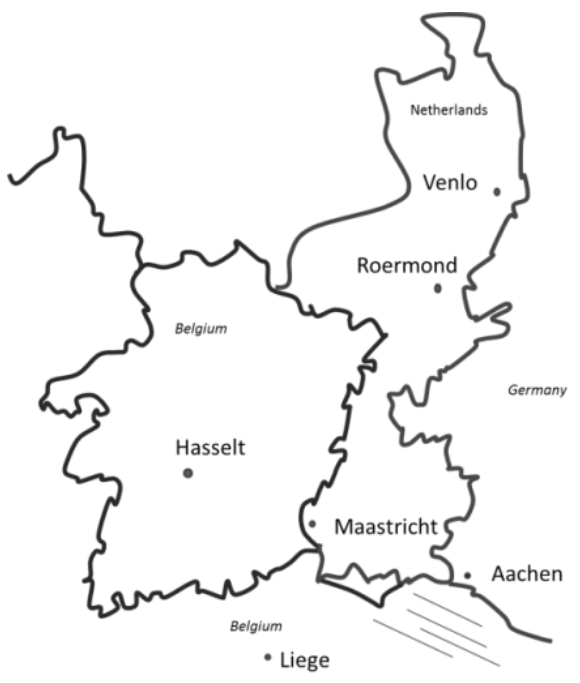

Figure 3: Map of the main areas where the Limburgish dialects are spoken

\footnotetext{
11 The Netherlands, a signatory of the 'European Charter for Regional Languages or Languages of Minorities,' formally recognized Limburgish as a separate language with minor recognition (i.e. without financial support), whereas the Flemish government rejected a similar request in 1999 (Cornips 2013: 378).
} 
A feature that distinguishes the Limburgish dialects from other Dutch dialect groups is the tonal accent. Most Limburgish and Ripuarian dialects show a contrast between two tonal accents, Accent 1 and Accent 2, which differ in terms of timing. ${ }^{12}$ Moreover, many Limburgish varieties have sandhi voicing, i.e. voicing of a consonant at the end of a word when the next word starts with a vowel, a phenomenon that also occurs in Ripuarian (Hermans 2013). On the level of morphosyntax, a large number of Limburgish dialects (except in the north of the Netherlands) have retained the old gerund, which is formed by adding the suffix - entere to the verb stem (De Schutter \& Hermans 2013: 364-65) (see $\S$ 7).

Traditionally, dialectologists distinguish six sub-groups of Limburgish based on isoglosses going from east to west: the transition zone between Ripuarian and Limburgish; the eastern-, central- and western dialects, a transition area close to the Belgian city of Genk, and a transition area between Brabantish and western Limburgish (Cornips 2013: 378-79; Hermans 2013: 337; Belemans 2009). ${ }^{13}$ According to this division, the Limburgish dialect Maaslands that is spoken in and around Eisden belongs to the group of central dialects. Maaslands is said to be spoken in the narrow area around the river Maas (Meuse) on the Belgian side of the Dutch-Belgian border region (Belemans \& Keulen 2004: 26-28).

Major isoglosses are the Uerdingen line that divides ik-ich 'I' and ook-auch 'also,' the Benrath line that distinguishes maken-machen 'make,' and the Panninger line or $s j$-/sch- isogloss. The Uerdingen line, which crosses Belgium, the Netherlands, and Germany, is the isogloss within West Germanic languages that separates dialects that preserve the $/ \mathrm{k} /$ sound in the first-person singular pronoun word $i k$ 'I' (north of the line) from dialects in which the word final $/ \mathrm{k} /$ has changed to word final /x/ in the word ich 'I.' Moreover, dialects north of the Benrath line have usually preserved the $/ \mathrm{k} /$ in 'to make' (maken), while those to the south use the / $\mathrm{x} /$ (machen). The Benrath line runs from western Germany (from Benrath close to Aachen) to the east, thereby dividing High German to the south from the rest of the West Germanic language area to the north and north-west.

The Maaslands dialect is traditionally situated in the east of the province and south of the Benrath line, implying that it has word final -ch in the word ich 'I.' But it is northwest of the Uerdingen line (maken 'to make'). ${ }^{14}$ Not all final $/ \mathrm{k} /$ are realized as a

12 For words with Accent 1 thus holds that the pitch change is realized fairly early in the stressed syllable, whereas it is realized later in words with Accent 2 (De Schutter \& Hermans 2013: 357; for a discussion see Hermans 2013).

13 This view is based on the assumption that dialect speakers spend their entire life in a fixed geographical location, which often is not the case. Furthermore, note that some dialectologists also include Kleverlands in the north of Venlo in Dutch-Limburg, which exhibits many features of Brabantish (van de Wijngaard \& Keulen 2007: 15-20).

${ }^{14}$ Note that the Uerdingen and Benrather line overlap. For a detailed map, I refer to van Bree (1996: 235). For discussions involving the German-Dutch border area, see Goossens (1988), van Hout (2006), and Bakker (2016). 
fricative in all lexical items in Maaslands. For some words, the dialect behaves in the same way as Dutch (e.g. zaak 'thing'), whereas for others (e.g. ich) Maaslands is closer to German. With regard to West Germanic /t/ and /p/, the dialect follows standard Dutch (e.g. dorp 'village') (for the isoglosses, see Goossens 1965; 1994a; 2012 [1977]; Bakker 2016; Schmidt \& Möller 2019: 517-19; Elmentaler 2019). Finally, the Panninger line runs from Panningen to the south and demarcates the word-initial eastern pronunciation [ $\left.\int\right]$ from western [sx-]. The central Limburgish dialects, to which Maaslands belongs, are found in between the Panninger line and the Panninger side-line (Panninger Zijlinie). East of the Panninger line, word-initial $-s$ is generally articulated as $s j$ - and $z$ - as $z j$ - (e.g. sjpele vs. spele 'play'). The Panninger side-line crosses Belgian-Limburg, dividing it into an eastern part with sj- (sjoen) and a western part with sch-(schoon) (Belemans 2007).

Nevertheless, the boundaries between different dialects or dialect groups are far from clear-cut, and scholars have more and more questioned a division based on isoglosses alone (see especially Taeldeman \& Hinskens 2013; Mesthrie 2009: 56-60). Isoglosses neither consider the socioeconomic mobility of present day speakers, nor the degree to which language varieties change under the influence of 'new speakers.' ${ }^{15}$ Likewise, today, as outlined in the previous section, dialects in Flanders are acquired not as autonomous varieties but rather on a continuum with the standard language (De Vogelaer \& Klom 2013: 162; Ghyselen \& Keymeulen 2016; Geeraerts 2001) .

Finally, Limburgish dialects are heterogeneous systems and reveal distinctive grammatical properties. The varieties spoken in the border region of Belgium, the Netherlands, and Germany often share several grammatical properties, whereas the Limburgish varieties spoken within the Dutch province of Limburg exhibit plenty of internal variation. In a similar vein, many 'Limburgish' features are not specific to Limburgish but likewise appear in other dialect groups (Cornips 2013: 379). Eastern Brabantish shares several features with the Limburgish dialects in the adjacent areas (Schutter 2013: 278), and 'Ripuarian features' have likewise been attested in some Middle Franconian varieties (e.g. reflexive adjunct middle). Furthermore, there is no single feature that distinguishes the Belgian from the Netherlandic Limburgish varieties (Cornips 2013: 379). Present-day Limburgish dialects can therefore be described as a range of features along a continuum. Not only do we observe differences across age groups - e.g. younger speakers seem to be more inclined to mix dialect features with Belgian Dutch than older speakers - but dialects have also been subject to change over the past decades, with some areas being more affected than others (Vandekerckhove 2009; Cornips 2013). ${ }^{16}$

15 The term 'new speaker' emerged as a reaction to the nativeness concept and labels such as 'L2 speaker,' and draws attention to speakers outside of the traditional communities. It therefore challenges the term of the 'non-native speaker,' which is often associated with imperfect and illegitimate language use (O’Rourke \& Pujolar 2013; 2015; Canagarajah 2014; Costa 2015; see also Kraft 2019).

${ }^{16}$ See Vandekerckhove (2009) and Cornips (2013) for recent developments, Hermans (2013) for phonology; De Schutter and Hermans (2013) for grammatical properties; and Belemans and Keulen (2004) for Belgian-Limburgish. In the remainder of this dissertation, I employ the term 'Limburgish' 


\subsubsection{Summary}

In this section I outlined how Dutch-speaking Belgium evolved from a diglossic into a diaglossic society. For a long time, Dutch in Flanders ranked second after French. After its recognition as single official language in 1932, the government introduced Netherlandic Dutch as standard language, which was often adapted by the media and in the context of education. Accordingly, when the speakers of this study grew up, they were exposed to Netherlandic and Belgian Dutch, while the Limburgish dialect Maaslands, spoken around Eisden, functioned as an important means of communication for the local population. More recently, the speaking of the dialect and the Belgian standard ('VRTDutch') are both on the decline. Instead, Dutch-speaking Belgium has developed a large range of features in between the spoken formal language and the regional dialects, and dialects are often acquired on a continuum with the standard language. For this study, the entire variation spectrum found in Belgian Dutch cannot be reviewed. Rather, I will concentrate on the features directly relevant to the analysis.

\subsection{State-of-the-art: Theoretical Background}

This dissertation is based on the theoretical assumption that language is adaptive and changes across different contexts. Grammar is therefore a reflection of the ways in which speakers use language, and linguistic structures are shaped by social interaction. I take the perspective that grammatical features can best be analyzed by drawing on audio data resulting from interactions in an informal environment. This follows an approach in sociolinguistics that considers language as a dynamic construct (see $\S 1.3 .1-1.3 .2$ ).

The research presented here is also informed by studies on language contact, to which I will devote some attention in this section. Due to the large number of approaches in this field, I will only outline the most important concepts ( $§ 1.3 .3)$. In addition, the grammatical analysis is based on specific insights about (dialectal) varieties of German and Dutch. For some features that are not well-established in the literature, I made use of speech corpora (see $\S 3$ ). To facilitate access to the material, the properties of the linguistic features discussed in this study will be addressed in Chapters 4 to 7.

\subsubsection{Sociolinguistic Approaches to Language Contact}

Since the seminal works by Einar Haugen (1950) and Uriel Weinreich (1953), sociolinguistic studies on phenomena related to language contact have produced a sustained understanding of language practices that involve more than one variety. However, in response to the increasing mobility of people, ideas, and goods, and advanced technologies enabling rapid communicating at any time across the globe - which

to refer to the local variety spoken in the area where Eisden is located. I do not designate the political label here (Cornips \& Knotter 2016). 
inevitably influence the way people interact - scholars have turned their analytical gaze toward the various resources that speakers have at their disposal. They investigate the diversity of language, rather than a single language, and this is based on the idea that speakers do not live in a social vacuum but come into contact with speakers of numerous languages throughout their lifetime. Similarly, migration trajectories are seldom linear, as people move on from one place to another, often more than once. ${ }^{17}$ For this reason, much contemporary work is characterized by a shift away from languages as fixed entities to language 'repertoires' (e.g. Otsuji \& Pennycook 2010; Blommaert 2010; Møller \& Jørgensen 2009; Rampton 2011b; Heller 2007; Wei 2011; Quist 2008; Eckert 2018; Jacquemet 2005). That the traditional conceptualization of people migrating in a straight line proves to be problematic is also demonstrated by the community of Eisden.

In the last fifteen years, linguists have created a large array of terms to examine the communicative and social practices of 'multilingual' speakers. These include 'heteroglossia' (Bailey 2007), 'truncated multilingualism' (Blommaert et al. 2005), 'truncated repertoires' (Blommaert 2010: 23), 'poly-lingualism and languaging' (Møller \& Jørgensen 2009), 'crossing' (Rampton 2014), 'transidiomatic practices' (Jacquemet 2005), 'translanguaging' (García \& Wei 2014), 'flexible bilingualism' (Creese \& Blackledge 2011), 'metrolingualism' (Otsuji \& Pennycook 2010), 'translingual practices' (Canagarajah 2014). Furthermore, the term 'heterolingualism' has been coined to describe the juxtaposing or mixing of language in written contexts (Grutman 2006; Pratt 2014). These concepts seek to draw attention to the linguistic features and social practices of speakers in particular contexts (see Bhatt \& Bolonyai 2019 for a critical discussion). The current study joins these approaches in regarding language as negotiable and dynamic rather than fixed, although I decided not to adopt any of these new terms as analytical concepts here.

\subsubsection{The Notion of Speech Community}

A terminology that has become central to sociolinguistic and anthropological enquiry is 'speech community.' Over the past decades, it has been variously used to refer to culturally heterogeneous and supposedly homogenous groups of speakers in both urban and rural areas, to speakers of particular language varieties, as well as to specific gender groups, age groups, or other social groups characterized by some particular aspect of language. Although defined in numerous ways, most approaches emphasize the relation between language and social structure (for discussions, see Rampton 2000; Patrick 2008).

\footnotetext{
${ }^{17}$ Similar approaches have been put forward in the field of migration studies, whereby migration is conceptualized as a continuous flow of people, ideas, and physical objects beyond national boundaries (see Mazzucato et al. 2004).
} 
While early approaches assumed that its members shared the same linguistic resources (Gumperz 1968; Gumperz \& Hymes 1986 [1972]), ${ }^{18}$ recent theories regard speech community as an analytical construct with unstable boundaries that are redefined in the process of data collection. Unlike in early approaches, speech communities are not demarcated in terms of geographic boundaries. With an increasing level of physical human mobility, the concept of the traditional speech community as marked by groups of people living in a completely isolated area with homogenous linguistic resources has become rare. In today's world, as mentioned, people move from one place to the next one and come into contact with individuals from diverse backgrounds, while social networks often change during the course of their lifetime. Consequently, the boundaries between members of one community and another are not clear-cut anymore (if they ever were at all), and individuals are engaged in multiple groups. For this reason, current approaches rather assume a degree of sharedness, with membership being a matter of gradation (Mortensen 2017; Eckert \& McConnell-Ginet 1992; Eckert 2006; Bucholtz 1999; Holmes \& Meyerhoff 1999; Rampton 2000; Patrick 2008; Silverstein 1996).

As an alternative, scholars who work at the intersection of sociolinguistics and anthropology proposed the notion of 'community of practice' (Eckert \& McConnell-Ginet 1992; Bucholtz 1999; Holmes \& Meyerhoff 1999), understood as 'a collection of people who engage on an ongoing basis in some common endeavor' (Eckert 2006: 683). ${ }^{19}$ This notion of community of practice focuses on variability, recognizing that membership categories are subject to change, and it aims to capture members who find themselves along the edges of the assumed categories. ${ }^{20}$

In the present work, I will employ the more general notion of 'community.' With this term, I designate those people who feel associated with the former mining community of Eisden that emerged in the 1930s. What members of the investigated community usually have in common is a shared experience based on their childhood and adulthood in the mining district of Eisden in the 1930s and 1940s. This includes presumed 'obvious' community members (because they worked as underground miner for many years) as well as those who may be regarded less typical (such as local residents active in another

\footnotetext{
${ }^{18}$ As one of the first, John Gumperz (1968) portrayed the 'linguistic community' as 'a social group which may be either monolingual or multilingual.' Next, William Labov (1972: 120-21) defined speech community as marked 'by participation in a set of shared norms.'

19 The term orginated from Lave and Wengers' concept (1991) of 'situated learning,' but Eckert and McConnell-Ginet (1992) can be credited with introducing the term in sociolinguistics.

${ }^{20}$ Another concept stressing the emergent character of present-day groups is 'transient communities' (Mortensen 2017), which concentrates on the links between language use and social order created in situ when participants possess rather different, and perhaps opposing, sociocultural backgrounds. While highly appropriate for describing contact situations in which people get together for a short period, for instance when running a marathon or participating in a play, it does not qualify for the present study. In the community of Eisden, people have known each other for many decades.
} 
profession) (for 'authenticity' in sociolinguistics, see Eckert 2003; Coupland 2003; Bucholtz 2003; O'Rourke \& Pujolar 2013: 57). ${ }^{21}$

Crucially, the community that is central to this study does not exclusively consist of speakers of Cité Duits, but also of their partners and children. The approach taken here is based on existing social structures, a shared background, and specific joint experiences. Despite the fact that Cité Duits emerged in a socially-isolated neighborhood, the community is diverse; individuals' linguistic repertoires may have changed during their lifetime (e.g. Blommaert 2010: 103-06; Blommaert \& Backus 2011), and personal histories differ in many ways (see $§ 2$ ).

\subsubsection{Language Contact Models}

Language contact research has developed various typologies to account for the processes and outcomes observed in language contact settings. The code-switching literature is probably most well-known for seeking explanations, on the structural level as well as on the social level. Code-switching, 'the alternation of two languages within a single discourse, sentence or constituent' (Poplack 1980: 538), is a widespread phenomenon and one of the most thoroughly investigated areas in contact linguistics, governed by linguistic and extra-linguistic factors (Treffers-Daller 1994; 1998; Auer 1995; 1998b; Stell \& Yakpo 2015; Wei 1998; Mæhlum 1996; Milroy \& Muysken 1995; Muysken 2000; De Fina 2007; Torres Cacoullos \& Travis 2015; Myers-Scotton 1988; 1993; Bullock \& Toribio 2012; Poplack 1980; Bentahila \& Davies 1995; Backus 2005; Gumperz 1976; Gardner-Chloros 1995; 2009; 2010; Di Sciullo et al. 1986; Thomason 2001: 131-53). Studies devoted to grammatical constraints (e.g. Poplack 1980) have shown that speakers tend to switch at specific syntactic boundaries of the clause, whereas discourse-oriented studies identified numerous factors that may trigger or inhibit switching (Auer 1995; 1998b; Wei 1998; Jørgensen 1998; Treffers-Daller 1994; 1998). Likewise, there has been much debate on how to distinguish code-switching from lexical borrowing or loanwords (Winford 2010: 182; Gardner-Chloros 2010: 195-97). ${ }^{22}$

Particularly influential have been the typologies by Shana Poplack (1980) and Pieter Muysken (2000) in the grammatical study of code-switching and -mixing, as well as the interactional models by Carol Myers-Scotton (1993) and Peter Auer (1998a). Poplack's (1980) 'free morpheme constraint' (switches are possible after any constituent that is not a bound morpheme) and her 'equivalence constraint' (switches should not violate the syntactic rules of the involved languages) focus on the syntactic restrictions that inhibit or allow switching. Muysken (2000), on the other hand, distinguishes three

\footnotetext{
${ }^{21}$ The 'authentic speaker,' as stressed by Eckert (2003), does not exist but is based on the belief that speakers who are the least mobile and always stay in one location, without contact to speakers from other languages and dialects, are 'more authentic' than others.

${ }^{22}$ For a survey, see Bullock and Toribio (2012); Gardner-Chloros (2009) and Milroy and Gordon (2003: 209-22). Note that code-switching is not a recent phenomenon but also found in historical sources. See Stolt (1964) on Luther's table talk; see also Ptashnyk (2016a); Mihm (2010).
} 
types of intra-sentential mixing: 'insertion' concerns single elements or constituents, 'alternation' describes a complete switch between language A and B, and 'congruent lexicalization' refers to convergence between two varieties in a clause. A particular concern here is with the typological characteristics of the languages involved (Muysken 2000: 30; 46).

Different types of switching have also been proposed by Auer (1998a) in his discourse-functional typology of 'code-switching,' 'language mixing,' and 'fused lects,' whereby these categories represent a continuum of language mixing phenomena. Furthermore, Myers-Scotton's (1993) Matrix Language Frame Model analyzes the underlying social motivations, with a focus on African contact settings. Interesting is here that code-switching can function as an unmarked choice in communities where such patterns are frequent. These models explain, if from different perspectives, how speakers negotiate their various languages.

It is often assumed that mixed languages derive from code-switching. The interest in mixed languages actually started with the work by Thomason and Kaufman (1988). While code-switching is little predictable and open to choice, mixed languages generally show regular patterns on a hybrid basis (Meakins 2018; Backus 2000: 104). Typically, mixed languages derive from two unrelated languages whose speakers came into contact, while the most prototypical cases show a split between the lexicon and grammar or between the nominal and verbal system. Still, they exhibit extensive diversity in terms of linguistic structure, sociohistorical origin, and function. What they have in common is the fact that they generally arise in settings where a shared language already exists. Accordingly, their function is not of a communicative nature but rather of a social one, an aspect that distinguishes them from pidgin and creole languages ${ }^{23}$ (Bakker \& Muysken 1995; Bakker \& Mous 1994; Matras 2000; Myers-Scotton 2003; Meakins 2018; Mazzoli \& Sippola forthcoming). Well-known examples are Michif, which is largely composed of the verbal system of Cree and the nominal system of French (Bakker 1994; 1997); Media Lengua, combining Quechua grammar and Spanish lexis (Muysken 1981); and Ma'á (Mbugu), which consists of Cushitic words and Mbugu grammar (Mous 2003). More recently investigated varieties with a high degree of mixture include Old Helsinki Slang (Jarva 2008) and Gurindji Kriol (Meakins 2011).

It remains debatable, however, how much mixing is required for the outcome to classify as 'mixed' (Meakins 2018), and how to deal with language mixing between closely related languages (Braunmüller 2009). Muysken (2000) proposed the term 'congruent lexicalization' for contact settings where two languages share the grammatical structure of a clause, either fully or partially. In such instance, the vocabulary stems from two or more languages, but may be shared as well. This can be observed in particular in varieties that are structurally similar (Muysken 2000: 127). In contrast, Auer and Hakimov

23 Typically, the term 'pidgin languages' designates varieties without native speakers, whereas 'creole languages' have native speakers and often function as community languages, although these labels are disputed. The most widely researched examples emerged in contact settings of a European and a non-European language (see Kouwenberg \& Singler 2011). 
(2020), as well as Auer (1998a), regard the process of mixing as a continuum of various degrees, with some contact situations showing a low degree of language mixture whereas others result in the fusion of features. From this perspective, mixed languages represent a radical case on one end of the continuum. As of yet, however, there is no widely established theoretical concept that describes the outcomes of intense language contact of structurally similar varieties.

\subsubsection{A Note on Previous Research}

Cité Duits remained largely invisible in sociolinguistics until recently. ${ }^{24}$ As far as I am aware, Piet van Avermaet (2008: 97) first mentioned the existence of Cité Duits in a scientific publication. In his in-depth study on the Italian community, he points to the widespread use of Cité Duits in and around the coalmine of Eisden, even though he does not go into further details. According to his observations, the miners who came before the Second World War to Eisden all spoke 'een soort 'cité-Duits" 'a kind of "cité German." And he adds that this language "was a mixed language created in and around the mines, strongly based on German but with the necessary loanwords from the other languages. ${ }^{25}$ To my knowledge, the first audio recordings of the language use of the former miners were conducted by Prof. Dr. Leonie Cornips in March 2012, and, together with Prof. Dr. Peter Auer, in October 2013. These recordings, which consist of informal interactions between male Cité Duits speakers, formed the cornerstone for several provisional assumptions (see $\S 3$ ).

\subsection{Outline of the Dissertation}

This dissertation consists of eight chapters and is structured along the following lines. Starting with the sociohistorical context and addressing research question one (RQ1), Chapter 2 elucidates which sociolinguistic processes contributed to the emergence of Cité Duits. It provides a broader understanding of the investigated community, its linguistic practices and social relations, and discusses social functions and meanings of speaking Cité Duits. In addition, this chapter addresses the role of women and the extent to which Cité Duits has been used by female speakers. Furthermore, it outlines whether the speech has been transmitted to subsequent generations.

\footnotetext{
${ }^{24}$ Cité Duits must not be confused with Citétaal as investigated by Marzo and Ceuleers (2011). Citétaal is used by adolescents in Belgian-Limburg and is 'characterised by a Dutch basis, but with very clear residuals from the original immigrant languages (in particular Italian, Moroccan and Turkish)' (Marzo \& Ceuleers 2011: 454, emphasis mine). Note that Cité Duits as spoken in Eisden emerged 30 years before the arrival of the first Turkish and Moroccan miners (see $\S 2$ for a historical review).

${ }^{25}$ Original: 'Deze taal was een in en rond de mijnen ontstane mengtaal, sterk gebaseerd op het Duits maar met de nodige leenwoorden van de andere talen' (van Avermaet 2008: 97).
} 
Chapter 3 elaborates on the methods of data collection and data analysis. To be transparent about my theoretical and practical decisions, this chapter is considerably detailed and comprises two parts. The first part dwells on the methods of gathering data and the participants of this study, while also discussing field relations and ethical issues that arose. The second part concentrates on the data analysis and transcription practices. Particular attention will be paid to the discrepancy between 'objective transcription' and the interpretative decisions made by the transcriber (Bucholtz 2000).

Chapters 4 to 7 are dedicated to the linguistic analysis of Cité Duits: Chapter 4 provides an overview of selected linguistic features, Chapters 5 and 6 are devoted to the use of personal pronouns and Chapter 7 to progressive aspect. In Chapter 4, I am concerned with the question of which linguistic features are typically employed by the speakers when speaking Cité Duits (RQ2). On the basis of attested examples, I will give a first characterization of lexical, morphosyntactic, and syntactic features, thereby highlighting similarities with and differences from spoken Belgian Dutch, Maaslands, and (dialects of) German. I will also demonstrate which other language varieties may have influenced the speech. By introducing some linguistic characteristics of Cité Duits, this chapter serves as starting-point for the subsequent empirical chapters.

The next two chapters address research question three (RQ3): 'how can the pronominal paradigm be characterized and which factors account for variation?' Chapter 5 deals with the distribution of pronominal forms and their phonological and lexical properties. Based on a frequency analysis, I will show which varieties are represented in the pronominal paradigm of Cité Duits, and evaluate whether the resulting pronominal forms are used in consistent ways. Likewise, I will examine whether pronominal forms have arisen that are unknown in spoken Belgian Dutch, Maaslands, and German. Next, in Chapter 6, I center on the factors that may be responsible for phonological variation in the data. Central to the analysis is the question of whether the occurrence of the various pronominal forms can be explained due to their position in relation to the finite verb in non-topicalized position or in relation to the complementizer.

In Chapter 7, which deals with research question four (RQ4), I shift my focus to the domain of aspectuality (Verkuyl 1996) by analyzing the use of progressive aspect in Cité Duits. From a strictly typological perspective, Belgian Dutch, Maaslands, and German count as non-aspect languages. Although there are several ways to denote progressivity, they lack a single morphological marker indicating progressive aspect, and explicit marking is often optional. Accordingly, the question arises if and how progressive aspect is marked in Cité Duits. While in the first part of this chapter I consider the attested progressive types and their frequencies in the data set, in the second part I analyze one construction more in-depth. I will examine in particular the semantic and syntactic variation of this construction. 
In the concluding Chapter 8, I sum up the findings and discuss Cité Duits from the perspective of language contact. Finally, I reflect on the theoretical implications and provide possible directions for future research. 


\section{Chapter 2: Sociohistorical Context and the Emergence of Cité Duits}

'[A]ny critical analysis of language, as in the study of linguistic ideology, inevitably entails its historicity' (Inoue 2004: 43)

Ich denk [...], dass diese Sprache so entstanden ist, weil jeder ein wenig gesprochen hat. Und jeder hat so seine Art zu besten gegeben, und da aus ist das eine Sprache geworden. (Marina, Interview 250815: 01.08.44-01.08.54)
'I think that this language developed because everyone spoke a little bit. And everyone shared his way [of speaking], and this is how a language developed.'

\subsection{Introduction}

In the 1930s, in the mining district of Eisden (Belgium), the male locally-born children of immigrant miners developed what they labeled Cité Duits, literally 'mining district German.' Since German was neither the home language of the speakers nor spoken by the residents of the area, the question arises of how it was possible at all for Cité Duits to emerge in Eisden. This chapter explores the underlying sociohistorical and linguistic processes that contributed to the emergence of Cite Duits in the 1930s and 1940s. It provides a broader understanding of the investigated speech community, the linguistic practices of its members, and their social relations. In much of the twentieth century, the infrastructure of the area was almost exclusively determined by the economic activity of coalmining, while the geographical space involved had a huge impact on the social relationships of mining families (Stuyck et al. 2010).

In this chapter, I will argue that Cité Duits developed due to specific sociolinguistic conditions that were present only in the cité of Eisden, but not in other mining districts of the Kempen, the region to which Eisden belongs. While the first part of this chapter consists of a historical review, the second part is of an analytical nature. The analysis in this chapter draws on data from semi-structured interviews, group recordings, sociolinguistic recordings, participant observation, a self-recording, and written sources (see $\S 3$ ). By exploring and discussing the processes that accounted for the development of Cité Duits, I specifically address research question one of this dissertation:

\section{(1) Which social processes and linguistic environment gave rise to the emergence of Cité Duits?}

Aside from focusing on this question, I will answer the following two sub-questions: (i) what have been the main social functions of speaking Cité Duits?, and (ii) why is Cité Duits confined to male speakers and how can the social spaces of women of the community be characterized? This chapter is structured as follows. I will start with a 
discussion of the relevant historical context ( $\$ 2.2)$ by introducing the coalmining industry and the resulting migration patterns pertaining to Belgian Limburg and Eisden in particular $(\S 2.2 .1)$. If the mining industry had a considerable effect on the labor market in this region of Belgium, the same applies to nearby regions in the Netherlands and Germany, and this significantly contributed to international migration and cross-border commuting in these various regions (Knotter 2008; 2012a; Delbroek 2008; 2016). Next, I elaborate on the concept of the Tuinwijk, or 'garden district' ( $\$ 2.2 .2)$, the place where Cité Duits has its origin and where the participants in this study grew up. Subsequently, I address the issue of female wage labor in the Belgian mining districts ( $\$ 2.2 .3$ ), followed by a brief sketch of the role of German in the former Habsburg Monarchy (§ 2.2.4). This historical review paves the way for understanding the social and linguistic dynamics at that time, which is relevant in particular as a basis for my argument in the ensuing sections. By providing a more nuanced understanding of what it meant to grow up as a child of an immigrant miner, I discuss the sociolinguistic conditions that enabled the emergence of Cité Duits in section 2.3, which constitutes the core of this chapter. This is followed by a consideration of the emic status of the speech, as well as its social functions and meanings (§ 2.4). In the final section I pursue the question of the role of female speakers in Cité Duits $(\S 2.5)$. I conclude this chapter by taking a brief look at the community's current situation, followed by a summary of the main findings ( $\$ 2.6)$.

\subsection{Historical Context}

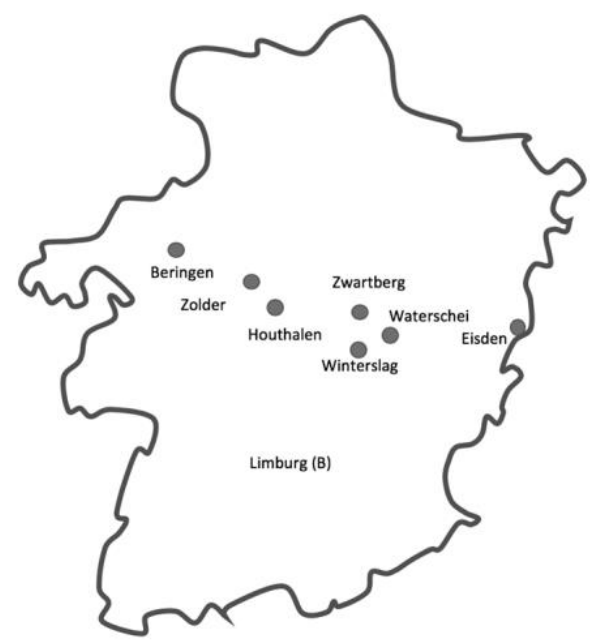

Figure 4: Location of the seven Kempen mines in the Belgian province of Limburg in the 1930s 


\subsubsection{Mining Industry and Migration Patterns}

Although the mining industry has a long tradition in the border region of Belgium, Germany, and the Netherlands (nowadays known as the Euregion Meuse-Rhine ${ }^{1}$ ), dating back as far as the 1830s (Knotter 2012a; 2008), coalmining in the Belgian Kempen (Campine) took off much more recently. ${ }^{2}$ In the night of August 2, 1901, the Leuven professor André Dumont discovered the first coal in the village of As, a watershed moment that marked the beginning of almost seven decades of coal production and that resulted in the foundation of seven mining locations in the Belgian province of Limburg (Figure above): Beringen, Zolder, and Houthalen in the middle-western part of the province; Eisden on its eastern edge; and Zwartberg, Winterslag, and Waterschei in the middle, as part of the municipality of Genk. While the first coal was extracted in Waterschei in 1917, most sites entered production in the early $1920 \mathrm{~s} .{ }^{3}$ Because coal provided the main source of energy for industrial sectors and transportation in the early twentieth century, the region became economically attractive, and eventually all mining companies were acquired by French and Walloon investors.

At that time, Eisden was a village of some 600 inhabitants, who spoke Maaslands and largely derived a livelihood through farming, such as by herding cows and sheep. In the sparsely populated area, there was no significant infrastructure and the arrival of the mining industry meant a drastic change for locals (Ganzelewski \& Slotta 1999: 94; Delbroek 2016: 24-26; Versteegh 1994: 127-31). Even though cross-border commuting was common for seasonal work, with each spring many a Maaslander and their family traveling as stone cutters to the Rhenish brickwork industries in Germany (Kohlbacher 2016), the majority of them was rather immobile and had little contact with people from elsewhere. Moreover, the shift from a traditional farming village to a modern industrial area was hardly welcomed in this Catholic region, as most local residents developed a deep aversion to industrial coalmining. Because most local residents were not eager to work in the construction of the mine, nor were they qualified for underground mining, it proved difficult to find skilled workers in the village and its immediate surroundings (Versteegh 1994; Delbroek 2016: 24-26; 2008: 81). Furthermore, according to Versteegh (1994: 135-36), once the mines entered production, the working conditions underground

\footnotetext{
${ }^{1}$ The Euregion Meuse-Rhine was created in 1976 and encompasses Dutch Limburg, the German region around Aachen, and the Belgian provinces of Liège, Limburg, and the Belgian-German area (Nelde \& Darquennes 2002: 65-66).

${ }^{2}$ See in particular Knotter $(2008$; 2012a) for a comparative perspective on mining labor markets in the Belgian-Dutch-German border area.

${ }^{3}$ The late exploitation of the Kempen coal basin goes back to political-economic reasons. Already in 1870, it was believed that this region was rich in coal reserves (for a review, see Ganzelewski \& Slotta 1999: 82-102; Delbroek 2016: 20-23; further Pinxten 1939).
} 
were inferior to those of the Walloon mines, the number of accidents being far higher while the wages were the lowest of all Belgian mining sites. ${ }^{4}$

The very first miners came from Wallonia (the French-speaking part of Belgium), from Limburg, and from the adjacent Belgian provinces of Antwerp and Brabant, while German and French drillers took care of the construction of the colliery and the first accommodations (for housing, see $\S 2.2 .2$ ). German engineers, however, were quickly replaced by Walloon staff as a result of the political climate during the decade of the First World War. Since the recently opened mines depended on qualified staff from other mining sites, workers who decided to transfer from the Walloon mines to the Kempen mines were usually promoted (Versteegh 1994: 136; Delbroek 2016: 91). In 1918, the majority of these workers came from the Walloon province of Hainaut (Henegouwen) in the South-West of Belgium (Delbroek 2016: 96-97). Workers who commuted within the country, the so-called treinmannen 'train men,' normally received cheap train tickets subsidized by the Belgian government (Caestecker 2008: 39). Nevertheless, comparably few miners moved from the southern part of Limburg to the Kempen (Delbroek 2016: 9697). ${ }^{5}$ With the outbreak of the First World War, the mining activities were decreased considerably, although they did not come to a halt. In the years that followed, Dutch miners from the border region started to cover the labor demand.

This situation changed abruptly in the 1920s. With the explosive growth of the collieries and an increasing demand for coal, the mining companies faced a severe shortage of workers (Delbroek 2008: 102; Knotter 2008: 26). Naturally, the Kempen mines were not an exception in this regard. According to Knotter (2012a: 125), in 'all mining regions in North-western Europe the recruitment of labour was a returning problem. Labour intensity, together with the often remote location of exploitation, forced mining companies to look for labour beyond the limits of local or regional supply' (see also Knotter 2008). Moreover, in 1926, many Dutch miners returned to the Netherlands due to the devaluation of the Belgian currency, while the opening of the large Maurits mine in Geleen ${ }^{6}$ just across the border also played a role, which, given its higher salaries, attracted not only Dutch miners but also miners from other countries. ${ }^{7}$ Eisden, however, was affected in particular by the absence of a local base of experienced miners, even more than the other Kempen mines. Being the mine furthest to the East, near the border, Eisden

\footnotetext{
${ }^{4}$ It took until the mining disaster of Marcinelle (Hainaut) in 1956 that the Kempen mines started to improve the safety conditions underground and introduced language classes for workers from abroad. Yet, it is questionable whether the Kempen mines were more dangerous than other mines. Apparently, most miners lost their life in larger accidents, which implies that these numbers need to be treated with caution (see Peet 2012: 266).

5 There are several reasons for this. It seems that miners preferred the mines in Liège, which had a better train connection with the villages in South Limburg. In addition, the agricultural sector attracted many workers (Delbroek 2016: 96-97).

${ }^{6}$ The distance between Eisden (B) and Geleen (NL) is only 10 kilometers.

${ }^{7}$ This changed in the late 1940s and early 1950s, however, when salaries were approximately 25 30 percent higher in the Belgian mines than in the Dutch ones (Langeweg 2012b: 88-89).
} 
also managed to attract fewer miners who commuted from within Belgium (Delbroek 2008: 86; 2016: 101-02; also Knotter 2008: 10). As a result, Eisden would prove to be much more dependent on migrant workers than the other mines in Belgian Limburg.

When the mining companies began to look for miners from other countries in Europe, the first large recruitment campaign took place in Northern Italy. Yet many of these workers had little or no experience in mining and dropped out in less than a year. From 1923 onward, the recruitment concentrated on Polish citizens from Silesia and the Ruhr region, who had the reputation of being highly skilled workers (Delbroek 2009; 2016: 99-100). The mines in the Ruhr region had been benefiting from Polish labor migration already since 1870 (Knotter 2008: 15). Some of these Ruhr-Poles originally came from the area of East Elbia, and they were German citizens. Importantly, Poles in Germany faced severe discrimination at the time. After the First World War, they were forced to take on either the German or the Polish nationality if they wanted to remain in the country (the so-called Optionsverfahren). Because 'foreigners' in Germany received a residence permit for one year only, the mines in Belgium provided a welcome alternative. In a similar vein, Polish miners were recruited from the mines in Northern France (Versteegh 1994: 149-51; Klessmann 1978; 1986). ${ }^{8}$

Accordingly, migration patterns were all but linear. Jef Brunsch, a former miner of Polish origin, reports how his father, who was born in the German town of Deuben, came to Eisden in the early 1930s: 'the family of my father, which had migrated to France in 1927, was expelled together with a large group of miners. [...] My father came back to Kopne [Kępno, small town close to the Polish city of Poznań], where Belgian recruiters were already looking for miners for the Limburgian mines. This is how my father ended up here in Eisden' (Eisden 2018b: 13-14). ${ }^{9}$ The migration history of his family was hardly an exception, as many of the recruited miners had lived in several places before moving to Belgium. Likewise, some of the Italian miners had worked in the Walloon mines before coming to the Kempen (Vanhinsberg 1996: 75) (see $\S 3.4 .3$ for the migration history of the speakers). In the following years, recruitment campaigns took place in Hungary, Slovenia, Austria, Croatia, Czechoslovakia, Yugoslavia, and Northern Italy, where the economic consequences of the First World War continued to be harsh and people were eager to find work elsewhere. The miners were usually joined by their families (Kohlbacher 2003: 135; also Versteegh 1994; Delbroek 2016). In time, these measures yielded an international composition of the workforce, with Eisden having the highest percentage of foreign workers in the Kempen, as illustrated in Figure 5 below (based on Delbroek 2008: 81-82). The mine of Houthalen is not listed as it was constructed in 1923 and did not go into production until 1939 (Delbroek 2008: 90).

${ }^{8}$ For Polish labor migration, see Klessmann (1978; 1986); Versteegh (1994); Beyers (2006).

${ }^{9}$ Original: 'Ja, de familie van mijn vader, die al in 1927 naar Frankrijk was uitgeweken, werd met een grote groep Polen uit Frankrijk gewezen. [...] Mijn vader kwam ook terug naar Kopne. Daar zochten Belgische ronselaars toen ook al mijnwerkers voor de Limburgse mijnen. Zo kwam mijn vader hier in Eisden terecht.' (Jef Brunsch, cited in Eisden (2018b: 13-14)). 


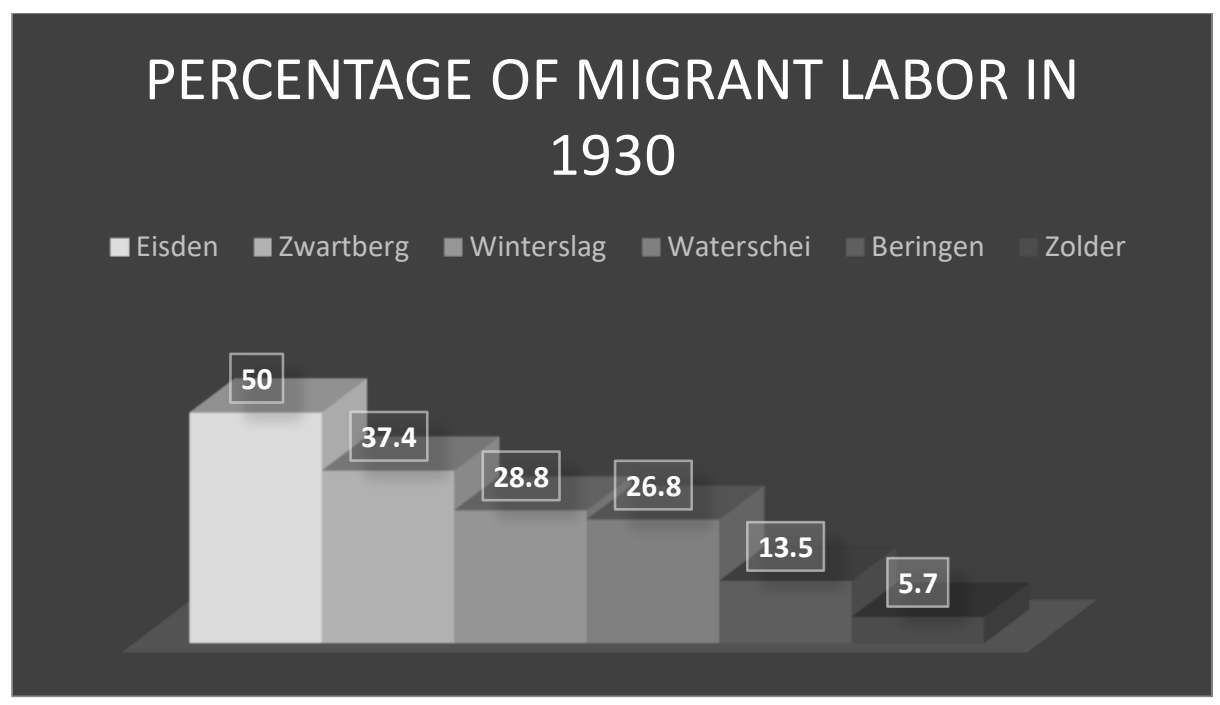

Figure 5: Percentage of non-Belgian labor force in the Kempen mines in 1930

As can be seen in Figure 5, the number of non-Belgian workers in the six Kempen mines differed significantly. The mining sites located in the East of Belgian Limburg attracted the highest percentage of immigrant workers, whereas those toward the West exhibited a much lower percentage. In 1930, half of the workers in the mine of Eisden was nonBelgian, whereas this number was notably lower in the other mines. Beringen, for instance, employed 13 percent non-Belgian miners and Waterschei roughly 27 percent. For Zolder holds that it started comparably late with the production of coal (in 1930), and the percentage of foreign labor was therefore much lower (Delbroek 2008: 82; see Auer \& Cornips 2018: 55-67 for a review). Naturally, some of the miners appearing in the census of 1930 sooner or later returned to their home countries, for instance as a result of re-migration campaigns. Between 1945 and 1950, approximately 10,000 Poles and a large number of Czechs left Belgium (Beyers 2008: 42; also Dorren 2013: 421). ${ }^{10}$ For the mine of Eisden, the development of Belgian workers compared to foreign workers between 1922 and 1933 is depicted in Figure 6 below (based on Pinxten 1939: 364). The numbers include workers employed underground and aboveground. This period is relevant here since the parents of the speakers of this study came to Eisden in the late 1920s and early 1930s.

\footnotetext{
${ }^{10}$ Envoys of several East-European countries tried to retrieve miners in Eisden for the reconstruction of their country, for instance by offering special education and vacation camps for their children (Dorren 2013: 421).
} 


\section{Total Number of Belgian Nationals and Foreign Workers in Eisden}

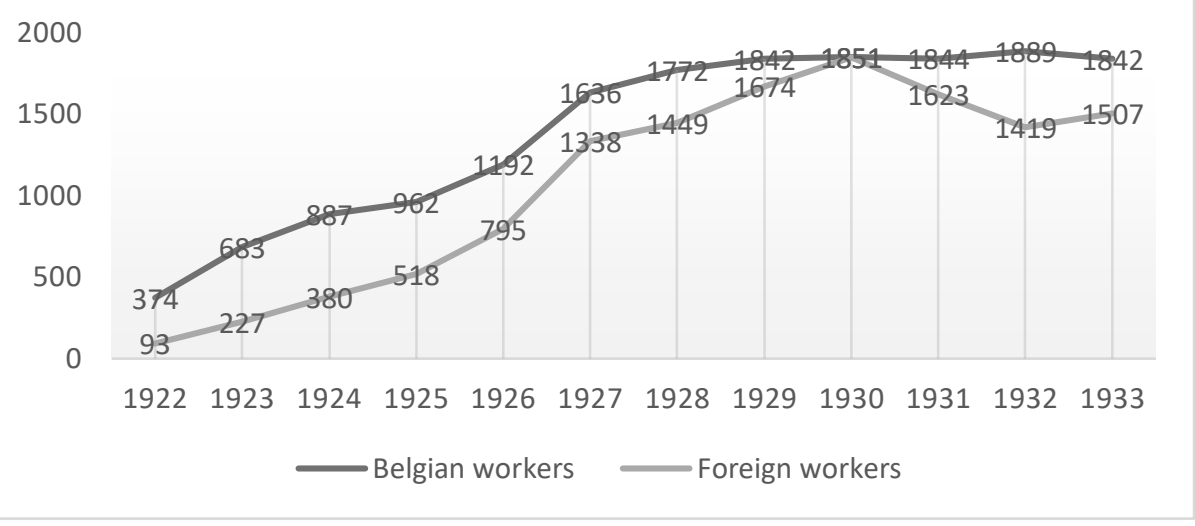

Figure 6: Development of labor force in Eisden between 1922 and 1933

The Belgian workers made up the lion's share during the first years of coal production. In 1922, just 25 percent (or 93 miners) in Eisden was registered as non-Belgian, as opposed to 374 Belgians. But after 1922 the proportion of immigrant labor slowly increased, and by 1930 the two groups were more or less of equal size. ${ }^{11}$ According to Versteegh (1994: 129), the consequences of the economic crisis affected the Kempen mines not until 1930, which clarifies why Eisden was still recruiting miners during the years of crisis. In 1931, the number of non-Belgians temporarily declined, which can be explained by the fact that Catholic associations and the government demanded the employment of Belgian workers (Delbroek 2008: 80; Caestecker 2008: 49). As Caestecker (2008: 49) points out in this context, 'foreigners were the first to leave the company. In particular aboveground work and supervisory jobs were reserved for Belgians. Belgian miners became privileged miners. ${ }^{12}$

During the Second World War, in 1942, the Germans took control over the mines, leading to the compulsory labor of numerous Ostarbeiter ('workers from the East'), forced to move from Ukraine and Belorussia to the Kempen (a total of 289 in Eisden). Within the same year, however, they were transferred to the mine of Waterschei and substituted by Russian prisoners of war (a total of 1,042 in Eisden in 1942). In 1945, the leadership of

11 While the graph shows absolute numbers, the proportion of immigrants increased radically between $1924(29 \%)$ and $1926(40 \%)$.

${ }^{12}$ Original: 'Indien er ontslagen vielen, hoorden de buitenlanders als eersten het bedrijf te verlaten. In het bijzonder de bovengrond en de functies van opzichters werden gereserveerd voor de Belgen. Belgische mijnwerkers werden geprivilegieerde mijnwerkers' (Caestecker 2008: 49). 
the mine closed a contract with the American and British military to accept German prisoners of war, with the first convoy arriving on May 21, 1945. These prisoners, who were repatriated in 1947, lived for the time being in the so-called 'Russian barrack camps,' consisting of sheds located in a segregated area of Eisden (Delbroek 2008: 94-96; Kohlbacher 1998; Delbroek 2016: 105-06) ${ }^{13}$ Furthermore, about 7,100 Eastern European refugees ('displaced persons') of mainly Ukrainian, Baltic, and Polish origin signed a twoyear contract for the Limburgish mines (Delbroek 2008: 96).

Around the same time, the kolenslag (lit. 'coal battle'), a recruitment policy introduced by Minister Achille Van Acker to increase the production of coal, yielded new immigration to Belgium. The aim of the kolenslag was to attract miners to speed up the country's economic reconstruction. After decades of stigmatization, miners were suddenly regarded as heroes who contributed to rebuilding the country. The ratification of a bilateral agreement with Italy in 1946 resulted in large numbers of Italian miners moving to Belgium, this time from the South of Italy. ${ }^{14}$ Over the years, Italians were followed by Greeks and Spaniards, and later by Turks and Moroccans (Delbroek 2016: 11; Beyers 2007: 13; Caestecker 2008: 49-50). The agreement between Italy and Belgium, however, was abruptly terminated after the mining accident of Marcinelle near the Walloon city of Charleroi in August 1956, which caused the death of 262 miners, including more than 130 Italians (Peet 2012: 266; Beyers 2007: 13; Knotter 2008: 22). With the beginning of the coal crisis of 1957, which led to the gradual closure of all coalmines in Belgium, the recruitment of new miners slowly decreased. ${ }^{15}$ If the mine of Eisden closed in December 1987, coalmining in the Kempen ended five years later, with the closure of Zolder (Delbroek 2008). ${ }^{16}$

\footnotetext{
13 These 'emergency shelters' were later used to accommodate South Italians (van Avermaet 2008: 93; Eisden 2018a: 32). The mining company accommodated miners there until 1966 (Delbroek 2016: 141).

${ }^{14}$ See van Avermaet (2008) for a comprehensive study on language use of the Italian community of Eisden. Note that van Avermaet concentrates on the Italians who moved to Belgium after World War II, whereas the speakers of this study, i.e. their parents, arrived in the interwar period.

${ }^{15}$ It must be emphasized that Belgium continued to recruit workers from Turkey and Morocco, even after it was known that the mines would close. During the final years of operation, these workers often served to fill the gaps created by the many experienced miners who began to look for work elsewhere, while their sons were no longer willing to work in the mine. The first Turkish miners came to Eisden in 1963 (Eisden 2013: 6-7).

16 A comprehensive overview of coal mining in Belgian Limburg is beyond the scope of this dissertation. For an in-depth survey of the labor market for miners in Belgian Limburg, see Delbroek (2016). For Dutch Limburg, see Langeweg (2012a; 2012b) and Knotter (2012b). Caestecker (2008) gives an overview of the composition of the labor force (including child and female labor) in the Belgian mining industry from 1830 until 1940.
} 


\subsubsection{Housing in Tuinwijken ('Garden Districts')}

Parallel to the construction of the collieries, the mining companies started building large working-class housing districts based on the English garden model of architecture. One of the basic tenets was that having healthy workers live in a green environment would lead to a higher output. The construction of these Tuinwijken or 'garden districts' (or cités, from the French cité ouvrière or 'workers' housing district') started in the Kempen in 1908. In the late 1920s, the cité of Eisden consisted of roughly 800 homes and two school buildings, i.e. one for girls and one for boys. This part of town is nowadays known as the Oude Cité or 'Old Cité.' The construction of a second Tuinwijk, the Nieuwe Cité or 'New Cité,' followed in 1936 because the number of workers and their families continued to increase. As a result, between 1900 and 1930, the number of inhabitants of Eisden decupled, from 604 to 6,077 (Delbroek 2016: 77; van de Wijngaard \& Crompvoets 2006: $5)$.

In having their own shopping facilities, libraries, educational institutions, kindergartens, community halls, sport fields, and a church, these carefully arranged and nice-looking garden districts were built with the purpose of attracting workers. The decision by the mining companies to opt for a rather exclusive garden city model, instead of constructing simple working-class accommodations, needs to be understood in the context of the era's socio-economic dynamics. ${ }^{17}$ First, as a side-effect of the growing mining activities, the area faced a severe shortage of housing. Mining companies were required to provide accommodation for employees and their families if they wanted to hire more workers. Second, the government gave inexpensive loans for housing, enabling the construction of affordable neighborhoods. In these Tuinwijken, every house came with electricity, running water, and a well-sized garden to plant vegetables. The rent was usually lower than in the surrounding towns. Furthermore, the mining companies offered a number of services, such as a certain amount of coal for each family per month, child allowances, and health insurance. Obviously, these were tied to attendance and job performance. While most immigrant families were entitled to a house, unmarried miners normally stayed as kostganger or 'boarder' with a family that provided accommodation, or they rented a room in one of the logementhuizen ('guest homes') in the mining district (e.g. the Cantine in Eisden). The kostganger-system was common in particular in the 1920s (Delbroek 2016: 135-42; 2008: 86-87).

The cités were designed not only to attract workers, but also to commit them to the mining company and stimulate their productivity. In guaranteeing a number of social services and low rents, the cité was an effective vehicle for exercising control over the miners. Since only mining employees were allowed to rent property, resigning from their job or being dismissed for low achievement meant at the same time that they immediately

\footnotetext{
${ }^{17}$ Note that the districts constructed at a later stage were less fancy, even though the homes were bigger. See Keunen (2010) on the architecture involved.
} 
lost their housing and welfare benefits, for themselves as well as their family members (Beyers 2007: 34; Delbroek 2016: 137; 2008: 87; further Stuyck et al. 2010: 75):

Maar tegelijk vormde ze een machtig middel tot het disciplineren van het personeel. De huurkosten, die rechtstreeks van het loon afgehouden werden, waren afhankelijk van de regelmatige aanwezigheid en de prestaties op het werk. Doordat invaliden, gepensioneerden en weduwen enkel in hun woning konden blijven als ze een zoon hadden die op de mijn werkte, werd ook de opvolging verzekerd. Bovendien stonden de inwoners van de tuinwijk onder constant toezicht van een eigen bedrijfspolitie. (Delbroek 2008: 87)

'At the same time, it [the cité] was a powerful means to discipline the work force. The cost of rent, which was deducted directly from their wage, depended on regular attendance and job performance. Because disabled and retired workers and widows could only stay on in their home if they had a son who worked in the mine, the mining companies likewise ensured their access to new miners. In addition, the garden district residents were under constant surveillance by their own company's police unit.'

Also, child allowances depended on job attendance (Versteegh 1994: 139). Accordingly, miners were dependent on their employer for both their income and their housing. With this strategy, the companies aimed to achieve fewer absences and dismissals, in particular among foreign workers, who were considered most mobile. Nevertheless, in the 1920s, the Kempen mines experienced a high turnover rate due to unauthorized absences (Delbroek 2008: 88). Jan Kohlbacher, who grew up as child of a miner in the cité of Eisden, describes the discrepancy between the mining company as a universal supplier and the company's own surveillance system, the garde, as a fake privileged lifestyle. Residents were taken care of 'from the cradle to the grave' (Kohlbacher 2003: 135, translation N.P.).

In addition, the mining company funded cultural associations and sports, in particular soccer (see § 2.3.2), which basically implied that residents never had to leave their district. These associations helped to improve the image of the company, while the prestigious character of the cité further enhanced chances that miners would strongly identify with their employer (Beyers 2007; 2008).$^{18}$ By constructing the Saint Barbara Catholic church, ${ }^{19}$ the tallest building in Eisden-cité, the mining company did not only aspire to ensure regular church attendance by miners, but the company also sought to raise its moral image and public standing in Catholic Limburg (Jaspers 2003: 4-6).

\subsubsection{Female Wage Labor and Gender Roles}

Unlike in the Liège mines, where women constituted a steady segment of the workforce, coalmining in Belgian Limburg was heavily male-dominated and there was no tradition

${ }^{18}$ For a detailed study on inter-ethnic relationships in the mining cités, see Beyers (2007); also Beyers (2006; 2008), who describes the life of Polish and Italian immigrants in the cité of Zwartberg. ${ }^{19}$ Saint Barbara is the patron saint of miners. 
of female wage labor (Hilden 1993; Roels 2008; Stuyck et al. 2010; Delbroek 2016: 6063). ${ }^{20}$ In 1930, women represented hardly 5.3 percent of the wage labor in Limburg, versus almost 18 percent on the national level (Delbroek 2016: 63). Usually, men took on the role of breadwinner, whereas women were responsible for domestic tasks, a situation that was reinforced by the mining industry. Although female workers were well represented in other parts of the country (e.g. in Ghent, East Flanders), notably in the textile sector, they were virtually absent in coalmining in Limburg (Stuyck et al. 2010). In his study of the labor market for miners in Belgian Limburg, Bart Delbroek (2016: 60-61) examined the distribution of workers in the Limburgian basin according to age and sex between 1919 and 1966. From this it follows that in 1919 only six women had formal employment in the entire area, compared to 2,269 men. Although the number of female workers increased in the 1920s, it never exceeded 139 individuals. During the peak in 1928, merely 0.8 percent of the employees registered as female in the Kempen. In comparison, that same year 2,126 women were employed by the mines of Liège. After the Second World War, the number of women employed by the Limburg mines continued to decline again.

Interestingly, as pointed out in the literature, in the 1920s individual women worked aboveground in the triage of Eisden, the place where the coal was cleaned and separated from other residue (Delbroek 2016: 62). According to my informants, working in the triage was an unpopular task, and these women commonly worked there only for a short period. Usually, it was the father who was 'asked' whether his daughter could help in the mine. A refusal, however, would have caused problems for the family, as the mining company tried to regulate each and every aspect of life (see also Eisden 2010: 11-19).

The (near) absence of female labor in the Limburg mines has to do with several factors: First, it should be noted that in 1911, a few years before the Kempen mines entered production, the government prohibited female labor underground (Delbroek 2016: 60; Caestecker 2008: 38). Naturally, this law did not prevent women from working aboveground. In the mines of Liège, for instance, where the number of female miners was much higher, women carried out specific tasks aboveground, as reflected by specifically female occupational titles: ${ }^{21}$ The hiercheuses transported the coal, the trieuses sorted the stones based on size, and the lampenistes cleaned and maintained the lamps. Female workers started at a young age and usually quitted as soon as they married. The Limburg mines, in turn, had a different distribution of labor from the beginning of underground

${ }^{20}$ In 1840, in the mines of Charleroi, the number of young female workers was even higher than the number of male workers, apparently because boys had more alternatives, such as working in the glass and metal industry (Caestecker 2008: 32). For more on the female labor force in the Belgian mines, see in particular Hilden (1993), Roels (2008; 2014: 83-93) and Caestecker (2008: 32; 34; 38). A historical account of women and gender roles in the Dutch Limburg mining area is provided by Wijers (1990).

${ }^{21}$ According to Hilden $(1993: 89 ; 110)$, the term hiercheuse was later used as a proud title for all female miners. In addition, both in Liège and Charleroi, these women wore a special uniform that was recognized in public. In the earliest phases of Belgian coalmining, however, it seems that there was no sex distinction (Hilden 1993: 87-89). 
mining. Due to technological progress, they used machines for processes designated to female workers in Liège (Roels 2008; 2014: 83-86). Yet next to a different distribution of labor in the mines of Limburg, compared to Liège, the general view on the role of women in society differed, a decisive factor when it comes to employment. In Limburg, the idea of traditional gender roles with the woman as homemaker and the man as moneymaker was widespread, and this allocation of gender roles was enforced by the patriarchal concept of the mining industry, with the Catholic Church serving as a driving force (Stuyck et al. 2010; Beyers 2007; Wijers 1990).

The mining industry, as the economic driver in the region, and the Church, as its moral and cultural counterpart, agreed about the place of women in society: a good wife should stay at home. Women were associated with the 'three K's': Keuken, Kinderen en Kerk (kitchen, children and Church). (Stuyck et al. 2010: 73)

Women in Limburg were expected to take care of the 'social reproduction' of their family, while men were in charge of 'economic production' to provide for their family (Stuyck et al. 2010: 73; also Beyers 2007: 30; 51; Dorren 2013: 419; for Dutch-Limburg see Wijers 1990; Rutten 2012). Catholic leaders had very clear ideas on the role of women in society. The woman's domain was her house, and 'good Catholic mothers' ensured that their husband and children lived according to the ideas propagated by the Catholic Church (Wijers 1990: 49-53). As Wijers states for Dutch Limburg: ${ }^{22}$

Niet alleen werden haar taken beperkt tot die van echtgenote, huisvrouw en moeder, maar als er iets misging, werden zij hiervoor aansprakelijk gesteld. Ruzies, een uithuizige man, moeilijke kinderen, het was voor een niet onbelangrijk deel het gevolg van háár falen als huismoeder, zo luidde de algemene opinie van katholieke leiders. (Wijers 1990: 53)

'Not only were her duties limited to that of wife, homemaker, and mother; if something went wrong, they were also held liable. The general opinion of Catholic leaders was that quarrels, a husband who was seldom at home, or difficult children were mainly the result of her failure as a housewife.'

Accordingly, women were made responsible for the behavior of their husbands, and this practice persisted into the 1950s (Wijers 1990: 49-53). Furthermore, while the coalmine funded sports and cultural associations for miners, it did not invest in leisure activities for women, who could only meet during the meetings of the KAV, the Kristelijke Arbeidersvrouwenbeweging (Christian Worker Women's Association) (Beyers 2007: 31; Stuyck et al. 2010: 77) ${ }^{23}$ If women pursued a paid job, it was usually in the mining district

22 The situation in the Dutch and Belgian Limburg mining regions was largely similar. In the Netherlands, however, a policy from 1810 prohibited female labor both aboveground and underground (Rutten 2012: 409).

${ }^{23}$ In this context, some authors also speak of gilde ('guild'). Note that the KAV changed its name several times and is nowadays known as FEMMA. In Dutch Limburg, KAV stood for Katholieke 
(Beyers 2007: 29). Moreover, women took care of kostgangers 'boarders,' which, aside from providing accommodation, implied the preparation of meals and doing the laundry (Delbroek 2016: 139). ${ }^{24}$ All of these activities took place in the home or its immediate surroundings. As shown by Leen Beyers (2007: 29) in her study on Polish and Italians in the cité of Zwartberg, women were usually less mobile than men, ${ }^{25}$ which meant that by and large their social contacts were confined to the mining district. Consequently, their life differed from that of their husbands. Naturally, the community of Eisden is diverse, and individual women took different paths, for instance by studying for a career and by gaining financial independence. I will elaborate on this issue when discussing the role of female speakers $(\S 2.5)$.

\subsubsection{German in the Habsburg Empire}

While the recruited miners and their families moved from different European countries to Eisden, they often had some active or passive knowledge of German. Many came from areas settled by German speakers or where German served as administrative language. Many Hungarian, Czech, and Slovak miners served in the Austrian-Hungarian military and therefore had some passive knowledge of German. In addition, quite a few Polish people from the Ruhr region grew up with Polish and German (Kohlbacher 1986; 2016; Auer \& Cornips 2018). As told to me by Anna, whose parents came from the North of Italy, the variety of Italian she acquired as a young child from her parents and grandparents contained several loanwords of German origin, such as Schrank ('cupboard').

Previous studies have shown that German was widely used in the countries of the former Habsburg Empire (on translation practices in the Habsburg Monarchy, see Wolf 2015; see Haslinger 2008 for the role of German between 1740-1914, and Gehl 2009: 10312 for inter-ethnic relations between Danube-Swabians, Hungarians, Serbians, and Rumanians around 1900). Although not officially regulated by law, German took priority over other languages of the Monarchy in the late nineteenth and early twentieth century (Wolf 2015: 42). ${ }^{26}$ In Moravia, Bohemia, Hungary, and the Slovene and Croatian regions, German was commonly the language used by guilds and local administration. Members of the upper class often communicated in German, which functioned more widely as language of the bourgeoisie (Haslinger 2008: 92). Likewise, knowledge of German

\footnotetext{
Arbeidersvrouwenvereniging 'Catholic Worker Women's Association.' For its position, see Wijers (1990: 57-59) and Rutten and Langeweg (2012: 494-502).

${ }^{24}$ Conversations with women reveal that the washing of clothes was largely done by hand and that it was back-breaking work, taking an entire day (also Rutten 2012: 398-400).

25 The observations by Beyers (2007) for the mine of Zwartberg are in line with my own findings. Furthermore, Beyers mentions that many Polish and Italian women born before 1910 never learned how to ride a bike, which limited their mobility even more. See Beyers (2007: 135-38) for mobility in the cités.

${ }^{26}$ Even though the constitution from 1867 recognized the equality of regional languages for public life, education and administration, German was prioritized (Wolf 2015: 42).
} 
became crucial for craftsmen and domestic servants due to migratory movements within the Habsburg Monarchy (Wolf 2015: 53-55; Gehl 2009: 106-09). According to Wolf (2015: 47), in the second half of the nineteenth century, German outnumbered other languages in books and its presence increased drastically.

In a similar vein, German was predominant in the Habsburg military around 1910 (ibid. 59-61) and widely used in the courts as well as in legislative texts (ibid. 72-83). Around 1900, foreign language learning, and of German in particular, was stimulated by the system of Tauschkinder, or 'exchange of children,' in parts of Hungary, Serbia, and Slovakia (Wolf 2015: 55-57; Gehl 2009: 109). As indicated by Wolf (2015: 56), '[m]ultilingualism in the villages of the Mecsek mountains north of Pécs, south-western Hungary, also gave rise to the exchange of children, who moved between Germanspeaking and Hungarian-speaking villages and often spent many years there, as did children in the Buda mountains.' The system of Tauschkinder implied that children lived for an extended period with a family speaking another home language (Wolf 2015: 55-57; Gehl 2009: 109). Considering the status of German during the Habsburg Monarchy it is hardly surprising, then, that many of the miners who migrated from Central and Eastern Europe to Eisden in the 1920s were acquainted with bits and pieces of the German language. In the following, I will elaborate on how the miners and their family members communicated with each other in the mine and at home.

\subsection{Sociolinguistic Conditions for the Emergence of Cité Duits}

In this section, I will discuss the sociolinguistic conditions that contributed to the emergence of Cité Duits. What did it mean to grow up as a child of an immigrant miner, and how did geographical space and processes of 'place-making' (Cresswell 1996; 2004; Johnstone 2010; 2014; Thissen 2018; Modan 2007) influence social relationships and linguistic practices in Eisden-Tuinwijk? I will first shed light on the linguistic environment (§ 2.3.1), after which I discuss the relevant social processes (§ 2.3.2).

\subsubsection{Linguistic Conditions}

Given that Eisden belongs to the province of Limburg in the Dutch-speaking part of Belgium (Flanders) (see § 1.2), most residents of Eisden spoke Belgian Dutch and the Limburgish dialect Maaslands. In this section, I will demonstrate that a completely different language situation developed in the mining district of Eisden in the 1930s.

\subsubsection{Language Situation Underground}

Since many of the first engineers, clerks, and miners came from the Walloon coalmines, Walloon had a strong impact on the language situation underground. What is more, all mining sites were acquired by Walloon and French investors ( $\$ 2.2 .1)$, which is why the leadership and all those in higher positions generally spoke French with each other 
(Versteegh 1994: 131; Delbroek 2009; 2016). Consequently, both French and Walloon influenced the technical vocabulary that developed in the mining sites of the Kempen. In contrast, because few workers came from the adjacent villages, the Maaslands dialect hardly had an impact. In Eisden, the mining terminology evolved into a mixture of French and Walloon. Common words that were used pertain to the different professional roles, such as ouvrier ('worker'), manoeuvre ('untrained worker'), conducteur ('supervisor'), porion ('controller'). boutefeux ('shotfirers'), and marqueur ('person who measured the progress in the mine') (for the professional hierarchy, see Delbroek 2016: 35-40). Likewise, the word kezem ('salary'), which is derived from the French quinzaine ('biweekly'), has its origin in the Walloon mines, which traditionally paid salaries biweekly. Although not all Kempen mines followed this tradition, ${ }^{27} \mathrm{kezem}$ became the general term for 'salary' and is still used in Eisden (see $\S$ 4.2.2). As outlined above, the miners who migrated to Eisden in the late 1920s and early 1930s spoke several different languages, but they were often unacquainted with French. As pointed out by Delbroek (2009) in this context:

Considering the many different nationalities in the Limburg coalmines, communication problems often caused accidents. French was the predominant language among engineers, and they considered it self-evident that middle management also spoke their language. For both Flemish and foreign miners, being able to speak French therefore seems to have been a necessary (and tacit) prerequisite for promotion. (Delbroek 2009: 208)

French was not only required to be able to communicate at work, but it was also closely linked to career prospects. For higher positions, such as conducteur or ingénieur, knowledge of French was indispensable. Importantly, the terminology in Belgium's Limburg mines differed considerably from the one in the Dutch Limburg mines just across the border, which was rather influenced by German (Knotter 2012b: 3; van de Wijngaard \& Crompvoets 2006: 5; Defoin 1962).

A study carried out in the 1980s (van de Wijngaard \& Crompvoets 2006) highlights that the mining vocabulary of Eisden differed in some ways from the other Kempen mines in containing certain terminologies of German origin. Eisden is therefore characterized as a 'transition zone' between the French-Walloon terminology on the Belgian side of the border and the German terminology on the Dutch side (van de Wijngaard \& Crompvoets 2006: 6; 11-15). While the mining terminology attested in Cité Duits clearly has a French-Walloon basis $(\S 4.2)$, it is possible that cross-border commuters and 'new' speakers who came after 1946 introduced words from the nearby Dutch mines. ${ }^{28}$ In the 1950 s, numerous Dutch miners chose to work in the Kempen because of higher salaries paired with a generous child allowance. In 1954, about 1,500

${ }^{27}$ In 1938, only Beringen and Zolder followed this tradition, whereas the mine of Eisden paid weekly salaries (Delbroek 2016: 133).

${ }^{28}$ As shown by Knotter (2012a), the existence of national borders was secondary when it came to the mobility of miners in the Belgian-Dutch-German border region. 
Dutch miners commuted between their job in Belgian Limburg and their home in the Netherlands (Langeweg 2012b: 88-89), and it is likely that these miners were acquainted with the technical terminology based on German.

In addition, although French was the working language during the first decades of the mining activities in Belgian Limburg, this changed in the early 1950s with the Cultureel Akkoord, ('Cultural Agreement'), which stipulated Dutch as sole language on the job. French-speaking engineers had to learn Dutch as fast as possible, and workers and supervising staff had to be addressed in Dutch (Delbroek 2016: 141). At the time, the speakers of Cité Duits who followed in their fathers' footsteps were about the age to start working underground, and this implied that these second-generation miners largely relied on Belgian Dutch as language spoken at work (excluding the technical vocabulary).

\subsubsection{Language Situation in the Tuinwijk}

Because the mine of Eisden had a high percentage of immigrant workers (§ 2.2, Figure 5) and because immigrants came first in the allocation of homes, Eisden-cité rapidly housed a high proportion of speakers from different linguistic backgrounds. These miners and their families had to find ways to communicate with each other. While the supervisory staff usually spoke French, also in the Tuinwijk - a common proverb was God spreekt hier Frans, or 'God speaks French here' - many of the miners were unacquainted with French and only knew German (beyond their home language). While some of them were only familiar with bits and pieces of German, such as military commands, others had an active knowledge of this language. As outlined in section 2.2.4, across Middle- and Eastern Europe, German was widely used in different fields (e.g. literature, legislative texts, trade). The is why the cité of Eisden, even though situated in a Belgian DutchMaaslands-speaking area, became a place where most residents spoke either French or German with each other, next to their home languages. During an interview, Marina explains the situation in the 1930s as follows: 'Hungarians, Slovenians, or Polish, all of them spoke a little bit of German. Everyone who came to Eisden-cité spoke some German. ${ }^{29}$ In a similar vein, Gabrielle Dorren, in her report on the opening of the girls' school in the mining district, writes:

[Frans] was de voertaal onder ambtenaren, kader en directie van de mijn. Ook de straatnaambordjes van Eisden-cité (dat later Eisden-tuinwijk werd genoemd) waren in het Frans. De meeste arbeiders spraken echter Duits onder elkaar; zij waren vooral afkomstig uit Oost-Europa en Italië en hadden vaak werkervaring in Duitsland achter de rug. (Dorren 2013: 417)

'[French] was the official language between officials, management and leadership of the mine. The street signs in Eisden-cité (later called Eisden-Tuinwijk) were in French. Yet, most of the

${ }^{29}$ Original: 'Oder Ungarn, oder eh Slovene, Pole. Alle spreche ein wenig Deutsch. Alle die hier ankomme(n), die sprechen ein wenig.' (Marina, 250815: 01.08.28-36). 
workers spoke German among themselves; they were primarily of East-European and Italian origin and had often gained job experience in Germany.'

The first housing regulations in Eisden-cité came in three languages: Dutch, French, and German. Unlike in the surrounding villages, the Limburgish dialect Maaslands played a minor role. Furthermore, there is evidence that many of the first-generation immigrants had some knowledge of written German. In the 1930 school year, most letters from parents were in German, whereas there were almost no letters in French (Kohlbacher 1986: 12). Among these speakers - the parents of the Cité Duits speakers - German quickly turned into a lingua franca. Often, they had lived in several places before moving to Eisden, migrating for instance from Poland to France to Eisden and sometimes moving back and forth (see § 3.4.3). This multi-directional movement of people (for transnationalism see Mazzucato et al. 2004; for mining sites see Cornips \& Muysken 2019) entails that speakers picked up numerous languages including different varieties of German on their way. Accordingly, what these miners and their wives spoke among themselves was neither standard German nor one particular dialect of German, but a combination of varieties of German as spoken across Europe in the early twentieth century. It may be the case that the Ruhr-German as spoken by Poles was comparably prominent, because many of them seem to have reached Eisden via the Ruhr region (see also Auer \& Cornips 2018: 67-70).

The second generation of immigrants, i.e. the children who were born and raised in Eisden-cité in the 1930s and 1940s, grew up speaking several language varieties. In the home context, they acquired the home language of their parents, for instance Slovenian, Italian, or Hungarian, if often a dialectal variety of it. Given that it was common to marry within one's ethnic group, both parents usually spoke the same language. In addition, many parents sent their children to language classes in the afternoon, largely because they expected to return to their country of origin after some years. According to my interviewees, already at the age of two, most children started attending pre-school classes, where they would mingle with children from various linguistic backgrounds. With regard to schooling, families could choose between Dutch and French primary education. From the 1930s until the beginning of the 1950s, both the boys' school and the girls' school had a French and a Dutch language track (Kohlbacher 1986: 4).

It should be emphasized that from 1912 onward the Sours de la Providence ('Sisters of Providence') provided schooling for the sons and daughters of the leadership and management staff of the coalmine, but they left in 1929, probably due to the growing opposition to the French language in Limburg (see $\S 1.2$ ). Although most of these nuns were Flemish, they often taught in French (Dorren 2013: 417-18). In a similar vein, the education in the miners school for an apprenticeship as porion and conducteur was in French (Delbroek 2016: 185) ${ }^{30}$ In addition, a number of individual teachers provided Dutch education to boys. In 1932, the congregation of the Zusters van de H. Joseph ('Sisters of Saint Joseph') initiated a Dutch-speaking educational track for girls. According to the observations of the nuns, roughly 25-30 percent of the children were

${ }^{30}$ See Delbroek (2016: 182-200) for an overview of vocational training for miners in the Kempen. 
Belgians in the first school year, whereas 70-75 percent came from elsewhere and did not speak any Belgian Dutch or French. Because many of these children only spoke their home language, the school provided extra classes with special staff for children from Slovenian, Polish, and Czech families until 1933 (Dorren 2013: 417-18; Kohlbacher 1986). Based on the numbers of school enrollment, it appears that most immigrant parents sent their children to the French track, whereas the Dutch track was largely chosen by Flemish. French carried a high prestige and was considered more useful than Dutch, in particular for Italians who aimed to return to their home country after some years. In addition, some of these children attended school in Zwartberg-cité in the initial years, which offered Italian education. ${ }^{31}$ Dutch only became more prominent in Eisden-cité during the 1930s, mainly for two reasons: the adoption of the Language Act (see $\S 1.2 .2$ ) and due to a higher percentage of Flemish miners (see Figure 6).

The remaining male speakers of Cité Duits largely followed education in Dutch. In turn, many of the women I talked to attended the French track. Interviews and informal conversations attest that multilingualism was widespread throughout the community of Eisden-cité during their youth. This multilingual environment provided a propitious ground for the emergence of Cité Duits. Most Cité Duits speakers report to have learned Belgian Dutch and another home language simultaneously, whereas the Limburgish dialect Maaslands was acquired at a later age, often during soccer games. Female speakers, in turn, do not always speak the dialect, which can be explained by the fact that girls were neither involved in soccer nor in other group activities where they would come in regular contact with the local population (see $\S 2.5$ ).

Extract (1), taken from a sociolinguistic recording from 2015, illustrates how the male speakers discuss their language use during childhood. Olaf (O.), age 81 at the time of the recording, grew up in Eisden-cité as son of Czech-speaking parents with Polish passports. He worked almost ten years as underground miner in Eisden until the announcement of the closure of the mines. Viktor (V.), age 79, grew up with Polish as home language, and his parents came via the Ruhr region to Eisden. Until his retirement at the age of 43, he worked as underground miner, mainly in Eisden and for a short period in Waterschei. Jan, age 79, grew up as son of Austrian parents and worked as a teacher in Eisden-cité (see $\S 3.4 .3$ for details).

(1) (231115_5: $610.585-619.27)$
01 O. ne zuHAUse hab ich tschechisch gesproche, at home I spoke Czech,

02 J. TSCHEchisch.

Czech.

\footnotetext{
${ }^{31}$ However, due to the growing ideologies of the fascist regime, most Italian families distanced themselves from this school (Eisden 2014: 52-53). See also Vanhinsberg (1996).
} 
03 O. met mein BRUder flämisch, with my brother Flemish,

04 J. JA?

Yeah?

05 O. un auf STRASse ja deutsch. and in the streets German.

06 L. cité deutsch. Mining district German. $\langle<$ voice overlap $>(\quad)\rangle$

08 V. wie hamma immer PoLnisch gesproche we have always spoken Polish.

While the sons of the miners grew up speaking Belgian Dutch ('Flemish,' line 03), some French and another home language such as Czech (line 01) or Polish (line 08), they heard their parents speaking a variety of German in public ('in the streets,' line 05) and picked up bits and pieces of German. Kohlbacher (1986: 16) describes his experience of growing up in Eisden-cité as 'another kind of bilingualism.' German mixed with Italian, Polish, Hungarian, and Slovenian words was used in the streets and in informal contexts, although prohibited in domestic and educational domains. As he claimed:

Wir, die Jugend, hatten eine schöne Jugendzeit. Und im Nachahmen der Erwachsenen ist die Jugend meistens erfolgreich. Wir waren es. Und so entwickelte sich eine Sprache die unser Vater Strassendeutsch nannte, und wir uns hüteten es in seiner Gegenwart zu sprechen. (written exchange, 2014)

'We, the young people, had a wonderful adolescence. And the young are usually successful in imitating the adults. We were at least. And this is how the language developed that our father called Street German, and we were careful not to speak it in his presence.'

What his father called 'street German' was what the speakers would later label Cité Duits 'mining district German,' and which developed as in-group speech among the boys. Crucially, while the first generation of immigrants needed a lingua franca, Cité Duits developed in addition to already available languages. If, in other words, Cité Duits did not emerge out of the need to communicate with each other, all speakers were already fluent in Belgian Dutch (Auer \& Cornips 2018). Cité Duits developed in adolescence when the speakers were young, and they continued to use it during their adult life. This language 
variety was mainly adopted by male second-generation immigrants who grew up in Eisden-cité in the 1930s and 1940s, and it was not passed on to subsequent generations. Although speaking Cité Duits has always been closely related to the profession of underground mining, it should be emphasized that some of the speakers chose a different profession, or worked only a limited number of years in the mine.

\subsubsection{Social Conditions}

In this section, I will argue that Cité Duits developed due to specific social conditions that were particular to the mining district of Eisden. These clarify why such an in-group variety does not seem to have emerged in other cités of the Kempen (Auer \& Cornips 2018).

\subsubsection{The Island Situation of Eisden-Tuinwijk}

The emergence of Cité Duits should be understood as the outcome of a multilingual environment in combination with a number of social and geographical factors. Geographically, most mining districts were situated close to the coalmine and at some distance from the next town, implying that their residents only had neighbors who also worked for the mining company. As such, the cités turned into communities separated from the outside world (Beyers 2007: 20). Importantly, this situation was much more pronounced in Eisden. Due to its geographically isolated location near the border and the presence of a large peat bog on its Western edge, there was little interaction with people from outside the mining district or with workers from other mines. To the East, the river Meuse served as a boundary of the district. What is more, Eisden-cité was separated from the village of Eisden by a canal, impeding regular exchange with the local population (see \$ 3.2.1 for a map), which turned the mining district into a 'social island.' Another factor is that the cite was in fact the private property of the mining company at that time. A French-Dutch signpost saying Route privée - Eigen Weg 'Private Road' (Kohlbacher 2016) reminded miners and their families, as well as people from outside the district of the fact that the cité belonged to the mine. While there was less access to transport than nowadays, Eisden was even more isolated than other Tuinwijken due to its geographical position. It is likely that this spatial division favored the social isolation of the mining community, and therefore contributed to a pronounced in-group (Auer \& Cornips 2018: 62-64). With the mine as an all-round supplier, it was not necessary to leave the district. Socialist unions therefore referred to life in the cités as 'Leven in een gouden kooi,' or 'Living in a golden cage' (Keunen 2010: 22).

Since the mine of Eisden had a high number of foreign workers $(\S 2.2 .1)$, the majority of the inhabitants of Eisden-cité was immigrant. These miners had little contact with the Belgian population. In the coalmine, there was generally a separation between Belgians and non-Belgians. While the work aboveground was less arduous and reserved for Belgians, the bulk of immigrants worked underground, stipulated by a clause in the employment contract. Only individuals who were successful as soccer players or 
musicians and therefore enhanced the prestige of the mine worked aboveground (Delbroek 2008: 88; 2016: 179-81; Beyers 2007: 50-70). Life was restricted in other domains as well by the mining company. In Eisden, for instance, the employment contract did not allow employees of the mine to be politically active without official consent (Beyers 2007: 52).

While other mines made a similar distinction between Belgian and non-Belgian miners in the work process, the Tuinwijk of Eisden differed in terms of district-internal policies from other cités. Generally, the allocation of houses was based on criteria related to the position in the mine or to ethnicity, leading to a segregation between Belgians and immigrants in the cité. ${ }^{32}$ In Zwartberg, for instance, the direction of the mine actively tried to attract Belgian workers by promoting a segregated housing district where Belgians would live without coming into contact with immigrants (Beyers 2007: 34; 2008). In Eisden, in turn, the selection depended on the number of children within the family. As a result, workers of numerous nationalities and linguistic-cultural backgrounds lived together in the same street and often in the same house (Delbroek 2008: 87-88; Kohlbacher 2003: 135; Auer \& Cornips 2018).$^{33}$ One of the participants in this study reports that only one Flemish family lived in his street, whereas all others had distinct nationalities. ${ }^{34}$ This is why the boys who grew up in the Tuinwijk of Eisden met speakers from numerous language-cultural backgrounds at school and when playing in the streets. It is likely that this multilingual and multicultural environment contributed to the development of Cité Duits.

A major bonding activity for boys was soccer. As Auer and Cornips (2018: 64) argue, while "ethnic boundaries were erased in the club, its young members developed a "we"-feeling when playing against other clubs, in particular from the villages, including the village of Eisden.' Most mining sites set up their own soccer teams (to enhance their prestige), an aspect that Eisden shared with other mining districts. In 1942, the mining company founded the soccer team Patro Eisden and started recruiting players from outside of the district. To attract the most valuable players, the mining company offered them a number of advantages such as a commodious flat in the cité and extra leisure time. Miners who belonged to the soccer team invariably received light work, although they appeared in the company books as underground miners and were paid accordingly (Delbroek 2008: 88; 2016: 179-81; Beyers 2007: 50-70). As one of the Cité Duits' speakers recalls, 'allemaal die wat voetball spielde bei Patro, die habe gute arbeit gekricht,' or: 'all of those who played soccer for Patro were assigned decent work.' ${ }^{35}$ According to the

\footnotetext{
${ }^{32}$ As Beyers (2008: 50) points out: 'The ethnic boundaries under ground had a direct impact above ground due to the close relationship between work and housing in the social structure of mining. Miners who were promoted were consequently housed in a better part of the mining town with bigger houses that were preserved for specialized miners and clerks.'

${ }^{33}$ In the Old Cité, most houses were semidetached houses accommodating two to four families.

${ }^{34}$ See Errinerunge wie ich noch klein wa... (annex): 'Bei uns in dè Strasse hat nur ein Flamische Familie gewohnt, die andere ware allemaal Auslendas: Pollakken, Slovenas, ein Hollenda, mein Fatta un Mutta ware Ungarische Schwaben.'

${ }^{35}$ Recording 0313_152448: 1432.7 - 1436.8, Raf.
} 
informants, the soccer team became one of the few contexts where the sons of miners came into contact with the local population, and where some of them would also acquire the Maaslands dialect.

In a similar vein, the mining company subsidized cultural associations. Many immigrant groups set up associations to meet on a regular basis, foster their home language, and celebrate traditions from their country (Beyers 2007: 43-82 for a detailed discussion). Many of these associations exist to this day. Moreover, in 1934, for the children of miners, the chaplain of Saint Barbara started a youth group for boys (Patronaat), followed by a similar initiative for girls by the Kleine Zusters van Sint Jozef (Kohlbacher 1995). But the influence of the mine was also present at school, where boys received training in all aspects related to underground mining. A visit to the mine was a fixed element of the curriculum (Dorren 2013: 418-19; Kohlbacher 1986: 17). The education of girls was geared to turning them into responsible housewives. Considering that Belgian primary school lasted six years, from age six to age 12, the education of boys and girls largely took place within the district and under the supervision of the mine. Boys generally began working underground at the age of 14, whereas girls left school at that age. ${ }^{36}$ Finally, the mines established special, district-internal holidays, which differed from holidays celebrated elsewhere in Belgian Limburg. One example is Saint Barbara Day on 4 December (which is celebrated to this day). All these various aspects contributed to the fact that the children who grew up in the cité would identify with the mine (Beyers $2007 ; 2008)$, which probably resulted in a strong in-group feeling.

In 1952, however, the provincial government put an end (at least officially) to this island situation. In response to the Cultureel Akkoord, which took effect on September 11, 1952, the company management of all seven mining sites agreed to open the cités to the province of Limburg and establish Belgian Dutch as common language in the mines and housing districts. Consequently, the French educational track disappeared, and from then on, Dutch would feature as the language of instruction at schools. While the agreement also granted miners the right to purchase their own home, it took another 15 years until the management complied with the latter (Delbroek 2016: 141; Keunen 2010: 22).

\subsubsection{Attitudes among the Local Population}

Another aspect that very likely contributed to a pronounced in-group feeling among the children of the immigrant miners concerns the relationship between the local Flemish population and the mining community, or rather the boundary between the two (Auer \& Cornips 2018). As argued by Nira Yuval-Davis (2006: 203), belonging 'is not just about social locations and constructions of individual and collective identities and attachments but also about the ways these are valued and judged.' In other words, to which degree people develop a sense of belonging is related to how they are received by others, and the

\footnotetext{
${ }^{36}$ Changes took place from the 1960 s onward, and more and more girls decided to enroll in secondary education (Dorren 2013: 420).
} 
attitudes toward them in a particular place. Excerpt (2), taken from a sociolinguistic recording I made of a group of male speakers born in the late 1930s, provides a glimpse of the attitudes of the local inhabitants from the surrounding villages toward the mining community and vice versa. Similarly, it exemplifies how practices of place-making can result in feelings of belonging. 'Place-making' refers to the process in which people develop emotional attachments to places and imbue them with meaning (Cresswell 2004), but this notion also describes the ways in which speakers linguistically affiliate with or distinguish themselves from others (Thissen 2018: 246). ${ }^{37}$

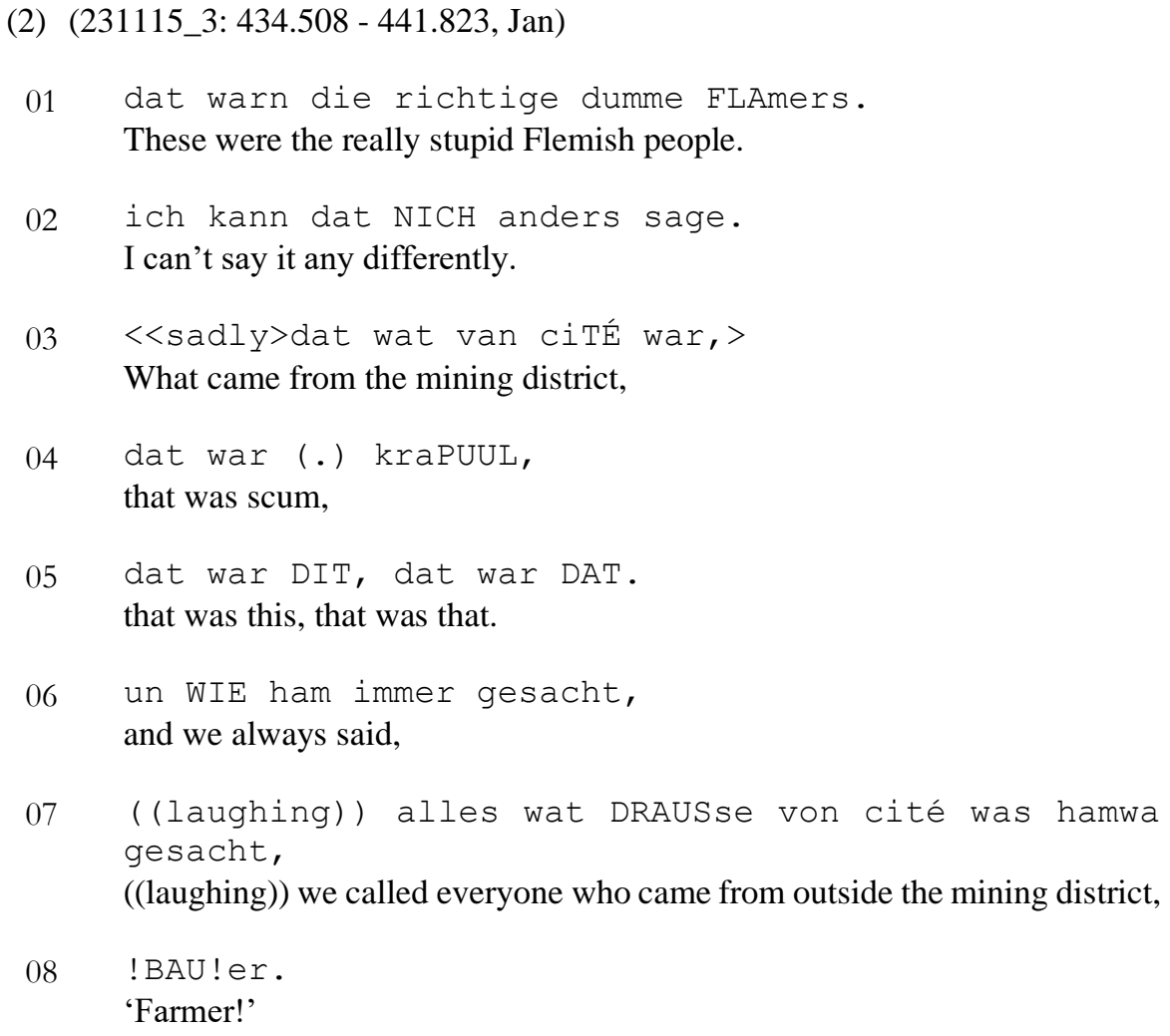

Jan, at that time in his late seventies, recalls in (2) how it felt to grow up as child of an immigrant miner. According to his memories, most Flamers (line 01) treated them as krapuul (line 04), a term that derives from Limburgish and broadly translates as 'scum' or

${ }^{37}$ Despite the fact that the theoretical notion of 'place-making' is a rather recent concept, the idea of 'place' in terms of social relations was already expressed by Massey (1994). See further Antonsich (2010) for 'place-belongingness.' 
'riffraff.' The miners' children, in turn, called the Flemish outside the district bauer (line 07-08), an expression that lexically resembles the German word for 'farmer' (Bauer). Bauer carries a negative connotation, and it is here that the stances of the mining community toward the locals are most clearly reflected.

Extract (2) shows on several levels how place-making processes 'result in feelings of being out of place' (Thissen 2018: 246): the immigrant children and their families were rejected by the local population and regarded as not belonging to the area. Strikingly, Jan chooses the word 'outside' in this context (drausse von cité, line 07), which suggests a (symbolic) boundary between 'us' from Eisden-cité and 'them' from Eisdenvillage. In a similar vein, in claiming belonging to the cité, the speaker includes his own group but excludes the local Flemish population from the district. Furthermore, the extract reveals how the speaker engages in linguistic place-making processes by employing particular lexical items: while he associates the villagers with the Limburgish dialect spoken in the area (krapuul), the miners' children from Eisden-cité are portrayed as speaking German/Cité Duits (Bauer). The narrative can therefore be considered as a form of linguistic place-making 'whereby linguistic forms are attached to a specific space' (Thissen 2018: 195).

Crucially, the pejorative stereotyping by the speaker in extract (2) does not seem to represent an individual case but largely corresponds to reports by other speakers and previous observations in the literature (Beyers 2007; 2008; Versteegh 1994; Delbroek 2008; 2016; Auer \& Cornips 2018; Vanhinsberg 1996). For many Belgians, the cités had a negative reputation (Beyers 2007: 34). In Catholic Limburg, the fear of familiar social structures being dismantled by new developments led to a widespread aversion to underground mining, as well as the immigrant miners. According to Versteegh (1994: 139), the large majority of the 'original' local inhabitants was strictly religious, extremely conservative, and 'fanatically Flemish' ('fanatiek vlaamsgezind'). In particular the Catholic cultural elite strongly opposed the construction of the coalmines, fearing that socialism would spill over into Limburg (ibid.). By introducing the garden city model, the Limburg elite hoped to maintain the 'Catholic purity' of the region, and to protect it from 'bad influences,' an idea that is materially reflected in the construction of the Saint Barbara church. ${ }^{38}$ Despite the fact that most of the miners were Catholic, from the perception of the locals and in particular in Catholic circles, miners represented immorality, socialism, and alcoholism (Delbroek 2008: 81). Locals openly criticized the cités and in particular the kostganger-system, where unmarried miners lived with families or widows (Delbroek 2016: 139). In 1920, several regional newspapers openly objected to the arrival of immigrant miners. In this period, the first group of Italians was expected to arrive in the region. In the fall of 1920, Ons Limburg, a paper associated with the Christian Workers Movement, voiced the worry that the Italian miners would bring along 'fleas' and

${ }^{38}$ As Jaspers (2003: 4) notes, the giant church building served to remind the locals of their regular duty to attend service, but the mining companies saw its presence also as a display of their poweras a way to enhance their prestige and radiate a sense of wealth and prosperity. 
'syphilis' (cited in Vanhinsberg 1996: 73). On November 22, the newspaper L'Echo de la Bourse raised similar concerns:

Deze vreemde arbeiders zijn geroepen om te verdwijnen. Men moet niet denken dat de maatschappij de bedoeling heeft om deze vreemde elementen binnen te brengen in de Kempen; er is nooit sprake [van] geweest en het is nooit de wens geweest. (L'Echo de la Bourse, November 22, 1920, quoted in Vanhinsberg (1996: 74))

'These foreign workers should be called upon to disappear again. One should not think that we meant to introduce these strange elements into our society here in the Kempen; this has never been the case and there has never been a wish to do so.'

Miners were viewed through the lens of pejorative stereotyping even before their arrival. In the years that followed, xenophobic reactions would persist. In his economic (!) study on the Kempen, Pinxten (1939: 336-337) articulated his concern about the 'decay of morals' in the Tuinwijken, and Broekx, in his introduction, surmised that church attendance would be the worst in the mining districts (Broekx 1939: : XIII-XIV). Because the mines operated seven days a week, the miners were blamed for disrespecting the sacred Sunday peace (as if it was their choice to work on Sundays). In addition, as some argued, the immigrants posed a threat to the Dutch language, which had been marginalized by the Belgian government for a long time ( $\$ 1.2)$. The mining schools, with their vocational training held in French, would 'frenchify' the area (Delbroek 2016: 182-200). In 1939, Eyskens wrote in this context:

De politiek van verfransching, welke zich heeft ontwikkeld rond het Limburgsch mijnbedrijf, waar meer wordt gedacht aan de gemakzucht van de bedrijfsleiding, het belang van inwijkelingen of van vreemdelingen, dan aan den eerbied voor de taal en zeden van de eigen Vlaamsche bevolking, is niet alleen een striemende vernedering, maar een belemmering voor cultureele verheffing. (Eyskens 1939: IX)

'The policy of frenchification, which has developed around the Limburg mining business where one is more concerned with pleasing the company management and the interests of immigrants or foreigners than with showing respect for the language and morals of the local Flemish population - is not just an excruciating humiliation but an obstacle to cultural edification.'

Obviously, incoming miners and their family members would hardly be capable to redress the tarnished reputation that preceded their arrival. For the few who found a home outside the cité, despite the prejudice, it proved difficult to become accepted by the local inhabitants. During an interview that I conducted with a woman who had lived for several years in a Maaslands village, she reported that contact with locals was unusual. In these 'typical villages,' as she pointed out, 'everyone just went on doing their own thing. ${ }^{39}$ Her

${ }^{39}$ I quote, 'In die tijd, eh, waren die mensen zeer, eh, wie moet ik daar zeggen? (Pause) In die dorpe, toen die Maasdorpe, die waren typische, typische dorpe. Hun eigen gang' (210815_1: 03.32 - 
family was the only migrant family and she often felt ignored if not excluded. As she put it, ik alleen was een koempel 'I was the only koempel." ${ }^{40}$ To be a koempel was nothing to be proud of at the time. While Kumpel means 'buddy' in German and served as a general term for a miner in the Ruhr region, it acquired a negative connotation in the Kempen, as a derogatory term used to refer to miners and their family members.

Prejudices against the mining community lived on at least until the 1980s. Although perceptions of miners slowly grew more positive after the kolenslag, after which miners were less stigmatized ( $\$ 2.2 .1)$, many community members faced discrimination and hostility during adulthood. Adriana (age 78), who grew up as daughter of a Slovenian miner and worked until her retirement as a teacher in Eisden-cité, recalled the following anecdote (3).

(3) (210815_1: $07.28-08.11$, Adriana):

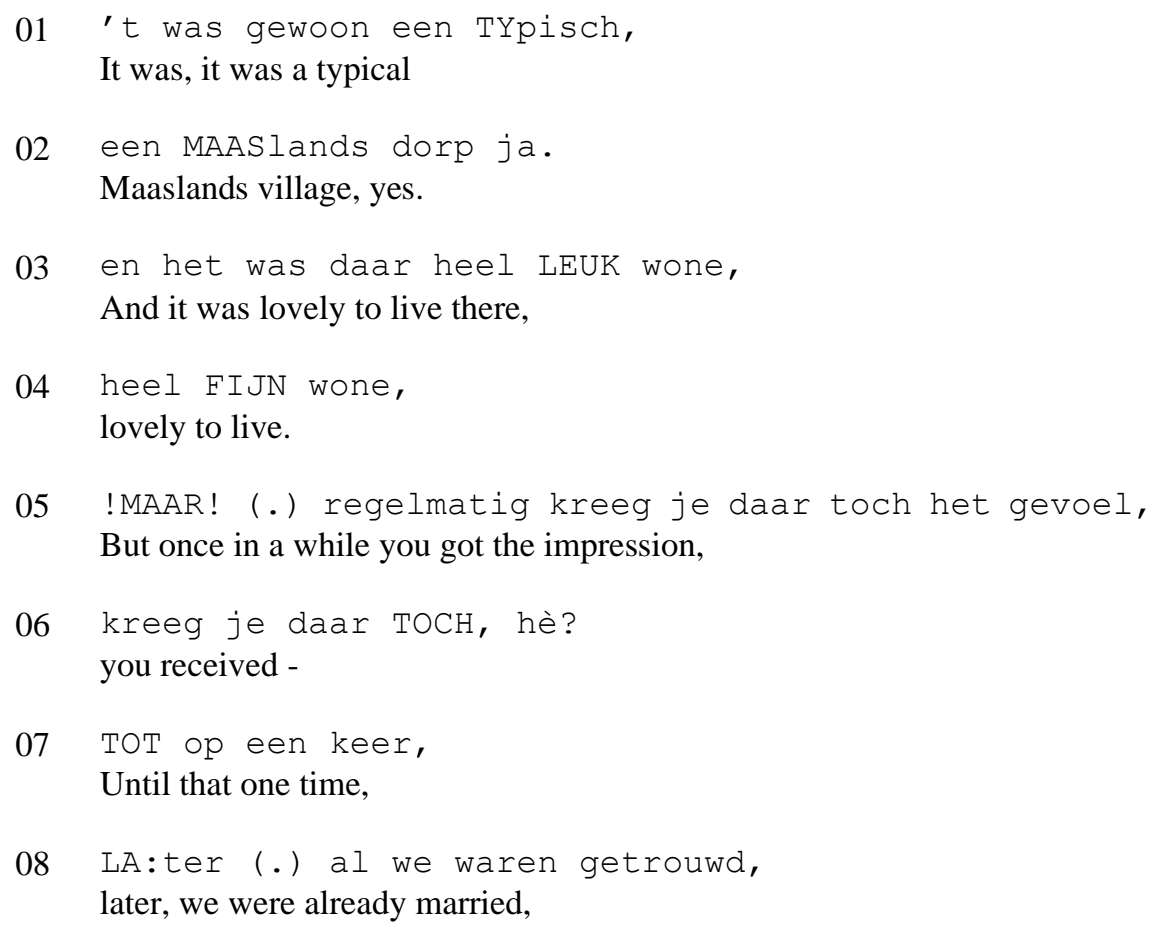

03.47). While the pause is subject to interpretation, it seems that she is being cautious in her word choice and does not want to offend the local population.

${ }^{40}$ Recording 210815_1: 00.26.11-00.26.13. 
09 en dan zijn we ook bij iemand op bezoEk gegaan in dat dorp,

and we also went to visit someone in that village.

10 en eh (.) die SCHOONzoon -

And the son-in-law,

11 <<acc>maar ik geloof wel dat die een par pintjes geDRUNke had zo,>

but I think that he had already had a couple of beers,

12 die was een BEETje maar toch -

he was a bit, but still;

13 en dan ZEI hij, and then he said,

14 ehm: (-) EIG(en)lijk (.) mogen jullie wel blijzijn, actually, you guys should be grateful ${ }^{41}$

15 dat jullie hier (.) kunne KOme (.) wone, jaja. that you are allowed to live here, yeah.

16 hè? (en) ik ZEG juist, $\mathrm{He}$ ? (And) then I responded,

17 en weet ge wie NOG blijer is?

And do you know who should be even more grateful?

18 ! JUL!lie allemaal. All of you guys!

The situation described in (3) took place in one of the villages close to Eisden-cité and probably in the 1970s or later, that is years after the kolenslag ('we were already married,' line 08). Adriana started out by emphasizing that she really enjoyed living in the area (lines 01-04), before summarizing what happened to her and her husband when being invited by someone from the village (lines $05-18$ ). At a certain point, during a conversation with a local inhabitant, he said to her, 'actually, you should be grateful that you are allowed to live here.' Note that the speaker employs the second person plural pronoun jullie 'you,' which can be interpreted as referring to the immigrant miners. In her quick response, 'and do you know who should be even more grateful? All of you!,' the pronoun jullie 'you' is

${ }^{41}$ Blij literally translates as 'glad' or 'happy.' 
a reference to the local Flemish population (line 18). As she later told me, when her father moved to Eisden to work in the mine, the local population was still wearing wooden clogs. The mining industry, in her words, brought industrialization to an 'uncultivated area.' Despite the fact that Adriana did not express negative evaluations and was cautious in her word choice (she first emphasizes that it was 'lovely to live' there, lines 03-04), the excerpt shows that Adriana made similar experiences than the male community members. In her narrative, (un)belonging is most clearly expressed by the use of second person plural pronouns.

Both excerpt (2) and (3) demonstrate that prejudice undermined the interactions between the local population and the mining community. And those who rebelled against the established social boundaries were disciplined, both in the mining district and in the villages. During another interview that I conducted in 2015, a Flemish woman reported to have dated an Italian boy from the cité when she was a teenager. It did not take long for the priest from the village to drop by at her parents' home and to tell her to quit going out with him. She replied by reminding this priest that even God knew that 'all human beings are the same,' but this hardly convinced him to change his view. It can be assumed that the lack of acceptance increased the feeling among the children of miners of not belonging to this place. Consequently, the young children living in the cite searched for different means to develop a feeling of 'place-belongingness' (Antonsich 2010), which they found, for instance, in developing and maintaining an in-group language. Nevertheless, Cité Duits is usually not spoken by the daughters of miners but only by their sons, an issue I will discuss below $(\$ 2.5)$.

In sum, the children of immigrant miners grew up in a kind of double isolation. Not only did they meet with prejudice from the local population toward inhabitants of the cité. Also, the overall concept of the mining company to provide for all aspects of life within the boundaries of the mining district in fact fostered the social isolation of the miners and their families. This contributed to a rather strict dividing line between the Belgian locals living in the old villages and the immigrant miners and their families living in the cité.

\subsection{Cité Duits: Social Functions and Emic Status}

In this section, I propose that speaking Cité Duits has carried different social functions and 'indexical meanings' (Eckert 2008) that were also subject to change. I therefore approach Cité Duits from the perspective of the speakers by examining the community attitudes and perceptions. Furthermore, I offer possible explanations for the moribund character of the speech.

\section{Indexical Meanings}

Michael Silverstein's (1985) tripartite concept of the 'total linguistic fact,' which is the relationship between linguistic form, linguistic ideology, and social praxis, gave rise to the study of social meaning in the field of sociolinguistics. Inspired by Silverstein's notion 
of 'indexical order,' Eckert $(2008 ; 2018)$ has shown how meanings become associated with social categories or with linguistic variables. Such indexical meanings depend on the social context and are not fixed. They constitute an 'indexical field,' based on potential meanings. For example, a particular clothing style may have multiple meanings, such as autonomy or self-confidence, and these may change over time. Cité Duits has always been indexical of various categories. Different people may relate different indexical meanings to Cité Duits, both from within and outside of the community of Eisden, and these meanings have changed over the decades.

While individuals may relate different indexical meanings to a linguistic variable or a type of speech, within the community of Eisden it seems that Cité Duits became very quickly indexical of 'male activities,' or, more specifically, activities associated with playing boys. According to the accounts of the speakers, their language use emerged in the streets, and more precisely during games such as catapult shooting, searching for artillery shells, and playing with knives. All these games were indexical of boys in Belgian Limburg of the 1930s. Speaking Cité Duits served to strengthen the feeling of cohesion and companionship among the sons of miners and to express their sense of belonging, to the cité as well as, later on, to the group of miners. When Cité Duits turned into a working language, spoken during and after work in informal contexts, it became indexical of the male miner from Eisden. To this day, in fact, this language use contains many mining terminologies and stories from work, paired with jokes related to the mine. Yet while the miners' children were proud to speak it, in the villages around Eisden, 'speaking German' became also indexical of being a koempel from the mining district (van de Wijngaard \& Crompvoets 2006: 5), which came with a negative connotation.

\subsubsection{Social Functions of Speaking Cité Duits}

While Cité Duits emerged as 'youth language'42 among the boys from Eisden-cité, the speakers would continue to speak it throughout their life. Over the decades, it carried different social functions that were also subject to change. I propose to characterize these functions by a three-way distinction that can be understood as a continuum, as its speakers passed through different life trajectories.

\footnotetext{
${ }^{42}$ The term 'youth language' covers a range of linguistic practices by young speakers in different parts of the world. Many, but certainly not all, youth languages emerge in multilingual settings (Kiessling \& Mous 2004; Mous 2009; Nortier 2018; Ziegler 2018; Rampton 2011a; Nortier \& Svendsen 2015). So far, only few cases are known where young speakers' linguistic practices are sustained beyond adolescence, as in Eisden (e.g. Rampton 2011a).
} 


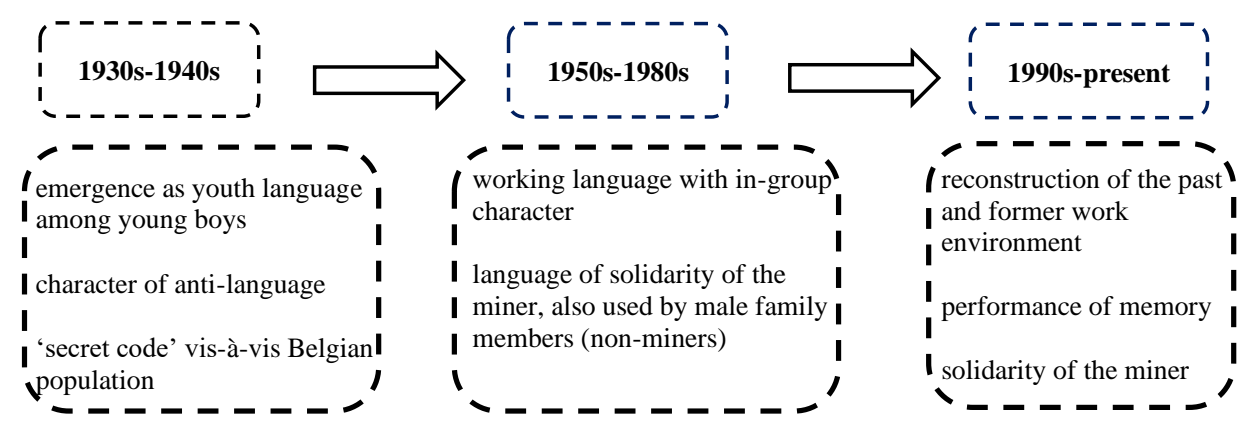

Figure 7: Changing social functions of Cité Duits

The main social functions of speaking Cité Duits correspond to different periods. In the 1930s and 1940s, when this speech developed among the boys, Cité Duits had the character of an 'anti-language' (Halliday 1976). Anti-languages often develop among speakers of stigmatized groups and are spoken as a form of revolt against existing social structures. Many youth languages are said to exhibit traces of anti-languages (Kiessling \& Mous 2004). As reported by several speakers, Cité Duits was forbidden at school and in public, especially during the Second World War. ${ }^{43}$ Similarly, considering that the inhabitants from the villages had a negative attitude toward the mining community, Cité Duits served as a 'secret code' unintelligible to the local Belgian population. As one of the speakers pointed out, 'die vlämingen ham uns nich verstehn. Wie haben ein eigen sprache gehabt 'the Flemish did not understand us. We had our own language. ${ }^{44}$

Over the decades, when the speakers became adults, Cité Duits turned into a working language that was spoken both inside and outside the coalmine, serving as vehicle for social and work-related communication. Miners would also use it, for example, when getting together for a drink after work. In addition, brothers of miners who chose a profession outside of the mine continued to speak Cité Duits to express solidarity with the underground miners and their way of life. My many conversations with miners and their wives and children revealed that Cité Duits was never spoken in the home context. Mining and social life were strongly intertwined, however, and the gradual disappearance of the mining industry in the Kempen region also implied a loss of mining culture, marked by changes in social values, norms, and interactional spaces. While the speakers' engagement

\footnotetext{
${ }^{43}$ Of course, German was highly stigmatized during WWII in many places outside Germany (see e.g. Keel 2015: 133).

${ }^{44}$ Recording 250815: 01.08.12-01.08.18.
} 
with coalmining is still present in their speech, it seems that this has become a matter of secondary importance.

When the mine of Eisden closed down in 1987, Cité Duits slowly evolved from a working language into a variety spoken to remember the past, a 'performance of memory' (Winter 2010; Assmann 2010). By speaking Cité Duits, speakers in a way recreate the linguistic atmosphere of their former work environment. To this day, they have been holding on to this practice, which becomes clear when taking a closer look at the content of the conversations from sociolinguistic recordings. Next to having a humorous character, they are characterized by anecdotes from childhood experiences and the work underground, with the same topics recurring in the recordings from 2012/13 and 2015/16. Speakers frequently talk about games played during childhood, misbehavior at school, their personal experiences during the Second World War, and their work in the coalmine. In so doing, they 'actively produce a past in the act of speaking itself' (Inoue 2004: 42). The fact that the few remaining speakers have kept Cité Duits alive until the present day can be seen as an endeavor to maintain and cultivate the social and symbolic function of Cité Duits. Today, because there are few speakers left, they speak it only occasionally, usually when being together with members of their group.

Consequently, Cité Duits is one of the few cases of a language variety that 'aged' together with its speakers: the variety emerged in early adolescence when the speakers were young, developed over the decades, and will vanish when all of its speakers have died. All of the phases of this language variety's development go hand in hand with the life phases of the speakers. From a linguistic perspective, it can be assumed that these phases were accompanied by structural changes and processes of sedimentation, in particular in the first decades after its emergence. During the last phase, in turn, some features may have disappeared. But the extent to which Cité Duits has changed over the decades remains subject to speculation due to the limited material available.

\subsubsection{Transfer to Following Generations}

While the end of coal mining in the Kempen explains to some degree why Cité Duits has not been transmitted to the younger generation of speakers, this is only part of the picture. Other factors have played a role as well. First, it is important to keep in mind that the miners who came to Eisden after the Second World War (\$ 2.2.1) were unacquainted with German. In his study on Italians in Eisden, van Avermaet (2008: 97) stresses that these speakers were often confronted with 'a double language barrier.' According to his observations, most miners in Eisden spoke a 'kind of Cité Duits' in informal contexts and Belgian Dutch in public, whereas the Italian miners who arrived in the late 1940s and 1950s were unacquainted with German and Dutch. The same holds for the workers from Turkey and Morocco recruited from the 1960s onward.

Second, many of the miners who grew up in Eisden in the 1930s and 1940s encouraged their children to choose an alternative profession. With the introduction of compulsory schooling, education was increasingly seen as offering opportunities beyond 
the mining districts (Caestecker 2008: 46). If in Eisden many among those in the second generation also ended up in the mines, like their father, most of those in the next generation (the children of the Cité Duits speakers) opted for a job outside of the coalmine. Finally, when it comes to passing on their language use to their sons, the ambivalent attitude of many miners toward their work perhaps played a role. As emphasized by Delbroek (2016: 9), most miners developed a 'hate-love relationship' with their mine. Cité Duits has always been closely linked to the mining district and the profession of the underground miner, and most miners hoped that their offspring would find employment outside of the coalmine. It can thus be assumed that they consciously avoided passing on Cité Duits to younger speakers.

\subsubsection{Emic Status of Cité Duits}

To arrive at a more comprehensive view of Cité Duits, this section addresses its emic status. Do the speakers perceive Cité Duits as a separate variety or rather as a bundle of features? While linguistic features are of course crucial when describing the language use of a given speech community, scholars have more and more acknowledged the importance of speakers' perceptions (Auer \& Hinskens 1996; Lenz 2010; Ghyselen \& De Vogelaer 2018; Grondelaers \& Van Hout 2016; Niedzielski \& Preston 2000). ${ }^{45}$ From a perceptual approach, it is assumed that varieties need to be experienced as such by their speakers to count as varieties. In turn, if cognitive boundaries are absent in a community, despite a coherent pattern of linguistic features, the language use is rather regarded as sublevel within a variety. While I will discuss linguistic features of Cité Duits at a later stage (see $\S 4-7)$, it is possible to shed some light on the participants' language perception by exploring meta-comments from the dataset.

Remarks made by different participants suggest that they experience Cité Duits indeed as a separate linguistic system. This becomes clear from comments such as wie haben ein eigen sprache gehabt 'we had our own language' (see above), thereby referring to Cité Duits, or when speakers define the kind of language variety they speak. Let us take a look again at extract (1) where the speakers recall their linguistic practices during childhood, repeated here in English: O. 'At home I spoke Czech.' J.: 'Czech.' Olaf: 'With my brother Flemish,' J. 'Yeah?' O. 'and in the streets German.' J. 'Mining district German.' The interaction then continues with another speaker chipping in that he spoke Polish at home. What is interesting here is the fact that Olaf argues to have spoken 'German' in the streets as a child (un auf strasse ja deutsch 'and in the streets German,' line 05 in extract (1)), suggesting that he associates Cité Duits with German. That the speakers are talking about their in-group language becomes clear in line 06, when Jan adds 'Cité Deutsch.' Not only the comments show that these speakers experience their language use as a separate variety; also the language label 'Cité Duits' (lit. 'mining district

\footnotetext{
${ }^{45}$ In particular in the field of perceptional dialectology, a number of fine-grained methods have been employed over the past decades (see also Long \& Preston 2002).
} 
German') reflects the perceptions of the speakers toward their language use. Crucially, this label was coined by the speakers themselves for their language use, rather than by the researcher $(\S 1.1)$. It can therefore be seen as an emic term for self-categorization. ${ }^{46}$

Another interesting observation is that other community members perceive the language of the male speakers as a distinct variety as well. The following excerpt (the quote from the opening paragraph) stems from a semi-structured interview with Marina, a woman in her late seventies. Unlike other community members, she grew up in the south of the Dutch province of Limburg and moved to Eisden-cité in her early twenties when getting married to an Italian miner. When I met her for the first time, it quickly became clear that she was fluent in numerous language varieties including Dutch, Limburgish, German, Italian, and French. The conversation with her took place in German.

(4) (Marina, Interview 250815: 01.08.44-01.08.54)

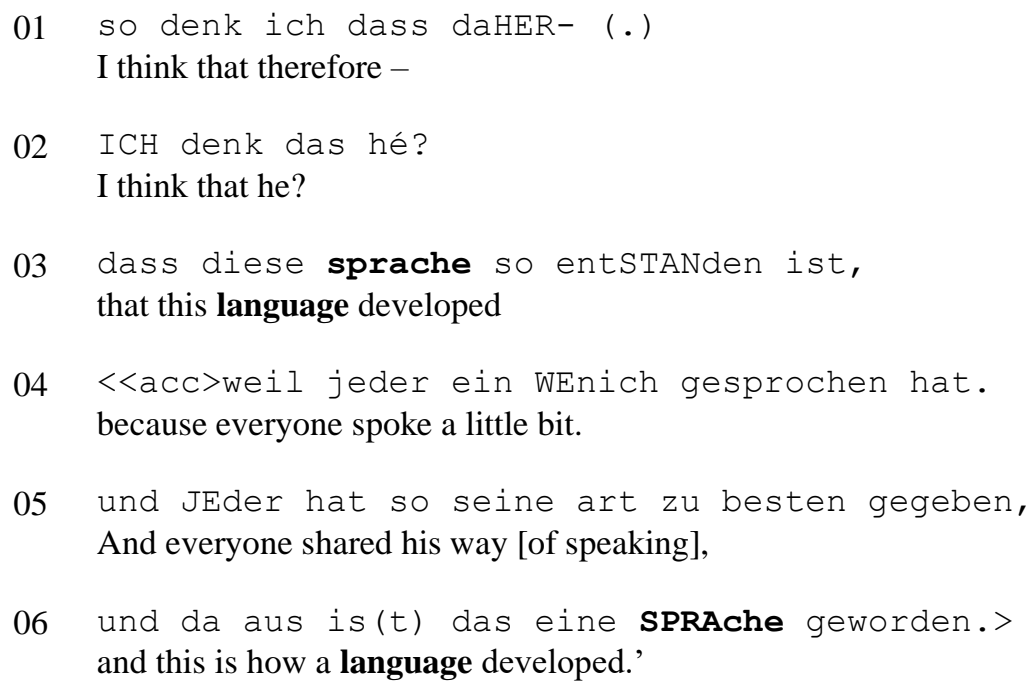

In excerpt (4), Marina explains how Cité Duits, in her view, could emerge in Eisden. In line with the male speakers, she describes it as eine Sprache 'a language,' first in line 03 ('that this language developed') and also in line 06 ('and this is how a language developed.'). While she does not specify whether she regards Cité Duits as (a variety of) German, the excerpt provides evidence of her perceiving it as a distinct 'language,' and Marina is not an exception in this regard. Even though these comments only reflect the

\footnotetext{
${ }^{46}$ In turn, the practice of language labeling can also have ideological implications, in particular when being adapted as a stigmatic term for a group of speakers (Cornips et al. 2014).
} 
perceptions of individual participants, there is evidence that most community members of the generation born in the 1930s attribute an emic status to Cité Duits. ${ }^{47}$

\subsection{Where are the Female Speakers?}

The findings presented so far indicate that Cité Duits is primarily spoken by males born and raised in Eisden-cité in the 1930s and 1940s. But how about the female speakers? Taking Eckert (2014) as a point of departure, I assume that there is no one-to-one relationship between the sex of a speaker and his language use. Rather, language reflects patterns of social practice. Considering that Cité Duits emerged at a young age 'in the streets,' one would expect that girls, although not allowed to work underground (§ 2.2.3), came into contact with the speech. While women born in the 1930s usually do not speak Cité Duits, they understand it perfectly.

\section{A Note on Women's Linguistic Practices}

Women's linguistic practices in this community have always been heterogeneous. All members of the community of Eisden are multilingual, and speakers use distinct varieties according to their social network, the context of the utterance, and the audience (Bell 1984; Bell \& Gibson 2011: 560). Like the men, the female participants in this study grew up with distinct home languages such as Slovenian, Polish, or Italian, and they have a command of different linguistic repertoires. ${ }^{48}$ In addition, these have often changed during their lifetime (see Blommaert 2010: 103-06 for 'truncated repertoires'; also Blommaert \& Backus 2011).

For instance, Anna, now in her late seventies, spoke Italian at home and French at school during her childhood. Nowadays, she speaks Belgian Dutch in the home context. She does not speak Limburgish. When talking to her sister, she speaks French, whereas she uses Italian with a number of Italian-speaking friends. Adriana, in turn, grew up with Slovenian as home language and acquired Belgian Dutch and French at school. Nowadays, she mainly speaks Belgian Dutch, whereas she speaks Slovenian only on particular occasions, for instance when attending the meetings of the Slovenian association and when visiting Slovenia once a year. With a number of friends and neighbors, she speaks Limburgish. Marina, in contrast, was raised with Limburgish and Netherlandic Dutch, but since being married to an Italian miner whose relatives only spoke Italian back then, she acquired Italian and she still speaks it with his relatives. Furthermore, many female speakers have a passive or active knowledge of German. This is tied not only to the large presence of German in Eisden-cité in their childhood, which served as a lingua franca for

\footnotetext{
${ }^{47}$ I cannot make any claims with regard to the following generation because the younger participants did not comment on this aspect during our conversations.

${ }^{48}$ Traditionally, 'repertoires' are defined as the 'totality of linguistic resources (i.e. including both invariant forms and variables) available to members of particular communities' (Gumperz \& Hymes 1986 [1972]: 20-21).
} 
their parents, but also to the increasing contact with German via the media, and television in particular, over the past decades. ${ }^{49}$

\section{Female Speakers of Cité Duits?}

Based on my fieldwork - participant observations in Eisden-cité, in-depth conversations with both female and male participants, and a large number of semi-structured interviews (§3) - it is safe to conclude that there are no female speakers left who actively speak Cité Duits. This does not yet exclude the possibility of female speakers in the 1940s, however. A number of community members mention that some girls spoke 'a type of German' back then. As soon as they had children, they would put more focus on speaking Dutch. In fact, there is evidence that individual girls who spent much time with their brothers picked up their language use. It remains unclear, however, whether female and male speakers used similar linguistic features, also because I have no audio materials from that period at my disposal. In this context, it should not be forgotten that there were female speakers in Eisden who acquired German in the home context. Accordingly, what others describe as 'a type of German' may have been a variety of German, but not per se Cité Duits as spoken by the boys. Generally, it appears that female speakers of Cite Duits were rather the exception. As noted by Marina in this context (extract (5)):

(5) (250815: 01.07.17-01.07.29, Marina)

01 weil das in die (.) GRUPpe gesprochen is, Because it [Cité Duits] is spoken within the group,

02 untereinander die MÄNner. among the men.

03 dat is so wie wie SCHIESsen. It's like shooting:

04 wer SCHIESST?

Who goes shooting?

05 normAlerweise männer. Usually men.

06 MANCHmal schiesst eine frau, Sometimes shoots a woman,

\footnotetext{
${ }^{49}$ Most families bought a TV set after the World Exposition in Brussels in 1958. Several participants reported that they watched German channels, also because few channels were available at the time. Radio, in turn, was generally in Belgian Dutch or French. For the role and development of Dutch on radio in Flanders (1935-1993), see van de Velde (1996).
} 
07 aber nicht OFT.

but not often.

In excerpt (5), Marina argues that women did not speak Cité Duits because it was an ingroup language confined to male speakers (line 01-02, 'it is spoken within the group'). She then compares Cité Duits to shooting, a sport typically practiced by men in Belgium (line 03-05), and adds, manchmal schiesst eine Frau, aber nicht oft 'sometimes shoots a woman, but not often' (line 06-07). With the latter comment, Marina raises a crucial point. While females can perform 'masculine' activities, there will be only a few who would want to engage in it. Cité Duits appears to have emerged as an in-group variety and gender-lect indexical of masculinity, and it is very likely that most females would not want to speak it.

While gender is culturally constructed in particular social practices (Holmes \& Meyerhoff 1999; Eckert \& McConnell-Ginet 1992; Eckert 2014; 1990), the authorities at the time put much effort in propagating a different education for girls and boys. As pointed out, the school in the cité prepared young women to become 'responsible mothers,' and female wage labor was clearly discouraged. A former female teacher told me that she had to choose between a career and a future husband. Until the 1960s, female teachers were not allowed to get married, nor were they permitted to walk with their partner through the cité, not even during holiday periods (see also Dorren 2013: 418-20). Many women married at a young age and stayed at home, and if they pursued paid employment, it was often within the mining district, such as in the role of saleslady in a shop.

Another aspect that contributed to the fact that Cité Duits was seldom spoken by females concerns spatial division, which is related to gender role patterns. From a young age, girls and boys occupied different social spaces, while children's leisure activities were determined by typical gender roles. Many boys were involved in the local soccer team, a sports activity inaccessible to girls. Likewise, when boys would play in the streets, girls would often be indoors, taking care of domestic tasks and younger siblings. During a group recording, Anna (age 77) and Emilie (age 82) recall the following from their childhood (extract (6)). Both have been living their entire life in Eisden-cité. Anna's parents came from the North of Italy and Emilie's parents were from Austria.

(6) (150915_3:00.35.46-00.36.01; A=Anna, E=Emilie)

01 A. als MEISje mocht je niet buite gaan spele met de JoNges (x) hè,

As a girl, you were not allowed to play outside with the boys, 
In this brief exchange (6), Anna remarks that as a girl she was not allowed to play outside with the boys, not even when the families were neighbors and well-acquainted with each other (line 01-02). She adds that this was the case at her house (line 03), which may imply that her parents were extremely strict. That this was not an exception, however, is confirmed by Emilie (line 05) who responds, 'daar waren toch veel van die eh ouders' 'but there were many of these parents.' The focus accent is on veel 'many,' underlining that a large number of parents shared these views. A similar point was made by Jan Kohlbacher, who grew up with two sisters: 'girls were called in early to help with the household in large families, and it was inappropriate for girls walking around in the streets, certainly with boys. ${ }^{50}$

Girls and boys would rarely engage in the same leisure activities or meet at school, nor would they have much contact in other social contexts. This division also held for the church service, where girls would sit on one side of the aisle and boys on the other side. Once married, the social activities of the husband were closely linked to the mine, as was true for their fathers. During a conversation with Rosa, who grew up as daughter of a miner, she described the situation in the cité as follows (field note):

De mannen werkten in de mijn en gingen na hun werk altijd naar de kantine. Elke cité had een kantine waar de mannen na afloop van hun werk in de mijn samen kwamen om bij te praten en te drinken. Het hele sociale leven ging in de kantine door. Ook de feestjes en evenementen. De vrouwen, aan de andere kant, bleven thuis. Ze gingen wel 'buren' met andere vrouwen, maar waren voornamelijk verantwoordelijk voor de huishouding. (Field note, 18 July 2017, Lanklaar)

'The men worked in the mine and always went to the 'canteen' after work. Each cite had a canteen where miners got together to chat and drink. All social life took place in the canteen, also parties and other events. Women, on the other hand, stayed at home. They did chat with other women, but they were mainly responsible for housekeeping [only].'

When I subsequently asked Rosa whether the women did not attend parties and social events, she replied: 'de vrouwen gingen wel naar de feestjes - om te koken' 'women did

\footnotetext{
${ }^{50}$ Original: 'De meisjes werden, in de grote gezinnen, vroeg ingeschakeld als hulp in het huishouden en het paste ook niet dat meisjes veel op straat en zeker niet met jongens rondliepen.' (Field note, 5 March 2016)
} 
go to parties - to do the cooking.' While her response was meant to have a jokingly character, it confirms previous observations from the literature: enduring gender role patterns had a major impact on the social spaces to which men and women had access. In contrast, Cité Duits was spoken in contexts where female speakers were not present, such as in the kantine, in the coalmine, and in the streets. That women were able to understand Cité Duits can be explained by the fact that they have been regularly exposed to (colloquial standard) German.

Studies on youth language highlight that young female speakers tend to develop their own register that fits their social norms (Kiessling \& Mous 2004: 318). ${ }^{51}$ Given that females were less often involved in group-building activities than males ( $\$ 2.2 .3)$, it seems that a common repertoire spoken by most young female speakers either did not emerge or was not retained over the years. Female speakers of Cité Duits were the exception. On the one hand, Cité Duits emerged as male gender-lect indexical of the underground miner, while the social environment with enduring gender ideologies resulted in females being socialized to speak a variety that fitted their social standing. On the other hand, divided social spaces between boys and girls, and later between men and women, resulted in females coming seldom into contact with Cité Duits.

\subsection{Summary and Concluding Remarks}

\section{Final Remarks on Labeling Practices}

In this chapter, I looked at the community of Eisden and their language use from a historical perspective. As illustrated above, the locally-born miners' children continued to be perceived as outsiders, as foreign to the region, also when they were growing older. Despite being born and raised in Belgium, the children of the immigrant miners did not enjoy the same privileges as Flemish children. Until requesting Belgian nationality in adulthood, they kept the nationality of their parents, and they had no access to employment in particular sectors. The attitude of the Flemish population toward the locally-born mining community appears to have changed gradually, and today its members are largely regarded as locals, whereas more recent immigrant groups are now categorized as foreign (Beyers 2008: 40). My findings suggest that most members of the community of Eisden identify themselves as 'Belgian.' Yet some of them employ a second self-label, namely papieren-Belg 'paper-Belgian.' This label highlights that they received the Belgian nationality only in adulthood, as part of a clerical procedure. In a similar vein, it may suggest a status in between being an outsider and being one of the 'local Flemish.' This 'in-between status' seems to emphasize their otherness. By using the self-label papieren-

\footnotetext{
51 The term 'register' refers to a constellation of linguistic features (lexis, syntax, etc.) associated with specific (cultural) practices and groups of people (e.g. politicians, mariners) (Duranti 2011: 42). A register is thus linked to the social context in which a speaker employs it.
} 
Belg, these community members deliberately differentiate themselves from the local Belgians, by whom they felt discriminated during childhood and early adult life..$^{52}$

\section{Summary}

This chapter has shown how Cité Duits could emerge in Eisden-cité (Tuinwijk) in the late 1930s and 1940s. I have demonstrated that the mining district of Eisden, although situated in a Belgian Dutch-Limburgish speaking area, provided a fertile ground for the emergence of such an in-group variety. By means of a historical review ( $\$ 2.2$ ), I first outlined how the shortage of local labor force led to the recruitment of large groups of miners from all over Europe. Crucially, the migration trajectories of the recruited miners were seldom linear, and as a consequence, they came into contact with various languages and dialects along their way. Because German was widely spoken in the countries of the former Habsburg Empire, many of them had a passive or active knowledge of German. In the late 1920s, these miners and their family members of different language-cultural backgrounds began living together in Eisden-cité.

Next, I argued that Cité Duits could only develop due to a combination of sociolinguistic conditions that were present in the cite of Eisden at the time $(\S 2.3)$. By addressing the language situation of this first-generation and second-generation immigrants $(\S 2.3 .1)$, I illustrated that German served as a lingua franca for the first generation, whereas Cité Duits developed in addition to already available languages among the Belgian-born sons (second generation). That is, all speakers of Cité Duits grew up speaking Belgian Dutch and another home language (e.g. Czech, Hungarian, Italian), implying that Cité Duits did not develop out of some communicative need. In the coalmine, in turn, the technical vocabulary evolved into a mixture of French and Walloon.

In addition, I proposed that Cité Duits' emergence in Eisden goes back to a combination of social factors ( $\$ 2.3 .2)$. First, as a result of the large number of immigrant workers and a specific housing policy, people from different linguistic-cultural backgrounds shared the same social spaces. Second, from a geographical and social perspective, Eisden-cité was more isolated than other cités, and the miners and their families were forced to adapt their professional and private life to the circumstances of this 'island lifestyle.' Except for soccer games, sons of miners seldom came into contact with the local population. Ultimately, this situation was reinforced by the prejudices and hostile attitudes of the inhabitants from the surrounding villages toward the mining community. This environment contributed to a pronounced sense of group membership among the children who grew up in Eisden-Tuinwijk. In this context, I demonstrated how practices of 'place-making' (e.g. Cresswell 1996) resulted in feelings of belonging. Speaking a variety such as Cité Duits that was unintelligible to the local Flemish population was also one way to develop a sense of belonging to the area.

52 Practices of ethnic labeling can have a variety of functions and are often context-dependent. Among other things, they can serve to construct a type of identity or can function as conversational strategies in talk-in-interaction (Chun 2011; Cornips \& Rooij 2013; Weerd 2019). 
From a perceptual perspective, both female and male community members of the generation born in the 1930s experience Cité Duits as a distinct variety, which suggests that it has an emic status $(\S 2.4)$. While the speech emerged as youth language, I proposed that the social functions of speaking and the indexical meanings attached to it changed over the decades as the speakers passed through different life trajectories. From its emergence in adolescence with an 'anti-language' character (Halliday 1976), Cité Duits turned into a working language employed for both social and work-related matters. Nowadays, more than 30 years after the closure of the mine, the speech appears to feature mainly as a 'performance of memory' (Winter 2010; Assmann 2010), with the remaining speakers all being men in their late seventies and eighties. Because coal mining and social life were strongly intertwined, many miners experienced the disappearance of the mining industry as a loss of their culture, including habits and rituals, traditions and language usage. While such socioeconomic changes may explain why Cité Duits failed to be transmitted to subsequent generations, I argued that this process of not passing on this language also resulted from several other socioeconomic factors, including changing migration patterns to Belgium, ambivalent attitudes of many miners toward their work, and career choices of their children who opted for a job outside of the mine.

Finally, I showed that Cite Duits is mainly spoken by the sons of the first generation of miners but not by their daughters, despite the fact that they all grew up in a multilingual setting $(\S 2.5)$. Assuming that gender is culturally constructed in social practices (Holmes \& Meyerhoff 1999; Eckert \& McConnell-Ginet 1992; Eckert 2014; 1990), I claimed that the absence of female speakers goes back to the fact that speaking Cité Duits has always been indexical of masculinity linked to the underground miner. Underground mining was clearly a male-dominated field, and there was hardly a tradition of female wage labor in Belgian Limburg. On account of enduring gender roles, women were confined to the home where they were supposed to perform domestic activities, while Cité Duits developed in the streets and continued to be spoken in male-dominated spaces to which women had little or no access. Girls from Eisden-Cité with numerous brothers may have picked up some Cité Duits, but it will have been hard to find a female speaker proficient in this language variety. 


\section{Chapter 3: Data and Methodology}

As long as we seek a transcription practice that is independent of its own history rather than looking closely at how transcripts operate politically, we will perpetuate the erroneous belief that an objective transcription is possible. (Bucholtz 2000: 1440)

\subsection{Introduction}

In the previous chapter I presented an overview of the origins of Cité Duits by providing a descriptive account of the historical background of the community and the sociolinguistic context that led to the development of this in-group language. This chapter addresses the data that I compiled and used for my analysis, how I gained insights into the community, and which analytical choices were made. I have been in touch with the community of Eisden since November 2014, starting my fieldwork only nine months later. This allowed me to establish several useful connections before engaging in actual fieldwork. The bulk of the fieldwork was conducted between August and December 2015, while a smaller share took place in 2016 and 2017.

This chapter consists of two parts and is organized as follows. Part one ( $\$ 3.2-$ 3.5) concentrates on the methods of data collection. I begin with field relations, the fieldwork location, and the effects of the researcher on the data (§ 3.2). Next, I address ethical issues that arise when studying human subjects (§3.3). Section 3.4 introduces the participants and their migration history. The methods through which the data was gathered are described in section 3.5. In part two (§ 3.6-3.7), I elaborate on the analysis and transcription practices. I present the software systems employed for transcribing, annotating, and editing the audio data, and I explain the methodology used to transcribe and annotate the primary data ( $\$ 3.6)$. Finally, in section 3.7, I describe a perception test carried out as part of the analysis. The concluding section ( $\$ 3.8)$ summarizes the main observations.

\section{Overview of Data}

Figure 8 provides an overview of the collected data, both primary and secondary sources, the fieldwork period and the resulting material. I will explain these methods in detail below (§ 3.5). To obtain the linguistic data analyzed in this work, I used a method of sociolinguistic fieldwork. As argued by Barbara Johnstone, however, 'knowledge about the cultural world in which speech is embedded is almost inevitably part of the knowledge sociolinguists bring to the analysis of these data' (Johnstone 2000: 84). To gain a deeper understanding of the sociocultural background of the community of Eisden, I combined 
methods of data collection from sociolinguistics and linguistic anthropology, two closely related fields that both focus on communication in its social context. ${ }^{1}$

All audio recordings were done with a handheld recorder (Marantz Professional PMD620); for the video recordings a digital video camera was used (Sony HD Handycam AVCHD, HDR-XR550); and the photographs of public signs I took with an iPad.

\begin{tabular}{|c|c|c|c|}
\hline $\begin{array}{l}\text { PRIMARY } \\
\text { DATA }\end{array}$ & $\begin{array}{l}\text { PERIOD OF } \\
\text { FIELDWORK }\end{array}$ & $\begin{array}{l}\text { COLLECTED } \\
\text { MATERIAL }\end{array}$ & $\begin{array}{l}\text { ANALYZED } \\
\text { FOR }\end{array}$ \\
\hline $\begin{array}{l}\text { Sociolinguistic } \\
\text { fieldwork by } \\
\text { myself }\end{array}$ & $\begin{array}{l}\text { November } 17, \\
2015 \\
\text { November 23, } \\
2015 \\
\text { June 8, } 2016\end{array}$ & $\begin{array}{l}\text { Audio recordings of } \\
\text { approx. } 220 \text { minutes and } \\
\text { video recordings of } 98 \\
\text { minutes, primarily in Cité } \\
\text { Duits, a total of } 11 \text { speakers } \\
\text { participated }\end{array}$ & $\begin{array}{l}\text { Linguistic } \\
\text { analysis in } \S \\
4,5,6,7\end{array}$ \\
\hline $\begin{array}{l}\text { Sociolinguistic } \\
\text { fieldwork by } \mathbf{L} \text {. } \\
\text { Cornips (and P. } \\
\text { Auer) }\end{array}$ & $\begin{array}{l}\text { March } 2012 \\
\text { October } 2013\end{array}$ & $\begin{array}{l}\text { Audio recordings of } \\
\text { approx. } 200 \text { minutes, } \\
\text { primarily in Cité Duits; a } \\
\text { total of nine speakers } \\
\text { participated }\end{array}$ & $\begin{array}{l}\text { Linguistic } \\
\text { analysis in } \S \\
4,5,6,7\end{array}$ \\
\hline $\begin{array}{l}\text { Written } \\
\text { document in } \\
\text { Cité Duits by } \\
\text { Josef (annex) }\end{array}$ & November 2015 & $\begin{array}{l}\text { Document Errinerunge wie } \\
\text { ich noch klein wa... }\end{array}$ & $\begin{array}{l}\text { Linguistic } \\
\text { analysis in } \S \\
4,5,6\end{array}$ \\
\hline $\begin{array}{l}\text { SECONDARY } \\
\text { DATA }\end{array}$ & $\begin{array}{l}\text { PERIOD OF } \\
\text { FIELDWORK }\end{array}$ & $\begin{array}{l}\text { COLLECTED } \\
\text { MATERIAL }\end{array}$ & $\begin{array}{l}\text { ANALYZED } \\
\text { FOR }\end{array}$ \\
\hline $\begin{array}{l}\text { Group- } \\
\text { recordings of } 15 \\
\text { female } \\
\text { participants }\end{array}$ & $\begin{array}{l}\text { August 28, } 2015 \\
\text { September 15, } \\
2015 \\
\text { October 6, } 2015\end{array}$ & $\begin{array}{l}5 \text { group recordings with } \\
\text { different participants in } \\
\text { mainly Belgian Dutch, }\end{array}$ & $\begin{array}{l}\S 2 \text { on socio- } \\
\text { historical } \\
\text { background }\end{array}$ \\
\hline
\end{tabular}

\footnotetext{
${ }^{1}$ Although there is much overlap, sociolinguistics developed from the field of dialectology and often favors quantitative methods, whereas linguistic anthropology rather turns its attention to small scale societies by applying qualitative methods. Obviously, sociolinguists also apply qualitative methods and make contributions to both fields, and vice versa (Johnstone 2000; Duranti 1997: 13; Meyerhoff et al. 2012: 122; Bowern 2013).
} 


\begin{tabular}{|c|c|c|c|}
\hline & $\begin{array}{l}\text { October } 8,2015 \\
\text { July } 18,2017\end{array}$ & $\begin{array}{l}\text { resulting in approx. } 360 \\
\text { minutes of speech }\end{array}$ & \\
\hline $\begin{array}{l}\text { Self-recording } \\
\text { of Victor, his } \\
\text { wife and } \\
\text { brother }\end{array}$ & $\begin{array}{l}\text { November } 2015 \text {, } \\
\text { day unknown }\end{array}$ & $\begin{array}{l}\text { One audio recording of } 48 \\
\text { minutes of speech in Cité } \\
\text { Duits and Belgian Dutch }\end{array}$ & $\begin{array}{l}\S 2 \text { on socio- } \\
\text { historical } \\
\text { background }\end{array}$ \\
\hline $\begin{array}{l}\text { Semi-structured } \\
\text { interviews with } \\
32 \text { participants }\end{array}$ & $\begin{array}{l}\text { August - } \\
\text { December 2015, } \\
\text { February - } \\
\text { November } 2016\end{array}$ & $\begin{array}{l}\text { approx. } 18 \text { hours of } \\
\text { recorded speech, different } \\
\text { languages, mainly Dutch }\end{array}$ & $\begin{array}{l}\S 2 \text { on socio- } \\
\text { historical } \\
\text { background }\end{array}$ \\
\hline $\begin{array}{l}\text { Participant } \\
\text { observation }\end{array}$ & $\begin{array}{l}\text { mainly August - } \\
\text { December } 2015\end{array}$ & $\begin{array}{l}\text { Field notes with } \\
\text { observations }\end{array}$ & $\begin{array}{l}\S 2 \text { on socio- } \\
\text { historical } \\
\text { background }\end{array}$ \\
\hline Written sources & $\begin{array}{l}\text { collected } \\
\text { between August } \\
2015 \text { and July } \\
2017\end{array}$ & $\begin{array}{l}\text { In Dutch: archive files, } \\
\text { letters, e-mails, } \\
\text { newspapers, magazines, } \\
\text { flyers of cultural events }\end{array}$ & $\begin{array}{l}\S 2 \text { on socio- } \\
\text { historical } \\
\text { background }\end{array}$ \\
\hline Visual material & $\begin{array}{l}\text { collected } \\
\text { between August } \\
2015 \text { and } \\
\text { November } 2016\end{array}$ & $\begin{array}{l}\text { Photographs of signs and } \\
\text { buildings } \\
\text { Video recordings during } \\
\text { sociolinguistic fieldwork }\end{array}$ & $\begin{array}{l}\text { Videos for } \\
\text { linguistic } \\
\text { analysis } \S 4 \text {, } \\
5,6,7\end{array}$ \\
\hline $\begin{array}{l}\text { Translation task } \\
\text { Dutch- } \\
\text { Maaslands }\end{array}$ & $\begin{array}{l}\text { September, } \\
\text { October and } \\
\text { November } 2016\end{array}$ & $\begin{array}{l}\text { Audio recordings of two } \\
\text { speakers (Adriana and Jan) }\end{array}$ & $\begin{array}{l}\text { Linguistic } \\
\text { analysis, } \\
\text { especially § } 7\end{array}$ \\
\hline
\end{tabular}

Figure 8: Overview of collected data 


\subsection{Field Relations and Location}

Before turning to the data, I will present the fieldwork location and I reflect on my role as fieldworker in gaining access to the community, on the (dis)advantages of collaborating with a gatekeeper, and on aspects related to reflexive methodology.

\subsection{1 $\quad$ Fieldwork Location}

The main site for data collection was the Tuinwijk (cité), a residential neighborhood of Belgian Eisden (see $§ 1.2$ for the location of Eisden), named after its architectural design, marked as it is by garden city arrangements. In sharp contrast with surrounding Belgian villages, housing in Eisden-cité is characterized by a nifty and uniform style, with homes having a well-kempt front yard and a generous backyard, the latter to give miners and their families the opportunity to plant their own vegetables. While the houses belong to private owners nowadays, the architecture of the district still reflects the former dominant position of the mining companies (see Nelissen 2006: 78-83 on architecture). ${ }^{2}$ Figure 9 illustrates the fieldwork site with its main roads. Numbers one to six highlight some relevant places.

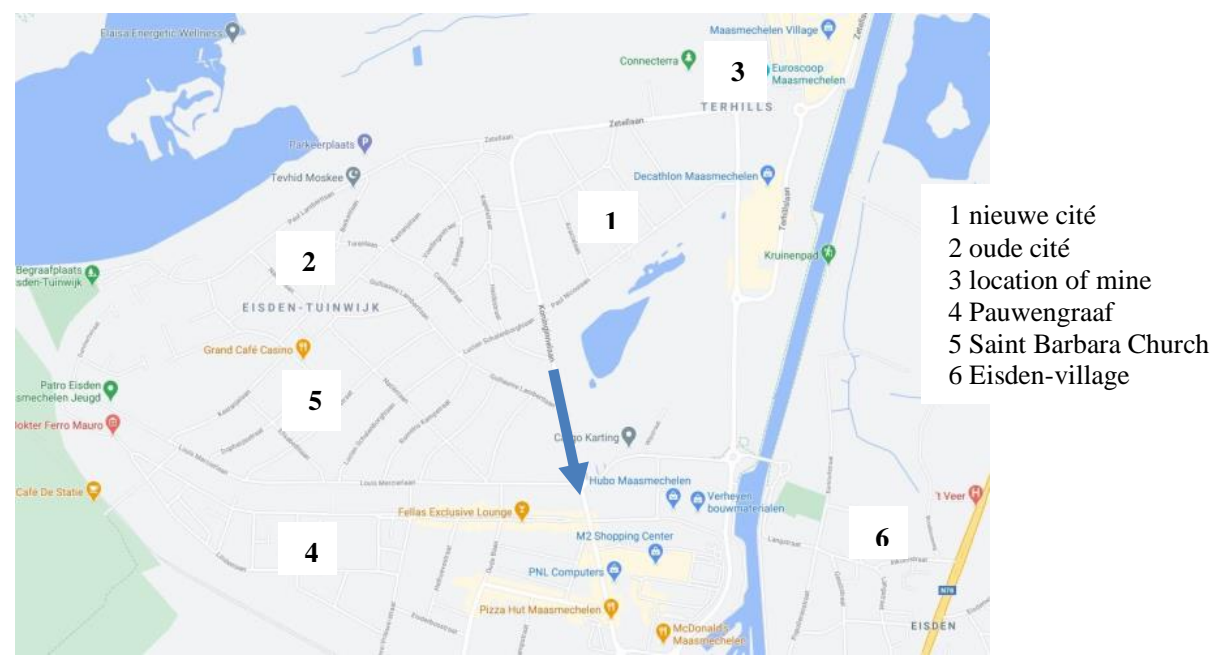

Figure 9: Map of Eisden-cité and surrounding area ${ }^{3}$

\footnotetext{
${ }^{2}$ When coalmining was in full swing, every house came with a hedge toward the road, and renters were not authorized to make changes to the properties. Although many of the characteristic hedges have disappeared, the district is generally quite green, with small parks and high chestnut trees lining the road.

${ }^{3}$ Image by google maps, July 12, 2019, courtesy of google maps. For general guidelines using screenshots of google maps for academic purposes and printed material, see https://www.google.com/ permissions/geoguidelines/\#general-guidelines.
} 
The cité encompasses the oude cité or 'old cité' (2), constructed mainly between 1911 and 1918, and the nieuwe cité or 'new cité' (1), built between 1936 and 1938. The principal road is the Koninginnelaan (blue arrow). Most of the Cité Duits speakers grew up in the oude cité, but later on moved to the nieuwe cité. One speaker lives in Mariaheide, a district built to accommodate miners who moved to Eisden after the Second World War. Because many of them came from Southern Italy (van Avermaet 2008: 93-94), there are still numerous Italian associations and stores in this part of the town. ${ }^{4}$

One of the principal buildings of the cité is the Saint Barbara church, built between 1936 and 1939 (5). As mentioned, Limburg was predominantly Catholic (§ 2), and many of the first-generation immigrants came from Catholic regions. While today the district is religiously diverse, the Saint Barbara church has remained the most prominent building by far. Directly next to the church are the elementary school and the parish hall. The Pauwengraaf, the principal shopping street (4), is a five-minute walk away. The coalmine (3) was located only a kilometer from the housing district. Accordingly, all aspects of life seemed to be provided for, and distances were rather short. Finally, Eisdencité and Eisden-Dorp ('village') were and still are separated by a canal (6). This spatial boundary also affected the mobility and the resulting social contacts in the previous century, with few interconnecting bridges between the two parts of the town.

After the closure of the mine in 1987, several changes took place. The most fundamental one was probably the opening of a large outlet-shopping center (3) on the former territory of the coalmine in the 1990s. As a result, some of the smaller stores disappeared from the Pauwengraaf. In a similar vein, the linguistic landscape of the cité has changed. ${ }^{5}$ While in the 1930s public signs were often in three languages - Belgian Dutch, French, and German - the former has meanwhile become most prominent, and is joined in some places by Arabic and Turkish.

Sociolinguistic fieldwork was conducted in the Museum van de Mijnwerkerswoning, a former miner's house from 1925 turned into a museum situated close to the church. Furthermore, most semi-structured interviews took place at the home of the interviewees, or in any other place they felt comfortable with, such as their backyard or the cafeteria of the parish hall. The setting was also important to me as researcher, because it may affect people's level of comfort, which in turn may influence their openness during the conversation (Hua 2016: 189). A few interviews with children of former miners (now adults) were conducted in the surrounding area. I arranged one interview with a daughter of a former miner in an office a few kilometers away, and another one in a kindergarten during a quiet moment. Whenever possible, I chose a place that was free of background noise that may affect the quality of the recordings. With some

${ }^{4}$ Many immigrant groups set up their own associations to meet on a regular basis, foster the home languages, and celebrate traditions from the home country. To this day, there is an Italian and a Polish church service in Mariaheide on Sundays.

${ }^{5}$ I follow the definition by Ben-Rafael et al. (2006: 7), where 'Linguistic landscape (LL) refers to linguistic objects that mark the public space.' 
community members, I talked in a variety of locations once we became better acquainted. Individual people offered me a ride or a guided walk through the cité, and took me to places in the area, such as neighboring villages, cemeteries, or churches - often places linked to their personal life trajectories.

\subsubsection{Access to the Community and the Role of Gatekeeper}

One of the challenges for many researchers is gaining access to the community. This pertains to the researcher's particular role and physical presence in a particular location, but also to access to information and negotiation with the gatekeeper and community members. Having permission to carry out fieldwork does not necessarily entail access to the relevant data (see Atkinson \& Hammersley 2007: 54-79 for field cases). ${ }^{6}$ In most settings, researchers must be willing to devote considerable time and effort to find individuals willing to contribute to the study. At the same time, particular research subjects may actually value being written about (Johnstone 2000: 84-88). ${ }^{7}$ The former miners of Eisden seemed to appreciate that their language use was being recorded. Considering the stigmatization of their profession in the past (see $\S 2.3$ ), it is possible that they welcomed my interest in their language. In addition, some of their speech had been recorded before by Leonie Cornips, who introduced me to the group in November 2014. As a result, I was not a complete stranger to them when I started my research, and most community members in fact proved to be quite open-minded and took time to engage in informal conversations and interviews with me.

At the beginning, I managed to gain access to the community through gatekeeper Jan. This notion of 'gatekeeper' I use to refer to a member of the community who has the authority to permit researchers to enter the field and carry out research (Smith 2001: 226). Jan, son of a miner and in his late seventies at that time, grew up in the cité and has been living there ever since. He is locally well-known for his active involvement in numerous types of community work, such as organizing expositions and social events. As editor of the district's magazine Eisden and one of the principal initiators of the local museum, he has a rich network of contacts, both within and outside of the cité. ${ }^{8}$ After a few visits, I found interviewees through the so-called snowball principle, which implied that I was introduced to friends and relatives of the people I talked to.

Entering the community via a gatekeeper comes with specific advantages but may also have some drawbacks (see Atkinson \& Hammersley 2007: 64-96 for field relations; Kristiansen 2003; Wanat 2008; Miller \& Boulton 2007: 2207). In particular

\footnotetext{
${ }^{6}$ Some authors distinguish between the official approval to conduct research ('access') and the willingness of the participants to cooperate ('cooperation') (e.g. Wanat 2008). Following Atkinson and Hammersley (2007), I understand 'access' as a broad notion here.

${ }^{7}$ Johnstone (2000: 90), for instance, describes a fieldwork case where they investigated people who earned their living as public figures, and who explicitly asked to be called by their real names.

8 Jan (co-)founded the Stichting Erfgoed Eisden in 1983, and the Museum van de Mijnwerkerswoning in 1989.
} 
during the first weeks, working together with a key informant who knows the community well facilitated the process of data collection, and Jan was eager to support me as much as possible. He made sure that I obtained access to written sources held by the Stichting Erfgoed Eisden ('Heritage Foundation of Eisden'), showed me around in the district, informed me whenever there was a social event, supported me in learning the Maaslands dialect, and, most significantly, introduced me to numerous community members who otherwise would not have been available to me. As a result, I spent much time talking to people in their private homes, which would have been impossible without prior introduction. ${ }^{9}$

The drawback of collaborating with a gatekeeper is, however, that he or she will often have some level of control over key informants and relevant information (Atkinson \& Hammersley 2007: 27). Such control may be deployed to 'attempt to guide the research in directions they prefer, or away from potentially sensitive areas' (Atkinson \& Hammersley 2007: 60). In a similar vein, a gatekeeper may wield social power by influencing others and the type of collected data (Atkinson \& Hammersley 2007: 41-62; Kristiansen 2003; Erickson \& Shultz 1982: 4; Wanat 2008; see Smith 2001: for a review). ${ }^{10}$ Crucially, Jan always left the location after having introduced me to an interviewee, allowing us to talk openly and undisturbedly with each other. Still, the method of being introduced by one particular person comes with the risk of being exposed to part of the picture only and missing out on relevant pieces of the puzzle (Modan 2007: 9-11). It can be assumed that the people to whom I was introduced by Jan shared his beliefs and ideas to some extent - and if they did not, they would probably not share them with me because they would not want to run the risk of spoiling the relationship with the gatekeeper who was a popular and highly valued person within the district. In other words, relying on a gatekeeper may lead to an a priori selectivity tied to particular members of the community and excluding others. By relying on the snowball principle, that is, by talking to and engaging with community members who were not part of Jan's immediate social network, I tried to obtain information from a broader range of sources.

Another aspect concerns the gatekeeper's use of language, which may have an impact on the discourse of the participants as well as on the data gathered (Kristiansen 2003; Erickson \& Shultz 1982). Although Jan was not present during the group recordings with women and the semi-structured interviews, he did participate in the sociolinguistic recordings. While I cannot determine whether the former miners would have spoken

${ }^{9}$ However, Miller and Boulton (2007: 2207) also describe a case where the input of an assumed 'gatekeeper' had the opposite effect: individuals refused to participate after the gatekeeper contacted them, believing that their confidentiality was violated. For case-studies, see Kristiansen (2003) and Erickson and Shultz (1982). Wanat (2008) in particular describes gatekeeper practices linked to granting or withholding access.

${ }^{10}$ For example, gatekeepers have been found to delay researchers because they worry about the uses of the obtained data, their liability, and the impact of the results (Smith 2001: 226). In a similar vein, fieldworkers may have fewer conversations with potential informants (Wanat 2008: 206). As pointed out, this was not the case in Eisden. 
differently in his absence, it is possible to establish the extent to which his use of Cité Duits varies from that of other members of the group. To this end, I will examine whether inter-speaker variation plays a role $(\S 6,7)$.

\subsubsection{Reflexivity}

Reflexive ethnography focuses on how the researcher affects the fieldwork location and the research process. As such, the concept of reflexivity has been employed in a variety of meanings (e.g. Johnstone 2006; Taylor 2000; Thissen 2018; Pollner \& Emerson 2001: 121-22; DeWalt \& DeWalt 2002: 68; Atkinson \& Hammersley 2007: 14-19; Davies 2002 [1998]; Heyl 2001: 377; Finlay \& Gough 2008).

In the present study, reflexivity pertains to several levels. First, my presence as researcher in the community: the background and the status of researchers will affect how people interact with them while different aspects of their identity will influence the process of data collection (Modan 2007; Thissen 2018). ${ }^{11}$ How a fieldworker is perceived depends on a number of factors, some are negotiable whereas others are not. Dressing, for example, can be used to demonstrate affinity to the community (yet inappropriate dressing may result in spoiling established relations). Furthermore, every fieldworker has a number of 'ascribed' characteristics, such as ethnicity and age, and these cannot as easily be negotiated (DeWalt \& DeWalt 2002: 83-88; Atkinson \& Hammersley 2007: 73). Although I adapted my clothing, I realized that there was no way to not affect the data I collected. Being 50 years younger than most participants, it was impossible to blend in, and my accent when addressing people in Dutch revealed my German language background.

Despite the fact that some scholars have convincingly shown that doing research close to home brings a number of benefits (Modan 2007: 11-14), entering the community as an 'outsider' also came with advantages in my case. First, I was completely fresh and unbiased vis-à-vis the social relationships in the district. Second, I did not speak a particular variety of Dutch that would reveal my social status, given that I had started to learn Dutch a year before starting fieldwork. ${ }^{12}$ Possibly because of my age, I was often treated as a friend of a young family member, allowing me to have open conversations on a range of topics. I cannot neglect that gender may have played a role as well. It proved easy to find a common topic of conversation with women, and men were perhaps more inclined to talk to a young female than to a male researcher (see Atkinson \& Hammersley

\footnotetext{
11 The concept of 'identity' has been subject to much debate. See especially Bucholtz and Hall (2005) for a linguistic approach, and Thissen (2018: 22-24) for a critical discussion.

${ }^{12}$ It has also been proposed that research subjects tend to be more open with foreigners than with someone from the same community (Atkinson \& Hammersley 2007: 74; Hua 2016: 187 for a discussion). I would like to stress that such observations cannot be generalized, and that it is decisive in this respect whether or not people regard you as a foreigner.
} 
2007: 73 for a discussion of gender).$^{13}$ While I initially hesitated to conduct fieldwork in a community where most members had experience of (the aftermath of) the Second World War, I never experienced any awkward situations.

A second aspect concerns the researcher's language background. Conducting fieldwork in a language that was not my home language (Belgian Dutch), as well as analyzing recordings of a variety that I do not speak myself (Cité Duits), came with a number of risks, such as misunderstandings during interviews that arise when the fieldworker's lexical knowledge of the language does not suffice. Nevertheless, such instances may equally produce richer linguistic descriptions from interviewees (Briggs 1986; Bernard 2000; Winchatz 2006). By broaching my linguistic difficulties, I rather benefited from the resulting data. Furthermore, the data I collected in Dutch was not the data that I used for the linguistic analysis. Of equal importance, I noticed, was being acquainted with the community and developing an understanding of the community's repertoire. ${ }^{14}$

Regarding Cité Duits, at the time I commenced my fieldwork in 2015, I was perhaps better acquainted with the speech than anyone outside the community, given that I have been transcribing recordings of Cité Duits since 2013 (see Pecht 2013). Having German as home language and substantial knowledge of Dutch, as well as being fluent in a number of Romance languages, facilitated my analysis of the speech considerably.

This raises another issue, namely whether my German language background influenced the Cité Duits of the speakers during fieldwork. It is well known that speakers adjust their language use to the one of their addressee (see the Audience Design Theory by Bell 1984, and the Communication Accommodation Theory by Giles 2016; and by Giles and Ogay 2007). Being aware of this, as I did not want to run the risk of speakers accommodating to my language use, I chose to address all speakers in Dutch before and after recording them (I did not intervene during the recordings, see $§ 3.5$ ). A comparison of my data from 2015/16 with the data collected in 2012 by Leonie Cornips - whose home language is southern Netherlandic Dutch - suggests that there are no significant differences between the two data sets. Speakers did not, for example, insert more German words in their Cité Duits in my presence.

A further aspect particularly relevant to the acquisition of the primary data relates to the famous observer's paradox (Labov 1972). The presence of both the researcher and the recording device influences people's speech. That is, speakers tend to talk differently when they are aware of being recorded, with most people adopting a more formal register. The aim of sociolinguistic research, in turn, is to find out how people talk during natural conversations when not being recorded. The fact that speech appears to change

${ }^{13}$ One male participant who lived by himself, however, feared that it could be 'inappropriate' to receive a female fieldworker at his home, after which we conducted the interview at the house of an acquaintance.

${ }^{14}$ Misunderstanding can also be a factor in 'native' speakers. Data collection and transcriptions are community based, and linguistic knowledge alone does not always suffice (Torres Cacoullos \& Travis 2015: 372). 
significantly in the presence of an observer - even if not actively involved in the conversation - poses a challenge to the fieldworker. There are several techniques, however, to reduce the awareness of speakers of their speech being recorded, which I employed during sociolinguistic fieldwork (see below, § 3.5). ${ }^{15}$

\subsection{Ethical Considerations}

While conducting fieldwork, but also when storing and dealing with the data, I reflected on the ethical implications that my research could have for others. ${ }^{16}$ Making ethical decisions implied that I respected at all moments the wishes of my participants; that I did no harm and treated them with respect, that I obtained informed consent, and that I informed people about my role as a researcher. I always prioritized the dignity of my research subjects. During conversations, I tried to avoid delicate topics that could potentially offend people. Before starting my fieldwork, I prepared myself on potential issues that could arise by reviewing the available materials about the fieldwork site (DeWalt \& DeWalt 2002: 197; Bowern 2013: 230-341). Naturally, participants had the right to withdraw from the study at any stage (see Toestemmingsformulier in annex), and I will make my results available to the community as a printed version of this book. ${ }^{17}$

In a similar vein, making ethical decisions meant the necessary confidential treatment of the data gathered during the entire trajectory of the research. The recordings of spontaneous-like speech and the interviews often involved the narration of private anecdotes, personal names and places that could possibly be identified by others. When conducting audio and video recordings, I stored the data in my personal folder of the university drive of Maastricht University immediately afterward, and I deleted the content from the recording device. I never made my data available to third parties, the only exceptions being my supervisors, Leonie Cornips and Peter Auer, and the students involved in the transcriptions. All students had to sign a form before receiving the data (see Privacy Verklaring Form in annex), ensuring that they would warrant the privacy of the research participants, that they would not share the data with anyone, and that they deleted the recorded material after having completed their work. Students never had access

\footnotetext{
${ }^{15}$ Note that participants have to sign a consent form before being recorded, and there are hardly any exceptions to this rule. Until the introduction of the General Data Protection Regulation (GDPR), it was permitted to record people in public spaces with a sign informing them. However, the GDPR, article $4, \S 11$ writes, "consent' of the data subject means any freely given, specific, informed and unambiguous indication of the data subject's wishes by which he or she, by a statement or by a clear affirmative action, signifies agreement to the processing of personal data relating to him or her.' Recital 32 further states: 'Silence, pre-ticked boxes or inactivity should not therefore constitute consent' (emphasis mine).

${ }^{16}$ For ethics in (socio)linguistic research, see Johnstone (2000: 39-57), Milroy and Gordon (2003: 79-87) and Dörnyei (2007: 63-72); see also Davies (2002 [1998]: 45-64) on ethnographic research, and DeWalt and DeWalt (2002: 195-208).

${ }^{17}$ Labov (1982: 173) speaks of the 'principle of the debt incurred': a researcher should return something to the community and make the linguistic data and results available to its members.
} 
to the entire corpus but only to those fragments that they would transcribe. In doing so, I also adhered to the 'Code of Ethics for Research in the Social and Behavioural Sciences Involving Human Participants' as recognized by the Deans of Social Sciences of Maastricht University in 2016. This document offers a number of general ethical guidelines. My Research Plan including the data management section was accepted by the board of the Faculty of Arts and Social Sciences of Maastricht University on August 22, 2016.

For all type of recordings, I asked participants for their (usually written) permission. ${ }^{18}$ To give people enough time to study the consent form, I would leave the room for a few minutes. All forms were signed by both parties, scanned in and saved together with further data material on the server of Maastricht University. In some cases, I decided to do a recorded verbal agreement, when the participants did not have their glasses with them and were perhaps unable to read the consent form well. ${ }^{19}$

Unless explicit consent was expressed to use the real name, I anonymized the names of speakers. Whenever giving public lectures, I ensured that the speech examples would not contain personal names. I recognize, however, that complete anonymity of all individuals cannot be guaranteed. In 2017, NRC Handelsblad, one of the leading newspapers of the Netherlands, published an article including photographs of some of the speakers. Furthermore, in April 2016, the University of Maastricht made a short video clip of the research project with some of my participants. ${ }^{20}$

Regarding the storage of my data, I saved all data in my personal folder of the university drive, which can be accessed by me only. Moreover, I stored the audio (but not the video) recordings from sociolinguistic fieldwork for my linguistic analysis in MOCA, a system administered by the Albert-Ludwigs-University of Freiburg (see also § 3.6). MOCA provides personalized access to spoken language corpora. Here, too, I am the only person who has access to the files. Crucially, I never used full names in the transcriptions. In making my research data not accessible to others who were not involved in this project, I also followed the regulations listed in the 'Research Data Management Code of Conduct' of Maastricht University as accepted in March 2014 by the Executive Board.

\subsection{Participants \\ 3.4.1 Participants in this Study}

A total of 42 participants took part in this study, from which 32 belonged to the second generation of immigrants and ten to the third generation. I employ the term 'second generation' to designate the participants born in the 1920s and 1930s. At the time of the

18 See Miller and Boulton (2007) for changing practices in consent procedures in qualitative research. Although the authors focus on the UK, many of the issues addressed are of general concern. ${ }^{19}$ Naturally, the process of aging differs per individual, affected by levels of sustaining social networks, physical and social activities, and so on (Pichler et al. 2018: 10).

${ }^{20}$ The article appeared in the weekend issue of February 18/19, 2017. The video clip is online, see https://www.youtube.com/watch?v=DoJGWUzjtd4 
recordings, they were in their late seventies, eighties, and - a few - in their nineties. With 'third generation,' I refer to the children of former miners, born between the late 1950s and the 1970s. When I talked to them, they were between 45 and 60 years of age.

\begin{tabular}{|l|l|l|l|}
\hline & $\begin{array}{l}\text { SECOND } \\
\text { GENERATION }\end{array}$ & $\begin{array}{l}\text { THIRD } \\
\text { GENERATION }\end{array}$ & TOTAL \\
\hline FEMALE & 17 & 7 & 24 \\
\hline MALE & 15 & 3 & 18 \\
\hline TOTAL & 32 & 10 & 42 \\
\hline
\end{tabular}

Table 1: Overview of participants in this study

As can be deduced from Table 1, 32 of the 42 participants belonged to the second generation and ten to the third generation. I interviewed and talked to 34 people: 24 females and 10 males. Because my initial concern was to find out more about the language use of the women born in the 1930s, and because most of the male speakers were recorded during sociolinguistic fieldwork, I did not interview an equal number of females and males. Out of these 42 participants, fifteen participated in the group recordings with females, three in the self-recording, and two in the translation task. The participants were chosen based on their link with the former mining community: except for one female participant, all second-generation speakers spent their childhood in Eisden as children of miners. Most of the women, including the participant who did not grow up in Eisden, were married to a former miner. Similarly, the 10 participants of the third generation, now adults, grew up in mining families in Eisden.

\section{Language Backgrounds}

The community is linguistically and culturally diverse. All second-generation speakers both women and men - grew up with (Belgian) Dutch and at least one other European home language, such as Hungarian, Slovenian, Polish, Italian, Portuguese, Czech, French, Austrian German, or Swabian, but usually this involved a dialectal variety of the language. Maaslands was generally acquired at a later stage (see $\S 2$ ). Participant observation revealed that some speak French in particular contexts, for instance with siblings. Finally, some community members learned the home language of their partner in adult life, in some cases to communicate with their parents-in-law.

The third generation grew up speaking Belgian Dutch and sometimes Maaslands. The home languages spoken by their parents were not always passed on to their children. It seems that Italian often continued to be spoken by subsequent generations, whereas languages with fewer speakers in the district, such as Hungarian, were rarely passed on. Most members of the community studied here were born and raised in Eisden, and they adopted the Belgian nationality. One female participant moved from Dutch Limburg to Eisden in the early 1960s. Another woman (now age 90) lived for many years in the United States and Canada before returning to Belgium. Furthermore, one female participant 
belonged to a family of treinmannen (miners who commuted by train) and settled later in Eisden, and two former miners were born in France but came to Eisden as young children.

\subsubsection{Participants in Sociolinguistic Fieldwork}

A total of 14 male speakers participated in the sociolinguistic fieldwork (primary data) between 2012 and 2016. Not all speakers who were recorded by Leonie Cornips in 2012/13 were present in 2015/16 and vice versa: two speakers passed away shortly after the first recording. Nine male speakers were recorded in 2012/13 and eleven in 2015/16, with most of these speakers being recorded more than once. At the time of the latest recording, they were between 77 and 84 years old. The figure below lists all speakers of Cité Duits, the language varieties they report to speak on a daily basis, the varieties they mention as home language(s) spoken in early childhood, and the rough number of recorded words in the Cité Duits corpus. I determined the latter based on fully-articulated words; hesitation markers and question tags were excluded from the count.

\begin{tabular}{|l|l|l|l|}
\hline SPEAKER & $\begin{array}{l}\text { LANGUAGES USED } \\
\text { DAILY NOWADAYS }\end{array}$ & $\begin{array}{l}\text { HOME LANGUAGES } \\
\text { 1930s }\end{array}$ & WORDS \\
\hline Jan & Belgian Dutch, Maaslands & Austrian German & 28000 \\
\hline Yanis & Belgian Dutch, Maaslands & Carpathian & 8900 \\
\hline Olaf & Belgian Dutch, Maaslands & Czech & 7900 \\
\hline Raf & Belgian Dutch, Maaslands & Italian & 7700 \\
\hline Ferenc & Belgian Dutch, Maaslands & Hungarian & 4200 \\
\hline Diego & $\begin{array}{l}\text { Belgian Dutch, probably } \\
\text { Maaslands }\end{array}$ & Portuguese, Italian & 3700 \\
\hline Victor & Belgian Dutch, Maaslands & Polish & \\
\hline Antonio & Belgian Dutch, Maaslands & Italian & 2300 \\
\hline Ralf & Belgian Dutch, Maaslands & Slovenian & 1300 \\
\hline Theo & Belgian Dutch, Maaslands & Polish & 1100 \\
\hline Josef & Belgian Dutch, Maaslands & Swabian & 1700 \\
\hline Vadik & Belgian Dutch, Maaslands & Polish & 650 \\
\hline Paolo & Belgian Dutch, Maaslands & Carpathian & 550 \\
\hline Tiano & Belgian Dutch, Maaslands & Italian & 350 \\
\hline
\end{tabular}

Figure 10: Overview of Cité Duits speakers who participated in sociolinguistic recordings (2012-2016)

The figure shows that the Cité Duits speakers grew up with a number of different home languages, whereas they generally speak Belgian Dutch and Maaslands nowadays. Several speakers also have knowledge of French but do not use it on a daily basis. The six most active speakers - the 'core speakers' - produced between 3,700 and 28,000 words, respectively. The quietest speaker who participated articulated around 170 words. These 
pronounced differences are partly related to the fact that certain individuals remained fairly silent, and partly to the fact that some of them contributed to all recordings over the years, whereas others were merely present once. A significant portion of the material was produced by one speaker with Austrian German as home language, adding an additional interesting layer to the analysis. Because I pursue the approach that there is no 'authentic speaker' (Eckert 2003), I included speakers of all home languages in the empirical analysis (see $\S 1.3 .2$ ). ${ }^{21}$ The possible role of variation in the data will be addressed in the frequency analysis in Chapter 5.

\subsubsection{Migratory Histories of Speakers}

This section gives insights into the migration histories of the families of the six core speakers of Cité Duits. I selected these speakers because they have the largest proportion of speech in the materials analyzed.

\section{Raf (1936-2018)}

Raf, son of an Italian mining family, was born in Eisden in 1936. Raf's father, together with his parents, left the Northern Italian province of Belluno around 1900, and the family would live and work in the Ruhr region until 1918. Because of the economic crisis in the region after the First World War, they returned to Belluno. Not for long, however. The extreme poverty in Italy forced them to emigrate again, this time to Belgium. They arrived in Eisden in 1926, where Raf's parents would meet and get married. They would have three children, two sons and a daughter, with Raf being the youngest. The father, however, who worked as underground miner all his life, died of silicosis at the age of 50 .

While the family spoke the Italian dialect at home, the children would speak Belgian Dutch in many other contexts. Raf later became fluent in French as well. He attended primary school in the Tuinwijk, followed by vocational training. At a young age, he worked for several years in the mine of Eisden, after which he found a job in a construction company in Liège, in the French-speaking part of Belgium. After his retirement (note that miners in Belgian Limburg could often retire around the age of 40), he and his wife returned to the Tuinwijk where they purchased a house. As mentioned, as a result of the Cultureel Akkoord, the mining companies started selling houses to former miners from 1967 onward ( $\$ 2.3$ ), usually at an affordable price. Raf died not long ago, after suffering a lung disease.

\section{Olaf (1934)}

Olaf grew up with Czech as home language, although his parents had Polish passports. With his brother he reports to have spoken Belgian Dutch, whereas he spoke Czech with both his parents. The migration trajectory of his parents was, as in many mining families,

21 The investigated community consists of people who feel associated with the former mining community, often based on a common childhood and adulthood in Eisden-cité (see $\S 1.3$ ). 
far from linear ( $\$ 2.2)$. In the 1920s, his parents first migrated to Northern France, where his father worked as underground miner. After a longer period of strikes, they decided to leave and moved to Eisden, where they became active members of the Czech community. The couple would have two sons, both born in Eisden.

Olaf attended primary school in the Tuinwijk. After the sixth grade, he chose to pursue vocational training to become a miner and then worked several years in the mine of Eisden. When the closure of the mine was announced, he was employed for a short period in a factory in Düsseldorf, after which he decided to continue his professional life in Brussels. He worked for different companies, in particular in the instruction industry. Olaf continues to live in Eisden-Tuinwijk in the former house of his parents.

Yanis (1938-2018)

Yanis grew up with his sisters and brother in the Tuinwijk, where he also went to school. The family of Yanis spoke Carpathian in the home context. The so-called 'Carpathians' were recruited by the mining companies in the 1930s, from a region were people were registered with different nationalities. Some people were officially Czechoslovakians, others had the Hungarian nationality. After the Second World War, this region became part of the Ukraine.

Yanis, similar to his father, began working in the mine at a young age, and spent all his professional life as an underground miner. In addition, he was on the local soccer team. Yanis continued living in Eisden-cité until his death in 2018.

\section{Jan (1936)}

Born in 1936 in Eisden, Jan grew up as son of Austrian parents who migrated to Belgium in 1925. His father belonged to a group of approximately 100 Austrian miners recruited by the mining company N.V Limburg-Maas in Eisden. The family would eventually have six children. Except for the oldest daughter who was born in Kainach, all children were born and raised in Belgium. In 1933, the family decided to move back to Austria. Yet, they quickly realized that the worldwide economic crisis had also affected Austria, and there were few employment opportunities, which soon forced them to return to Eisden.

As most mining families from abroad (see $\S 2.2 .2$ ), they received a tenement in the Tuinwijk, where their children would also attend school. While the language of instruction was Belgian Dutch, they spoke Austrian German in the home context. After the father died at the age of 52, the children had to work to ensure enough income for their family. One of the daughters started working in a factory in the area, and as soon as the youngest son turned 14 he started to work as an underground miner. As pointed out ( $§$ 2.2.2), at least one male family member had to work in the mine, or the family would lose various benefits tied to housing, education, and social security. Jan, being a few years younger, studied and became a teacher in the cité after acquiring Belgian nationality. $\mathrm{He}$ and his wife, the daughter of an Italian miner, had three children and continue to live in Eisden-cité. 
Diego (1936-2012) 22

Diego carried the nickname Portugeza ('Portuguese'), probably because this nationality was rare in Eisden's multicultural community. While his father came originally from Portugal, his mother was a member of the pre-war Northern Italian community in Eisden. Diego therefore grew up speaking (a dialect of) Italian, Portuguese, and Belgian Dutch. When Diego was eight years old, his father died as a resistance fighter during the Liberation Days of September 1944.

Although Diego attended school and leisure activities in the Tuinwijk, his family did not live in the district but in a mining house in the vicinity. After finishing school, he followed vocational school in Mechelen-aan-de-Maas, and then worked as underground miner in Eisden. He married an Italian woman with whom he had three children. After his retirement, he continued working in the construction industry. Until his death in 2012, he was an active member of the community of Eisden.

\section{Ferenc (1938)}

Ferenc's father came with a group of Hungarian miners to Eisden, recruited in the coal basin around Tatabanya in the late 1930s. His wife followed him with their four children in 1938. In the same year, Ferenc was born. As most miner's children, he attended primary school in the Tuinwijk. The father and his four sons would all eventually work underground.

While the family often spoke Hungarian, Ferenc and his siblings quickly learned Belgian Dutch. Apparently, Ferenc turned out to be an exceptionally good student and he enrolled in the College of Maasmechelen after primary education. Due to the lack of financial resources for further studies, he enrolled in training that would prepare him to be a mine surveyor. When the mining industry decided to reduce its activities in anticipation of its projected closure, this training stopped, and Ferenc joined the technical services department of the municipality of Maasmechelen, where he became a section manager. He also became the first secretary of the Heritage Foundation of Eisden. In addition, in the late 1950s, Ferenc joined the soccer club Patro Eisden, in a period when the team made it to the eredivisie, the highest level in Belgian soccer (see $\S 2.3 .2$ for soccer in the cité).

\subsection{Methods of Data Collection \\ 3.5.1 Sociolinguistic Fieldwork}

The linguistic analysis of this dissertation (§ 4-7) draws on data collected by a method of sociolinguistic fieldwork (Labov 1972; 2001). Leonie Cornips did the very first recordings in March 2012, as well as in October 2013, together with Peter Auer, resulting in roughly

22 I would like to point out that I never met Diego in person since he died unexpectedly in 2012. I have only the recordings of his voice. This information I derived from other community members and from what he reported during these recordings. 
200 minutes of recorded materials. I collected approximately 220 minutes of speech in 2015/16.

The aim of the employed method is to obtain speech data that is produced when speakers feel not being observed. We therefore conducted in-group recordings with small groups of well-acquainted male speakers, all of them born and raised in Eisden in the 1930s. These sessions were prearranged, as speakers did not get together anymore on a regular basis. To reduce their awareness of being recorded, we audio-recorded a limited number of speakers (four to eight speakers per group) with a dense network in an informal setting. We tried not to intervene, so that the speech of the group was influenced as little as possible. As pointed out, most recordings took place in the Museum van de Mijnwerkerswoning. This location was chosen because it has preserved the character of the early twentieth century, and a setting perceived as authentic may evoke a sense of the past among the speakers. The recordings had the character of an informal get-together and were usually accompanied by snacks and beverages.

In 2015/16, I recorded three sessions on several days and in different periods of the year. To facilitate data analysis (see $\S 3.6$ ), I video-recorded parts of the interactions (in total 98 minutes), which had not been done in 2012/13. Furthermore, the session in June 2016 took place at the home of one of the speakers and included speakers from earlier recordings, as well as a male speaker who emigrated in the 1960s from Eisden to California, but who maintained close social ties with family members and friends from Eisden-cité. $^{23}$

It should be emphasized that the recorded time is not equivalent to the available data for the final analysis. First, it would sometimes take a while until the speakers would interact in Cité Duits because they speak Belgian Dutch in daily life. Second, the recordings include the arrival of the speakers, an introduction in which they present themselves to the fieldworker (note that different constellations of speakers were recorded), and the participants' informed consent to being recorded. These interactions took place in Dutch, both with Leonie Cornips, a speaker of southern Netherlandic Dutch, and with me, a speaker of German. Yet during the recordings, once the men spoke Cité Duits with each other, they would only speak Dutch when directly addressing the fieldworker (or for quoting, see $\S 4.2 .1$ ).

\subsubsection{Group-recordings with Women}

To find out more about the language use of the women, I conducted five group recordings with females in groups of three to four speakers, including a total of 15 participants (six hours of recorded speech) (Figure 8). I reserve the term 'group-recordings' for the speech of the females throughout this chapter for clarity. One recording consisted of three women

${ }^{23}$ I initially aimed to analyze the speech of the participant from California. This endeavor, however, proved impossible because he turned out to be very quiet. Several community members migrated from Eisden to California, as well as to Canada, in the 1960s. At the time I began my fieldwork, however, most of them had passed away. 
who were in their fifties and early sixties at the time of the recording, one recording was an interaction of female speakers of different generations, aged approximately between 40 and 85, and three recordings took place between female speakers born and raised in Eisden in the 1930s. All women were married to a former miner (or widows), grew up as daughters and sisters in a family of miners in Eisden, and have known each other for many decades. Three recordings took place at the home of one of the speakers, one in the cafeteria of the parish hall, and one in a restaurant in a town at a distance of five kilometers from Eisden. While I applied similar methods as with the male speakers, it turned out to be difficult to overcome the observer's paradox, an aspect I address in more detail below (§ 3.5.8).

\subsubsection{Self-recordings}

Furthermore, I tried a method of self-recording that excluded the fieldworker (see Figure 8). This method involved that speakers received the audio recorder to record themselves in conversation with friends or family members, but in the absence of the fieldworker. Unlike in the famous dinner-conversation study by Tannen (2005 [1984]), I was not present myself. As such, I hoped to find out more about the language use of the women when talking to their husbands. In practice, however, it proved to be extremely difficult to find participants. One self-recording was carried out by a group of three, consisting of Victor (aged 79), his wife, and her brother in November 2015. Victor worked all his life as underground miner, mainly in Eisden and a short period in Waterschei, and one of his sons became a miner as well. Victor grew up with Polish and was an active member of the Polish community in his childhood. Nowadays he speaks Belgian Dutch at home. The parents of his wife and her brother came via the Ruhr region to Eisden in the 1930s. The group recorded 48 minutes of speech.

\subsubsection{Semi-structured Interviews}

Mainly between August and December 2015, but also between February and November 2016, I conducted semi-structured interviews with about 30 members of the community resulting in 18 hours of recorded speech (see Figure 8). Interviews were done with individuals and couples; one time their children and grandchildren spontaneously joined in. The interview length ranged from 20 minutes to one hour and a half. Next to recording most interviews, I took field notes to jot down observations, especially on what happened after and before I turned on/off the recording device. It happened, for instance, that I had just turned off the recorder when the phone rang, and the interviewee who had said to be speaking Dutch and Polish would engage in a conversation in French on the phone.

Interviews were done in the language(s) the speakers felt most comfortable with. Generally, this was Dutch, but in a few instances also German. During the interviews, I asked very broad questions and did not interfere, to give people the chance to tell personal anecdotes but also to make people feel more comfortable. Topics ranged from questions 
about language use in early childhood, adulthood, and the present, and when and where certain varieties were spoken, to growing up in the cité, traditions, work experiences, as well as leisure activities. I was careful to avoid potentially delicate topics, and did not ask directly about religious affiliations.

\subsubsection{Participant Observation}

The ethnographic method of participant observation was originally developed by anthropologists. The goal is to become part of the activities of the people being studied, so that the data reflects the point of view of the locals. In applying a bottom-up approach, the researcher gains the perspective of the researched. Participant observation requires a high degree of self-reflection, and often encompasses living in the community, learning the local language variety, doing informal observing such as 'hanging around,' participating actively in social activities, and taking detailed field notes (DeWalt \& DeWalt 2002: 1-3; Modan 2007: 9-15; Charmaz 2006: 21; for an overview, Atkinson \& Hammersley 2007; Scott-Jones \& Watt 2010). ${ }^{24}$

Nowadays, participant observation is increasingly integrated into qualitative research in sociolinguistics (Johnstone 2000: 80; Tagliamonte 2006: 20), ${ }^{25}$ and sometimes it is understood as a cover term for all types of observations and interviewing done by anthropologists (DeWalt \& DeWalt 2002: 1-4). In the present study, I used this technique mainly for interpreting the recordings from sociolinguistic fieldwork, as a means for understanding the social context of the speech. I would like to stress that unlike many anthropologists, I did not employ a bottom-up approach, and the collected data are perhaps less comprehensive (although contemporary ethnography tends to be less extensive or comprehensive than, say, a few decades ago; see the discussion in Johnstone 2000: 83$84) .{ }^{26}$

In 2015, over a period of five months (August-December), I commuted three days per week between my home in Maastricht and Eisden-cité. Some observations stem from 2016 and 2017 when I continued visiting Eisden (see Figure 8). I conducted observations in and around Eisden-cité, both at people's homes and in public. At the beginning, I chose to sit down at different cafeterias in the district and observe people who entered the place. I also spent time at the public service center, went to expositions, attended church service, and I was invited to the annual celebration of Saint Barbara Day on December 4. I further ensured to go to Eisden on different days. While most semistructured interviews took place on weekdays, I would sometimes visit Eisden on weekends as well, to attend specific public events. To keep records of my observations, I took field notes. After several weeks, once I was better acquainted with a number of

${ }^{24}$ Many anthropologists use insights from grounded theory. See Charmaz (2006) for a discussion. ${ }^{25}$ A well-known example is Penelope Eckert's study (2000) on students behavior in a high school in the US.

${ }^{26}$ My discussions with anthropologists revealed that there is no agreement on whether to use the term 'participant observation' in the present context or not. 
people, I was taken to places outside the cité, offered a ride to Maastricht or to the bus station. Four people in particular spent time with me on a regular basis. First, I was repeatedly invited at Jan's home and had the chance to talk to him and his wife on different occasions, and I also met his siblings and one grandchild. As mentioned, Jan grew up with Austrian German and his wife with Italian. Moreover, I repeatedly joined a friend of the family, who was a little younger (aged 66) and had worked in an administrative function of the mine for numerous years. He grew up with Belgian Dutch and started speaking Maaslands around the age of 20. Finally, I became well-acquainted with Adriana and spent much time at her house over the years. Adriana, a widow of a former miner (aged 78), grew up with Slovenian at home, after which she acquired proficiency in Belgian Dutch and Maaslands. She in particular provided insights into the diversity within the investigated community.

These observations did not so much provide additional data for my linguistic analysis but rather on the social context of the community. Cité Duits, as pointed out, has always been spoken in informal settings such as in the streets, but not in the home context, and not many speakers are left (see $\$ 2$ ). Situations in which speakers would use this language variety in a natural setting have become extremely rare today, if they still exist at all.

\subsubsection{Written Sources and Visual Materials}

\section{Written Sources}

In essence, Cité Duits has been used as on oral language variety rather than as a written means of communication. The only available primary source in written language is a text entitled Errinerunge wie ich noch klein wa... 'Memories of when I was little,' authored by one of the speakers. The complete text is provided in the annex. To maintain the original character of this document, I did not make any orthographical changes.

In addition, I consulted secondary sources (see Figure 8) to trace back the historical, economic, political, social, and linguistic background of the community, and to find information on the migratory countries, gender relationships, education, and the role of the church. I therefore scrutinized archive files stored by the Stichting Erfgoed Eisden and collected letters, e-mails, newspapers, magazines, and flyers of cultural events. Another valuable source was the magazine Eisden, which has been published four times a year since 1983 .

\section{Visual Materials}

To a limited degree I also gathered visual materials such as photographs as part of my data collection (see Figure 8). Photographs can reveal a lot about the linguistic resources used by the community and the power relationships within it, and they represent a potential 
way of uncovering social realities (Ben-Rafael et al. 2006: 9). ${ }^{27}$ I took pictures of the research setting as long as no people could be seen on them, such as, for instance, of public signs, names of streets, posters, buildings, and in the miner's museum. Aside from the linguistic resources that individuals and institutions use in the public domain, I was curious to find out more about possible changes that occurred over the past decades.

\subsubsection{Translation Task Dutch-Maaslands}

As part of the linguistic analysis, I examined to which extent Cité Duits resembles the local dialect Maaslands, preferably as spoken by speakers born in the 1930s. Although much research has been devoted to the group of Limburgish dialects (Vandekerckhove 2009; Cornips 2013; Hermans 2013; De Schutter \& Hermans 2013; Belemans \& Keulen 2004), literature on the dialect as spoken in Eisden and on progressive aspect ( $\$ 7.4$ ) seemed limited. The databanks DynaSAND (Dynamische Syntactische Atlas van de Nederlandse Dialecten) (Barbiers \& al. 2006) and MAND (Morfologische Atlas van de Nederlandse Dialecten) (Goeman et al. 2014) proved to be very useful for variation across Dutch dialects, and in the case of Eisden so-called Dialectzinnen are available (Van Keymeulen 2018). Nevertheless, it turned out that these do not provide enough information on the relevant grammatical structures.

To get a clearer picture of Maaslands, I asked two speakers to perform a translation task from Dutch to Maaslands (see Figure 8): one female speaker born in 1938 and one male speaker born in 1937. These individual sessions took place on several days in September, October, and November 2016 at the home of the speaker involved. Based on questionnaires, I instructed the speakers orally to translate sentences from Dutch to Maaslands, while I recorded their speech. The questionnaires, which comprised translations of and judgments on test sentences, had been used in an earlier project by Marjo van Koppen ('Diversity in Dutch DP Design,' March 2005 until January 2009). In addition, I created one translation task with relevant sentences myself.

\subsubsection{Evaluation of Data Collection}

The combination of methods enabled me to grasp the 'larger picture' and find out more about the linguistic resources of the community members. To gather the linguistic data analyzed for this dissertation, I relied on a sociolinguistic fieldwork method. Importantly, speakers appreciated being recorded, which is perhaps in part tied to the negative stereotyping of the mining profession in the past. That they were eager to participate and were pleased by my attention for their language certainly made it easier for me to gather data. Although they were aware of being recorded, they tended to ignore the presence of the recording device quite quickly. By recording a limited number of participants with a

27 The method of Linguistic Landscape has been proved to be a useful instrument for exploring language and measuring its dynamics within a territory (Modan 2007; Backhaus 2007; Ben-Rafael et al. 2006; Cenoz \& Gorter 2006). 
close social network and creating an informal environment in a location that reminded them of their past, it was possible to obtain data of Cité Duits.

The large number of semi-structured interviews contributed much to my understanding of the community. In some instances, interviewees were joined by family members and I had the chance to observe how they interacted with each other. Spending time at the home of the interviewees also gave me insights about the language choices they made regarding media, such as television, newspapers, and books. In a similar vein, written and visual materials such as photographs helped me at the initial stage of my research to gain a comprehensive understanding of how the district changed linguistically and culturally over the years.

During participant observation, I found out much about the situation of females and what it meant to grow up as a child of an immigrant miner. Regularly spending time with four community members raised my awareness of the diversity within the investigated community, in particular as to the various and distinct life trajectories people have chosen. This also allowed me to observe which language varieties speakers use in different contexts. While Jan and his wife would speak Belgian Dutch at home, including with their grandchild, Jan often spoke Maaslands with neighbors and friends. His wife does not speak the dialect. With her sister, she often speaks French, since both of them attended the French school, and with Italian acquaintances I observed her speaking Italian. Adriana, in turn, speaks Belgian Dutch and Maaslands with neighbors and friends, and Slovenian with Slovenian friends and Slovenian association members. She continues visiting family members in Slovenia every year in August. In addition, she has a passive knowledge of German, which she uses mainly for reading. But my observations did not yield more data on Cité Duits, which has always been spoken in informal settings only. Aside from the fact that few speakers are left, the specific social contexts for speaking Cité Duits have (virtually) disappeared (see $§ 2.4$ ).

Some of the methods I used came with drawbacks. In conducting grouprecordings in small groups of women, I aimed to uncover whether Cité Duits was spoken by girls/women at all. Although I applied methods similar to the ones I used during my sociolinguistic fieldwork, the women often seemed to want to accommodate to the fieldworker. Inevitably, this had a strong impact on the type of linguistic data I received. From my observations in their home context, I knew that they were all fluent in several languages. In turn, when being recorded, women usually spoke Belgian Dutch. The only exceptions were instances of inter-sentential code-switching to Italian or French. Codeswitching, however, has a variety of functions (see $\S 1.3 .3 ; 4.2 .1$ ) and it proved difficult to determine here whether the participants spoke 'freely' or rather performed for the fieldworker.

As a result, the group recordings do not provide any evidence that women speak Cité Duits or a variety resembling Cité Duits. The same holds for the self-recording: while the two male speakers interacted in Cité Duits, the woman would respond in Belgian Dutch. There are at least two possible interpretations: either the method of gathering spontaneous-like interactions failed, or the method was successful to the extent that the 
results show that these women do not speak Cité Duits but rather communicate in Belgian Dutch. Both seem to be the case to some degree. On the one hand, it proved a challenge to (partly) overcome the observer's paradox, despite the fact that some speakers would interact more freely than others and ignore my presence. On the other hand, observations and semi-structured interviews suggest that Cité Duits has always been confined to male speakers, whereas female speakers were rather the exception.

Finally, although the oral translation task from Dutch to Maaslands involving two speakers of the dialect worked out well, I want to emphasize that findings based on the language use of two single speakers must be regarded with some caution. The recorded answers only reflect what speakers claim to do, but not what speakers actually do (Labov 1966) when speaking the dialect. Furthermore, these results provide no indication of the actual frequency of use of the linguistic features involved. Some may be systematic, whereas others may occur only sporadically (Cornips \& Poletto 2005; see Milroy \& Gordon 2003: 51-53 for the (dis)advantages of questionnaires) (see also § 7.4).

\subsection{Transcription and Data Analysis}

In this section I elaborate on the methods of data analysis and reflect on the transcription practices. In addition, I provide details on further corpora and software systems used for the analysis.

\subsubsection{Transcribed and Analyzed Data}

For this dissertation, I transcribed all audio recordings from sociolinguistic fieldwork (2012-2016). In the remaining audio materials, I transcribed only those parts relevant to the analysis. Due to the large amount of data, the recordings of semi-structured interviews, the self-recording, the translation task, and the group recordings (in total approximately 25 hours of speech) were not fully transcribed. In the sociolinguistic recordings, interactions in Dutch with the fieldworker occurring at the beginning of a session were transcribed but excluded from the empirical analysis. The aim of this study is to analyze the language use of the speakers within their group, not the interactions with the fieldworker. About 340 minutes of recorded speech (5.7 hours) served for the empirical analysis of Cité Duits, with roughly 135 minutes from the audio recordings from 2012/13 and 206 minutes from 2015/16.

It must be emphasized that working with data from spontaneous-like interactions implies that transcribing takes a considerable amount of time. The researcher needs to figure out what is being said while different speakers talk simultaneously, but also who is saying what. Transcriptions of Cité Duits require much more time than of a corpus where language boundaries are clear-cut. It took approximately ninety minutes (1.5h) to transcribe one minute of spoken Cité Duits.

Some of these difficulties could be slightly reduced by filming parts of the interactions. While transcribing the early recordings from 2012/13, I noticed that a 
particular challenge consisted in identifying the voices of the individual speakers, especially in situations of voice-overlap. To facilitate data analysis, I decided to conduct video recordings. The video material was not transcribed separately but served as a helpful tool for analyzing the audio material, since videos include non-verbal interactions and clarify who talks to whom (see Meyerhoff et al. 2012: 144). Furthermore, I re-transcribed all 2012/13-recordings. Initial transcriptions were carried out by different transcribers (students) based on distinct conventions, and were subject to tremendous variation. The linguistic analysis of this dissertation (§ 4-7) contains all available speech data of Cité Duits. Only my analysis of inter-speaker variation is confined to the six 'core speakers,' because in most other cases there is not enough data available for a comprehensive analysis of the speech.

\subsubsection{Transcription Conventions}

Transcriptions in this dissertation follow the GAT 2 conventions by Selting et al. (2009) (Gesprächsanalytisches Transkriptionssystem 'Conversational-analytic Transcription System'). ${ }^{28}$ The phonetic transcriptions in Chapter 5 follow the International Phonetic Alphabet (IPA). Examples are numbered by chapter and accompanied by an English translation. Since this dissertation contains a large number of examples, I only provide glossing when necessary, based on the Leipzig Glossing Rules by Comrie et al. (2015). An overview of all abbreviations and transcription conventions is provided at the beginning of this dissertation. I chose the GAT 2 conventions because they are easy to read, which renders this dissertation and the speech examples more easily accessible to non-linguists. GAT 2 follows a number of Jeffersonian principles, but comprises some conventions which are more compatible with linguistic and phonetic analyses of spoken language, in particular for the representation of prosody (for details on transcriptions, see $\S 3.6 .5)$.

\subsubsection{Further Corpora and Databanks Used for Analysis}

Some features found in spoken language do not exist in written language or have a different frequency distribution, which means that spoken language corpora must be considered for the linguistic analysis (§ 4-7). For colloquial spoken German, I used the corpus Dialektintonation, compiled by the linguistics departments of Prof. Peter Auer and Prof. Margret Selting for the project Untersuchungen zur Struktur und Funktion regionalspezifischer Intonationsverläufe im Deutschen ('Studying structure and function

${ }^{28}$ The systematic establishment of linguistic transcription conventions started in the late 1960s and 1970s when research on spoken language corpora gained increasing attention (Wagener \& Bausch 1997: XIII; Thüne 2007: 12). Well-known are the conventions by Sacks et al. (1974), and Jefferson (2004). In addition to GAT 2, German linguistics often uses the Halbinterpretative Arbeitstranskription (HIAT) 'Semi-interpretative Working Transcriptions' by Ehlich and Rehbein (1976). 
of regional-specific intonation patterns in German'). The accessed data consists of informal interviews of approximately 1-1.5 hours per recording with mainly older male speakers gathered in six German cities - Berlin, Dresden, Mannheim, Cologne, Munich, and Freiburg - between 1998 and 2002. The interviews were carried out with speakers of dialectal and standard varieties of German, with a total of eight to ten speakers from each place.

In addition, I drew on a corpus consisting of interviews with nine former miners from Duisburg (Ruhr region). These recordings, conducted in the 1980s under the direction of Arend Mihm, consist of informal interviews with participants who were about the same age as the Cité Duits speakers (aged 63-70) (see Salewski 1998: 21-22 for details). They had been living in Duisburg for several decades and were retired at the time of recording. In some recordings the former Duisburg miners were joined by their wives. These interviews, however, have a slightly more formal character than the data of Cité Duits, with the fieldworker intervening regularly. They were fully transcribed already, based on the orthographic conventions for German.

For Dutch and Maaslands, I used in particular the online tool DynaSAND, the Dynamische Syntactische Atlas van de Nederlandse Dialecten (Barbiers \& al. 2006), developed for exploring syntactic and morphological microvariation of Dutch dialects, and sometimes the database MAND, the Morfologische Atlas van de Nederlandse Dialecten (Goeman et al. 2014). DynaSAND comprises a database, a search engine, a cartographic component, and a bibliography. The audio data is derived from three rounds of interviews from 2000 and 2003; the first round employed written questionnaires (393 test sentences) and was carried out in 321 locations in the Netherlands and Belgium; the second round involved an oral questionnaire (100 sentences); and the third round consisted of telephone interviews (331 sentences).

DynaSAND can be accessed online and searched for keywords, tags, lemmas, and location codes. The recorded data is transcribed, tagged, and linked to the corresponding sound file, which allowed me to listen to the relevant examples. While the databank provides extensive information on a large number of varieties of Dutch, which as such was suitable in particular for investigating where particular phenomena occur, it should be emphasized that none of the data is derived from informal speech. Because DynaSAND hardly contains audio material of informal face-to-face interactions but focuses on pre-fabricated test sentences, the frequency of occurrence of the respective features remains unclear. ${ }^{29}$

\subsubsection{Annotation Software and Programs}

While there are a number of suitable programs for compiling, managing and analyzing spoken language corpora, I transcribed the recordings with the Multimedia Annotator

${ }^{29}$ The databank only contains a few recordings of spontaneous speech from Dutch Brabant (access September 5, 2019), see http://www.meertens.knaw.nl/sand/spontane_spraak/. 
ELAN. I chose ELAN because time-alignment works extremely well and because the annotations are compatible with a number of other annotation systems and can easily be transferred. In a second step, to systematically tag or label the transcriptions, I exported the annotations from ELAN to MOCA (Multimodal Oral Corpora Administration). Furthermore, for cutting short sequences, I employed Audacity®.

\section{Multimedia Annotator ELAN}

The Multimedia Annotator ELAN is a tool for the creation of complex annotations of video and audio materials developed by the Max Planck Institute for Psycholinguistics in Nijmegen. An annotation may consist of a single word, a gloss, a longer sentence, a comment, or a translation. Annotations can be created on multiple layers, so-called tiers, which may be hierarchically interrelated. The figure below illustrates how an annotation in ELAN may look like.

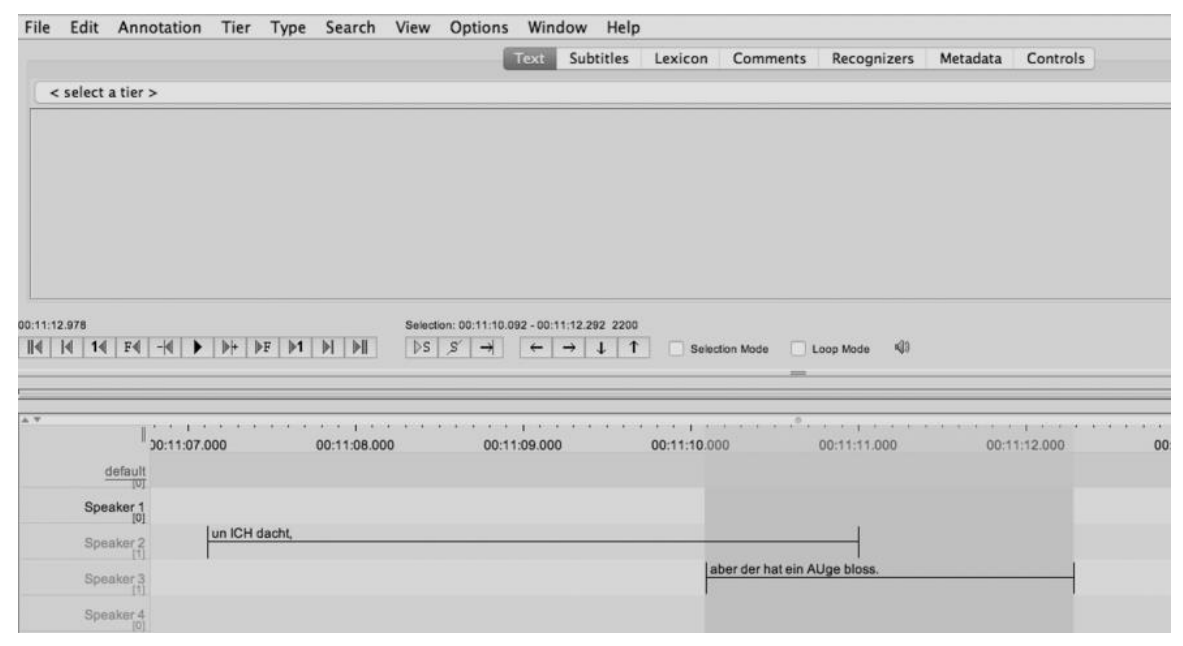

Figure 11: Screenshot of ELAN

In order to transcribe the recordings, I time-aligned the annotation to the respective audio file, which allowed me to re-listen to utterances or single words as many times as I wished. ELAN allowed me to select short stretches of speech, marked grey in the figure above. Furthermore, I was able to link several tiers to each speaker for glosses or translations.

\section{Multimodal Oral Corpora Administration (MOCA)}

I used MOCA, an online system for the administration of spoken language corpora developed by the University of Freiburg, to manually tag the transcribed data. MOCA stores audio recordings and the accompanying transcripts, which can then be accessed 
through an internet browser ${ }^{30}$ MOCA enabled me to search within the entire corpus for individual linguistic features, which resulted especially useful for the analysis of personal pronouns and of progressive constructions. While tagging the utterances, I re-transcribed where necessary. In addition, MOCA allowed me to listen to utterances directly preceding and following an utterance. This was in particular useful when tagging the data for third person pronouns, given that the respective antecedent could not always be deduced from the utterance itself ('he' > ?'the cat/the boy') Figure 12 illustrates how the search page of MOCA may look like. Potentially delicate information has been made invisible.

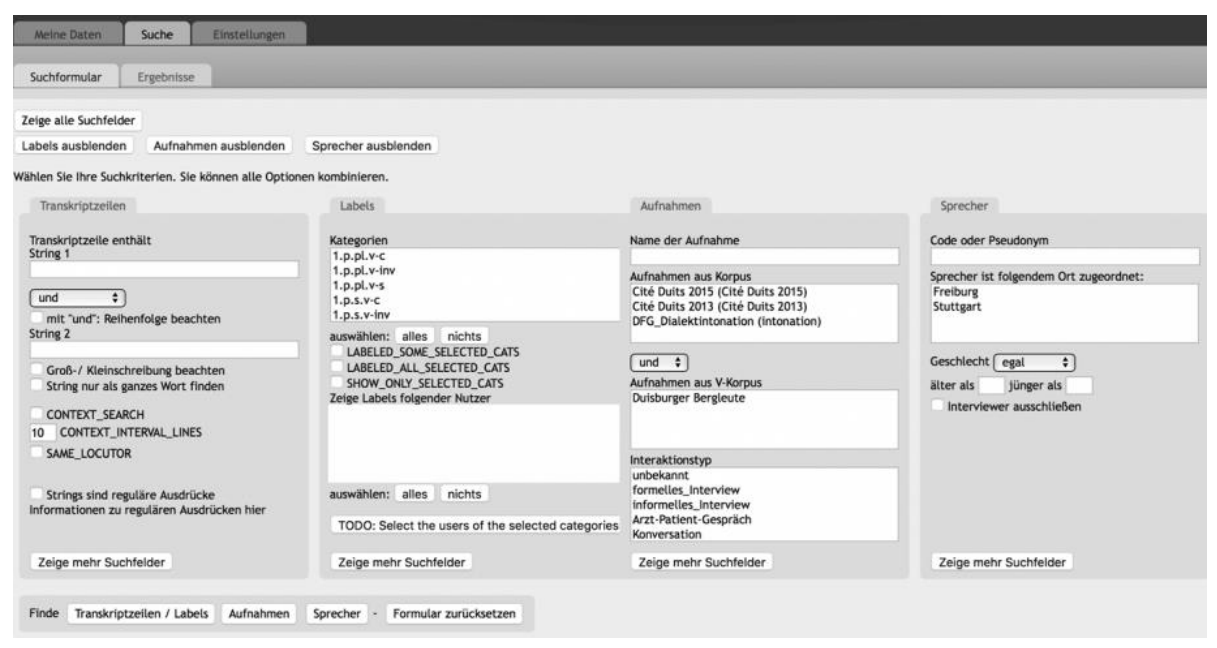

Figure 12: Screenshot of MOCA search form

For the linguistic analysis, I developed 56 categories and labeled every utterance in the corpus manually. As such, I was later able to conduct a fine-grained search by filtering the data automatically. Searches in MOCA can be confined, among other things, to one particular recording, one speaker, and a particular label (or several). The subsequent figure shows how a search may look like.

\footnotetext{
${ }^{30}$ While MOCA also enables structural administration of sociolinguistic metadata (e.g. setting of a recording, individual speakers etc.), I did not include this information.
} 


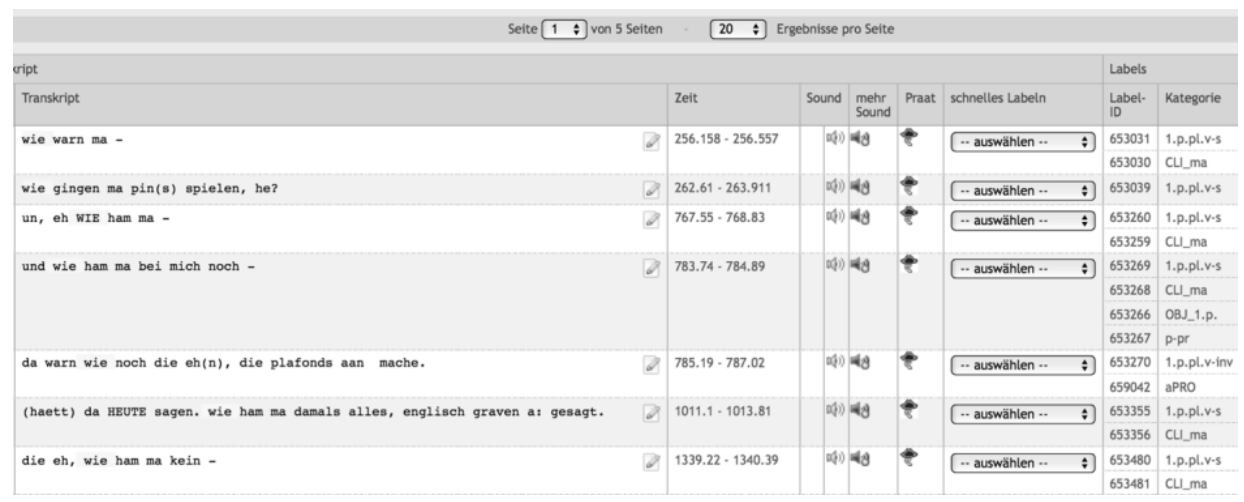

Figure 13: Screenshot of resulting search in MOCA

The advantage of tagging the corpus was that I could detect 'unexpected items,' that is words used in a grammatical function other than in the contact varieties. Instead of searching for specific forms such as gij 'you,' I identified all variants produced by the speakers for a respective pronoun. Tagging the data a priori guaranteed that I would not only end up with the forms that I expected to find. ${ }^{31}$

\section{Audacity®}

For trimming audio recordings, I worked with Audacity®, an open-source audio editor and recorder. For this work, I used version 2.2.2 of Audacity® recording and editing software. ${ }^{32}$ Figure 14 below represents a waveform view in Audacity of a sequence of 1.8 seconds.

${ }^{31}$ See $\S 5$ for details, in particular regarding the variants for the first-person plural and second-person plural.

32 The name Audacity ${ }^{\circledR}$ is a registered trademark of Dominic Mazzoni and distributed under the terms of the GNU General Public License, copyright (c) 1999-2019 Audacity Team; https://audacityteam.org/. 


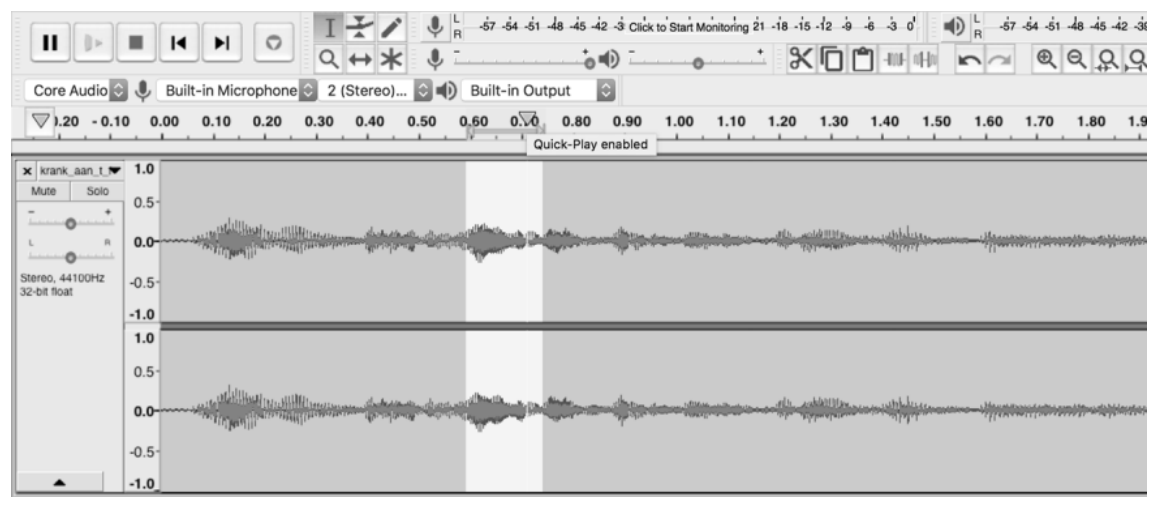

Figure 14: Screenshot of waveform view in Audacity

By zooming in, I could select, cut, and export extremely short sequences such as single vowels. I employed the software to elicit short sequences for the perception test, and for listening to individual sounds that were difficult to identify. After elicitation, I exported the new file as MP3. As such, one could listen to the sequence without being influenced too much by the preceding and following sounds.

\section{Challenges in Annotations}

During the process of annotating in MOCA, especially for personal pronouns, I faced a number of challenges. First, pronouns are short words and may appear as part of a syllable within another word. For example, Dutch azijn 'vinegar' contains the Dutch pronoun zij 'she,' and German immer 'always' contains the German pronoun er 'he.' I solved this issue by inserting a space, including at the beginning of an utterance. Second, some lexical items are spelled the same way as pronouns but have different grammatical functions. For instance, wie serves as first person plural subject pronoun ('we') but also as (adverbial) conjunction meaning 'how' or 'as' in Cité Duits. By checking the results manually, I prevented such instances from being counted as personal pronouns, which was feasible due to the comparably small size of the corpus. Third, the antecedent of a pronoun was not always deducible from the conversation, or an utterance was not clearly audible due to voice-overlap, which forced me to categorize some forms as 'unclear.'

\subsubsection{Reflections on Linguistic Transcriptions}

Transcribing is an ongoing and selective process. The discrepancy between an 'objective transcription' and the interpretative decisions made by the transcriber has perhaps most vividly been expressed by Bucholtz (2000), who calls for more awareness in transcription practices: 


\begin{abstract}
The choices made in transcription link the transcript to the context in which it is intended to be read. Embedded in the details of transcription are indications of purpose, audience, and the position of the transcriber toward the text. Transcripts thus testify to the circumstances of their creation and intended use. As long as we seek a transcription practice that is independent of its own history rather than looking closely at how transcripts operate politically, we will perpetuate the erroneous belief that an objective transcription is possible. (Bucholtz 2000: 1440)
\end{abstract}

That an objective transcription is impossible or highly difficult to achieve, as observed by Bucholtz, poses a challenge for the transcriber. During the first transcription phase, I developed my research questions based on the findings that emerged. This 'open transcript' was the starting point of the analytical process. Only in a second step, I retranscribed the relevant data based on predefined research questions, involving the selection of how and what to transcribe ('closed transcript') (Jenks 2013).

While transcription conventions provide guidelines regarding the form, as a transcriber I made a number of interpretative decisions such as whether to include unintelligible background voices and laughter, and whether the transcribed text should reflect the oral character of the speech (Bucholtz 2000; 2007; Jenks 2013; Jaffe \& Walton 2000; Ochs 1979). Transcriptions involve choices about the content (what is transcribed) and the form (how is it transcribed) (Bucholtz 2000: 1441), and both levels have an impact on the resulting transcript. Forming two extremes on a continuum of practices, a 'denaturalized transcript' obeys the principles of literacization, whereas a 'naturalized transcript' displays the oralness of the utterances. Yet while the former runs the risks of ignoring parts of what is actually said in the recording, the latter may be less accessible to readers unaccustomed with transcription practices (Bucholtz 2000: 1461). Similarly, a naturalized transcript bears the risk of encouraging stereotypical views of the speakers represented (Jaffe \& Walton 2000). For the transcriptions in this work, I carried out a rather naturalized transcription. The GAT 2 conventions were insofar suitable as they strive for a flexible approach.

Naturally, Cité Duits has no spelling conventions. Yet for the aims of the linguistic analysis, I needed a comprehensive and consistent transcript. To maximize traceability in the corpus, I decided to use the orthographic rules of German as much as possible. In line with the GAT 2 conventions (Selting et al. 2009: 360), words that could clearly be associated with another language than German and do not exist in spoken German were transcribed according to the respective spelling rules. Accordingly, words that could be associated with Dutch were transcribed according to Dutch orthography when they did not exist in German (e.g. paaseieren 'Easter eggs,' see German Ostereier). For the Maaslands dialect, I followed the conventions of the dialect organization Veldeke (Bakkes et al. 2003). Because there is sometimes word-internal mixture and boundaries are unclear, using both spelling conventions would have resulted in too many inconsistencies. Although closely related, Dutch and German differ in their orthography. From my experience of different students transcribing the data, I noticed that the palatalized fricative in German Speck / $\mathrm{p}$ ek/ 'bacon' was generally transcribed as /s/ by 
German but as /sj/ by Dutch transcribers. Likewise, a number of words are pronounced in a similar way in Dutch and German but spelled differently (noch/nog 'still'), or spelled in the same way but carry a different meaning and grammatical function ( $e r$ 'there'/'he'). This implies that words that can be associated with German and Dutch such as 'then,' spelled dann in German and dan in Dutch, follow German spelling in this dissertation. This approach enabled me to systematically search the transcript.

Another aspect that challenged a purely objective transcription concerns perception. What different listeners perceive is often influenced by the languages they speak. From my experience, the distinction between German mir 'me' and mich 'me' remained largely unnoticed by the Dutch transcribers. In other instances, familiarity with the community was required for the transcriptions (Torres Cacoullos \& Travis 2015: 372). The more time I spent in Eisden-cité, the better I became acquainted with the community. In re-transcribing the corpus, I achieved the degree of consistency that was necessary for the analysis. Due to voice-overlap, however, there are still passages that cannot be fully transcribed.

Naturally, I am as susceptible to my language background as any other transcriber. In order to prevent a language bias, I collaborated with three students who were speakers of Belgian/Netherlandic Dutch. The students transcribed parts of the corpus and I discussed the transcriptions with them individually. In addition, selected parts of the 2012/13-recordings were transcribed by Leonie Cornips and Peter Auer in collaboration (see Auer \& Cornips 2018). This allowed me to compare transcriptions of speakers of different language backgrounds. Finally, I would like to highlight that, in particular when working with mixed-language corpora, there is no sole version of a transcript. To some degree, the transcriptions in this work remain influenced by my own perceptions.

\subsubsection{Reflections on Data Analysis}

In this section I would like to highlight additional aspects related to the analysis of the primary data. I have outlined already some challenges that arose in the process of annotating and transcribing. A further difficulty with data of spontaneous-like interactions is that the quantity of tokens is not always sufficient in the data set to conduct a comprehensive analysis of a particular feature (see e.g. § 4.4 .5 on passive). Certain features were only attested once or twice. In addition, the full range of variants is not always available, as in the case of verbal inflection ( $\$$ 4.3.7) (see also Cornips 2002; Cornips \& Poletto 2005). Moreover, it can be difficult to determine whether individual tokens of a particular feature are the result of fast speech, instead of being systematic.

Likewise, there is no guarantee as to how many words an individual speaker produces. The amount of speech of the participants differs considerably, ranging from speakers who barely say a word to others who do most of the talking, which means that there is relatively sparse data for some informants. Consequently, unlike data from experimental settings in which each participant completes the same task, the data is less 
comparable. ${ }^{33}$ For particular features, the quantity of tokens varies extensively from speaker to speaker.

In order to find out whether particular features occur systematically in the corpus or not, I investigated their frequency distribution. Personal pronouns proved suitable in particular because they are highly frequent in the corpus. I identified a total of about 5,700 instances of personal pronouns $(\S 5,6)$. In contrast, progressive constructions or contexts associated with the progressive are comparably rare (see $§ 7$ ). Finally, comparing the Cité Duits corpus to other data sets and to results from previous studies requires much caution. Features of informal spoken language as identified in Cité Duits do not necessarily occur in formal language or may show a completely different distribution.

\subsection{Perception Test}

This final section describes the format, aims, and results of a speech perception test that I carried out as part of my analysis. Speech perception research aims at understanding how listeners recognize speech sounds and translate this information into meaningful units in spoken language. Yet multiple factors determine the way speech is perceived. On the one hand, speech production, such as the rate of speech, influences whether listeners can recognize speech sounds. Recordings of Cité Duits, where the speech rate varies from speaker to speaker, are therefore more difficult to perceive than carefully articulated speech produced in a laboratory. On the other hand, the recognition of sounds is subject to context effects and co-determined by other sounds in its immediate environment. Furthermore, certain sounds are associated with the same place of articulation (e.g. labial, alveolar) and may be difficult to differentiate for particular listeners. In addition, listeners are often biased by their home language(s) (for a survey see Mitterer \& Cutler 2006; for spontaneous speech see Mitterer \& Tuinman 2012). ${ }^{34}$ As mentioned, to prevent a language bias as much as possible, listeners of distinct home languages contributed to the transcriptions of the data.

\subsubsection{Background and Aims}

In my analysis of personal pronouns $(\S 5,6)$, I found that Cité Duits has a number of variants of the first-person plural subject pronoun 'we.' Due to their resemblance, they can be hard to distinguish, especially in allegro-speech. Most crucially, I identified a variant perceived as wie [vi:]. To find out how this variant was perceived by other listeners next to myself and the student transcribers, I conducted a perception test with four Dutch

\footnotetext{
${ }^{33}$ See also the contributions in Gudmestad and Edmonds (2018) for reflections on the analysis of 'spontaneous' speech data.

${ }^{34}$ Speech perception research is most widely used in the fields of phonology/phonetics and cognitive psychology. For example, it tries to find out how listeners distinguish two words that differ only in a single phoneme, such as 'word' from 'bird.' See Mitterer and Tuinman (2012) for a study on informal speech perception of German learners of Dutch.
} 
and three German raters in April and May 2018. The aim was to find out how the listeners perceived the wie-forms and whether they could identify them as belonging to a variety of Dutch or German.

\subsubsection{Test Design and Raters}

For the test, I sought 50 ratable examples of the first-person plural pronoun from the corpus of Cité Duits, produced by different speakers. I made sure to include different realizations (e.g. wie, wir, etc.). 'Ratable' means that the selected sequences were clearly audible without any voice overlap. Because speakers often talk at the same time in the recordings, many sequences resulted unsuitable. In a second step, I elicited these forms together with the preceding or following word with Audacity. To prevent a bias toward one of the contact varieties, I did not include longer sequences of more than four words. About half of the selected examples were pronouns before the finite verb ('we have') and about half of them after it ('have we'). In those utterances where the pronoun occurred in enclitic position I included an additional syllable.

Seven raters between 25 and 37 years of age with either German or Dutch and/or Limburgish as home language participated in the perception test. All four Dutch participants had a perceptive or active knowledge of German, and all German participants of Dutch. All of them had a university degree and were also fluent in English. Three participants came originally from Germany and had either lived for a longer period in a Dutch-speaking country (more than seven months) or had a Dutch-speaking partner and Dutch-speaking children. One of the German raters had been living for more than six years in Dutch Limburg. For the four Dutch raters holds that three of them grew up with both Limburgish and Dutch, and one with Dutch only. The Limburgish raters came from different parts of Dutch-Limburg and were therefore acquainted with different varieties of Limburgish.

The perception tests took place individually, according to the availability of the respective participant. The raters received the 50 short audio sequences in MP3-format and a numbered Excel-spreadsheet with the transcriptions of the audio fragments. The pronominal forms were substituted by a dummy $\mathrm{x}$ (e.g. betalen $\underline{x}$ sechstausend 'pay $\underline{\mathrm{x}}$ six thousand'). One example was provided. I instructed the raters to listen to the audio fragments carefully and indicate on the Excel-spreadsheet whether they heard a Dutch, German, or Limburgish pronoun. The instructions were provided in written form (in English) and discussed orally (either in Dutch or German). Because the volume, speed, and voices of the sequences varied, I suggested raters to listen to every example several times.

\subsubsection{Results}

The results show that the seven raters were able to identify the forms produced as wir [vi:e] and we [wə], but not those produced as wie [vi:]. Regarding the form wie [vi:], raters 
often opted for the language that they were least acquainted with. That is, Germans tended to categorize the pronominal forms as Limburgish and in a few instances as Dutch, whereas Dutch raters suggested that these forms may belong to 'a variety of Limburgish, but not to the variety spoken at home.' One rater found that none of the wie-forms could be categorized and put a question mark into the corresponding fields. This suggests that the raters were unable to associate the wie-variants with a familiar language variety.

These findings are interesting for several reasons. First, the test confirms my assumption that there is variation in the use of this pronoun, and that speakers use numerous pronominal forms for the first-personal plural pronoun. Second, the results indicate that the form wie [vi:] in Cité Duits cannot be clearly associated with a variety of German or Dutch. Third, the home languages of the listeners did not have a decisive effect on the classification of these pronominal forms. All raters expressed similar difficulties regarding the categorization of the wie-forms, irrespective of whether they had acquired German, Dutch or/and Limburgish as home language (see $\S 5,6$ for details).

\subsection{Summary and Concluding Remarks}

In this chapter I accounted for the methods of data collection and analysis. Data collection for this study took place in Eisden-cité, in a community of second-generation immigrants born in the 1930s, as well as their children. The linguistic analysis in this dissertation (§ 4-7) is largely based on primary data gathered by a method of sociolinguistic fieldwork between 2012 and 2016, but I will occasionally refer to a written document in Cité Duits as well. Part of the primary data was collected by Leonie Cornips and Peter Auer. For compiling the secondary sources (2015-2017), I conducted semi-structured interviews, participant observation, a self-recording, collected written documents and took photographs. This combination of methods enabled me to gain a profound understanding of the sociohistorical background and the linguistic resources of the community. In addition, I carried out a translation task from Dutch to Maaslands ( $\$ 3.5$ ). A total of 42 participants contributed to this study, with 14 Cité Duits speakers being recorded during sociolinguistic fieldwork. My overview of the migration histories of the families of the six 'core speakers' of this study - those with the largest proportion of speech in the corpus exemplified the diverseness in life trajectories of the community members $(\S 3.4)$.

In the first part of this chapter I focused on all aspects related to the data collection. First, I reflected on my role as researcher and the effect of the gatekeeper on the participants and the linguistic material ( $\$ 3.2$ ). Entering the community via a gatekeeper brought along a number of benefits, such as being allowed to interview people in their home environment. Yet being introduced by one person to all participants also bears the risk of missing out relevant information. This I tried to solve by adhering to the snowball principle, implying that participants introduced me to further members of their social network. In a similar vein, dealing with human subjects always involves ethical dilemmas (§ 3.3). I demonstrated that ethics begin already before data collection (in understanding the fieldwork site), and continue during it (in treating people with respect) 
but do not stop after data collection has been finished (in treating all data carefully and making the results available to the community).

Furthermore, I reflected on how I as a researcher affected the fieldwork location and the research process. In particular, I discussed to which extent my German language background influenced the Cite Duits of the speakers. To prevent speakers from being accommodating to my language use (e.g. Bell 1984), I spoke Dutch during sociolinguistic fieldwork. Likewise, I assessed in how far the recording device played a role. To obtain data of spontaneous interactions is an almost impossible endeavor in present-day linguistics' research. Speakers must be informed of being recorded, and this generally impacts the recorded material. While we employed a number of techniques to reduce their awareness of being recorded (Labov 1972), data collection was facilitated by the speakers who were eager to participate and pleased by the attention they received. Although speakers knew that they were being recorded, it was possible to create an informal setting and record them when speaking Cité Duits with each other.

Regarding the compilation of the secondary data, especially the semi-structured interviews, I outlined the potential risks involved in carrying out conversations in a language not being my home language (Belgian Dutch), but I also argued that stressing linguistic difficulties can yield richer linguistic descriptions by participants. In my final evaluation, I discussed the reasons for some methods being successful and others less so. While most methods worked out well, in particular the recordings of Cité Duits with the male speakers, but also the semi-structured interviews, I argued that the group-recordings with female speakers had their drawbacks because females tended to accommodate to the researchers' language use.

The methods of data analysis were central to the second part of this chapter ( $§$ 3.6-3.7). I will briefly summarize the main points. For the linguistic analysis, I employed a speech corpus of former miners from Duisburg, and a German corpus consisting of informal interviews with speakers of dialectal and standard varieties of German gathered in six German cities. For Belgian Dutch and Maaslands, MAND (Morfologische Atlas van de Nederlandse Dialecten) (Goeman et al. 2014) and the online tool DynaSAND (Dynamische Syntactische Atlas van de Nederlandse Dialecten) (Barbiers \& al. 2006) resulted extremely useful. In addition, three software systems facilitated the transcription and analysis of the empirical data: Multimedia Annotator ELAN, the MOCA system for the administration of spoken language corpora, and Audacity for eliciting audio sequences. I also addressed the benefits and difficulties associated with tagging and analyzing the data.

An important aspect of the analysis of Cité Duits form the transcriptions of the audio data. I showed that linguistic transcriptions do not only pave the way for the analysis but likewise form a substantial part of the analysis itself. Transcribing is about being faithful to the spoken discourse and at the same time making decisions on how much detail is relevant. An objective transcription, however, is almost impossible to achieve since the transcriber's beliefs unavoidably enter the transcript (Bucholtz 2000; 2007; see also Jenks 
2013; Jaffe \& Walton 2000; Ochs 1979). Cité Duits has no spelling conventions, yet orthographic conventions were necessary for the present analysis to achieve consistency in the final transcript. For this dissertation I decided to follow the GAT 2 conventions by Selting et al. (2009), largely based on the orthographic conventions of German. Dutch orthography was used for all words that could clearly be associated with Dutch and do not exist in German. For the transcriptions of personal pronouns in Chapter 5 I will further use the International Phonetic Alphabet (IPA). While I re-transcribed the entire corpus of Cité Duits for the 'closed transcript' based on my research questions, three students who were speakers of Dutch contributed to the 'open transcript' (Jenks 2013). This approach ensured that the resulting transcript was not too much biased by my own language background.

Finally, I conducted a speech perception test on the first-person plural pronoun wie. Because speech perception is influenced by numerous factors, I wanted to find out how other listeners perceived this form. The results show that the raters, irrespective of whether they had German or Dutch/Limburgish as home language, were unable to categorize this form. This confirms my assumption that speakers of Cité Duits produce a 'different' variant (see $\S 5,6)$.

I conclude this chapter with some words of caution on the analyzed data. Even though Cité Duits developed in the 1930s, the analysis is based on the Cité Duits as spoken at the time of writing. To my knowledge, there are no recordings available from the period of its emergence. Given the limited longitudinal evidence-base available to me, I cannot assess the degree to which the speech of the miners has changed over the course of the time. Over the years, the speakers have become less mobile and do not get together anymore on a frequent basis to speak Cité Duits. The analyzed recordings can thus be said to be a reconstruction of their language use. In a similar vein, there are only few speakers left, and the findings are based on the language use of these remaining individuals. 


\section{Chapter 4: Some Linguistic Features of Cité Duits}

[W]hen human creativity comes into play, there are no discernible linguistic limits to the possibilities for transferring any linguistic feature from one language to another. (Thomason 2001: 11)

\subsection{Introduction}

In the previous chapter I addressed the reasons behind the methods of data collection and analysis, also by outlining the challenges and opportunities that presented themselves in the efforts involved. From this point onward, I will concentrate on the linguistic features of Cité Duits. This chapter, which sets the stage for this study’s empirical analysis ( $\$ 5$ 7), discusses several preliminary insights into the linguistic character of Cité Duits in the domains of lexis, morphology, and syntax. Although much research has been devoted to the outcomes of language contact of Germanic language varieties (Nützel \& Salmons 2011; Putnam 2011; Boas 2016; Clyne 2003; Shah 2007; Maitz \& Németh 2014; Wiese et al. 2017b; Boas \& Höder 2018; Louden 1992; 2011), no systematic linguistic analysis has been conducted of the language use of the former miners from Eisden. This chapter and the subsequent chapters specifically concentrate on utterances such as those in (1): ${ }^{1}$

(1) (0313_152448: 491.2 - 494.815, Yanis)

01 und GUT.

02 und wie hamma da geARbeit_da:,

03 und auf einmal wart maLET.

01 and well.

02 and we have (there) worked there,

03 and suddenly it was lunch time.

This short sequence contains many lexical items that can be associated with spoken German, such as und 'and' (line 01-03), auf einmal 'suddenly' (line 03), $d a$ 'there' (line 02), and gut 'good/well' (line 01). Likewise, it holds for the participle gearbeit 'worked' (line 02) that the /g/ in the syllable onset is a stop and realized according to German phonology. In turn, malet 'lunch' (line 03) has its origin in the mining vocabulary of the Kempen, whereas the finite verb wart 'was' (line 03) can be associated with spoken

\footnotetext{
${ }^{1}$ I took the freedom to use lower case instead of upper case for nouns (e.g. Stuhl > stuhl 'chair') in the running text, because readers unacquainted with German orthography seem to stumble on these examples. For transcription conventions, as well as glossing and translation practices, I refer the reader to $\S 3.6$.
} 
Belgian Dutch. At the same time, however, not all words can be easily traced back to one particular language. This is the case, for example, with $d a$ 'there,' which is not only close to German but also to Belgian Dutch daar and Maaslands doa 'there.'

Because the linguistic outcomes of language contact are conditioned by factors related not only to the structures of the language varieties involved, but also to the social circumstances under which they emerged (Thomason \& Kaufman 1988; Weinreich 1953), language contact can take many paths. ${ }^{2}$ Many scholars agree, however, that some aspects of language are more susceptible to change than others. Generally speaking, lexis and phonology tend to be rather easily subject to change under the influence of language contact. In contrast, syntax and morphology are said to be less vulnerable (on borrowing hierarchies, see Haugen 1950; van Hout and Muysken 1994; for other relevant discussions see also Thomason 2001: 63-77; Sankoff 2004; Heine and Kuteva 2008; 2010). It can thus be expected that lexical items and phonological features are taken over by multilingual speakers earlier than morphological features and syntactic structures, which are assumed to remain more stable. ${ }^{3}$ This in particular makes these latter two domains interesting to study.

In this chapter, I am concerned with the question of which linguistic features are characteristic of Cité Duits (RQ2). My focus will be on lexis, morphosyntactic, and syntactic features. To limit my scope, I chose to exclude phonology, even though I will touch on phonological aspects whenever relevant. Based on an examination of specific examples, I aim to unravel some relevant aspects related to the linguistic character of this speech. The selection of features is largely based on frequency of occurrence. ${ }^{4}$ Apart from the audio data derived from sociolinguistic fieldwork, I include evidence from a written document by one of the speakers (see annex for the complete document), henceforth marked as (w). To illustrate the extent to which the speech resembles or differs from its 'contact varieties," I will compare the data to informal spoken Belgian Dutch, the Limburgish dialect Maaslands, and German. Due to the fact that different varieties of German provided the input for Cité Duits, which cannot all be considered here, I will use informal spoken German and Ruhr-German as basis for comparison, the latter because it has been a possible source (see $\S 2.2$ ). Moreover, when dealing with the lexicon, I will show that speakers employ lexical items that can be traced back to other, non-Germanic language varieties.

\footnotetext{
${ }^{2}$ Naturally, social forces do not directly affect the linguistic structures but rather the ways in which speakers use these linguistic resources (Sankoff 2004).

${ }^{3}$ But see the discussion by Corrigan (2010) with regard to syntax. While it is expected that vocabulary is 'borrowed' easier than structural elements, Thomason (2001: 63-69) proposes that principally anything can be borrowed. According to Heine and Kuteva (2008: 69-73), this does not necessarily hold for structural borrowing/grammatical replication, which is normally unidirectional. ${ }^{4}$ I will ignore features that occur only once or twice.

${ }^{5}$ When using the term 'contact variety,' I refer to the varieties with which Cité Duits has been in close contact. Some authors also speak of 'source languages.'
} 
This chapter, which consists of three main sections and a discussion, is structured along the following lines. After a survey of the lexicon ( $\$ 4.2)$, I examine morphological and morphosyntactic features $(\S 4.3)$, thereby elaborating on the formation of diminutives, determiners, plurals, possessive pronouns, adjectives, and negation markers ( $\$$ 4.3.14.3.6), as well as on verbal inflection, participles, prepositional phrases, and the use of the Dutch adverbial pronoun er in Cité Duits (§ 4.3.7-4.3.10). In section 4.4, I turn my attention to syntax, beginning with the V2-constraint ( $\$$ 4.4.1). Typically, Germanic languages - except English - are verb-second languages (V2), which implies that the finite verb remains in second position and is preceded by exactly one constituent in declaratives (Sudhoff 2010: 10). Specifically, I consider whether the V2-constraint also applies to Cité Duits. Next, I assess the position of the finite verb in clauses introduced with weil 'because' ( $\$ 4.4 .2)$, followed by an examination of the use of the verbal bracket ( $\$ 4.4 .3$ ), the order of verbal elements in the two-verb cluster (\$ 4.4.4), and passive voice (§ 4.4.5). Finally, I look more closely to the infinitival complementizers $u m \ldots z u$ and für...zu 'for ...to' ( $\$ 4.4 .6)$, as well as to constructions with komme 'come' and bleibe 'stay' combined with a bare infinitive as complement ( $\$ 4.4 .7)$. In the concluding section 4.5, I discuss the main findings that emerged from this overview, also as a way to set the stage for the ensuing empirical analysis.

\subsection{Lexicon}

At first sight, Cité Duits' lexicon resembles informal German. A closer look, however, reveals that numerous lexical items can (also) be associated with Belgian Dutch and Maaslands (for historical contact in the lexicon of present-day Dutch, see Gooskens et al. 2010; van der Sijs 2005; see Franco et al. 2019 for an analysis of loanwords in the Brabantic and Limburgish dialects of Dutch). As alluded to above, it is not always possible to determine the exact origin of a given word. An example is provided in (2). Subsequently, relevant items appear underlined.

(2) (0313_152448: $204.895-208.915$, Jan $)^{6}$

01 CoGnac mit ein ei und dann;

02 und dann dann wirs du STARK.

03 der hat $\overline{\mathrm{AUCH}}$ in bouveau gearbeit.

01 Cognac with an egg and then,

02 and then you will become strong.

$03 \mathrm{He}$ also worked in the gallery.

\footnotetext{
${ }^{6}$ This utterance alludes to one of the rumors circulating within the group of young miners: to become strong, they told each other to regularly drink cognac with an unboiled egg.
} 
While many lexical items in (2) resemble German, the words $e i$ 'egg' and dann 'then' in the first line and the preposition in 'in' in the third line also resemble Dutch $/$ Maaslands. Accordingly, these words cannot unambiguously be traced back to one particular variety. In contrast, bouveau 'gallery' originates from the French-Walloon mining terminology, referring to a passageway that runs down a slight slope to the shaft, used for instance for mine wagons. In this section I will first outline how I deal with longer stretches of speech in 'other' languages; next, I examine the use of words associated with the mining vocabulary of the area; and finally I review a number of words of non-Germanic origin.

\subsubsection{Code-switching in this Study}

Although the present study is not concerned with code-switching, I will briefly outline how I deal with it, given that instances of switching also occur in the data set. What constitutes a borrowing or a code-switch depends much on the classificatory framework that is taken (see $\S 1.3 .3$ ). It is true, of course, that this distinction constitutes an analytical simplification because some cases may belong to both categories (e.g. Treffers-Daller 1994: 75). In the present work, I treat longer stretches of speech as in (3) and (4) below as 'code-switching.' French appears in italics, Dutch in bold, and Cité Duits unmarked. Rather than being syntactically integrated, the switched clauses are often highlighted by intonation and pauses, and they appear mainly with reported speech and sometimes for addressing the fieldworker.

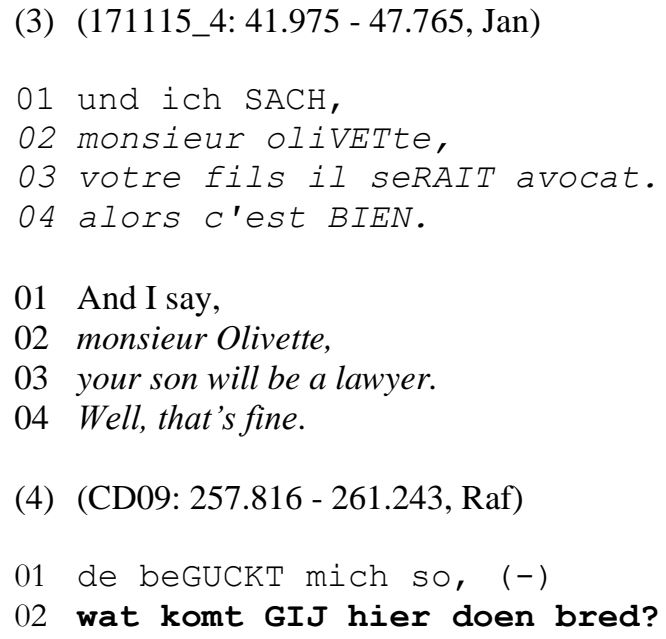

01 He looks at me,

\footnotetext{
${ }^{7}$ I use the notion 'Dutch' as a cover term to refer to Dutch as spoken in Belgium and the Netherlands.
} 


\section{2 what are you doing here, Bred?}

In example (3), the speaker switches from Cité Duits to French, whereas reported speech is overtly marked by ich sach 'I say' (line 01). In (4), the speaker switches from Cité Duits to Belgian Dutch for reported speech. Here, the intonation and the short break in line 01 reveal that the speaker quotes a third person. In the corpus, these (few) switches generally carry conversational functions and occur at clear prosodic and syntactic boundaries of the clause in the sense of Auer (1998a). In the linguistic analysis, then, I will not deal with longer stretches of speech that can unambiguously be identified as pertaining to other languages, as in (3) and (4). That speakers who are fluent in several language varieties are able to switch between languages has been demonstrated by much previous research. This study, in turn, deals with the linguistic features employed by the speakers when speaking Cité Duits, but not when speaking French, Italian, or Belgian Dutch.

\subsubsection{Mining Vocabulary}

As in other language varieties that emerged in the context of mining (Mesthrie 2019; Muysken 2019; Álvarez López 2019; Braber 2019), either as working language underground or in a large range of social contexts, the lexicon of Cité Duits reflects the mining terminology of the area (Defoin 1962; van de Wijngaard \& Crompvoets 2006; see also Delbroek 2016) ((5), (6)):

(5) (171115_3: 517.255 - 520.944, Ferenc)

01 ja: un DANN,

02 bei DINge,

03 maar von vatter keZEM abgetrokke.

01 And then,

02 (at things),

03 father's salary was subtracted.

(6) (0313_152448: 233.5 - 235.2, Yanis)

01 piQUEUR,

02 ich war immer piQUEUR.

01 Chipping hammer,

02 I was always [responsible for the] chipping hammer.

Further mining terminologies that are used in Cité Duits include bouveau 'gallery' (example (2)), malet 'lunch' (example (1)), ouvries 'workers,' conducteur 'supervisor,' 
marqueur 'miner who measured distances,' porion 'controller,' maneuver 'untrained worker' (from French manœuvre), boutefeu 'shotfirer,' bougement-sleutel, a type of tool, and chef taai, the latter being a nickname for a low status job in the mine. Loan translations of mining terminologies, in turn, are less common. The term fünfte ('fifth'), lexically resembling German, is used in some instances (from French cinquième), referring to a common form of punishment, which involved losing a fifth of the daily salary (example (26) below).

Almost all mining terminologies are nouns of French-Walloon origin, which is unsurprising given that the higher staff was required to speak French in the mine (Delbroek 2009: 208) (see $\S 2.3$ ). ${ }^{8}$ Nouns are also the most frequently 'borrowed' word class in other contact settings (Treffers-Daller 1994: 123; Poplack 1980; Gardner-Chloros 2010: 195). In Cité Duits, these nouns have become phonologically integrated, which is visible in (5). The term kezem 'salary,' has its origin in French quinzaine 'fifteen.' Incidentally, the spelling kezem is also found in the literature (Delbroek 2016: 131). It is relevant to emphasize, however, that French loanwords are widely used in Dutch across a number of semantic fields (van der Sijs 2005). Mining terminologies of non-French origin are less typical; examples are the German word Schraube 'screw'9 and the Dutch terms opzichter 'controller' and put 'pit.' Regarding the latter, it is possible that a 1952 agreement requiring the use of Belgian Dutch in the mine played a role (see $\S 2.2$ ).

\subsubsection{Non-Germanic Words}

Further non-Germanic words in Cité Duits developed in contact with the home languages of the speakers ( $\$ 3.4)$ and are of Slavic (i.e. Czech, Polish), Romance (usually Italian, French) and Hungarian origin. In utterances (7) and (8), japka and gruszkis can be associated with Polish jabłko 'apple' and gruszka 'pear.' In (9), schiski seems to resemble Polish szyszka 'fir cone' and schosko can be associated with Hungarian sóska 'herring.'

(7) (231115_3: 1304.007 - 1306.31, Ferenc)

01 JAPka, dat haben VIEL gesagt.

01 Many people said 'japka.'

(8) (231115_3: 1296.942 - 1301.022, Jan)

01 (für) BIRne,

02 GRUSZkis hamma gesagt.

${ }^{8}$ Although Belgian French differs in a number of aspects from French as used in France (TreffersDaller 1994: 27), these differences are irrelevant here.

9 The term possibly has a metaphorical function. Gehl (2009: 122) mentions the term Schraube 'screw' as referring to a person with a penchant for doing technical jobs. 
01 For pear,

02 we always said 'gruszkis.'

(9) (CD04: 306.755 - 332.34, Jan)

01 gehste mit naa(r) BUSCH,

02 SCHISkis rafen un SCHOSko esse?

03 DAT hamwa gesagt.

04 SCHISki war polnisch,

05 un SCHOSko war ungarisch.

01 Do you go to the forest

02 to collect fir cones and to eat herring?

03 That's what we said.

04 'Schiski' was Polish,

05 and 'schosko' was Hungarian.

Yet, a number of these words also resemble other Slavic languages such as Russian, where 'fir cone' translates as шишка (shishka), 'apple' as яблоко (jabloko) and 'pear' as груша (grusha). ${ }^{10}$ This suggests that the exact origin of a word cannot be fully determined. Unlike the French mining terminologies, which seem to function for filling 'lexical gaps' (Hickey 2010: 15), these words have mainly been attested on the metacommunicative level as contributing to the social character of the speech: speakers actively engage in discussions on the presumed origin of these words; e.g. (9) dat hamwa gesagt. Schiski war polnisch, un schosko war ungarisch 'that's what we said. 'Schiski' was Polish and 'schosko' was Hungarian.'

In addition, speakers use these words for puns, which form a crucial part of the discourse. ${ }^{11}$ Extract (10) is a joke about an Italian and a Polish man who collide on their bikes. The punchline is that Italian curva 'bend' resembles Polish kurwa, a pejorative term for 'prostitute.'

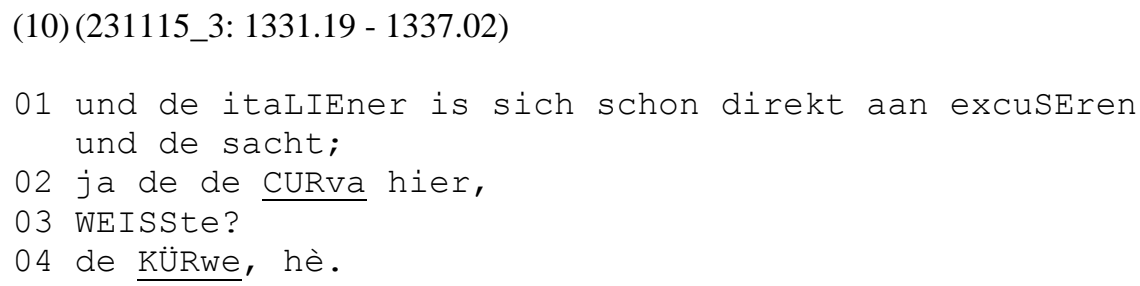

10 Thanks to Yulia Clausen.

${ }^{11}$ Speakers also employ gestures or other non-verbal forms of communication (e.g. head movement) for puns. A comprehensive analysis of puns is beyond the scope of this dissertation. 
01 And the Italian is already apologizing, and he says,

02 the 'curva' here,

03 do you know?

04 the 'kurwa.'

In summary, the lexicon of Cité Duits much resembles informal German, but also Belgian Dutch and Maaslands, with the boundaries often being fluent. Lexical items from the French-Walloon mining vocabulary are frequent in the speech and often have no equivalent. These differ from words of Slavic, Hungarian, and Romance origin, which generally appear in metacommunication.

\subsection{Morphosyntax}

By examining various types of morphosyntactic phenomena, I will show in this section that Cite Duits shares several features with Belgian Dutch, (Ruhr-)German, and the Limburgish dialect Maaslands. While some features can be associated with a particular language variety, I argue that others are rather the result of a fusion of features from the contact varieties. Because I aim to provide a general understanding of the nature of the speech, I will not treat these domains in great detail. Rather, I restrict this overview to examples characterizing each of these domains.

\subsubsection{Diminutives}

Diminutive formation in Cité Duits follows the Belgian Dutch/Limburgish/Ruhr-German pattern. In Limburgish dialects, which are used throughout the southern part of the Dutchspeaking language area in Belgium, and also in the German dialects in the Ruhr, the most common diminutive suffix is -(e)ke (De Schutter \& Hermans 2013: 360; Hinskens 1996: 136; for an overview of diminutives in Belgian-Limburgish, see Belemans \& Keulen 2004: 57-58; see also Belemans 2007 for central Limburgish). This suffix is also used in Cité Duits, both for nouns and adverbs. Standard German, in turn, uses -chen or -lein (Eisenberg 2013: 260-61) and Netherlandic Dutch -je(s) (Broekhuis 2013a: 310 for exceptions).

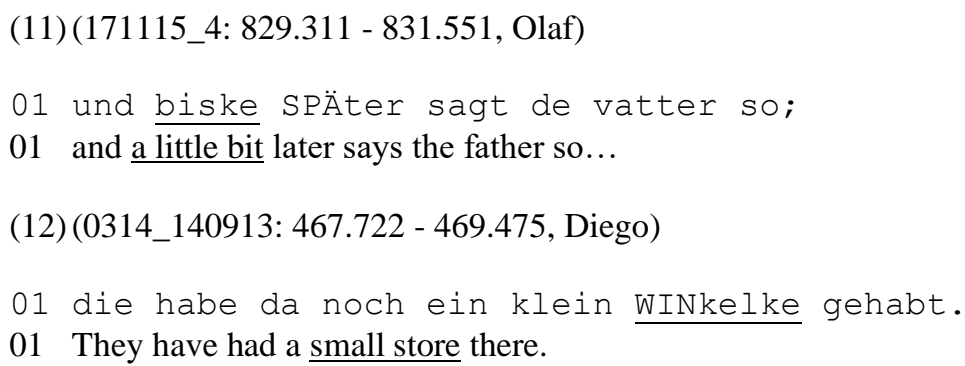




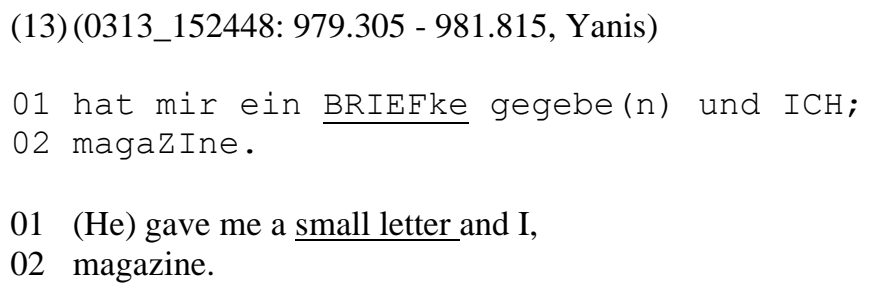

01 (He) gave me a small letter and I,

02 magazine.

In the examples above - such as biske 'a little bit,' winkelke 'store,' and briefke 'letter' diminutive formation follows the Belgian Dutch/Limburgish/Ruhr-German pattern. In my corpus I did not identify any diminutive suffixes resembling standard German -chen or lein or Netherlandic Dutch je(s).

\subsubsection{Plural Formation}

In Belgian Dutch and Limburgish, the most widespread plural suffixes for nouns are $-s$ and $-e(n)$; however, as word final $-n$ deletion is widespread across the whole Dutchspeaking language area, plural is often expressed by a final schwa. In total, there are four plural suffix types in Belgian Dutch and Limburgish, although these differ in terms of their lexical distribution (De Schutter \& Hermans 2013: 358). In German, in turn, where case and gender is marked on the noun, the plural can take a variety of suffixes including -n/en, $-e,-r / e r,-s$, or no ending at all. In Cité Duits, case and gender are usually not marked on the noun, but plural marking behaves in ways that are similar to Belgian Dutch/Limburgish. ${ }^{12}$ Four patterns can be distinguished in Cité Duits: (1) schwa ending (spatze 'sparrows'), (2) zero ending (fenster 'windows'), (3) -(e)n ending (strassenlampen 'street lights') and (4) -(e)s ending (perzikes 'peaches,' duitschers 'Germans'). Consider these two examples ((14), (15)):

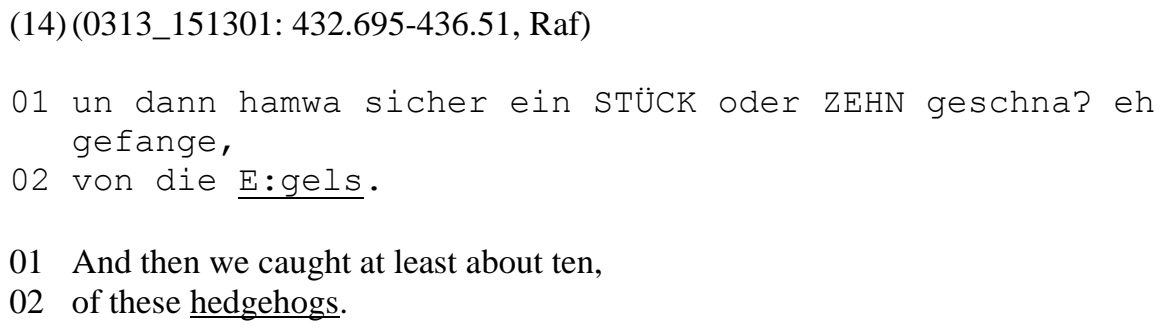

01 And then we caught at least about ten,

02 of these hedgehogs.

(15) (0313_151301 269.55 - 272.925, Yanis)

\footnotetext{
${ }^{12}$ Limburgish, in contrast to Belgian Dutch/German, also has tone contrasts for singular-plural distinctions (De Schutter \& Hermans 2013: 357-58).
} 


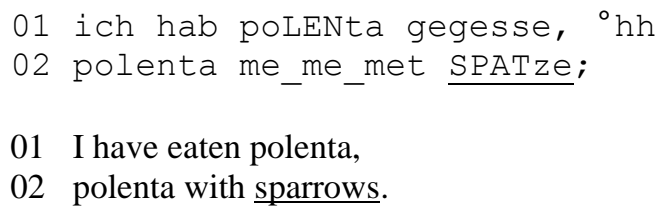

The -s suffix is also added to German-sounding nouns that would not require a plural suffix in German, such as engländers 'Englishmen' (see (28) below), which would have a zero suffix for nominative case in German (compare German plural Engländer). Furthermore, words with plural-schwa are sometimes subject to umlaut in Cité Duits, as in German (e.g. Bäume 'trees'), and therefore they differ from Limburgish, where plurals that end in schwa never have umlaut (De Schutter \& Hermans 2013: 359).

\subsubsection{Determiners}

While Belgian Dutch and Maaslands do not distinguish case but rather have a two-way $(d e, h e t)$ and three-way (de, $\partial t, d e n)$ gender distinction, respectively, German marks case on the definite article (der, die, das, den, dem) and indefinite article (ein, eine, einen, einem, eines). In Cité Duits, case is normally not marked: the indefinite article in Cité Duits is realized as ein (examples (12), (13) above), similar to the German masculine/neuter indefinite article ein and the Belgian Dutch/Maaslands indefinite article een. The singular definite article is generally $d e(r)$ (examples (11) above, (16) below), corresponding to Belgian Dutch/Maaslands (de) and to the German (der) masculine definite article (Auer \& Cornips 2018; see Belemans \& Keulen 2004: 45-47 for determiners in Belgian-Limburgish). Accordingly, the neuter definite article het as used in Belgian Dutch is normally not used in Cité Duits. This implies that nouns that require the neuter article in Belgian Dutch, Maaslands, and German - such as het huis/'t huus/das Haus 'the house' (see example (49) below) - likewise receive the article de. Moreover, in line with a number of German dialects (Werth 2017; Duden 2009: 398) and southern Dutch dialects (Broekhuis \& Keizer 2012a: 20), proper names are frequently preceded by the definite article, as illustrated below.

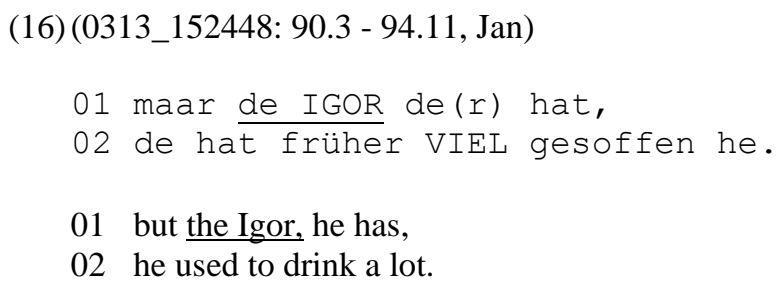

According to the Duden (2009: 398) for German grammar, the use of definite articles preceding personal names is becoming increasingly common in spoken German, 
suggesting that this feature is not particular to Cité Duits but rather found in a wide range of regional varieties of German ${ }^{13}$ (as well as in certain southern Dutch dialects). Furthermore, speakers employ die for demonstratives and plurals, which is homophonous with the definite German feminine and plural article, as well as with the Belgian Dutch/Maaslands demonstrative and relative pronoun. Crucially, unlike in Belgian Dutch and Maaslands, Cité Duits has a number distinction in definite articles (Auer \& Cornips 2018). At the same time, Cité Duits shows considerable flexibility as to whether an article is realized or not. After prepositions, for example, it is often obligatory to mark the definite article in the contact varieties, but this is not always realized in Cité Duits, an aspect I will discuss in more detail below $(§ 4.3 .9)$.

\subsubsection{Possessive Pronouns}

While the paradigm of possessive pronouns remains incomplete in the data, the attested variants strongly resemble German with some structural simplifications. Likewise, there is overlap with Belgian Dutch and Maaslands. For instance, the variants 'my' and 'his' correspond both to German mein/sein and to Belgian Dutch mijn/zijn (and show similarities with Maaslands) and cannot be analyzed as going back to one single language variety (Auer \& Cornips 2018). An example is the following:

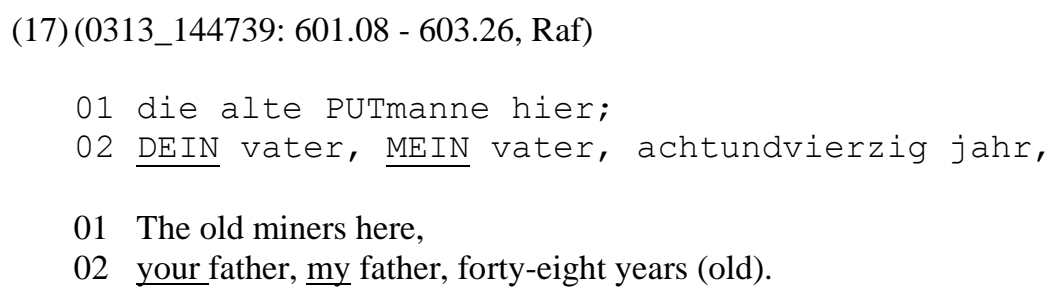

Figure 15 below illustrates the use of possessive pronouns in Cité Duits compared to its contact varieties. In German, the suffix is determined by the respective case (nominative, genitive, dative, accusative), and in Maaslands by gender. In Dutch, in turn, gender and number is only marked on the first-person plural in neuter nouns (compare ons boek 'our book,' onze pen ' 'our pen,' and onze boeken $P L$ 'our books') (Broekhuis \& Keizer 2012a: 7).

\begin{tabular}{|l|l|l|l|l|}
\hline & $\begin{array}{l}\text { CITÉ } \\
\text { DUITS }\end{array}$ & GERMAN & DUTCH & MAASLANDS M/F \\
\hline 1SG & mein & mein/e/es/er/em/en & mijn & $\begin{array}{l}\text { mi-jne(n)/mi- } \\
\text { jn/men(en) }\end{array}$ \\
\hline
\end{tabular}

\footnotetext{
${ }^{13}$ According to Werth (2017), this use is especially widespread in Middle- and Upper German varieties.
} 


\begin{tabular}{|l|l|l|l|l|}
\hline 2SG & dein & dein/e/es/er/em/en & jouw & di-jne(n)/di-jn/den(en) \\
\hline $\begin{array}{l}\text { 3SG. } \\
\text { M }\end{array}$ & sein & sein/e/es/er/em/en & zijn & zi-jnen/zi-jn/zen(en) \\
\hline 3SG.F & (ihr(e)) & ihr/e/es/er/em/en & haar & (h)äöre(n)/ (h)äör \\
\hline $\mathbf{1 P L}$ & unse(re) & unser/e/es/er/em/en & ons/onze & ooze(n)/oos/òze(n)/os \\
\hline 2PL & - & euer/e/es/er/em/en & jullie & eure(n)/eur \\
\hline 3PL & - & ihr/e/es/er/em/en & hun & (h)unne(n)/(h)un \\
\hline
\end{tabular}

Figure 15: Possessive pronouns in Cité Duits compared to Belgian Dutch, Maaslands, and German

As visible from Figure 15 above, the forms used by the speakers are mein 'my,' dein 'your,' sein 'his' and unse(re) 'our.' The feminine possessive pronoun ihr 'her' is extremely rare in the data, indicated by the brackets. Reliable instances of the secondperson and third-person plural are unattested (note that there is voice-overlap in the data, making it sometimes difficult to identify the respective form). Unlike in German, case is generally not marked on possessive pronouns:

$$
\text { (18) (0313_155010: } 111.017 \text { - 116.648, Yanis) }
$$

01 un sacht de conducteur zu sein FRAU,

01 And the supervisor says to his wife,

In (18), the possessive pronoun 'his' in the utterance $z$ u sein frau 'to his wife' would require dative case and thus -er suffix in German ( $z$ u seiner Frau), whereas it remains unmarked in Cité Duits (zu sein frau) (for a similar example, see (50)). Plural is rarely marked. In addition to the pattern depicted in Figure 15, speakers use definite noun phrases with the preposition von 'of' as in (19) to indicate possession:

(19) 0313_144739: $23.831-26.512$, Yanis)

01 de $v(r)$ ater von mich $\mathrm{AUCH}$,

02 wart neun (.) NEUNundfunfzig jahre.

01 The father of mine also

02 was fifty-nine years [old].

Similar examples include de kindere von mich 'the children of mine,' de bruder von mich 'the brother of mine' and de Hans von mich 'the Hans of mine' (referring to the husband). While indefinite constructions such as 'a nephew of mine' are perfectly possible in the contact varieties (e.g. Dutch een neef van me) (Broekhuis \& Keizer 2012a: 384), definite 
constructions usually give rise to an unacceptable result. Utterances with a specific (often negative) connotation constitute an exception to this rule. In Dutch, for instance, a demonstrative pronoun can be used for emphasis, e.g. die vader van mij is altijd te laat!, literally 'this father of mine is always to late!' ${ }^{14}$ It may be the case that in Cité Duits, possessive constructions as in (19) have an additional semantic component.

\subsubsection{Adjective Inflection}

Unlike in German, attributive adjectives are not inflected for case and number in Cité Duits but usually receive a schwa-ending (-e), depicted in (20), and sometimes a zero ending.

(20) (CD9: 407.114 - 410.74, Raf)

01 ich hab NIEmals kein schöne arbeit gehab.

01 I have never had no nice work.

Adjectival inflection in Cité Duits mostly resembles Dutch. Yet it differs from Dutch insofar as schwa seems to be the default ending (Auer \& Cornips 2018: 83), whereas Dutch adjectives preceding indefinite neuter nouns never receive $-e$-suffix: consider Dutch een fantastisch voorstel (neuter) 'a great suggestion' versus een interessante krant (common) 'an interesting newspaper.' In the data, in turn, the $-e$-suffix on attributive adjectives is also found in contexts where the contact varieties do not have - $e$-suffix or have a different suffix (e.g. -es):

(21) (231115: 4: 806.327 - 810.496, Jan)

01 auf de ofen stand immer (.) de kleine MOORke für warme wasser (x) -

01 On the stove stood always the small kettle for warm water.

Since the noun 'water' has neuter gender in Dutch and German (het water/das Wasser), the adjective 'warm' receives a zero suffix in Dutch (Dutch Op de oven stond altijd het kleine fluitketeltje voor warm water), and -es-suffix in German (Auf dem Ofen stand immer der kleine Kessel für warmes Wasser.)

\subsubsection{Negation}

The most frequent negation marker is nich 'not' in Cité Duits $(\mathrm{n}=395)$, which is also the 'standard negation marker' in German (i.e. nicht 'not') (Weiß 2017) (compare Dutch niet).

14 Thanks to Hans Broekhuis for pointing this out to me. 
In addition, Cité Duits uses the negative element kein 'not' $(\mathrm{n}=114)$. Yet, unlike in German where this form receives morphological case marking (kein/-e/-en/-er/-es/-em), case is usually not marked on the negative article (see previous example (20) kein schöne Arbeit versus German keine schöne Arbeit 'no nice work'). Furthermore, speakers employ niemals 'never' $(\mathrm{n}=49)$ as in German, and, less often, nie 'not' $(\mathrm{n}=36)$, which can be associated with Maaslands/German nie 'never' and Dutch niet 'not.' The negative element takes the same syntactic position as in the contact varieties. Moreover, some utterances exhibit negative concord ((22)(23), glossed), i.e. 'multiple occurrences of items overtly marked for negativity which do not cancel each other but form a single negation' (Cornips \& Poletto 2005: 950).

$$
\begin{aligned}
& \text { (22) (0313_144739: 650.155 - 652.575, Raf) } \\
& 01 \text { mein VATter hat niemals kein } \\
& \text { my father has } \underline{\text { never }} \\
& 02 \text { beroepsziekte geha (b)t, }
\end{aligned}
$$

My father has never had an occupational disease.

$$
\begin{aligned}
& \text { (23)(171115_5: } 934.695 \text { - 936.604, Olaf) }
\end{aligned}
$$

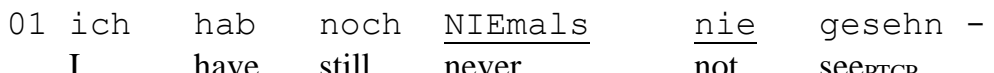

$$
\begin{aligned}
& \text { I have still } \underline{\text { never }} \text { not see }
\end{aligned}
$$

I have never seen ...

In (22) and (23), two negative elements yield one negation from a semantic perspective. The phenomenon of negative concord has been found across different spoken language varieties, including dialects of German and Dutch (Weiß 2002; Weiß 2017; Watanabe 2004; Haegeman \& Lohndal 2010; Zeijlstra 2004; Barbiers 2002; Brandner 2012: 121), but it is not unique to Cité Duits.

\subsubsection{Verbal Inflection}

It appears that verbal inflection in Cité Duits cannot be traced back unambiguously to one particular language variety. Consider the inflectional paradigm of 'to be' in present tense (Figure 16) and past tense (Figure 17) in comparison to spoken German, Belgian Dutch, and Maaslands. Due to its high frequency in the data, I will concentrate on the use of sein 'to be.' For the second-person plural present tense, there is only one token available. There are no attestations for the second-person plural past tense. 


\begin{tabular}{|l|l|l|l|l|}
\hline & CITÉ DUITS & GERMAN & $\begin{array}{l}\text { BELGIAN } \\
\text { DUTCH }\end{array}$ & MAASLANDS \\
\hline 1SG & bin & bin & ben & ben \\
\hline 2SG & bis & bist & bent & bes \\
\hline 3SG & is & ist & is & is \\
\hline 1PL & sin & sin(d) & zijn & zien \\
\hline 2PL & (sin) & seid & zijn & zien \\
\hline 3PL & sin & $\sin (d)$ & zijn & zien \\
\hline
\end{tabular}

Figure 16: Inflectional paradigm of 'to be' Present Tense

\begin{tabular}{|l|l|l|l|l|}
\hline & CITÉ DUITS & GERMAN & $\begin{array}{l}\text { BELGIAN } \\
\text { DUTCH }\end{array}$ & MAASLANDS \\
\hline 1SG & war & war & was & was \\
\hline 2SG & wars & warst & was & waos \\
\hline 3SG & war(t) & war & was/wart & woar \\
\hline 1PL & ware(n) & waren & ware(n) & woare \\
\hline 2PL & - & wart & ware(n) & woare \\
\hline 3PL & ware(n) & waren & ware(n) & woare \\
\hline
\end{tabular}

Figure 17: Inflectional paradigm of 'to be' Past Tense

As indicated by the above, the three contact varieties share a number of forms that are morphologically close. While the present tense paradigm (Figure 16) in Cité Duits resembles German (except for the second-person plural for which I attested just one example, which is realized as sin as opposed to seid in German), some forms show overlap with Dutch (is) and Maaslands (is, zien) as well. Similar observations hold for the past tense paradigm in Figure 17: The first-person singular war is completely in line with German, but it differs from Dutch/Maaslands where this form carries $-s$ inflection. In turn, the second-person singular wars shows overlap with all three contact varieties (but note that German has -t inflection). The available plural forms cannot be analyzed as instances going back to one particular language variety. While Cité Duits often exhibits word-final n-deletion $(\operatorname{ware}(n))$ in line with Dutch/Maaslands, there is also contraction of twosyllable verbs (warn, but also ham 'have'), as in informal German. A variant that stands out, however, is wart 'was' for the third-person singular, as illustrated below ((24), (25), but also (1), (19)), which resembles the Belgian Dutch form wart (e.g. gij wart 'you were') in spoken language. ${ }^{15}$

(24) (CD 09: 392.496 - 394.489, Raf)

15 Thanks to Truus De Wilde for pointing this out to me. 
01 in de zeit wart noch pasTOOR.

01 At that time, (there) was still a priest.

(25) (171115_4: 1301.582 - 1304.546, Yanis)

01 de wart GANZ gut.

02 de is noch uberall mit uns mitgegange toen.

01 He was (doing) quite well.

02 He still went anywhere with us back then.

Accordingly, wart 'was' seems to be motivated by Belgian Dutch where inflectional -t in the third-person is often realized after the consonants $1, \mathrm{r}, \mathrm{n}, \mathrm{m}, \mathrm{ng}, \mathrm{p}$ and $\mathrm{k}$ (e.g. woen- $t$ 'lives') (Belemans \& Keulen 2004: 65). The realization of inflectional $-t$ in the thirdperson is mainly phonetically conditioned and depends on the position of the finite verb before and after the subject, leading to quite some variation within and across dialects of Dutch (de Vogelaer 2007: 74-76). ${ }^{16}$ The data suggests that both war and wart are used in Cité Duits for the third-person singular. While German has the form wart for the secondperson plural, the dataset does not contain any examples of the second-person plural with the verb 'to be' in the past tense. ${ }^{17}$

\subsubsection{Participles}

Participles often constitute a fusion of the contact varieties, even though some conform to German and Maaslands. In Dutch, participles of non-prefixed verb stems (regular) take the prefix $\gamma \mathrm{e}$ - and add either $-t$ or $-d$ to the stem $(\mathrm{ge}+\mathrm{stem}+t / d$, e.g. maken $>$ ge-maak$t$, 'to make') (Broekhuis et al. 2015a: 73). Similar to German, strong verbs often receive the suffix -en (e.g. trekken >getrokk-en, 'to pull'). Verbs with the prefixes be-, er-, ge-, her-, ont- and ver- do not get ye-prefix. Limburgish, on the other hand, has no $d / t$ opposition in the suffix, i.e. $-d$ is always added. The prefix, however, does not appear with all participles that in Dutch would receive a $\gamma$ e (De Schutter \& Hermans 2013: 365). In German, three inflectional paradigms can be distinguished: weak (regular), strong, and mixed verbs. Weak and mixed verbs form the participle by adding inflectional $-t$ to the stem, the latter also have changes in the verb stem (e.g. weak: sag-en >ge-sag-t, 'to say';

${ }^{16}$ For an in-depth study on verbal inflection across Dutch dialects, see de Vogelaer (2007); see Belemans and Keulen (2004: 64-68) for verbal inflection in Belgian-Limburgish. The form woart 'was' has also been attested in the dialects of Eeklo and Lokeren in the West of Belgium (see DynaSAND) (Barbiers \& al. 2006).

${ }^{17}$ Interestingly, although wart 'was' appears quite often in the corpus, it is absent in the written source used, which may either suggest that this variant is used by speakers without them being aware of it, or that the author of the text simply does not happen to use it. 
mixed: bring-en >ge-brach-t, 'to bring'). 'Borrowed' verbs tend to receive $-t$ inflection. Strong verbs, in turn, take the suffix -en and show ablaut (e.g. sing-en >ge-sung-en, 'to sing'). In addition, participles in German are marked by a ge-prefix, occurring in all verbs with initial-syllable stress (Borik \& Gehrke 2019: 3; Deumert 2003: 582; Eisenberg 2013: 193). ${ }^{18}$ In Cité Duits, participles often show word-internal mixture ((26)-(28)).

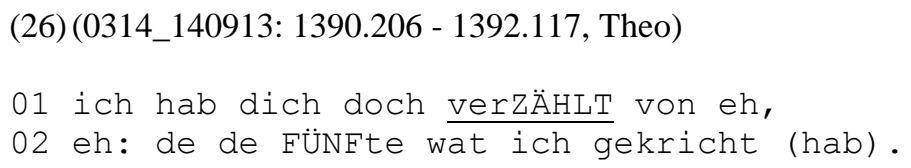

01 I have told you about

02 the 'fifth' [punishment] that I received.

(27)(171114_4: 740.325 - 742.995, Olaf)

01 und WEISS du wat gePASsert is mit de tandem?

01 Do you know what has happened to the tandem?

\section{(28) (171115_3: 80.955 - 83.45, Jan) \\ 01 kein ENGländers gehabt so, EINgequartiert? \\ 01 Never had Englishmen, accommodated?}

The participle verzählt 'told' in (26) does not correspond to Dutch verteld, German erzählt, or Maaslands vertèld; rather, it shows word-internal mixture, with the prefix vergoing back to Dutch/Maaslands and the stem $z \ddot{a} h l$ to German. This variant is quite frequent in the data $(\mathrm{n}=27)$, which means that its use is not random. ${ }^{19}$ Likewise, in (27), the participle gepassert 'happened' differs from the available forms in the contact varieties. Since German passieren is a regular verb without initial-syllable stress, no ge-prefix would be added (passiert). While the ge-prefix corresponds to Dutch/Maaslands at first sight, the /g/ in the syllable onset is a stop and realized according to German phonology, whereas the /g/ in Dutch gebeurd would carry an initial uvular fricative and in Maaslands gebäörd a velar fricative. In (28), the participle eingequartiert 'accommodated' resembles lexically German einquartiert - consider Maaslands ingekerteerd and Dutch

18 The Ripuarian dialect has je-prefix (jebrode > German gebraten 'fried' (Newton 2013: 177). For a discussion of form, meaning and use of participles in different languages including in German dialects, see Borik and Gehrke (2019).

${ }^{19}$ The verb verzählen exists in German with the meaning 'to count wrongly,' but the context reveals that the intended meaning is 'to tell' in all 27 utterances. Furthermore, the participle verzählt 'told' is productive in Upper German dialects such as Bavarian (Kürschner 2019: p.c.). Yet it rather seems that we are dealing with a mixed Belgian Dutch-German (-Maaslands) form. 
ingekwartierd - but, unlike in German, the participle contains a ge-infix. The /g/ is again realized as a stop. This pronunciation holds for all participles in Cité Duits that carry a geprefix or infix (further examples include for instance geoperiert 'had surgery' (50), gesach 'said,' genennt 'called'; getrunke 'drunk' gearbeit 'worked' (1), ausgestoche 'harmed').

\subsubsection{Prepositional Phrases}

As pointed out ( $\$ 4.3 .3$ ), definite articles in Cité Duits are not always realized in those contexts where the contact varieties would require an article. Prepositional phrases in particular exhibit a strong tendency for bare nouns. ${ }^{20}$ These occur mainly in locational and directional constructions such as auf strasse 'on [the] streets,' von dorp 'from the village,' in schule 'in [the] school,' in busch 'in [the] bush' or auf seite 'on [the] side.'

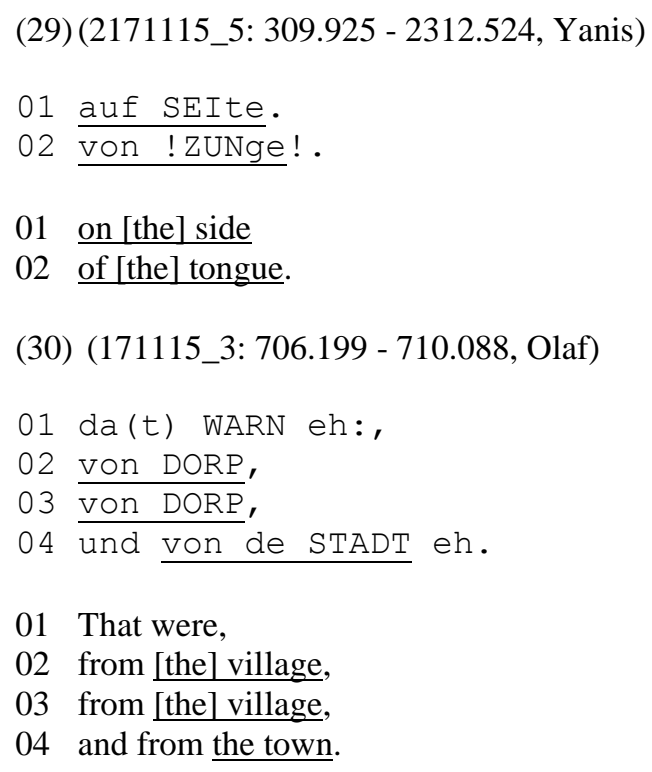

In both (29) and (30), the definite article between the preposition and the noun has not been realized, leading to a bare noun phrase. The singular definite article de does occur in von de stadt 'from the town/village' (incidentally, stadt is pronounced with the German onset), suggesting that both options are available in Cité Duits. Furthermore, temporal prepositional phrases generally appear with a preposition and without the definite article

${ }^{20}$ I refer to contexts where the bare NP is regarded to be ungrammatical in Belgian Dutch, Maaslands, and German. Note that standard Belgian Dutch, like English, allows for bare NPs such as Ik ga naar school 'I go to school.' For grammaticalization of definite articles in Dutch and German, see Schmuck (2020). 
(e.g. gestorbe in vierzig 'died in forty,' see annex, examples (27)-(29)), in line with Dutch but unlike in German, where the preposition is considered redundant (Er ist 1940 gestorben, lit. 'He died 1940'). In turn, contractions of a preposition and the definite article, typical of spoken German, are rare. For instance, beim 'at the' was only attested seven times and vom 'of the' 12 times. Similar findings were made by Auer and Cornips (forthcoming) on four of these speakers: In their comparison of Cité Duits with German multi-ethnolectal data from the city of Stuttgart, they report that contracted (clitic) forms such as ins, im, aufs, ans, am, vom are almost absent from Cité Duits, whereas they are extremely frequent in the respective German corpus. Likewise, they find the use of bare nouns in all Cité Duits speakers analyzed, which suggests that this feature is systematically used and not confined to a few individuals.

\subsubsection{The Dutch Adverbial Pronoun Er and Its Variants}

Besides het 'it,' Dutch has the adverbial pronoun er (see Wesseling 2018; Berends 2019; Berends et al. 2017; Grondelaers et al. 2002; Grondelaers 2000; Grondelaers \& Speelman 2001). Importantly, het and er cannot be used interchangeably. The same holds for Maaslands, which distinguishes ' $t$ and $d o a$. A Dutch example is provided in (31) (see $\S$ 5.4.6 for het 'it' in Cité Duits).

(31) Er wordt gedanst. (Dutch)

*Het wordt gedanst.

'There is dance.'

As shown above, the expletive het cannot be used in impersonal passives but er is required..$^{21}$ Dutch er can be used in quantificational phrases, in locative constructions, in expletive constructions, and in prepositional phrases (Figure 18). Furthermore, Dutch er has a number of variants, such as $d^{\prime} r$ or ' $r$, which can be used interchangeably without the meaning being affected. In contexts allowing a locative interpretation, daar 'there' and hier 'here' can be used as well, thereby conveying a distal or proximate feature, respectively. These forms may also be employed in expletive constructions and in prepositional phrases. In quantificational phrases, in turn, daar 'there' and hier 'here' cannot replace er (for a detailed analysis see Wesseling 2018).

\footnotetext{
${ }^{21}$ In a similar vein, het cannot follow a preposition but must be replaced by er or the strong form daar. For example, *een kopie van het 'a copy of it' would be ungrammatical because het triggers R-pronominalization when it functions as the complement of a preposition (see Broekhuis \& den Dikken 2012b: 628; 1131). This also holds for German where *eine Kopie von es 'a copy of it' yields an unacceptable construction (see Figure).
} 


\begin{tabular}{|c|l|l|l|l|}
\hline & FUNCTIONS & DUTCH & GERMAN & MAASLANDS \\
\hline 1 & $\begin{array}{l}\text { Quantitative } e r \\
\text { I still have three } \\
\text { (of them) }\end{array}$ & $\begin{array}{l}\text { Ik heb er nog } \\
\text { drie. }\end{array}$ & $\begin{array}{l}\text { Ich habe noch } \\
\text { drei. }\end{array}$ & $\begin{array}{l}\text { Iech höb der(s) } \\
\text { dri-j. }\end{array}$ \\
\hline 2 & $\begin{array}{l}\text { Locative } e r \\
\text { I have never been } \\
\text { there before. }\end{array}$ & $\begin{array}{l}\text { Ik ben er/daar } \\
\text { nog nooit } \\
\text { geweest. }\end{array}$ & $\begin{array}{l}\text { Ich bin da noch } \\
\text { nie gewesen. }\end{array}$ & $\begin{array}{l}\text { Iech bin dao nog } \\
\text { noets gewees. }\end{array}$ \\
\hline 3 & $\begin{array}{l}\text { Expletive } e r \\
\text { There is dance. }\end{array}$ & $\begin{array}{l}\text { Er/Daar wordt } \\
\text { gedanst. }\end{array}$ & $\begin{array}{l}\text { Es/Da wird } \\
\text { getanzt. }\end{array}$ & $\begin{array}{l}\text { Dao wuurt } \\
\text { gedanst. }\end{array}$ \\
\hline 4 & $\begin{array}{l}\text { Prepositional } e r \\
\text { a copy of it }\end{array}$ & $\begin{array}{l}\text { een kopie ervan } \\
\text { /daarvan }\end{array}$ & $\begin{array}{l}\text { eine Kopie } \\
\text { davon }\end{array}$ & 'n kopie devaan \\
\hline
\end{tabular}

Figure 18: Main functions of Dutch er with German and Maaslands counterparts

German, as shown in Figure 18 above, has es 'it' and $d a$ 'there.' While $d a$ can be used in locative, expletive, and prepositional constructions, es is only possible in expletive constructions. Thus, German es 'it' and $d a$ may only be used interchangeably in expletive constructions, as in (31) (but note that this does not hold for weather-verbs, see $\$ 5.4 .6$ ). Nevertheless, German has no pronoun that can be used in a similar way as the Dutch quantitative $e r{ }^{22}$ Neither German $d a$ 'there' nor es 'it' can function as the complement of a quantifier: Ich habe *da/*es drei 'I have there/it three' (Wesseling 2018: 158-59; Hartmann 2008: 185-221 for German da). This raises the question of whether and how er is expressed in Cité Duits. ${ }^{23}$ Returning to the data, a quantitative analysis of all constructions that would require the Dutch form er (or a variant of er) yields the following results (Table 2):

\begin{tabular}{|l|l|l|l|}
\hline & ER & DA & TOTAL \\
\hline $\mathbf{n}$ & 2 & 557 & 559 \\
\hline$\%$ & 0,4 & 99,6 & 100 \\
\hline
\end{tabular}

Table 2: Distribution of $e r$ and $d a$ in the Cité Duits corpus

\footnotetext{
${ }^{22}$ While German has no such quantitative pronoun, a similar form as in Dutch exists in Romance languages such as French (en) and Italian (ne) (Berends et al. 2017: 74).

${ }^{23}$ Dialects of German and Dutch differ in this regard. According to Strobel (2017: 221), based on Weise (1906), some East-Thuringian dialects display similar constructions as in Dutch with numerals, e.g. "Ich håå er draie." 'I have ER three-e.' See Strobel $(2016 ; 2017)$ for an overview of indefinite-partitive pronouns in varieties of German. Likewise, Heerlen Dutch allows for quantitative constructions without er (Cornips 1994). Furthermore, colloquial Dutch has inversion constructions in which the clause-initial position remains empty and er can be dropped (Broekhuis \& Corver 2019).
} 
Table 2 reveals that speakers neither use Dutch er nor German es. In my dataset, the form $e r$ as in Dutch occurs only two times. ${ }^{24}$ In contrast, the form $d a$ occurs in 557 utterances. This form is phonetically in line with or close to Dutch daar, German $d a$, and Maaslands dao, which may suggest that $d a$ developed as an intermediate form. While $d a$ is frequent in spoken German (Duden 2016: 858-63), it is possible that influence of Ruhr-German played a role, where a frequent use of $d a$, both as temporal and local adverb, has been attested (Becker 2003: 160-61). ${ }^{25}$

In addition, the data contains utterances where the contact varieties would realize a variant of er/dao/es, but where the position remains syntactically empty in Cité Duits. Example (32) is followed by a Dutch and German translation.

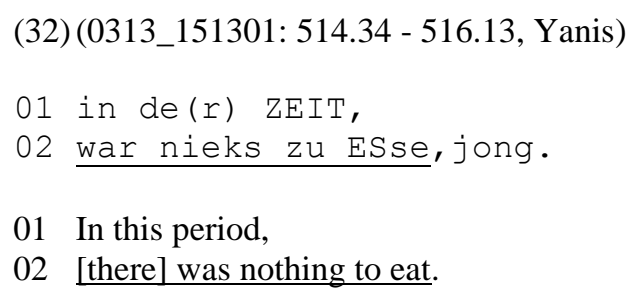

01 In this period,

02 [there] was nothing to eat.

Dutch: In die tijd was er niks te eten, vriend.

German: In der Zeit gab es nichts zu essen.

In (32), in the position after the finite verb, German would require es and Dutch a variant of $e r$, whereas this form is not realized in Cité Duits (see also example (24) above). Likewise, although the number of attested examples is limited, quantitative $\boldsymbol{e r}$ is not realized in Cité Duits (33). This use is in line with German:

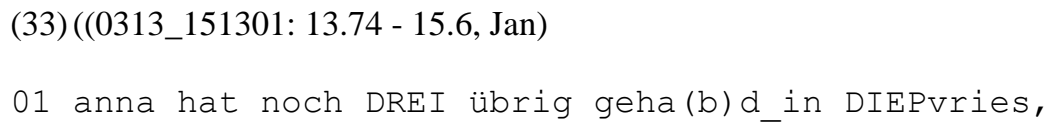

Dutch: Anna had er nog drie over in de diepvries.

German: Anna hat noch drei übrig gehabt im Gefrierfach.

Finally, it must be emphasized that speakers employ er according to Dutch grammar when talking in Dutch to the fieldworker (34):

${ }^{24}$ Crucially, er phonetically resembles the third-person singular masculine pronoun in Cité Duits (see $§ 5)$.

${ }^{25}$ Becker (2003: 160) finds that $d a$ shows a significantly higher distribution in Ruhr-German than in standard German. 
(34)(0313_152448: 1076.72 - 1081.6, Jan)

01 ik heb er thuis nog een koPIE van liggen.

01 I still have a copy of it at home.

Although speakers do not use er when speaking Cité Duits, example (34) shows that speakers employ er when speaking Dutch, which suggests that they are proficient in using er. In sum, while Dutch er is not found in Cité Duits, a closer look at the data reveals that it is subject to certain constraints: while er is not overtly expressed in quantitative constructions, in line with German, it is generally expressed by $d a$ in locative, prepositional, and expletive constructions. This form is phonetically close to the Dutch form daar, to German da, and to Maaslands doa.

\subsection{Syntax}

As I will demonstrate in this section, Cité Duits shares a number of syntactic patterns with Dutch and Maaslands that do not exist in German, but it also exhibits patterns untypical for the contact varieties.

\subsubsection{V2-constraint}

German, Dutch, and Limburgish belong to the West Germanic SOV languages that characteristically exhibit verb-second (V2). The term V2 refers to the fact that the finite verb remains in second position and is preceded by exactly one constituent in declarative main clauses (and in non-embedded wh-clauses). Verb-second is characteristic of all Germanic languages except for English (Sudhoff 2010: 10). Cité Duits generally displays the typical properties of being a V2 language, as indicated by a large number of previous examples (e.g. (22), (23), (24), (26)). In some utterances, however, the finite verb occupies the third position and is preceded by the subject, resulting in the order XSV, as depicted in (35) and (36).

$$
\begin{aligned}
& \text { (35) (0314_140913: 856.571 - 858.101, Diego) }
\end{aligned}
$$

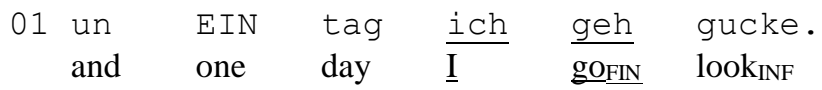

'And one day I take a look.'

(36) (0313_152448: 1290.11 - 1293.01, Raf) 


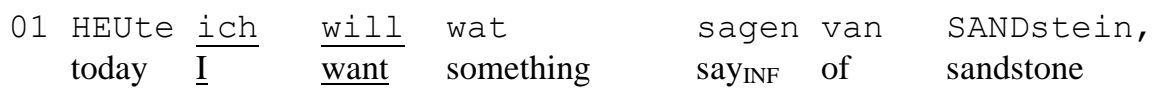

'Today I want to say something about 'sandstone."

As opposed to the regular V2 pattern XV, examples (35) and (36) shows no subject-verb inversion, resulting in a structure where an adverbial together with a personal pronoun precede the finite verb (XSV). Although these syntactic patterns are not extremely frequent in Cité Duits, they are interesting to consider because several non-standard Germanic varieties of Swedish, Danish, Norwegian, and German, but also West Flemish, make use of similar V3 word order patterns. In line with the attested examples in the present corpus, these patterns generally exhibit a low overall frequency (Greco \& Haegeman 2016; Haegeman \& Greco 2018; Freywald et al. 2015; Wiese et al. 2017a; Ganuza 2010; Quist 2008; Kern \& Selting 2006; Kotsinas 1998; Opsahl \& Nistov 2010). Nearly all of these V3-patterns are main clauses with a temporal adverb in first position, and a pronoun or less often a full NP in second position, therefore resembling examples (35) and (36) above. Furthermore, it seems that similar patterns may occur in (informal) spoken German (see Wiese \& Müller 2018; Schalowski 2015; Alexiadou \& Lohndal 2018; Müller \& Antomo 2018; Lohnstein \& Tsiknakis 2020), which suggests that they are not unique to Cité Duits.

What is remarkable, however, is that Cité Duits displays utterances with fronting of a wh-element together with a personal pronoun (37). In both Dutch and German, 'why' can be employed as an interrogative wh-expression and as a relative pronoun.

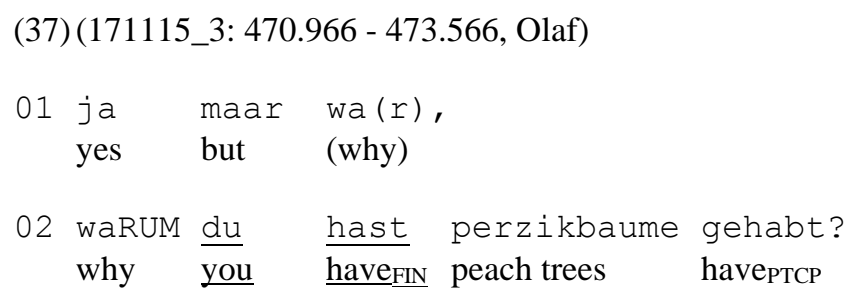

'But why did you have peach trees?'

This pattern is less common, and even overtly rejected in some varieties, for instance in West Flemish. As Haegeman and Greco (2018: 13) observe, the 'V3 pattern never arises with an initial wh-adjunct' and is considered 'ungrammatical for present-day speakers who accept non-inverted V3.' It may be the case that these patterns can be explained by information-structural and discourse-pragmatic effects (for similar thoughts, see Kern \& 
Selting 2006; Freywald et al. 2015; Haegeman \& Greco 2018; Wiese et al. 2017a). ${ }^{26}$ Since the number of attested XSV-patterns in the data set is rather small, however, it is impossible to draw substantiate conclusions.

\subsubsection{Weil 'Because' without Verb-final}

German weil 'because' has traditionally been described as a subordinating conjunction, which implies that the finite verb moves to clause-final position in clauses introduced with weil, similar to Dutch omdat 'because.' Dutch want 'because' and German denn 'because,' in turn, request V2-order (Abraham 2016: 122). In Cité Duits, weil is generally employed without verb-final. For illustrational purposes, examples (38) and (39) are followed by a translation to 'standard' German.

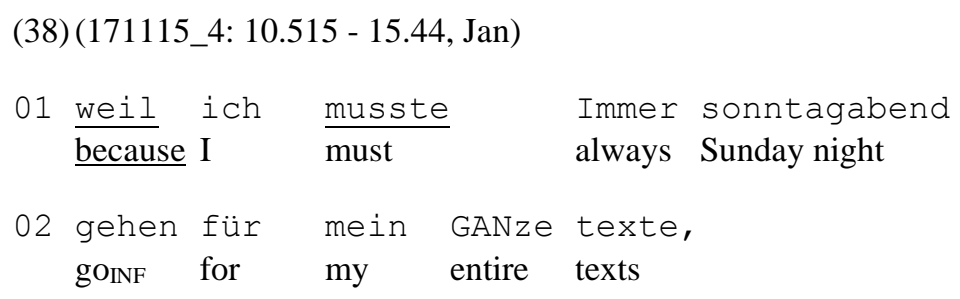

'Because I always had to go to get my texts on Sunday night.'

German: 'Weil ich am Sonntagabend immer für meine Texte [zur Schule/Kirche] gehen musste.'

(39)(231115_5: 1066.844 - 1069.982, Ralf)

$\begin{array}{llll}01 \text { weil die } & \frac{\text { haben dat bei }}{\text { because they }} & \text { UNS } \\ 02 \text { it auch auf } & \text { strasse } & \text { eh, } \\ \text { also on } & \text { street } & \text { H } & \\ 03 \text { geKI:PPT } & \text { dann; } \\ \text { emptyptcP } & \text { then }\end{array}$

'Because they have also emptied it in our street.'

German: 'Weil sie es auch bei uns auf die Strasse gekippt haben.'

\footnotetext{
${ }^{26}$ Following up on this, Haegeman and Greco (2018) propose to analyze the initial constituent in V3 patterns as an extra-sentential constituent that does not form part of the main clause.
} 
Unlike in German where the finite verb is expected in clause-final position, the verbs musste 'must' and haben 'have' appear in the position after the respective pronouns ich 'I' and die 'they.' In other words, the syntax follows the expected order in a main clause and not in a subordinate clause. More recently, patterns similar to those in Cité Duits have been reported for spoken Dutch (Abraham 2016; Degand 2016; Persoon et al. 2010) and German (Auer \& Günthner 2003; Gohl \& Günthner 1999; Abraham 2016; Freywald 2013; Henning 2006; Imo 2008: 159-64; Wegener 1993). Furthermore, it seems that similar tendencies are found with the German connectors wobei 'whereupon' and obwohl 'although' (Imo 2008: 163). These observations suggest that general tendencies of spoken language can be observed here.

\subsubsection{Extraposition: Elements outside the Verbal Bracket}

The use of the 'verbal bracket' (Satzklammer) is a typical feature of Germanic V2languages such as Dutch, Maaslands, and German. Following the Topological Field Model (Stellungsfeldermodell) by Drach (1937), the clause can be divided into three fields, as depicted below by means of a German example (Sudhoff 2010: 10; Müller 2002b: 1-4):

\begin{tabular}{|l|l|l|}
\hline PREFIELD & MIDDLEFIELD & POSTFIELD \\
\hline $\begin{array}{l}\text { Mein Freund } \\
\text { my friend }\end{array}$ & $\begin{array}{l}\text { hat gestern bis acht Uhr abends gearbeitet. } \\
\text { has yesterday until eight o'clock in the evening } \\
\text { worked }\end{array}$ & \\
\hline
\end{tabular}

Figure 19: Exemplification of Topological Field Model (German)

The prefield precedes the left verbal bracket ( $h a t$ 'has'), whereas the middlefield contains all other elements including the right verbal bracket (gearbeitet 'worked'). The postfield is typical for many subordinated clauses and clause-like elements, such as comparative constructions with wie and als ('as'), as well as for 'extraposed constituents' (Duden 2016: 1386). In the present context, I use the notion of 'extraposed' to refer to the positioning of verb-free elements after the closure of the potential right verbal bracket. ${ }^{27}$ While it was traditionally assumed that extraposition (Ausklammerung) of verb-free elements is untypical in German and that this field remained empty (Vinckel-Roisin 2011: 379; Bußmann 2002: 455), spoken German extraposes certain elements such as PP-adjuncts (Vinckel 2006: 2; Scherpenisse 1986: 137).

Nevertheless, Dutch/Maaslands and German differ to some extent in their use of the postfield. In addition to prepositional phrases, Dutch also allows for specific adverbials

${ }^{27}$ I ignore clause-like elements after the right verbal bracket such as da warn viel leute, die in de grube arbeite ('there were many people who work underground') and comparative constructions with wie and als ('as') because they can be considered clause-like (Vinckel 2006: 3). 
in the postfield. Moreover, the extraposition of prepositional phrases occurs significantly more often in Dutch than in German (De Sutter \& Velde 2008: 6-9; 12; further Lattewitz 1997: 162). In contrast, noun phrases without any kind of expansion are considered unsuitable for the postfield in Dutch and German. The placement after the bracket is only possible when these are coordinated phrases, i.e. enumerations. ${ }^{28}$ In Cité Duits, extraposition of material to the right periphery and in particular of prepositional phrases is extremely common ((40)-(44)).

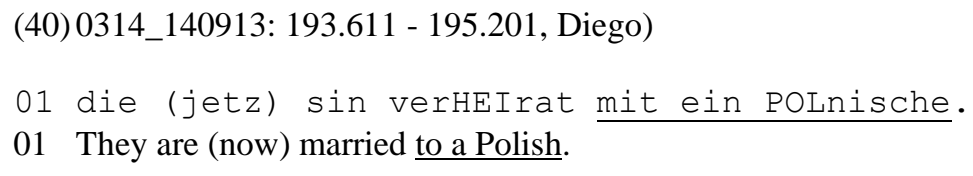

01 Winter, or what do I know.

02 I had to go by bike.

(42)(0314_140913458.717 - 461.362, Diego)

01 DA hat er gearbeitet bei prins de merode.

01 There he worked, at Prins de Merode.

(43) (CD1: 136.51 - 139.4, Josef)

01 un hab mich HINgelegen auf ein chaise longue.

01 And [I] laid down on a chaise longue.

(44) (0313_151301: 255.7 - 257.51, Jan)

01 du bis WEGgegange vom tisch OHne hunger.

01 You left the table without being hungry.

Examples (40) to (44) show that the postfield in Cité Duits is used both for PP-adjuncts and for PP-complements, while it allows for longer constituents such as in (44) (vom Tisch ohne Hunger). Given that Dutch exhibits a stronger tendency to extrapose prepositional

\footnotetext{
${ }^{28}$ For the extraction of PPs from the noun phrase, and the different behaviors of complement and adjunct PPs in Dutch, see Broekhuis and Keizer (2012a: 148-59). It seems that Maaslands behaves in line with Dutch here.
} 
phrases than German, these structures are unremarkable. Still, Cité Duits also allows for noun phrases and adverbial complements after the right verbal bracket ((45), (46)), a pattern that is rather uncommon in Dutch, Maaslands, and German:

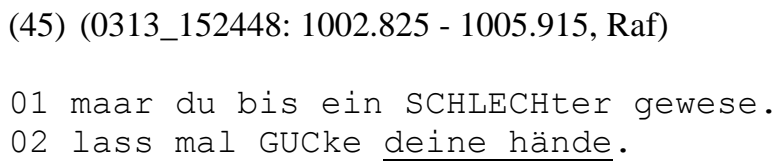

01 But you were a butcher. ${ }^{29}$

02 Let me see your hands.

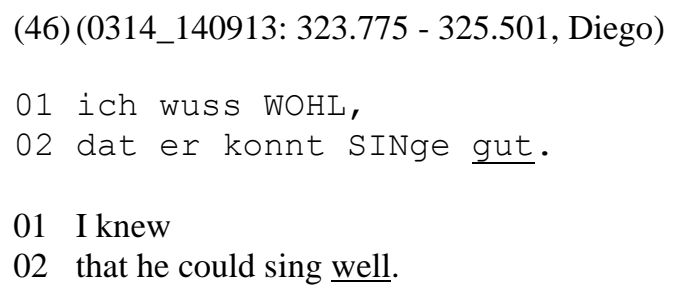

01 I knew

02 that he could sing well.

Although the data suggests that noun phrases and adverbial complements occur significantly less often in the postfield than prepositional phrases (see annex for further examples, also Pecht (2015)), it seems that Cité Duits has fewer constraints on the right periphery than its contact varieties. It is important to stress that none of these utterances contains a prosodic boundary between the right verbal bracket and the postfield (which usually increases the chance of extraposing material, see Zifonun et al. 1997: 1505). While the data contains both instances of extraposition with and without prosodic boundaries, there is evidence that speakers of Cité Duits systematically extrapose constituents that would rather occur in the middle field in Dutch, Maaslands, and German.

\subsubsection{Order of Verbal Elements in the Two-verb Cluster}

Although the contact varieties of Cité Duits share some syntactic patterns, they differ with regard to the order of verbal elements. While the order of verbal elements in German is fixed, allowing only the finite verb in clause-final position in the two-verb cluster (2-1order), Dutch allows both the finite verb and the past participle in this position (Wurmbrand 2004: 44-45; Barbiers 2009). In verbal clusters with modal or aspectual verbs combined with an infinitive, however, the order is more restricted in Dutch. Maaslands

${ }^{29}$ As indicated, not all utterances allow for a single interpretation. I took the freedom to translate schlechter as 'butcher' - compare German Schlachter - although 'a bad person' could also be meant (from schlecht 'bad'). The context of the conversation suggests that the former is more likely, because the response is ich hab mein fingers noch, hehe 'I still have all my fingers.' 
resembles Dutch inasmuch as the have-auxiliary usually occurs in first and the past participle in final position (1-2-order) (note that there is variation across dialects of Dutch) (Barbiers 2009). ${ }^{30}$ In the data, the 1-2-cluster dominates, both in perfective verbal clusters (47) and in clusters involving a modal or aspectual verb (48).

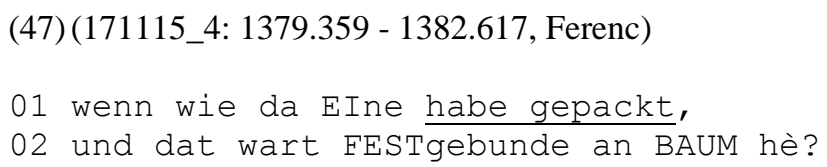

01 When we (have) caught one

02 and it was tied to the tree...

(48) (171115_3: 474.55 - 476.75, Ferenc)

01 maar bei iemand ANders gehen stehle.

01 But to (go) steal from someone else!

The order of the verbal elements habe gepackt 'have caught' and gehen stehle 'go steal' clearly follows the Dutch-Maaslands pattern and would be untypical in German. These findings are in line with previous observations by Auer and Cornips (2018: 84) on four of the speakers, who find that '[w]ord order in verbal clusters in Cité Duits seems to be constructed on the basis of the Dutch pattern since most of the tokens follow a word order ungrammatical in German.' From the analyzed examples (see also examples (59) - (65)), it seems that Cité Duits consistently employs the 1-2 cluster, whereas the 2-1 cluster hardly occurs.

\subsubsection{Passive Constructions}

Broadly speaking, passive is realized in a similar way in varieties of Dutch and German, which use either the passive auxiliaries worden/werden 'to become' or zijn/sein 'to be' followed by the past participle. ${ }^{31}$ Typically, Dutch worden + past participle is used for the imperfect tense and zijn + past participle for the perfect tense, corresponding to German werden + past participle and sein + past participle + worden. While the German agentive passive expresses ongoing actions, German also uses sein + past participle. This 'stative

${ }^{30}$ For research on verbal clusters in Germanic, see also Kaufmann $(2008 ; 2016)$.

${ }^{31}$ See Schlücker (2009) for a critical analysis of the German and Dutch zijn/sein + participle constructions. Note that Dutch (Broekhuis et al. 2015a: 403) and German (Müller 2002b: 119) unlike English - allow the passivization of intransitive verbs. This 'impersonal passive' has the nonreferential pronoun het (Dutch) or es (German) as subject, but has not been attested in Cité Duits. Crucially, not all verbs can have a passive (see Müller 2002: 119-120 for German verbs that resist passivization). 
passive' describes a state that results from a dynamic event (for German, see Müller 2002b: 117-72; Eisenberg 2006: 124-36; for Dutch, see Broekhuis et al. 2015a: 407-17; Cornelis \& Verhagen 1995; for a comparison, see Schlücker 2009). In addition, Dutch and German share the 'dative' or 'recipient passive,' which is formed with the verb krijgen/kriegen 'to get,' e.g. Dutch Ik kreeg het boek toegestuurd 'I received the boek.' Aside from kriegen 'to get,' German uses the verbs bekommen 'to receive' and, less often, erhalten 'to obtain' (Müller 2002b: 131-33; Broekhuis \& Corver 2015b: 625-26; Broekhuis \& Cornips 2012; Lenz 2017). Speakers of Cité Duits clearly have a preference for active voice. Despite the small number of attestations in the corpus, different types of passive constructions can be distinguished. First, the speech contains passives with werden/worden 'become' + participle, following the contact varieties ((49), (50)):

(49) (231115_3: 78.613 - 83.782, Jan)

01 bis de haus verkauft word un an WEN he.

01 Until the house is sold and to whom.

(50) (231115_5: 1567.322 - 1572.726, Victor)

01 ja mein FRAU wurde geoperiert,

02 vielleicht bin ich vierzehn TAge-

01 My wife underwent surgery,

02 maybe I am fourteen days...

Moreover, Cité Duits employs passive constructions with kriegen 'to get,' again in line with its contact varieties (51). Lexically, kriegen 'to get' follows German. ${ }^{32}$

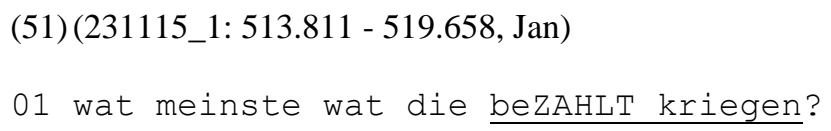

01 What do you think they get paid?

Finally, Cité Duits has another passive construction with similar properties than its contact varieties, the 'lassen passive' (see Müller 2002b: 141-43 for German). In Cité Duits, it is formed with the verb lassen 'to let' and a reflexive pronoun (52), in line with German (but note that German has umlaut in the third-person, i.e. lässt):

(52) (0313_152448: 60.81 - 63.41, Jan)

32 According to Heine and Kuteva (2008: 70), this passive construction is rather unusual across languages. See in particular Broekhuis and Cornips (2012) for krijgen 'to get' in Dutch, as well as Müller (2002b: 133) for bekommen /erhalten /kriegen in German. 


\begin{tabular}{|c|c|c|c|c|}
\hline $\begin{array}{l}01 \text { de } \\
\text { he }\end{array}$ & $\frac{\text { lasst }}{\underline{\text { lets }}}$ & $\frac{\mathrm{sich}}{\mathrm{REFL}}$ & $\begin{array}{l}\text { ein } \\
\text { a }\end{array}$ & $\begin{array}{l}\text { frau } \\
\text { woman }\end{array}$ \\
\hline $\begin{array}{l}\text { Von } \\
\text { from }\end{array}$ & $\begin{array}{l}\text { SloVEr } \\
\text { Slovenia }\end{array}$ & & & \\
\hline
\end{tabular}

'He has a woman come from Slovenia.'

Unlike in Dutch, however, where the passive with laten 'to let' is extremely productive (Broekhuis et al. 2015a: 391-95), the use of the reflexive pronoun would be untypical of standard Dutch (compare (52) above to the Dutch sentence hij laat een vrouw uit Slovenie komen). This is why the 'lassen-passive' with the use of the third-person reflexive pronoun sich should rather be associated with German. Likewise, a number of Limburgish dialects exhibit similar patterns (Barbiers \& al. 2006), which means that this passive cannot unambiguously be traced back to one particular language variety.

\subsubsection{The Infinitival Complementizers für ..zu and um...zu}

A typical feature of Cité Duits concerns the use of the infinitival complementizers $u m \ldots z u$ (53) and für ...zu (54) 'for... to,' with für ...zu clearly being the preferred variant in the speech ( $n=14$ versus $n=2$ in spoken corpus).

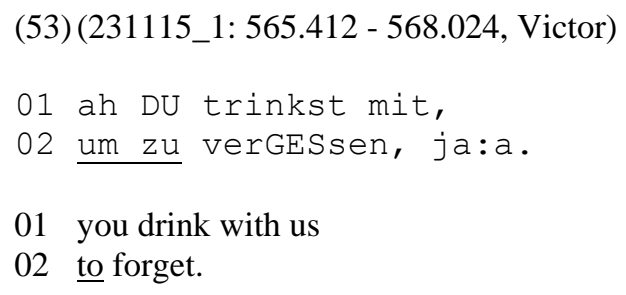

01 He was, to become a supervisor,

02 he had to be Belgian. 
Utterance (53) um zu vergessen 'to forget' is in line with German grammar (Newton 2013: 177). Note that Dutch generally employs om ... te (Broekhuis 2013b: 189). ${ }^{33}$ Such examples, however, are infrequent in the data. Instead, speakers tend to employ the infinitival complementizer für ...zu as in (54), attested in the language use of six speakers (see annex). This variant can be associated with German and Dutch dialects. Likewise, Moselle Franconian dialects have been reported to use fir...ze, e.g.' $t$ war eng Hetz fir d' Aarbecht fäerdeg ze kréien 'it was a rush to complete the work' (Newton 2013: 177). Moreover, Cité Duits' für ...zu resembles the infinitival complementizer voor ... te, which is found in a number of Belgian and Netherlandic regional varieties including in Limburgish, for instance Die ton is zwaar voor te drage 'This barrel is heavy to carry' (DynaSAND) (Barbiers \& al. 2006; also Cornips 2002: 87 for Heerlen Dutch).$^{34}$ In Cité Duits, the infinitival complementizer für ...zu occurs in different syntactic environments. It is used both with a direct object, as above (54), and without any type of complement (55):

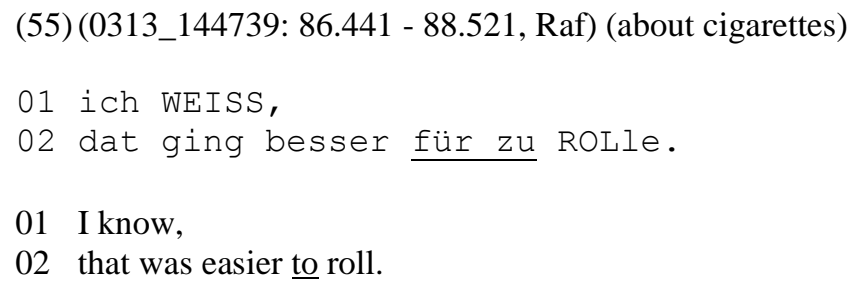

01 I know,

02 that was easier to roll.

(56) (231115_1: 421.597 - 426.23, Olaf) (about smuggling of people)

01 nee maar DIE hab,

02 die bezAHlen sechstausend euro für even na hier zu komme.

01 No, but they have;

02 they pay six-thousand euros in order to come here.

It seems that für ...zu is the general accepted variant, whereas $u m \ldots z u$ has a marginal status. In contrast, in the written document used (annex), there is more variation between the use of für ...zu and $u m \ldots z u$, both variants occurring almost as often. To conserve the original character of the text, all extracts are presented as spelled by the author, which implies that

\footnotetext{
33 The status of Dutch om is subject to debate. Some authors regard it as a regular preposition. Furthermore, the translation is only approximate because English 'for' and om do not share the same grammatical properties (Broekhuis 2013b: 189).

${ }^{34}$ For Heerlen Dutch, Cornips (2002: 86) finds that voor...te is used more frequently in purpose clauses than in non-purpose clauses. Whether this also holds for Cité Duits is impossible to say, given that the number of non-purpose as opposed to purpose clauses is limited.
} 
the spelling differs from the transcriptions and from standard German. Here, für is spelled as fie.

(57) (w)

Ein Pikeur hatma gebraucht in Put fie Kohle zu mache.

'We used a 'pikeur' to make coal in the mine.'

(58) (w)

Morgens früh is ein Soldat durch dè Strasse marsjiert un hat auf ein Doedelsack gespielt um die Soldate wacka zu mache.

'In the morning, a soldier marched through the streets and played bagpipes to wake up the soldiers.'

These observations suggest that, at least at the level of written language, there is intraspeaker variation, as one and the same speaker will use both variants. Variation between two variants is also found in Dutch dialects and regional varieties (Cornips 2002). A possible explanation is that the written source is stronger influenced by the 'standard variant' om ...te in Dutch, which resembles $u m$... zu. Finally, om ...te is used by the speakers when speaking Dutch with the fieldworker. ${ }^{35}$

\subsubsection{Komme 'Come' and Bleibe 'Stay' + Infinitive}

The verbs komme 'to come' and bleibe 'to stay' may function as main verbs in Cité Duits, in this regard following the contact varieties. When functioning as main verb, komme 'come' indicates movement and usually combines with a locational or directional complement, ${ }^{36}$ whereas bleibe 'stay' conveys lack of movement. Furthermore, both verbs can combine with a bare infinitive as complement, and may convey aspectual meaning. In particular the verb komme 'to come' with a verbal infinitive is productive (59) (see annex for a complete list of examples). Because Cité Duits often exhibits word-final n-deletion, the infinitives appear without final $-n$ here.

(59) (0313_151301: $15.795-16.915$, Jan)

$$
\begin{aligned}
& 01 \text { JOsef is nich komme esse, } \\
& \text { Josef is not } \underline{\text { come INF }}^{\text {eat INF }}
\end{aligned}
$$

\footnotetext{
${ }^{35}$ E.g. dat is, wat ze dede, om effekes (h)et verhaal te verklare 'This is what they did, to explain the story' (0313_152448: 619.4 - 622.68).

${ }^{36}$ The complement is not always realized in Cité Duits, see weil ich musste immer Sonntagabend [zur Schule/Kirche] gehen für mein ganze Texte.
} 
'Josef did not come for dinner.'

Example (59) is unremarkable insofar as a similar use can be found in the standard varieties of German and Dutch. From a semantic perspective, utterance (59) conveys the meaning that Josef did not join dinner. Yet, syntactically, the construction differs from German where a verbal participle is required (Josef ist nicht essen gekommen) and rather resembles Dutch (Josef is niet komen eten), which exhibits the Infinitivus Pro Participio (IPP) effect (Wurmbrand 2004: 46; Broekhuis \& Corver 2015b: 1052-78) ${ }^{37}$ Likewise, the order of verbal elements in these clusters invariably follows Dutch/Maaslands but not German. That is, in the data, 'to come' appears before the respective infinitive which is in clause-final position.

Yet, it appears that komme 'to come' + infinitive can also have an aspectual function in referring to the beginning of a state in Cité Duits, as illustrated in (60) and (61). In this instance, the resulting constructions express inchoative aspect,,$^{38}$ and they resemble Dutch (Broekhuis \& Corver 2015b: 1019-28). Similar uses have been reported for German dialects (see Kölligan 2004: 430; Drossard 2004: 127 for Ripuarian), but they are untypical of colloquial standard German. ${ }^{39}$

$$
\begin{aligned}
& \text { (60) (0314_140913: } 738.435 \text { - 739.04, Ferenc) } \\
& 01 \text { un mein MuTter } \\
& \text { and my mother } \\
& 02 \text { is immer (.) komme stehn; } \\
& \text { is always } \text { come }_{\text {INF }} \underline{\text { stand }}_{\text {INF }}
\end{aligned}
$$

'My mother always started to stand up.'

$$
\begin{aligned}
& \text { (61) (231115_4: 827.698-831.077, Jan) } \\
& \begin{array}{l}
01 \text { der } \underline{\text { kommt dich de ganze MATCH }} \text { de } \\
\text { he } \underline{\text { comes }} \text { you the entire game }
\end{array}
\end{aligned}
$$

\footnotetext{
${ }^{37}$ Note that German behaves like Dutch in having IPP when the modal verb is embedded under the perfective auxiliary verb: Sie hat das Buch nicht lesen wollen 'She did not want to read the book' (Schallert 2014: 249). See also Dirix et al. (2020) for IPP in Dutch and German.

${ }^{38}$ Note that some authors distinguish between 'inchoative' and 'ingressive' aspect, whereas others use these two notions interchangeably (Heinold 2015: 27).

${ }^{39}$ It seems that Bavarian uses kommen $+\underline{z u}+$ infinitive to convey inchoative aspect. The infinitive is usually employed with intransitive verbs (Maiwald 2004: 235-37), e.g. Da Kiaschbam kimmt zum Blian. 'The cherry tree starts to blossom' (ibid. 235, translation N.P.).
} 


$\begin{array}{lllll}02 & \text { wenn de mich } & \text { aan } & \text { SCHNEIde } & \text { war. } \\ \text { when he } & \text { me } & \text { PROG } & \text { cut INF }_{\text {INF }} & \text { was }_{\text {AUX }}\end{array}$

'He started telling you the entire game when he was cutting my hair.'

In contrast to utterance (59) above, the verb komme 'to come' does not translate to German without yielding an incomprehensible construction: compare (60) to the German utterance ?meine Mutter ist immer stehen gekommen and (61) to the German utterance ?er kommt dir das ganze Spiel erzählen. These patterns can rather be associated with varieties of Dutch. Unlike in Dutch, however, Cité Duits also allows for komme 'to come' with stative verbs such as wisse 'to know' as a bare infinitive as complement (62):

$$
\begin{aligned}
& \text { (62)(0314_140913: } 781.204 \text { - 784.33, Diego) }
\end{aligned}
$$

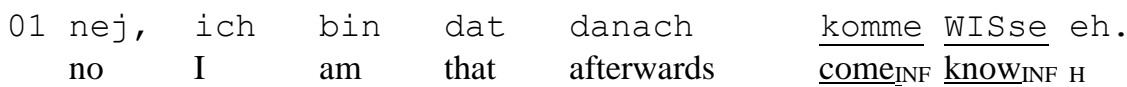

'I found out about it afterwards.'

Although it is grammatical to say in Dutch Ik ben dat erna te weten gekomen, Dutch differs from Cité Duits in requiring the use of $t e$ 'to' and a participle here. A similar construction does not exist in German, where the combination of the verbs 'to come' and 'to know' is untypical. These observations suggest that not all constructions in Cité Duits have a counterpart in the contact varieties. ${ }^{40}$

In addition, speakers employ the verb bleibe 'to stay' + bare infinitive. While German has a verbal participle here, this construction syntactically resembles Dutch (Broekhuis et al. 2015a: 20). On the one hand, bleibe + infinitive can have an aspectual character in denoting a state that continues to exist:

$$
\begin{aligned}
& \text { (63) 0313_140248: } 333.115 \text { - 335.181, Raf) }
\end{aligned}
$$

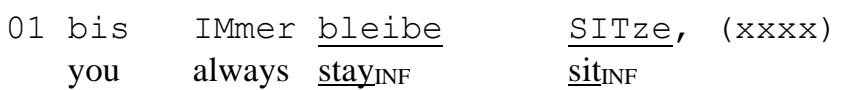

'You always continued to sit there.'

\footnotetext{
${ }^{40}$ In Dutch, blijven 'to stay' + infinitive and komen 'to come' + infinitive show different restrictions regarding the types of verbs they combine with. 'To stay' is compatible with the Vendlerian achievement verbs, whereas 'to come' is not. For example, the utterance het ijs blijft smelten 'the ice continues meltinF' expresses that the ice continues to melt. In turn, *het ijs komt smelten 'the ice comes meltinF' yields an unacceptable construction (Broekhuis \& Corver 2015b: 1020-30) (i.e. Dutch requires te here: het ijs komt te smelten).
} 
(64) (231115_4: 2205.35 - 2213.934, Jan)

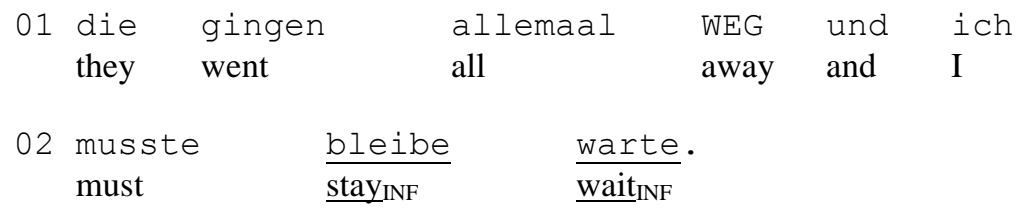

'They all left and I had to stay and wait.'

While the meaning of the main verbs sitze 'to sit' (63) and warte 'to wait' (64) remains the same, these utterances express continuity, similar to Dutch (Broekhuis \& Corver 2015b: 1019-28). But the same does not seem to hold for (65) below:

(65) (171115_5: 2253.806-2261.413, Olaf)

\begin{tabular}{|c|c|c|c|c|c|}
\hline $\begin{array}{l}1 \text { ich } \\
\text { out)) }\end{array}$ & bin & SCHNELler & gegange. & ( (3 seconds & left \\
\hline I & am & faster & goptCP & & \\
\hline $\begin{array}{l}\text { ja } \\
\text { yes }\end{array}$ & $\begin{array}{l}\text { dann } \\
\text { then }\end{array}$ & $\begin{array}{l}\text { bin } \\
\text { am }\end{array}$ & $\frac{\text { bleibe }}{\text { stay INF }}$ & $\frac{\text { STEHN }}{\text { stand }_{\text {INF }}}$ & $\begin{array}{l}\text { hè? } \\
\text { Q }\end{array}$ \\
\hline
\end{tabular}

'I walked faster, and then I stopped.'

Here, the speaker does not refer to the fact that he continued to stand in a location. Rather, he describes how he is quickly moving toward the location (ich bin schneller gegange) and then suddenly stops (dann bin ich bleibe stehn). Also example (65) syntactically resembles Dutch (dan ben ik blijven staan), whereas German would require a participle here (dann bin ich stehen geblieben $)^{41}$

\footnotetext{
${ }^{41}$ The verb gehe(n) 'to go' behaves similarly in Cité Duits insofar as it does not take the form of a participle but rather selects an infinitive. While the number of attestations is limited, it does not seem to be a future auxiliary because it is used with past events such as und alle warn gehn biechte 'and everyone was gone to confess.' Further examples include gehen stehle 'go steal,' gehen arbeite 'go work' and kole gehen mache, literally 'coal go make.'
} 


\subsection{Conclusion \\ 4.5.1 Discussion and Further Observations}

In this section, I will discuss the findings by linking them to the debate on spoken or 'conceptionally oral language' (Koch \& Oesterreicher 1985). ${ }^{42}$ Rather than being unique to Cité Duits, some linguistic features observed in the data reflect prominent examples of spoken language and language change. In a similar vein, Cité Duits displays features that can be associated with several informal and/or dialectal varieties of Dutch and/or German, as well as with language contact. For example, the 'absence' of case marking is typical of Dutch, Maaslands, Ruhr-German (Mihm 1985a; 1985b; Scholten 1988: 144-64), and contexts of language contact (Clyne 2003: 125-30; for heritage German in the U.S., see Yager et al. 2015; for case syncretism in Pennsylvania German, see Louden 1994; for Namibia German, see Shah 2007). ${ }^{43}$ Likewise, bare nouns in prepositional phrases with directional and locational function occur in Ruhr-German as well as in numerous German multi-ethnolects spoken in different German cities (for Stuttgart, see Auer \& Cornips forthcoming; Auer \& Siegel 2016; Siegel 2016: 127-86; for Berlin, see Wiese 2013a; Wiese \& Rehbein 2016).

Typical features of spoken language in Cité Duits concern the use of weil 'because' without verb-final ( $\$ 4.4 .2$ ), whereby weil functions as coordinating conjunction and not as subordinating conjunction, and probably as a type of discourse marker. Aside from in spoken German (Gohl \& Günthner 1999; Henning 2006; Freywald 2013; Abraham 2016; Imo 2008: 159-64; Auer \& Günthner 2003), similar tendencies have been observed in Dutch with regard to omdat 'because' (Persoon et al. 2010; Degand 2016). ${ }^{44}$ Another feature of spoken language concerns the frequent use of 'resumptive pronouns,' which I did not yet discuss and which is exemplified in (66):

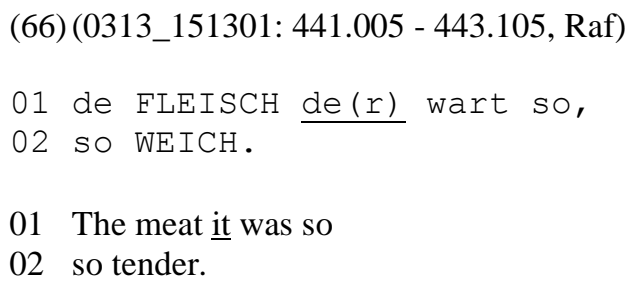

01 The meat it was so

02 so tender.

\footnotetext{
42 Koch and Oesterreicher (1985) introduced the idea of konzeptionelle Mündlichkeit by proposing that not only speech but also informal texts can have a 'conceptionally oral' character.

${ }^{43}$ Historically, a similar development can be observed in English, which lost its case distinctions and grammatical gender (Allen 1999). See also Blaxter and Trudgill (2019) for Norwegian.

${ }^{44}$ Degand (2016: 420), however, argues that the process of language change is further advanced in German than in Dutch. Accordingly, speakers increasingly employ weil to substitute denn, whereas Dutch omdat does not replace the coordinating use with want.
} 
In (66), the resumptive pronoun $d e(r)$ 'it' refers back to the NP de fleisch 'the meat.' While frequent in Cité Duits, such uses are typical of spoken varieties of Dutch and German. In addition, the contraction of two-syllable verbs (haben > ham 'have'; waren > warn 'were') resembles spoken German, whereas final n-deletion coincides with Belgian Dutch and Maaslands. Likewise, some features attested in Cité Duits can be associated with spoken language in general, for instance negative concord (Weiß 2002) (§ 4.3.6).

Not attested, in turn, are periphrastic 'to do' constructions, in which a cognate of 'to do' functions as supporting auxiliary together with a bare infinitive. Several varieties of German and Dutch use do-periphrases (Weber 2017; 2018; for Ruhr-German see Kölligan 2004; for Heerlen Dutch see Cornips 1994: 60-70; Cornips 1998; for Bavarian see Maiwald 2004: 239; for German dialects see Kuhmichel 2016: 73-74), ${ }^{45}$ whereas they are absent from Cité Duits. One possible explanation is that do-periphrases are only produced in specific contexts that do not appear in the corpus. For instance, in Heerlen Dutch (NL), periphrastic doen 'to do' is used to express the habitual status of an action (Cornips 1994: $60-70 ; 1998)$. Furthermore, it seems that this construction is not widespread in BelgianLimburg (De Schutter \& Hermans 2013: 368-69).

In addition, Cité Duits shares a number of features with Ruhr-German, such as the 'absence' of case marking (Mihm 1985a; 1985b; Scholten 1988: 144-64), bare nouns in prepositional phrases (Scholten 1988: 164-72), and constituents after the right verbal bracket (Menge 1985: 240). The two also share several phonological features, including plosives in dat 'that' and wat 'what' (Mihm 1985a: 167; 83-85; Scholten 1988: 47-59) and the spirantization of word-final -g (Kriech 'war,' fertich 'ready') (Mihm 1985a: 183-85; Salewski 1998: 34-35; Scholten 1988: 60-69).

While extraposition is common in spoken (Ruhr-) German (Menge 1985: 240), the extent to which elements appear after the verbal bracket is more pronounced in Cité Duits (§ 4.4.3, also annex), resembling other language contact settings (Riehl 2009: 86). Not only does Cité Duits extrapose PP-adjuncts and PP-complements; it also has NP- and certain adverbial complements after the right verbal bracket. Furthermore, the fact that Cité Duits allows for verb-third (V3) (§ 4.4.1) suggests that it has fewer constraints than its contact varieties in its left and right periphery. ${ }^{46}$

Yet a feature that clearly distinguishes Cité Duits from most varieties of German is the 1-2 order in the two-verb cluster (Wurmbrand 2004: 54). ${ }^{47}$ There have been various studies trying to account for verb-order variation in cases where multiple orders are

\footnotetext{
45 According to Weber (2018: 124), all (spoken) West Germanic languages except for Afrikaans have do-periphrases. The do-periphrasis is also used in Pennsylvania German (Louden 1992: 220 for Pennsylvania German) and in Mennonite Low German (Kaufmann 2016: 162-90).

46 The idea of a link between V3 and extraposition is, of course, not new: a systematic relationship between verb-first, verb-second and verb-final was established in previous descriptions of word order in West Germanic SOV languages (Sudhoff 2010: 10-26).

${ }^{47}$ Swiss German differs in that it shares the 1-2 order in certain patterns with Dutch (Seiler 2004; Wurmbrand 2004). Likewise, Alemannic dialects allow for 1-2 order (Schallert 2014; Rothmayr 2013).
} 
allowed (Seiler 2004; Wurmbrand 2004; Schallert 2014; Bloem et al. 2017; Meyer \& Weerman 2015; Barbiers 2009; Kaufmann 2016). For Dutch, it has been claimed that the 1-2 order is more frequent in contact situations and in regions with a high degree of language contact (Bloem et al. 2017; Meyer \& Weerman 2015). Given that the 1-2 order of Cité Duits is identical with the patterns in Dutch and Maaslands, it most likely developed in contact with the latter two varieties. The same holds for komme 'to come' and bleibe 'to stay' with a bare infinitive as complement. In turn, Cité Duits appears to exhibit fewer semantic constraints than Dutch in combining 'to come' with Vendlerian state verbs such as wisse 'to know.' Thus, while sharing a number of syntactic features with Dutch and Maaslands that do not exist in German, Cité Duits exhibits some individual features.

\subsubsection{Summary}

In this chapter, I examined a number of linguistic features of Cité Duits with a particular focus on morphosyntactic and syntactic characteristics. The resulting overview indicates that Cité Duits differs in several aspects from (dialectal varieties of) German and Dutch. While some of the attested features reflect general tendencies of spoken language or language contact, others can be associated with informal Belgian Dutch, Maaslands, and/or German. A number of features, however, rather seem to constitute a fusion of features from the three contact varieties.

On the level of lexis ( $\$ 4.2$ ), I have shown that the Cité Duits lexicon cannot be analyzed as going back to one particular language variety. While resembling informal spoken German, numerous lexical items can similarly be associated with Belgian Dutch and Maaslands. In addition, Cité Duits contains terms from the French-Walloon mining vocabulary, as well as non-Germanic nouns of Slavic, Romance, and Hungarian origin. The latter, however, are confined to meta-communication contexts.

With regard to morphosyntax (§ 4.3), I demonstrated that Cité Duits does not mark case on determiners, negative articles, attributive adjectives, and possessive pronouns. These findings correspond to Dutch and Maaslands, but distinguish Cité Duits from colloquial standard German, where morphological case marking of the nominative, accusative, and dative is still productive. Furthermore, it was noted that Cité Duits employs three default articles that exist in all three contact varieties: $d e(r)$ for singular definites, die for plural definites and singular demonstratives and ein for indefinites. In contrast to Dutch, Cité Duits has a number distinction in definite articles. The use of die as a singular demonstrative, in turn, resembles Dutch but differs from German. Proper names are often preceded by the definite article, similar to a number of German and southern Dutch dialects. The reverse picture is observed in prepositional phrases: These rather exhibit a strong tendency for bare nouns, in particular with locational and directional functions.

The paradigm of possessive pronouns can be characterized as resembling German with some structural simplifications, but it also overlaps with Dutch and 
Maaslands. In addition, speakers use definite prepositional phrases to mark possession (e.g. de Vater von mich 'the father of mine'). That all attested examples involve kinship terms and social relationships may indicate that these possessive constructions convey an additional semantic component. But there is insufficient evidence to corroborate this assumption. Morphological plural marking, in turn, corresponds mostly to Dutch and Maaslands. The most frequent negation markers are nich 'not' and kein 'not,' resembling German, whereas negative concord can be associated with dialectal and non-standard varieties of Dutch and German.

In addition, by scrutinizing the verb sein 'to be,' I have shown that verbal inflection cannot be associated with one particular language variety. Some forms correspond to German (e.g. bin, war, war(e)n), whereas others resemble colloquial Belgian Dutch (wart). Likewise, the three contact varieties share a number of forms that are phonologically close (e.g. is $(t)$; German bin and Dutch/Maaslands ben; German bis $(t)$ and Maaslands bes), making a single interpretation impossible. Simultaneously, participles frequently show word-internal mixture. If I did not elaborate phonological properties, the date revealed that the - $\mathrm{g}$ in the syllable onset is consistently realized as a stop according to German phonology (e.g. eingequartiert 'accommodated') and therefore differs from Dutch and Maaslands. In turn, final n-deletion as in komme(n) 'to come' resembles Dutch and Maaslands.

Unlike Dutch, Cité Duits does not use the adverbial pronoun er. For quantitative constructions it holds that the syntactic position remains empty, in line with German, whereas other functions are usually expressed by $d a$. Being phonetically close to Dutch daar 'there,' German $d a$ 'there,' and Maaslands doa 'there,' it is possible that $d a$ developed as an intermediate form. At the same time, spoken (Ruhr-)German exhibits a similar frequent usage.

My review of syntactic characteristics $(\S 4.4)$ suggests that Cité Duits exhibits fewer syntactic constraints than its contact varieties, but that it shares a number of syntactic patterns with Belgian Dutch and Maaslands that are untypical of German. For instance, the order of verbal elements in the two-verb cluster clearly follows the Belgian Dutch-Maaslands pattern (1-2-cluster) and therefore differs from German (2-1-cluster). Furthermore, I attested verbal infinitives where German has a participle, reflecting the IPP-effect of Dutch. The use of komme 'come' and bleibe 'stay' combined with a bare infinitive as complement indicates that Cité Duits shares certain syntactic and aspectual markers with Dutch. Passive constructions, although occupying a rather marginal position in the speech, seem to follow the contact varieties. Yet Cité Duits rather prefers active voice.

In addition, Cité Duits seems to exhibit a greater tendency to extrapose elements than its contact varieties. Likewise, while having the typical properties of being a verbsecond (V2) language, I demonstrated that Cité Duits allows for verb-third (V3) in certain contexts. Another characteristic feature is the infinitival complementizer für ...zu, a variant that can be associated with German dialects and with voor ...te in Dutch non-standard varieties. 
Finally, it is important to bear in mind that some features may be systematic whereas others may occur rather seldom. Because the analyzed data is based on spontaneous-like interactions, not all speakers use these features to the same extent. Two main questions still require further analysis. First, to which degree are linguistic features employed in consistent ways? Second, how can we account for variation in the data? Given that I hardly included frequency effects in this overview, a more thorough look is now needed to establish the extent to which these features are used systematically. To arrive at a more detailed and comprehensive view of the linguistic character of Cité Duits, the subsequent analyses of personal pronouns $(\S 5,6)$ and progressive aspect $(\S 7)$ will combine a quantitative and a qualitative view on the data. If this chapter established the linguistic nature of Cité Duits in a preliminary fashion, the analyses in the next chapters will further explore and substantiate the various observations presented. 


\section{Chapter 5: Pronominal Usage in Cité Duits}

\subsection{Introduction}

The observations in the previous chapter suggest that Cité Duits shares numerous linguistic features with spoken Belgian Dutch, Maaslands, and German. The aim of this chapter and the next two chapters is to examine to which degree these varieties have contributed to the internal structure of Cité Duits, and to what extent. How much stability does the 'grammatical system' exhibit? Do linguistic features occur randomly or in a rather systematic way? To determine whether to identify Cité Duits as a loose set of features or as a homogenous system with rather coherent patterns, I will analyze the degree of variation within the data.

This chapter and the following one ( $(6)$ are devoted to the use of personal pronouns in Cité Duits, and as such they address research question three (RQ3): how can the pronominal paradigm be characterized and which factors account for variation? My aim is to assess which varieties are represented in the pronominal paradigm of Cité Duits, and to examine whether the resulting forms are employed in consistent ways by its speakers. Since the cross-linguistic study by Forchheimer (1953) on pronominal marking, ${ }^{1}$ scholars have shown a growing interest in the analysis of pronominal elements (Bhat 2013; Simon \& Wiese 2002; Cysouw 2003; Corver \& Delfitto 1999; Cardinaletti \& Starke 1999; Bhat 2004; Audring 2009; Lenerz 1994; 1993; van Riemsdijk 1999). One of the fascinating properties of pronouns is that their meaning derives exclusively within the linguistic context in which they are embedded.

Pronouns are well-suited in particular for an investigation at the intersection of sociolinguistics and grammatical analysis because they form an important part of language. In addition, the behavior of pronominal forms in contexts of language contact elucidates the stability of linguistic features. In language contact situations that are mainly characterized by code-switching, we expect to identify pronominal forms from contact variety A and B and possibly C. Speakers who switch between two or more varieties make use of more than one system. Yet once these systems fuse and gradually evolve into a new variety, certain features lose ground while others take over. If situations of code-switching allow for much variation when several grammatical systems exist side by side, emerging contact varieties show a higher degree of homogeneity within the system itself (Auer 1998a; 2014). This raises several interesting questions. First, to which degree are pronominal forms used in consistent ways in Cité Duits, and, second, with which varieties do these forms exhibit congruence? Directly related to this is the question of whether pronominal forms have arisen that are not found in spoken Belgian Dutch, Maaslands, or

\footnotetext{
${ }^{1}$ While the study by Forchheimer (1953) is often viewed as ground-breaking, his way of data selection met with much criticism (Cysouw 2003: 25-26).
} 
German. While the data contains a broad set of pronominal elements, I will only elaborate on the paradigm of personal pronouns because these exhibit the highest frequency in relation to other pronouns in the data. ${ }^{2}$ Similarly, in German, personal pronouns make up about 33 percent of all pronouns, according to the 'Dictionary of frequency of spoken language' (Ruoff 1990: 189).

Empirically, my concern is in particular with three issues. (i) Frequency: what does the distribution of pronominal forms look like? (ii) Internal properties: do we encounter phonological or lexical variation for a given pronoun? (iii) Variation: how can variation in the pronominal paradigm be explained? While the present chapter ( $§ 5)$ deals with the distribution of pronominal forms and their phonological properties, the following chapter (§ 6) will examine the factors that may have caused form variation of certain pronouns. After some terminological clarifications ( $\S 5.2$ ), this chapter begins by reviewing the use of personal pronouns in spoken Belgian Dutch, the Maaslands dialect, and German (\$ 5.3). The ensuing sections will discuss pronominal variation in Cité Duits by focusing on subject pronouns ( $§ 5.4)$ and object pronouns $(\S 5.5)$.

\subsection{Terminological Clarifications}

The theoretical discussion in this chapter is based on the attested features dealt with in detail in the subsequent sections ( $\$$ 5.3-5.5). A number of developments in the use of personal pronouns in Belgian Dutch, Maaslands, and German have been excluded or limited to some major aspects to keep this chapter within its scope.

\subsubsection{Clitic Pronouns}

In traditional terminologies, 'cliticization' refers to the phonological reduction of a pronoun, or more specifically, to the process by which a clitic attaches to its 'host' and forms a phonological unit (Kolmer 2012: 72; Abraham \& Wiegel 1993: 3). For instance, in fast speech, personal pronouns (and other function words) tend to show reductions when unaccented, such as the first-person singular subject pronoun ' $I$ ' in English in '[ə] don't know' (Howe 1996: 7). The most common hosts for pronouns are verbal elements, but also other elements may serve as hosts (ibid. 88).

In the literature, reduced pronominal forms or 'clitics' have been much discussed with different questions in mind, yielding a broad array of diverging definitions. Next to phonological constraints, scholars emphasized the syntactic peculiarities of clitics (Cardinaletti \& Starke 1999; van Riemsdijk 1999; de Vogelaer 2007; Abraham \& Wiegel 1993; Halpern 1995; Zwicky 1985; 1994; Kolmer 2012; 2010; Zwart 1993; Kayne 2000;

\footnotetext{
${ }^{2}$ See Bresnan (2001) and Bhat (2004) for a discussion of the concept 'pronoun' and its neighboring categories. See also von Heusinger (2002).
} 
Nevis 1985). ${ }^{3}$ An approach that received much approval in the literature stems from Zwicky (1977), who distinguished between 'simple clitics' and 'special clitics.' The term 'simple clitics' refers to optional variants of full forms, whereas 'special clitics' are variants without a corresponding full form with the same distribution. ${ }^{4}$ Frequently cited examples for the first are phonetically reduced pronouns in informal spoken language, as in the English example above. Clitic pronouns in German, for instance, are generally considered 'simple clitics' since they can be substituted by the full form (Nübling 1992: 304; Howe 1996: 28-29 for discussions). ${ }^{5}$ Special clitics, on the other hand, are typically related to clitic pronouns in Romance languages (Kolmer 2012; Kayne 2000; Cardinaletti \& Starke 1996), although some personal pronouns in Germanic languages have been argued to behave as special clitics.

In the present study, the notion of 'clitic' will be used for referring to reduced pronominal forms that attach phonologically to another element, as illustrated for Netherlandic Dutch in (1) and (2) (examples from Linke \& Kirstein 2018). ${ }^{6}$
(1) [txat]
't gaat (goed). (proclitic)
'It goes (well).'
(2) [kom.ti]
Komt-ie? (enclitic)
'Does he come?'

\footnotetext{
3 Much attention has been paid to languages that allow for clitic doubling such as French (Cardinaletti \& Starke 1999), Italian (Kolmer 2010) or Albanian (Kapia 2014), as well as to crosslinguistic analyses (Kayne 2000). Recent work also focused on the role of reduced or weak pronominal forms in Germanic language varieties including dialects of German and Dutch (de Vogelaer 2007; Kolmer 2012; Zwart 1993; Abraham \& Wiegel 1993; Nübling 1992; Howe 1996).

${ }^{4}$ Zwicky (1977: 3-6) describes the general differences as follows: Special clitics: 'cases where an unaccented bound form acts as a variant of a stressed free form with the same cognitive meaning and with similar phonological makeup.... The weak or clitic pronouns of many Romance and Slavic languages are standard examples' (ibid. 3). Simple clitics: 'Cases where a free morpheme, when unaccented, may be phonologically reduced, the resultant form being phonologically subordinated to a neighboring word. Cliticization of this sort is usually associated with stylistic conditions, as in the casual speech cliticization of object pronouns in English; there are both formal full pronouns and casual reduced pronouns' (ibid. 5).

5 Opinions differ in this regard. Howe (1996: 29) discusses German es 'it' and Dutch het 'it' as examples of 'special clitics' in certain contexts where a corresponding full form is not available. Note that these pronouns can often be substituted by the demonstrative das/dat 'that' (Ehlich 1982; Audring 2009).

${ }^{6}$ A number of different phonological processes apply to these two groups in Dutch. For an overview including literature references, see Linke and Kirstein (2018).
} 
The examples above illustrate that pronominal clitics can principally be either adjoined to the following or incorporated into the preceding prosodic word, occurring in 'preverbal' and 'postverbal' position, respectively. Subsequently, I will employ the notion of 'proclitic' when the clitic form appears before (example (1)), and 'enclitic' when the respective form appears after the verbal element or complementizer (example (2)).

\subsubsection{Weak, Strong and Demonstrative Pronouns}

Another relevant distinction made in this study will be between 'weak,' 'strong' ('full') and 'demonstrative pronoun.' Since different concepts are understood for these notions, a brief clarification is necessary (see Kaiser \& Trueswell 2004; Audring 2020; 2018). The category that is most universally accepted is the notion of 'strong' or 'full' pronoun, which, in contrast to its reduced counterparts, is understood as an (anaphoric or deictic) element that may carry pitch accent (de Vogelaer 2007: 21). Besides anaphoric and deictic uses, personal pronoun can have a generic reference. In impersonal constructions such as 'it is raining,' the pronoun 'it' has no anaphoric or deictic use (Audring 2018).

'Weak pronouns,' in turn, are reduced forms that cannot carry pitch accent and occur in a limited set of contexts. Weak pronouns are not necessarily clitics, although weak pronominal forms may behave as clitics when forming a phonological unit with another element. A Dutch example for both strong (3) and weak (4) pronouns is provided below (examples Howe 1996: 30): ${ }^{7}$

About people (de mensen)

(3) Zij staan hier al een hele tijd.

(strong/full)

(4) Ze staan hier al een hele tijd. (weak)

'They have been standing here for quite a while.'

Weak pronouns may occur after Zwicky (1977) both as special and simple clitics, which is the case in certain dialects of Dutch (de Vogelaer 2007: 389). ${ }^{8}$ According to Gunther de Vogelaer (2007: 152), the type of weak pronouns (doffe pronomina) that exist in varieties of Dutch are rather scarce across languages of the world. Usually, these forms are confined to a limited number of environments in Dutch, i.e. directly before or after the verb, in the

\footnotetext{
${ }^{7}$ The Dutch weak and strong third person forms are subject to different restrictions in that the strong form $z i j$ 'they' cannot be employed for non-animate referents such as 'the books,' according to normative grammar (see below).

${ }^{8}$ A number of syntactic properties of clitics versus weak pronouns are discussed in van Riemsdijk (1999: 3-5), based on Kayne (1975). From this perspective, weak pronouns are XPs since they may occur clause-initially and do not have to be adjacent to the verb, whereas clitics are heads, i.e. they move together with the verb when the latter is moved to a higher position. Unlike other elements, a clitic can never be modified or stressed and depends on the presence of a host.
} 
first place in the subordinate clause and in enclitic position after the conjunction (plus after the particles yes and no in certain dialects) (de Vogelaer 2007: 152).

Finally, this study will employ the notion 'demonstrative pronoun' to designate demonstrative forms that serve anaphoric or deictic purposes similar to personal pronouns (5). Demonstrative pronouns are frequently employed when a new discourse referent is introduced (deictic usage) (Linke \& Kirstein 2018, including example) (see $\S 5.4 .5$ for grammatical gender). ${ }^{9}$

About the house (het huis)

(5) Dat staat leeg. (demonstrative)

'That is empty.'

Note that in the literature on German, some scholars employ the notion of 'strong' pronoun (Ahrenholz 2012: 78) to refer to forms as in (5). ${ }^{10}$ In the given context, this results problematic since the term 'strong pronoun' is often used synonymous with 'full' pronoun in the literature on Dutch and denotes examples as in (3) (zij 'they'). In the present study, I therefore reserve the term 'strong'/'full' pronoun for examples as in (3), in line with the literature on (dialects of) Dutch (de Vogelaer 2007; Linke \& Kirstein 2018; Kaiser \& Trueswell 2004). ${ }^{11}$

\subsubsection{Summary}

While weak and strong pronouns may theoretically occur in all positions as long as this is not impeded by syntactic or grammatical constraints, clitic pronouns need an element to which they attach, a so-called 'host.' Pronominal clitics most frequently attach to a verb, but they can also attach to other elements such as complementizers. In addition, demonstrative pronouns often 'substitute' personal pronouns in spoken language. In this study, the notion of 'demonstrative pronoun' will be used to refer to free (anaphoric or deictic) forms as in (5), whereas the notion of 'strong'/'full' pronoun will denote pronominal forms as in (3). These may appear both with and without accent. 'Weak' pronouns, in contrast, are generally unaccented forms. Furthermore, I understand the term 'reduced' pronominal form as an umbrella term to describe a pronoun that does not occur

\footnotetext{
${ }^{9}$ According to normative usage, the grammatical gender of the demonstrative pronoun in (5) needs to agree with the grammatical gender of the antecedent in Dutch (het huis $s_{N}>d a t$, but de fles $>$ die), and the same holds for German and Maaslands.

${ }^{10}$ Others use the term 'rhematic reference pronoun' (Weinrich et al. 2003: 380) or 'd-pronoun' (Bader \& Portele 2019).

${ }^{11}$ Importantly, while demonstratives and personal pronouns can often be used interchangeably, this is not possible in all contexts (for Dutch, see Audring 2020; Kaiser \& Trueswell 2004; for German, see Bader \& Portele 2019; Weinert 2007). Besides syntax, salience of the antecedent and contrast have been argued to play a role.
} 
in its full form, either as weak pronoun or as clitic. When pronominal forms occur directly before or after a verb, independent of their status as weak, strong, or demonstrative pronouns, I will refer to them as occurring in 'preverbal' or 'postverbal' position, respectively.

\subsection{An Overview of Personal Pronouns in Cité Duits Contact Varieties}

To understand the role that Belgian Dutch, Maaslands, and German may have played in the development of personal pronouns in Cité Duits, this section introduces their pronominal paradigms. Since the analyzed data consists of informal spoken language, I mainly concentrate on the behavior of pronouns in their spoken form. As pointed out, this chapter cannot provide a full discussion of personal pronouns in Cité Duits contact varieties, but will consider the most prevailing forms.

\section{Some Initial Words on Belgian versus Netherlandic Dutch}

Since Belgian speakers have oriented toward and been exposed to Netherlandic Dutch for a long time (§ 1.2), I will briefly outline the main differences regarding their pronominal paradigms. First, speakers use distinct second-person singular pronouns. While the south of the Dutch language area employs gij (strong) and ge (weak), northern standard varieties rather use $j i j$ and $j e$. In the latter, the use of $g i j$ and $g e$ is regarded as archaic (Broekhuis \& den Dikken 2012b: 781; also Vandekerckhove 2005: 395). ${ }^{12}$ Nevertheless, Belgian speakers are aware of both paradigms because the jij/je-paradigm is found in the domains of education, media and written language (Vandekerckhove 2005: 386). ${ }^{13}$

Second, the weak form of the third-person singular masculine pronoun hij is usually ' $m$ [əm] in Belgian Dutch but -ie in Netherlandic Dutch. Unlike other weak forms, the latter has no schwa (Audring 2006: 86), is restricted to certain phonological contexts such as after $-t$ and may not occur in sentence-initial position (de Vogelaer 2007: 147; further Kaiser \& Trueswell 2004: 138; Rozendaal 2008: 27) (6).

$\begin{array}{llllll}\text { (6) a. } & \text { heeft } & \text {-ie } & \text { morgen } & \text { tijd? } \\ \text { has } & \text { he } & \text { tomorrow } & \text { (Netherlandic Dutch) } \\ \text { time } & \end{array}$

'Does he have time tomorrow?' 'He has time tomorrow.'

\footnotetext{
12 The gij/ge-paradigm is also found in some southern parts of the Netherlands and not entirely restricted to Belgium. In Northern Dutch, gij is restricted to old texts and prayers (Vandekerckhove 2005: 359).

${ }^{13}$ In Dutch, a remarkable change took place around 1500 when the pronoun $d u$ for the second-person singular was replaced by jij, which also affected the verbal paradigm (Aalberse 2009: 254).
} 
Third, Belgian and Netherlandic Dutch differ on the level of phonology as to the pronunciation of particular pronouns. In Belgian Dutch, the third-person form het 'it' is usually pronounced as [(h)at] when occurring in its full form, whereas in Netherlandic Dutch, het is pronounced as [(h)et] with an open mid-front unrounded vowel. Finally, Belgian and Netherlandic Dutch show structural differences. Whereas Netherlandic Dutch distinguishes between formal ( $u$ 'you') and informal pronominal forms (jij/je 'you'), spoken Belgian Dutch does not mark this contrast on the pronoun. The pronoun $u$ 'you' is used in the Belgian varieties for both formal (V) and informal (T) addressees (Vandekerckhove 2005: 383; Geeraerts 2010: 250). ${ }^{14}$

\subsubsection{Belgian Dutch}

The pronominal paradigm for Belgian Dutch for both strong and weak forms is represented in Figure 20. For ease of exposition, all forms appear in written and in phonetic spelling following IPA. In colloquial Belgian Dutch, much more phonological and morphological variation is found, but this is beyond the scope of this survey. An indepth analysis of pronouns in Belgian Dutch based on regional, situational and social factors can be found in Plevoets (2008). See further Velde and Geeraerts (2013) and Plevoets et al. (2008) for Belgian Dutch. For pronouns of address, see Vandekerckhove (2004; 2005) and Mieroop et al. (2016); for a close examination of pronominal variation across Dutch dialects, see de Vogelaer (2007) and DynaSAND (Barbiers \& al. 2006). For a detailed overview of clitic pronouns in Dutch dialects, see Schutter (1989). For the development of Dutch pronouns from a diachronic perspective, see Howe (1996: 203-12).

\begin{tabular}{|c|c|c|c|c|c|}
\hline \multirow[b]{2}{*}{ SG } & & SBJ FULL & IPA & SBJ WEAK & IPA \\
\hline & 1 & ik & [Ik] & 'k & {$[ə \mathrm{k}][\mathrm{k}]$} \\
\hline & 2 & $\mathrm{gij} / \mathrm{jij}$ & [үعI] [jeI] & ge/je & [уә] [jə] \\
\hline & $3 \mathrm{M}$ & hij/die & [heI] [di:] & 'm & [əm] \\
\hline & $3 \mathrm{~F}$ & zij/die & [zeI] [di:] & ze & [zo] \\
\hline & $3 \mathrm{~N}$ & het/dat & [hət][dat] & 't & {$[ə t][t]$} \\
\hline & V & $\mathrm{u}$ & [y] & $\mathrm{u}$ & [y] \\
\hline \multirow[t]{3}{*}{ PL } & 1 & wij & [wer] & we & [wə] \\
\hline & 2 & jullie & ['jyli] & ge & [४ә] \\
\hline & 3 & zij/die & [zeI] [di:] & ze & [zə] \\
\hline
\end{tabular}

\footnotetext{
14 The terms V and T, abbreviations for socially-differentiated pronominal forms of address, stem from Latin vos and $t u$. For a discussion, see Howe (1996: 5).
} 


\begin{tabular}{|c|c|c|c|c|c|}
\hline & & OBJ FULL & IPA & OBJ WEAK & IPA \\
\hline \multirow[t]{6}{*}{ SG } & 1 & $\mathrm{mij}$ & [mei] & me & [mə] \\
\hline & 2 & $\mathrm{u}$ & [y] & $\mathrm{u}$ & [y] \\
\hline & $3 \mathrm{M}$ & hem & [hem] & 'm & [əm] \\
\hline & $3 \mathrm{~F}$ & haar & [ha:r] & ze/'r & {$[\mathrm{z} \partial][\mathrm{r}][\mathrm{R}]$} \\
\hline & $3 N$ & het & [hət] & 't & [ət] \\
\hline & $\mathrm{V}$ & $\mathrm{u}$ & [y] & $\mathrm{u}$ & [y] \\
\hline \multirow[t]{3}{*}{ PL } & 1 & ons & [ons] & - & - \\
\hline & 2 & jullie & ['jyli] & - & - \\
\hline & 3 & die & [di:] & ze & [zə] \\
\hline
\end{tabular}

Figure 20: Full and weak subject and object pronouns in Belgian Dutch ${ }^{15}$

Probably the most eye-catching fact is that Belgian Dutch displays an opposition between 'strong' and 'weak' pronominal subject forms. This holds for southern and northern varieties of Dutch including most dialects (de Vogelaer 2007). The only exception in subject pronouns is the second-person plural which has no weak form (although ge is possible instead of jullie).

\section{Subject Pronouns in Belgian Dutch}

For subject singular pronouns holds the following (left columns in Figure 20): The firstperson is $i k$ [Ik] and its reduced counterpart ' $k[\partial \mathrm{k}] /[\mathrm{k}]$. The latter may occur both in preand postverbal position. There is an additional emphatic form, ikke [Ikə], which is normally used in isolation and not with a finite verb (Broekhuis \& den Dikken 2012b:

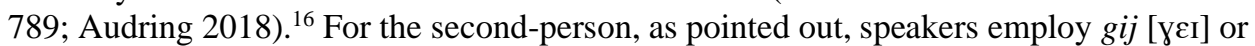
the reduced form $g e$ [уə] in spoken language. ${ }^{17}$ In colloquial speech, the diphthong /ei/ is often realized as a monophthong.

For the third-person masculine holds that next to the full form hij and its weak counterpart ' $m$ [əm], the demonstrative pronoun die [di:] is often used. In Dutch, die is not specified for biological gender and is also employed for the third-person feminine, next to $z i j$ [zEI] and its reduced counterpart ze [zə] (de Vogelaer 2007: 189; Audring 2018). Unlike

${ }^{15}$ With many thanks to Hans Van de Velde.

16 There is dissention on the emphatic status of $i k k e$, see the discussion between Hoeksema (2000) and Zwart (2000).

${ }^{17}$ There is a tremendous amount of variation in the second-person pronoun in casual speech, such as gulder and the clitics -de and -degij in VSO patterns (Plevoets 2008; further Mieroop et al. 2016: 40; Barbiers \& al. 2006). Furthermore, gij can be used as plural pronoun, e.g. gaat gij allemaal mee? 'Do you all go along?' (van de Velde 2018, p.c.). I leave these forms aside since irrelevant for the present analysis. 
the respective masculine form ' $m$, the feminine weak form ze may occur sentence-initially (Kaiser \& Trueswell 2004: 138). For neuter, het [hət] is employed, whereby the reduced form $t[a \mathrm{t}] /[\mathrm{t}]$ is most common, both as pro- and enclitic. Note that $/ \mathrm{h} / \mathrm{in}$ hij 'he' and het 'it' tends to be deleted (Plevoets 2013: 191; De Wulf 2003: 217-18). The neuter demonstrative form is $d a t$ [dat]. For subject plural forms, the most common pronouns are the full form wij [weI] and reduced we [wə] for the first-person, ${ }^{18}$ jullie ['jyli] and ge [үə] for the second-person and the full form $z i j[\mathrm{z} \varepsilon I]$, reduced $z e$ and the demonstrative pronoun die [di:] for the third-person. ${ }^{19}$

\section{Object Pronouns in Belgian Dutch}

Similar to subject pronouns, object pronouns in Belgian Dutch have a weak and a strong form (right columns in Figure 20), although not all pronouns follow this pattern: The firstperson and second-person plural ons and jullie have no weak form. For the first-person singular object, $m i j[\mathrm{~m} \varepsilon \mathrm{i}]$ and reduced $m e$ [mə] are used. The second-person singular has only one form, namely $u$ [y]. The third-person singular masculine is hem [hem] and reduced $m$ [əm]. For the third-person singular feminine, the full form is haar [ha:r], often pronounced with an uvular/r/ as [ha:R] in Belgian-Limburg, whereas the weak form may be realized either as ze [zə] or $r[\mathrm{r}] /[\mathrm{R}]$. Again, deletion of word-initial $/ \mathrm{h} / \mathrm{is}$ typical here. For object plural pronouns holds that ons [ons] is used for the first-person, jullie ['jyli] for the second-person and the demonstrative pronoun die [di:] as well as the weak form ze [zə] for the third-person. ${ }^{20}$

\section{Explanatory Notes on Subject and Object Pronouns}

Regarding the behavior of weak versus strong pronouns in Belgian Dutch, several additional notes on their grammatical properties are relevant. First, from a strictly grammatical perspective, weak and strong forms may often be used interchangeably (de Vogelaer 2007: 153), as illustrated for the second-person subject pronoun in (7).

(7) $\mathbf{G e / g i j ~ b e n t ~ o p ~ t i j d . ~}$

'You are on time.'

Some idiomatic expressions, however, require the weak form (Linke \& Kirstein 2018; Zwart 1993: 125). In turn, the strong form is the only grammatical option in finite

\footnotetext{
${ }_{18}$ In Netherlandic Dutch, in contrast, 'we' is usually pronounced as (strong) [0عi] or (weak) [0ə]. Furthermore, in Belgian Dutch, the /w/ is sometimes realized as [ $\beta$ ] (Mennen et al. 2007: 410).

${ }^{19}$ Not mentioned is men 'one,' which can exclusively be employed as the animate subject of a finite clause. Formally, men is a third person singular pronoun, indicated by the inflection on finite verbs (Broekhuis \& den Dikken 2012b: 775). I excluded this form since only scarcely attested in the data. ${ }^{20}$ From a normative perspective, the strong forms hen [hen] and hun [hyn] are used for the third person. Yet, the distinction between accusative hen and dative hun is mostly restricted to writing and formal speech contexts (Broekhuis \& den Dikken 2012b: 782-83).
} 
imperatives with overt subject pronouns (Broekhuis et al. 2015a: 92). ${ }^{21}$ The strong form wij 'we,' for example, is obligatory in vocatives, oppositions, comparisons, reactions to a previous utterance and with attributes like ook 'also' and zelfs 'even' (see Broekhuis and Corver 2015b: 787 for a discussion on the syntactic environments in which weak forms may not occur; see Temmerman 2014 for 'we'), exemplified below (example Temmerman 2014: 248).

(8) Zelfs wij/*we werden uitgenodigd.

'Even we were invited.'

Second, the strong third-person subject pronoun zij is restricted to animate referents, as depicted in (9) (Zwart 1993: 124 including examples). ${ }^{22}$

(9) $\mathbf{Z e} / * \mathbf{z i j}$ zijn uit voorraad. (bikes)

'They are out of stock.'

The strong third-person singular masculine form hij 'he,' in contrast, may be used for animate and non-animate referents. Third, demonstrative pronouns, unless focused, normally do not occur in situ when animate (Postma 2018: p.c.).

(10) a. *Ik heb die gezien. (children)

b. Ik heb die gezien. (books)

'I have seen them/those.'

In (10), die may be used to refer to non-animate antecedents such as 'books' (b) but would be rather untypical when having an animate referee such as 'the children' (a).

\subsubsection{Maaslands}

Similar to Belgian Dutch, Maaslands has a set of full and weak personal pronouns, depicted in Figure 21. The forms that normally occur as enclitics are indicated in italics. For pronouns across Dutch dialects, I refer to Goeman et al. (2014) and de Vogelaer (2007), for pronouns in Limburgish see van Hout (2006); Goossens (1994b; 1996) and Stevens (1949/1985), as well as Belemans and Keulen (2004: 59-64) for Belgian-Limburg.

${ }^{21}$ Dutch has finite imperative constructions which obligatorily contain an overt subject in subject position (Broekhuis et al. 2015a: 92).

${ }^{22}$ Some West-Flemish dialects seem to allow for full forms to refer to non-human antecedents (de Vogelaer 2007: 318). 


\begin{tabular}{|c|c|c|c|c|c|}
\hline & & SBJ FULL & IPA & SBJ WEAK & IPA \\
\hline \multirow[t]{6}{*}{ SG } & 1 & i:ch & [i:ç] & $c h$ & [ç(:)] \\
\hline & 2 & di:ch & [di:ç] & de/te & {$[\mathrm{d} ə][\mathrm{tə}]$} \\
\hline & $3 \mathrm{M}$ & (h)eeë(r)/dè & [e:e] [də] & er & {$[\mathrm{e}:]$} \\
\hline & $3 \mathrm{~F}$ & zi-j/dièj & [zęij][di:j] & $\mathrm{ze} / \mathrm{se}$ & [zə] \\
\hline & $3 \mathrm{~N}$ & (h)et/dèt & {$[\mathrm{h} \partial \mathrm{t}][\mathrm{d} \partial \mathrm{t}]$} & t/et & {$[\partial t][t]$} \\
\hline & V & geer & ['ye:R] & ger & [yer] \\
\hline \multirow[t]{3}{*}{ PL } & 1 & weer & [ve:R] & wer & [ver] \\
\hline & 2 & geer & ['ye:R] & ger & [yer] \\
\hline & 3 & zi-j/dièj & [zęi $]\left[\mathrm{di}^{\mathrm{j}}\right]$ & $\mathrm{ze} / s e$ & [ze] \\
\hline
\end{tabular}

\begin{tabular}{|c|c|c|c|c|c|}
\hline & & OBJ FULL & IPA & OBJ WEAK & IPA \\
\hline \multirow[t]{5}{*}{ SG } & 1 & mi:ch & [mi:ç] & mich & [miç] \\
\hline & 2 & di:ch & [di:ç] & dich & [diç] \\
\hline & $3 \mathrm{M}$ & (h)äöm & [œ:m] & (h)em & [əm] \\
\hline & $3 F$ & (h)äör & [œ:R] & (h)er & [eR] \\
\hline & $3 \mathrm{~N}$ & (h)et & [hət] & t/et & {$[t][\partial t]$} \\
\hline \multirow[t]{3}{*}{ PL } & 1 & oos & {$[\mathrm{o}: \mathrm{s}]$} & òs & [os] \\
\hline & 2 & uuch & [y:ç] & uch & [yç] \\
\hline & 3 & (h)un & [hyn] & ze & [ze] \\
\hline
\end{tabular}

Figure 21: Full and weak subject and object pronouns in Maaslands ${ }^{23}$

Figure 21 shows that all personal pronouns are available as full and weak forms in Maaslands, with the main difference often being one of vowel length. While full forms generally carry a long vowel, their weak counterparts have a short vowel (for example [di:ç] vs. [diç]). The phonological development known as the Zweite Lautverschiebung or 'High German consonant shift' affected central and southern German dialects but usually not the dialects of Dutch, except in parts of Limburg where the stop-sound $/ \mathrm{k} / \mathrm{in} i k$, ook, lijk and maken developed into the fricative /x/, as in German ich, auch, -lich, machen (Marynissen \& Janssen 2013: 85). In Maaslands, this is especially visible in the firstperson singular (see also § 1.2.4).

\footnotetext{
${ }^{23}$ With many thanks to Rob Belemans. Not included is the Maaslands form $m$ ' $n$ 'one,' which can exclusively be employed as the animate subject of a finite clause, similar to Dutch men and German man.
} 


\section{Subject Pronouns in Maaslands}

Starting with subject pronouns (left columns in Figure 21), the first-person singular is $i$ :ch [i:ç] and reduced 'ch [ç(:)]. Similar to Belgian Dutch, the latter may occur in preverbal position. For the second-person singular, the full form is di:ch [di:ç]. Historically, this form seems to have developed out of the accusative object form, thereby replacing the original pronoun $d u$. Except for a few fixed expressions, $d u$ has mainly disappeared from the dialect (Stevens 1949/1985: 6) ${ }^{24}$ Furthermore, Maaslands has two weak forms that differ slightly as to their behavior as clitics: while de [də] mainly occurs before the finite verb, $t e[\mathrm{t}$ ] $]$ is confined to the position after the finite verb and complementizer (Goeman et al. 2014). ${ }^{25}$

The third-person singular masculine is $(h) e e \ddot{e}(r)$ [e: $\mathrm{p}]$ and reduced er [e:], sometimes realized as schwa [ə]. Although $(h)$ еeё( $(r)$ [e: that the initial consonant is slightly fading away and no longer pronounced. ${ }^{26}$ For the thirdperson singular feminine, the forms $z i-j$ [zej] and reduced ze [ze] as well as the demonstrative pronoun dièj [di:i] are employed. The third-person singular neuter is $(h) e t$ [hət] and reduced ' $t[\partial t] /[\mathrm{t}]$, whereas the demonstrative form is dèt [dət]. The polite forms

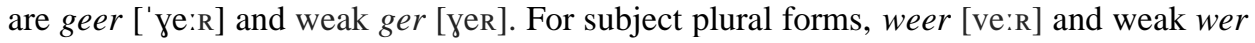
[ver] are used for the first-person, geer ['ye:R] and weak ger [yen] for the second-person and $z i-j$ [zęj], weak $z e$ and the demonstrative pronoun dièj [di:j] for the third-person.

\section{Object Pronouns in Maaslands}

As to the properties of object pronouns (right columns in Figure 21), the full forms for the first-person and second-person carry a long vowel ([mi:ç], [di:ç]), similar to the full subject forms, whereas their weak counterparts do not. The latter are usually realized as

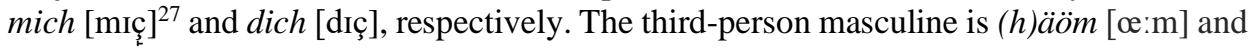
reduced $(h)$ em $[ə \mathrm{~m}]$. For the third-person feminine, $(h) \ddot{a} \ddot{o r}[œ: \mathrm{R}]$ and the weak pronoun (h)er [eR] are employed, usually with deletion of $/ \mathrm{h} /$. The neuter pronoun is [(h)at], thereby corresponding to the respective subject pronoun. For object plural pronouns, the firstperson is realized as oos [o:s] and weak òs [os], the second-person as uuch [y:ç] and weak $u c h$ [yç] and the third-person as (h)un [hyn] and weak ze [zo].

\footnotetext{
${ }^{24}$ Note that $d u / d o u$ has been conserved in the southeast of Dutch Limburg and in a few dialects around Twente, Groningen and Friesland. In Belgian Limburg, dialect speakers mainly use dich (de Vogelaer 2007: 170).

25 The second-person has attracted remarkable attention. See in particular Aalberse (2009) for a detailed analysis.

26 As emphasized in $\S 1.2$, dialects are not acquired as autonomous varieties but rather on a continuum with the standard language nowadays (De Vogelaer \& Klom 2013: 162; Ghyselen \& Keymeulen 2016; van de Velde 1996: 31; Geeraerts 2001).

${ }^{27}$ MAND also lists [mex] (access May 1, 2018) (Goeman et al. 2014).
} 


\section{Explanatory Notes on Subject and Object Pronouns}

Regarding the status of weak versus strong pronouns in Maaslands, there are some differences between Belgian Dutch and the dialect. For the second-person singular subject, Belgian Dutch has a single weak form ge that may occur both in pre- and postverbal position, whereas two weak forms are found in Maaslands. While de occurs before the verb, $t e$ is confined to the position after a verb or complementizer, in line with a number of Limburgish dialects (De Schutter \& Hermans 2013: 364). In addition, unlike Belgian Dutch, Maaslands has maintained the V-T distinction on personal pronouns: Whereas

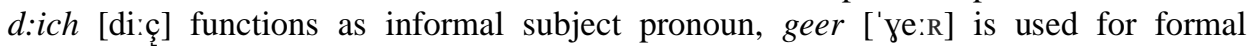
addresses, next to its use as second-person plural.

\subsubsection{German}

In German, the distinction between accusative and dative, or direct and indirect object forms, is still productive. The paradigm for personal pronouns in colloquial standard German is provided in Figure 22 (based on Nübling 1992: 303; Howe 1996: 263; Zifonun et al. 1997: 316-20). ${ }^{28}$ While there are regional differences, these are too extensive to be discussed here. ${ }^{29}$

Traditionally, German has four cases (nominative, accusative, dative and genitive). Due to their low occurrence in spoken German (Zifonun et al. 1997: 1298; Barbour \& Stevenson 1990: 84; for dialects, see Fleischer 2006), genitive forms are not dealt with here. Note that the outer four right columns are divided according to case and not based on the distinction between strong and weak pronouns. Clitic forms are marked in italics. For clitics in German, see Zifonun et al. (1997: 316-20) and Nübling (1992); for case distinction and levelling in personal pronouns across German dialects, see Howe (1996: 262-82); for the development of German pronouns from a diachronic perspective, see Howe (1996: 241-61). See Bader and Portele (2019) and Weinert (2007) for personal versus demonstrative pronouns in spoken interaction.

\begin{tabular}{|l|l|l|l|l|l|}
\hline & & SBJ FULL & IPA & SBJ CLI & IPA \\
\hline SG & 1 & ich & {$[$ iç] } & - & - \\
\hline & 2 & du & {$[\mathrm{du}:]$} & 'te/'de & {$[\mathrm{t} ə][\mathrm{d} ə]$} \\
\hline & $3 \mathrm{M}$ & er/der & {$[\mathrm{e}: \mathrm{e}][\mathrm{de}: \mathrm{e}]$} & '’ $a$ & {$[\mathrm{e}]$} \\
\hline & $3 \mathrm{~F}$ & sie/die & {$[\mathrm{zi}:][\mathrm{di}:]$} & 'se & {$[\mathrm{zə}]$} \\
\hline & $3 \mathrm{~N}$ & es/das & {$[\varepsilon \mathrm{s}][\mathrm{das}]$} & 's & {$[\mathrm{s}]$} \\
\hline
\end{tabular}

\footnotetext{
28 The paradigm of clitics in Nübling (1992: 303) is based 'on the colloquial language of the nationwide spoken variety of German' (translation N.P.).

${ }^{29}$ To give an example, Low German dialects retained the unshifted consonants /p/, /t/, / / / Hence, in these dialects, the first person singular is /ik/ and the third person demonstrative form is /dat/ (Schönfeld 1990: 95).
} 


\begin{tabular}{|l|l|l|l|l|l|}
\hline & V & Sie & {$[\mathrm{zi}:]$} & 'se & {$[\mathrm{zə}]$} \\
\hline PL & 1 & wir & {$[\mathrm{vi}: \mathrm{e}]$} & 'wa/'ma & {$[\mathrm{ve}][\mathrm{me}]$} \\
\hline & 2 & ihr & {$[$ ?i:e $]$} & 'a & {$[\mathrm{e}]$} \\
\hline & 3 & sie/die & {$[\mathrm{zi}][\mathrm{di}:]$} & 'se & {$[\mathrm{zə}]$} \\
\hline
\end{tabular}

\begin{tabular}{|c|c|c|c|c|c|}
\hline & & OBJ ACC & IPA & OBJ DAT & IPA \\
\hline \multirow[t]{6}{*}{ SG } & 1 & mich & [mıç] & mir/'ma & {$[\mathrm{mi}: \mathrm{e}][\mathrm{me}]$} \\
\hline & 2 & dich & [diç] & $\operatorname{dir} /{ }^{\prime} d a$ & [di:e] $][\mathrm{de}]$ \\
\hline & $3 \mathrm{M}$ & $\mathrm{ihn} /$ 'n & {$[\mathrm{i}: \mathrm{n}][\mathrm{n}]$} & $\mathrm{ihm} /{ }^{\prime} m$ & [i:m][əm] \\
\hline & $3 \mathrm{~F}$ & sie/'se & [zi:][zə] & ihr & [?i:en] \\
\hline & $3 \mathrm{~N}$ & es/'s & {$[\varepsilon s][\mathrm{s}]$} & $\mathrm{ihm} /{ }^{\prime} m$ & [i:m][əm] \\
\hline & $\mathrm{V}$ & Sie & [zi:] & Ihnen & ['Pi:nən] \\
\hline \multirow[t]{3}{*}{ PL } & 1 & uns & [ons] & uns & [uns] \\
\hline & 2 & euch & [Pગ્ઞç] & euch & [?oIç] \\
\hline & 3 & sie/se & [zi:][zə] & ihnen & ['Pi:nən] \\
\hline
\end{tabular}

Figure 22: Full and reduced subject and object pronouns in German

From Figure 22, it can be observed that solely three personal pronouns, namely the first and second-person singular as well as the third-person singular masculine, possess a distinct form for every single case. All other pronouns either have a joint accusative-dative or nominative-accusative form (Howe 1996: 262). Vowel reduction is typical, especially in allegro (fast) speech. In subject pronouns, all pronouns have a full form and a reduced form, except for the first-person singular ich 'I' (but see below for a discussion).

\section{Subject Pronouns in German}

For subject pronouns holds the following (left columns in Figure 22). The first-person singular is realized as ich [iç]. Generally, it is assumed that colloquial standard German has no corresponding clitic form (Nübling 1992: 304). Nevertheless, according to the 'Grammar of German language' (Zifonun et al. 1997: 318), German has the proclitic ch, although it is rarely used. As enclitic, it is regionally constrained (see also Howe 1996: 263-271 for regional differences). ${ }^{30}$

For the second-person holds that the full form is $d u$ [du:] - also realized as [dv] or [du] (Howe 1996: 263) - and the clitic forms are de [də] and te [tə], both confined to

\footnotetext{
${ }^{30}$ As pointed out, there is regional variation. For instance, I attested the first-person singular pronoun /i:/ in speakers from Munich (German corpus), e.g. nei $\boldsymbol{i}$ bin grad am über[legen/ und $\boldsymbol{i}$ war halt ständig am ausmisten weißt=/.. aber $\boldsymbol{i}$ zieh jo nit aus ne ('I am thinking.'/and I was constantly cleaning up./but I am not moving.').
} 
enclitic position (Zifonun et al. 1997: 317-18; Nübling 1992: 22; 307). The full form $d u$ ('you') is then attached to the verb while the consonant is omitted, and the vowel becomes a schwa (Zifonun et al. 1997: 317), illustrated below (example Nübling 1992: 15):

$\begin{array}{rll}\text { (11) } \text { hast du } & > & \text { haste } \\ \text { [hasdu:] } & > & \text { [hastə] } \\ \text { have you } & > & \text { have you }\end{array}$

Cliticization of second-person singular forms as in (11) is frequent in spoken German, the $d u$-Enklise 'you-enclitic' has occasionally been attested in informal written texts (Nübling 1992: 307).

For the third-person singular masculine, the full form $\operatorname{er}[\mathrm{e}: \mathrm{p}]$, the clitic ' $a[\mathrm{r}]$ and the demonstrative pronoun der [de:e] are employed. The third-person singular feminine is sie [zi:], also realized as clitic 'se [zə] or in form of the demonstrative pronoun die [di:]. The neuter third-person pronoun is es [ $[\varepsilon]$, and reduced 's $[\mathrm{s}] .{ }^{31}$ The demonstrative form is das [das]. Furthermore, German has maintained the T-V distinction between formal and informal pronouns of address. The polite pronoun of address (etymologically a thirdperson, Howe 1996: 266) is Sie [zi:] and reduced 'se [zə]. For plural forms, the full pronoun wir [vi:e] and the reduced forms ' $w a[\mathrm{ve}]$ and ' $m a[\mathrm{me}]$ are used for the firstperson, ihr [?i:ę] and reduced ' $a$ [e] for the second-person and sie [zi:], the reduced form 'se [ze] and the demonstrative pronoun die [di:] for the third-person. For the third-person plural holds that cliticization to 'se [zo] is common (Zifonun et al. 1997: 317-19). ${ }^{32}$ From a phonological perspective but not indicated in the figure, the near-open central vowel $[\mathrm{e}]$ is often not fully articulated after another vowel, which means that the following

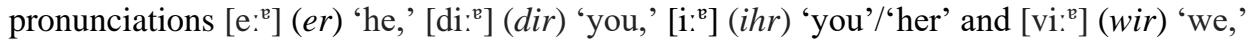
as well as the pronunciation without final [e] are sometimes found as well (Howe 1996: 263).

\section{Object Pronouns in German}

In object pronouns, a number of pronouns do not show phonological reduction, such as the first and second-person accusative (mich 'me'/dich 'you'), the first and second-person plural accusative and dative (uns 'us'/euch 'you') as well as the third-person plural and third-person feminine singular dative (ihnen 'them'/ihr 'her') (Nübling 1992: 303).

Except for the first and second-person plural uns 'us' and euch 'you,' German exhibits a distinct object pronoun for every accusative and dative form (right columns in Figure 22). While the first-person singular accusative form mich [mıç] is normally not cliticized (Nübling 1992: 303), the dative form mir [mi:e]] has the reduced form 'ma [me]

\footnotetext{
${ }^{31}$ For the different functions of es 'it,' see Zifonun et al. (1997) and Eisenberg (2016: 173-76). For a discussion of clitic 's, see Abraham and Wiegel (1993).

${ }^{32}$ See Weinert (2007: 1) for the paradigm of demonstratives in German. In the paradigm of object pronouns, demonstratives display case distinctions, which I decided to exclude here (such as den/dem).
} 
in fast speech. The picture is similar for the second-person singular. The accusative form dich [dıç] is usually articulated as full form, while the dative has both a full, i.e. dir [di:en], and a reduced form, i.e. 'da [de]. For the third-person singular masculine holds that both the accusative form ihn [i:n] and the dative form ihm [i:m] may occur as clitic, namely as ' $n$ [n] and ' $m$ [əm], respectively. The third-person singular feminine accusative forms are sie [zi:] and reduced 'se [zə]. The respective dative pronoun is ihr [?i:en], without clitic. The neuter accusative form is $e s[\varepsilon s]$, frequently reduced to 's [s]. The neuter dative form is realized as $i h m$ [i:m] and reduced ' $m$ [əm].

The polite V-form exhibits two distinct object forms, i.e. Sie [zi:] for accusative and Ihnen ['?i:nən] for dative case. For plural forms, the first-person is uns [ons] and the second-person is euch [?วIç] for accusative and dative case. To my knowledge, a clitic form does not exist here (see Nübling 1992: 303). Finally, the third-person accusative is realized as sie [zi:] and reduced as 'se [zə], while the dative form is ihnen ['?i:nən]. The latter is generally not cliticized (Nübling 1992: 303; Howe 1996: 262-282).

\section{Explanatory Notes on Subject and Object Pronouns}

While spoken German has a number of clitics, it does not have a set of weak personal pronouns that may occur both before and after the finite verb (see Abraham \& Wiegel 1993: 3; Lenerz 1993: 119). ${ }^{33}$ All reduced forms are enclitics and must attach phonologically to their host. That is, reduced and full pronominal forms may not be used interchangeably, as shown in (12).

$\begin{array}{cllll}\text { (12) a. } & \begin{array}{l}\text { Hast } \\ \text { have }\end{array} & \begin{array}{l}\text { te } \\ \text { you }\end{array} & \begin{array}{l}\text { morgen } \\ \text { tomorrow }\end{array} & \begin{array}{l}\text { Zeit? } \\ \text { time }\end{array} \\ \text { b. } & \begin{array}{l}\text { Du/*te } \\ \text { you }\end{array} & \text { hast } & \begin{array}{l}\text { morgen } \\ \text { have }\end{array} & \begin{array}{l}\text { Zeit? } \\ \text { tomorrow }\end{array} \\ & \text { time }\end{array}$

'Do you have time tomorrow?'

Moreover, German clitic pronouns are subject to a number of phonological and syntactic constraints. For instance, the second-person plural pronoun $i h r$ [?i:e] 'you' can be reduced to ' $a$ [ $\mathrm{b}$ ], whereas the homophonous third-person singular feminine dative form $i h r$ [?i:e tends to occur in its full form, as exemplified in (13) and (14) (Nübling 1992: 303-304 including examples).

$$
\begin{aligned}
& \text { (13) ['habta] }=\text { habt ihr } \\
& \text { 'have you' }
\end{aligned}
$$

\footnotetext{
${ }^{33}$ Crucially, dialects of German may exhibit a different behavior. In Bavarian and Alemannic, for instance, personal pronouns seem to occur exclusively as clitics (Abraham \& Wiegel 1993: 3-4; further Kolmer 2012: 71; Lenerz 1993: 119).
} 


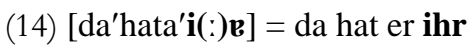

'there has he her'

The only pronoun that exhibits a somehow different behavior is es 'it,' with the clitic 's mainly being subject to phonological and not to syntactic constraints (Abraham \& Wiegel 1993; Müller 2002a) (for es in German, see $\S 5.4 .6$ below). Finally, although case distinctions on personal pronouns are still productive for accusative and dative forms, this does not hold for most dialects of German. Case distinctions are retained the strongest in southwestern German-speaking areas. In turn, Low German dialects often do not distinguish case on personal pronouns, similar to Dutch (Howe 1996: 266-271). ${ }^{34}$

\subsubsection{Summary}

In spite of the close typological relationship between Belgian Dutch, Maaslands, and German, the pronominal paradigms differ in some respect, as illustrated in Figure 23 for subject and in Figure 24 for object pronouns (IPA). While the paradigm of Belgian Dutch and Maaslands consists of strong and weak (reduced) forms, reduced forms in German always occur as enclitics. Weak forms are grammaticalized in Belgian Dutch, whereas clitics in German are confined to spoken language. In turn, case marking is still productive on personal pronouns in present-day German, unlike in Belgian Dutch/Maaslands. While case distinctions are normally better maintained on personal pronoun than on other elements such as nouns, they have hardly been conserved in Dutch (de Vogelaer 2007: 151 ), with the exception of some possessive and referential pronouns (Broekhuis \& den Dikken 2012b: 782-83).

\begin{tabular}{|c|c|c|c|c|}
\hline & & BD & MA & $\mathbf{G}$ \\
\hline \multirow[t]{6}{*}{ SG } & 1 & [Ik] [ək] [k] & [i:ç] [ç:(:)] & [Iç] \\
\hline & 2 & 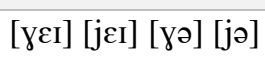 & [di:ç] [də][tə] & {$[\mathrm{du}:][\mathrm{t} ə][\mathrm{d} ə]$} \\
\hline & $3 \mathrm{M}$ & [heI] [di:][ әm] & [e:p] [də] [e:] & [e:en][de:e्र][e] \\
\hline & $3 \mathrm{~F}$ & [zeI] [di:][zə] & [zęij][di:j] [zə] & [zi:][di:][zə] \\
\hline & $3 \mathrm{~N}$ & [hət] [dat][ət] [t] & {$[\mathrm{d} \partial \mathrm{t}][\partial \mathrm{t}][\mathrm{t}]$} & {$[\varepsilon s][$ das $][\mathrm{s}]$} \\
\hline & V & [y] & ['ye:R] & [zi:] [zə] \\
\hline \multirow[t]{3}{*}{ PL } & 1 & [weI][wə] & [ve:R] [ver] & [vi:e्ন][ve][me] \\
\hline & 2 & ['jyli] [үعા][үə] & ['ye:R] [yer] & [?i:en][e] \\
\hline & 3 & [zeI] [di:] [zə] & [zęi] [di:j] [zə] & [zi:][di:][zə] \\
\hline
\end{tabular}

${ }^{34}$ The accusative-dative distinction in the third person singular masculine pronoun is often levelled out, except for the dialects spoken in the central-west and (partly) south-west (Howe 1996: 270-271, see map). See Fleischer (2006) for a discussion of morphological (dative) case in German dialects. 
Figure 23: Subject pronoun forms in Belgian Dutch, Maaslands, and German (IPA)

\begin{tabular}{|c|c|c|c|c|c|}
\hline & & BD & MA & G ACC & G DAT \\
\hline \multirow{6}{*}{ SG } & 1 & [mei] [mə] & [mi:ç] [mıç] & [mIç] & [mi:e् ] [me] \\
\hline & 2 & [y] & [di:ç] [dıç] & [dıç] & [di:e] ][de] \\
\hline & $3 \mathrm{M}$ & [hem] [əm] & [œ:m] [əm] & [i:n]/[n] & [i:m][əm] \\
\hline & $3 \mathrm{~F}$ & $\begin{array}{l}\text { [ha:r] } \quad \text { [zə] } \\
\text { [r] [R] }\end{array}$ & [œ:R] [eR] & [zi:] [zə] & [Pi:p] [e] \\
\hline & $3 \mathrm{~N}$ & [hət] [ət] & [hət] [t][ət] & {$[\varepsilon s][s]$} & [i:m][əm] \\
\hline & V & [y] & & [zi:] [zə] & ['Pi:nən] \\
\hline \multirow[t]{3}{*}{ PL } & 1 & [ons] & [o:s] [os] & [uns] & [uns] \\
\hline & 2 & ['jyli] & [y:ç] [yç] & [?oIç] & [Porç] \\
\hline & 3 & [di:] [zə] & [hyn] [zə] & [zi:] [zə] & ['Pi:nən] \\
\hline
\end{tabular}

Figure 24: Object pronoun forms in Belgian Dutch, Maaslands, and German (IPA)

As Figure 23 reveals, the full first-person singular subject pronoun ich [Iç] ' $\mathrm{I}$ ' is pronounced with a voiceless palatal fricative and a short vowel in German, whereas $i: c h$ [i:ç] 'I' carries a long vowel and a voiceless post-palatal fricative in Maaslands, articulated slightly more back than in German. In Dutch, both the full and weak form have a final /k/. For object pronouns (Figure 24), a similar picture emerges for the strong first and secondperson singular. Where Maaslands has a long vowel and a voiceless post-palatal fricative (mi:ch [mi:ç] 'me'/di:ch [di:ç] 'you'), German has a short vowel and a voiceless palatal fricative (mich [mıç] 'me'/dich [dıç] 'you'). Unlike Maaslands and Belgian Dutch, German has two distinct forms for accusative (mich 'me'/dich 'you') and dative case (mir 'me'/ dir 'you'). This also holds, for example, for the third-person masculine object pronoun 'him.' While German distinguishes between accusative ihn [i:n] and dative ihm [i:m], Maaslands and Belgian Dutch use a single form, i.e. (h)äöm [œ:m] and hem [hem], respectively.

In contrast, all three varieties share the reduced form 'em [əm] 'him.' Another form that is found in all three varieties is the third-person plural and singular feminine reduced form 'se/ze [zə] 'they, them, she, her.' Note, however, that [zə] may occur in preand postverbal position in Belgian Dutch/Maaslands, but that it behaves as enclitic in German. In addition, German has distinct forms for the dative case, namely ihnen ['Pi:nən] 'them' and $i h r$ [?i:en] 'her.'

Furthermore, Maaslands shows overlap with German in second-person singular subject weak forms $d e$ [də] and te [tə] 'you.' While Maaslands and German have a number of forms that are phonetically close, there is little overlap between Belgian Dutch and 
German, or Belgian Dutch and Maaslands. The latter share, besides the weak forms $z e$ [zə] and 'em [əm], the third-person singular neuter het 'it' [(ə)t].

As to object pronouns, Maaslands has a weak pronoun for the first and secondperson plural object that Belgian Dutch does not exhibit, namely òs [os] 'us' and uch [yç] 'you/yourselves.' Finally, the three varieties exhibit differences in usage. While the full pronoun zij 'they' must be animate in Belgian Dutch, the respective German form sie 'they' serves for both animate and non-animate referees (for grammatical gender, see $\S$ 5.4.5). Furthermore, in Maaslands, the form geer 'you' functions both as V-pronoun and as second-person plural form. German, in contrast, has distinct forms here: While $i h r$ 'you' is the second-person plural subject pronoun (informal), Sie 'you' is the polite pronoun of address.

\subsection{Subject Pronouns: Frequency and Phonological Properties}

This section and the following deal with the distribution of pronominal forms in Cité Duits and their phonological and lexical properties. By analyzing the frequency distribution, I will examine whether the resulting forms are used in consistent ways. Simultaneously, I will assess whether pronominal forms have arisen that do not exist in Belgian Dutch, Maaslands, and German. The total number of tokens is based on the pronoun forms found across all speakers when interacting in Cité Duits. Since the data contains many instances of stumbling, repetitions and broken utterances, repetitions of the same form within one utterance have been counted as a single token. In addition, a few utterances in the corpus clearly belong to other languages than Cité Duits, as in line 04 in example (15). These instances of quoting do not form part of the analysis (see also $§ 4.2 .1$ ). The quote is in italics.

(15) (171115_5: 1997.115 - 2000.613, Olaf)

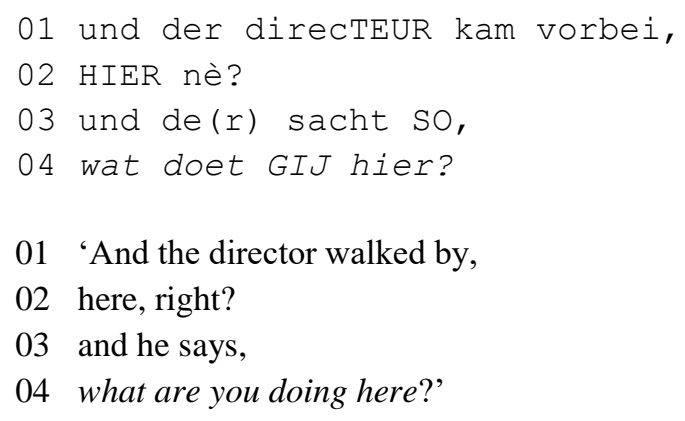

01 'And the director walked by,

02 here, right?

03 and he says,

04 what are you doing here?'

In (15), the utterance in line 01 to 03 is in Cité Duits, whereas the quotation after the verbum diciendi is entirely in Belgian Dutch (line 04). Note that the pronominal form $d e(r)$ 
used for the third-person in the first line does not exist in Belgian Dutch, and that the verbum diciendi is pronounced as sacht 'says' and not as Belgian Dutch zegt 'says.'

\subsubsection{First-person Singular}

Table 3 presents the total number of attested first-person singular subject pronoun forms (1SG.SBJ) and their percentages. The bar chart underneath (Figure 25) illustrates their distribution.

\begin{tabular}{|l|l|l|l|l|l|l|l|}
\hline 1SG & ich [Iç] & ik [Ik] & i:ch [i:ç] & i [i] & ie [i:] & $\begin{array}{l}\text { ikke } \\
\text { [Ikə] }\end{array}$ & Total \\
\hline $\mathbf{n}$ & 1282 & 11 & 4 & 22 & 11 & 1 & 1331 \\
\hline $\mathbf{\%}$ & 96.4 & 0.8 & 0.3 & 1.7 & 0.8 & 0.1 & 100 \\
\hline
\end{tabular}

Table 3: Frequency in absolute numbers and percentages of first-person singular subject pronoun forms in Cité Duits

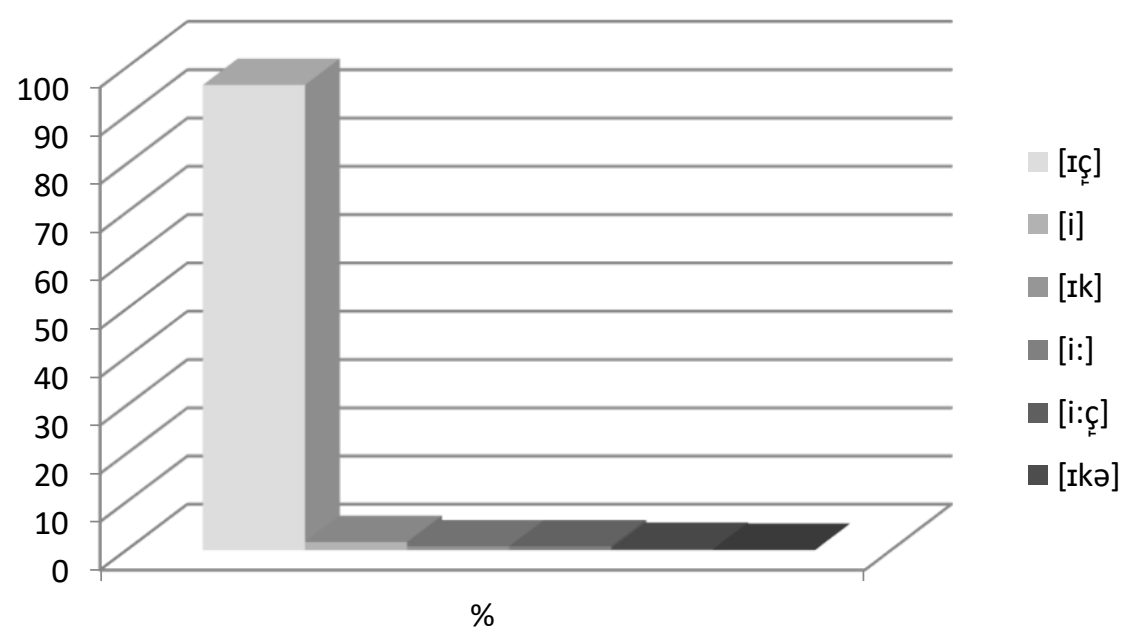

Figure 25: Distribution of first-person singular subject pronoun forms in Cité Duits

The speakers produce in total 1331 tokens of the 1 SG.SBJ pronoun, which exhibits six different realizations. Yet, the overwhelming majority of these forms is realized as ich [Iç], pronounced with a voiceless post-palatal fricative as in Maaslands, articulated slightly more back compared to German, but with a short vowel as in German/Belgian Dutch. It 
seems that speakers use an intermediate variant here. This form accounts for 96.4 percent $(n=1282)$ of the 1331 tokens.

Other attested forms are ie [i:] ( $\mathrm{n}=11$ or $0.8 \%)$, and $i: c h$ [i:ç] pronounced as in Maaslands $(\mathrm{n}=4$ or $0.3 \%)$. The most frequent form following ich [Iç] is the short form $i$ [i], representing 22 tokens or 1.7 percent. While the short form $i$ [i] has also been attested in Ruhr-German in allegro-speech (Schiering 2002: 19), it is difficult to say whether it may be a type of weak pronoun, as it is extremely rare in the data. Rather, it shows that the full form $i c h$ [Iç] is preferred by the speakers over possible weak or other strong forms. The form $i k$ [ $\mathrm{rk}]$ as in Belgian Dutch is hardly represented $(\mathrm{n}=11$ or $0.8 \%)$. The strong form $i k k e$ [Ikə] was used only once $(0.1 \%) .{ }^{35}$ These realizations of the final and wordinternal $/ \mathrm{k} /$, considering the low number of tokens, probably occur because speakers sometimes switch to Belgian Dutch for quotations. What we potentially observe here are a few examples of transition effects at clause boundaries when speakers switch to another variety, as illustrated in (16). The quotation is in italics, relevant forms appear underlined in the transcripts.

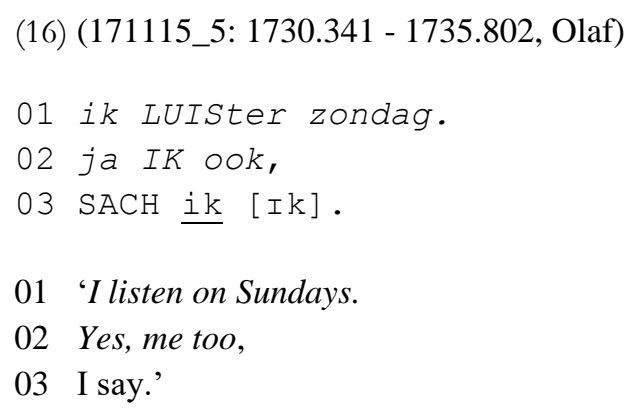

In (16), the speaker narrates a conversation between him and the local priest and therefore uses Belgian Dutch (lines 01-02), but realizes the 1SG.SBJ pronoun after the actual quote in line 03 as $i k$ [rk] with a final $/ \mathrm{k} /$.

\subsubsection{Second-person Singular}

Table 4 provides the same information in terms of the percentage and absolute numbers for the second-person singular subject pronoun (2SG.SBJ) in Cité Duits. Note that the overall number of tokens is lower $(n=730)$ than for the 1 SG.SBJ.

\footnotetext{
35 The emphatic form ikke occurs in Dutch usually in question-answer pairs such as Wie gaat er met me mee? Ikke! 'Who is coming with me? I will!,' or to express indignation or surprise on a preceding utterance (Broekhuis \& den Dikken 2012b: 789). Since ikke normally occurs without a finite verb, both in Dutch and in the data, it is difficult to determine whether this form actually belongs to Cité Duits.
} 


\begin{tabular}{|c|c|c|c|c|c|c|c|}
\hline 2SG & $\operatorname{du}[d u:]$ & de[də] & te[tə] & je[jə] & ge[४ә] & gij[ҮEI] & Total \\
\hline n & 573 & 4 & 145 & 2 & 6 & 2 & 730 \\
\hline$\%$ & 78.3 & 0.5 & 19.8 & 0.3 & 0.8 & 0.3 & 100 \\
\hline
\end{tabular}

Table 4: Frequency in absolute numbers and percentages of second-person singular subject pronoun forms in Cité Duits

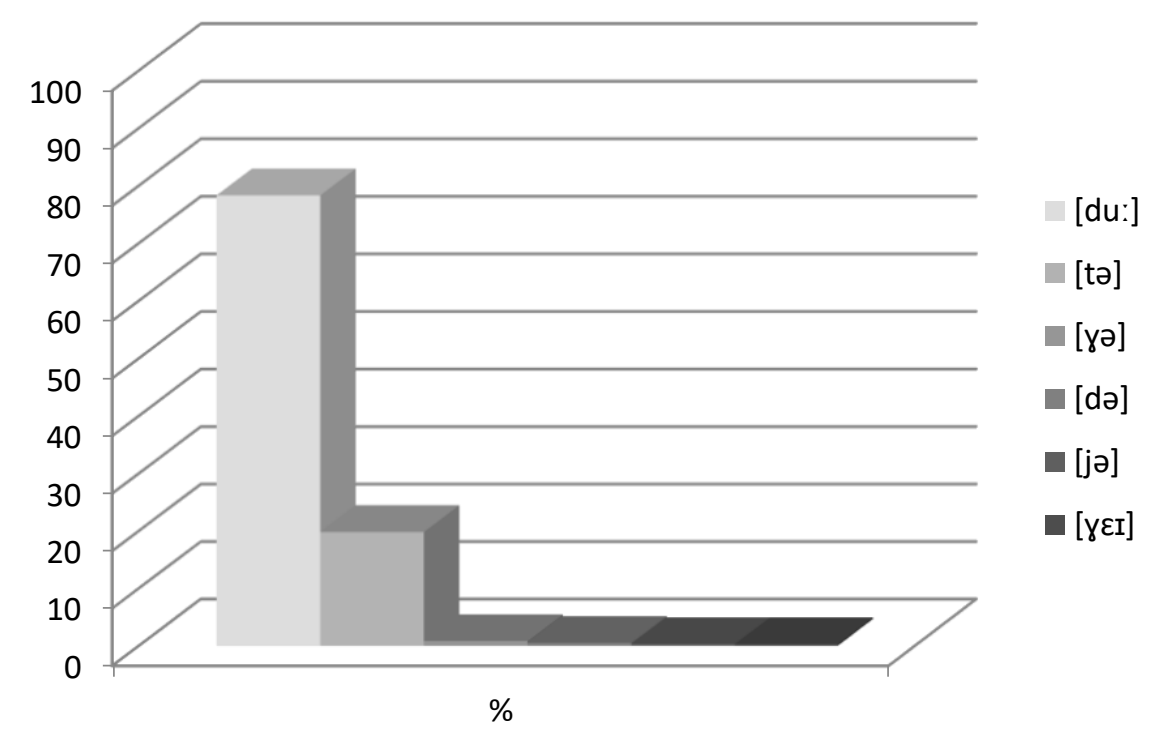

Figure 26: Distribution of second-person singular subject pronoun forms in Cité Duits

The picture appears to be less homogenous, with two forms scoring the highest, namely $d u$ [du:] (78.3\% or $\mathrm{n}=573)$ and te [tə] $(19.8 \%$ or $\mathrm{n}=145)$. These forms, however, make up together 98.1 percent, whereas hardly two percent of the tokens go back to other forms. Phonetically, both $d u$ [du:] and te [tə] are in line with the pronunciation of the 2SG.SBJ pronoun in German, and te [tə] with Maaslands. For Belgian Dutch, it holds that neither $d u$ nor te are used. The Maaslands/German reduced form de [də] appears only in four tokens. ${ }^{36}$ In addition, eight of the 730 tokens resemble Belgian Dutch, i.e. gij [yeI] (0.3\%) and $g e$ [үə] $(0.8 \%)$, whereas $j e$ [jə] $(\mathrm{n}=2)$ and $j i j[\mathrm{j} \varepsilon \mathrm{I}](\mathrm{n}=0)$ are almost absent. The absence of the je/jij-paradigm is not surprising, since it is more typical of formal registers in Belgian Dutch (Vandekerckhove 2005).

${ }^{36}$ I attested two examples of dich [dıç], but due to voice overlap and background noise, it is unclear whether we are dealing with a subject or object pronoun. These two forms had to be excluded from analysis. 


\subsubsection{Third-person Singular Masculine + Human}

The third-person singular masculine subject pronoun (3SG.SBJ.M) is with 1301 tokens almost as often represented as the 1SG.SBJ in the data. All forms carry the feature + human (Table 5). Pronouns referring to animate, non-human antecedents were only included when the sex of the referent was morphologically or lexically marked (e.g. ${\text { German } \text { Katze }_{F} \text { 'cat' vs. Kater }}_{M}$ 'cat') (see $\S 5.4 .5$ below for third-person singular pronouns with a non-human antecedent).

\begin{tabular}{|c|c|c|c|c|c|c|}
\hline $\begin{array}{l}\text { 3SG. } \\
\text { M }\end{array}$ & hij [hEI] & ie [i] & er [e:k] & $\begin{array}{l}\operatorname{de}(r) \\
{[\operatorname{de}: r][d e:]}\end{array}$ & die [di:] & Total \\
\hline n & 2 & 2 & 232 & $104 \hat{7}$ & 18 & 1301 \\
\hline$\%$ & 0.2 & 0.2 & 17.8 & 80.5 & 1.3 & 100 \\
\hline
\end{tabular}

Table 5: Frequency in absolute numbers and percentages of third-person singular masculine subject pronoun forms + human in Cité Duits

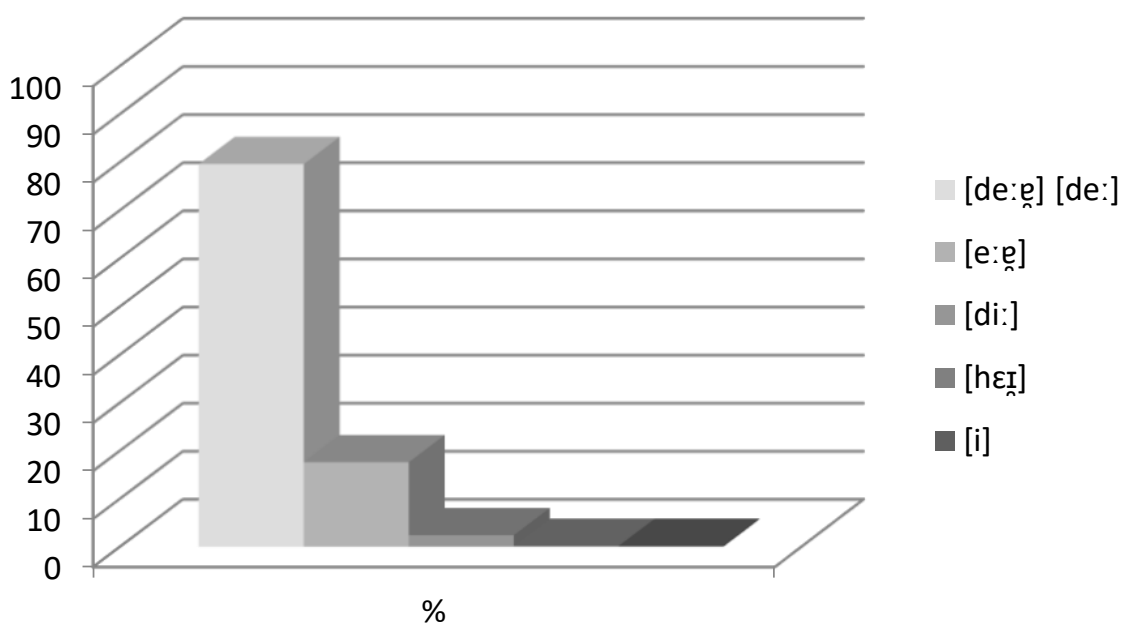

Figure 27: Distribution of third-person singular masculine subject pronoun forms + human in Cité Duits

As illustrated by the above, the most frequent form is $d e(r)$ [de: $:] /[\mathrm{de}:]$ with 80.5 percent of the tokens $(n=1047)$, followed by $\operatorname{er}$ [e:e] $(n=232)$ with 17.8 percent. Together, there is a chance of 98.3 percent that either $e r$ or $d e(r)$ are produced for the 3SG.SBJ.M. In the data, particularly in fast speech, it was difficult to distinguish between $d e r$ [de: 
[de:], which I regard as phonetic variants of the same form here. In turn, it resulted little problematic to distinguish between the 'der-variants' and the 'er-variants.' Phonetically, er [e: $\mathrm{p}]$ - in few instances realized as $a$ [e] - shows overlap with the strong form $(h) e e \ddot{e}(r)$ [e:p] in Maaslands and $\operatorname{er}[\mathrm{e}: \mathrm{e}]$ in German, while $a[\mathrm{e}]$ can be associated with the respective reduced form in German. In a similar vein, the form $d e(r)$ resembles the German and Maaslands masculine demonstrative pronoun. The two varieties only differ insofar as the demonstrative pronoun dè [də] in the dialect has no final /r/, as opposed to German der [de:p]. That these forms are indistinguishable in Cite Duits may indicate that there is convergence between German der [de:p]] and Maaslands dè [də], since it seems that speakers often produce de [de:]. The forms er and der do not exist in Belgian Dutch (Figure 20).

The remaining three percent of the forms are spread among the forms die [di:] $(\mathrm{n}=18$ or $1.3 \%)$, resembling the Belgian Dutch (feminine, masculine, plural) and the German (feminine, plural) demonstrative pronoun, $h i j$ [heI] $(\mathrm{n}=2$ or $0.2 \%)$, in line with the respective Belgian Dutch strong pronoun, and $i$ [i] $(\mathrm{n}=2$ or 0.2 percent), similar to the Netherlandic Dutch weak pronoun.

\subsubsection{Third-person Singular Feminine + Human}

The third-person singular feminine subject pronoun (3SG.SBJ.F) exhibits some more variation, with six variants in total (Table 6). Similar observations have been made by Plevoets (2008: 84) in his corpus study on morphosyntactic variation in spoken Belgian Dutch, who found considerably more variation for the third-person singular feminine than masculine. ${ }^{37}$

\begin{tabular}{|c|c|c|c|c|c|c|c|}
\hline 3SG.F & sie [zi:] & $\begin{array}{l}\text { ze/se } \\
\text { [zə] }\end{array}$ & $\begin{array}{l}\text { der } \\
\text { [de:b] } \\
\text { [de:] }\end{array}$ & die [di:] & er [e:b] & $\mathbf{e}(\mathbf{r})[\varepsilon]$ & Total \\
\hline n & 7 & 29 & 9 & 117 & 1 & 1 & 164 \\
\hline$\%$ & 4.3 & 17.7 & 5.5 & 71.3 & 0.6 & 0.6 & 100 \\
\hline
\end{tabular}

Table 6: Frequency in absolute numbers and percentages of third-person singular feminine subject pronoun forms + human in Cité Duits

\footnotetext{
${ }^{37}$ Data in Plevoets comes from the Flemish part of the Corpus Gesproken Nederlands (CGN) 'Corpus of spoken Dutch,' collected 1998-2003 (Plevoets 2008: 19). The CGN is a collection of 900 hours (almost 9 million words) of contemporary Dutch speech, originating from Belgian- and Netherlandic-Dutch speakers. The speech fragments consist of both spontaneous and controlled speech.
} 


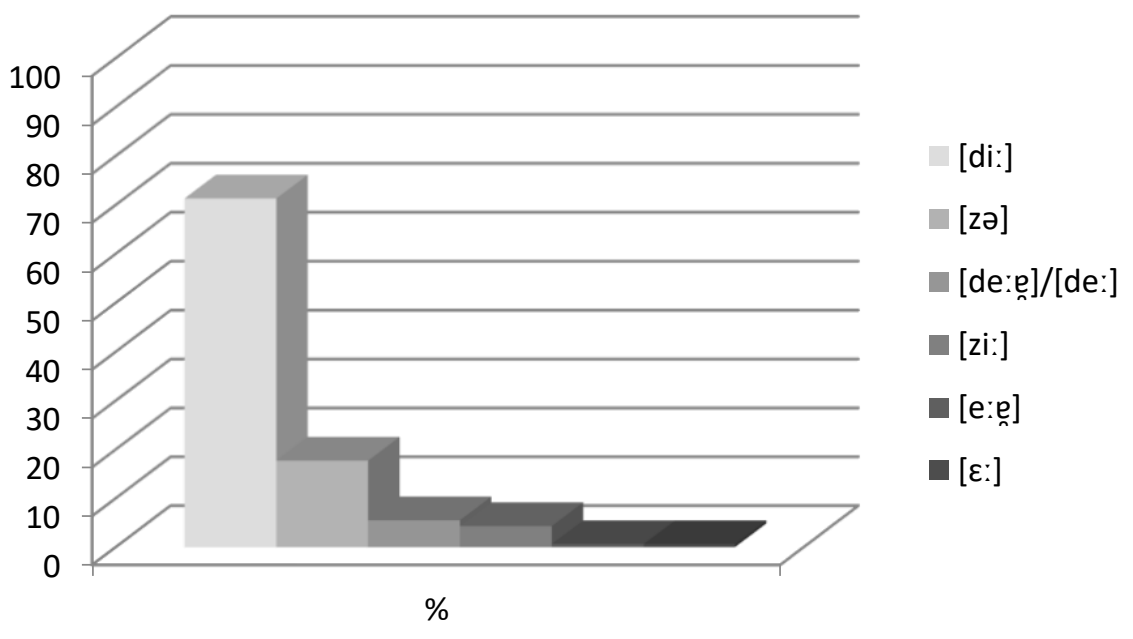

Figure 28: Distribution of third-person singular feminine subject pronoun forms + human in Cité Duits

Next to the form die [di:], which accounts for 71.3 percent of the tokens $(\mathrm{n}=117)$, speakers employ in 17.7 percent the form ze/se [zə] $(\mathrm{n}=29)$. While the latter conforms to the 3SG.SBJ.F weak pronoun in Belgian Dutch, Maaslands, and German, the form die resembles the Belgian Dutch (feminine, masculine, plural) and German (feminine and plural) demonstrative pronoun and is close to the Maaslands demonstrative dièj [di:j]. Together, die and ze account for 89 percent of the tokens. Pronominal forms resembling the Belgian Dutch and Maaslands strong pronouns $z i j$ [z ż] and $z i-j$ [zeej] are absent from the speech, while the respective form sie [zi:] as in German is produced in 4.3 percent $(\mathrm{n}=7)$. The lack of the strong pronominal form $z i j$ in Cité Duits may derive from the fact that this form is hardly encountered in informal speech (see Plevoets 2008: 84).

In addition, speakers produce the forms $\operatorname{der}[\mathrm{de}: \mathrm{e}] /[\mathrm{de}:](\mathrm{n}=9$ or $5.5 \%)$ and $e r / e(r)$

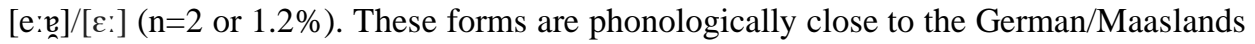
masculine demonstrative pronoun $\operatorname{der}$ [de: $\mathrm{d}] / \mathrm{dè} \mathrm{[də],} \mathrm{and} \mathrm{to} \mathrm{the} \mathrm{masculine} \mathrm{pronoun} \mathrm{er}$ $[\mathrm{e}: \mathrm{e}] /[\mathrm{e}] /[\mathrm{e}:]$, respectively. Furthermore, the latter forms slightly resemble the Maaslands weak pronoun for the third-person singular feminine object - not subject - (h)er [eR]. Their use is illustrated in utterances (17) to (21).

(17) (171115_5: 2242.076 - 2248.751, Olaf, story about two nuns)

01 der eine (-) GUCKT, (-)

02 de $(r)$ [de:] war schon in KLoster,

03 BINne, 
04 die andere kommt SPÄter,

'One [of the nuns] looked around, she was already in the monastery, the other one arrived later...'

(18) (231115_3:1428.258 - 1432.367, Olaf)

01 un(d) da war so ein FRAU,

02 de [de:] (.) der [de:e] stand so BuIten, hè?

'And there was a woman, she stood outside.'

(19) (0314_140913: 839.781 - 842.223, Diego)

01 komm einer FRAU bei mich,

02 SACHT er $[\varepsilon:]$,

03 eh LUC,

04 SACHT er [ $[\varepsilon$ : ].

'A woman comes over and she says, hy Luc, she says.'

(20) (171115_4: $67.507-70.284$, Jan)

$01 \mathrm{AH}$ : sacht er [e:e],

02 mein MANN eh.

03 wie DER sich einsetzt.

'Oh, she says, my husband, he is actively engaged.'

(21) (171115_3: 511.999 - 516.955, Ferenc)

01 un(d) da war der Mutter van (.) wim richter.

02 der [de:e] hat uns verRAte.

'There was the mother of Wim Richter, she told on us.'

In (17), which is a story about two nuns walking to the monastery, the pronominal form $d e(r)$ [de:] 'she' is produced (line 02) to refer to one of the nuns. In this example, the use of the typically masculine pronoun for a feminine human antecedent may possibly be 
explainable by 'structural priming' (Cacoullos \& Travis 2018). In structural priming, 'the use of a certain structure in one utterance 'primes' or prompts the same structure to be subsequently repeated' (Cacoullos \& Travis 2018: 88). ${ }^{38}$ Since $d e(r)$ is the most common definite article in Cité Duits (§ 4.3.3) (see also Auer \& Cornips 2018), it is possible that the use of this form in line 01 has triggered the pronominal form $d e(r)$ for the same referent in line $02 .{ }^{39}$ In other words, $d e(r)$ 'she' may have been influenced by the form last chosen by the speaker.

Structural priming, however, is not a possible explanation for utterances (18) to (21), where the pronominal forms $d e(r)[\mathrm{de}:(\mathfrak{p})]$ and $e(r)[\varepsilon:]$ are used to refer to the NP frau 'woman' (18), (19), 'wife' (20) and mutter 'mother' (21), respectively. How to account for this type of variation will be discussed in the following chapter (§ 6.2.4).

\subsubsection{Third-person Singular Non-human}

So far, I have outlined how third-person pronouns are used by the speakers when referring to male or female human beings. But how do speakers refer to non-human antecedents such as 'the table' or 'the flower'? Obviously, Cité Duits has no reference grammar with grammatical categories. The three contact varieties differ with regard to their use of grammatical gender, which means that pre-established categories such as 'masculine' or 'neuter' are not useful when investigating grammatical gender on pronouns in Cité Duits. Nouns that are assigned masculine grammatical gender in German are sometimes neuter in Belgian Dutch, or vice versa. Grammatical gender on personal pronouns in Belgian Dutch, Maaslands, and German can be schematized as follows (Figure 29):

\begin{tabular}{|l|l|l|l|}
\hline 3SG & BELGIAN DUTCH & MAASLANDS & GERMAN \\
\hline $\mathbf{M}$ & hij/die & (h)eeër/er/dè & er/der \\
\hline $\mathbf{F}$ & zij/ze/die & zi-j/ze/dièj & sie/'se/die \\
\hline $\mathbf{N}$ & het/'t/dat & (h)et/dèt & es/'s/das \\
\hline
\end{tabular}

Figure 29: Overview of third-person singular pronouns

In German, der Tisch $_{M}$ 'the table' is a masculine noun and referred to with er/der 'he,' while die Blume ${ }_{F}$ 'the flower' is a feminine noun and referred to with the pronoun sie/die 'she.' Neuter nouns such as das Wasser $_{N}$ 'the water' are referred to with es/das 'it.' Accordingly, speakers of German have three different definite articles as well as three

\footnotetext{
${ }^{38}$ Cacoullos and Travis (2018: 88) use the notion of 'Coreferential subject priming,' i.e. the tendency to repeat the previous pronoun, which may also be separated by an intervening clause. Since the form preceding the pronoun der is a determiner and not a personal pronoun, the term 'priming' seems more adequate here.

${ }^{39}$ As illustrated in $\S 4.3 .3$, the form die seems to function as demonstrative in Cité Duits, which explains why the speaker employs the form die in die (eine) 'that (one).'
} 
different pronouns at their proposal. Dutch, in contrast, has a 'mismatch' between the pronominal genders and the gender morphology. It has the morphological means to distinguish three or four genders on anaphoric pronouns, but only two genders on other agreement targets (determiners, adjectives, relative pronouns).$^{40}$ That is, in definite DP's, Dutch distinguishes neuter gender, i.e. nouns carrying the article het, versus common gender, i.e. masculine and feminine nouns, both carry the article de. Moreover, Dutch pronouns can take different genders for the same referent depending on semantic (biological gender) or grammatical agreement, which means that there is variation in the way speakers actually use pronouns (Audring 2006; 2009), as depicted below.

(22) common > neuter

Ik draag geen merkkleding $[\mathrm{C}]$, tenzij het $[\mathrm{N}]$ erg goedkoop is.

'I don't wear brand-name clothing unless it is very cheap.' (Audring 2006: 88)

(23) common > masculine

De hun/hen-discussie $[\mathrm{C}]$ laat ik voor wat hij $[\mathrm{M}]$ is.

'The hun/hen-discussion I leave for what it (lit.: he) is.' (Audring 2006: 88)

Example (22) is an instance of a neuter gender pronoun (het, 'it') for the common gender noun merkkleding 'brand-name clothing' whereas in (23), the noun discussie 'discussion,' which has common gender is referred to with the masculine pronoun hij ('he'). While the pronoun for neuter gender nouns can be assigned unambiguously in Dutch, there is no straightforward mapping of adnominal and pronominal gender in Dutch. ${ }^{41}$ For Cité Duits holds the following:

\begin{tabular}{|l|l|l|l|l|}
\hline $\begin{array}{l}\text { 3SG } \\
{[-h u m]}\end{array}$ & der $[\mathbf{d e}:(\mathfrak{k})]$ & er $[\mathbf{b}]$ & die $[\mathbf{d i}:]$ & Total \\
\hline $\mathbf{n}$ & 18 & 1 & 1 & 20 \\
\hline$\%$ & 90 & 5 & 5 & 100 \\
\hline
\end{tabular}

Table 7: Frequency of third-person singular subject pronoun forms non-human in Cité Duits (specific)

According to Table 7, speakers mainly use the form $\operatorname{der}[\mathrm{de}:] /[\mathrm{de}: \mathrm{e}]$ when referring to nonhuman antecedents $(90 \%$ or $n=18)$, which is phonologically close to the German and

${ }^{40}$ See Roodenburg and Hulk (2008: 70-71) for gender in the adnominal domain in Dutch.

41 It seems that the tendency of 'resemanticization' (Audring 2009), i.e. the replacement of grammatical gender agreement by semantic agreement, is further advanced in Netherlandic than in Belgian Dutch (De Vogelaer \& Klom 2017: 125). 
Maaslands masculine demonstrative pronoun $\operatorname{der}$ [de:e $] / d \grave{e}$ [də]. There are, however, few utterances where an individual antecedent with specific use could be identified $(n=20)$.

In addition, the forms $e r[\mathfrak{e}]$ and die [di:] have been attested once. In the following, I will discuss a number of examples from the data (24)-(34). The antecedent of the noun is provided in square brackets.

(24) (CD_09: 583.174 - 584.638, Ferenc) [türe 'the door']

01 und BUMM,

02 fiel der [de:e] ZU.

'And BUM, it was shut.'

In example (24), the antecedent is türe 'the door,' which strongly resembles German Türe (compare Belgian Dutch/Maaslands de deur $/ \mathrm{d} \overline{\mathrm{r}} /$ ). ${ }^{42}$ In German, the noun die Tür $r_{F}$ has feminine gender and therefore the pronoun sie/die is expected. In (24), in turn, it is referred to with the pronoun $\operatorname{der}$ [de:p].

(25) (171115_3: 485.522-493.944) [Conversation between Ferenc and Jan about trees]

01 (de) GANze cité wart voll van die bäume.

02 na HIER steht auch noch eine ja.

03 der [de:e] tragt auch viel VIEL hier drausse(n) der [de:e].

'The entire district was covered with trees.' 'Here is also one [tree]. It also carries a lot [of leaves]'

In (25), the antecedent is 'tree' and again, der [de:t] is used. In this example, the pronominal form der [de:p] is in line with the grammatical gender in German and Maaslands, where 'tree' has masculine gender (der Baum ddè boum $\left._{M}\right)$. Dutch has common gender here (de boom). Although the antecedent is plural bäume 'trees,' the inflection of the finite verb trag- $t$ 'carries' indicates that we are dealing with a singular pronoun here, resembling verbal inflection in the contact varieties (e.g. Dutch draag-t, German träg-t).

(26) (0313_144739: 1403 - 1405.78, Jan) [teig ‘dough']

${ }^{42}$ For the dialect, see van der Sijs et al. (2017). 
01 aber de(r) TEI eh,

02 der [de:e] da darfte nich eh (-) SJEUren, hè?

'But the dough, it may not be moved.'

In (26), the resumptive pronoun der [de:

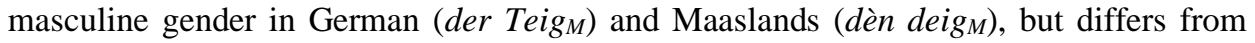
Belgian Dutch, where 'dough' has neuter grammatical gender (het deeg $\mathrm{N}_{\mathrm{N}}$ ).

A somehow different case is utterance (27) below ob der frisch is 'whether it is fresh.' The antecedent 'bread' has neuter gender in all the three contact varieties - das Brot/het broodl't broed - which means that either das or (h)et would be employed in the contact languages. In line with previous utterances, $d e(r)$ [de:] is produced.

(27) (0314_134351: 532.905 - 534.705, Jan) [brot 'bread']

01 an der BROT fühle ob de(r) [de: ] FRISCH is.

'To feel the bread whether it is fresh.'

The next two utterances (28) and (29) are examples of pronominal reference of animate, non-human antecedents ('mouse'/'hedgehog'). The noun 'mouse' has feminine/common

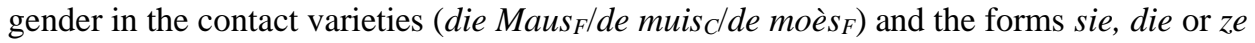
would usually be expected, ${ }^{43}$ but $\operatorname{der}$ [de:p] is used. In (29), er [e] is used, resembling the reduced masculine pronoun in German and corresponding to grammatical gender of

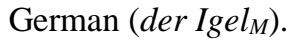

(28) (171115_5: 376.865 - 379.733, Olaf) [maus 'mouse']

01 wenn da ein MAUS binne is,

02 dann springt der [de:e] RAUS.

'When there is a mouse inside, it jumps out.'

(29) 0313_151301: 422.825 - 424.715, Jan) [igel 'hedgehog']

\footnotetext{
${ }^{43}$ Both German and Maaslands refer to 'the mouse' with the feminine pronoun sie/ze. In spoken Dutch, we may also find examples of hij 'he' and possibly het 'it' to refer to de muis 'mouse,' although the latter is not in line with grammatical gender (see Audring (2009) for an overview, see also Broekhuis and den Dikken (2012b: 781-82)).
} 
01 für dat er [e] sich Open legt, hè?

'That it opens itself.' ${ }^{44}$

In (30), the form de [de:] is pronounced with a monophthong and not with a diphthong, resembling Maaslands. The antecedent 'the mine' has feminine/common gender in the contact varieties (die Zeche $F /$ de mijn $d$ de pöt $t_{F}$ ). The same holds for (31), where the pronoun der [de:p] refers to 'school.' As visible from these examples, Cité Duits generally uses the pronominal form der, also in instances where the contact varieties would either use sie, die or ze (or es/das/(he)t).

Similar observations can be made for the last three examples. In (32), the form der [de:ê] refers to 'car,' which has neuter gender in German (das Auto> es/das), common gender in Belgian Dutch (de auto > hij/die) and masculine gender in Maaslands (dèn ottoo $>(h) e e \ddot{e}(r) / d \grave{e})$. Paardenbloem 'dandelion' in (33) corresponds to Dutch where this noun has common gender, and furgonne 'pick-up truck' in (34) resembles the French-Walloon noun la fourgonette, which has feminine gender.

(30) (0314_134351: 1087.52 - 1091.1, Theo) [mijn 'coal mine']

01 JETZ muss ich hier weggehn.

02 want de(r) [de:] geht DOCH zu.

'Now I have to leave, because it is going to close anyway.'

(31) (231115_5: 1310.347 - 1312.054 Victor) [schippersschool = school for children of mariners]

01 DAT wart de,

02 =jetz is $\underline{\text { de }(r)}$ [de:] NICH mehr her.

'That was the; now it is not here anymore.'

(32) (231115_4: 1098.643 - 1099.984, Antonio) [auto 'car']

01 der [de:e] is NICH (.) so alt.

'It is not that old.'

\footnotetext{
${ }^{44}$ The speakers talk about roasting hedgehogs. A literal translation of the reflexive pronoun sich into English does therefore not work.
} 
(33) (0313_144739: 1250.9 - 1252.05, Jan) [paardenbloem 'dandelion']

01 VoORdat de(r) [de:] blüht.

'Before it blossoms.'

(34) (231115_5: 1036.745 - 1041.187, Olaf)

01 und de(r) furgonne,

02 der [de:el war für vierhundert kilo (.) KOHle.

'The pick-up truck, it was for four hundred kilogram coal.'

Even though the number of examples of third-person singular pronouns with a non-human antecedent is limited $(\mathrm{n}=20)$, it is obvious that speakers mainly produce the pronoun $d e(r)$, realized as [de:p] and [de:]. However, these forms are sometimes difficult to distinguish. Phonetically, they are close to or homophonous with the German/Maaslands demonstrative masculine form [de: $\mathrm{v}] /[\mathrm{d}]$. Moreover, the form [e] is produced once in the position after the complementizer, in line with the reduced pronominal form er in German. While these observations need to be regarded with caution, considering the low number of tokens, the pattern encountered in the data obviously points to the use of $d e(r)$ as the prevalent pronominal form to refer to non-human third-person singular antecedents in subject position. In some examples, grammatical gender conforms to its use in Maaslands and German. However, speakers also produce $d e(r)$ when the antecedent has neuter grammatical gender in all three contact varieties (see example (27)). In other words, while Belgian Dutch, Maaslands, and German distinguish three different pronouns according to grammatical gender and/or semantic agreement, Cité Duits employs a single pronominal form or a phonological variant of it.

\subsubsection{Third-person Singular 'it'}

This section examines the use of the third-person singular pronoun 'it' (3SG.N) in Cité Duits. The contact varieties distinguish a number of functions for 'it,' as schematized in Figure 30, based on German grammar (Eisenberg 2016: 173-76; Helbig \& Buscha 2001; Gallmann 2006). ${ }^{45}$

\footnotetext{
${ }^{45}$ Some authors convincingly argue for a more fine-grained categorization (Fahrner 2016; Zifonun et al. 1997). For the given purpose, however, the schema suffices.
} 


\begin{tabular}{|l|l|l|l|l|}
\hline & $\begin{array}{l}\text { FUNCTIONS OF } \\
\text { IT }\end{array}$ & DUTCH & GERMAN & MAASLANDS \\
\hline $\mathbf{1}$ & $\begin{array}{l}\text { Phoric it } \\
\text { the house }>\text { It is } \\
\text { empty. }\end{array}$ & $\begin{array}{l}\text { Het huis }> \\
\text { Het/Dat staat } \\
\text { leeg. }\end{array}$ & $\begin{array}{l}\text { Das Haus }> \\
\text { Es/Das steht } \\
\text { leer. }\end{array}$ & $\begin{array}{l}\text { 't Hoes }>\text { Et/Dèt } \\
\text { stuit lèg. }\end{array}$ \\
\hline $\mathbf{2}$ & $\begin{array}{l}\text { Frontfield it } \\
\text { There were many } \\
\text { guests. }\end{array}$ & $\begin{array}{l}\text { Er kwamen } \\
\text { veel gasten. }\end{array}$ & $\begin{array}{l}\text { Es kamen viele } \\
\text { Gäste. }\end{array}$ & $\begin{array}{l}\text { Doa kème veul } \\
\text { gaste. }\end{array}$ \\
\hline $\mathbf{3}$ & $\begin{array}{l}\text { Expletive it } \\
\text { It is raining. }\end{array}$ & Het regent. & Es regnet. & 't Règent. \\
\hline $\mathbf{4}$ & $\begin{array}{l}\text { Correlational it } \\
\text { It is good that... }\end{array}$ & $\begin{array}{l}\text { Het is goed } \\
\text { dat... }\end{array}$ & $\begin{array}{l}\text { Es ist gut, } \\
\text { dass... }\end{array}$ & 't Is good dat... \\
\hline
\end{tabular}

Figure 30: Overview of 'it'-functions in Dutch, German and Maaslands

Phoric it typically functions to substitute a noun phrase with neuter grammatical gender, for example 'the house' > 'it.' This noun has neuter grammatical gender in all three contact varieties. Similarly, the respective demonstrative dat/dèt/das 'that' may be used (Ehlich 1982: 319; Eisenberg 2016; Broekhuis \& den Dikken 2012b; Audring 2009; Fahrner 2016). In addition, phoric it can refer to an antecedent that is unmarked for number and gender, for instance Sie hofft, dass es regnet, und sie glaubt es auch. 'She hopes that it will rain, and she also believes it.' (Eisenberg 2016: 174). ${ }^{46}$ Regarding 'frontfield it,' as shown already, Cité Duits tends to use the form $d a(\S 4.3 .10)$.

Furthermore, expletive it or 'impersonal het' has the syntactic function of a 'place-holder.' The most typical examples are weather-verbs such as 'it is raining' (Broekhuis \& den Dikken 2012b: 779; Eisenberg 2016: 174). Dutch impersonal het is also found in a number of fixed expressions (Broekhuis \& den Dikken 2012b: 780). Finally, correlational it functions as correlative to a subordinate clause introduced with 'that' and serves as the subject of a clause or infinitive group. In Cité Duits, the distribution of forms for the 3SG.N looks as follows (Table 8). ${ }^{47}$

\begin{tabular}{|l|l|l|l|l|l|l|l|}
\hline $\begin{array}{l}\text { 3SG. } \\
\mathbf{N}\end{array}$ & $\begin{array}{l}\text { het } \\
{[\text { [hət] }}\end{array}$ & 't $[\mathbf{t}]$ & $\begin{array}{l}\text { dat } \\
{[\mathbf{d a t}]}\end{array}$ & $\begin{array}{l}\text { dèt } \\
{[\mathbf{d} \partial t]}\end{array}$ & es $[\mathbf{\varepsilon s}]$ & 's[s] & Total \\
\hline $\mathbf{n}$ & 1 & 3 & 521 & 4 & 3 & 2 & 534 \\
\hline
\end{tabular}

\footnotetext{
${ }^{46}$ Phoric es may only appear in the prefield in subject but not in object function: 'Das Kind lernt laufen. *Es hat der Opa an der Hand.' (Eisenberg 2016: 174) 'The child is learning to walk. *It holds the grandfather by the hand.' For grammaticality, es would have to move to the middle field (see also Duden $2016 \S 1382$ ).

${ }^{47}$ In the data, the form das [das] is only found as a reduced form for 'that is' dat is $>d a$ 's. Reduction of $/ \mathrm{t} /$ also takes place in 'that are' dat $\operatorname{sind}>$ da $\sin (\mathrm{d})$ (e.g. dasin leute die geld HAbe, hè? 'That are people who have money,' 231115_1: 448.009 - 449.91, Ferenc).
} 


\begin{tabular}{|l|l|l|l|l|l|l|l|}
\hline$\%$ & 0.2 & 0.6 & 97.6 & 0.7 & 0.6 & 0.4 & 100 \\
\hline
\end{tabular}

Table 8: Frequency in absolute numbers and percentages of third-person singular pronoun forms for 'it' in Cité Duits

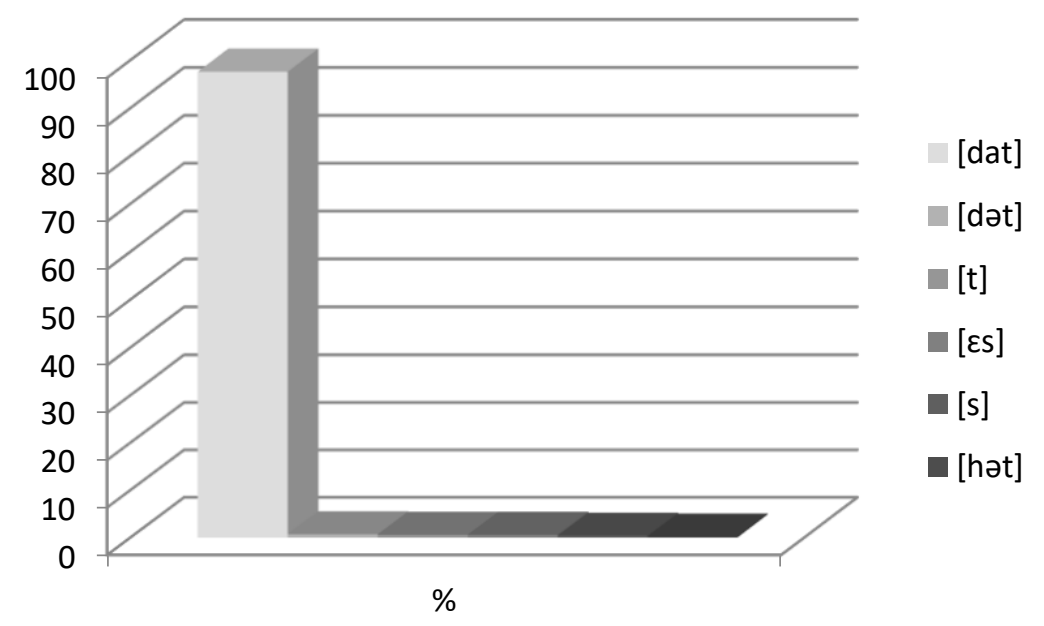

Figure 31: Distribution of third-person singular subject pronoun forms for 'it' in Cité Duits

Speakers realize 534 tokens from which 521 tokens $(97.6 \%)$ are realized as dat [dat] (examples (35), (36)) with a final stop as in Belgian Dutch/Maaslands. Es [es]/'s [s] occurs five times, and dèt [dət] and het [hət]' $t$ [t] four times, respectively. It seems that two of the three tokens of $e s$ constitute examples of priming. ${ }^{48}$ Aside from resembling the Belgian Dutch/Maaslands demonstrative, dat [dat] is typical of German dialects of the Rhineland (Schiering 2002: 173; Barbour \& Stevenson 1990; Salewski 1998: 27). ${ }^{49}$

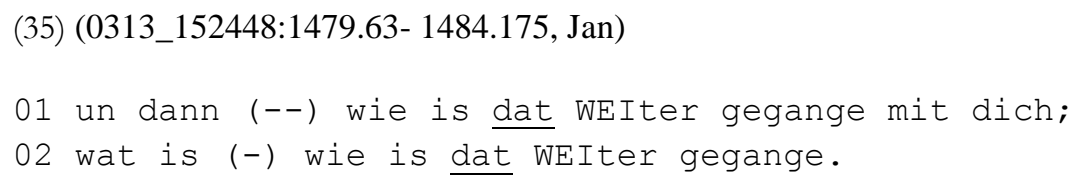

'And then, how did it/that continue with you, what is, how did it/that continue?'

${ }^{48}$ The German clitic pronoun 's may be attached to any word independent of its word class (Nübling 1992: 22). As shown by others, German es has a special status insofar as it displays clitic-like behavior, comparable to Romance languages. For a discussion, I refer to Cardinaletti and Starke (1996).

${ }^{49}$ See Becker (2003: 287) for the frequency of occurrence of dat in Ruhr-German. 
(36) (171115_5: 1632.935 - 1636.039, Olaf)

01 un dat war en EEUwigheid für mich, hè?

'And it/that was an eternity for me.'

The replacement of 'it' by the neuter gender demonstrative 'that' does not only occur in Cité Duits, but also in spoken varieties of Dutch and German. In German, das 'that' instead of $e s$ ' it' is frequent in colloquial language. However, das is not possible in all contexts (Eisenberg 2016: 324; Fahrner 2016; Ehlich 1982)..$^{50}$ This is insofar interesting as Cité Duits makes use of a single form, namely dat [dat]. In Dutch, 'unspecific dat can be used for nouns of any semantic class, even for humans, as long as no specific referent is involved' (Audring 2009: 105). Furthermore, the demonstrative dat is used for both masculine and feminine antecedents in Dutch (Audring 2009: 115-16). This suggests that the use of dat [dat] in Cité Duits shows much overlap with spoken Dutch, and less with German.

\subsubsection{First-person Plural}

There is quite some variation in the use of the first-person plural (1PL.SBJ) $(n=556)$. Six different forms occur, with four of them being frequently produced (Table 9).

\begin{tabular}{|l|l|l|l|l|l|l|l|}
\hline $\mathbf{1 P L}$ & we [wə] & $\begin{array}{l}\text { wir } \\
\text { [vi:: }]\end{array}$ & wie [vi:] & $\begin{array}{l}\text { ma } \\
\text { [me] }\end{array}$ & wa [ve] & $\begin{array}{l}\text { wer } \\
\text { [veR] }\end{array}$ & Total \\
\hline $\mathbf{n}$ & 81 & 203 & 81 & 149 & 38 & 4 & 556 \\
\hline$\%$ & 14.6 & 36.5 & 14.6 & 26.8 & 6.8 & 0.7 & 100 \\
\hline
\end{tabular}

Table 9: Frequency in absolute numbers and percentages of first-person plural subject pronoun forms in Cité Duits

${ }^{50}$ As Eisenberg argues, 'Das betonbare Gegenstück zu es ist das. Es kann einige, aber nicht alle der Positionen besetzen, die dem Korrelat-es unzugänglich sind' (Eisenberg 2016: 324). See further Ehlich (1982) for a discussion of German es versus das. 


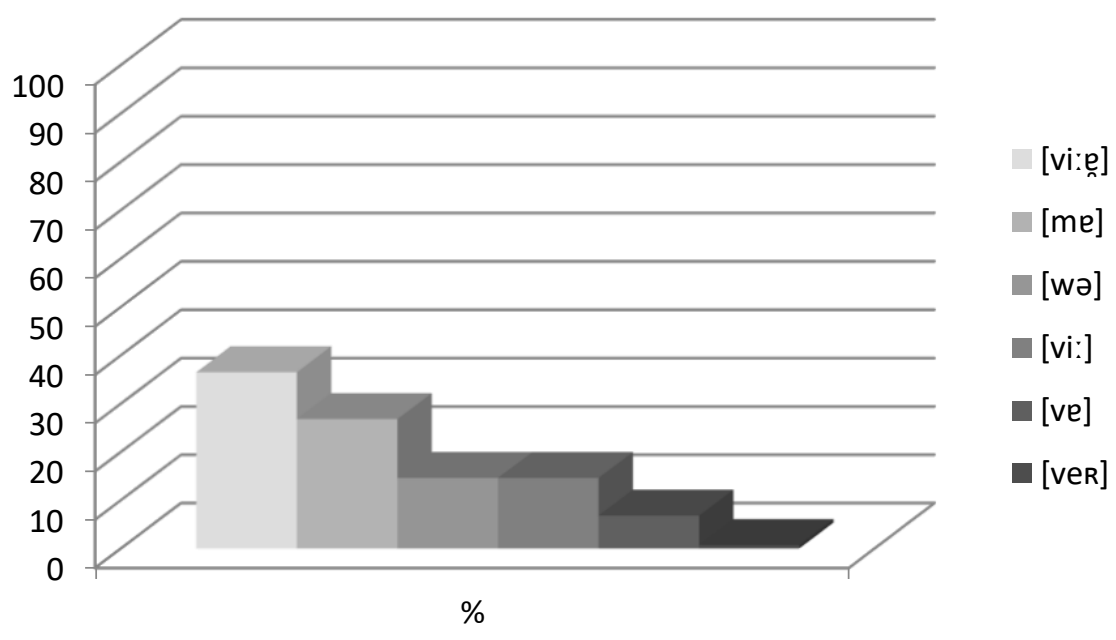

Figure 32: Distribution of first-person plural subject pronoun forms in Cité Duits

The two most frequent forms, wir [vi:p] $(\mathrm{n}=203$ or $36.5 \%)$ and $m a[\mathrm{me}](\mathrm{n}=149$ or $26.8 \%$ ), are pronounced according to German phonology. While wir is the full pronoun in German, ma is confined to the enclitic position (e.g. wir haben > wir ham 'we have' vs. hamma [hame] 'have we'). The form wa [ve] ( $\mathrm{n}=38$ or $6.8 \%)$, occurring less often, is also similar to the German enclitic ( $\$ 5.3)$.

Furthermore, there are 81 examples realized as we [wə] (14.6\%), matching the Belgian Dutch weak pronoun we [wə]. Note that we [wa] is phonetically quite close to the German enclitic $w a[v e]$, although the /w/ is realized differently in the two varieties. The Belgian Dutch strong pronoun wij [weI] is absent from the speech. ${ }^{51}$ Wer [ver], resembling Maaslands weak form, was produced in merely four examples. A noticeable variant that cannot be analyzed as being homophonous to one of the available forms in the contact varieties is wie [vi:], a form that accounts for 14.6 percent of the tokens $(n=81)$. This form is neither Belgian Dutch, German nor Maaslands: the $/ \mathrm{w} /$ is generally realized as a voiced labiodental fricative [v] as in German/Maaslands, and not as a voiced velar approximant [w] as in Belgian Dutch, but it is followed by a long vowel [i:], whereas the final $/ r /$ is not realized. These findings strongly suggest that the position of these forms before and after the finite verb and complementizer is crucial to consider. Are all forms allowed for in preand postverbal position, or does Cité Duits exhibit certain preferences - and if so, are these similar to one of the contact varieties? I will come back to the first-person plural pronoun in the following chapter ( $\$ 6.2 .6$ ), where I analyze the variation encountered in the data.

${ }^{51}$ Crucially, for the 1PL.SBJ, it seems that the weak form is more frequent than the full form in spoken Belgian Dutch (see Plevoets 2008: 128). 


\subsubsection{Second-person Plural}

The forms for the second-person plural (2PL.SBJ) in Cite Duits are given below (Table 10). Because of the limited number of tokens, no bar chart has been provided.

\begin{tabular}{|l|l|l|}
\hline 2PL & euch [2JIç] & Total \\
\hline $\mathbf{n}$ & 6 & 6 \\
\hline $\mathbf{\%}$ & 100 & 100 \\
\hline
\end{tabular}

Table 10: Frequency in absolute numbers and percentages of second-person plural subject pronoun forms in Cité Duits

It was possible to establish only six tokens, all of which realized as euch [? with the second-person plural object form in German and phonologically fairly close to the Maaslands object pronoun uuch [y:ç]. This use is exemplified in (37) and (38).

(37) (0313_152448: 1314.21 - 1316.79, Raf)

01 HEUte musse euch viel meters mache;

'Today youpL had to make many meters.'

(38) (231115_4:1649.742 - 1653.566, Jan)

01 sin euch auch gehn BIECHte?

'Did youpL also go to confession?'

Other variants - such as German ihr [?i:e् ] or Belgian Dutch jullie ['jyli] or ge [ұə] - were not used. Yet the form $i h r$ [?i:en] has been attested in a German quote, produced by a speaker with Hungarian as home language, which suggests that (some) speakers are aware of this pronoun (39):

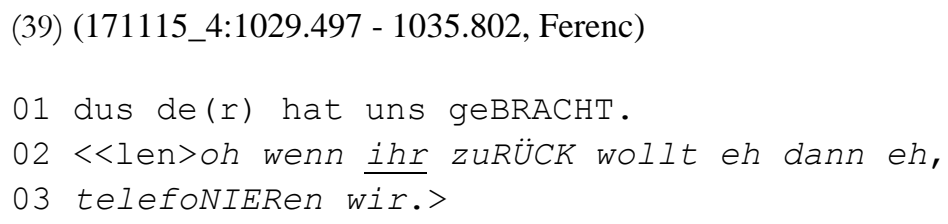

01 'Thus he gave us a ride 
02 [and said], when you ${ }_{P L}$ want to return, then

03 we phone.'

At the clause boundary of the German quote, the speakers' voice audibly slows down, indicating that the speaker quotes the driver. This is, nonetheless, the only instance where speakers use the German pronoun ihr for the 2PL.SBJ.

\subsubsection{Third-person Plural}

The distribution of the third-person plural subject pronoun (3PL.SBJ) forms is illustrated in Table 11. Since gender is not distinguished on plural pronouns, neither in Cité Duits nor in the contact varieties, no distinction is made between feminine and masculine plural forms. ${ }^{52}$

\begin{tabular}{|l|l|l|l|l|l|}
\hline $\mathbf{3 P L}$ & $\mathbf{z i j}[\mathbf{z \varepsilon}] \mathbf{l}$ & $\mathbf{s i e}[\mathbf{z i}:]$ & $\mathbf{z e} / \mathbf{s e}[\mathbf{z}]$ & $\mathbf{d i e}[\mathbf{d i}:]$ & Total \\
\hline $\mathbf{n}$ & 2 & 26 & 168 & 421 & 617 \\
\hline $\mathbf{\%}$ & 0.3 & 4.2 & 27.2 & 68.2 & 100 \\
\hline
\end{tabular}

Table 11: Frequency in absolute numbers and percentages of third-person plural subject pronoun forms in Cité Duits

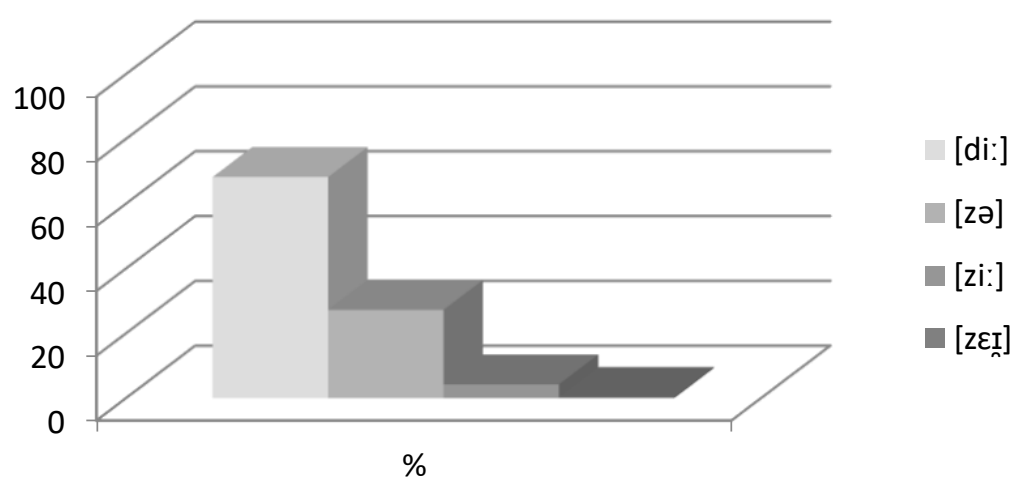

Figure 33: Distribution of third-person plural subject pronoun forms in Cité Duits

Two forms make up the lion's share. The most frequent form is die [di:], accounting for 68.2 percent, which is homophonous with the Dutch/German demonstrative pronoun, and

\footnotetext{
52 Many Romance languages distinguish gender on subject plural pronouns. For example, Spanish distinguishes (1PL) nosotros/as, (2PL) vosotros/as and (3PL) ellos/as. The masculine plural form is also employed when referring to a group of women that includes a single man. See Roodenburg and Hulk (2009) for a discussion of grammatical gender in Dutch compared to Romance languages.
} 
close to Maaslands dièj [di:j]. In addition, speakers use ze/se [zə] (27.2\%), resembling the respective German enclitic and the Dutch/Maaslands weak pronoun. These two forms account together for 95.4 percent. Note that the three varieties share the reduced form [zo]. In turn, the Dutch full form $z i j$ [zeI] is almost absent from the data ( $\mathrm{n}=2$ or $0.3 \%)$, whereas sie [zi:] as in German is used in 4.2 percent $(\mathrm{n}=26)$.

Considering that the contact varieties provide the same forms for the 3SG.SBJ.F and 3PL.SBJ, namely (Belgian Dutch) zij/ze/die, (German) sie/'se/die and (Maaslands) zi$j / z e / d i-j$, we would expect to receive a similar picture for the two pronouns. In fact, the distribution of the most frequent form die [di:] is close to what we encountered for the 3SG.SBJ.F pronoun $(68.2 \%$ versus $71.3 \%)$. The form ze/se [zo], in turn, scores significantly higher here $(27.2 \%$ versus $17.7 \%)$. This higher percentage is insofar interesting as it means that the plural pronoun shows less variation than the feminine singular pronoun (see $\S 5.4 .4$ ).

\subsection{Object Pronouns: Frequency and Phonological Properties}

This section discusses the distribution of object pronoun forms in Cité Duits. The number of tokens, however, is remarkably lower than for subject pronouns, and not all pronouns are equally represented in the data. At this point, I will not distinguish between accusative and dative object forms, since only German has this distinction whereas Dutch and Maaslands do not.

\subsubsection{First-person Singular}

Table 12 presents the total number of first-person singular object pronoun forms (1SG.OBJ) in the data set and their percentages.

\begin{tabular}{|l|l|l|l|l|l|}
\hline 1SG.OBJ & mij [mei] & mir [mi:en] & mich [mıç] & mich [mi:ç] & Total \\
\hline $\mathbf{n}$ & 1 & 8 & 119 & 1 & 129 \\
\hline $\mathbf{\%}$ & 0.8 & 6.2 & 92.2 & 0.8 & 100 \\
\hline
\end{tabular}

Table 12: Frequency in absolute numbers and percentages of first-person singular object pronoun forms in Cité Duits 


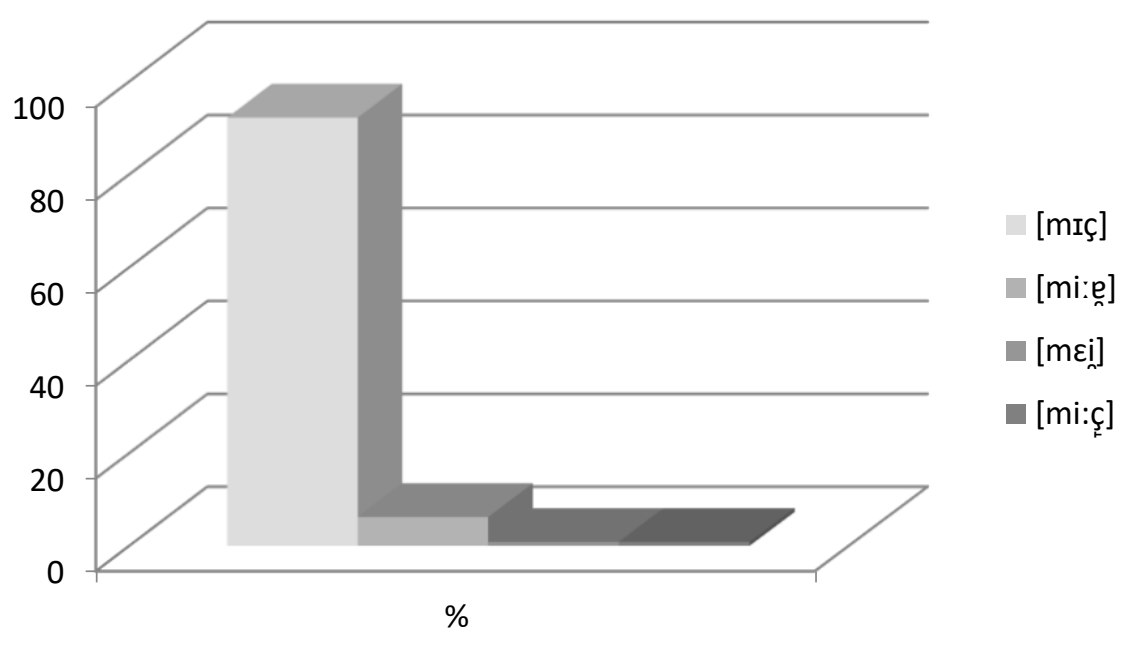

Figure 34: Distribution of first-person singular object pronoun forms in Cité Duits

The data of Cite Duits contains in total 129 tokens for the 1SG.OBJ pronoun, of which 119 tokens are realized as mich [miç] (92.2\%), eight tokens as mir [mi:en] (6.2\%) and one token as mich [mi:ç] and mij [mei], respectively. The most frequent form is pronounced with a voiceless palatal fricative and a short vowel as the German first-person direct object (accusative) form, and not with a voiceless post-palatal fricative and a long vowel as in Maaslands mich [mi:ç] (or the weak form [mıç] with a short vowel). The second most frequent form, mir [mi:e] , is homophonous with the German form for the indirect object (dative). In other words, about 98 percent of the $1 \mathrm{SG} . \mathrm{OBJ}$ forms are in line with German phonology, while one example is similar to the Belgian Dutch strong 1SG.OBJ pronoun mij [mei], and one to the 1SG.OBJ Maaslands pronoun mi:ch [mi:ç]. These findings suggest that the most-frequently produced forms resemble German, and to a certain degree Maaslands. German, however, marks case on object pronouns by distinguishing between accusative (mich) and dative (mir) object forms, whereas Belgian Dutch and Maaslands do not. It remains to be seen whether these forms also behave as accusative and dative objects in Cité Duits ( $\$$ 6.3.1).

\subsubsection{Second-person Singular}

For the second-person singular object $(2 \mathrm{SG} . \mathrm{OBJ})$ pronoun, we receive the following distribution (Table 13): 


\begin{tabular}{|l|l|l|l|}
\hline 2SG.OBJ & dir [di: $:$ ] & dich [dıç] & Total \\
\hline $\mathbf{n}$ & 3 & 63 & 66 \\
\hline$\%$ & 4.5 & 95.5 & 100 \\
\hline
\end{tabular}

Table 13: Frequency in absolute numbers and percentages of second-person singular object pronoun forms in Cité Duits

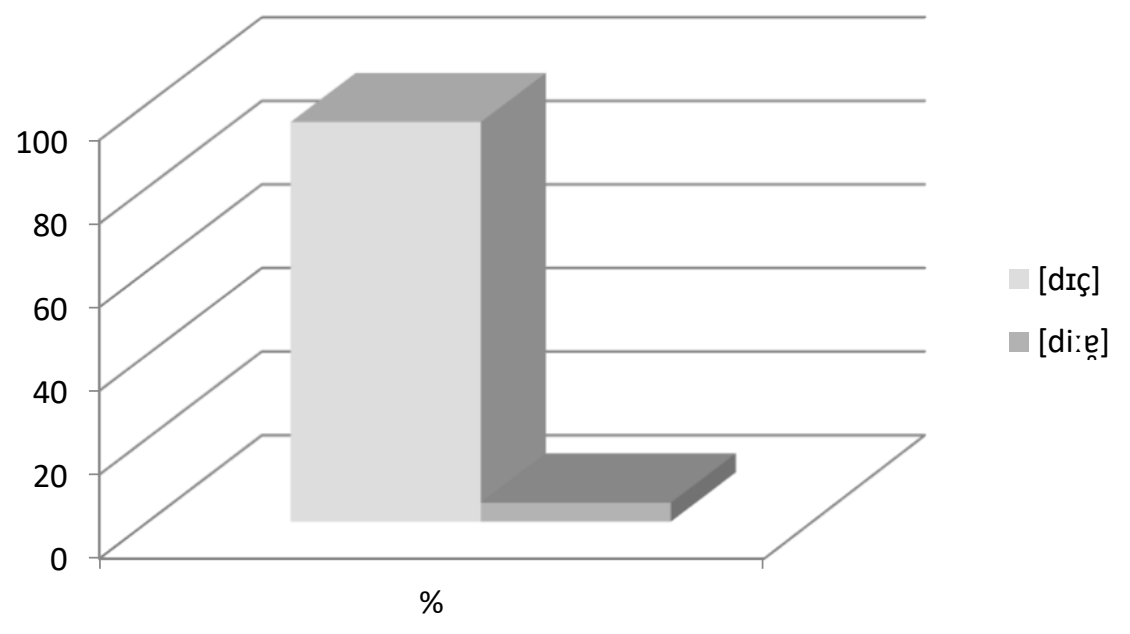

Figure 35: Distribution of second-person singular object pronoun forms in Cité Duits

Again, the picture is very homogenous. Note, however, that the number of total tokens with 66 forms is remarkably lower than for the 1SG.OBJ pronoun. Speakers use in 95.5 percent $(n=63)$ the form dich [diç], and only in 4.5 percent $(n=3)$ the form $\operatorname{dir}$ [di:te]. Phonetically, both forms behave according to German pronunciation. Nonetheless, speakers use the voiceless post-palatal fricative as in Maaslands when quoting in the dialect (40), which suggests that speakers use different (phonetic) variants when speaking Cité Duits as opposed to Maaslands (or Belgian Dutch).

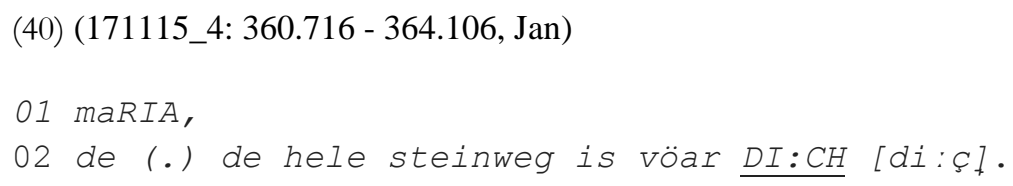

'Maria, the whole path is for you.' 
Although there is little variation in the use of the 2SG.OBJ pronoun, it will be crucial to find out how dir and dich behave when considering their position within the clause as accusative and dative object $(\$ 6.3 .2)$.

\subsubsection{Third-person Singular Masculine + Human}

More variation exhibits the third-person singular masculine object (3SG.OBJ.M) pronoun + human, with four attested variants (Table 14):

\begin{tabular}{|l|l|l|l|l|l|}
\hline 3SG.OBJ.M & ihn [i:n] & ihm [i:m] & 'm [əm] & de(r) [de:] & Total \\
\hline $\mathbf{n}$ & 8 & 58 & 5 & 15 & 86 \\
\hline $\mathbf{\%}$ & 9.3 & 67.4 & 5.8 & 17.4 & 100 \\
\hline
\end{tabular}

Table 14: Frequency in absolute numbers and percentages of third-person singular masculine object pronoun forms + human in Cité Duits

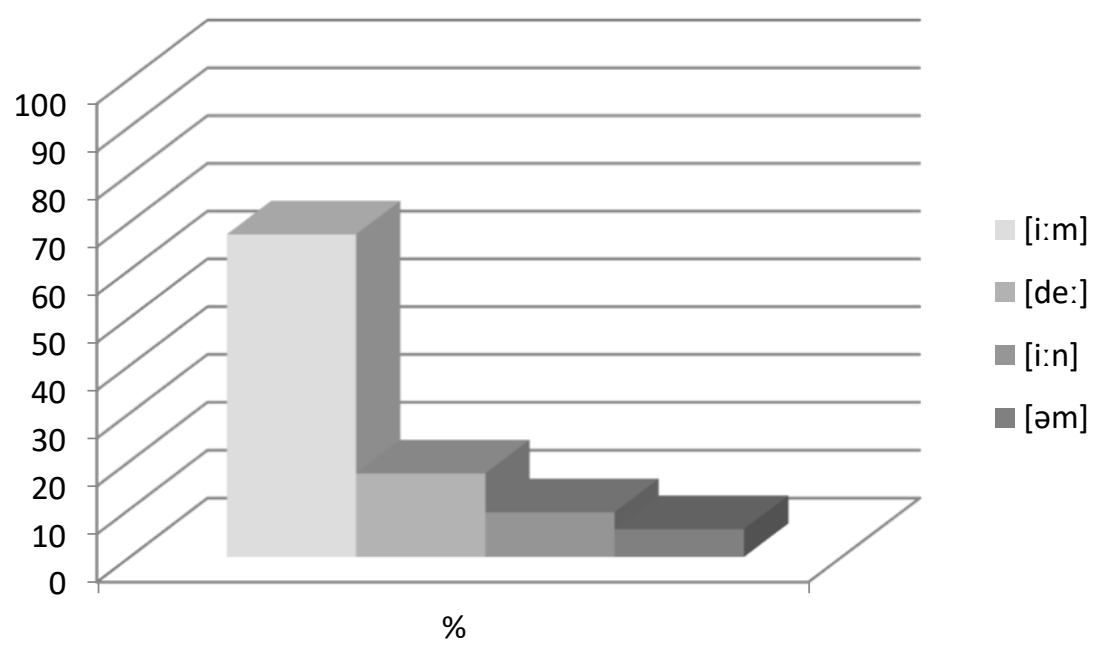

Figure 36: Distribution of third-person singular masculine object pronoun forms + human in Cité Duits

The speakers produce a total of 86 forms for the 3SG.OBJ.M pronoun. The majority of these pronominal forms is realized as ihm [i:m], accounting for 67.4 percent $(n=58)$, homophonous with the German dative pronoun. Moreover, speakers produce $d e(r)$ [de:], resembling the German (der [de: $\left.{ }^{\prime}\right]$ ) and Maaslands (dè [də]) masculine demonstrative pronoun ( $\mathrm{n}=15$ or 17.4 percent). The remaining tokens are realized as $i h n$ [i:n], in line with the respective German accusative pronoun $(n=8$ or 9.3 percent), and as ' $m$ [əm] $(n=5$ or 
5.8 percent). The latter form corresponds to the respective reduced pronoun in all three contact varieties. Ihn [i:n] and ' $m$ [əm], however, have a low incidence. A possible scenario is that speakers distinguish case on this particular pronoun, similar to German. Another possible reason is that there is inter-speaker variation in Cité Duits, with certain forms being produced by particular speakers (see $\S 6.3 .3$ ).

\subsubsection{Third-person Singular Feminine + Human}

The third-person singular feminine object (3SG.OBJ.F) pronoun + human is barely represented in the data set, with three tokens in total (Table 15).

\begin{tabular}{|l|l|l|}
\hline 3SG. OBJ.F & die $[$ di: $]$ & Total \\
\hline $\mathbf{n}$ & 3 & 3 \\
\hline $\mathbf{\%}$ & 100 & 100 \\
\hline
\end{tabular}

Table 15: Frequency in absolute numbers and percentages of third-person singular feminine object pronoun forms + human in Cité Duits

All three forms for the 3SG.OBJ.F pronoun are realized as die [di:], which corresponds to the respective demonstrative pronoun in German and Belgian Dutch, and resembles the Maaslands demonstrative pronoun [di:j]. Other forms that occur in the contact varieties, such as Belgian Dutch haar [ha:r], Maaslands (h)äör [œ:R], German ihr [?i:ø] ], or ze [zə] have not been attested in Cité Duits for the 3SG.OBJ.F pronoun. Evidently, the number of tokens is too small to draw conclusions. ${ }^{53}$

\subsubsection{Third-person Singular Non-human}

The number of object pronouns referring to singular non-human antecedents is low, with 10 tokens in total (Table 16).

\begin{tabular}{|l|l|l|l|l|}
\hline $\begin{array}{l}\text { 3SG.OBJ } \\
\text { N-hum. }\end{array}$ & dat [dat] & den [de:n] & de [de:] & Total \\
\hline $\mathbf{n}$ & 5 & 3 & 2 & 10 \\
\hline$\%$ & 50 & 30 & 20 & 100 \\
\hline
\end{tabular}

Table 16: Frequency in absolute numbers and percentages of third-person singular object pronoun forms in Cité Duits [-hum]

\footnotetext{
${ }^{53}$ Crucially, it was not always possible to identify the antecedent of a pronoun when two or more pronominal forms occurred in one clause, especially when dealing with die, which is both a subject and object pronoun, may refer to singular and plural, and is used as a demonstrative determiner in Cité Duits. Forms where the antecedent was unclear could not be included.
} 
For object pronouns with a non-human antecedent, I attested three variants, namely dat [dat], den [de:n] and de [de:]. Here, a clear tendency toward forms functioning as demonstrative pronouns in the contact varieties can be observed: den and der are phonologically close to the available forms in German/Maaslands, whereas dat resembles the Belgian Dutch/Maaslands neuter gender demonstrative. An example from the data is given in (41).

(41) (0313_144739: 133.273 - 135.875, Jan) [antecedent: tabac]

01 die haben de(r) [de:] in CoGnac gelegt, hè?

'They put it [lit. him] in cognac.'

While utterance (41) lexically resembles German, it differs from German with regard to the object pronoun, which is inflected according to accusative case (ihn/den) in German. Nevertheless, the small number of tokens does not allow drawing substantiate conclusions here.

\subsubsection{First-person Plural}

Unlike the 1PL.SBJ pronoun, the first-person plural object (1PL.OBJ) does not exhibit any variation (Table 17).

\begin{tabular}{|l|l|l|}
\hline 1PL.OBJ & uns [ons] & Total \\
\hline $\mathbf{n}$ & 89 & 89 \\
\hline $\mathbf{\%}$ & 100 & 100 \\
\hline
\end{tabular}

Table 17: Frequency in absolute numbers and percentages of first-person plural object pronoun forms in Cité Duits

All 89 tokens in the data are produced homogenously as uns [uns], according to German phonology. This form is also phonetically close to the respective Belgian Dutch form ons [ons]. Most of these pronouns occur after a preposition. Note that German has one single form here for accusative and dative. Neither the Maaslands strong form oos [o:s] nor its weak counterpart òs [os] are used by the speakers in Cité Duits. In other words, the 1PL.OBJ pronoun corresponds to German and to a lesser extent to Belgian Dutch, but differs from the dialect. 


\subsubsection{Second-person Plural}

A similar picture can be observed for the second-person plural object (2PL.OBJ) pronoun, although the number of tokens found in the data is quite small (Table 18).

\begin{tabular}{|l|l|l|}
\hline 2PL.OBJ & euch [20Iç] & Total \\
\hline $\mathbf{n}$ & 14 & 14 \\
\hline$\%$ & 100 & 100 \\
\hline
\end{tabular}

Table 18: Frequency in absolute numbers and percentages of second-person plural object pronoun forms in Cité Duits

The speakers produce in total 14 instances of the 2PL.OBJ pronoun, all of them realized as euch [?गIç]. Again, this form is homophonous with the German object pronoun in this position. In German, euch [?Iㄷ] functions both as accusative and dative object pronoun. Importantly, there is no weak form in the paradigm of German or Belgian Dutch. Only Maaslands has next to the full form uuch [y:ç] a weak form, namely uch [yç]. Although more tokens would be needed here to substantiate the findings, it is obvious from Table 18 that the 2PL.OBJ pronoun is phonologically in line with German and clearly differs from Belgian Dutch, which has the full form jullie ['jyli] here.

\subsubsection{Third-person Plural}

For the third-person plural object (3PL.OBJ) pronoun, a total of 30 examples has been found in the data (Table 19).

\begin{tabular}{|l|l|l|l|}
\hline 3PL.OBJ & ze $[\mathbf{z}$ ] & die $[\mathbf{d i}:]$ & Total \\
\hline $\mathbf{n}$ & 12 & 15 & 27 \\
\hline $\mathbf{\%}$ & 44.4 & 55.6 & 100 \\
\hline
\end{tabular}

Table 19: Frequency in absolute numbers and percentages of third-person plural object pronoun forms in Cité Duits 


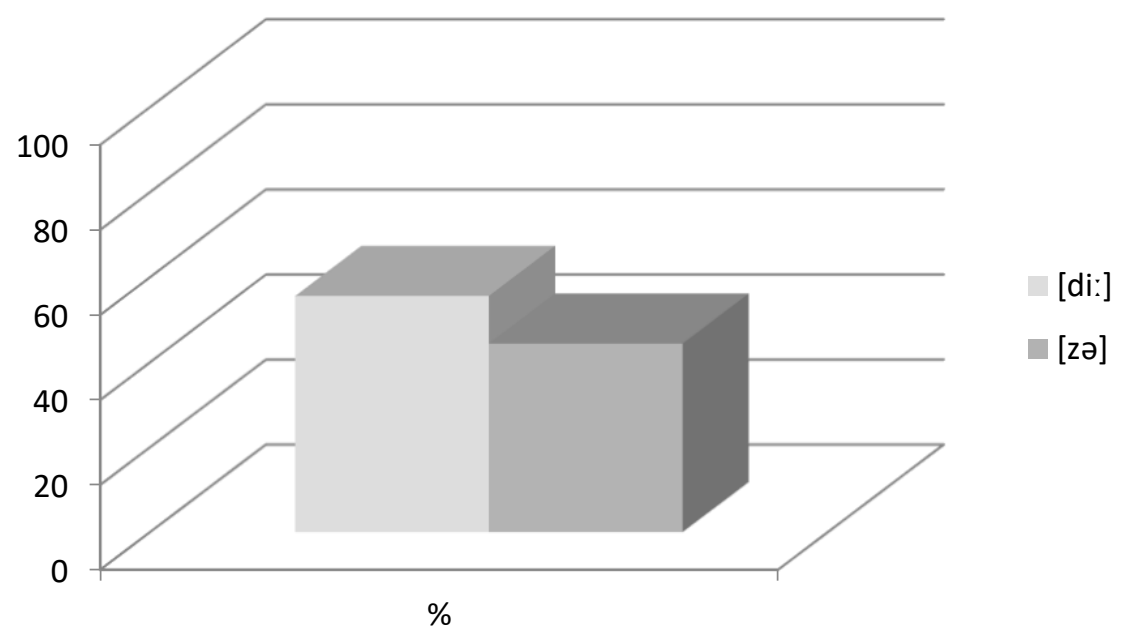

Figure 37: Distribution of third-person plural object pronoun forms in Cité Duits

The distribution of the 30 forms for the third-person plural object (3PL.OBJ) pronoun is almost evenly spread between two forms: $z e$ [zə] ( $\mathrm{n}=12$ or 44.4 percent) and die [di:] ( $\mathrm{n}=15$ or 55.6 percent). While the three contact varieties share the reduced form ze/'se [zo], the form die resembles again the respective plural demonstrative pronoun. This form, or a phonologically similar variant such as [ $\left.\mathrm{di}^{\mathrm{j}}\right]$ in Maaslands, is available in all three contact languages, although it underlies restrictions related to case in German.

\subsection{Conclusion: Distribution of Personal Pronouns in Cité Duits 5.6.1 Overview of Personal Pronouns}

I conclude this chapter by providing the paradigm of personal pronoun forms in Cité Duits based on the forms with the highest distribution in the data (IPA). Round brackets indicate that the respective form either has a low number of tokens in total (e.g. 3SG.OBJ.F, $\mathrm{n}=$ 3 ), or accounts for a significant lower percentage (e.g. mir (6\%) as compared to mich ( $92 \%$ ) for the 1SG.OBJ). Up to this point, the paradigm can be schematized as follows ( Figure 38 and Figure 39).

\begin{tabular}{|c|c|c|c|c|c|}
\hline & & CD & $\mathbf{G}$ & MA & BD \\
\hline SG & 1 & [Iç ] & [Iç] & [i:ç] [ç] & [Ik] [ək] [k] \\
\hline & 2 & [du:][tə] & [du:][tə][də] & [di:ç][tə][də] & 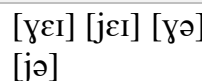 \\
\hline
\end{tabular}




\begin{tabular}{|c|c|c|c|c|c|}
\hline & $\begin{array}{l}3 \\
\mathbf{M}\end{array}$ & [de:(v) $)][e: \mathfrak{p}]$ & [de:e]][e:en] [r] & [də] [e:: ] [e:] & [di:][hعI][əm] \\
\hline & $\mathbf{3 F}$ & [di:][zə] & [di:] [zi:] [zə] & [di:j] [zej] [zo] & [di:] [zeI] [zə] \\
\hline & $\begin{array}{l}3 \\
\mathbf{N}\end{array}$ & [dat] & [عs] [das] [s] & [hət] [dət] [(ə)t] & [hət][dat] [(ə)t] \\
\hline & $\begin{array}{l}3^{*} \\
54\end{array}$ & [de:(p) $]$ & \multicolumn{3}{|c|}{ See Figure 23 and Figure 29 for third-person forms } \\
\hline & $\mathbf{V}$ & - & [zi:] & ['ye:R] & [y] \\
\hline \multirow[t]{3}{*}{ PL } & 1 & $\begin{array}{l}\text { [vi:e] }][\mathrm{vi}][\text { wə] } \\
{[\mathrm{me}]([\mathrm{ve}])}\end{array}$ & [vi:e] $][\mathrm{ve}][\mathrm{me}]$ & [ve:R] [ver] & [weI][wə] \\
\hline & 2 & ([?วIç] $])$ & [Pi:en][e] & ['ye:R] [yer] & ['jyli] [yə] \\
\hline & 3 & [di:][zə] & [zi:][di:][zə] & [zę̦j] [di:j] [zə] & [zEI] [di:] [zə] \\
\hline
\end{tabular}

Figure 38: Most frequent subject pronoun forms in Cité Duits compared to the contact varieties (IPA)

\begin{tabular}{|c|c|c|c|c|c|c|}
\hline & & CD & G ACC & G DAT & MA & BD \\
\hline \multirow[t]{6}{*}{ SG } & 1 & {$[$ miç] $]([\mathrm{mi}: \mathrm{e}])$} & [miç] & [mi:en] [me] & [mi:ç] [mıç] & [mei] [mə] \\
\hline & 2 & {$[$ diç] $([$ di:e्: $])$} & [diç] & [di:e] $][\mathrm{de}]$ & [di:ç] [dıç] & [y] \\
\hline & $\begin{array}{l}\mathbf{3} \\
\mathbf{M}\end{array}$ & $\begin{array}{l}\text { [i:m][de:] } \\
([\mathrm{i}: \mathrm{n}])\end{array}$ & [i:n][n] & [i:m][əm] & [œ:m] [əm] & [hem] [əm] \\
\hline & $3 \mathbf{F}$ & ([di:]) & [zi:][zə] & [?i:e্র] [e] & [œ:R] [eR] & $\begin{array}{ll}{[\text { ha:r] }} & \text { [zo] } \\
{[\mathrm{r}][\mathrm{R}]} & \end{array}$ \\
\hline & $3^{*}$ & $\begin{array}{l}\text { ([dat][de:n] } \\
\text { [de:]) }\end{array}$ & \multicolumn{4}{|c|}{ See Figure 24 for third-person forms } \\
\hline & $\mathbf{V}$ & - & [zi:][zə] & ['Ri:nən] & & [y] \\
\hline \multirow[t]{3}{*}{ PL } & 1 & [ons] & [ons] & [ons] & [o:s] [os] & [ons] \\
\hline & 2 & [?orç] & [?onç] & [Ponç] & [y:ç] [yç] & ['jyli] \\
\hline & 3 & [di:][zə] & [zi:][zə] & ['Pi:nən] & [hyn] [zə] & [di:] [zə] \\
\hline
\end{tabular}

Figure 39: Most frequent object pronoun forms in Cité Duits compared to the contact varieties (IPA)

It is striking that some pronouns do not exhibit any or hardly any variation. Those pronouns that show variation generally have two variants that are dominant in the data,

${ }^{54} 3 *$ refers here to the third-person singular with a non-human referent. 
while variants that diverge from the frequency pattern often do not exceed two percent. In subject pronouns, usually not more than two variants are encountered frequently for a given pronoun, except in the case of the first-person plural. A similar observation can be made for object pronouns. Regarding the overall frequency, the pronouns most often used by the speakers are the first-person singular subject (1SG.SBJ) with 1331 tokens, and the third-person singular subject masculine (3SG.SBJ.M) with 1301 tokens. In contrast, singular feminine pronouns have a comparably low frequency, both in subject forms $(\mathrm{n}=164)$ and object forms $(\mathrm{n}=3)$.

\subsubsection{Subject Pronouns}

Regarding the phonological and lexical characteristics of subject pronouns, the following can be observed. A pronoun that shows particularly little internal variation is the firstperson singular (1SG.SBJ), which is realized in roughly 96 percent of the tokens as ich [Iç] 'I.' This form seems to be a Belgian Dutch-Maaslands-German intermediate form, pronounced with a voiceless post-palatal fricative as in Maaslands, but with a short vowel as in German/Belgian Dutch. As to the second-person singular (2SG.SBJ), the most frequent form is $d u$ [du:] 'you' (78\%), phonologically in line with German but not with Belgian Dutch/Maaslands. In addition, speakers use te [tə] 'you,' which can be analyzed as a Maaslands/German component of the speech.

The most frequent third-person forms are homophonous with or resemble the available demonstrative pronouns in German (der [de:p] 'he' and die [di:] 'they, she'), Maaslands (dè [də] 'he' and dièj [di:j] 'they,' 'she'), and, to a lesser degree, Belgian Dutch (only die [di:] 'they, 'he,' 'she'). This is true for both singular and plural forms. In contrast, full forms as found in the contact varieties have a much lower frequency, such as Belgian Dutch hij 'he'/zij 'she,' Maaslands $z i-j$ 'she'/(h)eeë(r) 'he,' or German sie 'she.' For the third-person singular masculine (3SG.SBJ.M) + human, we find two prevailing forms, namely $d e(r)$ [de: $]$ ]/[de:] and $\operatorname{er}$ [e:ten] 'he.' The realization of $d e(r)$ 'he' [de:] possibly points toward a process of convergence between the German der [de: $\mathrm{e}]$ and the Maaslands dè [də]. The form er 'he' can be analyzed as either German or Maaslands. As mentioned, the forms $d e(r)$ and $e r$ do not exist in Belgian Dutch. Furthermore, speakers use $d e(r)$ as a third-person singular pronoun to refer to non-human antecedents.

The third-person singular feminine (3SG.SBJ.F) + human die [di:] 'she' in Cité Duits shares all phonological characteristics with the Belgian Dutch/German demonstrative and resembles the respective form diè [ $\mathrm{di}^{\mathrm{j}}$ ] in Maaslands. Next to the form die [di:] 'she,' speakers also employ the form $z e$ [za] 'she' here, although less often. The latter conforms to the 3SG.SBJ.F reduced pronoun in Belgian Dutch, Maaslands, and German. Yet, a few tokens diverge from this pattern: In total, there are 11 forms realized as [de:t] $] /[\mathrm{e}: \mathrm{e}] /[\varepsilon:]$ in line with, or close to, the German/Maaslands masculine singular pronoun. In Chapter 6, I will discuss this type of variation encountered in the data in more detail. 
Furthermore, 'it' and 'that' correspond to the form dat [dat]. Apparently, optional forms have become obligatory in Cite Duits. Note that this is the only form that is completely homophonous with Belgian Dutch/Maaslands and at the same time not found in colloquial standard German. But it is possible, however, that influence of Ruhr-German can be observed here, which also uses dat 'that' as a neuter article and pronoun (see Schiering 2002: 4; Salewski 1998: 27).

In turn, the first-person plural (1PL.SBJ) shows an exceptional range of internal variation, with four frequently-attested variants, namely wir [vi:e]], wie [vi:], we [wə] and $m a[\mathrm{me}]$ (and, rarely, $w a[\mathrm{ve}]$ ). Three of these variants are realized according to one of the available forms in the contact varieties: wir 'we' is homophonous to the German strong, and $m a$ 'we' to the reduced form, while we 'we' resembles the weak form in Belgian Dutch. The form wie 'we,' however, is neither Belgian Dutch, nor Maaslands or German. The most obvious explanation, given the phonetic closeness of the German strong pronoun wir [vi:en] 'we' and the Belgian Dutch weak pronoun we [wə] 'we,' is that wie [vi:] 'we' developed as an intermediate form. I will come back to this type of variation in Chapter 6. So far, it can be concluded that the 1PL.SBJ pronoun shows more variation than other pronouns, and that not all available forms in Cité Duits are found in one of the contact varieties.

The 2PL.SBJ pronoun is always realized as euch [?ㄲç] 'you' in line with the second-person plural object form in German. Yet there are few tokens available here. Regarding the 3PL.SBJ pronoun, the distribution of the most frequent forms die [di:] and $z e$ [zo] 'they' is close to what we encountered for the 3SG.SBJ.F pronoun, although the plural pronoun exhibits less variation than the singular pronoun. These or phonetically similar forms exist in all three contact varieties for the 3PL.SBJ pronoun, which means that their use cannot be traced back to one particular 'source.'

\subsubsection{Object Pronouns}

Object pronouns are, generally speaking, less well represented in the data set. As to first and second-person singular object pronouns, a clear preference by the speakers for the forms mich [mıç] 'me' and dich [dıç] 'you,' respectively, can be observed, both realized in line with the corresponding accusative pronoun in German, as well as phonologically close to the Maaslands object pronouns mi:ch [mi:ç][mıç] 'me' and di:ch [di:ç][dıç] 'you.' The forms mir [mi:e] 'me' and dir [di:en] 'you,' corresponding to the respective dative pronouns in German, clearly show a low frequency. In Chapter 6 (§ 6.3), I will analyze whether Cité Duits distinguishes between accusative case and dative case.

The third-person singular masculine (3SG.OBJ.M) pronoun, in contrast, exhibits more variation. The most frequent form ihm [i:m] 'him' is phonologically in line with the German dative pronoun, not the accusative pronoun. Speakers also produce, if significantly less often, the form $d e(r)$ [de:] 'he/him,' close to the German/Maaslands demonstrative. The form ihn [i:n] 'him,' which is in line with the respective German accusative pronoun, occurs rarely. For the third-person singular feminine (3SG.OBJ.F) 
pronoun, the form die [di:] 'she' has been attested, resembling the Belgian Dutch/German/Maaslands demonstrative. Also, for the third-person singular with a nonhuman antecedent, demonstrative forms are used, i.e. dat [dat], den [de:n] and de(r) [de:]. Yet the number of attested tokens is extremely small.

For the first-person and second-person plural object pronouns, all tokens are realized according to German phonology, namely as uns [ons] 'us' and euch [?orç] 'you.' Because the available forms for the first-person plural (1PL.OBJ) are phonetically close, it is possible that Belgian Dutch and Maaslands had a reinforcing effect on the development of uns [uns] 'us.' The same does not hold for the 2PL.OBJ, however, which differs lexically and phonetically from the Belgian Dutch pronoun jullie ['jyli]. Finally, similar to the third-person subject pronouns (SG.F and PL), the third-person plural (3PL.OBJ) pronoun has two forms in Cité Duits, $z e$ [zə] and die [di:] 'them,' resembling available forms in all three contact varieties.

\subsubsection{Concluding Remarks}

In sum, the overall picture is that many pronouns phonetically resemble spoken German, and partly Maaslands. Cité Duits uses two intermediate forms, namely wie [vi:] 'we' and ich [rç] 'I.' Convergence between Maaslands and German also seems to play a role in the 3SG.SBJ.M pronoun $d e(r)$ [de:] 'he.' Furthermore, a number of forms can be analyzed as a Maaslands and German component of the speech, meaning that these forms exist in both varieties ( $e r$ 'he,' te 'you'). In a similar vein, some forms show overlap with an available form in all three contact varieties (die 'they,' 'she,' Belgian Dutch also 'he' (demonstrative)), and ze/se 'they,' 'them,' 'she,' 'her'). Furthermore, there are a few pronominal forms that are lexically close to Maaslands but differ phonologically from it (mich 'me,' dich 'you').

Regarding third-person singular pronouns, my analysis gave rise to two major observations. On the one hand, it can be concluded that Cité Duits distinguishes biological gender on personal pronouns. Unlike in Dutch, where die is not specified for biological gender, Cité Duits distinguishes between die for feminine and $d e(r)$ for masculine human referents. On the other hand, in contrast to the contact varieties, Cité Duits does not distinguish grammatical gender on personal pronouns, but uses a single form here for specific referents, i.e. $d e(r)$.

Polite (V-) pronouns are completely absent, which is unsurprising since Cité Duits emerged as in-group variety in informal contexts (see $\S 2$ ). Interestingly, except for we 'we', Cité Duits does not have pronominal forms that correspond to Belgian Dutch and at the same time do not exist in Maaslands or German. The form dat 'that,' however, is always pronounced with a final stop as in Belgian Dutch/Maaslands/Ruhr-German, and therefore differs from colloquial standard German, which has a final fricative. In what follows ( $\$$ ), these findings shall be analyzed with a major question in mind: how can pronominal variation in the data be explained? This analysis shall be another step toward understanding the grammatical character of Cité Duits. 


\section{Chapter 6: Explaining Variation in Personal Pronouns}

[V]ariation should be exploited rather than disregarded in investigating language. (Pierrehumbert 1994: 234)

\subsection{Introduction}

Having established the basic outline of the pronominal paradigm for personal pronouns in Cite Duits ( $\$ 5)$, I now turn to the question of variation. How can variation in the pronominal paradigm be explained (RQ3, iii, see $\S 5.1)$ ? Why do some pronouns show more variation than others and which factors are responsible for this variation? Studies devoted to the pronominal domain point to the syntactic position of the verb as a pivotal factor for determining form variation of a pronoun (Benincà \& Poletto 2005: 278; de Vogelaer 2007: 145). For Cité Duits contact varieties, we have already seen that not all pronominal forms are equally found in all positions. For example, reduced forms in German typically appear as enclitic attached to the finite verb or complementizer, whereas in Belgian Dutch and Maaslands, many reduced forms ('weak pronouns') occur both before and after the finite verb $(\$ 5.3)$. This chapter analyzes the findings of the previous chapter in terms of internal variation of pronominal forms in relation to their position.

Some pronouns (e.g. 1SG.SBJ, 2PL.SBJ) exhibit hardly any phonological variation in Cité Duits, whereas others have two or more phonological variants that occur frequently in the dataset. I will consider a variant as 'frequent' when it occurs in five percent or more of the respective tokens. ${ }^{1}$ While spontaneous speech always exhibits a certain degree of variation, ${ }^{2}$ these variants in the dataset generally account for around 17 percent or more (see $\S 5.4-5.5$ ), which suggests that they cannot be ascribed to production effects. Rather, there seems to be co-occurrence of several forms for a number of pronouns in Cité Duits. This raises the question of whether the occurrence of these various forms can be explained either by their position in relation to the finite verb in non-topicalized position or by the complementizer. Are all forms equally used in pre- and postverbal position, or do we encounter differences as to their distribution? What is more, does Cité Duits allow for the same positions as its contact varieties? Aside from considering

\footnotetext{
1 When to consider a variant or construction as frequent remains controversial and is often determined based on the kind of data and aim of the study (for discussions see Bybee 2007; 2013; Pierrehumbert 2001). Given that the occurrence of most forms is considerably below or above five percent, it seems reasonable to use it as dividing line here.

${ }^{2}$ This does not mean that 'anything goes' in spoken language. Yet, spoken language exhibits features that are absent from written language, such as anacoluthon, repetitions, recipient signals, interjections, and repairs (see Auer 2000; Auer 2010; Westpfahl 2020: 37-50; Henning 2006; Deppermann \& Reineke 2018; Fiehler et al. 2004; for syntax, see Jansen 1981; and the contributions in Adli et al. 2015).
} 
previous studies on personal pronouns, I will compare some of the findings to the speech of miners from Duisburg.

In the analysis below, I distinguish three patterns: (i) the pronoun occurs in verbinitial position in the main clause, the so-called V2-straight order (subject-verb order or $\mathbf{S}-\mathbf{V}$ ); (ii) the pronoun follows the finite verb in the main clause, the V2-inverted order (verb-subject order or $\mathbf{V}-\mathbf{S}$ ); and (iii) the pronoun occurs after a complementizer (COMP-S). To explain variation in the data, I will concentrate on the pronouns with two or more variants and the most frequent forms as identified in Chapter 5. For object pronouns, I will analyze whether the attested forms behave as accusative or dative object within the clause.

This chapter is structured as follows. The subsequent sections address subject ( $\S$ 6.2) and object pronouns ( $\S 6.3$ ). Next, in section 6.4 I discuss one specific form encountered in the data more in detail, namely the first-person plural form $m a$. The final section 6.5 provides an analysis of the findings, thereby considering inter-speaker variation, while also summarizing the main results.

\subsection{Subject Pronouns}

In the previous chapter I analyzed the frequency distribution and lexical-phonological properties of personal pronouns in Cité Duits. This section analyzes variation in subject pronouns in relation to their position with respect to the finite verb in non-topicalized position, as well as to the complementizer. I mainly focus on the most frequent variants (> 5\%) attested in $\S 5.4$. In addition, I consider a number of other factors that may have caused variation in the data, whereby I also take into account variants with a lower frequency. Note that I covered the third-person singular referring to non-human antecedents in detail already (see $§ 5.4 .5$ ), which is why it will be ignored here.

\subsubsection{First-Person Singular}

There is little variation in the 1SG.SBJ pronoun, realized in 96 percent $(n=1282)$ of the 1331 examples as $i c h$ [ıç], a German-Maaslands-Belgian Dutch intermediate form (see $\S$ 5.4.1). While most other subject pronouns have two or more frequent forms, this pronoun has a single form that occurs both before $(\mathrm{n}=897$ or $70 \%)$ and after the finite verb $(\mathrm{n}=332$ or $25.9 \%$ ) as well as after the complementizer ( $\mathrm{n}=53$ or $4.1 \%$ ). Despite the large number of tokens, then, roughly 96 percent is realized as ich [iç]. A possible explanation is related to the features of this pronoun in Cité Duits' contact varieties. In German, this pronoun is the only subject pronoun that normally does not have a reduced form (although cliticization exists in regional varieties of German, see $\S 5.3$ ). Similarly, in and across varieties of Dutch, this pronoun displays the least variation within the paradigm. Although Belgian Dutch has a reduced form (' $k$ ), unlike most other pronouns, the 1SG.SBJ does not change in different syntactic environments. There is only geographical variation across Dutch dialects with regard to the final consonant of the pronoun. Where most dialects in 
the South of the Limburg provinces and in the East of Flemish Brabant have a final -ch, elsewhere in the Dutch language area a $-k$ is used (de Vogelaer 2007: 161).

\section{The 1SG form $i$}

The second most frequent form is the short form $i$ [i]. This form, with two percent of the 1SG.SBJ tokens, is extremely rare. A closer look at the data reveals that $i$ [i] occurs before $(\mathrm{n}=16)($ example (1)) and after the finite verb $(\mathrm{n}=6)$ (example (2)), which suggests that it is not an enclitic ${ }^{3}$ pronoun.

(1) (0313_152448: 1490.61 - 1495.41, Yanis)

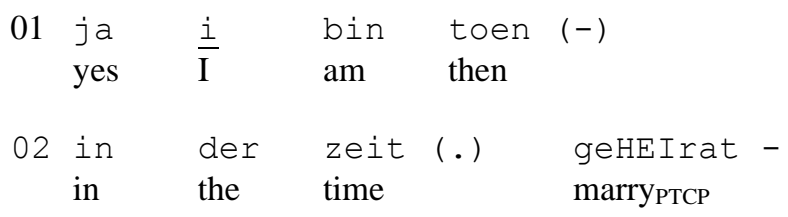

'Yes, I got married at that time.'4

(2) (0314_134351: $1164.6-1169.11$, Theo)

01 dann in september.

then in September

$\begin{array}{lllll}02 \text { de } & \text { erste september } & \text { war } & \text { i } & \text { beGONne - } \\ \text { the first } & \text { September } & \text { was } & \text { I } & \text { startPTCP }\end{array}$

'Then in September, I started on the first of September.'

Elision of the final fricative in the 1SG.SBJ pronoun has also been attested in RuhrGerman (Schiering 2002: 19), a variety that possibly influenced the language use of the very first miners who came to Eisden (see $\S 2$ ). In Ruhr-German, elision of word-final ch also occurs in first and second-person singular object pronouns in allegro-speech ( $m i(c h)$, di(ch)) (Schiering 2002: 19-20), and in words such as do(ch) 'still,' no(ch) 'else,' $a u(c h)$ 'also' and $n i(c h)$ 'not' (Schiering 2002: 21; Mihm 1995: 21). In the data of Cité

\footnotetext{
${ }^{3}$ As explained in $\S 5.2$, a clitic depends on the presence of a host, such as a verbal element, and cannot be modified or stressed. Weak pronouns, in turn, may theoretically occur in all positions (for language-specific constraints of weak forms, see $\S 5.3$ ).

${ }^{4}$ While the participle geheirat lexically resembles German, the auxiliary 'to be' would be untypical in German.
} 
Duits, however, 'elision' of final -ch is only attested sporadically in other words, ${ }^{5}$ and the form $i$ [i] makes up hardly two percent (1.7\%) of all 1SG.SBJ tokens. For this reason, a systematic influence of Ruhr-German cannot be confirmed here. Although these examples likely emerged as a result of fast speech, inter-speaker variation is possible, with individual speakers using the reduced form whereas others do not, an aspect I will discuss in the final section $(\S 6.5)$.

\subsubsection{Second-Person Singular}

Unlike the first-person singular, the second-person has two frequent variants: $d u$ [du:] and te [tə] (see $\S 5.4 .2$ ). While $d u$ [du:] is in line with the pronunciation of the respective full pronoun in German, te [tə] can be regarded as a component of both Maaslands and German, used in both varieties in enclitic position. Likewise, Ruhr-German makes use of the same forms (Schiering 2002: 21), which means that a reinforcing effect of the latter cannot be excluded. Given that the contact varieties have full and reduced forms, it will be interesting to examine whether Cité Duits uses these two forms in all positions. Table 20 illustrates their distribution before the finite verb (S-V), after the finite verb (V-S), and after the complementizer (COMP-S). I further distinguish between main clauses (MC) and complementizer clauses.

\begin{tabular}{|c|c|c|c|c|c|c|}
\hline 2SG & {$[\mathbf{d u}] \mathbf{~ n}$} & $\mathbf{\%}$ & {$[\mathbf{t}$ ] $\mathbf{~ n}$} & $\mathbf{\%}$ & Total-n & $\mathbf{\%}$ \\
\hline S-V & 203 & 30.8 & 0 & 0 & 203 & 30.8 \\
\hline V-S & 313 & 47.5 & 143 & 21.7 & 456 & 69.2 \\
\hline Total MC & 516 & 78.3 & 143 & 21.7 & 659 & 100 \\
\hline Total COMP-S & 57 & 96.6 & 2 & 3.4 & 59 & 100 \\
\hline
\end{tabular}

Table 20: Second-person singular subject forms according to their position in Cité Duits

Table 20 demonstrates that $d u$ [du:] provides all tokens ( $\mathrm{n}=203$ or $30.8 \%)$ in the position before the finite verb, whereas $t e[t$ ] $]$ is exclusively attested in the position after the finite verb $(n=143$ or $21.7 \%)$ and the complementizer ( $n=2$ or $3.4 \%)$, with the latter occurring seldom. This means that $t e$ is very likely an enclitic pronoun in Cité Duits, in line with Maaslands and German. The use of both forms is exemplified in (3) and (4).

(3) (231115_4: 365.597 - 369.803, Victor)

\begin{tabular}{|c|c|c|}
\hline $\begin{array}{l}\text { dat } \\
\text { that }\end{array}$ & $\begin{array}{l}\text { dabs } \\
\text { should }\end{array}$ & \\
\hline
\end{tabular}

${ }^{5}$ I did attest the negation marker $n i$ [ni:] 'not' in a few examples. This, however, could be an influence of Belgian Dutch, where $n i$ [ni:] with deletion of final [t] occurs as well (niet 'not') (van Oostendorp 2006: 34). 
'You should normally not say that.'

(4) (0313_144739: 199.513 - 203.725, Raf)

01 un da dachs-te in dein eigen WIE?
and there thought you $_{2 S G}$ in your own how

'And you thought by yourself, how?'

The findings above correspond to the Austauschbarkeitskriterium or 'criterion of exchangeability' by Nübling (1992: 23), from which follows that the full form may syntactically appear in any place where the clitic may appear as well, but not the other way around. ${ }^{6}$ As Nübling shows for German, $d u$ occurs both pre- and postverbally, while its reduced counterpart is confined to postverbal position. The reduction of $d u$ to te can probably be explained by phonetic rules of German: while weakening of the vowel $(u>$ $e)$ goes back to the tendency of centralization, the elision of the alveolar plosive $(d>t)$ derives from assimilation with [s] after the finite verb (Schiering 2002: 21).

Importantly, the most frequent form in postverbal position is $d u(\mathrm{n}=313$ or $47.5 \%$ ). That such a large number of full forms appears after the finite verb suggests that influence of Ruhr-German is minor, since Ruhr-German has a tendency of cliticization (Schiering 2002; Salewski 1998; Becker 2003). To be precise, Schiering (2002: 18), in his study on pronominal use in Ruhr-German, finds that enclitic forms generally make up approximately 70 percent of the respective tokens for a given pronoun. The form te in Cité Duits, in turn, accounts for roughly 20 percent (Table 20). Thus, the two variants $d u$ and te in Cité Duits behave in a rather consistent way which resembles spoken German, both phonetically and as to their position before and after the finite verb (Nübling 1992: 30307), and to a certain degree Maaslands (only te, Maaslands uses di:ch as full 2SG.SBJ form). While $d u$ is clearly the most frequent form for the 2SG.SBJ occurring in all positions, te appears to be an enclitic pronoun.

\section{Complementizer Agreement in 2SG}

Furthermore, Cité Duits exhibits complementizer agreement with second-person singular pronouns, illustrated in (5), (6) and (7) $(n=6)$. Note, however, that the number of complementizer clauses is comparably low across the entire paradigm (for 2SG.SBJ $\mathrm{n}=59$ ). Complementizer agreement in West Germanic varieties refers to agreement with the embedded subject and is found on the complementizer of finite clauses. Strictly speaking, complementizer agreement may also occur on wh-words, i.e. in clauses without

\footnotetext{
${ }^{6}$ Zwicky (1977) postulated similar ideas. Nübling (1992) elaborated them with focus on varieties of German. An exception is the German es 'it' (see § 5).
} 
a complementizer (van Koppen 2017: 4-5). In the data, this type of agreement appears mostly with wenn 'when/if.'

(5) (231115_5: $1437.961-1439.877$, Jan)

01 und wenn-s-te HEUte sachs(t) and when-s-you 2 sG today say

'And when you say today...'

(6) (171115_5: 138.58-143.78, Vadik) $\begin{array}{lllll}01 \text { wenn-s } & \text { du } & \text { die } & \text { beZAHI (e) } & \text { muss, } \\ \text { when-s } & \text { you } 2 \text { SG them } & \text { payINF } & \text { must }\end{array}$

'If you have to pay for them, ...'

(7) (0314_134351: 560.85 - 565.34, Raf)

01 und wenn- $\underline{s}$ du DANN has vergesse, and when-s you ${ }_{2 S G}$ then has forgetPTCP

'And when you then forgot them,...'

In the examples above, the complementizer wenn 'when/if' carries an enclitic [s], which is followed either by the 2SG.SBJ form te (5) or $d u$ (6)(7). Agreement on the complementizer usually depends on the agreement with the finite verb (van Koppen 2017: 7). This can also be observed in utterances (5), (6) and (7), where both the complementizer and the verb have an $s$-suffix. A substantial number of West-Germanic dialects display complementizer agreement, and studies on Dutch and German dialects refer to similar agreement types as encountered in the data (van Koppen 2017; Haegeman \& Van Koppen 2012; Barbiers et al. 2005; de Vogelaer 2007: 138; Zwart 2006; Weiß 2005).

In Cité Duits, complementizers agree only with the 2SG.SBJ and not with other pronouns, a pattern also observed in Limburgish dialects (de Vogelaer 2007: 138). In fact, in varieties with complementizer agreement, it is often the $2 \mathrm{SG} . \mathrm{SBJ}$ that exhibits this feature. ${ }^{7}$ Accordingly, Cité Duits behaves here in line with dialectal varieties of Dutch and German. Although few utterances exhibit complementizer agreement in the data, this is unsurprising. First, the total number of tokens after the complementizer is limited $(n=59)$.

\footnotetext{
${ }^{7}$ Yet, some Bavarian dialects also show complementizer agreement on the 1PL.SBJ and 3PL.SBJ (Bayer 1984). West Flemish, furthermore, has a more generalized complementizer agreementparadigm. Not only (second person) pronouns trigger complementizer agreement; other elements do so as well (see Haegeman \& Van Koppen 2012; Haegeman 1992).
} 
Second, for most Germanic varieties holds that complementizer agreement is an unstable feature that is employed optionally. Unlike subject-verb agreement, complementizer agreement is often facultative and does not occur in the entire paradigm (Zwart 1993: 27; 2006).

\subsubsection{Third-person Singular Masculine + Human}

For the third-person singular masculine + human, speakers use the forms $d e(r)$ and $e r$, which are phonologically close to the respective German/Maaslands forms. The distribution of both forms is given below (Table 21). Note that I regard [de:e] and [de:] as phonetic variants. As mentioned (§ 5.4.3), there appears to be convergence between the German der [de:ę] and the Maaslands dè [də], while speakers most often seem to produce de $\left[\mathrm{de}:{ }^{8}{ }^{8}\right.$

\begin{tabular}{|c|c|c|c|c|c|c|}
\hline 3SG.M & [de:] n & \% & [e: $:$ ] n & \% & Total-n & \% \\
\hline S-V & 703 & 56.5 & 11 & 0.9 & 714 & 57.4 \\
\hline V-S & 315 & 25.3 & 215 & 17.3 & 530 & 42.6 \\
\hline Total MC & 1018 & 81.8 & 226 & 18.2 & 1244 & 100 \\
\hline $\begin{array}{c}\text { Total COM- } \\
\text { S }\end{array}$ & 29 & 82.9 & 6 & 17.1 & 35 & 100 \\
\hline
\end{tabular}

Table 21: Third-person singular masculine forms + human according to their position in Cité Duits

Despite the variation that appeared at first sight, Table 21 reveals that $d e(r)$ and $e r$ have a preference for different positions. While $d e(r)$, being the most frequent form $(>80 \%)$, most common before the finite verb, amounting to 57 percent $(n=703)$, only 0.9 percent $(\mathrm{n}=11)$ of the tokens is realized as er. In the position after the finite verb, the form er occurs in about 17 percent $(\mathrm{n}=215)$ and $d e(r)$ in 25 percent $(\mathrm{n}=315)$ of the examples. The position after the complementizer is again the least common one, with 29 tokens realized as $d e(r)$ and six tokens as $e r$. Accordingly, the form $d e(r)$ - which resembles the respective demonstrative in German and Maaslands - occurs in pre- and postverbal position as well as after the complementizer, whereas er generally appears in postverbal position. An example from the data is provided in (8).

(8) (CD5: 196.508 - 202, Ferenc)

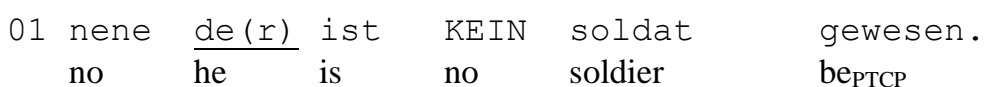

${ }^{8}$ In a few instances, [e: $]$ ] is realized as [e], in line with the respective reduced form in German. 
'No, he was not a soldier.'

In (8), the speaker uses the form der in the position before the finite verb is $(t)$ 'is,' which is the most typical position for the 3SG.SBJ.M. pronoun. That speakers regularly use a demonstrative pronoun instead of a personal pronoun is unremarkable. Many languages use demonstratives for third-person pronouns (Forchheimer 1953: 6). ${ }^{9}$ This also holds for the contact varieties, where demonstrative pronouns may replace third-person pronouns (see $§ 5.3)$.

Demonstrative and personal pronouns, however, differ functionally and cannot be used interchangeably in all contexts in Dutch and German. Previous studies (for German, see Eisenberg 2016: 158; Ehlich 1982: 331; Bosch et al. 2007; for Dutch, see Broekhuis \& den Dikken 2012b: 851; Audring 2020; Rozendaal 2008) have shown that a number of factors such as topic continuity, salience of the antecedent and contrast determine whether speakers choose a demonstrative or a personal pronoun. In a corpus of spoken German, we would expect to encounter both demonstrative and personal pronouns.

\section{SG.M in the Duisburg Corpus}

To find out whether German-speaking miners from Duisburg use er and der (+ hum) in a similar way as the Cité Duits speakers, I examined the position of both variants in the Duisburg miners corpus (see $\S 3$ for details).

For the analysis, I used the databank MOCA, which allowed me to extract and listen to all pronominal forms. In a second step, I examined how often the extracted forms occurred in preverbal position, in postverbal position, and after a complementizer. Next, I filtered a random sample of 200 tokens. Since the corpus was not tagged for pronouns, it would have been a costly undertaking to extract all third-person pronouns and determine the antecedent. Note that $d e r$ is not only a demonstrative pronoun but also a definite article in German. In addition, I had to ensure that all forms carried the feature thuman. This was necessary in order to be able to compare the results to the Cité Duits data, where I distinguished between third-person singular pronouns with a human and a non-human antecedent (see $\$ 5.4$ ). I therefore checked every utterance individually by considering the context in which these pronouns appeared. I excluded forms where the antecedent remained unclear.

A shortcoming of this method is that it does not allow for a comparison across pronouns, since the numbers do not say anything about their overall frequency in the Duisburg corpus. Nevertheless, the findings provide clearer insights into the behavior of these pronominal forms with regard to their position before and after the finite verb and complementizer, in addition to the available literature. Table 22 depicts the distribution of the 3SG.SBJ.M forms er and der in the Duisburg corpus.

\footnotetext{
${ }^{9}$ Historically, demonstratives are often regarded to be the ancestors of definite articles and personal pronouns (Audring 2009: 105).
} 


\begin{tabular}{|l|l|l|l|l|l|l|}
\hline 3SG.M & der & $\mathbf{\%}$ & er & $\mathbf{\%}$ & Total & $\mathbf{\%}$ \\
\hline S-V & 63 & 35 & 18 & 10 & 81 & 45 \\
\hline V-S & 28 & 15.6 & 71 & 39.4 & 99 & 55 \\
\hline Total MC & 91 & 50.6 & 89 & 49.4 & 180 & 100 \\
\hline Total COM-S & 9 & 45 & 11 & 55 & 20 & 100 \\
\hline
\end{tabular}

Table 22: Third-person singular masculine forms + human according to their position in the Duisburg corpus

Table 22 demonstrates that the form der occurs in the position before and after the finite verb and complementizer, and it is produced most frequently in preverbal position $(n=63$ or 35\%). This distribution resembles the one in the Cité Duits corpus (Table 21) insofar as der is produced in both corpora twice as often after the finite verb as before it. Similarly, the position after the complementizer, occurring in 20 tokens, is the least common position, which corresponds to the findings for Cité Duits.

Regarding the form $e r$, it can be observed that it is most common in postverbal position ( $\mathrm{n}=71$ or $39.4 \%$ ), again in line with Cité Duits. In preverbal position, however, the Duisburg speakers seem to produce er considerably more often $(10 \%)$ than the speakers from Eisden ( $0.9 \%$ ). Thus, although both corpora have in common that the form $e r$ is particularly infrequent in preverbal position, there is evidence that Cité Duits differs slightly from informal spoken Duisburg-German. While Cité Duits only uses der before the finite verb, German has both der and er before the finite verb. Unlike in DuisburgGerman, er seems to be an enclitic pronoun in Cité Duits. Because discourse-related factors may well be involved, these numbers offer a rough indication at best.

\subsubsection{Third-person Singular Feminine + Human}

For the third-person singular feminine + human pronoun, speakers mainly use die [di:] and less often ze/se [zo]. Both forms can be associated with all three contact varieties (see $\S 5.4 .4) .{ }^{10}$ The distribution of both variants is given in Table 23. In addition, speakers use a number of less-frequent forms, discussed below.

\footnotetext{
${ }^{10}$ As pointed out $(\S 5.3)$, die partly has different functions in the contact varieties. In Dutch, die is a demonstrative (and relative pronoun) for all third persons, whereas in German/Maaslands, it is restricted to third person plural and singular feminine forms (cf. Broekhuis \& den Dikken 2012b: 773-74).
} 


\begin{tabular}{|l|l|l|l|l|l|l|}
\hline 3SG.F & {$[\mathbf{z}] \mathbf{n}$} & $\mathbf{\%}$ & {$[\mathbf{d i}:] \mathbf{n}$} & $\mathbf{\%}$ & Total & \% \\
\hline S-V & 0 & 0 & 91 & 66.4 & 91 & 66.4 \\
\hline V-S & 27 & 19.7 & 19 & 13.9 & 46 & 33.6 \\
\hline Total MC & 27 & 19.7 & 110 & 80.3 & 137 & 100 \\
\hline Total COM-S & 2 & 22.2 & 7 & 77.8 & 9 & 100 \\
\hline
\end{tabular}

Table 23: Third-person singular feminine forms + human according to their position in Cité Duits

From Table 23, it can be observed that the form die [di:] accounts for all tokens before the finite verb $(\mathrm{n}=91,66.4 \%)$, whereas $s e$ [zo] is confined to the position after the finite verb $(n=27,19.7 \%)$ and complementizer $(n=2)$. This distribution suggests that the latter functions as an enclitic pronoun, in line with German. In Belgian Dutch and Maaslands, the weak form $z e$ [zo] can appear in pre- and postverbal position, which means that the position of this form is more predictable in Cité Duits than in Belgian Dutch and Maaslands. In turn, die appears in all of the three positions in Table 23, with a clear preference toward the preverbal position. The use of both variants is exemplified in (9) and (10).

(9) (0313_155010: 258.104 - 264.615, Yanis)

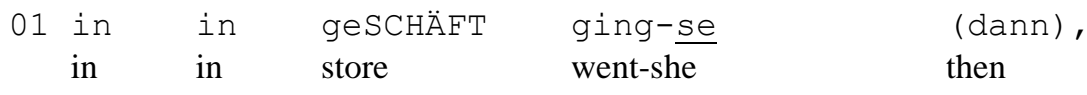

'She went to the store then.'

(10)(171115_5: 1782.91 - 1785.104, Olaf)

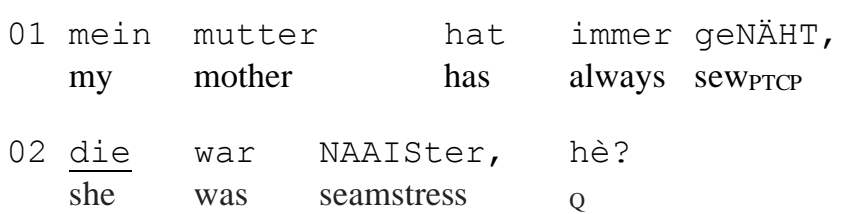

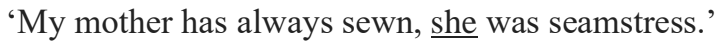

In (9), the pronoun (se) appears as an enclitic attached to the finite verb ging 'went', whereas in (10), the pronoun (die) precedes the finite verb (war 'was'). Usually, se is adapted to the pronunciation of the preceding sound and the [s] is produced voiceless, 
which means that Cité Duits behaves in line with German and Dutch (for (de)voicing in German and Dutch, see Grijzenhout 2000; Grijzenhout \& Krämer 1998). ${ }^{11}$

\section{'Masculine' Pronouns for Female Human Antecedents}

Strikingly, speakers also use the forms $d e(r)$ and $e(r)$ for women, i.e., forms typically used for masculine antecedents. Although their overall frequency remains low $(n=11)$, the question arises of how these examples can be explained.

Variation between feminine and 'non-feminine' pronouns, however, is not specific to Cité Duits, but has been reported for a number of Dutch dialects, including Limburgish (Bakker 1992; Weijnen 2003 [1966]: 299; Piepers \& Redl 2018; de Vogelaer 2007: 200-01). Bakker (1992) describes the use of the neuter gender forms det/(he)t for female individuals in the dialect spoken in Venlo in Dutch-Limburg, and Piepers and Redl (2018) show that the possessive pronoun zien 'his/its' can refer to women in certain Limburgish varieties. While it seems that neuter gender for female individuals is widespread in Limburg, Wijnen (2003 [1966]: 299) and de Vogelaer (2007: 200-01) also observe the (sporadic) use of typically masculine pronouns for females. To be precise, de Vogelaer attested the personal pronouns $e r$ and $e$ for women in the Belgian and Dutch provinces of Limburg (as well as in Gelderland and Overijssel). Similar to Cité Duits, it appears that dialect speakers use these forms rather occasionally. ${ }^{12}$ This suggests that we observe influence of the local dialect in Cité Duits.

Furthermore, it may be the case that these examples show semantic instead of syntactic agreement (Audring 2009; De Vogelaer \& Klom 2017), whereby the syntactic distance between the pronoun and the antecedent can play a role, an idea that goes back to Corbett (1979). According to Corbett's agreement hierarchy illustrated below, it is assumed that the more syntactic distance increases, the likelihood of semantic agreement increases as well. The further left an element is situated in the hierarchy, the more likely syntactic agreement is to occur, and the further right an element is situated, the more likely semantic agreement is to occur. ${ }^{13}$

\section{Agreement Hierarchy}

Attributive> Predicate> Relative Pronoun> Personal Pronoun (Corbett 1979: 204)

\footnotetext{
${ }^{11}$ Dutch generally displays devoicing of syllable-final obstruents (cf. van Oostendorp 2006: 58-65). Stem-final obstruents, however, have been shown to retain the underlying specification for voicing in Dutch, which means that the clitic 'se is produced voiceless (Grijzenhout 2000: 6-7).

12 Neuter gender assignment is also found in Moselle-Franconian, Swiss German and Lower Alemannic. Nübling (2015) found that pragmatic factors related to kinship and social distance determine whether speakers assign feminine or neuter gender to female first names (on personal pronouns and determiners). While neuter usually denotes young females, female family members, and female friends, feminine gender is used for women of a higher social status.

${ }^{13}$ Corbett (1979: 204) uses the term 'agreement' in the broadest sense 'to cover any instance where the form of one syntactic element is modified so as to match properties of another.' Word order also affects agreement but is predicted to behave according to the hierarchy.
} 
Accordingly, personal pronouns are assumed to have a higher chance of exhibiting semantic agreement than other pronouns. Distance effects have also been found within third-person pronouns in Dutch, where syntactic agreement decreases with a greater distance between the pronoun and the preceding noun (Audring 2009: 165-68; 217). In this light, a greater distance between the antecedent and the referring pronoun may correlate with the use of der/er for human female referents in Cité Duits. To see whether a large syntactic distance favors the use of der/er for feminine human referents, a followup analysis measuring the word distance would be revealing. Yet, it appears that the syntactic distance varies considerably. Based on the number of fully articulated words between the pronoun and the female referent, I found that the syntactic distance ranged from two up to 13 words. While these observations suggest that syntactic distance does not correlate with semantic agreement, the number of attested tokens is too small to be representative $(n=11)$. To establish whether syntactic distance has an effect on the use of these pronominal forms, more empirical evidence is needed.

\subsubsection{Third-person Singular 'it'}

\section{The Duisburg Corpus}

In the previous chapter ( $\$ 5.4 .6)$, I have shown that 'it' and 'that' correspond to the form $d a t$ [dat] in Cité Duits, which implies that speakers neither use $(e) s /(h e) t$ 'it' nor das 'that' with a final fricative. This section examines the frequency distribution of dat, das and det 'that' as well as of 's and es 'it' in the Duisburg corpus (see $\S 6.2 .3$ ). Not only Belgian Dutch and Maaslands, but also German dialects of the Rhineland make use of dat with a final stop (Schiering 2002: 173; Barbour \& Stevenson 1990; Salewski 1998: 27). A frequent use of dat can also be found in the Duisburg corpus (Table 24).

\begin{tabular}{|l|l|l|l|l|l|l|}
\hline 3SG.N & dat [das] & das [das] & es [Es] & 's [s] & det [dət] & Total \\
\hline $\mathbf{n}$ & 739 & 378 & 82 & 45 & 28 & 1272 \\
\hline$\%$ & 58.1 & 29.7 & 6.5 & 3.5 & 2.2 & 100 \\
\hline
\end{tabular}

Table 24: Distribution of third-person singular forms 'it' and 'that' in the Duisburg miners' corpus

Table 24 demonstrates that the form dat 'that,' used in 58 percent of the tokens, is much more frequent than das with a final fricative, which occurs in roughly 30 percent. Furthermore, about two percent are realized as det, while es 'it' and the reduced form 's account together for ten percent. The Duisburg speakers, unlike the Cité Duits speakers, 
thus use a number of phonological variants for the demonstrative form (das, dat, det). ${ }^{14} \mathrm{In}$ addition, they use the form es/'s 'it' as a third-person pronoun. These forms occur in different positions. That is, es 'it' is realized in the position before and after the finite verb and complementizer. ${ }^{15}$ While the latter has a low frequency, at ten percent ( $e s=6.5 \%$ and 's $=3.5 \%)$, it is more common than in Cité Duits, where this form is almost absent (1\%).

\subsubsection{First-person Plural}

Having five frequent variants, the first-person plural pronoun exhibits quite some variation in the data ( $\$ 5.4 .7)$. Table 25 provides the distribution according to their position. The respective percentages appear below the actual numbers.

\begin{tabular}{|c|c|c|c|c|c|c|}
\hline 1PL & [vi:] & [vi:e] & [wə] & {$[\mathbf{m r}]$} & [ve] & Total \\
\hline S-V & 65 & 154 & 30 & 0 & 0 & 249 \\
\hline$\%$ & 12.4 & 29.3 & 5.7 & 0 & 0 & 47.4 \\
\hline V-S & 15 & 34 & 41 & 149 & 37 & 276 \\
\hline$\%$ & 2.9 & 6.5 & 7.8 & 28.4 & 7 & 52.6 \\
\hline Total MC & 80 & 188 & 71 & 149 & 37 & 525 \\
\hline$\%$ & 15.3 & 35.8 & 13.5 & 28.4 & 7 & 100 \\
\hline $\begin{array}{l}\text { Total } \\
\text { COMP-S }\end{array}$ & 1 & 15 & 10 & 0 & 1 & 27 \\
\hline$\%$ & 3.7 & 55.6 & 37 & 0 & 3.7 & 100 \\
\hline
\end{tabular}

Table 25: First-person plural forms according to their position in Cité Duits in total numbers

As Table 25 reveals, all five variants may occur after the finite verb, but only three variants appear before the finite verb, namely wie [vi:] (12.4\%), wir [vi:en] (29.3\%), and we [wo] (5.7\%). Crucially, wir [vi:p] and wie [vi:] occur more than four times as often before the finite verb than after it, which means that both variants have a preference for preverbal

${ }^{14}$ It may be the case that the variation between dat, das, and det is related to speaker-individual differences, an aspect I have not investigated for the Duisburg corpus. Also, influence of the fieldworker on the speech of these miners can play a role here. It is worth noting that this corpus consists of informal interviews, which means that the fieldworker intervened regularly, unlike in the recordings of Cité Duits.

${ }^{15}$ Examples for preverbal position from the Duisburg corpus are und tatsächlich es ging dann ab du 'And really, it came off.' (du_05: 2142.74486 - 2144.83762); es wurde mir versprochen... 'it was promised to me...' (du_07: 399.52027 - 401.09431). For the different functions of $e s$ 'it' in German, see $\S$ 5.4.6. 
position. The form we [wə] has not such a clear distribution with regard to its position, being produced 41 times after the finite verb $(7.8 \%)$ and 30 times before it $(5.7 \%)$. In contrast, $m a[\mathrm{me}](28.4 \%)$ and $w a$ [ve] (7\%) are clearly confined to postverbal position, as exemplified in (11) and (12). The number of tokens in the position after the complementizer is again low for all variants $(\mathrm{n}=27)$, whereby the form wir is most frequent $(\mathrm{n}=15)$.

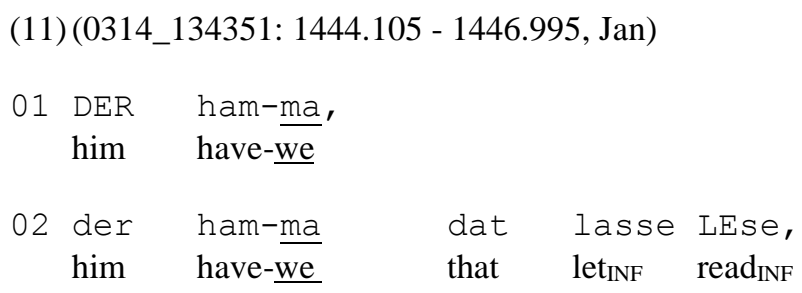

'We had him, we had him read that.'

(12) (231115_5: 1469.366-1471.797, Victor)

01 dann ham-wa gebaut

then have-we builtpTCP

02 un ich ging WOHne(n),

and I went live $\mathrm{INF}$

'Then we built [a house] and I started living [there].'

Both $m a$ and $w a$ correspond to the position in spoken German ( $\$ 5.3)$, where these forms are enclitics. Also, studies on Ruhr-German (Schiering 2002: 20) mention the use of these two variants, in particular in combination with the finite verb 'to have.' In the Duisburg miners' corpus, I attested similar examples, illustrated in (13) below.

(13) (Du05: 2516.1146 - 2517.73791) (Duisburg-corpus)

01 un(d) hier auf_m pütt ham-wa da BLAU gemacht. and here on-the mine have-we there blue make

'And here in the mine, we skipped a day.'

Utterance (13) from the Duisburg corpus resembles (11) and (12) in Cité Duits insofar as the 1PL.SBJ form wa appears as enclitic attached to the finite verb ham 'have.' In the Duisburg corpus, I attested the 1PL.SBJ enclitic form $w a$ in 23 utterances (3\%) and $m a$ in 
11 utterances (1.4\%), whereas the full form wir occurs 730 times $(95.5 \%) .{ }^{16}$ These numbers suggest that both $w a$ and $m a$ have an extremely low frequency $(<3 \%)$ in the speech of the Duisburg miners. In the Cité Duits corpus, in turn, the form ma makes up more than one-fourth of all 1PL.SBJ tokens $(28 \%)$. While the numbers attested in the Duisburg corpus need to be regarded with some caution, ${ }^{17}$ it seems that $m a$ is more frequent in Cité Duits than in informal spoken Duisburg German. In addition, closer analysis of the Cité Duits corpus reveals that ma may co-occur with a full 1PL.SBJ pronoun (for a more detailed discussion of this form, see $\S 6.4$ ).

\subsubsection{Second-person Plural}

\section{An Object Pronoun in Subject Position}

Only six tokens have been attested for the second-person plural subject pronoun (§ 5.4.8), all of them realized as euch [?적], in line with the second-person plural object form in German. Accordingly, a pronoun with object function serves as a subject pronoun in Cité Duits. This seems striking, considering that euch [?oIç] does not show any resemble with the available subject pronouns in the contact varieties, which have the forms ihr [?i:e] /' $a$

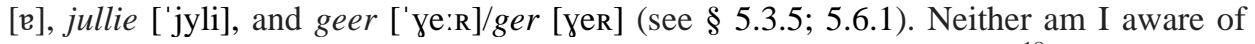
German dialects that use the pronominal form euch as 2PL.SBJ pronoun. ${ }^{18}$

Yet, such processes are no exception in varieties of Dutch. From a historical perspective, it can be observed that Maaslands as well as a number of other Limburgish dialects used to have doe/du 'you' as subject form, which was later replaced by the object form dich 'you' (Stevens 1949/1985: 6). While the latter form gained ground, the former disappeared (see also § 5.3.3). Moreover, a somehow similar evolution is currently observed in varieties of Dutch (Audring 2018; Broekhuis \& den Dikken 2012b: 783; de Vos 2013: 181; de Vogelaer 2007: 209-11). In colloquial Belgian Dutch, the third-person singular masculine object form hem 'him' seems to be spreading toward the subject position ( $h i j>$ hem 'he'). In a similar vein, in Netherlandic Dutch, the pronoun hun 'them' is developing more and more into an 'omnipurpose' pronoun for the third-person plural $z e$ (ze > hun 'they') (Broekhuis \& den Dikken 2012b: 783). Finally, it is worth pointing out again that the Dutch second-person plural form jullie is both a subject and object pronoun (see $\S 5.3$ ).

\footnotetext{
${ }^{16}$ Furthermore, $m a(l)$ occurs as a reduced lexical item in the Duisburg corpus and broadly translates as 'one time,' e.g., in imperatives such as guck ma 'look,' geh ma 'go,' tu ma 'do.' Such uses are typical of informal standard German. I did not find any instances of wie or we as 1PL.SBJ pronoun. ${ }^{17}$ Given that the Duisburg corpus was not set up for the analysis of personal pronouns, it is possible that not all reduced forms were fully transcribed, which would mean that the numbers are actually higher.

18 Maitz et al. (forthcoming) report a similar use (i.e. eu) for Unserdeutsch or 'Rabaul Creole German,' a moribund contact variety that emerged among children in German boarding schools in Papua New Guinea (see also Maitz 2017).
} 
Accordingly, the 2PL.SBJ form euch in Cité Duits phonologically resembles German, but can be associated with varieties of Dutch from a syntactic perspective. Interestingly, while the respective object and subject forms currently exist side-by-side in varieties of Dutch (i.e. speakers use both ze and hun for the 3PL.SBJ), it appears that this use is no longer optional in Cité Duits, and that euch [?วIç] has become the only possible option.

\subsubsection{Third-person Plural}

Table 26 outlines the distribution of the third-person plural variants $z e / s e$ [zə] and die [di:]. In addition, roughly four percent $(\mathrm{n}=26)$ of the respective tokens are realized as sie [zi:] (see $\S 5.4 .9)$. The latter occur exclusively after the finite verb $(n=24)$ and complementizer $(n=2)$, which suggests that sie is an enclitic form. Due to their low relative frequency, the realizations of sie [zi:] are not included in the table below.

\begin{tabular}{|l|l|l|l|l|l|l|}
\hline 3PL & {$[\mathbf{z o}]$} & $\mathbf{\%}$ & {$[\mathbf{d i}:]$} & $\mathbf{\%}$ & Total & $\mathbf{\%}$ \\
\hline S-V & 0 & 0 & 289 & 54.3 & 289 & 54.3 \\
\hline V-S & 154 & 28.9 & 89 & 16.7 & 243 & 45.7 \\
\hline Total MC & 154 & 28.9 & 378 & 71.1 & 532 & 100 \\
\hline Total COMP-S & 14 & 35.9 & 25 & 64.1 & 39 & 100 \\
\hline
\end{tabular}

Table 26: Third-person plural subject forms according to their position in Cité Duits

From Table 26, it can be observed that $s e$ [zo] is confined to the position after the finite verb $(n=154$ or $28.9 \%)$ and the complementizer $(n=14)$, whereas the more frequently used form die [di:] shows a strong tendency toward the position before the finite verb $(n=289$ or $54.3 \%)$. The use of both forms is exemplified below (14)(15).

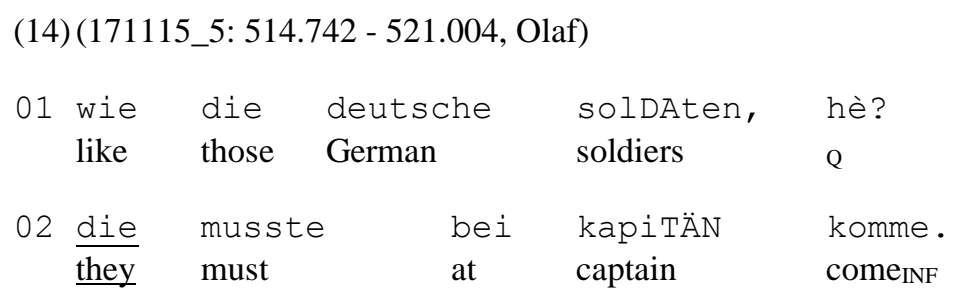

'Like the German soldiers. They had to go and see the captain.'

(15) (231115_4: 1577.356 - 1583.08, Ralf)

01 da gehn-se überall KRANK. 
there go-they everywhere ill

'They always become sick there.'

The distribution of se and die corresponds roughly to their distribution for the 3SG.SBJ.F pronoun ( $\$ 6.2 .4$ above). It seems that ze behaves as an enclitic pronoun in Cité Duits this holds for both singular and plural forms - whereas die appears in all positions. This means that sie and se exhibit the same behavior with regard to their position. In the final section ( $\$ 6.5 .1)$, I will assess whether inter-speaker variation plays a role in the realization of sie.

\subsubsection{Summary}

As my analysis of subject pronouns revealed, much of the earlier attested variation (see $\S$ 5.4) can be explained by the position of the pronoun in relation to the finite verb in nontopicalized position, as well as in relation to the position of the complementizer. A number of forms are largely confined to the position after the finite verb and complementizer, namely 2SG te, 3SG.M er, 3SG.F se, 1PL ma, 1PL wa, and 3PL se. Except for er, these forms correspond to the respective reduced (enclitic) pronouns in (Ruhr-)German, whereby te similarly matches the Maaslands and se the Maaslands and Belgian Dutch weak form. These findings strongly suggest that most of the reduced pronominal forms are enclitics and must attach to another element, such as a finite verb or complementizer.

For the $1 \mathrm{SG}$, I demonstrated that Cité Duits uses a single form for all positions, i.e. ich [Iç]. From a phonological perspective, this form can be described as a BelgianDutch-Maaslands-German intermediate form. Furthermore, it resembles these varieties in displaying little variation with regard to the position before and after the finite verb. For the 2SG, in turn, Cité Duits has two variants. While $d u$ is the most frequent form and occurs in all positions, te seems an enclitic confined to postverbal position, therefore corresponding to German and Maaslands.

For third-person pronouns, Cité Duits frequently uses demonstrative forms - i.e. de(r) (3SG.M), dat (3SG.N) and die (3SG.F, 3PL) - which appear in all positions, whereas the 3SG.M form er and the 3SG.F/3PL form se are largely confined to postverbal position. This is insofar interesting as $e r$ is a full pronoun in German that may occur in preverbal position. Similarly, se may occur in preverbal position in Belgian Dutch and Maaslands (ze), whereas it occurs exclusively in the position after the finite verb and complementizer in Cité Duits, in line with German. The comparison with the Duisburg corpus for the 3SG.M and 3SG.N suggests that the German-speaking miners use similar forms as the speakers of Cité Duits, but with slightly different distributions. While the Duisburg speakers usually vary between demonstrative, full, and reduced forms for third-person pronouns, Cité Duits uses the respective demonstrative form as a general third-person form. 
Unlike other pronouns, the 1PL displays quite some variation: While $w a$ and $m a$ exclusively appear after the finite verb, therefore resembling (Ruhr-)German, Cité Duits has three 'full' forms (wie, wir, we). That is, variation can only be justified to some extent by the position of the pronominal form. In turn, the $2 \mathrm{PL}$ form is always realized as euch. The use of euch as subject pronoun, which corresponds phonetically to the respective German object pronoun, has been argued to go back to similar developments in Dutch.

\subsection{Object Pronouns}

Most object pronouns in Cité Duits phonologically resemble German, and to some degree Maaslands (see $\S 5.5$ ). Yet, while German distinguishes between accusative (direct) and dative (indirect) object pronouns, Cité Duits often uses a single form (but note that German has a common dative-accusative form for the 1PL.OBJ and 2PL.OBJ, see § 5.3.4). In this section, I will show that Cité Duits does not distinguish case on object pronouns. Furthermore, Cité Duits has hardly any reduced object forms, in contrast to subject pronouns. Table 27 briefly reviews the findings from the frequency analysis of the previous chapter $(\$ 5.5)$. As this table shows, the large number of object pronouns exhibits little or no variation, which means that a follow-up analysis is not justified for all pronouns. There is significantly less variation in object than in subject pronouns. ${ }^{19}$

\begin{tabular}{|c|c|c|c|c|c|c|}
\hline & & $\begin{array}{l}\text { Most } \\
\text { frequent } \\
\text { variants }\end{array}$ & $\%$ & $\begin{array}{l}\text { Less- } \\
\text { frequent } \\
\text { variants }\end{array}$ & $\%$ & Variation \\
\hline \multirow[t]{4}{*}{ SG } & 1 & [mıç] & 92 & [mi:e] & 6 & Few \\
\hline & 2 & [diç] & 96 & [di:en] & 4 & Few \\
\hline & $3 \mathrm{M}$ & [i:m] & 67 & $\begin{array}{l}{[\mathrm{de}:]} \\
{[\mathrm{i}: \mathrm{n}]}\end{array}$ & $\begin{array}{c}17 \\
9\end{array}$ & Yes \\
\hline & $3 F$ & [di:] & 100 & - & 0 & No \\
\hline \multirow[t]{3}{*}{ PL } & 1 & [ons] & 100 & - & 0 & No \\
\hline & 2 & [?oIç] & 100 & - & 0 & No \\
\hline & 3 & [di:] & 56 & [zə] & 44 & Yes \\
\hline
\end{tabular}

Table 27: Frequency of object pronouns in percentages in Cité Duits as attested in $§ 5.5$

Principally, only the 3SG.OBJ.M and the 3PL.OBJ pronoun have more than one frequent variant. There is no variation in the 3SG.OBJ.F nor in the 1PL.OBJ and 2PL.OBJ, and

${ }^{19}$ I ignore individual tokens, which explains why not all numbers reach 100 percent. Furthermore, I leave the 3 SG.OBJ with a non-human antecedent aside. The low number of tokens $(n=10$, see $\S$ 5.5) does not justify a follow-up analysis. 
there is little variation in the 1SG.OBJ and 2SG.OBJ $(<6 \%)$. In the following, I will deal with those pronouns that exhibit variation, with a focus on case distinctions. As suggested by the table above, it was possible to identify reduced forms only for the 3PL.OBJ.

\subsubsection{First-person Singular}

Speakers mainly use mich [miç] and rarely use mir [mi:e्]] for the 1SG.OBJ, phonologically resembling German and to a lesser degree Maaslands (which uses mi:ch [mi:ç]). Yet, are these forms also used according to German grammar, i.e. as accusative and dative objects?

Table 28 illustrates the distribution of mich and mir in the position of the accusative (ACC) and dative object (DAT), based on German grammar. Most forms appear either after a preposition or after a finite verb. ${ }^{20}$ 'Not assignable' (NA) refers to utterances for which case cannot be assigned, usually because the finite verb is absent from the utterance.

\begin{tabular}{|l|l|l|l|l|l|l|l|l|}
\hline 1SG.OBJ & ACC & \% & DAT & \% & NA & \% & Total-n & \% \\
\hline [mi:: $]$ & 1 & 0.8 & 5 & 3.9 & 2 & 1.6 & 8 & 6.3 \\
\hline [miç] & 48 & 37.8 & 64 & 50.4 & 7 & 5.5 & 119 & 93.7 \\
\hline Total & 49 & 38.6 & 69 & 54.3 & 9 & 7.1 & 127 & 100 \\
\hline
\end{tabular}

Table 28: First-person singular object forms in Cité Duits according to standard German ${ }^{21}$

Table 28 illustrates that mich has a high frequency both in the position of the accusative (37.8\% or $n=48$ ) and dative pronoun (50.4 or $n=64$ ), which suggests that Cité Duits, unlike German but in line with Maaslands, does not distinguish case, as exemplified in (16).

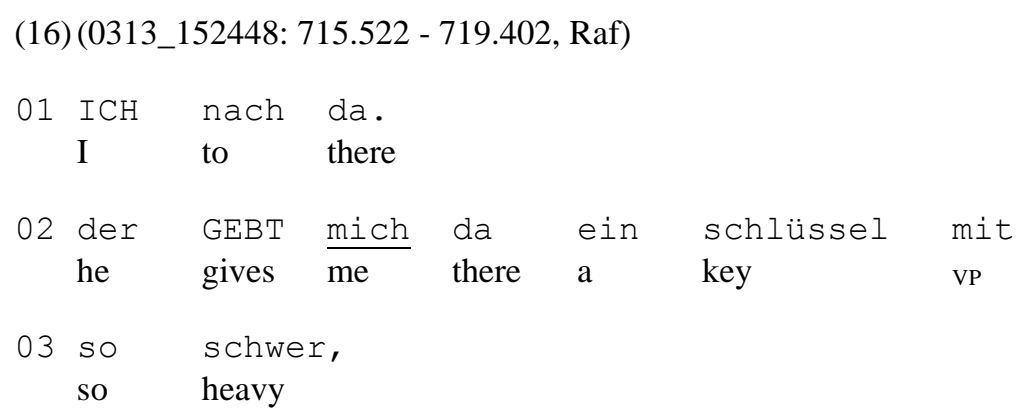

\footnotetext{
${ }^{20}$ Since prepositions in German can assign both accusative and dative case, depending on the preposition, I do not distinguish between prepositional objects and those without a preposition.

${ }^{21}$ I do not consider realizations that I attested solely once or twice in $\S 5.5$.
} 
'I go over there. He gives me a key that heavy.'

In (16) above, the speaker realizes the form mich, whereas mir is expected from the perspective of German grammar. Regarding mir, this form is extremely rare in the data. Five tokens (3.9\%) occur in the position of the dative object, exemplified in (13), thereby following German grammar, and one example in the position of the accusative object (0.8\%). Like mich, mir appears both after prepositions and finite verbs.

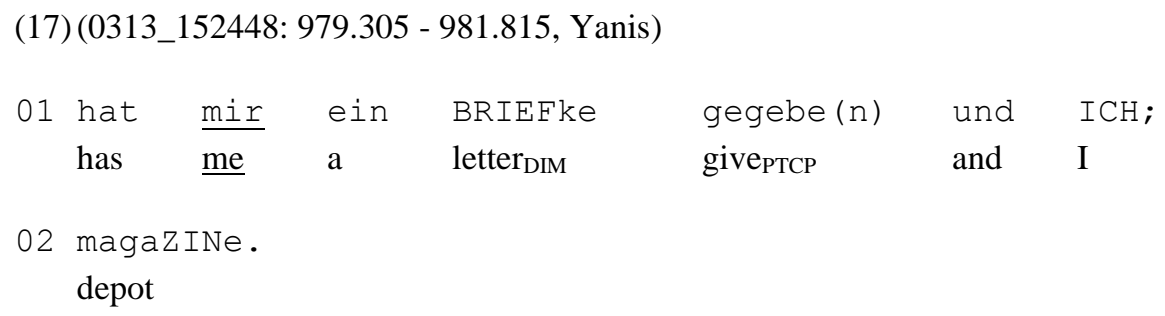

'He gave me a small letter and I went to the depot.'

Considering the low number of mir-tokens and the fact that mich functions both as accusative and dative pronoun in the data, it can be concluded that case is not distinguished on the 1SG.OBJ pronoun. Whether the realizations of mir stem from a particular speaker will be discussed below (see $\S 6.5 .1$ ). Finally, there is no evidence that different full and reduced forms are used. In this regard, Cité Duits resembles German but differs from Belgian Dutch/Maaslands.

\subsubsection{Second-person Singular}

There is hardly any variation in the $2 \mathrm{SG} . \mathrm{OBJ}$ pronoun, which is generally realized as dich [diç] $(95.5 \%$ or $\mathrm{n}=63)$ and seldom as $\operatorname{dir}$ [di:e $]$ ( $4.5 \%$ or $\mathrm{n}=3)$ (see $§ 5.5 .2)$.

\begin{tabular}{|l|l|l|l|l|l|l|l|l|}
\hline 2SG.OBJ & ACC & $\mathbf{\%}$ & DAT & $\mathbf{\%}$ & NA & $\mathbf{\%}$ & Total & $\mathbf{\%}$ \\
\hline [di: : $]$ & 0 & 0 & 3 & 4.5 & 0 & 0 & 3 & 4.5 \\
\hline [dıç] & 32 & 48.5 & 26 & 39.4 & 5 & 7.6 & 63 & 95.5 \\
\hline Total & 32 & 48.5 & 29 & 43.9 & 5 & 7.6 & 66 & 100 \\
\hline
\end{tabular}

Table 29: Second-person singular object forms in Cité Duits according to standard German

Table 29 indicates that the 2SG.OBJ form dich is used both as accusative ( $48.5 \%$ or $n=32)$ and dative object (39.4\% or $\mathrm{n}=26$ ), which suggests that case is not distinguished (18). 


$$
\begin{aligned}
& \text { (18) (231115_4: } 979.733 \text { - 981.023, Yanis) } \\
& \begin{array}{cll}
01 \text { ich WERD } & \text { dich } & \text { verzählen. } \\
\text { I } & \text { will you tell }
\end{array}
\end{aligned}
$$

'I will tell you.'

In example (18), dich appears in the position of the dative object where German would require the form dir. In turn, the three tokens of dir occur in the position of the dative object and therefore correspond to German grammar, exemplified in (19).

$$
\begin{aligned}
& \text { (19) (231115_4: } 1341.018-1343.400 \text {, Jan) } \\
& \begin{array}{clll}
01 \text { ich hab dir } & \begin{array}{l}
\text { doch } \\
\text { I }
\end{array} \text { haverz̈̈HLT, } \\
\text { tell } & \text { you }
\end{array}
\end{aligned}
$$

'I have told you.'

In the data, dir occurs once after the finite verb as in (19), once after a preposition and once after a 1SG.SBJ pronoun. This observation indicates that dir does not occur in specific positions (e.g. after finite verbs). In the final section I will examine whether the few examples of dir can be explained by inter-speaker variation (§ 6.5.1). From the frequency distribution in Table 29, however, it is evident that dich is the common 2SG.OBJ pronoun, which strongly resembles Maaslands but differs from German. There is no indication that speakers use reduced forms. ${ }^{22}$

\subsubsection{Third-person Singular Masculine +Human}

There is more variation in the 3SG.OBJ.M + human. The most common form is ihm (ca. $67 \%$ ), corresponding to the full German dative form, followed by the demonstrative form $d e(r)(17 \%)$. Moreover, eight tokens are realized as ihn, phonologically in line with the German accusative form, and five tokens as ' $m$, corresponding to the reduced form in all three contact varieties (see $\S 5.5 .3$ ). Although there are few tokens of $i h n$ and ' $m$ in the data, these forms are worth considering since their relative frequency is over five percent.

\footnotetext{
${ }^{22}$ Another possible scenario is that utterances that would require the dative form are hardly produced
} by the speakers. In this case, all tokens of dich would appear in the position of the accusative object. 


\begin{tabular}{|l|l|l|l|l|l|l|l|l|}
\hline $\begin{array}{l}\text { 3SG. } \\
\text { OBJ.M }\end{array}$ & ACC & $\mathbf{\%}$ & $\mathbf{D A T}$ & $\mathbf{\%}$ & $\mathbf{N A}$ & $\boldsymbol{\%}$ & Total & $\mathbf{\%}$ \\
\hline$[\mathbf{i}$ ] $]$ & 8 & 9.3 & 0 & 0 & 0 & 0 & 8 & 9.3 \\
\hline$[\mathbf{i}: \mathbf{m}]$ & 23 & 26.7 & 32 & 37.2 & 3 & 3.5 & 58 & 67.4 \\
\hline [de: $]$ & 7 & 8.1 & 8 & 9.3 & 0 & 0 & 15 & 17.4 \\
\hline$[$ [əm] & 4 & 4.7 & 1 & 1.2 & 0 & 0 & 5 & 5.9 \\
\hline Total & 42 & 48.8 & 41 & 47.7 & 3 & 3.5 & 86 & 100 \\
\hline
\end{tabular}

Table 30: Third-person singular masculine object forms +human in Cité Duits according to standard German

As can be seen in Table 30, ihm functions both as accusative (27\% or $\mathrm{n}=23)$ and dative object (37\% or $\mathrm{n}=32$ ) in Cité Duits, exemplified in (20) in (21) below, and similar observations can be made for $d e(r)$. The form ' $m$ appears four times in accusative and once in dative position, and always in postverbal position, suggesting that it functions as enclitic pronoun. Yet, the number of attested tokens is too small here to make any claims. The form $i h n$, in turn, is always realized as accusative object in the data $(9 \%$ or $\mathrm{n}=8)$, in line with German. Although $d e(r)$ resembles the masculine demonstrative in German, it is not used according to standard German grammar, which would require den as accusative and dem as dative object form ((ACC) Ich habe den doch gerade gesehen 'I have just seen him'; (DAT) Ich habe dem schon den Brief gegeben 'I already gave him the letter.').

$$
\begin{aligned}
& \text { (20) (0314_134351: } 632.395 \text { - 634.705, Diego) }
\end{aligned}
$$

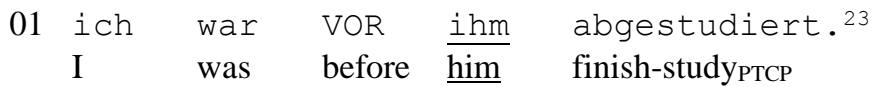

'I finished my studies before he did.'

$$
\begin{aligned}
& \text { (21) (231115_5: 350.596-351.877, Victor) } \\
& 01 \text { ich hab } \begin{array}{lll}
\text { ihm } & \begin{array}{l}
\text { noch } \\
\text { I }
\end{array} \text { heSEHN } & \begin{array}{l}
\text { ge } \\
\text { see }
\end{array}
\end{array}
\end{aligned}
$$

23 The participle abgestudiert 'to graduate from school/university' lexically resembles Dutch afgestudeerd, but the /g/ is pronounced according to German phonology with a stop. There is no one-to-one translation to German. 
'I still saw him.'

While the 3SG.OBJ.M pronoun ihm in utterance (20) corresponds to its use in German, this does not hold for (21) where the form ihn would be required in German. Given that the form for the first and second-person singular corresponds to the accusative pronoun in German, this use of the dative form is particularly striking. In turn, the fact that speakers use the demonstrative pronoun $d e(r)$ is broadly in line with the previous observations for subject pronouns.

\subsubsection{Third-person Plural}

For the 3PL.OBJ, the number of attested tokens $(\mathrm{n}=27)$ is limited. Speakers either use die $(=15)$ or $s e(n=12)(\S 5.5 .8)$. Similar to subject pronouns, the form se is confined to the position after the finite verb, suggesting that it functions as enclitic (reduced) form. All examples of die/se occur in the position of the direct object, exemplified in (22), therefore corresponding to German grammar.

$$
\begin{aligned}
& \text { (22)(171115_4: } 7.91 \text { - 10.01, Jan) } \\
& 01 \text { die FRAU hat die (.) nach, } \\
& \text { this woman has to } \\
& 02 \text { nach STAsie }{ }^{24} \text { gebracht - } \\
& \text { to station bring }
\end{aligned}
$$

'This woman brought them to the station.'

In German, the demonstrative die may replace plural forms in object position but underlies restrictions to case: it may replace the accusative (sie), but not the dative object pronoun with the feature + human (ihnen) (see § 5.3). ${ }^{25}$ The corpus, however, did not include such examples. While the data suggest that case is not distinguished, the examples found do not justify any substantial conclusions here.

\subsubsection{Summary}

Object pronouns generally display less variation than subject pronouns, but are also lesswell represented in the data, implying that there is not always enough empirical evidence available (see § 5.5). Except for the 3PL.OBJ, a clear tendency toward full forms can be

${ }^{24}$ The term stasie derives from Limburgish for 'train station.'

${ }^{25}$ While Belgian Dutch has with hun-hen a similar distinction as German (see $§ 5.3$ ), hun and hen are mainly found in formal (written) language, whereas case distinctions are still productive in spoken German. 
observed, whereas reduced forms are seldom in the paradigm of object pronouns. Unlike German, Cité Duits does not distinguish between accusative and dative object pronouns but usually has a single form. This use resembles the Maaslands dialect. For the first and second-person singular, the respective form resembles phonetically the German accusative and partly the Maaslands (full and weak) form, whereas for the third-person singular masculine, the most frequent form corresponds to the German dative pronoun. The neutralization toward the dative form is remarkable, because forms corresponding to the dative are generally absent from the paradigm.

For the 1PL.OBJ and 2PL.OBJ, Cité Duits uses in all attested tokens a form that corresponds to the joint German dative-accusative form, i.e. there is no variation in the data. For third-person pronouns, demonstratives are quite common (die/de(r)). The 3PL.OBJ is the only object pronoun which has a full (die) and a reduced (enclitic) form $(s e)$. Finally, the variants mir [mi:e], dir [di:en], and ihn [i:n] are often used in line with German grammar. Yet, these have an extremely low frequency.

\subsection{The Form ma: Pronominal Clitic or Verbal Agreement Marker?}

In this section, I will dive deeper into the data analysis by discussing one particular form more in-depth, namely the 1PL.SBJ form $\mathrm{ma}$. This form displays an interesting behavior in occurring in different constellations in the data.

\subsection{1 ma in Cité Duits}

While I have shown that $m a$ exhibits a regular behavior in being confined to the position after the finite verb and complementizer $(\S 6.2 .6$ ), closer analysis suggests that $m a$ frequently co-occurs with a full 1PL.SBJ form, leading to the order 1PL.SBJ-V $\mathrm{FIN}_{\text {FN }} \mathrm{MA}$. This does not hold for $w a{ }^{26}$ Typically, the full form (e.g. wie) appears in preverbal position and $m a$ in postverbal position (23).

$$
\begin{aligned}
& \text { (23) (0313_152448: } 1520.52 \text { - 1521.737, Yanis) } \\
& 01 \frac{\text { wie }}{\text { 1PL.SBJ ham-ma }} \begin{array}{llll}
\text { van } & \text { from the plastieke } & \text { HOse }(\mathrm{n}) & - \\
\text { trousers }
\end{array}
\end{aligned}
$$

'We have plastic pants.'

At first sight, $m a$ seems to be the second element of a pronominal doubling construction consisting of a full pronoun and a clitic. Yet, another possible interpretation is that $m a$ forms part of agreement morphology of the finite verb ham 'have.' This raises the question

${ }^{26}$ From this, it could be concluded that $m a$ and $w a$ differ functionally while exhibiting the same behavior of an enclitic pronoun at first sight. Yet, it may also be the case that the smaller number of tokens for wa explains why this form is not found in doubling constructions. 
of whether $m a$ shall be analyzed as verbal agreement marker (affix) or as pronominal enclitic. Because both appear as morphemes attached to free words to the right of a verbal element, the distinction is not always straight forward. Agreement markers appear like clitics in fixed positions, but do not exhibit any variation (Zwicky \& Pullum 1983: 502; further Zwicky 1994; Zwicky 1977; Abraham \& Wiegel 1993: 3; van Riemsdijk 1999; Halpern 1995; Fuß 2005).

For V2 languages (see $\S 4.4$ ), it has been argued that verbal agreement markers may develop out of clitic doubling, with the verb-second syntax favoring the reanalysis of an enclitic as agreement morpheme in inversion constructions. ${ }^{27}$ For instance, a full pronoun may be employed to reinforce the prosodically weak clitic form. Once the doubling construction receives a wider distribution and becomes obligatory in all contexts, the original clitic may serve as agreement marker (Fuß 2005: 132-48). '[O]ptional doubling signals that the clitic is still a pronominal element, while obligatory doubling indicates that the clitic probably has been reanalyzed as an agreement marker' (Fuß 2005: 132-33). Accordingly, if a full 1PL.SBJ form optionally precedes the finite verb and $m a$ follows it, we may assume that example (23) is an instance of clitic doubling. If this is, however, the only option in the data, $m a$ has probably turned into an inflectional marker. Moreover, if $m a$ always occurred as enclitic and no full 1PL.SBJ pronoun preceded the finite verb - which is not the case, as suggested by (23) - ma could be analyzed as a pronoun. As depicted in utterance (24) and earlier in (11), Cité Duits, aside from using 'doubling constructions,' also uses constructions with $m a$ as only subject marker in the clause:

$$
\begin{aligned}
& \text { (24) (0314_134351: } 699.805 \text { - 702.905, Diego) } \\
& 01 \text { un peter SOK ham-ma gesacht. } \\
& \text { and Peter Sok have } \overline{A U X}_{\text {MA }} \text { sayPTCP }
\end{aligned}
$$

'And we have said 'Peter Sok.'

Crucially, if Cité Duits allows for leaving out the pronominal subject in the 1PL.SBJ, the form $m a$ in (24) could as well be an example of affixing with an empty pronominal position. Nevertheless, it has been shown that there are syntactic environments in which overt pronominal forms still remain optional, which means that it is not always clear whether a form still counts as clitic or has made its way into the category of agreement morphology. In Old High German, for example, it appears that the overt realization of a subject pronouns remains optional when a constituent other than the subject appears in

27 That is, the finite verb and the subject pronoun occur in adjacent position (as opposed to VO languages), e.g. (Dutch) Morgen komt Piet 'Tomorrow comes Piet.' Importantly, the V2 property is only one out of several possible scenarios that may trigger the reanalysis of pronouns as agreement markers. Clitics have also developed into markers of verbal agreement in non-V2-languages (Fuß 2005: 148-53). See further Siewierska (1999: 14) for a discussion of diachronic developments. 
preverbal position. This optional behavior does not necessarily extend to the entire paradigm, but is only found in particular pronouns (Siewierska 1999: 3). In order to establish how $m a$ is typically used in Cité Duits, Table 31 depicts the distribution of $m a$ in relation to other forms.

\begin{tabular}{|c|c|c|c|c|c|c|c|}
\hline & $\begin{array}{c}\text { wir } V_{\text {FIN }} \\
\text { ma }\end{array}$ & $\begin{array}{c}\text { wie } V_{\text {FIN }} \\
\text { ma }\end{array}$ & $\begin{array}{c}\text { we } V_{\text {FIN }} \\
\text { ma }\end{array}$ & $\mathbf{V}_{\text {FIN }}$ ma & $\begin{array}{c}\text { COMP } \\
\text { ma }\end{array}$ & $\begin{array}{c}\text { V.N }_{\text {Fin }} \text { ma } \\
\text { wie }\end{array}$ & Total \\
\hline $\mathbf{n}$ & 59 & 35 & 5 & 46 & 3 & 1 & 149 \\
\hline$\%$ & 39.6 & 23.5 & 3.4 & 30.9 & 2 & 0.7 & 100 \\
\hline
\end{tabular}

\section{Table 31: Distribution of $m a$ in Cité Duits}

Table 31 reveals that in 67 percent of the tokens, ma occurs with a full 1PL.SBJ pronoun (wir, wie or we), whereas roughly one-third of the examples displays $m a$ as single subject marker in the clause. With one exception (discussed below), $m a$ always occurs directly after the finite verb, and the respective full form directly before this verb. ${ }^{28}$ Furthermore, as depicted in Table 32, ma occurs with a limited number of verbs.

\begin{tabular}{|c|c|c|}
\hline$X(+\mathbf{m a})$ & $n$ & $\%$ \\
\hline haben 'to have' as perfect auxiliary & 77 & 51.7 \\
\hline haben 'to have' as main verb & 11 & 7.4 \\
\hline haben 'to have' not assignable ${ }^{29}$ & 10 & 6.7 \\
\hline Total 'to have' & 98 & 65.8 \\
\hline sein 'to be' as perfect auxiliary & 13 & 8.7 \\
\hline sein 'to be' as copula & 4 & 2.7 \\
\hline sein 'to be' in aspectual constructions ${ }^{30}$ & 6 & 4 \\
\hline sein 'to be' as main verb & 4 & 2.7 \\
\hline sein 'to be' not assignable & 4 & 2.7 \\
\hline Total 'to be' & 31 & 20.8 \\
\hline müssen 'must' as modal verb & 2 & 1.3 \\
\hline gehen 'to go' as aspectual verb & 4 & 2.7 \\
\hline gehen 'to go' as main verb & 5 & 3.4 \\
\hline kommen 'to come' as main verb & 2 & 1.3 \\
\hline sagen 'to say' as main verb & 2 & 1.3 \\
\hline stehen 'to stand' as main verb & 1 & 0.7 \\
\hline
\end{tabular}

\footnotetext{
${ }^{28}$ As illustrated in $\$$ 6.2.6, $m a$ always appears directly after the finite verb or complementizer, which means that the order Vin-1PL-MA does not occur.

29 'Not assignable' refers to unfinished utterances such as wie ham ma auch eh, ich hab - 'we have also, I have ...' (0313_151301: 52.485 - 53.205).

${ }^{30}$ For example, und wie warn ma drausse am warten, hè, 'and we were waiting outside' (see § 7).
} 


\begin{tabular}{|l|l|l|}
\hline wissen 'to know' as main verb & 1 & 0.7 \\
\hline Complementizer & 3 & 2 \\
\hline Total-n & $\mathbf{1 4 9}$ & $\mathbf{1 0 0}$ \\
\hline
\end{tabular}

Table 32: Types of elements preceding $m a$ in Cité Duits

As revealed by Table 32, in roughly 66 percent of the tokens, $m a$ follows the finite verb of 'to have' (ham), and most frequently attaches to the respective perfect auxiliary (52\%). Another 20 percent of the tokens occur after the finite verb of 'to be,' which occurs both in present tense ( $\sin / \operatorname{sim}, \mathrm{n}=21)$ and past tense (warn, $\mathrm{n}=10)$, whereby perfect auxiliaries again make up the lion's share. In turn, I did not identify past tense uses with 'to have.' Furthermore, 'to go' appears in six percent $(n=9)$, both as aspectual verb $(n=4)$ and as main verb $(n=5)$, whereas the remaining forms are almost evenly spread between a number of other (mainly main) verbs. Looking at the general distribution of finite verbs in the data, these are the verbs attested most often. ${ }^{31}$ It is likely that the preference of $m a$ for these verbs largely relates to their high frequency of occurrence.

In this context, it must be pointed out that the form $w a$, which has a significantly lower frequency in the corpus $(\mathrm{n}=38)$, shows a similar behavior in attaching mainly to the perfect auxiliary ham 'have' $(\mathrm{n}=32)$, as well as to the finite verbs of 'to be' $(\mathrm{n}=3)$ and 'to go' $(\mathrm{n}=3)$. Unlike $w a, m a$ attaches sometimes to complementizers $(2 \%$ or $\mathrm{n}=3)$, exemplified in (25).

(25)(171115_5: 278.805 - 280.994, Josef)

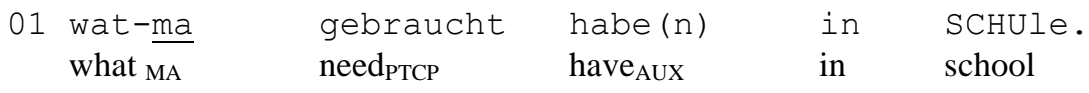

'What we needed at school.'

In complementizer clauses such as (25), $m a$ is typically the only subject marker in the clause. In main clauses, however, there is variation. The available examples indicate that when an object or adverbial, either as NP or pronoun, appears before the finite verb in the main clause, the form $m a$ is often used as single 1PL.SBJ form, as illustrated in (26).

$$
\begin{array}{llll}
\text { (26) (231115_4: 636.19 } & -637.969, \text { Jan }) & \\
\text { da } \quad \text { sim-ma } & \text { SP ̈̈ter } & \text { gegange } \\
\text { there } & \operatorname{are}_{\mathrm{MA}} & \text { later } & \text { gOРTCP }
\end{array}
$$

${ }^{31}$ For the 1PL.SBJ, 'to have' clearly outnumbers other verbs (e.g. present tense of 'to have' $n=231$; 'to be' n=39; 'to go' $n=54)$. 
'We went later.'

Principally, the adverbial may also move to the position after $\mathrm{V}_{\mathrm{FIN}}-\mathrm{MA}$, as in (27):

$$
\begin{aligned}
& \text { (27) (0314_134351: } 329.6 \text { - 332.32, Diego) } \\
& 01 \text { STOND-ma da naak(t), } \\
& \text { stood }_{\mathrm{MA}} \text { there naked }
\end{aligned}
$$

'We stood there naked.'

Yet, in the large majority of $m a$-constructions, $m a$ occurs with a full 1PL.SBJ pronoun (Table 31), and follows the finite verb of 'to have' ham, as in (28).

$$
\begin{aligned}
& \text { (28) (231115_4: } 1704.276 \text { - 1706.622, Ralf) } \\
& \text { wie ham-ma kein DUsche gehabt, nix. } \\
& \text { IPL.SBJ have } \overline{M A} \text { no shower hadPTCP nothing }
\end{aligned}
$$

'We did not have a shower, nothing.'

The use of $m a$ remains optional, which becomes clear when looking into the overall distribution of 1PL.SBJ forms. Although $m a$ is frequent in the data, it only appears in roughly 28 percent of the tokens that contain a 1PL.SBJ pronoun.

\section{VFIN-MA-1PL.SBJ?}

Besides the pattern (1PL.SBJ-) $\mathrm{V}_{\mathrm{FIN}}-\mathrm{MA}$, there is one example in the data that has the order $\mathrm{V}_{\mathrm{FIN}}-\mathrm{MA}$-wie, as illustrated in (29).

(29) (CD_09102.138 - 104.554, Theo)

$\begin{array}{llll}\text { so ham-ma } & \text { wie } & \begin{array}{l}\text { geSPIELT, } \\ \text { so hong }\end{array} & \begin{array}{l}\text { hove-MA } \\ \text { we? }\end{array}\end{array}$

'We played/used to play together, boy.'

In contrast to other $m a$-clauses where the full 1PL.SBJ always appears before the finite verb, in (29), both $m a$ and wie occur after the finite verb in this 'verb-second' clause. If wie is a pronoun here, then this example strongly resembles patterns of clitic doubling in varieties of Dutch (van Craenenbroeck \& van Koppen 2002; Haegeman 1992; De Vogelaer \& Devos 2008), as shown in (30): 
$\begin{array}{lllll}\text { (30) Werkt } & \text { ze } & \text { (zij) } & \text { in } & \text { Brussel? (De Vogelaer \& Devos 2008: 252) } \\ \text { Work } & \text { she } & \text { she } & \text { in } & \text { Brussels }\end{array}$

'Is she working in Brussels?'

Both (29) and (30) combine a clitic and a full pronoun. Accordingly, (29) could be analyzed as clitic doubling. Yet, all other doubling constructions follow the order 1PL.SBJ- $\mathrm{V}_{\text {fin }}-\mathrm{MA}$. Since there is only a single example in the data, I cannot determine with certainty whether this utterance is an instance of clitic doubling.

\section{Ruhr-German}

As pointed out earlier ( $\$ 6.2 .6$ ), the form $m a$ as 1PL.SBJ enclitic form also exists in RuhrGerman (31). The frequency distribution remains unclear. Schiering (2002: 20) states that this form has been 'at least attested once.' According to Salewski (1998: 275), who investigated coal miners' speech in the Ruhr region, ham-ma is an allegro form that exclusively occurs in fast speech.

(31) Ruhr-German (Schiering 2002: 20, adapted)

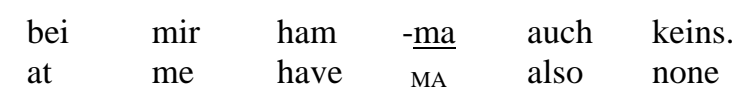

'At my place, we don't have one either.'

In Ruhr-German, $m a$ generally occurs with the verb 'have,' reduced to ham-ma 'have we' (Salewski 1998: 275; Schiering 2002: 20; Becker 2003: 92), whereas Cité Duits also displays a number of other verbs as well as complementizers. Interestingly, unlike in Cité Duits, there is no indication of co-occurrence of a full 1PL.SBJ form and $m a{ }^{32}$ Nevertheless, the optional use of ma/me( $n$ ) does exist in a number of German and Dutch varieties, as I will demonstrate subsequently.

\subsubsection{Similar Developments in Other Germanic Varieties}

The development of pronominal clitics into verbal agreement markers has been identified for several language varieties such as Italian and Rhaeto-Romance (Poletto 2000; Tortora 2003; Lindner 1987; Roberts \& Roussou 2003; Rizzi 1986; Haiman \& Benincà 1992), but also for a number of Germanic dialects such as Bavarian and East-Flemish (Weiß 1998;

\footnotetext{
${ }^{32}$ It is possible, however, that 1PL-VFIN-MA is productive in Ruhr-German as well but that it has simply not been addressed in the literature.
} 
de Vogelaer 2007: 72; Bayer 1984; Lessiak 1963; Wiesinger 1989). ${ }^{33}$ In the Dutch language area, a similar phenomenon as described for Cité Duits exists in East-Flemish and West-Flemish for the 1PL.SBJ, namely the optional use of me and men in main clauses (32) (de Vogelaer 2007: 72).

$$
\begin{array}{llll}
\text { (32) we } & \text { ga } & \underline{-m e} & \text { (de Vogelaer 2007: 72) } \\
\text { we } & \text { go } & \text { ME } &
\end{array}
$$

The use of me/men as illustrated in (32) has been attested in almost the entire East-Flemish speaking area and seems to be confined to main clauses with subject-verb order. ${ }^{34}$ These forms differ from other pronouns insofar as they combine easily with sentence-initial weak pronouns (we in the example above), and because they occur after every verb form of the 1PL.SBJ and tend to be obligatory. Although these forms behave syntactically more like inflectional markers, they may occur as only subject markers in a clause (de Vogelaer 2007: 72). These findings show interesting parallels to $m a$ in Cité Duits: whereas $m a$ has been shown to be optional, it often occurs as single subject marker in a clause.

Similarly, some Lower Bavarian dialects display a tendency toward overt agreement morphology in complementizers on the 2SG.SBJ and the 1PL.SBJ. While affixing the complementizer is obligatory for the 2SG.SBJ, it has been argued to be optional for the 1PL.SBJ (Bayer 1984: 251) (33). ${ }^{35}$

$\begin{array}{rllll}\text { (33) daß } & - \text { ma } & \text { (mir) } & \text { noch } & \text { Minga fahr-n } \\ \text { that } & \text { MA } & \text { we } & \text { to } & \text { Munich drive }\end{array}$

'That we drive to Munich...'

In Lower Bavarian (33), -ma directly follows the complementizer and may optionally be followed by the full pronominal 1PL.SBJ form mir 'we'. This is not possible once the full form precedes the finite verb (34) (ibid.):

\footnotetext{
${ }^{33}$ In addition, Kolmer (2012: 161) mentions pronominal clitics as congruence markers in Cimbro. Walser German seems to exhibit a similar feature on other persons; i.e., enclitic pronouns in Walser German are developing more and more into inflectional affixes. Likewise, Fuß (2005: 166), based on Lessiak (1963), reports a similar feature as $m a$ for a number of Carinthian dialects, which are related to Slovene.

${ }^{34}$ In turn, examples such as '... dat we morgen naar Brussel ga-me(n)' 'that we go-me to Brussels tomorrow' were rejected by all 121 participating speakers of East-Flemish and West-Flemish (de Vogelaer 2007: 73). The data used by de Vogelaer are based on questionnaires.

${ }^{35}$ Bayer (1984) focuses on the dialect spoken around the town of Landshut. For a syntactic analysis of clitics in Bavarian, see also Abraham and Wiegel (1993) and Weiß (1998: 137-52).
} 


$\begin{array}{llllll}\text { (34) Mir fahr } \underline{\text {-ma }} & & (* \text { mir) } & \text { noch } & \text { Minga } & \text { (Bayer 1984: 251) } \\ \text { We drive } & \text { ma } & \text { we } & \text { to } & \text { Munich } & \\ \text { 'We drive to Munich.' } & & & \end{array}$

While (34) resembles the order of 1PL.SBJ- $\mathrm{V}_{\mathrm{FIN}}-\mathrm{MA}$ in Cité Duits, the order $\mathrm{V}_{\mathrm{FIN}}-\mathrm{MA}$ 1PL.SBJ is untypical for Cité Duits and occurred only once (example (29)). Unlike in Lower Bavarian, Cité Duits does not display complementizer clauses with $m a$ followed by a full pronoun (example (25)). In fact, most instances of $m a$ appear in main clauses with S-V order in Cité Duits (Table 31). In Lower Bavarian, according to Bayer (1984: 251 ), the distribution of $m a$ in complementizer-position is fully regular. Unlike for the 2SG.SBJ, for which a similar feature has been established, the Bavarian form $m a$ is normally not found in the position after the finite verb in subordinated clauses. ${ }^{36}$

\subsubsection{Discussion: Clitics versus Agreement Markers}

In this section, I review some of the criteria for distinguishing between clitics and agreement markers and show how they can be applied to the data. The criteria proposed by Zwicky and Pullum (1983), elaborated by Fuß (2005), serve as starting point. First, clitics can theoretically attach to words of any category, while affixes are more selective and attach only to specific elements ('criterion of selection'). ${ }^{37}$ Given that $m a$ only attaches to finite verbs and complementizers, but not to all word categories, it seems to exhibit the selective behavior of an agreement marker. Note, however, that the data set is limited, which automatically leads to a limited range of combinations.

Second, clitics can attach to elements that already contain a clitic, whereas affixes cannot (Zwicky \& Pullum 1983: 503-04). As outlined above, there are no instances in the data in which another element occurs between the finite verb or complementizer and $m a$. Likewise (Table 31), there are no instances of $m a$ after a 1PL.SBJ form (e.g. * $V_{F I N}$ $\left.+w a+m a ; * V_{F I N}+w i e+m a\right)$. These observations favor an analysis of $m a$ as agreement marker. Third, a pronominal clitic has typically evolved into a marker of agreement when the 'doubling construction' (which, in fact, is not an instance of pronominal doubling anymore) has become obligatory (see Fuß 2005: 133-35). As illustrated above, about 30 percent of all $m a$-tokens contain $m a$ as single 1PL.SBJ pronoun in a clause. This observation, unlike the previous two, would support the analysis of $m a$ as pronominal clitic. Moreover, while 100 clauses (including $\mathrm{V}_{\text {FIN }}$-MA-1PL.SBJ) can be characterized as 'doubling construction' containing both a full form and $m a$, it must be noted that the data contains a total of 556 tokens of the first-person plural. Only 149 are realized as $m a$, which indicates that adding $m a$ to a finite verb or complementizer in the first-person plural is optional in Cité Duits.

${ }^{36}$ Yet, in (Bavarian) dialects that do not have this double construction, $m a$ is a clitic pronoun (Bayer 1984: 252).

${ }^{37}$ For instance, the Dutch superlative -st(e) exclusively attaches to adjectives (mooi-st 'nicest'), while the plural affix -eren attaches to nouns (e.g. ei-eren 'eggs,' kind-eren, 'children'). 
A fourth criterion has to do with the properties of the double. In doubling constructions, the full nominal is expected to be definite, which means that indefiniteness may indicate that the respective 'clitic' is rather a marker of agreement in the data. There is no occurrence of clauses with a DP in first position and $m a$ in third syntactic position. $M a$ occurs both with a pronoun (35) and an NP (36) in first position, but not with a DP.

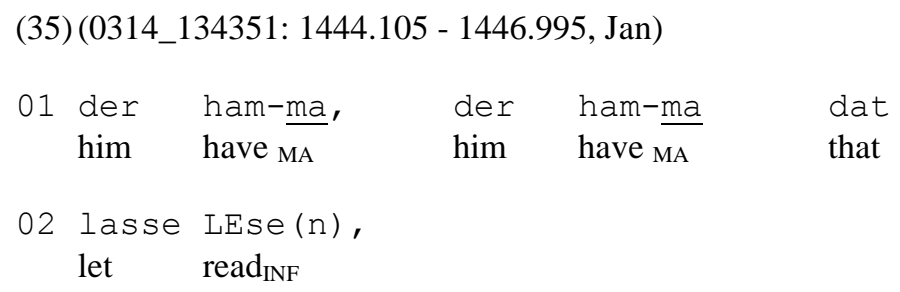

'We did not leave dead people alone.'

Because $m a$ exclusively occurs in indefinite constructions, this would indicate following, in this instance, in particular the proposal by Fuß (2005) - that $m a$ shall rather be analyzed as agreement marker.

The fifth criterion concerns syntax: if $m a$ shows up in environments where from a syntactic perspective one would not expect to see a subject pronoun, $m a$ is more likely to be a marker of agreement than a pronominal clitic (ibid 2005: 133-135; 151). Ma regularly appears in clauses that contain a full 1PL.SBJ pronoun (Table 31). Accordingly, from a syntactic perspective, $m a$ behaves more like an inflectional marker.

Four out of five tested criteria suggest that $m a$ shares most features with an inflectional marker, while one criterion, the criterion of obligation, points toward the clitic status of $m a$. However, if $m a$ had fully developed into a verbal agreement marker, it would not appear without the respective full pronoun. Of course, these may be instances of affixing with an empty pronominal position. ${ }^{38}$ On the other hand, if the PRON-V $\mathrm{V}_{\mathrm{FIN}}-\mathrm{MA}$ constructions were instances of clitic doubling, I would expect the clitic to occur in more environments.

\footnotetext{
${ }^{38}$ While Cité Duits leaves out third-person singular pronouns, there is no empirical evidence that this holds for the first-person plural.
} 
An alternative approach has been proposed by Siewierska (1999), who assumes that the development from a pronoun to a marker of agreement is reflected by the gradual disappearance of syntactic and phonological independence. The 'grammatical bondedness cline' is based on the idea that agreement markers differ in the last stages of grammaticalization, illustrated below.

independent pronoun > unstressed pronoun > clitic > affix (Siewierska 1999: 231)

This typology can be understood gradually. ${ }^{39}$ The form $m a$, I suggest, is situated in between clitics and affixes in the middle-right part of the cline: it exhibits a low degree of independence insofar as it needs to attach to specific hosts. In contrast to most grammatical agreement markers, $m a$ remains optional in Cité Duits. While it shows a strong preference for the verb ham 'have,' a larger number of verbs appears without $m a$, which indicates that $m a$ has not developed into an obligatory grammatical marker.

The foregoing analysis suggests that $m a$ in Cité Duits exhibits many features of an agreement marker. Doubling, however, remains optional. I propose that such 'doubling constructions' are not instances of clitic doubling. Rather, following the 'grammatical bondedness cline' by Siewierska (1999), I argue that $m a$ exhibits the properties of an ambiguous agreement marker situated in between clitics and affixes. The form $m a$ only appears with selected verbs, whereas agreement markers that are fully grammaticalized are assumed to have lost their referentiality (Siewierska 1999: 5). A decisive factor, however, is that $m a$ can be accompanied by a full pronoun but may as well appear as the only subject marker in a clause. Such constructions only occur with $m a$, but not with the enclitic form $w a$. Considering that $m a$ most often occurs after the finite verb of 'to have' (ham), it seems that assimilation plays a role: the form ham-ma probably derives from assimilation of [v] with [m] (Schiering 2002: 20), which means that the finite verb and the enclitic pronoun form one phonetic unit and are interpreted as such by the speakers.

\subsubsection{Summary}

Following Siewierska (1999), I have argued that the 1PL.SBJ form ma in Cité Duits exhibits the properties of an ambiguous agreement marker situated in between clitics and affixes. Although $m a$ exhibits many features of an agreement marker, doubling of a full and a reduced pronominal form remains optional. While $m a$ always follows the finite verb or complementizer, a full 1PL.SBJ pronoun may optionally precede the verb, similar to me/men in East-Flemish and West-Flemish (de Vogelaer 2007: 72). This does not hold for the 1PL.SBJ form wa in Cité Duits, which has a lower frequency and always occurs as single subject marker in a clause.

${ }^{39}$ Accordingly, anaphoric agreement markers show the highest degree of phonological and syntactic independence and tend to favor the left sections; ambiguous agreement markers are situated in the middle-right with a lower degree of independence, and grammatical agreement markers are always of affixal nature and situated at the end of the cline (Siewierska 1999: 231-32). 


\subsection{Analysis and Conclusion 6.5.1 Analysis}

This section discusses the findings from the previous sections. We have seen that phonological variation in personal pronouns often goes back to the position of the pronoun in relation to the both finite verb in non-topicalized position and the complementizer. Not all variants, however, can be justified by their position. For the 1PL.SBJ holds that, next to $m a$ (and, in a rare case, $w a$ ), it has three 'full' forms (wie, we, wir). ${ }^{40}$ All of them occur frequently in my set of data $(\S 6.2 .6)$. An aspect that requires further analysis is whether differences between individual speakers cause variation in the data. Given that speakers of Cité Duits have acquired different, often typologically distinct languages in their home context (see $\S 3.4$ ), it is conceivable that inter-speaker variation plays a role. Moreover, there are some variants in the data with a very low frequency (between $n=3$ and $n=22$, or $1.7 \%)$ that differ phonologically from the forms typically used. These include the subject pronouns 1SG $i$, 3PL sie and the object forms 1SG mir, 2SG dir, and 3SG.M ihn (see $\S$ 6.2-6.3).

\section{Inter-speaker Variation}

For the analysis of inter-speaker variation, I concentrate on the six core speakers, i.e., those with the greatest proportion of recorded speech. Table 33 provides an overview of the pronominal forms $i$, sie, mir, dir, and ihn per individual speaker in absolute numbers. In addition, since the amount of recorded speech differs across these six speakers, Figure 40 illustrates their distribution in relation to the speech share in the corpus, based on the total number of words produced per speaker (see $\S 3.4$ for a table).

\begin{tabular}{|l|l|l|l|l|l|}
\hline & i & sie & mir & dir & ihn \\
\hline Jan & 4 & 8 & 1 & 3 & 2 \\
\hline Yanis & 3 & 9 & 1 & 0 & 0 \\
\hline Raf & 0 & 3 & 1 & 0 & 0 \\
\hline Olaf & 3 & 1 & 0 & 0 & 1 \\
\hline Ferenc & 3 & 2 & 1 & 0 & 2 \\
\hline Diego & 4 & 0 & 1 & 0 & 2 \\
\hline n-total & 17 & 23 & 5 & 3 & 7 \\
\hline
\end{tabular}

Table 33: Low-frequency variants in Cité Duits according to speaker in absolute numbers

${ }^{40}$ As outlined in $\S 5.3$,we 'we' is a weak form in Belgian Dutch. 


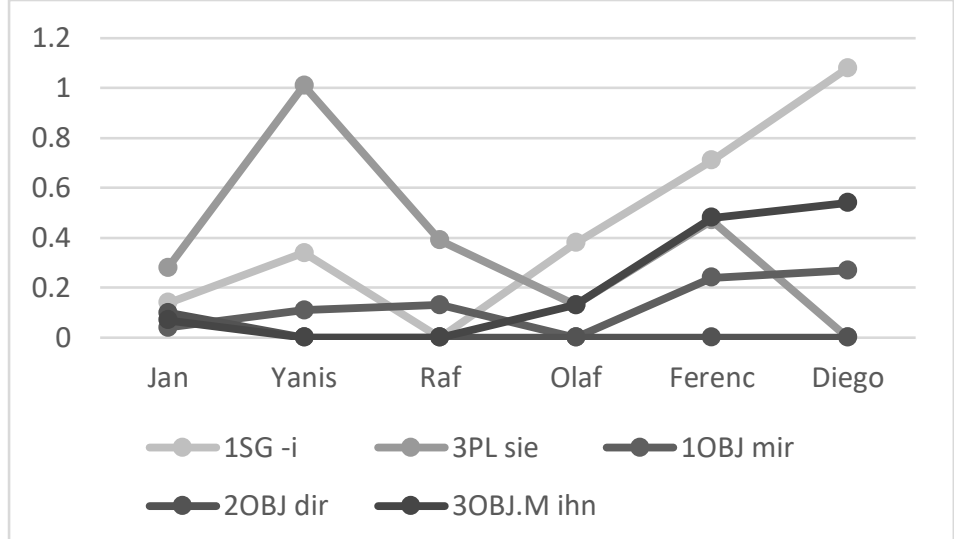

Figure 40: Low-frequency variants according to speaker in relation to speech share

Table 33 shows that most of these variants were produced by several speakers. The 2SG.OBJ form dir constitutes an exception, with all three tokens stemming from Jan. It is also noticeable that a large number of tokens realized as sie go back to Jan as well. In this respect, it is relevant that he acquired (Austrian) German as home language (§ 3.4). Furthermore, Raf hardly produced any of these lesser-frequent forms, which possibly suggests that he mainly uses highly frequent forms shared by all speakers. Thus, it appears that one particular speaker, namely Jan, produced a larger number of these variants than any of the other speakers. Yet, in relation the amount of recorded speech (Figure 40), these differences prove to be insignificant. As observable in Figure 40, Yanis produced the largest proportion of 3PL.SBJ tokens (sie), whereas Diego differed in his use of the reduced 1SG.SBJ forms $i$. A cautionary note is in order, however, because the number of attested variants is extremely small.

A slightly different observation can be made for the three full forms of the 1PL.SBJ pronoun. Table 34 illustrates the distribution of wie, we, and wir in absolute numbers per individual speaker, while Figure 41 demonstrates how these variants are distributed in relation to the share of speech.

\begin{tabular}{|l|l|l|l|l|}
\hline 1PL.SBJ & wie & we & wir & Total \\
\hline Jan & 36 & 29 & 94 & 159 \\
\hline Yanis & 17 & 12 & 22 & 51 \\
\hline Raf & 7 & 8 & 2 & 17 \\
\hline Olaf & 3 & 6 & 21 & 30 \\
\hline Ferenc & 6 & 6 & 12 & 24 \\
\hline Diego & 4 & 0 & 8 & 12 \\
\hline n-total & 73 & 61 & 159 & 293 \\
\hline
\end{tabular}


Table 34: Full first-person plural forms in Cité Duits according to speaker in absolute numbers

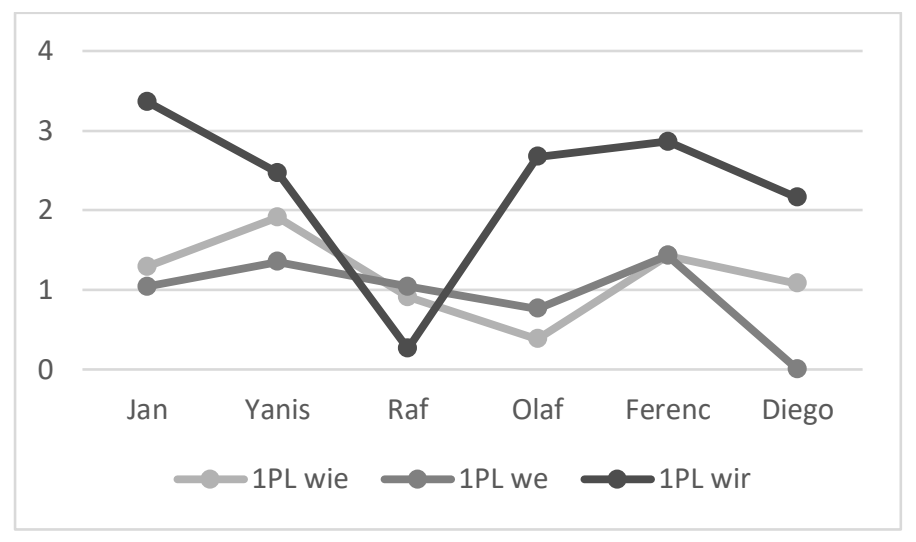

Figure 41: Full first-person plural forms according to speaker in relation to speech share

Table 34 reveals that Jan produced a signficantly larger number of wir-tokens ( $\mathrm{n}=94)$ than the other five speakers, whereas Raf realized a strikingly small number of wir-forms $(\mathrm{n}=2)$. The remaining speakers produced between eight (Diego) and 22 tokens (Yanis, Olaf). The form we has generally a lower frequency, whereby Diego did not produce any examples of we. ${ }^{41}$ All speakers regularly used wie. This distribution remains largely the same in relative numbers (Figure 41). Particularly interesting is the fact that a large number of tokens realized as wir can be associated with Jan. This could be an indication for German influence on this form, as wir in Cité Duits is homophonouns with the respective German full pronoun. These results suggest that some of the variation in the data can be explained by the fact that one speaker produces a comparably large number of pronominal variants that conform with standard German, but differ from those variants typically used by the other Cité Duits speakers.

\section{The First-person Plural Subject}

It is interesting that the 1PL.SBJ pronoun 'we' in particular exhibits more variation than all other pronouns, whereas the 1SG.SBJ exhibits very little variation. We have seen that the position of the 1PL.SBJ pronoun ( $\$$ 6.2.6) and the language use of one particular speaker explain some, but not all of the variation in the data. A possible explanation has to do with the distinctive semantic and syntactic features that make up these pronouns, i.e., their feature composition, an idea that goes back to Benincà and Poletto (2005). Their proposal rests on the distinction between deictic and non-deictic persons. The 1SG.SBJ

\footnotetext{
${ }^{41}$ It must be noted that Diego has a small proportion of speech in the corpus.
} 
corresponds to [+here, + speaker]. In contrast, the 1PL.SBJ, which exhibits much variation in Cité Duits, includes speaker and hearer and/or persons who are not present, implying that it can be used both inclusively ('we, you and I, and maybe others') and exclusively ('we, but not you'). Accordingly, feature specifications of first-person plural pronouns are more complex than the respective singular pronouns (cf. Benincà \& Poletto 2005: 27880). Under this assumption, the 1PL.SBJ shows more variation than the 1SG.SBJ because it expresses a larger number of features. ${ }^{42}$

Cité Duits emerged as in-group variety, spoken to create a 'we-feeling' (§ 2.32.6). This poses the question of whether certain 1PL.SBJ forms can be regarded as markers of Cité Duits that are used to create and reassure social closeness and in-group feelings. The use of these forms may be relevant for the social character of Cité Duits. As illustrated in (37) and (38) below, wie and ma are also employed in the written document by one of the speakers, which suggests that speakers also associate both forms with the 1PL.SBJ. Spelling follows the original document.

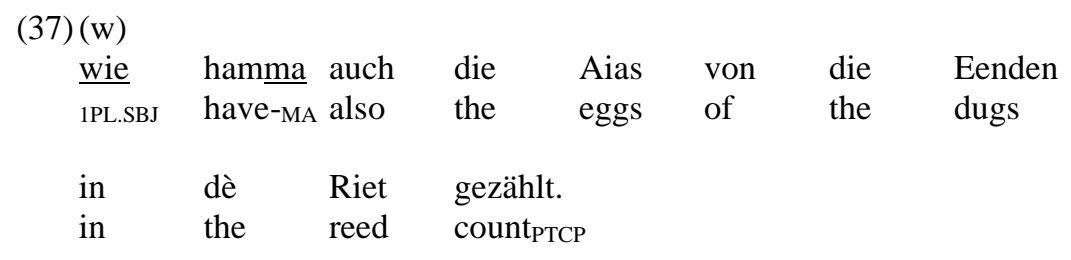

'We also counted the duck eggs in the reed.'

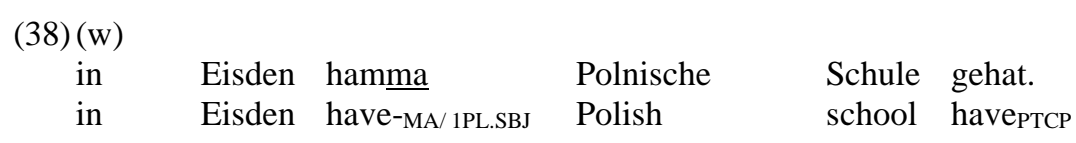

'We had a Polish school in Eisden.'

In (37), $m a$ occurs with the full pronoun wie 'we'. In (38), introduced by an adverbial, $m a$ is the only subject marker in the clause. In both instances, $m a$ directly follows the finite verb ham 'have.' These examples fully correspond to the findings for spoken Cité Duits (see § 6.4). The fact that speakers perceive $m a$ as affix as in (38) could be an indication of the symbolic function of this form. In a similar vein, it is interesting to observe that the full form wie 'we' in (37) matches the earlier identified intermediate variant (see § 5.4.7)

\footnotetext{
${ }^{42}$ It is worth noting that their hypothesis is based on data from a number of closely related Northern Italian dialects, which have a set of reflexive clitic pronouns.
} 


\section{Explaining (Absence of) Variation in Other Pronouns}

But, why is there less variation in object pronouns ( $\$ 6.3)$ ? Unlike in the paradigm of subject pronouns, several object pronouns do not display any variation, namely the thirdperson singular feminine (die) and the first (uns) and second-person plural (euch). Only the third-person plural has two forms that are almost equally frequent in the data (die and se). This homogenous use is likely related to two factors. First, the number of tokens is significantly smaller than for subject pronouns. For some pronouns, only few tokens were attested, and this is reason for caution. Second and more importantly, for object pronouns, there are fewer forms available in the contact varieties (see § 5.3). On the one hand, object pronouns do not always have a reduced form. The fact that there are few reduced object forms in the data probably goes back to their low frequency in speech. On the other hand, there are no distinct accusative and dative forms for the 1PL.OBJ and 2PL.OBJ in German, but uns and euch function both as dative and accusative pronoun, respectively. Here, Cité Duits fully corresponds to German.

It is likely that the contact varieties reinforced each other for a number of object forms. Considering that Maaslands shares the 1SG.OBJ mich 'me' and the 2SG.OBJ dich 'you' with German, although these differ phonologically, it can be assumed that both the Maaslands dialect and German play a role in the frequent use of mich and dich in Cité Duits. Similarly, the 3SG.OBJ.M ihm 'him', resembling the respective German dative pronoun, has probably been reinforced by the Belgian Dutch-Maaslands form $(h) e m$ and Maaslands' häöm 'him.' This may clarify why - from the perspective of German grammar - speakers use the accusative object pronouns for the first-person and second-person singular, but they use the dative form for the third-person singular masculine.

Similar observations can be made for third-person pronouns, where a reinforcing effect of all three contact varieties is present. We have seen that Cite Duits tends to use demonstrative instead of personal pronouns, both in object and subject position. The form die, which can be associated with Belgian Dutch, Maaslands, and German, has a variety of functions in Cité Duits. ${ }^{43}$ It serves as demonstrative determiner (plural and singular), third-person plural pronoun for both animate and non-animate referents (subject and object), subject third-person singular feminine pronoun, and object third-person singular feminine pronoun.

In contrast to Belgian Dutch, however, die is typically not used for referring to male human referents, but speakers use $d e(r)$. Likewise, speakers use $d e(r)$ as a thirdperson singular form for non-human referents, whereas the form er is largely confined to postverbal position, in this regard resembling an enclitic pronoun. While these forms can be associated with German and Maaslands, it may be the case that Belgian Dutch influenced the high frequency of the demonstrative, given that the demonstrative pronoun (here die) is often used as a general third-person pronominal form in Belgian Limburg (de Vogelaer 2007: 189).

${ }^{43}$ Boef (2013: 176-77) refers to such pronouns as 'multipurpose pronouns,' i.e., 'pronouns that can have more than one function and may appear in more than one syntactic configuration. For example, the Dutch pronoun die may function as a demonstrative and as a relative pronoun.' 
Finally, a small number of 3PL.SBJ forms was realized as sie. While these realizations were rare, occurring in only four percent of the cases, they were found across speakers, with one speaker realizing these forms slightly more often than the others. A possible interpretation is that this form is a residual of a form that disappeared when the language use of the speakers became more stable and sedimentated. Nowadays, speakers use die [di:] and se [zə]. The forms sie and se only differ in terms of the vowel. While German has the high front unrounded vowel [i], Dutch and Maaslands use here the midcentral vowel [ə]. When comparing [zi:] to [di:], the vowel is shared and the fricative becomes a plosive.

\subsubsection{Conclusion}

In this chapter I investigated pronominal variation in Cité Duits. Building on the results from Chapter 5 on lexical-phonological properties of personal pronouns and their frequency distribution, this chapter considered the factors that cause variation of pronouns. Central to the analysis was the question of whether the occurrence of the various pronominal forms could be explained by their position in relation to the finite verb in nontopicalized position or in relation to the complementizer. For object pronouns, I examined their use as accusative and dative object. As to the outcomes, particularly striking is the pattern to differentiate between clitic and full subject pronouns. Another interesting feature is the neutralization toward the German dative case in the third-person singular object pronoun ihm 'him.'

Below, I briefly recapitulate the main findings. Figure 42 summarizes the paradigm of full and reduced subject and object pronouns in Cité Duits. Brackets designate that the respective form is infrequent in the corpus. An additional column indicates with which language varieties the respective forms can be associated (LA= Languages Associated with). 


\begin{tabular}{|c|c|c|c|c|c|c|c|}
\hline & & $\begin{array}{l}\text { SBJ } \\
\text { FULL }\end{array}$ & $\begin{array}{l}\text { SBJ } \\
\text { CL }\end{array}$ & LA & $\begin{array}{l}\text { OBJ } \\
\text { FULL }\end{array}$ & $\begin{array}{l}\text { OBJ } \\
\text { CL }\end{array}$ & LA \\
\hline \multirow[t]{6}{*}{ SG } & 1 & [I⿳亠口] & 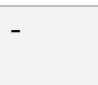 & $\begin{array}{l}\text { G, MA, } \\
\text { BD }\end{array}$ & [mıç] & - & G, MA \\
\hline & 2 & {$[\mathrm{du}:]$} & [tə] & $\mathrm{G}, \mathrm{MA}$ & [dıç] & - & $\mathrm{G}, \mathrm{MA}$ \\
\hline & $3 \mathrm{M}$ & [de:(p) $)]$ & {$[\mathrm{e}: \mathrm{e}]^{44}$} & G, MA & $\begin{array}{l}{[\mathrm{i}: \mathrm{m}]} \\
\text { [de:(p)] }\end{array}$ & - & $\begin{array}{l}\text { G, (MA, } \\
\text { BD) }\end{array}$ \\
\hline & $3 \mathrm{~F}$ & ([di:]) & [zə] & $\begin{array}{l}\text { G, MA, } \\
\text { BD }\end{array}$ & [di:] & - & $\begin{array}{l}\text { G, MA, } \\
\text { BD }\end{array}$ \\
\hline & $3 \mathrm{~N}$ & [dat] & - & MA, BD & [dat] & - & MA, BD \\
\hline & $3 *$ & [de:] & [e:en] & G, MA & $\begin{array}{l}([\text { dat }]) \\
([\text { de:n] } \\
[\text { de: }])\end{array}$ & - & $\begin{array}{l}\text { MA, BD } \\
\text { G, MA }\end{array}$ \\
\hline \multirow[t]{3}{*}{ PL } & 1 & $\begin{array}{l}\text { [vi:e]][vi:] } \\
\text { [wə] }\end{array}$ & $\begin{array}{l}{[\mathrm{me}]} \\
([\mathrm{ve}])\end{array}$ & $\begin{array}{l}\text { G, MA, } \\
\text { BD }\end{array}$ & [ons] & - & $\mathrm{G},(\mathrm{BD})$ \\
\hline & 2 & ([?गIç] $]$ ) & - & $\mathrm{G}$ & [?Jİ̧] & - & G \\
\hline & 3 & [di:] & [zo] & $\begin{array}{l}\text { G, MA, } \\
\text { BD }\end{array}$ & [di:] & [zo] & $\begin{array}{l}\text { G, MA, } \\
\text { BD }\end{array}$ \\
\hline
\end{tabular}

Figure 42: Paradigm of full and clitic subject and object pronouns in Cité Duits

The analysis of subject pronouns revealed that not all pronominal forms occur in all positions. While full pronouns (left columns) appear before and after the finite verb and complementizer, reduced forms (right columns) are typically confined to the position after the finite verb and complementizer. These observations suggest that reduced forms in Cité Duits are usually enclitics and must attach to another element, such as a finite verb. Except for the 3SG.M form er, this is in line with German. In other words, although Cité Duits has a number of reduced forms, it does not have a set of full and weak pronominal forms as in Belgian Dutch and Maaslands. Only the 1PL form we possibly functions as a type of weak pronoun. While being attested in all positions in the corpus, unlike other full forms, it exhibits a higher frequency after the finite verb and complementizer than before the finite verb.

Crucially, the full forms generally have a significantly higher frequency than the respective reduced forms in Cité Duits (usually 80\% versus 20\%). From this, it can be concluded that the influence of Ruhr-German, which tends to use reduced forms (Schiering 2002), is less prominent than expected. ${ }^{45}$ An exception regarding frequency is

${ }^{44}$ Seldom [e].

${ }^{45}$ For Ruhr-German, Schiering (2002: 18) mentions the following reduced pronouns: 1SG $i$ 'I,' 2SG (t)e 'you,' 3SG.M $a$ 'he,, 3SG.F se 'she,' $s /$ ' $t$ 'it,' 1PL wa 'we,' 2PL $a$ 'you,' and the object forms 1SG $m i$ 'me,' 2 SG $d i$ 'you,' and 3SG.M $n$ 'him.' Many of these forms are also found in spoken German. 
the 1PL.SBJ form $m a$, which has a high frequency in the data. Following Siewierska (1999), I have argued that $m a$ has a status in between a pronominal element and an inflectional affix. While enclitic $m a$ also exists in (Ruhr-) German, $m a$ has a wider distribution in Cité Duits, appearing both as only subject pronoun in a clause and serving as inflectional marker together with a full 1PL.SBJ form.

For the paradigm of object pronouns holds that speakers generally use full pronouns. Only the 3PL.OBJ displays a distinction between the enclitic (reduced) form se and the full form die. Given that the contact varieties do not have an elaborated paradigm of reduced object forms (see $\S 5.3$ ), this is unsurprising. Likewise, Cité Duits does not distinguish between accusative and dative case, in contrast to German, but uses a single form. In this regard, Cité Duits resembles Maaslands and Belgian Dutch. Yet, while the first and second-person mich 'me' and dich 'you' correspond to the German accusative, and much resemble the Maaslands full and weak form, the third-person singular masculine $i \mathrm{hm}$ 'him' is in line with the German dative pronoun. The neutralization toward the dative can perhaps be explained by the fact that Belgian Dutch and Maaslands share the form (h)em, phonologically resembling ihm 'him.'

Moreover, there is a general tendency in Cité Duits to use demonstrative (die/de(r), dat) instead of personal pronouns, both for object and subject forms. A comparison with the Duisburg corpus shows that Cité Duits' tendency to differentiate between reduced and full pronominal forms differs in some respects from Duisburg German. Strikingly, the 2PL form euch functions in Cité Duits both as subject and object pronoun. While homophonous with 2PL.OBJ in German, from a syntactic perspective, this use rather resembles Dutch. Unlike in (dialects of) German, object forms in subject position are common in varieties of Dutch (e.g. historical Limburgish $d u>d i c h$; presentday Belgian Dutch hij>hem; present-day Netherlandic Dutch $z e>h u n)$. In a similar vein, Cité Duits shares numerous features with dialectal varieties of Dutch, such as complementizer agreement on the 2SG.SBJ and typically 'masculine' pronouns for referring to women, whereby complementizer agreement is also found in German dialects.

The examination of inter-speaker variation revealed that one particular speaker (Jan) produced all 2SG.OBJ tokens realized as dir 'you,' as well as a comparably large number of the 1PL.SBJ form wir 'we.' Although most of the examined variants were used by several speakers, these results suggest that some of the variation can be explained by the language use of one particular speaker with German as home language. Accordingly, if the tokens by this speaker are disregarded, there is even less variation in the data.

Returning to the question of variation, both Chapters 5 and 6 have shown that Cité Duits displays a quite coherent pattern of personal pronouns. Speakers do not switch between pronominal forms from language variety A, B, and C when speaking Cité Duits, but have developed one pronominal paradigm. This paradigm consists of pronominal variants that phonologically and lexically often resemble German, and/or Maaslands and Belgian Dutch, including three intermediate variants (see also $§ 5.6$ ). While ich [ıç] ' $\mathrm{I}$ ' is a Belgian-Dutch-Maaslands-German form, pronounced with a voiceless post-palatal fricative as in Maaslands but with a short vowel as in German/Belgian Dutch, wie [vi:] 
'we' resembles the German full form wir [vi:e] and the Belgian-Dutch reduced form we [wə]. In contrast, de [de:] 'he' can be associated with the German der [de:p] and the Maaslands dè [də], but not with Belgian Dutch. That the form wie [vi:] cannot be categorized as belonging to one of the contact varieties also confirms the result from a perception test (see § 3.7). Moreover, for some pronouns, Cité Duits uses a single form where the contact varieties distinguish between several variants (e.g. dat> 'it, that'; mich vs. German mich/mir; dich vs. German dich/dir). Although there is variation in the data, this type of variation is not more pronounced than in spoken varieties of German and Dutch. 


\section{Chapter 7: Progressive Aspect in Cité Duits}

All natural languages - whether or not they have a designated grammatical category conventionally referred to as 'progressive' or 'continuous' - can convey the idea that an event is progressing dynamically over a timeframe opened up by an utterance. (Mair 2012: 803)

\subsection{Introduction}

The preceding two chapters provided a quantitative and qualitative analysis of the use of personal pronouns, making evidence-based assumptions on the linguistic character of Cité Duits. In order to further refine the hypothesis on the linguistic structure of this contact variety, the present chapter will explore the domain of aspectuality ${ }^{1}$ (Verkuyl 1996), a domain that is often sensitive to semantic, syntactic, and morphological contrasts and that is less transparent than the pronominal system. Because information about tense and grammatical aspect appears combined in many languages (Comrie 1976: 1; Klein 2009: 40), aspect remains a rather fuzzy category.

By investigating the use of progressive aspect in Cité Duits, this chapter strives to answer research question four (RQ4): how is progressive aspect expressed in Cité Duits? 'Progressive' or 'continuous' aspect conveys the information that an event or

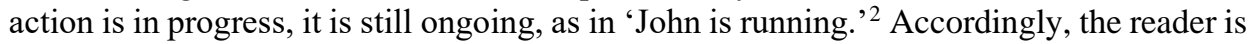
'placed in the midst of the action' (Klein 2009: 54; further Comrie 1976: 1-6). In contrast to English, a language that marks progressive aspect grammatically by the verbal ending -ing ('runn-ing') (Mair 2012; de Wit \& Brisard 2014), varieties of Dutch and German do not have a morphological marker, but rather a range of means to convey progressive aspect. In Cité Duits, we find, for instance, utterances as in (1).

(1) (0313_152448: 84.31 - 88.01, Raf)

\begin{tabular}{|c|c|c|c|c|c|}
\hline de & $\begin{array}{l}\text { war }(t) \\
\text { was }\end{array}$ & & $\begin{array}{l}\text { teleVIsie } \\
\text { television }\end{array}$ & & \\
\hline & ihm & au (ch) & de & (au) & AUge \\
\hline
\end{tabular}

'He was watching television when his eye got hurt.'

\footnotetext{
${ }^{1}$ Following Verkuyl (1996: 11), I understand 'aspectuality' as umbrella term that covers both grammatical and lexical aspect.

${ }^{2}$ While 'progressive' and 'continuous' aspect are often used interchangeably, Mair (2012) argues for keeping the two notions apart. Although this distinction is adequate when studying languages which have grammaticalized them both (e.g. Cantonese), it is unnecessary in the given context.
} 
In (1), the speaker reports a situation in the past where two events took place simultaneously. He uses first a progressive construction $(\operatorname{war}(t)+a n+\mathrm{V}$-INF), indicating that the situation he referred to continued, and then switches to the simple past tense (flog). The construal of an ongoing event overlapping with the reference time is typical of progressive constructions. Progressive is expressed here by means of an plus V-INF plus sein-FINITE 'at V-INF be-FINITE', henceforth referred to as 'an-construction.' ${ }^{\text {'3 }}$ Such constructions normally express duration but no endpoint. These and similar uses will constitute the core of the subsequent analysis.

The investigation of progressive constructions is particularly intriguing because the linguistic means in Cité Duits contact varieties differ to some extent but also overlap. From a strictly typological perspective, these count as non-aspect languages. Belgian Dutch, Maaslands, and German lack a single progressive construction. Although there are several ways to denote progressivity, there is no 'standard' progressive marker. Aside from this, explicit marking of progressive aspect is optional in many contexts (see § 7.3.2) (Behrens et al. 2013: 95; Blevins 2018: 80; Broekhuis et al. 2015a: 150; Ebert 1996; Krause 2002; Tomas 2018: 53; Kuhmichel 2016: 67; Witt 2015: 5; Anthonissen et al. 2016: 9; Flecken 2010: 18). Nevertheless, it has been argued that Dutch has grammatical means to indicate progressive aspect, whereas German is said to have no grammaticalized aspectual markers (Flecken 2011a: 62; Athanasopoulos \& Albright 2016: 666).

Keeping these observations in mind, the question arises if and how progressive aspect is marked in Cité Duits. The sub-questions I will investigate are: (i) how is progressive aspect expressed in Cité Duits? (ii) Is there a progressive type that is specific to Cité Duits and not found in the contact varieties? (iii) Which syntactic and semantic restrictions do the respective (verbal) constructions display? Because of the limited size of the data set, I will concentrate both on present- and past tense-progressive constructions.

The outline of this chapter is as follows. An introduction of tense and aspect ( $\S$ 7.2) is followed by a revision of the semantic classification originally proposed by Vendler (1957), and a description of progressive aspect in Belgian Dutch, Maaslands, and German (§ 7.3). After some words on methodological challenges (§ 7.4), the subsequent section examines progressive aspect in Cité Duits with a focus on the different attested progressive types and their frequencies ( $\$ 7.5-7.6)$. Section 7.7 analyzes the an-construction more indepth. This section first examines the semantic categories of verb classes (Vendler 1957) that yield progressive aspect, followed by a discussion of syntactic variation. Section 7.8 concludes the analysis by considering inter-speaker variation and the question of whether there is a progressive aspect type characteristic of Cité Duits.

\footnotetext{
${ }^{3}$ The term 'an-construction' does not suggest that this construction always yields the morphological realization 'an,' but appears to be the most suitable term. Others speak of 'aan het progressive' for Dutch or 'am-Progressiv' for German (e.g. van Pottelberge 2004; Flecken 2011a; 2010). Furthermore, Henriksson (2006) applies the term 'am+Infinitiv-Konstruktion.'
} 


\subsection{Progressive Aspect}

The study of grammatical aspect proliferated in the early 1970s with a study by Comrie (1976). Since then, a significant amount of linguistic research has been directed towards the different faces of aspectuality (for a cross-linguistic overview, see the contributions in van Hout et al. 2005; see also Verkuyl et al. 2006: 8-12 for an overview including references; see also Binnick 2012). In the 1970s and 1980s, a growing number of studies explored the acquisition of tense-aspect in spontaneous speech production. Crosslinguistic studies in the 1990s, often based on experimental studies, paved the path for current trends in the research on aspect. In the 1980s, the question was raised whether aspect could be regarded as a universal category. In the following, I only review a limited set of the approaches to progressive aspect presented in the literature, thereby concentrating on studies investigating Germanic varieties. There are semantic, pragmatic, and morphosyntactic approaches to explain variation. This selection is meant to outline those approaches that are used for the subsequent analysis, but it does not aim at providing a balanced overview of the existing approaches to the study of aspect.

\subsubsection{Introducing Tense and Aspect}

The linguistic categories 'tense' and 'aspect' are both concerned with time. In many IndoEuropean languages, they are conveyed by a single grammatical construction (Klein 2009: 40). ${ }^{4}$ Yet, the two notions refer to distinct categories. Tense locates a given situation in time in relation to the moment of speaking (situation-external time). It is often manifested in derivational affixes on the verb (e.g. present tense 'he jump s' vs. past tense 'he jumped'). The most common tenses are present, past, and future (Comrie 1976: 1-2). Aspect, in its traditional understanding, provides information on how an event unfolds through time. It thereby refers to the internal structure of a situation (situation-internal time) (Comrie 1976: 1; Klein 2009; Krause 2002: 19-20; Rothstein 2008a). As Comrie (1976: 3) puts it in his pioneering work on verbal aspect, 'aspects are different ways of viewing the internal temporal constituency of a situation.' For example, in the sentence Jean lisait quand j'entrai 'John was reading when I entered,' the first verb lisait presents the background of the event, whereas the second verb entrai introduces the event itself (Comrie 1976: 3, including example).

While perfective aspect normally indicates that an action has been completed (e.g. 'John had driven home'), progressive aspect - which is often associated with the imperfective (Comrie 1976; Henriksson 2006: 102; Flick 2016: 166; but see Klein 2009:

\footnotetext{
${ }^{4}$ Since it proved difficult to untangle features of aspect in many languages, some authors concentrate on Tense-Modality-Aspect (TMA). Fischer (2016: 4), for instance, speaks of Tempus-AspektSystem, arguing that tense forms in German always denote both temporal and aspectual meaning. For a discussion of the category 'aspect,' see Heinold (2015: 59-72) and Klein (2009); for temporal representations in Dutch, see Broekhuis and Verkuyl (2014); for progressive in Germanic, see Henriksson (2006: 102-05), Krause (2002: 19-54), and Witt (2015: 26-33).
} 
56 for a discussion) - describes an action that is in progress (e.g. 'John is talking on the phone.'). 'Progressives present a situation, whether telic or atelic, as ongoing at reference time, without respect to boundaries' (Ebert 1996: 42). ${ }^{5}$ The typical feature of the progressive is its constraint to dynamic verbs and predicates (Mair 2012: 806).

Authors often distinguish between 'lexical aspect' or 'Aktionsart' and 'grammatical aspect' (Rothstein 2008a: 1). In the literature, a variety of terms are employed to refer to 'lexical aspect' including 'actionality,' 'situation aspect' (Binnick 2001: 557), 'derivational aspect,' 'aspectual character,' and 'inherent aspectual meaning' (Lindstedt 2001: 772). For grammatical aspect, also the notion of 'viewpoint aspect' is found (Smith 1991: 171-73). ${ }^{6}$ From this perspective, progressive aspect can be expressed via the semantic properties of a verb (lexical aspect) or through morphological markers on the verb (grammatical aspect) (for examples see Rothstein 2008: 1; for lexical aspect see Filip 2012; for verbal aspect see de Zwart 2012). While early approaches treated aspect as a category that referred to grammatical aspect alone, recent approaches often understand aspect as a wider notion. For instance, some authors regard temporal adverbials such as 'now' as markers of progressive aspect in German, although they are optional (e.g. Er arbeitet gerade 'He works right now') (Ebert 1996: 47-48; Henriksson 2006: 110-12; Witt 2015: 236-46; Mair 2012: 805; Gárgyán 2010: 38). Desclés and Guentchéva (2012: 126) even propose adding a third category called Aspect 3 , which includes verbal phases and discourse markers.

For the given analysis, I maintain a broad definition of 'aspect.' By following the views postulated by Comrie (1976), Bybee and Dahl (1989), and Mair (2012), among others, I consider aspect as a cross-linguistic category that exhibits a number of different realization strategies. In the remainder of this chapter, the term 'progressive aspect' is used to refer to durative events that take place at reference time, following Ebert (1996). Accordingly, in line with numerous authors (Ebert 2000; 1996; Mair 2012; Blevins 2018; Klein 2009; Witt 2015; Krause 2002; Lemmens 2012; Gárgyán 2010), I understand the category 'progressive' as including both progressive constructions and lexico-semantic markers.

\subsubsection{Aspect Cross-linguistically}

'Aspect' was for a long time regarded as a category mainly found in Slavic languages. Unlike Germanic, Slavic languages have morphological distinctions that mark the opposition between perfective and imperfective on the verb (Dickey 2000; Gvozdanović 2012; Klein 2009: 55-56; Kuteva 1999: 193 for Bulgarian; Guentchéva 2016: 3; Bertinetto

\footnotetext{
${ }^{5}$ The telic-atelic distinction was introduced by Garey (1957). In contemporary linguistics, telic verbs or VPs refer to events with an endpoint, whereas atelics are events without inherent endpoint. See also Comrie (1976: 44).

${ }^{6}$ Other authors (e.g. Mair 2012: 805) also employ the notions 'progressive aspectuality' (semantic) and 'progressive aspect' (grammatical category).
} 
et al. 2000: 525-26). ${ }^{7}$ How languages mark progressive, however, varies within and across languages, and languages differ in terms of when the progressive form can be used (Comrie 1976: 35). In Romance languages like French, progressive occurs most often with imperfective tense. Hungarian, in contrast, seems to combine syntax with a specific intonation to indicate progressive meaning (Bertinetto et al. 2000: 525). In English, as noted earlier, progressive aspect is marked grammatically by a derivational suffix. This progressive form, which is often considered the 'prototypical form' from a cross-linguistic perspective, is obligatory when reporting present-time events that are ongoing (Mair 2012: 823; Henriksson 2006: 102; van Pottelberge 2007: 101; Comrie 1976: 33). ${ }^{8}$

In most Germanic languages, however, progressive aspect is not grammaticalized to the same degree as in English, reflected by the large range of available aspectual markers. Most Germanic varieties have at least two types of progressive constructions (Ebert 2000: 605-07). Dutch and Maaslands use both the aan het-progressive and posture verb constructions with zitten/staan/liggen 'to sit/stand/lie' (see § 7.3.4). German, in turn, has no posture verb constructions denoting progressive aspect, but uses dabei sein $z u$ 'to be in the process of' (see § 7.3.5) and the am-progressive, among other options.

\subsubsection{Vendler's Classification}

Over the last sixty years, a number of semantic classifications for aspectual classes have been proposed (Aktionsart classifications), often inspired by Aristotle's dichotomy kinêsis ('motion') versus energeia ('activity') (for discussions, see Filip 2011; Broekhuis et al. 2015a; Verkuyl 1972; 1989). ${ }^{9}$ Best-known is probably Vendler's (1957) four-way classification into states, activities, achievements, and accomplishments, which proved to be fruitful for most classifications set up at a later stage. ${ }^{10}$ This model proposes to group together activities and accomplishments as processes, and states and achievements as nonprocesses. The division of processes in activities versus accomplishments is based on whether or not a given event has a natural termination point. While the classification by

\footnotetext{
${ }^{7}$ Particularly Russian has clear devices in the verbal system to mark the perfective-imperfective distinction. See also the contributions in Rothstein (2008b: 191-320) and Thelin (1990) for aspect in Slavic languages.

${ }^{8}$ Yet it is possible to use contextual devices to express progressive meaning in English (Blevins 2018: 74). Moreover, the progressive with -ing has extended to contexts that do not express progressive meaning (Comrie 1976: 38-40), as well as to verbs that are considered impossible with the progressive form (Flecken 2010: 84).

9 One of the most influential contributions to the semantic analysis of tense is the theory by Reichenbach (1947), which I leave aside since this chapter deals with progressive aspect only.

${ }^{10}$ A number of alternative approaches that build on Vendlers' classification have been put forward (e.g. Dowty 1979: 180-85). I refer the reader to Broekhuis et al. (2015a: 46-62) for a survey. Furthermore, recent schemas convincingly argue for adding a fifth category, the 'semelfactives' (e.g. Ehrich \& Vater 1989: 117), 'instantaneous activities' in the terminology of Broekhuis et al. (2015a: 46-62). Because semelfactive verbs (e.g. 'to sneeze') are not encountered in the data, however, such a distinction would be unsuitable for the given analysis.
} 
Vendler suggests a classification of different types of verbs, I will use the notion of 'verbal events' or 'states of affairs,' following Broekhuis et al. (2015a: 41) and Verkuyl (1972), illustrated in Figure 43.

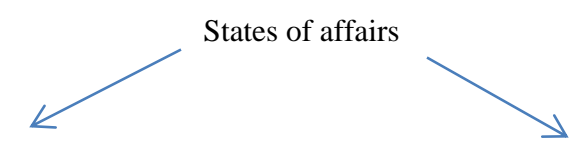

Processes

[+continuous tense]

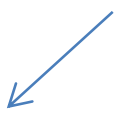

Activities

[-bounded]

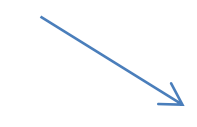

Accomplishments [+bounded]

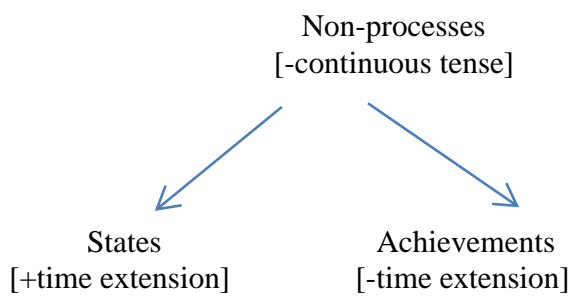

Non-processes

[-time extension]

Figure 43: Vendler's classification (Broekhuis et al. 2015a: 37)

The basic idea is that these principles involve the opposition between progressive and nonprogressive, and apply to any natural language. Accordingly, it is assumed that accomplishments and activities can have a progressive form, whereas states and achievements do not. Moving from left to right, activities are considered verbs such as 'to listen,' 'to swim,' or 'to eat' (intransitively); accomplishments are for instance 'to eat up'; typical states are 'to love' and 'to know'; and achievements are 'to arrive' or 'to win' (Broekhuis et al. 2015a: 38-41).

However, this division received some warrantable criticism (see especially Verkuyl 1989; Dowty 1979). Several authors have demonstrated that the syntactic environment determines how to classify a given verb. 'To eat,' for instance, functions as activity when used as intransitive verb, but as accomplishment when used as transitive verb (Broekhuis et al. 2015a: 41-42; Verkuyl 1989), as illustrated in (2) (adapted from Broekhuis et al. (2015a: 42)).

(2) a. John was eating spaghetti. [activity]

b. John ate a plate of spaghetti. [accomplishment]

Objects following the verb, as well as other factors, may trigger a different interpretation that affects the aspectual nature of the event, i.e. (in Dutch) whether the subject is definite/indefinite plural, or whether the verb occurs with a PP-complement. In other words, many verbs that are typically 'state verbs' or 'achievement verbs' allow for being combined with the progressive in certain syntactic environments (Broekhuis et al. 2015a: 37-43; Verkuyl 1989: 47-49). Consequently, semantic and syntactic properties are interrelated, and a classification of verbal events based on their aspectual properties needs 
to consider both semantic as well as syntactic information (e.g. number and types of nominal arguments of a verb). This goes often beyond the VP and extends to the entire sentence. Furthermore, the classification by Vendler, but also other schemas developed subsequently, motivate a diagnostics based on English, but these are not always valid for other languages (Filip 2011: 1192). Nevertheless, this four-fold division shall therefore serve as starting-point for the semantic classification of verbal events (see $\S$ 7.7.3), whereby I consider both semantic and syntactic properties. Since many studies have followed (a version of) Vendlers' classification, it is almost indispensable when contrasting the present data with earlier studies. ${ }^{11}$

For distinguishing these categories, several tests have been proposed (Broekhuis et al. 2015a: 38-41), including a number of question-answer pairs briefly summarized as follows. (i) Processes versus non-processes: process verbs can provide an answer to interrogative progressive constructions such as 'What is Marie doing?': (activity/process) 'She is listening to Peter' but not (state/non-process) *She is liking spinach.' (ii) Activities versus accomplishments: interrogatives as 'How long did it take to finish your meal?' can be used for verbs denoting accomplishments, 'It took 10 minutes to finish my meal,' but not with activities '*It took 10 minutes to listen to him.' (iii) In contrast, for activities, the time span can be asked for, for instance, 'For how long did you listen to him?', but not '*For how long did you finish your meal?' (iv) Furthermore, temporal adverbial phrases can distinguish activities and accomplishments: 'during an hour' or 'for an hour' are normally used with activities, whereas 'within an hour,' which measures the time span, rather occurs with accomplishments. Finally, states versus achievements: questions such as 'At what time did Subject V ...?' occur with achievements, e.g. 'At what time did the bomb explode?', whereas states do not easily combine with such questions. Compare (state) '*At what time did he love her?' (see Broekhuis et al. 2015a: 38-41, including examples).

\subsection{Progressive Aspect in Cité Duits Contact Varieties}

This section surveys the literature on progressive aspect in Dutch ${ }^{12}$ and German (dialects), and sketches the main progressive types in Cité Duits contact varieties, thereby providing the backbone for the subsequent data analysis. While progressive aspect can principally be conveyed by similar formal means, the three varieties exhibit a number of differences.

\subsubsection{Some Contributions to the Study of Progressive Aspect in Germanic}

Progressive marking in Germanic languages other than English was for a long time virtually neglected in the literature (Ebert 2000: 605; Witt 2015: 5-7). Only over the past

11 Note that Vendler (1957: 152) already mentions that many activity, accomplishment or achievement verbs can at the same time function as states, depending on the context.

${ }^{12}$ As stated in $\S 4.2$, I use the notion 'Dutch' as a cover term to refer to Dutch as spoken in Belgium and the Netherlands. 
three decades has linguistic work started to focus more closely on the analysis of aspectual distinctions in and across other Germanic varieties. Abraham and Janssen (1989) published one of the earliest volumes on Tense-Modality-Aspect in Germanic languages that contained a number of contributions on aspect. Around this time, progressive aspect in German and Dutch started receiving more attention. Boogaart $(1999 ; 1991)$ discussed progressive aspect in Dutch, and Bhatt and Schmidt (1993) looked into the German dialect of Cologne. ${ }^{13}$ Furthermore, Andersson (1989) sketched some characteristics of progressive constructions in Ruhr-, Low- and standard German, and Ebert (1989) compared aspectual markers in Fering (North Frisian) to a number of Germanic languages. Shortly after, Ebert (1996) described the use of progressive aspect in Dutch and German.

More recently, a number of cross-linguistic studies appeared with focus on progressive aspect in Dutch and German (van Pottelberge 2004; Krause 2002; 1994; Behrens et al. 2013; Flecken 2011a; 2010). Furthermore, Henriksson (2006) published an in-depth study on progressive in German compared to Swedish; Gárgyán (2010) analyzed German compared to Hungarian; Slater (2012: [Reimann 1996]) focused on German and English, and Tomas (2018) wrote about the am-progressive in Pennsylvania German. Progressive aspect in German (dialects) has also been investigated by Glück (2001), and lately by Witt (2015), by Ramelli (2015), by Anthonissen et al. (2016), by Flick and Kuhmichel (2013) and Kuhmichel (2016); and in Dutch by Lemmens (2005; 2012) and Booij (2008). A contrastive analysis on progressive constructions in Dutch and Afrikaans was conducted by Breed et al. (2017). Posture verbs denoting progressive aspect have been the focus of the study by Fraser and Pots (in preparation).

The majority of these studies stress that the use of progressive aspect in German is less grammaticalized than in Dutch. Yet, although German is often described as 'nonaspect language' (Flecken \& Gerwien 2013: 2310; Athanasopoulos \& Albright 2016: 666; Flecken 2011a; 2010), numerous studies have demonstrated that spoken German 'has some weakly grammaticalized ways of conveying progressive aspectuality, particularly in dialectal, regional, and informal usage' (Mair 2012: 804). More precisely, it seems that the German am-progressive is slowly on its way to become grammaticalized (Fischer 2016: 134; Krause 2002: 87; Imo 2008). ${ }^{14}$

\section{German}

A number of constructions are associated with progressive aspect in German. (i) The amprogressive or Rheinische Verlaufsform, (ii) the beim-progressive, (iii) the im-progressive, (iv) the dabei sein $z u$-construction ('to be in the process of'), and (v) the absentive (see

\footnotetext{
${ }^{13}$ Moreover, Kölligan (2004) and Drossard (2004) have compared different 'Aktionsarten' in the Cologne dialect.

14 One of the first definitions of 'grammaticalization' goes back to Meillet (1912). The terms 'grammaticization' and 'grammaticalization' are normally used interchangeably, and refer to the process in which grammatical morphemes or specific structures gradually become part of the core grammar of a language variety, with their use becoming obligatory in certain contexts (Bybee et al. 1994: 4).
} 
below for examples). In addition, temporal adverbs such as gerade 'just now' can mark progressive meaning (Ebert 1996: 41-49; Krause 2002; Witt 2015: 240; Dahl 1985: 90).

\section{Belgian Dutch}

Dutch has principally four constructions to convey progressive meaning. (i) The aan-hetprogressive, ${ }^{15}$ (ii) posture verb constructions, (iii) the bezig zijn te-construction ('to be busy with'), (iv) and the absentive (see below) (Ebert 1996: 51-56). Moreover, Dutch uses temporal adverbs such as nu, nou, net 'just now' (Krause 2002: 155; 1994).

\section{Maaslands}

In Maaslands, the following progressive aspect types are attested: (i) the aon 'tprogressive, (ii) posture verb-constructions, (iii) the bezig zijn te-construction ('to be busy with'), (iv) the absentive, and (v) the gerund with -entere (Aarts 2005; 2001; Barbiers \& al. 2006) (but see below). Similar to Dutch and German, Maaslands uses temporal adverbs such as z.jus 'just.' Albeit much literature has been devoted to Dutch and German, it seems that little research has been done on progressive aspect in the Maaslands dialect.

\subsubsection{Non-marked Progressives or Implicit Use}

In many contexts, explicit marking of progressive meaning remains optional in Dutch, Maaslands, and German. Unlike in English, speakers can use the present (or past) tense in order to refer to ongoing events (Behrens et al. 2013: 95; Blevins 2018: 80; Broekhuis et al. 2015a: 150; Ebert 1996: 41, 45; van Pottelberge 2007: 123; Anthonissen et al. 2016: 9; Flecken 2010: 18; Flick \& Kuhmichel 2013: 54-55). For instance, as answer to the question 'what is he doing?', a speaker of German is likely to respond using the simple present tense (3):

(3) $\mathrm{Er} \quad$ arbeitet. (German, Mair 2012: 804)

he works

'He is working.'

Some authors use the notion 'present tense (progressive) construction' to denote those constructions where 'context is necessary in order to distinguish between progressive and non-progressive meanings' (Blevins 2018: 84), others apply the term 'non-progressive' (van Pottelberge 2007: 123). In the remainder of this chapter, I will speak of 'non-marked progressives' to refer to those utterances where the progressive meaning has to be deduced from the context. Examples as (3) are not overtly marked for progressive. Despite being

\footnotetext{
${ }^{15}$ It seems that the Dutch aan het-construction can be traced back at least to the $17^{\text {th }}$ century (Booij 2008: 81; van Pottelberge 2004: 92), which suggests that it does not involve a recent development.
} 
associated with progressive aspect, such constructions can have a wide range of possible interpretations.

Crucially, cross-linguistic studies (Flecken 2010; 2011a) found that Dutch speakers are more likely to mark progressive aspect overtly than German speakers, who frequently use non-marked progressives as in (3). Unlike German speakers, Dutch speakers rated the non-marked constructions (e.g. Ik werk 'I work') completely unacceptable in certain contexts (Flecken 2010: 85).

\subsubsection{Aan het/Aon 't/Am-constructions}

The most common means to express progressive aspect overtly is the aan het/aon 't/ amconstruction (Krause 2002: 88-95; Flecken 2011a: 64; Anthonissen et al. 2016: 1; Gárgyán 2010: 3; van Pottelberge 2004), exemplified in (4). ${ }^{16}$

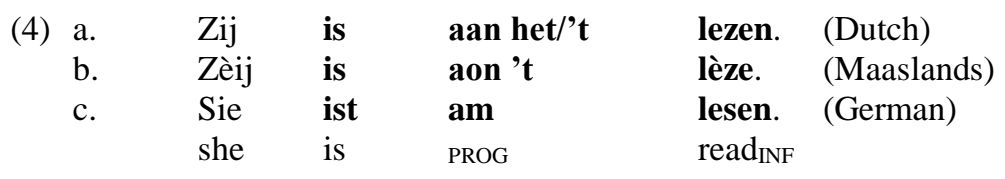

'She is reading.'

This construction is formed with be $\mathrm{FinITE}+$ aan het/aon ' $t / a m+\mathrm{V}_{\text {-INF. }}$ In Dutch (4)(a) and Maaslands (4)(b) aan/aon is followed by het / $t$, whereas German (4)(c) uses am. ${ }^{17}$ In Dutch, other finite verbs such as the modal verbs lijken 'to appear,' schijnen 'to seem,' and blijken 'to turn out' are likewise possible (van Pottelberge 2004: 29-51; Broekhuis et al. 2015a: 152; Booij 2010: 150-59). In German, in turn, other finite verbs are seldom and the resulting constructions (e.g. jemanden am Arbeiten halten 'to keep someone working') rather have a causative-durative meaning instead of a progressive meaning (Flick 2016: 168; for examples, see van Pottelberge 2004).

Although the three varieties have similar formal means to indicate progressive aspect, the Dutch construction is further grammaticalized and exhibits more variability in use than its German equivalent, on the level of both syntax and semantics (Krause 1994: 24-27; 2002: 1; van Pottelberge 2004: 325; for Dutch, see also Lemmens 2012: 285). ${ }^{18}$ While the Dutch aan-het-progressive is common in all text types and varieties (van Pottelberge 2004: 5), the German am-progressive displays regional variation (see also $\S$ 7.7 below) (Andersson 1989; Bhatt \& Schmidt 1993; Ebert 1996: 49; Flick \& Kuhmichel

${ }^{16}$ While productive in Maaslands, I am not aware of its relative frequency. Note that Breed et al. (2017: 322) find that posture verbs are most frequent in Dutch. I will discuss the frequencies in $\S$ 7.6.

${ }^{17}$ In German, the finite verb form may be capitalized, depending on its interpretation as verbal element or nominalized infinitive. See Tomas (2018: 71-73) for a discussion.

${ }^{18}$ See also van Pottelberge (2004: 154-162) for Belgian Dutch. 
2013; van Pottelberge 2004: 210-24).$^{19}$ Originally, the am-progressive was considered a feature of the dialects spoken in the Rhineland south of the Benrath-line (van Pottelberge 2004: 210; Ebert 1996: 43; Kuhmichel 2016: 67; Flick \& Kuhmichel 2013: 54; Witt 2015: 5; Tomas 2018: 70). Yet, recent linguistic work stresses that it has turned into a supraregional linguistic phenomenon (van Pottelberge 2004: 216; Krause 2002; Flick \& Kuhmichel 2013: 54; Anthonissen et al. 2016: 2-3; Fischer 2016: 134).

Furthermore, cross-linguistic studies (Flecken 2010; 2011a) using an acceptability judgment task have shown that speakers of Dutch and German differ in the extent to which the progressive construction is used: while the aan-het progressive is extremely frequent in Dutch, the am-progressive occurs comparably seldom in German. For example, with activity verbs (see Vendlerian classification $\S 7.2 .3$ ), Dutch speakers always use the progressive construction, whereas German speakers also use non-marked progressives combined with lexical means (ibid.) (see § 7.3.2). ${ }^{20}$

\subsubsection{Posture Verb Constructions in Dutch/Maaslands}

Dutch and Maaslands regularly use posture verbs to indicate progressive aspect (5) (for Dutch, see Broekhuis et al. 2015a: 152; Lemmens 2005; 2012; Fraser \& Pots in preparation; Flecken 2011a: 64-65; Breed et al. 2017; Pots 2018). Even though posture verbs denoting progressive aspect are widespread in Germanic languages, they do not exist in German (Ebert 1996; 2000; 1989).

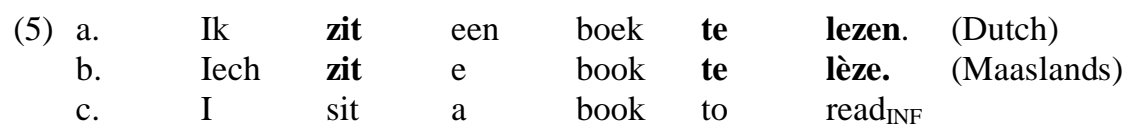

'I am reading a book.'

Posture verb constructions are formed with the finite verb of a postural verb, i.e. zitten/staan/liggen 'to sit/stand/lie,' followed by te and a verbal infinitive. In the (plu)perfect, the posture verb appears in the infinitive, since Dutch exhibits the Infinitivus Pro Participio (IPP) effect (see also § 4.4.7) (Broekhuis \& Corver 2016: 1012-13). In addition, Dutch has the motion verb lopen 'walk' (e.g. Ik loop te bellen 'I am walking and

\footnotetext{
${ }^{19}$ The am-progressive is said to have two 'sources regions,' i.e. the Ruhr region and Switzerland. In both areas, it is highly frequent and has few semantic and syntactic restrictions (van Pottelberge 2004; Flick 2016; Elspaß \& Möller 2011).

${ }^{20}$ Speakers of Dutch tend to encode events with a focus on ongoingness, while speakers of German rather describe the event holistically (see also Flecken 2010). As far as I am aware, similar studies with speakers of Limburgish have not been carried out yet.
} 
phoning'). Yet, it seems that lopen is less frequent than the postural verbs (see figure in Breed et al. 2017: 337; Lemmens 2005: 211-14). ${ }^{21}$

Typically, posture verb constructions are used in contexts where the physical posture corresponds with the respective posture verb. Yet, over the past decades, zitten 'to sit' has acquired a more general meaning, appearing in contexts where the agent is not sitting but either standing or walking, and is sometimes combined with lexical verbs incompatible with postural positions (Fraser \& Pots in preparation; van den Berg \& Oosting 2017). In addition, posture verbs are frequently employed in other, nonprogressive contexts to indicate a location, e.g. De sleutels liggen op de tafel 'The keys are on the table' (Lemmens 2005: 189-90; see further Ebert 1989: 311-13 for examples).

\subsubsection{Beim/Im-constructions in German}

While German has no posture verb constructions, it has two other constructions that have no direct equivalent in Dutch and Maaslands, namely the beim- and im-constructions. These are formed with sein-FINITE 'to be' plus beim/im and V-INF, as illustrated in (6) and (7).

(6) Das Buch ist im Erscheinen. (Ebert 1996: 48)

the book is PROG appear ${ }_{\text {INF }}$

'The book is appearing.'

(7) Anna ist beim Kochen. (Ebert 1996: 46)

Anna is PROG cook INF

'Anna is cooking.'

Both constructions have a significantly lower frequency than the am-construction (Ebert 1996: 46-48; Witt 2015: 142; Krause 2002: 88). ${ }^{22}$ Generally, am is possible in all constructions where beim is possible but not vice versa (Miller et al. 2017). Importantly, beim 'at' and im 'at/in' are not freely exchangeable but the range of possible verbs is much smaller (8).

(8) *Mein Nachbar war im Essen. my neighborwas in food/?eat ${ }_{\mathrm{INF}}$

(Andersson 1989: 97)

? 'My neighbor was eating.'

\footnotetext{
${ }^{21}$ Dutch also uses hangen 'to hang,' which is less grammaticalized (Lemmens 2005: 211-14; Ebert 1996: 53). See Newman (2002) for a cross-linguistic overview; and Lemmens (2002) for the semantics of Dutch posture verbs.

${ }^{22}$ While the beim-construction is listed in the Kleines Wörterbuch der Verlaufsformen im Deutschen (Engelberg et al. 2013), this does not hold for the im-construction.
} 
While Mein Nachbar war am/beim Essen 'My neighbor was eating' expresses ongoingness, example (8) conveys the meaning that the subject was literally 'sitting in the food' (Andersson 1989: 97). Note that the German verbal infinitive essen 'to eat' is homophonous with the noun (das) Essen 'the food.' According to Ebert (1996: 46), the im- and beim-progressives are mutually exclusive: Whereas beim is confined to a small number of agentive verbs, im may only occur with certain non-agentive verbs (see further Andersson 1989: 97-98; Witt 2015: 11; van Pottelberge 2004: 198; Krause 2002: 235-36; Gárgyán 2010: 33-34; Miller et al. 2017). ${ }^{23}$

\title{
7.3.6 Bezig zijn te/Dabei sein zu-constructions
}

In addition, the contact varieties denote progressive meaning with 'to be busy with/to be in the process of' (Lemmens 2012: 286; Breed et al. 2017; Krause 2002; Gárgyán 2010; Ebert 1996), although not all authors agree on classifying these constructions as progressives (for Dutch, see van Pottelberge 2007: 113-15; Breed et al. 2017). Despite the fact that the use of dabei sein $z u$ has a wide distribution in German (Krause 2002: 89), it received comparably little attention in the literature (Witt 2015: 177). Consider the constructed examples in (9).

\begin{tabular}{|c|c|c|c|c|c|c|}
\hline 9) a. Hij & is & bezig & een & cake & te & bakken. (BD) \\
\hline b. $(\mathrm{H})$ eeë(r) & is & bezig & 'ne & kook & te & bakke. (MA) \\
\hline $\begin{array}{l}\text { c. Er } \\
\text { he }\end{array}$ & $\begin{array}{l}\text { ist } \\
\text { is }\end{array}$ & $\begin{array}{l}\text { dabei, } \\
\text { (busy) }\end{array}$ & $\begin{array}{l}\text { einen } \\
\mathrm{a}\end{array}$ & $\begin{array}{l}\text { Kuchen } \\
\text { cake }\end{array}$ & $\begin{array}{l}\mathbf{z u} \\
\text { to }\end{array}$ & $\begin{array}{l}\text { backen. }(\mathrm{G}) \\
\text { bake }\end{array}$ \\
\hline
\end{tabular}

'He is baking a cake.'

In Dutch (9)(a) and Maaslands (9)(b), this construction is formed with bezig zijn-FINITE 'to be busy,' followed by (om) te 'to' plus V-INF, or met 'with' and an NP. In German (9)(c), dabei sein-FINITE is followed by $z u$ 'to,' broadly translating as 'to be in the process of,' plus

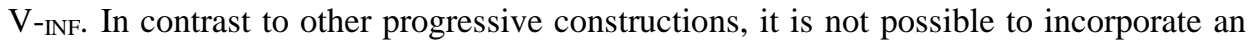
object: *te cake bakken/*te kook bakke/*zu kuchenbacken '[He is busy] to cake bake' (Ebert 1996: 48; 52).

\subsubsection{Further Progressive Types}

\begin{abstract}
Absentive
Recent works on progressive aspect (Ebert 1996: 52; Flick 2016: 169; Krause 2002; Tomas 2018: 193-99; Bertinetto et al. 2000; Engelberg et al. 2013) often mention the 'absentive,' i.e. constructions 'conveying the meaning of an event occurring in a place

${ }^{23}$ Furthermore, a recent experimental study by Miller et al. (2017: 222-24), in which subjects watched video clips, shows that native speakers of German clearly distinguish between am and beim in verbs of low dynamicity.
\end{abstract}


(characteristically reserved for a given purpose) displaced from the deictic centre' (Bertinetto et al. 2000: 527). A Dutch example is given in (10).

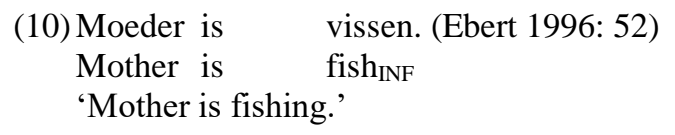

From a semantic perspective, (10) differs from other progressive constructions insofar as the utterance does not necessarily imply that the protagonist is actually fishing, but she might as well be on her way to the fishing place (Ebert 1996: 52). Yet it is controversial whether the absentive can be regarded as progressive type (see e.g. Witt 2015: 12).

\section{Temporal Adverbs}

In particular in non-marked progressive constructions, progressive meaning is often marked by temporal adverbs (Dahl 1985: 90; Ebert 1996: 49; Krause 2002: 155; Henriksson 2006: 110-12; Witt 2015: 236-46; Nicolay 2007: 2; 42):

$$
\begin{aligned}
& \text { (11) Er arbeitet gerade. (German) } \\
& \text { he works just } \\
& \text { 'He is working right now.' }
\end{aligned}
$$

Adverbs such as gerade 'just' as in (11) are often combined with other progressive constructions. While some authors consider gerade as a systematic marker of progressive (Dahl 1985: 90), there is no consensus of whether temporal adverbs shall be regarded as progressive types or not (van Pottelberge 2007: 111).

\section{Limburgish Gerund with -entere}

Finally, there is a progressive construction specific to the Limburgish dialects, formed with 'to be' plus the stem of the respective verb and the ending -entere (12) (Aarts 2005: 70; 2001: 146; Barbiers \& al. 2006) (example Aarts 2005: 70).

$$
\begin{aligned}
& \text { (12) zeet geer mèt de fiets? -Nein, veer zien loupentere. } \\
& \text { are you with the bike no we we are walk } \\
& \text { 'Are you by bike? -No, we have been walking.' }
\end{aligned}
$$

While the gerund with -entere is still productive in the dialect of Maastricht (Aarts 2005; 2001), its use has considerably declined over the past decades in the dialect of Eisden. Nevertheless, it should be kept in mind that it possibly had a wider distribution when the Cité Duits speakers acquired Maaslands. 


\subsubsection{Summary}

In sum, Cité Duits contact varieties share a number of means to denote progressive aspect. First, speakers may use the present or past tense to refer to durative events occurring at reference time. Generally, such 'non-marked progressives' or 'implicit uses' are more common in German than in Dutch. Second, progressive aspect can be marked explicitly, with the most common construction being the aan-het/aon't/am-progressive. In Dutch, however, this construction is further grammaticalized than in German and has fewer semantic and syntactic restrictions (more in $\S 7.7$ below). Moreover, Dutch and Maaslands frequently use posture verbs such as 'to sit' for expressing ongoingness. These or similar uses do not exist in German. In turn, German has the beim- and im-progressive. In addition, the three varieties express that an event is ongoing with bezig zijn (om) te or with dabei sein zu, literally 'to be busy with' or 'to be in the process of.' Moreover, Limburgish dialects, although not very productive anymore, have the gerund-progressive with -entere. Further means to express progressive include the absentive construction and the optional use of temporal adverbials.

\subsection{Methodological Challenges}

The investigation of aspectual distinctions in Cité Duits implies several methodological challenges. First, how do we decide whether a given construction denotes progressive meaning? A construction that can be translated in the same way, for instance, does not automatically carry the same functions. As van Pottelberge points out, following Saussure (1968-1974 [1916]),

a specific linguistic sign, e.g. the progressive in one of the Germanic languages, cannot be delimited simply by checking which expressions are used to refer to a 'progressive' state of affairs or an 'ongoing action', as reference to an ongoing action in itself does not imply that the linguistic structure in question is necessarily associated with ongoing action as its linguistic (i.e. grammatical) meaning. ... Conversely, a difference in form does not necessarily imply the existence of an independent linguistic entity. (van Pottelberge 2007: 105-06)

Consequently, in order to determine whether an utterance had a potential progressive meaning, I considered the context and decided case by case. ${ }^{24}$ The advantage of a small data set - as opposed to a large one - is that you can check or address every single utterance made by the speakers. In particular for non-marked progressives and absentives, there is no contextual device to search for. Moreover, contextual devices such as am or aan in the am-/aan het-construction appear not only in progressive contexts (e.g. ich bin am spielen

\footnotetext{
${ }^{24}$ Next to their prototypical function of conveying ongoingness, progressive-like constructions have been shown to appear with future events and temporary habits in German and Dutch, being used to reflect the speaker's attitude (Anthonissen et al. 2016; 2019).
} 
'I am playing'), but also with NPs (e.g. ich bin am Bahnhof 'I am at the station'). Working with the database MOCA (Multimodal Oral Corpora Administration) allowed me to label all examples, making it possible for the results to be filtered automatically (see $\S 3.6 .4$ ). As such, the database gave me the chance to examine progressive uses within the contextual information of the utterances. The final product was a database that could be filtered for several sorting options. In these examples, I controlled manually whether the utterance had a potential progressive meaning.

Second, from an empirical perspective, dealing with spontaneous speech implies that constructions not produced by the speakers cannot be analyzed. The probability of certain patterns occurring more than once is much smaller than in a large corpus. In addition, progressives tend to have a much lower frequency than, for instance, personal pronouns. ${ }^{25}$ Note that the written document that I considered for previous analyses (see $\S$ 4.4.6, § 6.5) does not contain any constructions that could be associated with the progressive.

Third, on the theoretical side, a major problem pertained to the absence of empirical analysis regarding the progressive aspect in Maaslands. Although crosslinguistic investigations with speakers of Dutch and German have been conducted (e.g. Flecken 2010; 2011a; Behrens et al. 2013), I have no evidence on how progresssive constructions behave in Maaslands in terms of frequency. Of course, I consulted the databanks DynaSAND (Dynamische Syntactische Atlas van de Nederlandse Dialecten) and MAND (Morfologische Atlas van de Nederlandse Dialecten), as well as a number of studies devoted to grammatical properties of Limburgish dialects (e.g. De Schutter \& Hermans 2013). ${ }^{26}$ But, as pointed out (§ 1.2.4), Limburgish dialects, rather than being homogenous in use, have distinct lexical and grammatical properties (Cornips 2013). I tackled this issue in the following way. I conducted translation tasks in the dialect with two speakers from Eisden (one male, one female, age around 80) and audio-recorded them. Yet this kind of data needs to be regarded with caution, as there is often a gap between what speakers claim to do and what they actually do (Labov 1972). In addition, these results provide no indication on the actual frequency of use of the respective constructions.

Fourth, many previous studies base their analysis on written language, or on a mix of written and (formal) spoken language (see Lemmens 2005: 187; Breed et al. 2017: 320; van Pottelberge 2004: 154; 81), while the data of Cité Duits consists of informal conversations. Moreover, Dutch data often stems from Netherlandic Dutch, and in mixed Netherlandic-Belgian corpora, a minor part of the data comes from Belgium (e.g. 90\% versus 10\%) (Lemmens 2005). An exception forms the Lassy Groot corpus in the study by Breed, Brisard, and Verhoeven (2017), in which both varieties are substantially represented. In turn, a number of studies have examined progressive use based on data of

${ }^{25}$ Similar observations were made for Dutch: in their corpus analysis of spontaneous spoken Dutch (CGN), Anthonissen et al. (2019: 1128) find that progressive verbs do not occur more often than in one percent of the cases.

${ }^{26}$ I also consulted the dialect sentences for Eisden (Van Keymeulen 2018), but these do not contain much information on the progressive. 
spoken German (Krause 2002; Anthonissen et al. 2016), in German dialects (Bhatt \& Schmidt 1993; Kuhmichel 2016; Ramelli 2015) and across different German-speaking areas such as Austria and Switzerland (van Pottelberge 2004; Flick 2016; Elspaß \& Möller 2011). In addition, the online-version of the Kleines Wörterbuch der Verlaufsformen im Deutschen 'Concise dictionary of progressive aspect in German' (Engelberg et al. 2013) provides an overview of verbal infinitives in the progressive including examples, based on the Deutsches Referenz-Korpus 'German Reference Corpus' (DeReKo, Institut für Deutsche Sprache). The latter, however, is based on text corpora.

Unlike its Dutch counterpart, ${ }^{27}$ the am-progressive displays a large degree of (regional) variation. In section 7.7, I will therefore consider a German corpus consisting of interview recordings with speakers of dialectal and standard varieties of German from seven different German cities. The recordings are approximately the same length, with six fully transcribed recordings conducted in Duisburg, 11 in Cologne, seven in Dresden, nine in Freiburg and ten in Mannheim, Munich, and Berlin, respectively. The largest proportion of recorded speech comes from speakers in Southern Germany (29 recordings), while a roughly equal number comes from speakers in Middle-West and East Germany (17 recordings) (see § 3.6.3).

\subsection{Progressive Aspect in Cité Duits}

Having set the stage for the subsequent analysis, I will now turn to the issue of progressive aspect in the data (sub-questions (i) and (ii)). Based on frequency of occurrence, I will demonstrate that there is one most common construction for conveying progressive meaning. This construction, as I will illustrate, has developed a morphological variant not found in the contact varieties. Furthermore, I will show that Cité Duits shares one construction with German that does not exist in Dutch or Maaslands, and one construction with Dutch and Maaslands not found in German.

\subsubsection{Frequency Distribution of Progressive Constructions}

This section discusses the different means in Cité Duits to express that an event is ongoing. Table 35 presents an overview of the constructions identified and their frequency distribution.

\begin{tabular}{|l|l|l|}
\hline $\begin{array}{l}\text { PROGRESSIVE } \\
\text { CONSTRUCTION }\end{array}$ & N & \% \\
\hline an-construction & 77 & 89.5 \\
\hline beim V-INF Sein & 4 & 4.7 \\
\hline
\end{tabular}

${ }^{27}$ Previous studies suggest that there is little regional variation in the Dutch aan-het progressive. Flecken (2011b: 498), however, finds differences related to age, i.e. younger speakers use the progressive more often than older speakers. 


\begin{tabular}{|l|l|l|}
\hline bezig über NP & 3 & 3.5 \\
\hline posture verb & 2 & 2.3 \\
\hline im V-INF sein & 0 & 0 \\
\hline dabei sein zu V-INF & 0 & 0 \\
\hline absentive & 0 & 0 \\
\hline gerund & 0 & 0 \\
\hline Total & 86 & 100 \\
\hline
\end{tabular}

Table 35: Overview of progressive constructions in Cité Duits

Table 35 reveals that in roughly 90 percent $(n=77)$ of the examples speakers employ the an-construction for conveying progressive aspect. In addition, if to a much lesser extent, speakers use posture verb constructions $(\mathrm{n}=2$ or $2.3 \%)$, constructions with beim $(\mathrm{n}=4$ or 4.7\%), as well as constructions that resemble the bezig-construction in Belgian Dutch and Maaslands $(n=3$ or $3.5 \%){ }^{28}$ These findings raise the question of whether the contact varieties exhibit similar distributions. Before elaborating on these frequencies, I will discuss these constructions by means of examples from the corpus (see appendix for a complete list). ${ }^{29}$

\subsubsection{An-construction}

The an-construction, which is the most frequent progressive construction in Cité Duits (Table 35), is invariably formed with the verb sein-FINITE 'to be' and the respective infinitive of a verb, in this regard corresponding to German, Maaslands, and Belgian Dutch. In contrast, the 'introductory element' has a number of variants, realized as an [an] (13), aan [a:n] (14), am [am] (15) and aan't [a:nt] (16). While the $t$-variant resembles Belgian Dutch (aan't) and Maaslands (aon't), the am-variant corresponds phonologically to the respective German form (am). In turn, an or aan are untypical for the contact varieties.

${ }^{28}$ Furthermore, the corpus contains one example that could be interpreted as either absentive or '(an/beim)-progressive without an/beim, namely wie warn esse 'we were eating' (231115_4: 122.041 - 124.827). The context suggests that the speaker reports an event where he is present, rendering an absentive meaning unlikely. But as Tomas (2018: 199) observes, it can be difficult to draw a line between the absentive and the am-progressive.

${ }^{29}$ In addition, speakers use a number of temporal adverbials. Because it remains debatable whether such lexical items can be regarded as progressive types - their use is optional, after all, and they often appear combined with one of the progressive constructions above (Mair 2012: 804; Gárgyán 2010: 38; Henriksson 2006: 110-12; Witt 2015: 240) - I will not provide an exhaustive description here. The most frequently used temporal adverbials in Cité Duits are noch 'still' and jetz 'now.' This preference by the speakers differs from spoken German, where gerade 'still' is the most common temporal adverb in progressive use (Witt 2015; Nicolay 2007: 2; 42; Dahl 1985: 90; Henriksson 2006: 110-12; Gárgyán 2010: 38). 


$\begin{array}{llllll}\text { (13)(0314_140913: } 789.858 & -790.753, \text { Diego) } & \\ \text { die } & \text { war } & \text { für } & \text { NON } & \text { an } & \text { lerne. } \\ \text { she } & \text { was } & \text { for } & \text { nun } & \text { PROG } & \text { studyINF }\end{array}$

'She was studying to become a nun.'

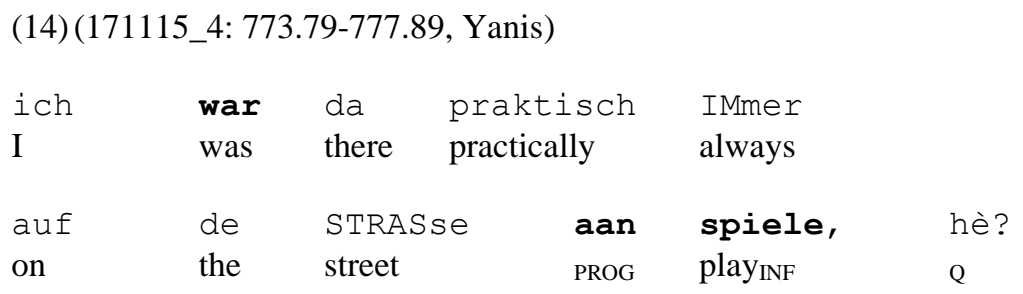

'I was always playing there on the street.'

(15) (0313_152448: 873.82 - 877.41, Yanis)

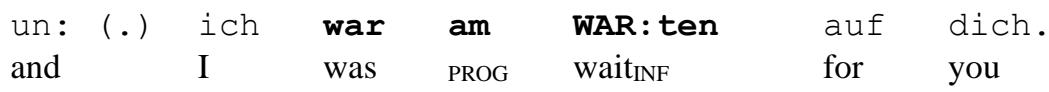

'And I was waiting for you.'

\begin{tabular}{|c|c|c|c|c|c|}
\hline $\begin{array}{l}\mathrm{DA} \\
\text { there }\end{array}$ & $\begin{array}{l}\text { warn } \\
\text { were }\end{array}$ & $\begin{array}{l}\text { wir } \\
\text { we }\end{array}$ & $\begin{array}{l}\text { noch } \\
\text { still }\end{array}$ & $\begin{array}{l}\text { mit } \\
\text { with }\end{array}$ & $\begin{array}{l}\text { de } ;= \\
\text { the }\end{array}$ \\
\hline $\begin{array}{l}=\text { die } \\
\text { those }\end{array}$ & $\begin{array}{l}\text { plafe } \\
\text { ceiling }\end{array}$ & JDS & $\begin{array}{l}\operatorname{aan}^{\prime} t \\
\text { PROG }\end{array}$ & $\begin{array}{l}\text { macl } \\
\text { make }\end{array}$ & \\
\hline
\end{tabular}

'We were still reworking the ceilings.'

Closer inspection of the data reveals that these forms have a clear distribution, depicted in Table 36. As it was not always possible to distinguish between the long and short vowel, I treat aan [a:n] and an [an] as a single variant.

\begin{tabular}{|l|l|l|}
\hline REALIZATION & $\mathbf{N}$ & $\mathbf{\%}$ \\
\hline$[\mathrm{a}: \mathrm{n}][\mathrm{an}]$ & 47 & 61 \\
\hline$[\mathrm{am}]$ & 26 & 33.8 \\
\hline
\end{tabular}




\begin{tabular}{|l|l|l|}
\hline [a:nt] & 4 & 5.2 \\
\hline Total & 77 & 100 \\
\hline
\end{tabular}

Table 36: Realization of 'an' in the an-progressive in Cité Duits

As can be deduced from Table 36, the form aan/an [a:n]/[an] without $-t$ makes up the lion's share ( $\mathrm{n}=47$ or $61 \%$ ), whereas am [am] is employed significantly less often (34\%). Strikingly, the realization with ' $t$ as in Belgian Dutch and Maaslands is limited to four tokens $(5 \%)$. In other words, speakers most often produce a form that would not be used in Belgian Dutch, Maaslands, or German (although aan/an exists as preposition). How this form can be interpreted will be discussed at the end of this subsection.

\section{An-constructions without Finite Verb}

Moreover, the data contains an-constructions without finite verb $(n=3)$, illustrated in (17) and (18).

\begin{tabular}{|c|c|c|c|c|}
\hline de $(r)$ & aan & aan & BELlen, & hè? \\
\hline he & PROG & PROG & phone $_{\text {INF }}$ & Q \\
\hline $\begin{array}{l}\text { un dann } \\
\text { and then }\end{array}$ & $\begin{array}{l}\text { kommt } \\
\text { comes }\end{array}$ & $\begin{array}{l}\text { de } \\
\text { the }\end{array}$ & $\begin{array}{l}\text { frau; } \\
\text { woman }\end{array}$ & \\
\hline
\end{tabular}

'He [is] talking on the phone, and then comes the woman.'

(18) (231115_3: 1503.342 - 1508.626, Jan)

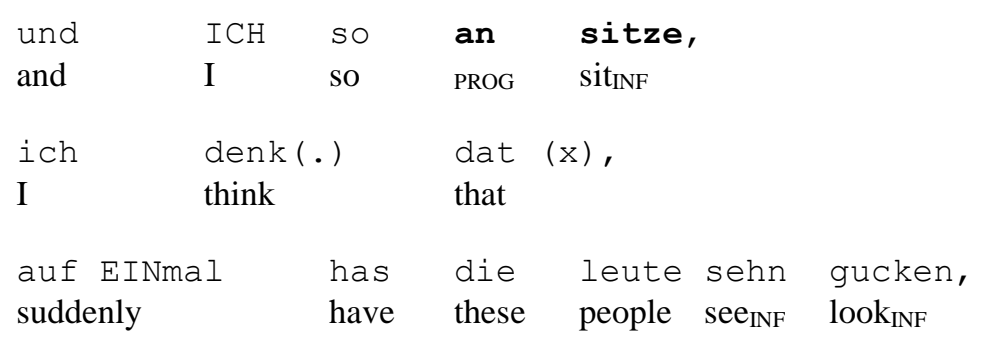

'I [was] sitting there, and I think that- suddenly you saw those people looking at me.'

In previous studies, it often remains unclear how the authors dealt with utterances in which no finite verb was articulated. Only the study by van Pottelberge (2004: 166-172; 192) reports similar uses ('absolute' aan-het Phrasen). According to van Pottelberge, 
progressive constructions without copula verb are common in Dutch and also exist in colloquial standard German.

\subsubsection{Beim-construction}

In line with German (§ 7.3.5), the beim-construction is usually formed with sein-FINITE 'to be' plus beim and V-INF in Cité Duits, depicted in (19).

$$
\begin{aligned}
& \text { (19) (231115_3: 258.041 - 262.89, Raf) } \\
& \text { un da war se beim Essen oder so, } \\
& \text { and there was she PROG eat INF or so }
\end{aligned}
$$

'And she was eating or something.'

From a syntactic and semantic perspective, (19) corresponds to German. Likewise, it would be acceptable to use am instead of beim without yielding an ungrammatical construction (und da war sie am essen). While the beim-progressive has been argued to be confined to agentive verbs in German (§ 7.3.5), this seems to hold for Cité Duits as well, although the number of examples is too small for such generalization. At the same time, however, the comparably small number of tokens may also indicate that the beimprogressive does not occur because similar semantic restrictions apply to Cité Duits, and this would imply that the range of possible uses remains restricted. ${ }^{30}$ Progressive constructions with im did not occur (Table 35). In fact, im in Cité Duits has a low frequency in general $(n=22)$, which could suggest that speakers use other lexical items instead such as in. This is not the case here, however. Although speakers often employ in 'in' as preposition, they do not use it as a progressive marker.

\subsubsection{Bezig über-construction}

The bezig-construction is formed with the adjective bezig 'busy,' lexically resembling Belgian Dutch and Maaslands, plus a PP introduced by über 'about,' lexically resembling German, followed by an NP ((20), (21)).

$$
\begin{aligned}
& \text { (20)(171115_3: 593.809-599.242, Jan) } \\
& \begin{array}{llll}
\text { HIER warn se bezig über chaRAKters. } \\
\text { here were they busy about characters }
\end{array}
\end{aligned}
$$

\footnotetext{
${ }^{30}$ For the beim-construction, see also Witt (2015: 140-75); Gárgyán (2010: 32-33); for restrictions of beim versus im, see Gárgyán (2010: 43), and for beim versus am, see Miller et al. (2017). Moreover, Emmel (2005) analyzed the beim-construction in the German of speakers from Pomerode, Brazil.
} 
'Here, they were talking about characters.'

(21) $\left(171115 \_5: 261.541-263.404\right.$, Jan $)$

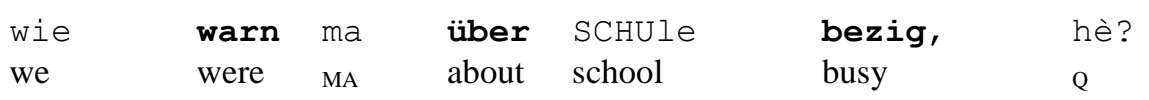

'We were just talking about school.'

As visible from above, the construction is formed with 'sein-FINITE + bezig + über' 'to beFINITE + busy + about' and followed by an NP, in contrast to German, where dabei sein zu 'to be in the process of' requires a verbal infinitive. The dabei sein zu-construction, which is fairly frequent in German (see $\S 7.6$ below), was not used by the speakers.

In Belgian Dutch, the bezig-progressive has several options: bezig may be followed by te, om te and by a prepositional phrase introduced by aan or met plus verbal infinitive (NP), and may also occur without a complement, i.e. Ik ben bezig 'I am busy' (van Pottelberge 2007: 1131-114; Breed et al. 2017), literally corresponding to German Ich bin beschäftigt.$^{31}$ In the data, the bezig-construction is exclusively employed with the meaning 'to talk about something,' which raises the question of whether this construction can be regarded as a distinctive progressive construction. If this construction primarely denotes ongoingness, I would expect it to occur across several contexts. Based on the available data, it rather seems that this construction is restricted in use (and also to a single speaker). Although a similar construction is found in the contact varieties to express ongoingness, I propose that 'sein + bezig + über $+N P$ ' cannot be classified as a fully established progressive construction.

\subsubsection{Posture Verb Construction with sitzen zu}

The posture verb constructions are formed unanimously with the posture verb sitzen 'to sit,' yielding the construction 'posture verb $+z u+\mathrm{V}_{-\mathrm{INF}}$,' exemplified in (22) and (23).

\begin{tabular}{|c|c|c|}
\hline $\begin{array}{l}\text { in_iTALje, } \\
\text { in Italy }\end{array}$ & $\begin{array}{l}\text { (da) } \\
\text { there }\end{array}$ & $\begin{array}{l}\text { sitzen } \\
\text { sit }\end{array}$ \\
\hline $\begin{array}{ll}\text { allemaal } & \mathbf{z u} \\
\text { all } & \text { to }\end{array}$ & $\begin{array}{l}\text { WARte } \\
\text { wait }_{\text {INF }}\end{array}$ & $\begin{array}{l}\text { schon. } \\
\text { already }\end{array}$ \\
\hline
\end{tabular}

${ }^{31} \mathrm{~A}$ similar use without complement would theoretically be possible in German, I suspect, but only confined to specific question-answer contexts (e.g. Ich bin dabei as answer to the question 'Have you finished $\mathrm{x}$ ?'). 
'In Italy, everyone is already (sitting and) waiting there.

\begin{tabular}{|c|c|c|}
\hline un sassen & wie & $\mathrm{zu}$ \\
\hline and sitPST & we & to \\
\hline
\end{tabular}

'And we were (sitting and) eating.'

These constructions are remarkable to the extent in which they correspond syntactically to Belgian Dutch and Maaslands, but resemble German in terms of lexis. The finite verbs of 'to sit' (present tense sitzen/past tense sassen) are homophonous with the respective German verbs, whereas the syntax corresponds to the Belgian Dutch/Maaslands posture verb construction 'posture verb $+t e+\mathrm{V}$-INF.' $Z u$ 'to' can be associated with German lexis (see also $\S$ 4.4.6). ${ }^{32}$ As outlined above (§ 7.3.4), German does not have posture verb constructions with progressive meaning. ${ }^{33}$ Furthermore, from a semantic perspective, the available examples appear in contexts where the physical posture corresponds with the posture verb, that is, where the respective agent is actually sitting, in line with Belgian Dutch and Maaslands.

\subsubsection{Non-marked Progressives}

Having shown that Cité Duits' contact varieties do not necessarily mark progressive meaning overtly, especially German (§ 7.3.2), it raises the question of whether Cité Duits always marks progressive overtly or whether the present/past tense may be used instead. Principally, non-marked progressives are possible in Cité Duits (24).

\begin{tabular}{|c|c|c|c|}
\hline $\begin{array}{l}\text { wenn } \\
\text { when }\end{array}$ & $\begin{array}{l}\text { die } \\
\text { they }\end{array}$ & $\begin{array}{l}\text { da } \\
\text { there }\end{array}$ & $\begin{array}{l}\text { SASsen, } \\
\text { sitpst }\end{array}$ \\
\hline $\begin{array}{l}\text { un de } \\
\text { and he }\end{array}$ & $\begin{array}{l}\text { kaom } \\
\text { come }\end{array}$ & $\begin{array}{l}\text { da } \\
\text { there }\end{array}$ & $\begin{array}{l}\text { FIETSke } \\
\text { bike }_{\text {DIM }}\end{array}$ \\
\hline
\end{tabular}

${ }^{32}$ Unlike Dutch/Maaslands, most Germanic languages have a coordination pattern (e.g. Swedish Jag sitter och läser 'I sit and read') (Ebert 1989; 1996; 2000; Bertinetto et al. 2000). I did not establish such coordination patterns in my sample. Furthermore, the data contains examples with 'to sit' and 'to lie' as locational verb (e.g. dat saß da voll mause 'It was teeming with mice.'). These constructions, however, do not have a primarily progressive meaning.

${ }^{33}$ Yet it appears to be the case that the German dialect of the Westerwald has posture verb constructions with 'to sit' (Ebert 1996: 50). 
'When they were sitting there, and he arrived by bike...'

In (24) the speaker narrates a situation in which the first verb sassen 'sat' expresses an ongoing event in the past, whereas the second verb kaom (aan) 'arrived' introduces the event itself. But such examples are quite rare. The verb sitzen 'to sit,' for example, occurs in twenty overtly-marked progressive constructions, whereas it occurs only seven times in non-marked progressives (five examples are present tense and two examples are past tense use) ${ }^{34}$ Interestingly, Cité Duits allows for an-constructions with posture verbs as main verbs, as we will see below (§ 7.7.3).

Generally, non-marked progressives occur with a number of verbs that do not easily allow for a progressive interpretation, such as leben 'to live,' which occurs in 31 examples with none of them in the progressive form (25).

$$
\begin{aligned}
& \text { (25) (231115_4: } 1938.014-1939.503 \text {, Victor) } \\
& \text { wat die } \quad \text { LEBT noch? }{ }^{35} \\
& \text { what } \quad \text { she lives still }
\end{aligned}
$$

'What? Is she still alive?'

Although the German utterance sie ist am Leben ('she is alive') yields a fully grammatical construction, this construction is not compatible with progressive meaning. As shown by others (Flick 2016: 172-73), German has a number of lexically specified phrases that have the form of the am-construction and look like a grammatical progressive, but do not denote ongoingness (but see $\S 7.7 .3$ for the semantics of the an-progressive). Likewise, the verb sagen 'to say' always appears in the present or past tense. From a Vendlerian perspective, this verb does not easily combine with the progressive in Dutch and German (e.g. ? Er ist am sagen dass... 'He is saying that...'). Aside from these uses, there is evidence that speakers rather mark progressive aspect overtly instead of leaving it implicit.

\subsubsection{Interpretation of $a n$}

In this section, I propose that an can be analyzed as a progressive marker in Cité Duits whose emergence can be explained by cross-linguistic evidence on the one hand, and by the linguistic structure of Cité Duits on the other hand. As illustrated above (§ 7.5.2), the

\footnotetext{
${ }^{34}$ Furthermore, sitzen 'to sit' appears with modal verbs, e.g. die hat auf zwei stuhle musse sitze, lit. 'she had to must sit on two chairs' (0314_140913: 279.105 - 281.105) and with bleibe 'to stay' (die sind nich bleibe sitze, ne? 'They did not remain seated' (0313_152448: 194.91 - 199.8), rendering a progressive construction redundant.

${ }^{35}$ The final plosive in wat can be associated with Dutch/Maaslands, whereas standard German has a fricative here. The finite verb lebt 'lives' is realized according to German pronunciation.
} 
an-progressive has different realizations of the progressive marker, the most frequent variant being (a)an, a variant that does not exist in Belgian Dutch, Maaslands, or German.

The existence of different variants in the progressive construction is not unique to Cité Duits, but is also found in, for example, Low German and Pennsylvania German (Andersson 1989: 104; van Pottelberge 2004: 225-30; Tomas 2018: 78; Louden 1994). In his analysis of the am-progressive in Pennsylvania German, Tomas (2018: 78) finds that speakers alternate between $a m$ and $a n$, with 25 percent realized as $a n$. This distribution differs considerably from the Cite Duits data, where an is with 61 percent the most common realization. Similarly, Low German has been reported to use two variants, namely $a n$ and $a n$ 't, depicted in (26) and (27) (examples van Pottelberge 2004: 226, internet source).

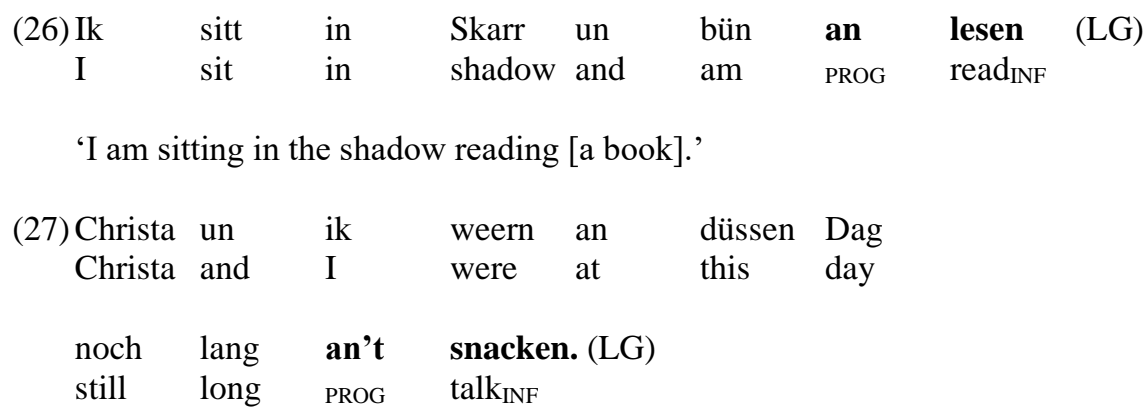

'Christa and I were talking for a long time that day.'

Similar to Cité Duits, the two variants may co-occur in the same context (ibid.). It is clear that transfer to Cité Duits can be excluded as a possible explanation, since there was no direct and enduring contact with speakers of Low German (see § 3.4.3). Contact with Ruhr-German is much more likely. While the am-progressive is characteristic of RuhrGerman (Becker 2003: 400; Schiering 2002: 3), none of these studies mention progressive constructions with an. ${ }^{36}$

Across a number of Germanic languages, speakers use similar elements to convey progressive meaning, namely elements that resemble prepositions, which suggests a general mechanism (Booij 2008). Aside from Dutch and German, also Afrikaans, Frisian, Fering/Föhr Frisian, Danish, and Icelandic use 'prepositional constructions' (Ebert 2000: 607; 1989; Booij 2008; van Pottelberge 2004). Furthermore, from a historical perspective, it is interesting to note that Old English had a preposition as well ('She was at hunting') (Denison 2014: Ch. 13).

\footnotetext{
${ }^{36}$ Yet, an instead of am is attested in contexts of determiner reduction (Scholten 1988: 164-72; Schiering 2002: 3; Mihm 1995: 21-22; Becker 2003: 231).
} 
In the literature, however, there is no consent on the internal structure of aan het in Dutch and am in German. While some characterize am in the German progressive construction as a contraction of the preposition an and the determiner dem in the dative case (Witt 2015: 6), a number of authors (Tomas 2018: 75-86; Bhatt \& Schmidt 1993: 7583; Broekhuis et al. 2015a: 151-56; Ramelli 2015: 208-14; Booij 2008; Bergstra 2019: 129-32) convincingly argue that the assumed determiner does not fulfill the role of a determiner here. For instance, Dutch het cannot be replaced by the common gender determiner de in the progressive (*Zij is aan de lezen 'she is reading'), nor is it possible to substitute the nominalized infinitive by a definite NP such as *zij is aan het de krant lezen, literally 'she is PROG the newspaper reading.' Similarly, in German, where the amprogressive is not yet as grammaticalized as in Dutch, progressive am cannot be

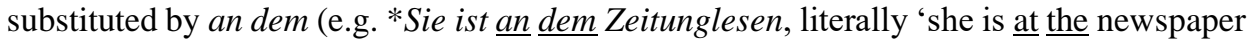
reading'). ${ }^{37}$ Accordingly, neither German am nor Dutch aan het has the typical properties of a PP with a nominalized infinitive as P-complement. Rather, it appears that these elements form part of the progressive construction. Prepositions have been demonstrated to be particularly suitable for turning into grammatical markers because they usually consists of a single syllable and tend to merge easily with other elements (Tomas 2018: 80, based on Abraham 2004: 156). ${ }^{38}$

Given that the aan het/am-construction is one of the most frequent means to express ongoingness in varieties of Dutch and German (see also $§ 7.6$ ), it is plausible that an in Cité Duits developed out of the Belgian Dutch/Maaslands/German progressive markers aan 't, aon ' $t$ and $\mathrm{am}$. The fact that all three contact varieties use a phonologically related marker to convey progressive meaning certainly played a role in this development. In contrast, given the recent history of emergence of Cité Duits $(\S 2)$, it is unlikely that an as a progressive marker first became productive as a lexical element in Cité Duits, and later turned into a grammatical marker indicating progressive aspect. The fact that there are still traces of aan ' $t$ as well as a significant number of am-examples in the data rather indicate that an developed out of the existing progressive markers in the three contact varieties.

In this regard, it can be observed that an as progressive marker forms part of a larger set of linguistic properties that make up the grammatical character of Cité Duits. Unlike Belgian Dutch and Maaslands, Cité Duits does not use het/'t, neither as a personal pronoun $(\$ 5.4 .6)$ nor as a definite determiner ( $\$ 4.3 .3)$. In a similar vein, the data hardly contains contractions of a preposition and a determiner such as im 'in the' or vom 'of the,' which are typical of spoken German (§ 4.3.9) (Auer \& Cornips forthcoming).

\footnotetext{
${ }^{37}$ See $§ 7.7 .4$ below for syntactic properties of the aan het/am progressive. It should be emphasized that these restrictions do not hold for Pennsylvania German, which has fewer syntactic and semantic constraints than colloquial standard German (see Tomas 2018).

38 Whether these markers are already fully grammaticalized in Dutch and German remains an ongoing debate. For discussions, see Tomas (2018: 75-86) on German and Broekhuis et al. (2015a: 151-56) on Dutch.
} 


\subsubsection{Summary}

In this section I discussed a number of different means for expressing ongoingness in Cité Duits, including non-marked progressives ('implicit use'). Most of the attested constructions differ in some way from their 'contact variety counterparts.' By means of a frequency distribution, I demonstrated that speakers most often use the an-construction (an $\mathrm{V}_{\text {-INF }}$ sein) for conveying progressive aspect. While an is either realized as [an]/[a:n], [am] or [a:nt], the realization as an is most frequent, i.e., a variant that does not exist in the contact varieties. In this context, I have argued that $a n$ can be analyzed as a progressive marker, one that is specific to Cité Duits.

In addition, Cité Duits shares one construction with German that neither exists in Belgian Dutch nor Maaslands (beim-progressive), and one construction with Belgian Dutch and Maaslands that does not exist in German (posture verb progressive). Both exhibit a low frequency. The latter is confined to contexts where the physical posture corresponds to the posture verb, which may suggest that it is subject to semanticcontextual constraints. Unlike in Dutch and Maaslands, this construction is formed with

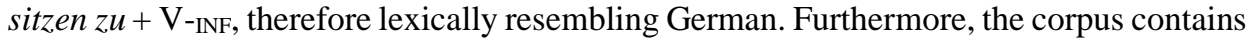
instances of bezig über + NP. Although slightly resembling the bezig-progressive in Belgian Dutch/Maaslands, I proposed that this construction does not exhibit the properties of a progressive marker due to its restriction to a single context.

\subsection{Discussion of Frequencies and Types}

While Cité Duits contact varieties share some formal means to express progressive aspect (see $\S 7.3$ ), previous research revealed that these constructions do not always show the same distribution in native speakers' production (see especially Flecken 2010). This section compares the frequency distributions in the Cité Duits corpus to data of German and Dutch. As mentioned, data similar to Maaslands is not available. I will mainly draw on a study by Krause (2002), which analyzed data of both informal German and Dutch based on a comparable number of tokens. The data of informal Dutch stems from a Dutch chat-corpus and can be regarded as 'conceptually oral' (Koch \& Oesterreicher 1994). Data of spoken German largely derived from television, radio, and everyday conversations. ${ }^{39}$

\subsubsection{Frequency of Progressive Constructions in German}

Table 37 displays the frequency distribution of progressive constructions in spoken German (based on Krause 2002: 89, 'Einzelbelege des gesprochenen Deutschen').

\footnotetext{
${ }^{39}$ Most other studies prove to be unsuitable for comparison because they focus on one specific progressive construction only, on a single language, and/or on formal language (see $\S 7.4$ above).
} 


\begin{tabular}{|l|l|l|}
\hline PROGRESSIVE TYPE & N & $\%$ \\
\hline am-construction & 74 & 61.7 \\
\hline beim + V-INF + sein & 10 & 8.3 \\
\hline dabei sein + zu + V-INF & 22 & 18.3 \\
\hline im V-INF + sein & 6 & 5.0 \\
\hline absentive & 8 & 6.7 \\
\hline Total & 120 & 100 \\
\hline
\end{tabular}

Table 37: Frequency distribution of progressive constructions in German

According to Table 37, the am-progressive is used in roughly 60 percent of the cases, and as such it is the most frequent construction in spoken German, followed by the dabeiprogressive (18\%). Importantly, the corresponding an-progressive in Cité Duits accounts for 90 percent of the tokens, while I did not establish the use of dabei sein $z u{ }^{40}$ Although Krause (2002: 89) points out that the dabei-progressive is predominantly found in formal contexts, it makes up roughly 20 percent in his data of informal spoken German. In contrast, the beim-progressive (8\%), the im-progressive (5\%), and the absentive (7\%) exhibit a low frequency. Compared to the Cité Duits' corpus, it can be stated that the beimprogressive is even less frequent (4.7\%) than in German. ${ }^{41}$

\subsubsection{Frequency of Progressive Constructions in Dutch}

The frequency distribution of progressive constructions in informal Dutch is depicted in Table 38 (based on Krause 2002: 91, 'Bereich II: Chat').

\begin{tabular}{|l|l|l|}
\hline PROGRESSIVE TYPE & N & \% \\
\hline aan het-construction & 81 & 57.9 \\
\hline staan te V-INF & 2 & 1.4 \\
\hline zitten te V-INF & 33 & 23.6 \\
\hline liggen te V-INF & 3 & 2.1 \\
\hline lopen te V-INF & 5 & 3.6 \\
\hline bezig & 2 & 1.4 \\
\hline absentive & 14 & 10 \\
\hline Total & 140 & 100 \\
\hline
\end{tabular}

Table 38: Frequency distribution of progressive constructions in Dutch

\footnotetext{
${ }^{40}$ But see also Systematische Korpora des gesprochenen Deutschen in Krause (2002: 88), where the dabei-construction amounts to merely 3\%. Interestingly, Krause (2002: 88-94) finds the German am-progressive scoring much lower when including written sources (37.5\%), which confirms again that informal and formal language differ significantly here.

${ }^{41}$ Yet, in the German data used by Flecken (2010: 206-07), the beim-construction scores the highest.
} 
Table 38 suggests that the aan-het progressive exhibits the highest frequency in Dutch. With roughly 58 percent, it has a similar frequency as its German counterpart. It is followed by the posture verb construction with zitten 'to sit' (24\%), whereas other posture verbs such as staan 'stand' or liggen 'lie' occur comparably seldom $(\mathrm{n}<5 \%)$. The results by Krause are largely in line with the studies by Behrens et al. (2013) and Flecken (2010), which propose that Dutch speakers produce the aan het-construction more often than posture verb constructions. In contrast, Anthonissen et al. (2019: 1122) find that the aan het- and the zitten-construction have an almost equal frequency, and the study by Breed et al. (2017: 322) even reports a higher frequency of the posture verb construction. ${ }^{42}$

Despite these apparently contradictory results, most studies point toward a high frequency of the zitten-progressive (also Lemmens 2005) and the aan het-progressive, while the other progressive constructions are found less often. In the Cité Duits data, in turn, posture verb progressives have an extremely low incidence (3.5\%) and are confined to the verb sitzen 'to sit,' which means that Cité Duits differs from Dutch in this regard. The bezig-progressive, however, is hardly identified in informal Dutch (1.4\%), as is the case in Cité Duits (3.5\%).

\subsubsection{Interpretation of Frequency Distributions}

Table 39 summarizes the frequency distributions of the progressive constructions in Cité Duits compared to Dutch and German in percentages (based on Krause 2002: 89-91).

\begin{tabular}{|l|l|l|l|}
\hline PROGRESSIVE TYPE & $\begin{array}{l}\text { CITÉ } \\
\text { DUITS } \\
\text { (N= 86) }\end{array}$ & $\begin{array}{l}\text { DUTCH } \\
(\mathbf{N}=\mathbf{1 4 0})\end{array}$ & $\begin{array}{l}\text { GERMAN } \\
(\mathbf{N}=\mathbf{1 2 0})\end{array}$ \\
\hline an-/aan het-/am-construction & 89.5 & 57.9 & 61.7 \\
\hline posture verb 'to sit' & 2.4 & 23.6 & 0 \\
\hline posture verb 'to stand' & 0 & 1.4 & 0 \\
\hline posture verb 'to lie' & 0 & 2.1 & 0 \\
\hline motion verb 'to walk' & 0 & 3.6 & 0 \\
\hline beim V-INF sein & 4.7 & 0 & 8.3 \\
\hline bezig sein über NP & 3.5 & 0 & 0 \\
\hline bezig zijn (om) te & 0 & 1.4. & 0 \\
\hline dabei sein zu & 0 & 0 & 18.3 \\
\hline
\end{tabular}

42 The study by Anthonissen et al. (2019: 1122) is based on the Corpus Gesproken Nederlands (CGN), whereas Breed et al. (2017: 322) analyzed data of written Dutch. In the latter, the aan hetprogressive makes up only 13 percent, whereas posture verb constructions account for 80 percent (zitten $=35.6 \% ;$ staan $=35.7$; liggen $=9.6 \%)$. Considering that posture verb progressives are subject to semantic-contextual constraints, it seems that the type of data (informal-formal language, production task versus interview etc.) makes a crucial difference in frequency distribution. 


\begin{tabular}{|l|l|l|l|}
\hline im V-INF be & 0 & 0 & 5.0 \\
\hline absentive & 0 & 10 & 6.7 \\
\hline Total in \% & 100 & 100 & 100 \\
\hline
\end{tabular}

Table 39: Comparison of progressive constructions in percentages

Table 39 shows that the an-construction exhibits a much higher frequency than the aan het/am-progressive in Dutch/German. Some caution is advised here, however. As established by empirical studies (Flecken 2010: 213) on the aan het/am-progressive involving production tasks, this construction scores significantly higher in Dutch than in German, which contradicts the findings above. Since it has been argued that the Dutch construction is further grammaticalized than its German equivalent, also by others (e.g. van Pottelberge 2004: 325), we would generally expect a higher frequency than in German.

While it remains questionable whether different corpora allow for comparison, Table 39 also shows that Dutch and German use at least two constructions frequently which is in line with previous research (see § 7.3) - whereas Cité Duits mainly uses the an-progressive. These observations indicate that Cité Duits differs to some extent from Dutch and German. Since also a productive pattern in Maaslands, it is likely that the contact varieties reinforced each other. In addition, it is possible that the an-progressive is used significantly more often in Maaslands than in Dutch and German, an aspect that cannot be verified here. Another factor that must be considered is a possible influence of Ruhr-German where this construction has a much wider distribution than in colloquial standard German (Andersson 1989; Bhatt \& Schmidt 1993; van Pottelberge 2004: 212).

Compared to Dutch, it is striking that Cité Duits hardly uses posture verbs to denote progressive meaning, in this regard resembling German (which has no postureverb progressives). A crucial difference with German is that Cité Duits does not use the dabei-construction, which is fairly frequent in German. In turn, the low frequency of the beim-progressive in Cité Duits roughly corresponds to German. The fact that the absentive does not appear in Cité Duits is likely to go back to the speech context, since the absentive is confined to particular contexts, indicating that a protagonist is displaced from the respective center.

\subsubsection{Summary}

As demonstrated by the frequency distribution of different progressive constructions, the an-progressive in Cité Duits is produced more often than the aan het-lam-progressive in informal Dutch/German. While Dutch and German have at least two progressive constructions that occur frequently, Cité Duits uses a single construction in 90 percent of the attestations. The fact that the an-construction exhibits such a high frequency distribution may have several reasons. First, it may be the case that we observe influence of the Maaslands dialect, which uses a similar construction. Second, Ruhr-German may 
have played a role here, given that the am-construction is particularly productive and has a much higher frequency than in colloquial standard German. Finally, as I have shown, studies on the progressive in Dutch and German report different frequencies, while I also indicated that one should be careful about drawing conclusions based on comparison of different types of corpora.

\subsection{Variation in the An-progressive}

In this section I concentrate on syntactic and semantic characteristics of the anprogressive, thus addressing sub-question (iii): which syntactic and semantic restrictions do the respective (verbal) constructions display? From a semantic perspective (§ 7.7.3), I will demonstrate that Cité Duits systematically combines 'states' with the an-construction, i.e. 'non-processes' in the Vendlerian classification and therefore less likely to appear in the progressive form. In this context, I will argue that Cité Duits allows for certain verbal events with the an-construction that are untypical for its contact varieties. On the level of syntax (§ 7.7.4), I will show that Cité Duits' progressive has similar restrictions as Dutch and Maaslands but fewer restrictions than colloquial standard German, co-occurring with PPs and object complements.

\subsubsection{Corpus of Regional Varieties of German}

For the following analysis, in order to find out to which extent Cité Duits' progressive differs or resembles regional varieties of German, I use a German corpus on regional and dialectal varieties (see $\S 7.4$ for details). To this end, I extracted all attested amconstructions $(\mathrm{n}=78)$ from the corpus (see annex for a complete list). As pointed out earlier, the Dutch aan-het construction displays less semantic and syntactic variation than its German counterpart.

\begin{tabular}{|l|l|l|l|l|}
\hline $\begin{array}{l}\text { AM- } \\
\text { CONSTRUCTIONS }\end{array}$ & $\begin{array}{l}\text { MIDDLE- } \\
\text { WEST } \\
\text { GERMANY }\end{array}$ & $\begin{array}{l}\text { EAST } \\
\text { GERMANY }\end{array}$ & $\begin{array}{l}\text { SOUTH } \\
\text { GERMANY }\end{array}$ & TOTAL \\
\hline $\mathbf{n}$ & 49 & 15 & 14 & 78 \\
\hline $\boldsymbol{\%}$ & 62.8 & 19.2 & 18 & 100 \\
\hline
\end{tabular}

Table 40: Overview of attested am-constructions in the German corpus according to region

As can be seen from Table 40, the am-progressive is used across the German-speaking area, if to different extents, which is largely in line with previous research (e.g. Flick and Kuhmichel 2013; Flick 2016; Krause 2002; van Pottelberge 2004). More than 60 percent $(\mathrm{n}=49)$ of the am-progressives was produced by speakers in Middle-West Germany (Cologne and Duisburg), 20 percent $(n=15)$ by speakers from the Eastern part of Germany 
(Berlin and Dresden), and 18 percent $(n=14)$ by speakers from Southern Germany (Freiburg, Mannheim, and Munch). The latter is particularly striking since there is more data available from Southern Germany than from the other two areas ( $\$ 7.4)$. These distributions suggest that the am-construction is still frequent in particular among speakers in the Ruhr-area, where it allows for more semantic and syntactic variation than colloquial standard German, and in speakers from places close to this area (Andersson 1989; Bhatt \& Schmidt 1993; van Pottelberge 2004: 210-24). ${ }^{43}$

\subsubsection{General Characteristics}

In the following, I will examine examples as in (28). While Dutch (see § 7.3.3) principally allows for other finite verbs such as lijken 'to appear' or schijnen 'to seem,' Cité Duits always employs 'to be' in the finite verb slot (or no finite verb) (see $§ 7.5 .2$ ).

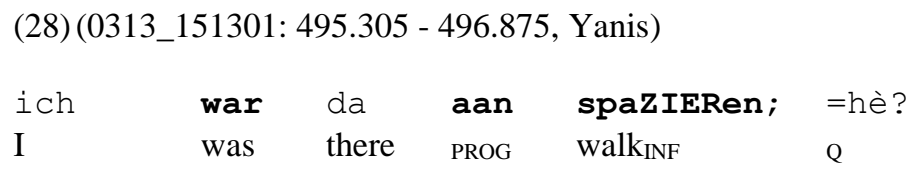

'I was walking there.'

Importantly, past tense constructions far outnumber present tense constructions ( $\mathrm{n}=5$ or $6.6 \%$ ). If surprising at first sight, perhaps, one should understand this outcome within the context of the speech. Because the corpus contains more past than present tense verbs, the number of past tense constructions is much larger here.

Moreover, in line with the contact varieties, none of the attested constructions are passivized ${ }^{44}$ As discussed, speakers clearly prefer active voice ( $\left.\$ 4.4 .5\right)$. In addition, it can be observed that the an-progressives usually have an animate subject. While animate subjects in the am-progressive are seldom in German, as argued by Kuteva (2001:

\footnotetext{
${ }^{43}$ This high frequency includes the Dutch-German border region near Aachen. Of course, we may encounter differences in use related to other factors such as mobility, age and social networks of the speakers.

${ }^{44}$ To which extent a progressive construction has become grammaticalized is often reflected in its compatibility with the passive. While passivization is unusual in Dutch and German, including in most dialects (see Ramelli 2015: 237; 14 for Rhenish Franconian; Tomas 2018; Krause 2002: 112), it is productive in varieties where the progressive shows a high degree of grammaticalization, such as English, e.g. 'The apple is being eaten.' For Pennsylvania German, it has been shown that the am-progressive can be passivized (Tomas 2018: 240-56). Furthermore, it seems that Afrikaans allows for passivization of posture verb- and besig-progressives, but not of the aan die/'t-progressive (Breed et al. 2017: 372).
} 
34), they seem to be more frequent in Dutch (Lemmens 2005). ${ }^{45}$ In the corpus, only four an-constructions (5.3\%) contain an inanimate subject as in (29).

(29)(0314_140913:498.873-500.715, Jan)
$\begin{aligned} & \text { un dann warn die die die die SCHÖne } \\ & \text { and then were the the the the beautiful } \\ & \text { die die PAASeiere, ne an LIEge, } \\ & \text { the the Easter eggs } \mathrm{H} \text { PROG lieINF }\end{aligned}$

'And the beautiful, the Easter eggs, were lying there.'

Given that animate subjects are generally much more frequent in the corpus (see for instance the frequencies in $\S 5.4$ on personal pronouns), these observations are unsurprising.

\subsubsection{Semantic Behavior}

It is generally assumed that the progressive is subject to semantic restrictions in that it typically features verbal events or 'states of affairs' associated with activities and accomplishments (see § 7.2.3). It most naturally combines with dynamic and atelic verbs that do not involve an inherent endpoint. The basic idea that exclusively activities and accomplishments continue in time has been argued to justify their compatibility with the progressive, and this therefore distinguishes them from achievements and states. Figure 44 summarizes the main properties of the four verbal classes as proposed by Vendler, ranging from 'most likely' to 'least likely' in the progressive.

\begin{tabular}{|l|c|c|c|}
\hline & DURATIVE & DYNAMIC & TELIC \\
\hline ACTIVITY & + & + & - \\
\hline ACCOMPLISHMENT & + & + & + \\
\hline ACHIEVEMENT & - & + & + \\
\hline STATE & + & - & - \\
\hline
\end{tabular}

Figure 44: Verbal classes according to feature bundles based on Vendler (1967) (adapted)

45 Kuteva (2001: 34) proposes that animacy in the progressive is related to the process of grammaticalization. Once the construction has become grammaticalized, the subject may also be inanimate. From this perspective, it is conceivable that Dutch exhibits a larger tendency for inanimate subjects than German. 
Accordingly, we would expect a large number of activities and accomplishments, and no or few instances of achievements and states in the data. Despite the fact that there are a number of criteria for determining to what class a verbal event belongs, certain verbal events can be assigned to more than one category. The four classes in Figure 44 thus serve rather as prototypes. As shown by others (e.g. Krause 2002: 169-214), the progressive can principally combine with all four Vendlerian classes in Dutch and German. Yet, while activities are most productive with the progressive, states remain extremely unusual. Achievements are not very productive either.

Importantly, colloquial standard German and Dutch differ in some regards: while German typically combines the am-progressive with atelic-dynamic verbal events, Dutch allows for both telics (accomplishments and achievements) and atelics (activities). Maaslands appears to resemble Dutch, although, as mentioned, no empirical studies have been carried out on the semantic properties of progressive constructions in the dialect. Similarly, Ruhr-German resembles Dutch in combining the progressive with most semantic classes except for states (Andersson 1989: 101).

\subsubsection{Distribution of Verbal Events}

For distinguishing the four verbal classes, I considered semantic and syntactic information (see $§ 7.2 .3$ ). For instance, 'Are you smoking' inquires about an activity, whereas 'Do you smoke?' asks for a state (Vendler 1957: 151). Figure 45 illustrates the distribution of the four verbal events in Cité Duits an-progressive compared to the am-progressive in the German corpus. It should be noted, however, that certain verbal classes may have a higher overall frequency than others in the corpora. I will discuss the four classes by means of examples below.

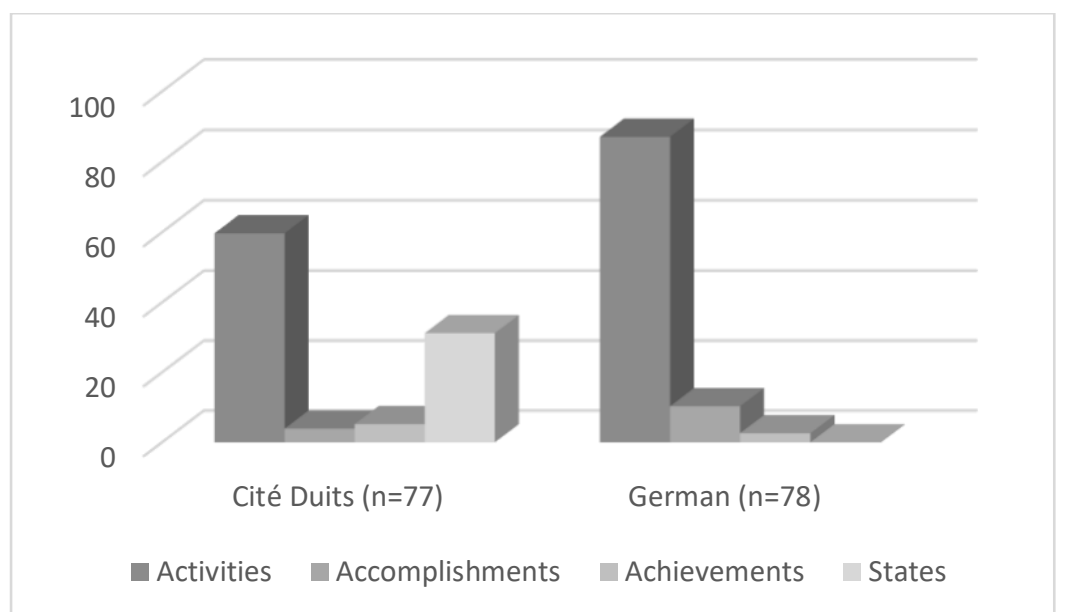

Figure 45: Distribution of verbal events in Cité Duits and in regional varieties of German in percentages 
In both corpora, constructions related to activities make up the lion's share (CD 60\% or $n=46$ and German $87 \%$ or $n=68$ ). Considering that activities combine easily with the progressive, these large numbers are unremarkable. Furthermore, accomplishments $(\mathrm{CD}$ $3.9 \%$ or $n=3$ and German $10 \%$ or $n=8)$ and achievements (5.2\% or $n=4$ and German 3\% or $n=2$ ) have a low incidence in both data sets, with a slightly higher number of accomplishments in the German corpus than in the Cité Duits corpus. From a Vendlerian perspective, these distributions largely conform to the feature bundles outlined in Figure 44. In turn, the large number of states in the Cité Duits data is striking. States make up one third of all examples in Cité Duits ( $31 \%$ or $n=24)$, whereas they remain absent from the German corpus. Usually, 'stative verbs do not have progressive forms, since this would involve an internal contradiction between the stativity of the verb and the nonstativity essential to the progressive' (Comrie 1976: 35). Although languages differ as to the interpretation of the dynamic of a situation (Comrie 1976: 35), states are extremely rare in the progressive in varieties of Dutch and German (van Pottelberge 2004; Krause 2002; for German, see Flecken 2010; for Dutch, see Booij 2008: 84). The question arises, then, whether specific verbs trigger an interpretation as state. In what follows, I will demonstrate that, semantically speaking, there are a number of 'unusual progressives' in Cité Duits that cannot be explained by similar constructions in the contact varieties.

\subsubsection{Activities}

In combining the features [+durative], [+dynamic] and [-telic], activities are most suitable for appearing in the progressive (Comrie 1976; for varieties of Dutch and German, see Flick 2016; Flecken 2010; van Pottelberge; Krause 2002). It is thus unsurprising that activities outnumber other verbal events in the data of Cité Duits, depicted by two examples in (30) and (31):

\begin{tabular}{|c|c|c|c|c|c|c|}
\hline und & $\mathrm{ICH}$ & war & am & warte $;=$ & & \\
\hline and I & was & PROG & wait INF $_{\mathrm{I}}$ & & & \\
\hline $\begin{array}{l}\text { und } \\
\text { and }\end{array}$ & $\begin{array}{l}\text { dat } \\
\text { that }\end{array}$ & $\begin{array}{l}\text { war } \\
\text { was }\end{array}$ & & $\begin{array}{l}\text { EEUWIGheid } \\
\text { eternity }\end{array}$ & $\begin{array}{l}\text { für } \\
\text { for }\end{array}$ & $\begin{array}{ll}\text { mich, hè? } \\
\text { me }\end{array}$ \\
\hline
\end{tabular}

'And I was waiting, and it felt an eternity to me.'

(31)(171115_5: 1283.616 - 1290.022, Olaf)

$\begin{array}{lllllll}\text { un und }(.) & \text { de }(r) & \text { war } & \text { aan } & \text { LEse } & \text { so } & \text { he? } \\ \text { and and } & \text { he } & \text { was } & \text { PROG } & \operatorname{read}_{\mathrm{INF}} & \text { so } & \mathrm{Q}\end{array}$


'And he was reading.'

The an-constructions in (30) and (31) are typical activities in expressing duration but no endpoint (see also (28)). Activities are also the most common verbal event in the German corpus, exemplified in (32).

$$
\begin{aligned}
& \text { (32) (du_07: 1607.70929 - 1612.76569) (German corpus, speaker from Duisburg) } \\
& \text { in oldenburch is_es am SCHNEI:en und am regnen. } \\
& \text { in Oldenburg is =it PROG snow } \overline{I N F} \text { and PROG rain }{ }_{\text {INF }}
\end{aligned}
$$

'In Oldenburg, it is snowing and raining.'

In a similar vein, both corpora display an/am-constructions with mental states such as 'to think,' depicted for Cité Duits in (33).

$$
\begin{aligned}
& \text { (33) (231115_3: } 1093.425-1097.245 \text {, Olaf) } \\
& \begin{array}{lllll}
\text { NEne, } & \text { ich } & \text { bin } & \text { aan } & \text { NAdenken, } \\
\text { no no } & \text { I } & \text { am } & \text { PROG } & \text { think }_{\text {INF }}
\end{array}
\end{aligned}
$$

'No, I am thinking ...'

'Mental states,' as established in previous research, can receive a dynamic interpretation in certain contexts. As such, nadenken 'think about' functions as activity here (Flick 2016: 177). As Flick states for German:

Zeitlich klar begrenzte mentale Handlungen, z.B. nachdenken (quasi >temporale States $`$ ) sind hingegen in der Umgangssprache kaum markiert. Ein Ausspruch wie Ich bin am Nachdenken macht den geistigen Zustand als dynamischen Prozess für den Adressaten sichtbar. (Flick 2016: 177)

'Mental actions that are temporally clearly restricted, e.g. to think/reflect (quasi 'temporal states'), are hardly marked in colloquial language. A sentence like 'I am thinking' makes the mental state visible as a dynamic process for the addressee.'

Similar observations have been made for Dutch. Crucially, the Dutch verb denken 'to think' requires either the verbal particle $n a$ or needs to select a PP complement to appear in the aan het-progressive (Broekhuis et al. 2015a: 43). It holds for a number of Dutch and German verbs that the verbal particle leads to a difference in meaning, which implies that these verbs cannot appear in the progressive without the respective particle (for German, 
see Nicolay 2007: 84) ${ }^{46}$ In the German corpus, überlegen/überlejen 'to think' is one of the most frequent verbs in the am-progressive (used in eight percent of the cases $(n=6)$ ). While there is only one example of 'to think' in the Cité Duits corpus, there is strong evidence that the construction ich bin am nachdenken/überlegen (German)/ik ben aan het nadenken (Dutch) 'I am thinking' is conventionalized in the progressive (Andersson 1989: 99; Kuteva 2001: 33; Flick 2016: 177; Broekhuis et al. 2015a: 43; Anthonissen et al. 2016). Furthermore, there are a number of examples in the data of Cité Duits in which the meaning of the verbal event can only be deduced by considering the complement, such as krank 'ill' in utterance (34).

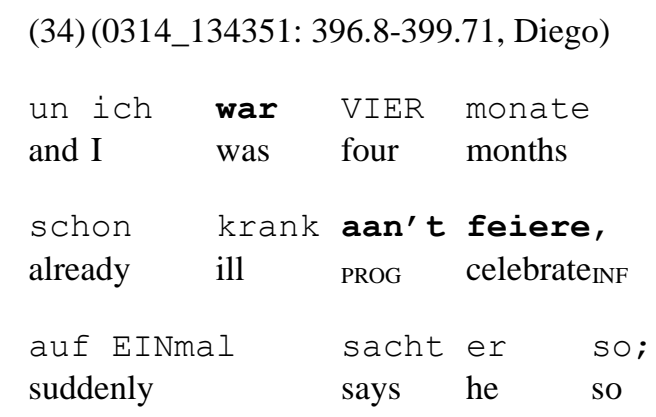

'I had been 'celebrating [being] sick' for four months already, and suddenly he says so....'

Although 'being ill' is a state with inherent endpoint, krank feiern 'to celebrate sick' in (34) describes an activity here due to the combination with the verbal infinitive feiern 'to celebrate.' In contrast, utterance (35) below allows for more than one interpretation:

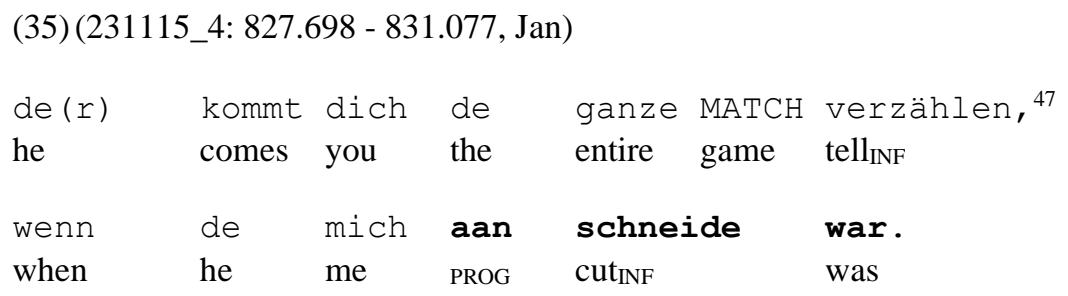

'He started to report on the entire game when he was cutting my hair.'

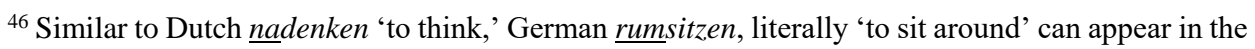
progressive, whereas this does not hold for sitzen 'to sit' (see below).

${ }^{47}$ See $\S 4.4 .7$ for inchoative aspectual constructions expressed through kommen $+\mathrm{V}$-INF, which indicate 'beginning.'
} 
Utterance (35) wenn de mich aan schneiden war means literally 'when he was cutting me.' I propose that the verbal event can be interpreted either as accomplishment or as activity. While schneiden 'to cut' as intransitive verb describes an activity, the transitive use of schneiden has a clear beginning and endpoint. In the example above, however, no direct object is realized (e.g. 'hair'). Since Cité Duits does not distinguish between accusative and dative object pronouns (see $\S 6$ ), it is difficult to determine whether we are dealing with an accomplishment or an activity here.

\subsubsection{Accomplishments}

Accomplishments freely combine with temporal adverbial phrases that measure the time span, for instance 'to eat a plate of spaghetti' (§ 7.2.3) ${ }^{48}$ Although compatible with the progressive since [+durative] and [+dynamic], accomplishments exhibit with four percent the lowest productivity in Cité Duits, exemplified in (36) (see also (16)). They usually involve transitive verbs.

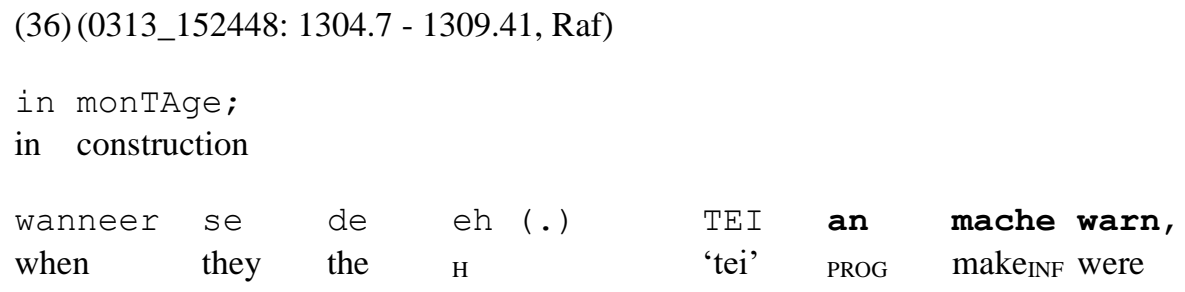

'At the construction site, when they were making the 'tei' [mining terminology].'

In (36), the verb mache 'to make' appears with a complement, and it is precisely the verbal complement (tei) that triggers an interpretation as accomplishment. If the verbs appeared bare, the construction would describe an activity without inherent endpoint. Yet, although accomplishments are considered typical 'processes' in the Vendlerian terminology, telic verbs (accomplishments and achievements) are less compatible with the semantics of the progressive. The focus is on a change of state, not on the verbal action itself. In the German corpus, am-progressives with accomplishments are not very common either (10\%). This is in line with earlier research that suggests that informal varieties of German and Dutch tend to have a low number of accomplishments in the progressive (Krause 2002: 185191). In this regard, Cité Duits seems to resemble its contact varieties. ${ }^{49}$

${ }^{48}$ For a critical discussion, see Filip (2011: 1189-93).

${ }^{49}$ In turn, in their analysis of German, Austrian and Swiss newspapers, Flick (2016) and Flick and Kuhmichel (2013: 61) find that accomplishments constitute the second-largest group with 15\% (Austria), 35\% (Germany) and 42\% (Switzerland). This may indicate that accomplishments are more frequent in formal German. 


\subsubsection{Achievements}

Achievements typically describe punctual situations (e.g. at three o'clock). In combining the features [-durative] and [+telic], achievements do not easily combine with the aan het/am-progressive (see also Ebert 1996; van Pottelberge 2004: 205). As such, it appears interesting that Cité Duits allows for achievements in the progressive (37).

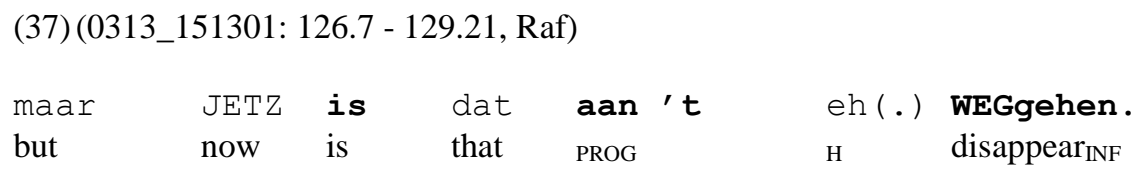

'But now it is disappearing.'

The verb weggehen 'to go away,' lexically resembling German, denotes a situation with a clearly defined endpoint. In combination with the progressive form, however, the construction seems to be re-interpreted by the speaker as 'dynamic' and 'ongoing,' thereby turning a punctual event into an ongoing event. While constructions as (37) are untypical in colloquial standard German due to their telic and non-durative character, Dutch as well as some regional varieties of German allow for more variation (Bhatt \& Schmidt 1993; Andersson 1989: 101; Krause 2002), as illustrated by an example from the German corpus (38). ${ }^{50}$

(38) (mu06: 2403.05268 - 2404.86538) (German corpus, speaker from Munich)

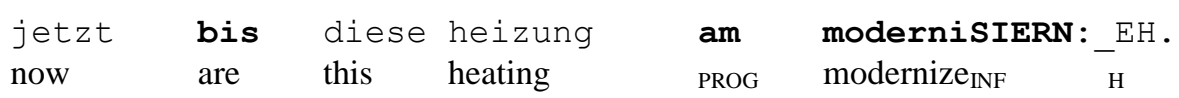

'Now you are modernizing the heating.'

While Cité Duits differs from colloquial standard German, the findings from the German corpus suggest that regional varieties of German allow for similar progressive constructions as Cité Duits. In both corpora, achievements are infrequent.

Moreover, there are certain an-constructions in the Cité Duits corpus that look like achievements at first sight, but are extremely productive in colloquial standard German and Dutch. In utterance (39), sterbe 'to die' is interpreted as a process, rather than as a punctual event.

(39) (171115_4: 346.91 - 357.426, Jan)

\footnotetext{
${ }^{50}$ Achievements were barely attested in the study by Flick (2016) and Flick and Kuhmichel (2013: $61)$. In fact, only the Swiss newspapers contain a few examples (2\%).
} 


$\begin{array}{lllll}\text { de war } & \text { schon am } & \text { STERbe } & \text { de } & \text { mann; }=\text { he? } \\ \text { he was } & \text { already PROG } & \text { die }_{\text {INF }} & \text { the } & \text { guy }\end{array}$

'He was already dying, this guy.'

Similar uses as in (39) have been noted for Dutch and German (Krause 2002: 199; Broekhuis et al. 2015a: 209; Flick 2016: 174), which indicates that 'sterben/sterven + progressive' is a productive progressive construction. According to the Syntax of Dutch (Broekhuis et al. 2015a: 209), 'the verb sterven 'to die' refers to an eventuality that involves the transition of some entity from the state 'alive' to the state 'dead',' which speaks against its typical character of an achievement. Another particularity of this example is that the progressive cannot be replaced be a non-marked progressive (past tense) without yielding an ambiguous meaning (Anthonissen et al. 2016). While der war am sterben 'he was dying' indicates that someone was in the process of passing away (which may take several weeks), the simple past tense construction er starb 'he died' suggests that he had already passed away. Accordingly, the progressive construction adds a semantic component to the utterance that cannot be expressed by the simple past tense.

\subsubsection{States}

In referring to permanent situations that are [-dynamic], states are extremely rare in the progressive in Dutch and German (Ebert 1996; 2000; Tomas 2018; van Pottelberge 2004; Flick 2016; Krause 2002; Booij 2008), including Ruhr-German (Andersson 1989: 101). Stative verbs are, according to Tomas (2018: 143), 'Prädikate von Zuständen' or 'predicates of states,' which makes a combination with the progressive form redundant. Flick (2016: 177) specifies in this regard, 'a state cannot be represented as a process because it is, unlike an action, inherently persistent and static (translation N.P.). ${ }^{51}$ Constructions such as 'he is staying' - i.e. hij is aan het blijven/er ist am bleiben - are generally impossible in the progressive (van Pottelberge 2004: 205). Accordingly, it is striking that the Cité Duits corpus contains a large number of states (31\%), as reflected in the examples below ((40), (41), (42), (43); see also (49)). Note that these examples stem from four different speakers, which means that these constructions cannot be explained by the language use of one particular speaker.

$$
\text { (40) (0314_134351: } 448.29 \text { - 453.71, Jan) }
$$

${ }^{51}$ Original: 'Ein Zustand lässt sich nicht als Prozess darstellen, da er - im Gegensatz zu Handlungen - von sich aus andauernd und statisch ist' (Flick 2016: 177). Nevertheless, semantic restrictions differ cross-linguistically. In English, a language with a fully grammaticalized progressive, many states can have a progressive form, often with a special interpretation; e.g. 'I am loving it' with the meaning 'I am enjoying it' (Flecken 2010: 84). 


de war TOT auf de tisch an liege,
he was dead on the table PROG lie INF

'He was lying dead on the table.'

(41) (0313_144739: 177.24-180.425, Raf)

$\begin{array}{lllll}\text { de }(r) & \begin{array}{l}\text { wart da } \\ \text { he }\end{array} & \begin{array}{l}\text { aan } \\ \text { there }\end{array} & \begin{array}{l}\text { SITze, } \\ \text { sit INF }\end{array} \\ \text { de wart } & \text { BLIND so } & \text { gesach, } & \text { hè? } \\ \text { he was blind so } & \text { said } & \text { Q }\end{array}$

'He was sitting there, he was actually blind.'

\begin{tabular}{|c|c|c|c|}
\hline ich & $\begin{array}{l}\text { war } \\
\text { was }\end{array}$ & $\begin{array}{l}\text { DRAUSse } \\
\text { outside }\end{array}$ & an \\
\hline
\end{tabular}

'I was sitting outside.'

$$
\text { (43)(171115_5: } 1545.005 \text { - 1546.64, Olaf) }
$$

$\begin{array}{lllll}\text { und } & \text { ich } & \text { war da an } & \text { SITze, } \\ \text { and } & \text { I } & \text { was there } & \text { PROG } & \text { sit INF }\end{array}$

'And I was sitting there.'

Examples (40) to (43) have in common that they have a posture verb, i.e. sitze(n) 'to sit' or liege 'to lie,' as verbal infinitive. In contrast to posture verb progressives (see $\$ 7.5 .5$ ), the posture verb appears here in the infinitive and not in the finite verb slot of the construction. It functions semantically as head of the clause, whereas agreement is between the respective subject pronoun $(d e, i c h)$ and the finite verb (war $(t))$. These anconstructions are insofar remarkable as posture verbs have been claimed to be incompatible (Ebert 1996: 44) or highly questionable (van Pottelberge 2004: 214) with the progressive in Dutch and German. These observations correspond to findings in the Kleines Wörterbuch der Verlaufsformen im Deutschen 'Concise dictionary of progressive aspect in German' (Engelberg et al. 2013), which does not contain a single example of sitzen 'to sit', liegen 'to lie' or stehen 'to stand' in combination with the am-progressive. In addition, in Figure 45, I established already that there are no instances of states in the German corpus, which suggests that these are uncommon in regional varieties of German. 
In a similar vein, for Dutch, it has been found that states never go together with the aanhet progressive (see Flecken 2010: 85 for an empirical study). ${ }^{52}$

At the same time, Bhatt and Schmidt (1993: 73), in their analysis of the amprogressive in Cologne- and colloquial standard German, claim that posture verbs in the progressive form are possible in particular contexts. Apparently, example (44) below is possible when following the utterance, 'I can't see it on the picture,' whereas (45) with a PP-complement between the finite verb and the am-infinitive yields an impossible construction (examples Bhatt \& Schmidt 1993: 73; following Bhatt 1991: 14). It remains unclear, however, whether examples such as (44) have been identified more than once.

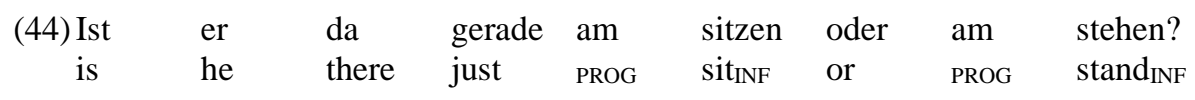

'Is he just sitting or standing there?'

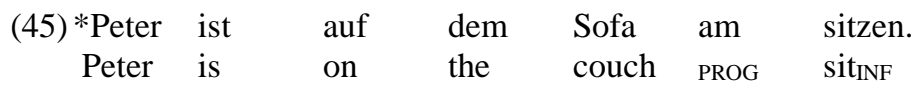

'Peter is sitting on the couch.'

While most authors clearly reject posture verbs with the progressive in German and Dutch, it seems that such constructions may occur in exceptional cases in colloquial language. ${ }^{53}$ In Cité Duits, in turn, an-progressives with posture verbs in the infinitive slot are extremely productive. In other words, such examples are systematically used and do not form an exception. These observations suggest that Cité Duits has fewer semantic constraints than most varieties of Dutch and German. Furthermore, Cité Duits combines an-constructions with a posture verb and a PP-complement (see $\S 7.7 .4$ ), i.e., a construction considered impossible in the contact varieties.

\subsubsection{Summary}

By taking Vendler's four-way classification as starting-point, I discussed semantic characteristics of the Cité Duits an-progressive. To account for regional variation in the German progressive, I compared my findings to a German corpus. Based on an almost equal number of attested tokens and by means of examples, I have shown that activities

\footnotetext{
${ }^{52}$ Likewise, van Pottelberge (2004: 214) emphasizes that posture verbs are impossible with the aanhet progressive: 'Nebenbei ist darauf hinzuweisen, dass derartige Beispiele auch im modernen Niederländisch zumindest sehr zweifelhaft, wenn nicht geradezu unmöglich wären ${ }^{*}$ aan het zitten /staan zijn').

53 The authors do not provide much information on the data but refer to an unpublished manuscript. As a native speaker of German, I have never come across these or similar uses.
} 
('processes') combine most easily with the progressive in both corpora. In addition, I proposed that an-progressives with accomplishments and achievements display a similar behavior in Cité Duits as in informal varieties of Dutch and German. Although such constructions remain infrequent, I demonstrated that regional varieties of German display similar uses. Likewise, these constructions can be associated with Dutch (and possibly Maaslands), which has fewer semantic restrictions than colloquial standard German.

In turn, the large proportion of states is remarkable and distinguishes Cité Duits from its contact varieties, including regional varieties of German, where the progressive form with states is uncommon. In Cité Duits, constructions that combine with states make up one third of all examples, which points toward a systematic use. In this context, I have shown that Cité Duits most often combines these an-progressives with posture verbs, which generally do not have a progressive form in the contact varieties (Krause 2002; van Pottelberge 2004; Flecken 2010; Ebert 1996), whereby the posture verb appears in the infinitive slot, not in the finite verb slot.

\subsubsection{Syntactic Behavior}

On the level of syntax, I will discuss by means of several examples whether Cité Duits allows for transitive and intransitives uses in the an-progressive, and whether the an + $\mathrm{V}_{\mathrm{INF}}$-sequence ('an-phrase') can be interrupted by other elements. Since syntactic restrictions underlying the aan het/aon't/am-progressive differ to some extent in the contact varieties, I will briefly outline the main differences before turning to the data.

\subsubsection{Syntactic Restrictions in the Contact Varieties}

Generally speaking, Dutch and Maaslands allow for transitive and intransitive uses, whereas colloquial standard German is restricted to intransitive verbs (Krause 2002: 12760; van Pottelberge 2004: 141-53; 205-10; Flick \& Kuhmichel 2013). ${ }^{54}$ Regional varieties of German, however, allow for more variation. In Swiss and Ruhr-German, for instance, the am-progressive is also productive with object complements (Elspaß \& Möller 2011; Flick \& Kuhmichel 2013; Andersson 1989; Bhatt \& Schmidt 1993). As illustrated in (46) below, Dutch/Maaslands and German display different syntactic preferences (for crosslinguistic empirical studies, see Flecken 2010; Behrens et al. 2013).

$\begin{array}{cllllll}\text { (46) a. Ze } & \text { is } & \text { de } & \text { krant } & \text { aan't } & \text { lezen. } & \text { (Dutch) } \\ \text { b. Zèij } & \text { is } & \text { de } & \text { gezèt } & \text { aon't } & \text { leze. } & \text { (Maaslands) } \\ \text { she } & \text { is } & \text { the } & \text { newspaper } & \text { PROG } & \text { read INF } & \end{array}$

\footnotetext{
54 It seems that Maaslands largely resembles Dutch. Furthermore, according to van Pottelberge (2004: 146), there are no significant regional differences in Dutch on the level of syntax, although he found that transitive uses appeared earlier in Belgian Dutch historical sources than in Netherlandic Dutch ones.
} 
$\begin{array}{rllll}\text { c. Sie } & \text { ist } & \text { am } & \text { Zeitunglesen. } & \text { (German) } \\ \text { she } & \text { is } & \text { PROG } & \text { newspaper-read } & \end{array}$

'She is reading the newspaper.'

In Dutch and Maaslands (a, b), the noun (krant/gezèt) tends to appear between the finite verb (is) and the progressive marker (aan't/aon't), whereas it is incorporated into the verbal infinitive (zeitunglesen) in German. While noun incorporation - i.e., the process in which a nominal has been incorporated into a verb to form a complex verb - is considered obligatory in the German construction (Bhatt \& Schmidt 1993: 78; Flick \& Kuhmichel 2013: 64; Ebert 1996: 45; Tomas 2018: 264), it seems less common in Dutch where the aan het $+\mathrm{V}_{\mathrm{INF}}$-sequence may not be interrupted. Nevertheless, incorporation is possible with specific lexical items that form a fixed collocation, such as aan het pianospelen/thee zetten/paard rijden (Booij 2008; Bergstra 2019: 102; 41-43; Broekhuis et al. 2015a: 154).

Furthermore, for Dutch holds that verbal particles can be separated from aan het, e.g. $i k$ ben in aan het pakken but also $i k$ ben aan het inpakken 'I am wrapping up' (Flecken 2010: 191), in contrast to German, e.g. ich bin am einpacken, but not *ich bin ein am packen (Bhatt \& Schmidt 1993: 74 for similar examples). Dutch also extraposes prepositional phrases (PPs) more easily than German, especially clauses introduced with van 'of' (Flecken 2010: 190-191; van Pottelberge 2004: 66; Ebert 1989). Finally, varieties of Dutch and German share a number of syntactic restrictions. It is considered impossible to incorporate an adjective (e.g. ?ze is aan het langzame krant lezen, lit. 'she is PROG slowly newspaper read'), a personal pronoun (?zij is aan het hem troosten, 'she is PROG him give comfort'), or a determiner (e.g. *ze is aan het een krant lezen, lit. 'she is PROG a newspaper read,' between the progressive marker and the respective verbal infinitive. ${ }^{55}$

\subsubsection{Prepositional Phrases and Extraposition}

The an-progressive in Cité Duits combines both with transitive and intransitive verbs, and with different types of complements. In Cité Duits, prepositional phrases (PPs) are particularly frequent and appear in two positions: Either between sein FINITE $_{\text {and the an- }}$ phrase (47), or following the an-phrase (48)(49)(50). Note that Cité Duits does not distinguish case, in contrast to German. The German corpus does not contain similar examples.

55 Across varieties of Dutch and German, I attested such examples only in Pennsylvania German: Ich bin am ein Buch lesa 'I am PROG a book read' (Tomas 2018: 259, example 499). 
(47) (171115_3: 421.308 - 427.548, Jan)

$\begin{array}{llllll}\text { wars } & \text { te } & \text { auf de } & \text { ZAdel an } & \text { sitze; } \\ \text { were } & \text { you } & \text { on } & \text { the } & \text { seat } & \text { PROG } \\ \text { sit INF }\end{array}$

'You were sitting on the seat.'

From a syntactic (but not semantic) perspective, (47) auf de zadel aan sitze can be associated with Dutch/Maaslands, where the PP-complement 'on the seat' typically occurs before the aan het $+\mathrm{V}_{\mathrm{INF}}$-sequence. ${ }^{56}$ In addition, numerous PP-complements appear extraposed in the data. The prepositional phrase then appears after the closure of the verbal bracket, directly following the an-phrase, as illustrated in (48), (49) and (50).

\begin{tabular}{|c|c|c|c|c|c|}
\hline $\begin{array}{l}\text { Eric } \\
\text { Eric }\end{array}$ & $\begin{array}{l}\text { war } \\
\text { was }\end{array}$ & $\begin{array}{l}\text { sein } \\
\text { his }\end{array}$ & $\begin{array}{l}\text { haare } \\
\text { hair }\end{array}$ & $\begin{array}{l}\text { aan ' } t \\
\text { PROG }\end{array}$ & $\begin{array}{l}\text { schneiden } \\
\text { cut }_{\mathrm{INF}}\end{array}$ \\
\hline von & joep & & & & \\
\hline
\end{tabular}

'Eric was cutting Joep's hair.'

(49) (0313_152448: 96.1 - 98.5, Jan)

$\begin{array}{lllllll}\text { dann } & \text { warn } & \text { we } & \text { in } & \text { kanTIne } & \text { an } & \text { sitze } \\ \text { then } & \text { were } & \text { we } & \text { in } & \text { cafeteria } & \text { PROG } & \text { sit INF }\end{array}$

am bufEET hè?

at counter Q

'We were then sitting in the cafeteria at the counter.'

(50) (0314_134351: 329.6 - 332.32, Diego)

STOND_ma da naak (t),

stood $=$ we $\quad$ there naked

\footnotetext{
${ }^{56}$ While the finite verb appears in first position (wars-te), this pattern can probably be associated with informal spoken language. Colloquial Dutch, for instance, has inversion constructions in which the clause-initial position remains empty (Broekhuis \& Corver 2019).
} 


$\begin{array}{llllll}\text { un alle } & \text { ZWEI } & \text { warn_ma } & \text { an } & \text { gucke mit } & \text { pimmelkes. } \\ \text { and all } & \text { two } & \text { were=we } & \text { PROG } & \text { look }_{\text {INF }} \text { with } & \text { penises }\end{array}$

'We stood there naked, and both of us were looking [at him] with our penis.'

Unlike in colloquial standard German, where the extraposition of PPs with the amprogressive is extremely uncommon (Bhatt \& Schmidt 1993: 80), extraposition is highly productive in Cité Duits. These constructions follow the syntactic patterns of Dutch but differ from German including Ruhr-German, where the am-phrase usually has clause-final position. Although the am-progressive allows for all kinds of complements in RuhrGerman, without restrictions in number, it seems that these must appear before am + VINF-Sequence (Andersson 1989: 99-100).

\subsubsection{Object Complements}

Object complements as full NPs usually occur between $\operatorname{sein}_{\text {FINITE }}$ and the an-phrase in Cité Duits (51)(52):
(51)(0313_152448: 84.31 - 88.01, Raf)

'He was watching television when his eye got hurt.'
(52) (231115_4: 897.563 - 900.408, Antonio)
die warn $\mathrm{AUCH}$ kohle am raffe(n).
they were also coal PROG collectiNF

'They were also collecting coal.'

Syntactically, examples (51) and (52) correspond to Dutch, Maaslands, and Ruhr-German (Bhatt \& Schmidt 1993; Andersson 1989), but are uncommon in colloquial standard German, which rather incorporates the noun into the verbal infinitive (am fernsehgucken, am kohlesammeln). 


\subsubsection{Adverbial Phrases}

As pointed out above (§ 7.7.3.1), in Dutch, Maaslands and (Ruhr-)German, the adverbial phrase may not occur between the progressive marker and the verbal infinitive leading to the order *aan het/aon't lam $+\mathrm{x}+\mathrm{V}$-INF. In other words, *Ze zijn het hek aan het lichtblauw verven 'They are painting the wall light blue' yields an ungrammatical construction (Broekhuis et al. 2015a: 154 on Dutch; Bhatt \& Schmidt 1993: 77 on German). In my corpus, adverbial phrases always appear between sein $n_{\text {FINITE }}$ and the anphrase, but never between an and the verbal infinitive, depicted in (53).

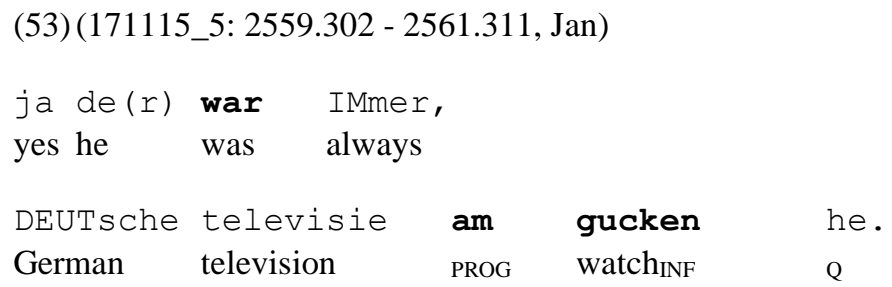

'He was always watching German television.'

Construction (53) with the adverbial phrase deutsche televisie 'German television' can be associated with Dutch, Maaslands and Ruhr-German. In this regard, Cité Duits resembles its contact varieties except for colloquial standard German, where constructions in which the complement precedes the progressive marker are untypical, regardless of the position of the adverbial phrase. I did not run into similar examples in the German corpus.

\subsubsection{Noun Incorporation}

As illustrated by a large number of previous examples, the an $+\mathrm{V}$-INF-sequence is usually bare in Cité Duits, with complements appearing either directly before or after the anphrase. Yet a single example contains an element between the progressive marker and the verbal infinitive, leading to the order an $+\mathrm{x}+\mathrm{V}$-INF, depicted in (54).

\begin{tabular}{|c|c|c|c|c|c|c|}
\hline $\begin{array}{l}\text { und } \\
\text { and }\end{array}$ & $\begin{array}{l}\text { die } \\
\text { they }\end{array}$ & $\begin{array}{l}\text { warn } \\
\text { were }\end{array}$ & $\begin{array}{l}\text { da } \\
\text { there }\end{array}$ & $\begin{array}{l}\text { am } \\
\text { PROG }\end{array}$ & $\begin{array}{l}\text { VOD } \\
\text { vodka }\end{array}$ & $\begin{array}{l}\text { brauen, } \\
\text { brew }_{\text {INF }}\end{array}$ \\
\hline $\begin{array}{l}\text { mit } \\
\text { with }\end{array}$ & $\begin{array}{l}\text { WAS } \\
\text { water }\end{array}$ & & $\begin{array}{l}\text { (die) } \\
\text { they }\end{array}$ & $\begin{array}{l}\text { so } \\
\text { so }\end{array}$ & & \\
\hline
\end{tabular}

'And they were making vodka with water.' 
I propose that the sequence (54) am vod brauen 'making vodka' can be analyzed as an example of noun incorporation. The nominal vod 'vodka' is incorporated here into the verbal infinitive brauen 'brew', yielding the complex verb vodbrauen 'vodka-making. ${ }^{57}$ While it is generally assumed that the aan het/am $+\mathrm{V}$-INF-sequence may not be interrupted (Broekhuis et al. 2015a: 154 for Dutch; Andersson 1989: 99 for Ruhr-German), noun incorporation or processes similar to noun incorporation are principally possible in both Dutch $^{58}$ and German. For Dutch, it is claimed that the incorporation of a noun into the verbal infinitive is only possible with particular lexical items that form a fixed collocation, or with conventionalized activities (Booij 2008; Broekhuis et al. 2015a). As stressed in the Syntax of Dutch,

if the verb forms a fixed collocation with a bare noun, as in paard rijden 'to ride horseback', or a predicative adjective, as in dronken voeren 'to ply someone with liquor', the nonverbal part of the collocation noun can be either external or internal to the aan het + Vinfinitive sequence (Broekhuis et al. 2015a: 154).

In colloquial standard German, as stated above (see § 7.7.3.1), noun incorporation is often obligatory between am and the verbal infinitive, for example am radfahren but not * Rad am fahren 'riding a bike' or am eislaufen but not *Eis am laufen 'ice-scating' (Bhatt and Schmidt 1993: 78; further Ebert 1996: 45; Tomas 2018: 264). My findings from the German corpus, however, suggest that noun incorporation is infrequent with the German am-progressive. Roughly three percent $(\mathrm{n}=2)$ of all constructions display noun incorporation (i.e. am winterspeck bekämpfen and am fensterputzen). These observations correspond to previous findings. Although productive in German, such patterns have a low frequency (Anthonissen et al. 2016: 5) ${ }^{59}$ Accordingly, noun incorporation with the progressive is not very common in either German or Dutch - which is in line with Cité Duits. Although I am not aware of the role of Maaslands, I would assume that noun incorporation is possible and perhaps even more productive than in Dutch. ${ }^{60}$

Although I cannot determine whether am vodbrauen 'vodka-making' counts as a fixed collocation in Cité Duits, the making of vodka can be regarded a conventionalized activity (Booij 2008) that occurred regularly in the mining district. From this perspective,

${ }^{57}$ Given that the speaker uses the verb 'to brew,' vod may as well denote a type of beer or another alcoholic beverage. Another interpretation is that vod is an adjective. For the proposed analysis, the exact meaning is secondary. In both cases, we receive the order an $+\mathrm{x}+\mathrm{V}$-INF, pointing towards a process of (or being similar to) incorporation.

58 For Dutch, it has been argued that these processes differ structurally from 'real' noun incorporation. Bergstra (2019: 142) therefore speaks of 'pseudo-noun incorporation', whereas Booij (2008) uses the term 'quasi-incorporation.'

${ }^{59}$ I would assume that speakers rather use dabei sein zu (Er ist dabei, Fenster zu putzen) or nonmarked progressives (Er putzt gerade Fenster) with longer sequences (see $§ 7.3$ ).

${ }^{60}$ In Frisian (NL), for instance, nouns can productively incorporate into the verb. The study by Bergstra (2019) has shown that speakers allow for more patterns in Frisian than in Dutch. 
it justifies the emergence of am vodbrauen 'vodka-making' as a lexical unit, similar to Dutch aan het pianospelen 'piano-playing' and aan het paard rijden 'horseback riding.'

\subsubsection{Summary}

By examining syntactic characteristics of the an-progressive, I demonstrated that it combines with transitive and intransitive verbs and allows for different types of complements, therefore syntactically resembling Dutch, Maaslands, and Ruhr-German. In addition, I argued that the tendency toward extraposition of PPs strongly resembles Dutch and Maaslands. In contrast, the an-constructions often differ syntactically from colloquial standard German, where transitive uses and PPs are uncommon. Furthermore, apart from the possibility to have object complements and extraposed PPs, Cité Duits allows for elements between the progressive marker and the verbal infinitive ( $\mathrm{an}+\mathrm{x}+\mathrm{V}$-INF). While I could identify just one instance, I proposed that this sequence can be analyzed as an example of noun incorporation, similar to Dutch aan het pianospelen 'piano-playing' and German am radfahren 'bike-riding.'

\subsection{Conclusion}

\subsubsection{Discussion}

In this final section I discuss the question of whether there is a progressive aspect type typical to Cité Duits, and I assess whether individual speakers differ from the rest of the group in their use of the progressive. The preceding analysis has shown that the Cite Duits progressive displays a number of characteristics that distinguish it from informal and regional varieties of German and Dutch. While much of the syntax resembles Belgian Dutch and Maaslands, the combination of the progressive with Vendlerian 'states' is remarkable. Moreover, Cité Duits mainly uses a single progressive construction, whereas the contact varieties have several means to convey progressive aspect.

\section{Inter-speaker Variation}

In section 7.5.2, I have pointed to variation in the progressive marker, which is most often realized as an (61\%), but also as am (34\%) and seldom as aan't (5\%). These findings lead to the question of whether this type of variation can be explained by inter-speaker variation. ${ }^{61}$ It may be the case that an individual speaker always produces the progressive marker $a m$, whereas the rest of the group uses an. For the examination of inter-speaker variation, I concentrate on the six core speakers. While there may also be variability within individual speakers, the limited number of tokens per speaker does not allow for an analysis of intra-speaker variation. Of the attested an-constructions, 66 out of 76 examples

\footnotetext{
${ }^{61}$ I ignore the bezig-, sitzen $z u$ - and beim-construction because these hardly occurred in my data set. Except for the bezig-construction, which does not primarely serve to denote ongoingness, the examples were produced by different speakers.
} 
were produced by these six speakers, whereas 10 examples stem from other speakers. Since the amount of recorded speech and the number of attested constructions differs across speakers, I determined the frequencies in relation to the number of attested anconstructions. Figure 46 illustrates the use of the three progressive markers an, am, and aan't at the individual level in relative frequencies.

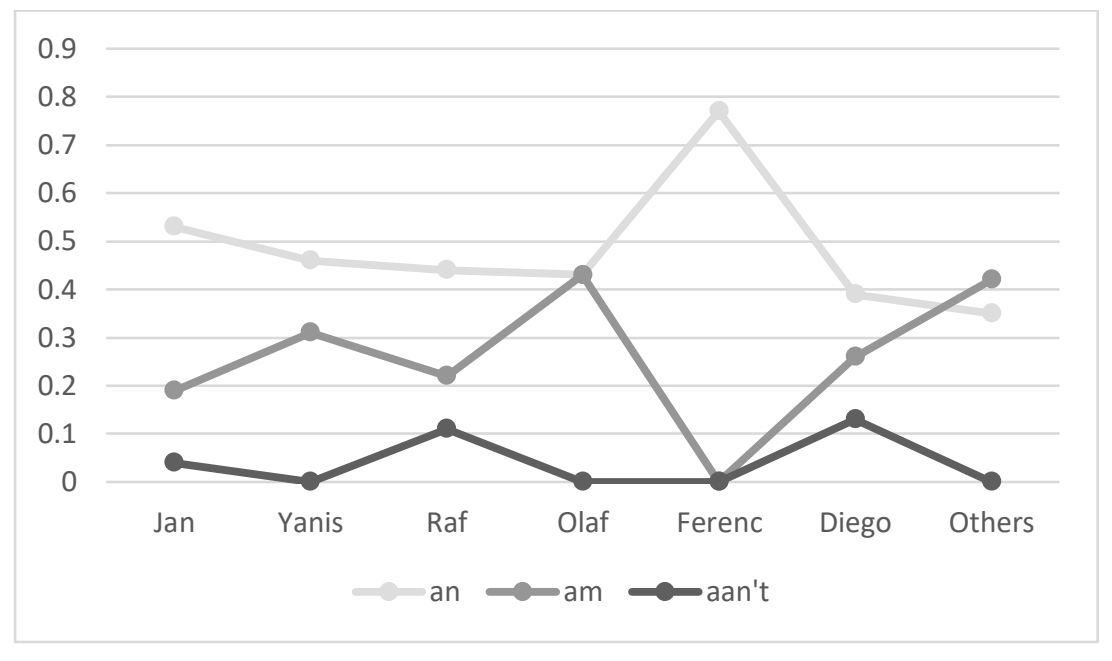

Figure 46: Realization of progressive markers according to speaker

Figure 46 shows that the progressive marker an is produced by all six speakers, whereas none of them frequently uses aan't. The latter is unsurprising, given that I hardly encountered the use of aan't. Crucially, all speakers except for Ferenc use next to an also am. Most speakers, interestingly, produce an more or as often as am. While the number of produced an-constructions differs between the six speakers, a general tendency across all individuals can be observed: the variant $a n$ is generally produced most frequently, whereas the variant aan't is produced least often. In this regard, all six speakers behave in the same way. Aside from an, all speakers make use of the variant $a m$, with the exception of Ferenc. For this speaker, however, little material is available. In relative frequencies, am shows the smallest distribution in Jan and Ferenc. While inter-speaker variation does not explain variation in the data, these observations corroborate my assumption that $a n$ is a fully established progressive marker in Cité Duits (see § 7.5.7). Since it seems that most speakers use both variants, it can be concluded that Cité Duits has two progressive markers in the an-construction, a feature that is also found in Pennsylvania German (Tomas 2018: 78; Louden 1994).

Unlike Cité Duits, most Germanic languages have at least two types of progressive markers (Ebert 2000: 605-07). Only English, a language with a fully 
grammaticalized aspectual system, uses a single progressive construction, i.e. the morphological ending -ing ( $\$ 7.1$ ). In a similar vein, the English progressive combines with many Vendlerian states, often with a special meaning (Flecken 2010: 84). In this context, it has been proposed that certain states are more likely to appear in the progressive than others (Krause 2002: 206): Accordingly, verbal events associated with (a) repose combine most easily with the progressive, followed by those of (b) sensual perception and emotional attitudes, whereas (c) mental states and (d) verbs of relations are highly unlikely (see Krause 2002: 206). Given that the 'state-constructions' all have a posture verb as head of the clause (e.g. sitzen 'to sit'), it could be argued that Cité Duits behaves similar to English where verbal events associated with 'repose' are most likely to have a progressive form within the group of states. But there are certain caveats here. Mental states classify as 'highly unlikely,' whereas we have seen in section 7.7.3 that nadenken/überlegen 'to think' is extremely productive in the progressive in Dutch, German, and Cité Duits.

On the level of semantics, however, Cité Duits exhibits fewer restrictions than informal Dutch and German, which places Cité Duits closer to languages in which the progressive is fully grammaticalized, such as English. Across varieties of German and Dutch, I found patterns similar to those in Cité Duits also in Pennsylvania German, a variety that has been in contact with English for a long time (Tomas 2018). This may suggest that we observe general mechanisms of language contact. According to Aboh (2015), an emergent contact variety may recombine syntactic and semantic features differently from the existing languages, which means that the outcome may differ from the language(s) spoken in the community. I will return to this approach in the following chapter $(\S 8)$, where I bring together and discuss the main findings of this dissertation.

\subsubsection{Summary and Concluding Remarks}

This chapter examined the use of progressive aspect in Cité Duits. The question that I explored is how speakers convey progressive meaning, and which semantic and syntactic restrictions the resulting constructions display. As my analysis revealed, speakers primarily use the an-construction to express ongoingness, whereas the contact varieties have several progressive types and use at least two constructions frequently. Although the an-construction resembles an existing progressive construction in Belgian Dutch, Maaslands and German, it differs in a number of aspects. First, Cité Duits has a morphological variant of the progressive marker that does not exist in the contact varieties. Second, the Cité Duits progressive clearly exhibits fewer semantic restrictions than varieties of Dutch and German including regional varieties. Third, despite the fact that much of the lexis can be associated with German, the constructions often differ syntactically from colloquial standard German, but rather resemble Dutch and Maaslands. Taken together, it can be formulated that the an-progressive in Cité Duits has several characteristics that distinguish it from Dutch, Maaslands and (regional varieties of) German. 
My analysis started off with an examination of the various types for expressing ongoingness ( $\S 7.5$ ). Based on frequency of occurrence, I demonstrated that speakers mainly use the an-construction (an $\mathrm{V}$-INF sein), whereas other means such as the beim-and the posture verb construction have a low incidence. Non-marked progressives only occur with specific verbs (e.g. 'to say') that do not allow easily for the progressive form from a Vendlerian perspective. The beim-construction (beim V-INF sein) corresponds to German, whereas the posture verb construction (sitzen $z u \mathrm{~V}$-INF) can syntactically and semantically be associated with Belgian Dutch and Maaslands, but lexically with German.

With respect to the an-progressive, Cité Duits has similar formal means to denote ongoingness as Belgian Dutch, Maaslands, and German in the case of the aan het/aon't/am-progressive. As I uncovered, however, Cité Duits uses the an-progressive significantly more often than Dutch and German (§ 7.6). It may be the case that we observe an influence of the Maaslands dialect, or Ruhr-German, where the am-progressive is particularly productive (Andersson 1989; Bhatt \& Schmidt 1993; van Pottelberge 2004: 212). In addition, I have pointed to the potential caveats when comparing different data sets.

Another characteristic feature of the an-construction is the use of an [an]/[a:n], a variant that does not exist in the three contact varieties. I proposed that an can be analyzed as a progressive marker that is specific to Cité Duits (§ 7.5.7), and that it is part of a larger set of linguistic properties that make up its grammatical character. The fact that the corpus comprises traces of aan ' $t$, as well as a significant number of am-examples, suggests that an developed out of the progressive markers aan 't, aon 't, and am.

In the second part of the analysis ( $\$ 7.7)$, I concentrated on semantic and syntactic characteristics of the an-progressive. In the introductory section of this chapter (§ 7.3), I noted that German and Dutch/Maaslands differ in their use of the aan het/aon't/amprogressive. Compared to colloquial standard German, the Dutch construction is further grammaticalized and has less semantic and syntactic restrictions. The German amprogressive, in turn, displays a large degree of regional variation on the level of semantics and syntax. For the subsequent analysis, I considered previous findings on colloquial standard German and Ruhr-German, and I compared the results with a corpus of regional varieties of German. In this context, I extracted $78 \mathrm{am}$-constructions produced by speakers from the Middle-West, Eastern, and Southern parts of Germany.

The analysis of semantic characteristics ( $§$ 7.7.3) showed that Vendlerian 'activities' combine most easily with the progressive in both corpora, whereas 'accomplishments' and 'achievements' remain infrequent. Based on attested examples, I argued that Cité Duits displays a similar behavior as informal varieties of Dutch and German in this regard. Although it is generally assumed that achievements do not easily combine with the progressive due to their telic and non-durative character, I established that the German corpus contains examples similar to those attested for Cité Duits, but also that achievements are extremely infrequent.

Furthermore, the analysis demonstrated that Cité Duits systematically expresses 'states' by the an-construction, i.e. 'non-processes.' Such examples are not attested in the 
German corpus. Across varieties of Dutch and German, including Ruhr-German, states are unusual in the progressive (Ebert 1996; 2000; Tomas 2018; van Pottelberge 2004; Flick 2016; Krause 2002; Booij 2008). Another finding from this analysis was that Cité Duits often has a posture verb in the respective verbal construction, which appears in the infinitive slot rather than in the finite verb slot ( $\mathrm{an}+\mathrm{V}_{\mathrm{INF}}+$ posture verb). While I proposed that certain 'mental states' such as nadenken 'to think' are conventionalized in the progressive, therefore receiving a dynamic interpretation (§ 7.7.2.2), posture verbs with the aan het/am-construction are highly unlikely (e.g. Ebert 1996: 44; van Pottelberge 2004: 214; Flecken 2010) and appear only in exceptional contexts (see example (44)) (Bhatt and Schmidt 1993). Given that these examples make up one third of all anconstructions, there is evidence that Cité Duits exhibits fewer semantic restrictions than the contact varieties.

On the level of syntax ( $\$ 7.7 .4)$, I demonstrated that the Cité Duits progressive combines with transitive and intransitive verbs and allows for different types of complements, which is why it has fewer restrictions than colloquial standard German. Many of these constructions resemble syntactically Dutch and Maaslands. Some examples can also be associated with Ruhr-German, while others are untypical for most varieties of German. In addition, I illustrated that Cité Duits allows for noun incorporation.

Finally, at the individual level ( $\$ 7.8 .1$ ), I concluded that most speakers use both an and am, whereas aan't is used seldom. Although the number of attested constructions is too small for assessing whether there are significant differences, inter-speaker variation does not seem to determine variation in the use of these progressive markers. In sum, while the lexis of the attested progressive constructions - including the beim- and sitzen zu progressive - can often be associated with German, the observations from section 7.7 place Cité Duits closer to Dutch and Maaslands, whose progressive constructions exhibit fewer semantic and syntactic constraints. 


\section{Chapter 8: Conclusion}

Cité Duits (lit. 'mining district German') emerged as a Belgian Dutch-Maaslands-German contact variety among the sons of immigrant miners in the coalmining district of Belgian Eisden in the 1930s and 1940s. Following a sociolinguistic and grammatical framework, this dissertation examined the linguistic character of Cité Duits with a focus on personal pronouns and progressive aspect. The main aim of this dissertation was to study the underlying language contact dynamics, and to unravel which language varieties contributed to its linguistic structure. In this chapter, I will relate the findings from the preceding analyses to the overarching research question of this dissertation. I will first give a short overview of the main results ( $\$ 8.1$ ), after which I discuss the conclusions that can be drawn ( $\$ 8.2)$. In the final section, I reflect on the theoretical implications and provide possible directions for future research $(\S 8.3)$.

\subsection{Main Findings \\ 8.1.1 Sociolinguistic Characterization}

As this investigation set out to explore the emergence and social functions of Cité Duits in the community of Eisden ( $(2)$, four major observations came to the fore. First, Cité Duits emerged in a setting of multilingualism where speakers already shared a common language (Belgian Dutch), and therefore it served to mark an in-group identity but not to ensure communication. Second, Cité Duits could only develop due to a combination of sociolinguistic conditions present in the cité of Eisden (Tuinwijk) in the 1930s. Third, this language variety has not been transmitted to subsequent generations of speakers and is clearly moribund. Fourth, it is typically not spoken by females but confined to male speakers born and raised in Eisden-cité in the 1930s. These findings will be elucidated below.

Due to its geographically isolated location in the border area, the mine of Eisden was heavily dependent on migrant workers in the late 1920s. Together with their families, they received accommodation in the cité. Most of them had some knowledge of German, which was widely spoken in the countries of the former Habsburg Empire. Furthermore, many Polish miners had acquired German during previous stays in the Ruhr region. Because Eisden pursued a specific housing policy of placing families of diverse ethnic backgrounds in the same street, its inhabitants had to find a way to communicate with each other.

Although the technical vocabulary underground became French-Walloon based, a variety of German turned into a lingua franca for the first generation of speakers. It can be assumed that this lingua franca consisted of a mixture of different dialects and nonstandard varieties of German as spoken in Europe at the beginning of the twentieth 
century. The second generation - the speakers featured in this study - grew up with Belgian Dutch, the home language of their parents, and some French. In public, however, they heard their parents speaking 'German.' These varieties provided the input for what the speakers themselves would later label 'Cité Duits.'

As in most cités in Belgian Limburg, work, schooling and social life took place within the boundaries of the mining district, implying that the miners' children grew up with little contact to people from outside the cité. The social isolation of the mining community was further reinforced by the hostile attitudes of the local population. These circumstances very likely contributed to a strong in-group feeling among the miners' children. In this context, I argued that practices of place-making created feelings of belonging (Cresswell 1996; Thissen 2018; Auer \& Cornips 2018).

Even though females grew up as multilingual as males, Cité Duits has always been confined to male speakers. Gender role patterns confined girls and women as housekeeper to the home, while at the same time it appears that speaking Cité Duits became indexical of masculinity linked to the male underground miner. While there is evidence that girls with numerous brothers may have spoken Cité Duits, this phenomenon seems to be an exception. In addition, Cité Duits has not been transmitted to subsequent generations, which can be explained by socioeconomic transformations, as well as by the ambivalent attitude of many miners toward their work. The changing composition of the work force in the 1960s, followed by the closure of the mining industry in the early 1990s, led to the gradual disappearance of the social contexts necessary to speak and maintain Cité Duits. Nowadays, the language use is moribund, with the few remaining speakers all being men in their late seventies and eighties.

\subsubsection{Linguistic Characterization}

Despite the speakers' label Duits 'German,' the linguistic analysis (§ 4-7) revealed that Cité Duits cannot be easily characterized as a variety of German, or Dutch. Rather, there is much evidence toward an amalgamation of features due to intensive language contact between Belgian Dutch, the Maaslands dialect spoken in Eisden and varieties of German. If the lexicon resembles colloquial German, next to words from the French-Walloon mining vocabulary, boundaries between the three contact varieties are often blurred. While much of the syntax can be associated with Belgian Dutch and Maaslands, Cité Duits exhibits fewer constraints, also on the level of semantics.

For instance, the order of verbal elements in the two-verb cluster (\$ 4) clearly follows the Belgian Dutch-Maaslands pattern (1-2-cluster) and therefore differs from (dialects of) German (2-1-cluster). Similarly, Cité Duits has verbal infinitives where German has a participle, reflecting the IPP-effect of Dutch. Furthermore, Cité Duits does not mark case on personal and possessive pronouns, determiners, negative articles, and attributive adjectives, in contrast to colloquial standard German, but in line with varieties of Dutch. In turn, participles frequently show word-internal mixture. Likewise, Cité Duits appears to have fewer constraints than its contact varieties in its left and right periphery 
of the clause: on the one hand, Cité Duits allows for verb-third (V3) in certain contexts. On the other hand, it tends to regularly extrapose PP-complements, as well as NPs and adverbial complements, after the closure of the right verbal bracket.

\section{Personal Pronouns}

My analysis of personal pronouns $(§ 5,6)$ established that Cité Duits displays a quite coherent pattern of personal pronouns. Speakers do not switch between pronominal forms when speaking Cité Duits, but have developed one pronominal paradigm. While there is clearly some variation in the data, this type of variation often resembles spoken varieties of Dutch and German. Cité Duits shares a large part of its pronominal paradigm with colloquial standard German and to some degree with the Maaslands dialect. There are hardly any variants that correspond to Belgian Dutch alone. Similarly, while Cité Duits does not have a paradigm of weak and full pronominal forms, reduced forms in Cité Duits are usually enclitics and must attach to another element, in line with German.

I identified three intermediate forms: the first-person singular subject ich [Iç] 'I,' the first-person plural subject wie [vi:] 'we,' and the third-person singular masculine subject $d e(r)$ [de:] 'he,' whereby 'I' and 'he' are likewise the pronouns with the highest frequency in the corpus. Ich [Iç] 'I' seems a Belgian Dutch-Maaslands-German form, pronounced with a voiceless post-palatal fricative as in Maaslands, but with a short vowel as in German and Belgian Dutch, whereas wie [vi:] 'we' exhibits congruence with the German full form wir [vi:e] and the Belgian Dutch weak form we [wə]. That wie [vi:] cannot be categorized as belonging to one of the contact varieties also confirms the result from a perception test. In contrast, $d e(r)$ [de:] 'he' can be associated with the German der [de:

For third-person pronouns, Cité Duits typically uses variants that resemble demonstrative instead of personal pronouns, both in subject and object position. Unlike its contact varieties, Cité Duits does not distinguish grammatical gender but has a single form for specific referents, i.e. $d e(r)$ [de:]. Biological gender, in turn, is specified. Similar to German and Maaslands but unlike in Dutch, die [di:] designates feminine and $d e(r)$ [de:] masculine human referents. Yet Cité Duits differs in some pronouns from German. While German has the form ihr [?i:e] in subject position but euch [?orç] in object position for the second-person plural, Cité Duits uses euch [?गIç] as a joint subject-object pronoun for the second-person plural. Another feature that distinguishes Cité Duits from colloquial standard German is the fact that object pronouns do not display case distinctions. Furthermore, 'it' and 'that' correspond to the form dat [dat] in Cité Duits, realized with a final stop as in Belgian Dutch, Maaslands and Ruhr-German.

Regarding object pronouns, which have a much lower overall frequency, there is less variation and reduced forms are rare; only the third-person plural displays a distinction between the full die [di:] and the enclitic form se [zo]. The first-person and second-person singular mich [miç] 'me' and dich [dıç] 'you' correspond to the respective German accusative pronoun, and exhibit much congruence with Maaslands. In turn, the thirdperson singular masculine ihm 'him' has neutralized toward the dative case from the 
perspective of German grammar, which I explained by Belgian Dutch-Maaslands influence of $(h) e m$ 'him.' For feminine human referents, speakers use die [di:]. Similar to German, the first-person plural is uns [uns] and the second-person plural is euch [?orç].

By means of a frequency analysis, I showed that speakers use pronominal variants quite systematically. What looked like variation at first sight could often be explained by the position of the pronoun in relation to the finite verb in non-topicalized position, as well as in relation to the position of the complementizer. Most enclitic forms correspond phonetically to German (te [tə], $m a$ [me], wa [ve], se [zə]). A particular case, however, is the first-person plural subject $m a$. While enclitic $m a$ also exists in (Ruhr-) German, I argued that $m a$ has a wider distribution in Cité Duits, appearing both as only subject pronoun in a clause and serving as inflectional marker together with a full firstperson plural pronoun.

The first-person plural subject further stands out in having several variants: the enclitic form $m a$ [me] (and seldom $w a$ [ve]), as well as the forms wir [vi:e], wie [vi:], and we [wə]. While $m a$, wa, and wir correspond phonetically to German, and we to Belgian Dutch, wie does not exist in the contact varieties but represents an intermediate variety. Furthermore, for some pronouns Cité Duits uses a single form where the contact varieties distinguish between several variants (e.g. 3SG.SBJ dat > Dutch (he)t/dat; 1SG.OBJ mich $>$ German ACC mich/DAT mir; 2SG.OBJ dich > German ACC dich/ DAT dir; 2PL.SBJ/OBJ euch > German SBJ ihr/OBJ euch).

\section{Progressive Aspect}

My analysis of progressive aspect ( $(7)$ demonstrated that Cité Duits mainly uses the anprogressive (an $+\mathrm{V}$-INF + sein-FINITE), whereas spoken varieties of Dutch and German have numerous means to express ongoingness. While I also attested the beim-progressive, resembling German, and the posture verb progressive with 'to sit,' which can be associated with Belgian Dutch and Maaslands, these have a very low incidence. The latter, then, is formed with sitzen $z u+\mathrm{V}_{-\mathrm{INF}}$, lexically resembling German.

If Cité Duits an-progressive appears to resemble the aan het-laon'tlamprogressive, it has several characteristics that distinguish it from Belgian Dutch, Maaslands and (regional varieties of) German. First, Cité Duits has a morphological variant of the progressive marker that does not exist in the contact varieties (an). In this context, I proposed that an can be analyzed as a progressive marker that is specific to Cité Duits. While an is the most common progressive marker in the corpus, most speakers vary between an and $a m$.

Second, the an-progressive exhibits fewer semantic restrictions than varieties of Dutch and German, including Ruhr-German. Cité Duits systematically expresses Vendlerian 'states' by the an-construction, whereby it often has a posture verb in the respective verbal construction, which appears in the infinitive slot rather than in the finite verb slot ( $a n+\mathrm{V}$-INF + posture verb). Posture verbs with the progressive are considered impossible in spoken Dutch and German (van Pottelberge 2004; Booij 2008; Ebert 1996), and my analysis of a corpus of regional and dialectal varieties of German corroborates 
these observations. While absent from the German corpus, such examples make up 30 percent in the Cité Duits data, which points toward a systematic use.

Third, the progressive constructions differ syntactically from colloquial standard German, and often resemble Dutch and Maaslands. To be precise, Cité Duits progressive combines with transitive and intransitive verbs and allows different types of complements. While some constructions can be associated with Ruhr-German, next to Dutch, Cité Duits exhibits fewer restrictions than colloquial standard German.

\subsubsection{Methodological Implications}

Cité Duits has always been an informal oral variety that has hardly been used in writing (§ 3). The linguistic analysis of this work was largely based on an audio corpus of spontaneous-like group interactions, collected by adopting a specific method of sociolinguistic fieldwork (Labov 1972; 2001). From a methodological perspective, it became evident that the analysis of recordings resulting from interactions involving multiple speakers yields particular drawbacks, but also specific avenues for future research.

First, it can be assumed that both my role as researcher and the presence of the recording device have influenced the recordings. Speakers are usually aware of being recorded, and this impacts the recorded material, although to different degrees. In a similar vein, changing consent procedures exacerbate the recording of 'natural' speech data for research purposes.

Second, regarding the transcriptions, the transcriber's beliefs unavoidably enter the transcript, and the way in which the recorded data was rendered into text had an impact on the analysis (Bucholtz 2000). Cité Duits is not codified, but the analysis required consistency in the final transcriptions. For this reason I chose German orthography as matrix. Dutch orthography was used for all words that could clearly be associated with Dutch and do not exist in German. Although parts of the material was transcribed by and discussed with speakers of Dutch, to some degree, the transcriptions in this work remain influenced by my own perceptions.

Third, data of spontaneous-like interactions are less comparable. On the one hand, the quantity of tokens in the corpus is not always sufficient to conduct a comprehensive analysis of a given feature. Some features appear only once or twice. On the other hand, the amount of speech differs per individual, which means that the number of attested tokens for a linguistic feature differs across speakers. In a similar vein, the full range of a particular feature is not always available $(\S 4,5)$. Likewise, object pronouns showed a much lower frequency than subject pronouns, while pronouns with a female human antecedent were generally rare. In addition, due to the informal character of Cité Duits, comparison with previous studies or other corpora based on slightly more formal language require caution, in particular because certain features show a frequency distribution in spontaneous-like language which completely differs from that in interview contexts or in informal written sources. 


\subsection{Discussion}

This dissertation has shown that Cité Duits has amalgamated features from three source varieties, as well as structures of its own. According to Aboh's approach (2015) to the emergence of hybrid grammars, an emergent contact variety may recombine syntactic and semantic features in ways differently from the source varieties. Although a wide array of phenomena has been identified in sociolinguistic research on language contact, Cité Duits differs from most previously established categories $(\S 1.3)$.

First, it is obvious that Cité Duits is not code-switching in its traditional understanding (e.g. Gumperz 1976; Poplack 1980; Auer 1998a), whereby it is usually possible to distinguish stretches of speech from a language A, B and C. Rather, boundaries are often fluent and elements from Belgian Dutch, the Maaslands dialect and German cannot easily be delimited. While code-switching is conducive to variation when several grammatical systems exist side by side, Cité Duits exhibits a considerable degree of consistency. On the one hand, we have seen that speakers use one - and not two or three - pronominal paradigms when speaking Cité Duits, including three intermediate forms ( $\S$ $5,6)$. Moreover, speakers employ a progressive construction that differs in some aspects from all three contact varieties $(\S 7)$. In contrast, many syntactic patterns attested follow the Belgian Dutch-Maaslands order but differ from (dialectal varieties of) German ( $\$$, 7). On the other hand, a number of features of spoken Belgian Dutch, Maaslands or German remain absent from Cité Duits, such as the Dutch er and the forms hetles 'it' ( 5). If Cité Duits was code-switching, features from all three language varieties should be represented.

Second, Cité Duits does not characterize as a 'fused lect' in the sense of Auer (1998a), that is a fully stabilized mixed variety. As illustrated by my analysis, there are elements of fusion - e.g. the pronominal forms ich [iç] 'I,' wie [vi:] 'we,' and $d e(r)$ [de:] 'he,' the aspect marker an, participles, and (in)definite determiners - and the speech exhibits a certain degree of sedimentation, shown by particular regularities. Yet from a methodological perspective, I cannot always establish the degree of mixing. Because the contact varieties are so close, it sometimes remains an impossible endeavor to determine whether a given feature should rather be associated with Belgian Dutch, Maaslands or German. What is more, dialectal and non-standard varieties of Dutch and German often display similar features. For instance, Ruhr-German shares several features with Dutch, such as the realization of dat 'that' with a final stop, as well as fewer semantic and syntactic restrictions in the progressive. A fused lect, strictly speaking, presupposes a complete conventionalization of language mixing on all levels. It could be argued, however, that Cité Duits displays fusion or amalgamation of numerous features if approaching fusion as a gradual process on a continuum (Auer \& Hakimov 2020). For example, although the large number of pronominal forms are fully established and have become obligatory, there is still alternation in the first-person plural 'we.'

Third, in consisting of features of structurally similar varieties, Cité Duits clearly differs from 'mixed languages,' which usually derive from two unrelated languages whose 
speakers came in contact (e.g. Bakker \& Mous 1994; Bakker 1994; 1997; Meakins 2018; Muysken 1981; Mous 2003; Matras 2000), and as such represent an extreme case of a 'fused lect.' What is special about Cité Duits, then, is its sociolinguistic status and its history of emergence, which are similar to those of many mixed languages. Although I can only reconstruct the phases of its emergence, there is evidence that Cité Duits developed in a very short time span, and functioned for a long time as a vehicle for identifying with one particular group (coal miners and family members) and disidentifying with others (local population). Accordingly, what Cité Duits has in common with typical examples of mixed languages is the fact that it arose in a setting of multilingualism where a shared language already existed (Belgian Dutch), implying that its primary function was not to ensure communication but rather to mark an in-group identity $(\S 2)$. The latter also distinguishes Cité Duits from pidgin and creole languages (Kouwenberg \& Singler 2011; Meakins 2018: 2).

Cité Duits can perhaps best be associated with Muysken's (2000) concept of 'congruent lexicalization,' which describes the convergence between two varieties in a clause, whereby the grammatical structure may be shared fully or partially $(\S 1.3)$. The type of linguistic fusion found in Cité Duits also differs from the processes observed in structurally unrelated languages. Rather, they resemble those of contact settings involving one or more Germanic varieties, which suggests that the typological characteristics play a role, as emphasized by Muysken (2000). For example, Cité Duits progressive shares many features with Pennsylvania-German, where the existing structure has turned into an obligatory grammatical structure with a wider range of uses on the level of syntax and semantics (Tomas 2018; Louden 1994) (see § 7). Another feature that Cité Duits shares with many German contact varieties is the extraposition of elements after the right verbal bracket (Riehl 2009: 86), and the fact that these typically do not mark case (Clyne 2003: 125-30; Yager et al. 2015; Louden 1994; Shah 2007).

Naturally, there are areas where closely related Germanic varieties have been in contact for several centuries such as the Faroe Islands (Faroese and Danish) and the German-Danish border area (German, Danish and South Jutish) (Braunmüller 2009; Fredsted 2000). ${ }^{1}$ Cité Duits, however, did not emerge in a German-Dutch-speaking community but in a linguistically diverse group of speakers of various home languages in Belgium $(\S 2,3)$. This, I propose, also makes it unlikely that Cité Duits developed out of code-switching (as often claimed for 'mixed languages').

Finally, my analysis demonstrated that the grammatical structures that occur in language contact situations are not always new, but often reflect general patterns of language change. The object pronoun in subject position in Cité Duits can be associated with present-day spoken Dutch ( 6 6.2.7), whereas particular features of the an-progressive in Cité Duits are found in spoken varieties of Dutch and German as well, if less commonly.

\footnotetext{
${ }^{1}$ See Fredsted (2000: 139-48) on Sydslesvigdansk 'South Schleswig Danish.' Further research on language contact of closely related varieties has been conducted by van Bree $(1994 ; 2001)$ on Stadsfries 'Town Frisian,' by Riionheimo and Frick (2015) on Finnish and Estonian, and by Tsiplakou (2014) as well as Tsiplakou et al. (2016) on Cypriot and Standard Greek.
} 
Similarly, 'because' without verb-final is fully established in spoken German (§ 4.4.2). At the same time, language contact settings often trigger similar processes, making it difficult to determine which features of Cité Duits are the result of language contact or change.

\subsection{Directions for Future Research}

The present investigation has shown that Cité Duits can offer closer insights into many aspects of language contact between closely related varieties. In the narrowest sense, this dissertation provides an analysis of personal pronouns and progressive aspect in Cité Duits. But in a broader sense, since both dialects and colloquial standard varieties are involved, it contributes to our general understanding of spoken and informal language. In addition, by highlighting the ways in which Cité Duits is unique and similar to spoken Belgian Dutch, Maaslands, and German, the analysis of Cité Duits provides evidence for specific directions of language change, while also offering a unique possibility for crosslinguistic research into these partly new developments.

In this final section, I propose three broader directions for future research related to the findings of this dissertation. First, I suggest that linguistics research should pay closer attention to informal speech data. As emphasized in this dissertation, informal language differs significantly from formal language such as produced in experimental settings. Yet the large majority of existing studies, at least on progressive aspect, is based on text corpora, questionnaires, experimental settings, or even intuitions, rather than on spontaneous-like speech data (see § 7). Larger speech corpora that could be used for this purpose are, among other ones, the Dutch CGN (Corpus Gesproken Nederlands), and the German FOLK (Forschungs- und Lehrkorpus Gesprochenes Deutsch) at the Institute of German Language in Mannheim.

A second potential research direction relates to the discourse practices and narratives of the former miners. For many decades, these speakers belonged to a marginalized community whose language and work practices were under-rewarded and hardly recognized, which is also reflected in the content of their narratives $(\S 2)$. These narratives still need to be analyzed. In addition, 'mining varieties' resulting from the interplay of labor migration and specific sociolinguistic settings have been attested in different parts of the world (Cornips \& Muysken 2019; Braber 2019; Álvarez López 2019; Mesthrie 2019; Muysken 2019), and it may be interesting to examine whether these display similarities with the language practices of the speakers from Eisden.

Third, it may be worth taking a closer look at the role of women in the BelgianLimburg mining cités, both from a sociohistorical and linguistic perspective. In this dissertation, I could address 'female' language practices only to a limited extent ( $\$ 2)$, and few studies have been devoted to the role of women in this respect. Their experiences and identifications through language practices in the Belgian cités deserve to be scrutinized more in-depth. 


\section{Annex}

\section{Constructions with $u m \ldots z u$ and für...zu}

The following examples have been attested with the infinitival complementizers für ...zu und $u m \ldots z u$, both in the audio data and in the written document. ${ }^{1}$ Relevant items are marked in bold.

(1) (231115_1: 565.412 - 568.024, Victor)

01 ah DU trinkst mit,

02 um zu verGESsen, ja:a.

(2) (CD5: 207.325 - 212.995, Jan)

01 FRÜher war nich so einfach um belga zu worden.

(3) (CD5: 283 - 291.29, Ferenc) (about his brother who wanted a higher position in the mine)

01 de war (.) für conducteuR zu were,

02 musste er BELgische sein.

(4) (0313_151301: 109.375 - 111.945, Jan)

01 PAPrika un so weiter.=

02 =für zuHAUse $\mathbf{z u}$ kunne koche.

(5) (171115_5: 609.347-611.725, Jan)

$01 \mathrm{JA}$ : dat is schon -

02 für zu ZEICHnen is dat (schwer).

(6) (0313_144739: 86.441 - 88.521, Raf) (talk about cigarettes)

01 ich WEISS,

02 dat ging besser für zu ROLle.

(7) (0313_144739: 1343.445 - 1344.615, Yanis) (talk about grinding poppy seed)

${ }^{1}$ The only utterance that has been excluded is the following German quote, Sind Sie gekommen um den Kriech zu gewinnen oder um Kohle zu verkaufen? 'Did you come to win the war or to sell coal?' 


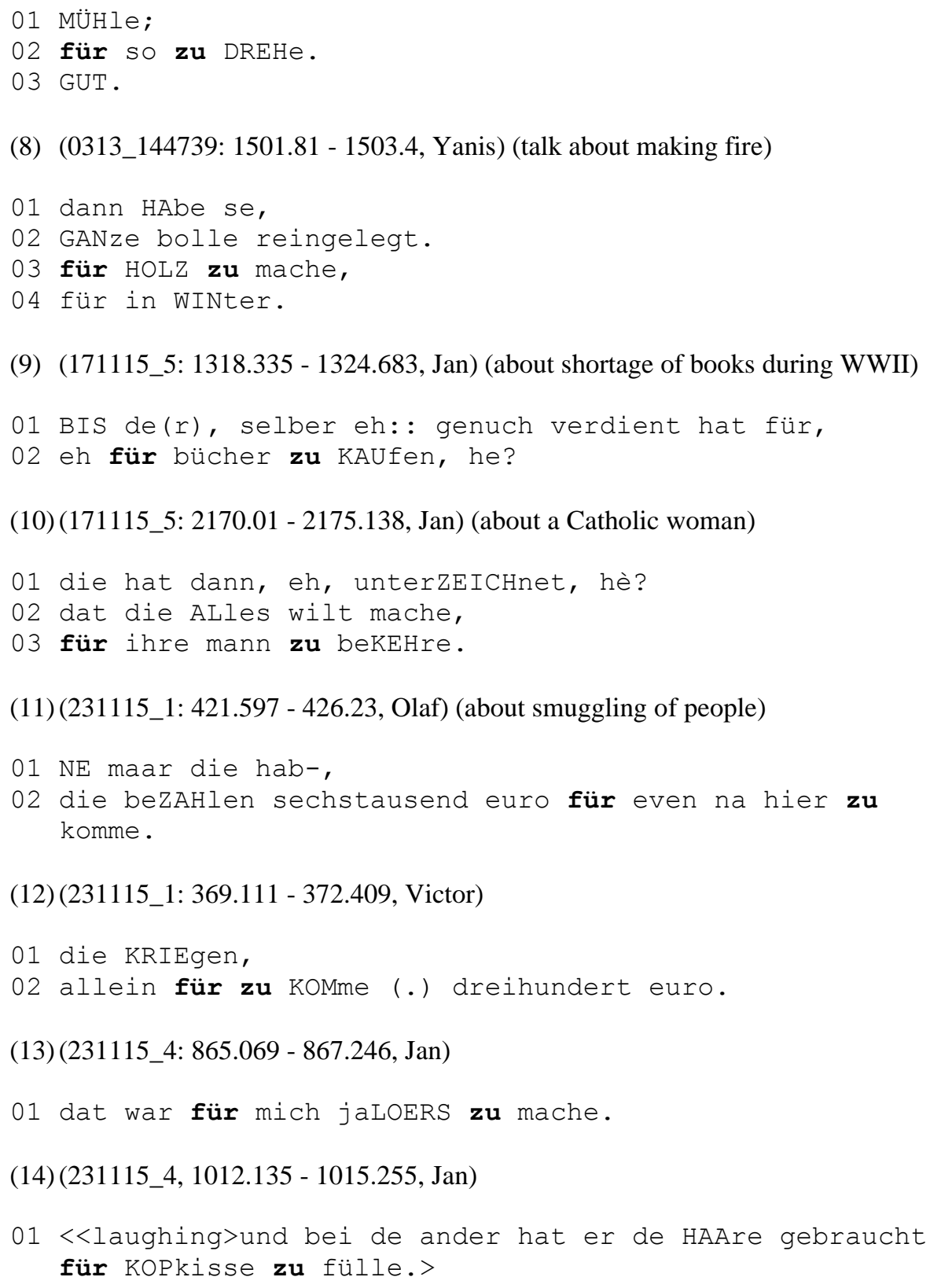


(15) (0313_152448: 422.5 - 425, Raf)

$01 \mathrm{Ja}$, fier se PLAATse zu setze.

(16) (231115_3: 966.497 -973.342, Jan)

01 die sin noch gut für zu ESse.

\section{Written document:}

Note that für is spelled as fie here.

(17)

dan gebrauch ich dat fie zu esse.

(18)

Ein Pikeur hatma gebraucht in Put fie Kohle zu mache.

(19)

Morgens früh is ein Soldat durch dè Strasse marsjiert un hat auf ein Doedelsack gespielt um die Soldate wacka zu mache.

(20)

und dè Piene in dè andere Hand mustma ein Schlag gebe auf dè Piene um ihm so weit wiema konnte hinta dè Linie zu kriege.

Da ware auch viel verschillige metodes um Kniekas zu spiele, auch zu viel um alles aus zu lege. 


\section{Constructions with kommen 'come' + infinitive}

The following examples have been attested with the verb kommen 'come' followed by a bare infinitive as complement.

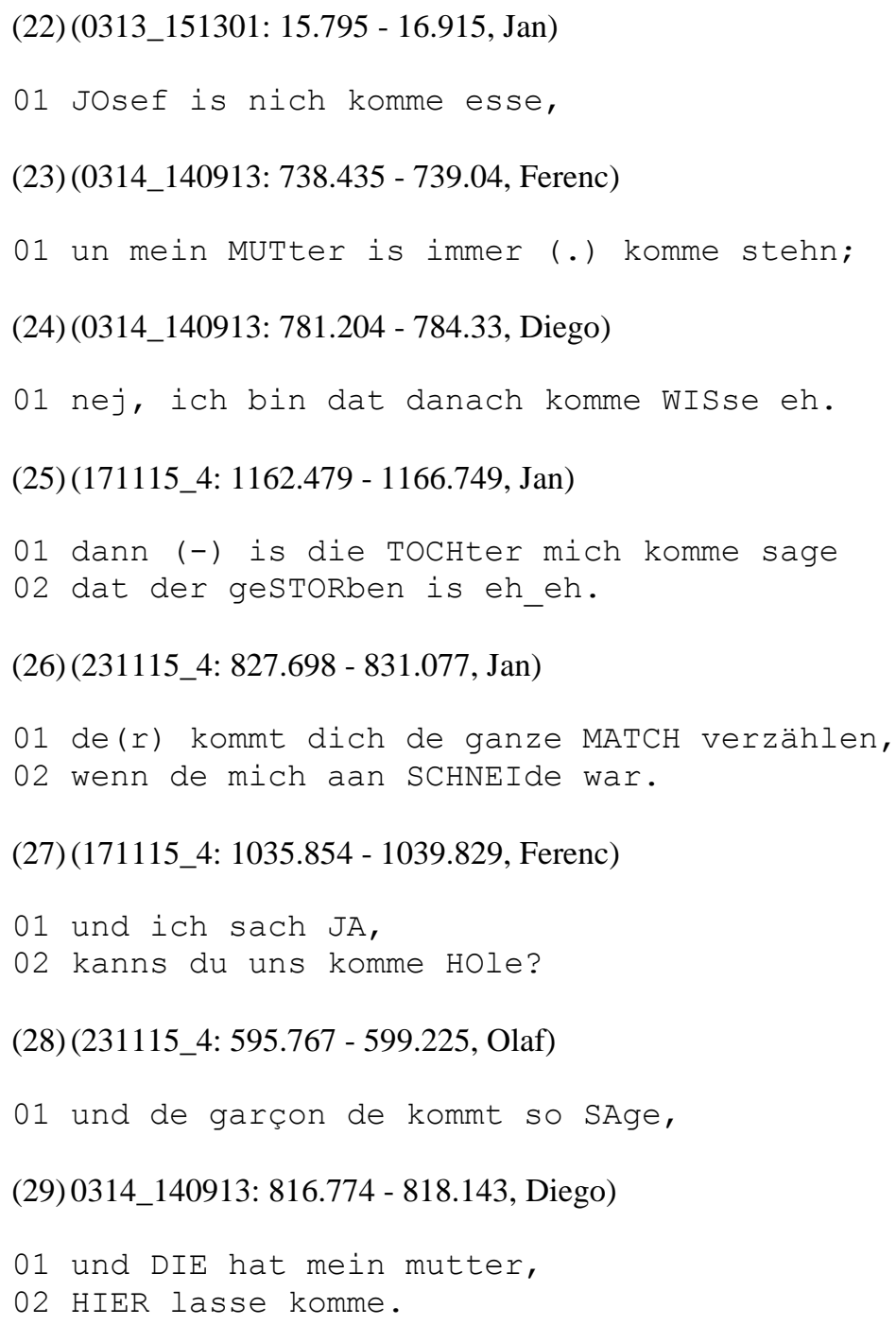




\section{List of Extraposed Constituents}

The following examples document the phenomenon of extraposition (Ausklammerung) in Cité Duits, with the relevant extraposed constituents marked in bold. Most of the examples stem from my Master thesis (unpublished script, defended November 14, 2014), but note that the list is incomplete due to their high frequency in the corpus. I included examples with and without a prosodic boundary between the closure of the right verbal bracket and the extraposed constituent. Examples with a prosodic boundary are also typical of spoken German and Dutch.

(1)

01 WINter of weet ich eh (nix).

02 ich musste FAHren mit de fiets.

(2)

01 un hab mich HINgelegen auf ein chaise longue.

(3)

01 wenn die uns geSCHICKT habe, ne?

02 eh_eh (.) i:n BUSCH,

03 SCḦISkis grafe $(n)-$

(4)

01 de $(r)$ het geBAUT? (-)

02 ! IN! langklaar.

(5)

01 ich war in neununddreissig eh geBOre_in september, 02 = mei VAter war o?,

(6)

01 habe se dich unter auch,

02 wie du VIERzehn (.) jahre wars(t),

03 auch (-) so geSCHICKT eh, (.)

04 nach magazIN?

(7)

01 un ! DER! hat se - (--)

02 gefange mit NETze;

(8)

01 wie haben ein ÖSterreichische trainer gehat hier,

02 van de ERSCHte mannschaf; 
(9)

01 un dann ham wa sicher ein STÜCK oder ZEHN geschna? eh gefange,

02 von die E:gels.

(10)

01 und DAmals hat man genennt, (-)

02 kaDETT,

01 da be uns (.) tsegenÜber, ne? ${ }^{\circ} \mathrm{hh}$

02 da hat gewohnt (.) de LANge, (-)

(12)

01 und dann (ert) is er nar PO:le gezoge. (-)

02 de (r) heideMAcher;

01 dat_dat war (-) die kon all perfekt lese un SCHREIben,

$02=($ de) italIEni;

(14)

01 nächste mal bring ich mal leckere unga:risch APple mit,

02 GRÜne un Rote;

(15)

01 und da warn (.) KLEIne fische, ne?

$02<<$ acc $>$ DIcke und GROsse he>,

(16)

01 ich hab polenta gegesse, ${ }^{\circ} \mathrm{hh}$

02 polenta me_me_met SPATze;

(17)

01 und dann ging_we (.) dann met PAsen da; he.

$02<<f>$ naar de $\bar{M} E S>$, (.)

03 drei STUNde,

01 karPAtisch is, 
02 dat is zwischen ukraine un un un DINge,

03 un_un slowaKEI drinne; ne?

(19)

01 du bis WEGgegange vom tisch OHne hunger.

(20)

01 we hadde (doch) gester gesproche vom bo MEIer, ne?

(21)

01 die jetz sin verHEIrat mit an POLnische,

01 und de $(r)$ is toen nar Pole gegange mit die frau.

01 un dann (--) wie is dat WEIter gegange mit dich;

02 wat is (-) wie is dat WEIter gegange.

01 die ham (-) die ham geMACHT,

02 wat se zuHAUse gehört hab of deutsch,

01 und die hat geFAHre naar de STA:si.

01 DA hat er gearbeitet bei prins de merode.

01 ja un MEIne eltern,

02 mei(n) vatter war gestorben in VIERzig; ne?

01 mei SCHWIEgervater ist jekomme in neunzehnneunundzwanzig dreissig;

01 un dann hat mein MUTter gesacht,

02 die sin (hier) aan neunzehnhundertfünfundzWANzig, he? 
01 anna hat noch DREI übrig geha(b)d in DIEPvries, (31)

01 so is dat geWEse früger;

02 muss ma unsere tsch? ZUNge rausstecke,

01 ich hab polENta gegesse früher auch,

$02=$ bei uns ham se immer mit MILCH,

01 in italie sitze(n) se allemal zu WARte schon.

01 wie sin ma zusamme naar scHule gegange hier,

01 ich wuss WOHL,

02 dat er konnt singe gut.

(36)

01 reKLETT so heisst,

$02<<a l l, p>$ WIE ham immer gesacht reklett .

01 maar du bis ein scHLECHter gewese.

02 lass mal GUCke deine hände.

01 dat !IS! mein mutter nicht;

02 dat is mein TANte. 


\section{List of Attested Progressive Constructions in Cité Duits}

Repetitions of the same utterance have been counted as single examples (e.g. de war am gucke, am gucke). I did not to transcribe background voices nor voice-overlap.

(1) (0313_144739: 368 - 372.044, Yanis)

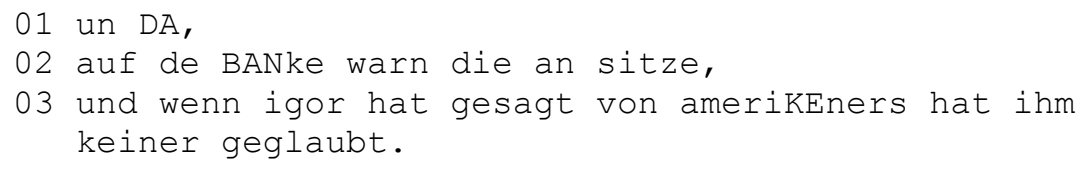

(2) (0313_152448: 96.1 - 98.5, Jan)

01 dan warn we in kantIne an sitze am bufFet nè?

(3) (0314_140913: 339.483 - 343.183, Josef)

01 WENN du,

02 da_sin(d) zwei STuNde wa_sie (bove) am sitze.

(4) (171115_5: 849.701 - 851.906, Ferenc)

01 und ich hab DRAUSse,

02 ich war DRAUSse an sitze-

(5) $\left(171115 \_5,877.413-878.811\right.$, Ferenc)

01 der war der so aan SITze hè.

$02 \mathrm{so}$.

(6) (171115_5: 1545.005 - 1549.64, Olaf)

01 un ich war da an SITze,

02 un un un FACHschule un da college war da,

03 Alles nè?

(7) (171115_6, 238.286-245.573, Jan)

01 der vater AUCH.

02 want der wohnte in (de HAUS).

03 der war IMmer an SITze so. 
04 am PORsche,

(8) (231115_3, $1503.342-1508.626$, Jan)

01 und ICH so aan sitze ich denk, dat (x),

02 auf EINmal has die leute sehn gucke,

(9) (231115_4: 119.623 - 122.041, Olaf)

01 und (.) da WARN ma dann,

02 in der KÜche aan sitze,

(10) $\left(231115 \_4,124.827-126.378\right.$, Victor $)$

01 LIES war da aan sitze,

02 und ERIC sacht-

(11) (231115_4: $813.262-819.612$, Jan)

01 schon ein stunde HAre geschnitten,

02 =warst noch IMmer am sitze (kos für betaal hè).

(12) (231115_4: 2193.591 - 2199.211, Jan)

01 wie warn ma auf der zoLder an sitze; =

02 =weil da warn zu wenig PLAATse.

(13) (231115_5: 69.78 - 73.94, Josef)

01 de hans SCHMID; =

02 =de war am SITze, (.)

03 BEN war effekes raus,

04 WEISS=du?

(14) (231115_5: 229.999-233.579, Jan)

01 BORrel un KAFfee un KOEKSkes; nè?

02 un die warn an SITze un,

03 un LASse sein vater ...

(15) (231115_5: $1175.8-1177.866$, Jan)

01 NIX. 
02 warn die an SITze.

03 dat hab ich noch NIEmals in ein FILM gesehn,

(16) (CD 9209.742 - 211.619, Jan)

01 de(r) war in in in (de) kaBIne an sitze.=

$02=$ die WARN schon-

(17) (0313_144739: 177.24-180.425, Raf)

01 JAja.

02 de(r) wart da aan SITze;

03 de wart BLIND so gesach, hè?

(18) (171115_3: 421.308-427.548, Jan)

01 warste auf de ZAdel an sitze; =

02 =maar bist nie mehr an de peDAle gekomme(n), ne?

03 konnst auch nie mehr stoppe.

(19) (231115_4: 1093.425 - 1097.245, Jan)

01 der WAR,

02 de(r) war am sitze.

03 Eric war sein haare aan 't schneiden von joep,

(20) (0314_140913: 498.873 - 501.349, Jan)

01 un dann warn die die die die scHÖne-

02 die die PAASeiere, ne?

03 an LIEge,

(21) (0314_134351: 448.29 - 453.71, Jan)

01 da war EIne de(r),

02 de war TOT auf de tisch an liege.

03 und maLEIS,

04 niet Ademen; =

05 =niet beWEgen.

(22) (0314_140913: 724.517 - 727.428, Jan)

01 ja so wie HIER de zimmer. 
02 und dann war der hier an LIEge(n), he?

03 de (r) Tote;

(23) (231115_5, 1117.155 - 1119.724, Jan)

01 unte in keller noch war die kohle $z 0$ an liege;

02 und von oben de ganze (schnitze) war SAND.

(24) (231115_5: 1169.325 - 1172.048, Jan)

01 mi mit der BOEKtas gegen de TÜre an stehn und-

(25) (0313_144739 785.19 - 787.02, Jan)

01 DA warn wir noch mit de; =

02 =die plaFONDS aan't mache.

(26) (0313_152448 1304.7 - 1309.41, Raf)

01 in monTAge;

02 wanneer ze de eh (.) TEI an mache warn,

03 de NEUe.

(27) (0313_144739, 460.06 - 462.79, Raf)

01 und die warn da am VOD brauen,

02 mit WASser (die) so.

(28) (0313_144739, 932.18 - 934.05, Raf)

01 wart de(r) an STRUnze (x),

(29) (0313_151301: 126.7 - 129.21, Raf)

01 maar JETZ is dat aan 't eh (.) WEGgehen.

(30) (171115_3: 834.212 - 839.629, Antonio)

01 die WAR doch immer mit so,

02 mit die SCHLAPpe un_ein FIETS, he?=

$03=$ am GEHN.

(31) (0314_140913786.314 - 788.956, Diego) 
01 mein mutter war $<<f f>$ für NON geworde,

02 für NON am gehn.>

(32) (0314_140913, 789.858 - 790.753, Diego)

01 die war für NON aan lerne.

(33) $\left(0314 \_140913,791.063\right.$ - 792.068, Jan)

01 war die für NON an lerne?

(34) (0313_151301: 495.305 - 496.875, Yanis)

01 we, ich war da (a) an spazIEren; =he?

(35) (0313_152448: 644.4 - 647.5, Jan)

01 DA wart wat aan krake da.

02 SACHT $=e r$,

03 ich hab ANGST gekricht.

(36) (0313_152448: 84.31 - 88.01, Raf)

01 de war(t) televisie an gucke,

02 flog ihm au(ch) de au AUge kaputt.

(37) (0314_134351: 329.6 - 332.32, Diego)

02 STOND ma da naak(t),

03 un alie ZWEI warn ma an gucke mit $<<$ laughing $>$ pimmelkes haha. >>

(38) (0314_140913: 750.678 - 752.051, Jan)

01 und de(r) war am GUCke na dein mutter-

02 (..) ob die nich AUFhört.

(39) (171115_5: 2559.302 - 2561.311, Jan)

01 ja de(r) war IMmer,

02 DEUTsche televisie am gucken he. 
(40) (231115_3812.012 - 815.316, Olaf)

01 und wir habe de(r) MANneke gepakt.

02 un am GUCke,

03 un am GUCke.

(41) $\left(231115 \_4,2350.679-2362.126\right.$, Olaf $)$

01 un de GANze klasse war dat; =

02 =de FLIEge aan gucke so.

(42) (231115_5: 1363.508 - 1366.618, Paolo)

01 ich bin gerade am gucke of de UHR (oder ich sach);

(43) (231115_3: 1158.404 - 1163.953, Jan)

01 ich war na sein FUSS aan gucke,

02 ich war na sein fuss aan gucke für ontertitels;

(44) (0313_152448: 873.82 - 877.41, Yanis)

01 na magazINE daar.

02 un: (.) ich war am WAR:ten auf dich.

(45) (171115_5: $416.96-419.235$, Jan $)$

01 UND,

$02<<$ laughing $><$ wie warn ma drausse am WARte he.>

(46) (171115_51632.935 - 1636.039, Olaf)

01 und ICH war am warte; =

02 =und dat war ne EEUWIGheid für mich, hè?

(47) (0314_134351: 503.79 - 506.21, Jan)

01 wie HAMma;

02 da warn au noch karpAte an wohne eh.

(48) (0314_134351:396.8 - 399.71, Diego) 
01 un ich war VIER monate schon krank aan't feiere,

02 auf EINmal sacht er so;

(49) (0314_134351: 417.41 - 420.51, Diego)

01 auf EINmal,

02 ich war aan SNUIten so he,

03 und da KAM,

04 auf EINmal kam-

(50) (0314_140913: 773.911 - 776.311, Jan)

01 auf EINmal,

02 de (r) BENno,

$03<<a l l>$ dein mutter war noch IMmer am BEte,

04 un de BENo; $>$

(51) (0314_140913 741.504 - 743.312, Paolo)

01 itaLIEnisch he?

02 warn die am BIDde he?

(52) (171115_3: 640.028 - 647.Jan)

01 DU: peter.

02 wenn we auf STRASse an spielen ware;

03 da ist doch (k) immer de juffvrouw van STOKkem gekomme,

04 UNgarische juffvrouw.

(53) (171115_4: 773.79-777.89, Raf)

01 ich war da praktisch IMmer auf de strasse aan spiele hè?

(54) (231115_4: $2109.89-2112.817$, Jan)

01 und dann warn wie Hinte in;

02 auf der graasMESke an spiele he. 
(55) (171115_3 436.971 - 439.055, Yanis)

01 de(r) war I:Mmer aan zählen.

(56) $\left(231115 \_5,1181.883-1183.556\right.$, Jan $)$

01 warn die an Z̈̈Hlen;

$02<<$ acclweil dat 'S NACHTS verkauft>.

(57) $\left(171115 \_4,346.91-357.426\right.$, Jan $)$

01 der war schon am STERbe de(r) mann; =he?

02 da war DIE,

03 de die de(r) SOHN,

04 die Tochter,

05 de die FRAU,

(58) $\left(171115 \_5,249.257-254.662\right.$, Jan $)$

01 wie du schon die GANZ zeit gegen die an quatsche warst, (-)

02 gleich schon wieder von VoRne beginn(en).

(59) (171115_5951.353 - 954.43, Olaf)

01 und (.) mit de (r) am QUATschen -

02 und daneben kommt noch EIner ne?

(60) (171115_5, 974.098 - 978.745, Jan)

01 die warn AUCH nebeneinander so,

02 aan- an PISse(n) hè?

(61) (171115_5: 954.43 - 957.015, Olaf)

01 und der war am PISsen wie in ein SPRÜHem so.

(62) (171115_5, 958.214-959.142, Olaf)

01 der war am SPRÜhen he.

(63) $\left(171115 \_52108.977-2111.928\right.$, Ferenc) 
01 de $(r)$ aan aan BELlen hè?

02 und dann kommt de frau;

(64) (171115_5: 1283.616-1290.022, Olaf)

01 un und (.) der war aan LEse so he?

02 un auf LETZte,

03 lest der $\mathrm{SO}$;

(65) (231115_3: 110.014 - 116.957, Jan)

01 und und die FRAU die hat,

02 die die war auf letzte am SINgen hè.

03 die die is mal in KIRche,

04 is die auf de PREKstuhl gegange(n).

(66) (231115_3: 1331.19 - 1337.02, Jan)

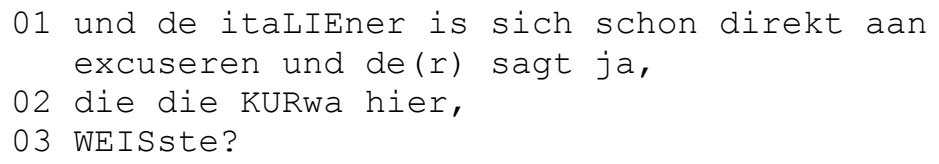

(67) (231115_3, 1093.425 - 1097.245, Olaf)

01 NEne, ich bin aan NAdenken,

(68) (231115_4: 827.698 - 831.077, Jan)

01 de(r) kommt dich de ganze match verzählen,

02 wenn de mich aan SCHNEIde war.

(69) (231115_4: 855.612 - 861.003, Jan)

01 de war dich aan SCHNEIde,

02 BERNhard war dich aan schneide und dann hat de -

03 HIER hat de de kamm,

(70) (231115_4: 805.1 - 806.327, Theo)

01 Alles war am lache.

02 und de OF- 
(71) (231115_4: 1555.042 - 1557.007, Ralf)

01 und JOS mein bruder,

02 und de war am bezAHlen.

03 und da kam (m) ich de SOHN (xx),

(72) (231115_4: 433.311 - 436.446, Victor)

01 STSTST.

02 dann biste met paPIER am fegen,

(73) (231115_5: $897.563-900.408$, Antonio)

01 die warn $\mathrm{AUCH}$;

02 die warn AUCH kohle am raffe(n).

(74) (231115_5: 916.953 - 919.44, Antonio)

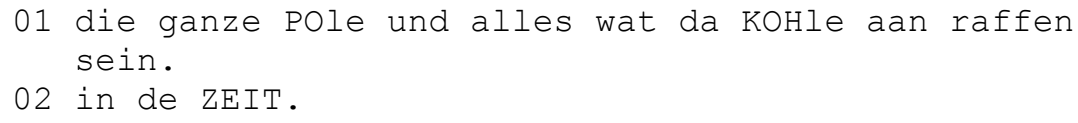

(75) (231115_5: 913.745 - 916.939, Antonio)

01 de wart am !BLUte!.

02 da warn ganz (NET) te leute.

(76) (CD 4, 97.023 - 110.974, Jan)

01 wie warn ma da Ebe schon aan spreche-

02 über (.) ESse un un DINge.

03 geMÜSE, he?

(77) (0314_140913, 1439.886 - 1443.286, Yanis)

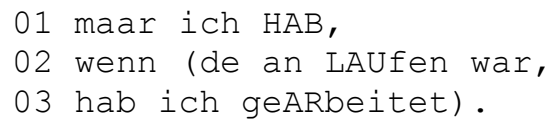

\section{Beim-constructions}


(78) (231115_3: 258.041 - 262.89, Raf)

01 da war se beim ESsen oder so,

02 (war dann) und DANN hast,

(79) (171115_4: 588.22 - 591.08, Jan)

01 wenn die Über,

02 beim DUsche habe gesproche vom put-

(80) (231115_3: 134.032 - 136.324, Yanis)

01 wie FRÜger beim feiern,

02 mit vier mann sin_ma geGANge.

(81) (171115_4: $598.855-603.82$, Jan)

01 (dat war) beim DUschen.

02 alles wat mit PUT zu machen hat,

\section{Posture verb constructions}

(82) (0313_151301: 325.56 - 327.48, Jan)

01 in_iTAlje,

02 da sitzen se allemal zu WARte schon.

(83) (0313_144739: 1168.53 - 1169.59, Yanis)

01 mit MESser.

02 (radweg) und REST,

03 (.) hat GUT wat.

04 ra: (RADweg).

05 <<all>und sassen wie zu ESsen.>

\section{Bezig-ïber constructions}

(84) (171115_3: 593.809-599.242, Jan)

01 HIER warn se bezig über,

02 chaRACters. 
(85) (171115_5: $261.541-263.404$, Jan)

01 wie warn_ma über scHule bezig he?

(86) (171115_5: 257.068 - 259.199, Jan)

01 du warst auch ü ü über SCHUle (al) bezig.

Overview of Constructions According to Speaker

\begin{tabular}{|l|l|l|l|l|l|}
\hline & $\begin{array}{l}\text { beim- } \\
\text { construction }\end{array}$ & $\begin{array}{l}\text { sitzen zu- } \\
\text { construction }\end{array}$ & $\begin{array}{l}\text { bezig- } \\
\text { construction }\end{array}$ & $\begin{array}{l}\text { an- } \\
\text { construction }\end{array}$ & Total-n \\
\hline Jan & 2 & 1 & 3 & 35 & 41 \\
\hline Yanis & 1 & 1 & 0 & 6 & 8 \\
\hline Raf & 1 & 0 & 0 & 7 & 8 \\
\hline Olaf & 0 & 0 & 0 & 10 & 10 \\
\hline Ferenc & 0 & 0 & 0 & 3 & 3 \\
\hline Diego & 0 & 0 & 0 & 6 & 6 \\
\hline Others & 0 & 0 & 0 & 10 & 10 \\
\hline Total-n & 4 & 2 & 3 & 77 & 86 \\
\hline
\end{tabular}

Table 41: Progressive constructions according to speaker in absolute numbers

\begin{tabular}{|l|l|l|l|l|}
\hline & $(\mathbf{a}) \mathbf{a n}$ & am & aan't & Total-n \\
\hline Jan & 24 & 9 & 2 & 35 \\
\hline Yanis & 4 & 2 & 0 & 6 \\
\hline Raf & 4 & 2 & 1 & 7 \\
\hline Olaf & 5 & 5 & 0 & 10 \\
\hline Ferenc & 3 & 0 & 0 & 3 \\
\hline Diego & 3 & 2 & 1 & 6 \\
\hline Others & 4 & 6 & 0 & 10 \\
\hline Total-n & 47 & 26 & 4 & 77 \\
\hline
\end{tabular}

Table 42: Realization of progressive marker in the an-construction according to speaker in absolute numbers 


\section{List of Am-progressives in the German Corpus}

The attested am-progressives in the German corpus are ordered according to city and region (total $n=78$ ). The transcriptions follow the original transcriptions encountered in the corpus.

\section{East Germany $(\mathbf{n}=15)$}

(1) Berlin $\quad k r a f t(($ lachend)) is wieder am zUnehm

(2) Berlin kraft am zUnehm) da fahr ick äh: is s doch

(3) Berlin (.) VIEL am Arbeitn

(4) Berlin da kann mal VIEL am quatschen ( )

(5) Berlin (aber ick war Immer am Überlegen)

(6) Berlin is die KRAFT wieder am zUnehm (.) `so

(7) Berlin sie sind jetz Ooch noch am Arbeitn

(8) Berlin eijentlich immer noch am berLINern; wa,

(9) Berlin die=die sind ja OOCH am berlinern so; wa,

(10) Berlin is äh: am laufn

(11) Dresden da bin isch jetz am forschen

(12) Dresden sind sie jetz am forschen

(13) Dresden [der] (mikes) ist ja ooch de am verfallen

(14) Dresden =und das war so am verfallen

(15) Dresden [weil weil ja meine tochter die is [jetzt och am überlegen

\section{Middle-West Germany (n=49)}

(16) Duisburg sind se schon zigaretten am rauchen

(17) Duisburg da warn=wer hier am essen

(18) Duisburg und wenn einer am versaufen war,

(19) Duisburg wenn=de wirklich viel am feiern warst ne dann

(20) Duisburg ja und da waren die immer am jammern und so weiter, ne

(21) Duisburg ganze wasser war am brennen (.) ne

(22) Duisburg nur am fressen nich

(23) Duisburg euer vater is da am spinnen

(24) Duisburg is die mutter am weinen

(25) Duisburg die ganzen tanker am brennen (.)

(26) Duisburg gänse und enten sind ja nur am fressen

(27) Duisburg [dann bist du vierzehn tage am kränkeln

(28)Duisburg der war doch [noch am erzählen

(29) Duisburg der vater war ja auch noch am arbeiten 
(30) Duisburg

(31) Duisburg

(32) Duisburg

(33) Duisburg

(34) Cologne

(35) Cologne

(36) Cologne

(37) Cologne

(38) Cologne

(39) Cologne

(40) Cologne

(41) Cologne

(42) Cologne

(43) Cologne

(44) Cologne

(45) Cologne

(46) Cologne

(47) Cologne

(48) Cologne

(49) Cologne

(50) Cologne

(51) Cologne

(52) Cologne

(53) Cologne

(54) Cologne

(55) Cologne

(56) Cologne

(57) Cologne

(58) Cologne

(59) Cologne

(60) Cologne

(61) Cologne

(62) Cologne

(63) Cologne

(64) Cologne in oldenburch is=es am schnei:en und am regnen

=die sind nich am arbeiten=

[e die nachbarin war am fenster putzen

[und dann bin ich im kel[ler am basteln ( )

un dann wa der am heulen

tja die kinder sin noch am spielen

wat weiß isch wie lange am arbeite bist

so [un jetzt bin isch nimmi am arbeite

war besoffen un am tanzen ((lacht))

ja du warst ja nit so am lachen

is schon widder am besser werden ne

un isch bin de teppich am knüpfe

[ich bin am überlegen ob ich wieder an zu rauchen fang am montach

nochher bist am schreie

isch bin nur am telefonieren>

da sitzt die in der küsche is am weinen

ich sitz nur noch da bin am grübeln (.)

biste am schwitze (.)

er is jetz am überlejen wat er macht (.)

( $s=$ hier) am frühstücken und lässt die wäsche up hängen

isch bin hier ja am verhüngere

ob der die ä:tse noch am pflöcke is

du bist aber nit am lachen oder [so

ich vermut dat sin se wieder am abreissen

oder die bremsen sin am schmoren

da bin ich am staunen

in der südkurve waren die leute sich die stühle am abmachen

un de bänke am abreißen

die sin am ersten am pumpen

alle sind die noch vor uns am pumpen

da bin ich hier meistens am basteln

ä:h da merk ich [dann jar nimmer dat ich richtig kölsch am re' am

reden bin ne

un bis din zehntes alt am trinken

un da sin auch äh: sehr viele leute mit drinne am schimpfen

oder $\mathrm{sa}=\mathrm{ma}=\mathrm{mal}$ das typisch rheinische (.) äh am am essen 


\author{
South Germany (n=14) \\ (65) Freiburg BI:N scho hundert johr am ausziehe aber i zieh jo nit aus ne \\ (66) Mannheim ah=ja deswege hawwe se a so en schbass [dran am tanze \\ (67) Mannheim die dialekte sin halt am aussterben \\ (68) Mannheim [soviel verkehr am vorbei rauschen \\ (69) Mannheim [der iss bloß am schelle \\ (70) Mannheim bloß am schelle \\ (71) Mannheim do is do laufend einer einziehe un am ausziehe ne \\ (72) Munich \\ nei i bin grad am über[legen \\ (73) Munich \\ mir sein immer am ausmisten (.) \\ (74) Munich \\ (75) Munich \\ und i war halt ständig am ausmisten weißt= \\ die san ja jetzt eh am aussterben=gell (.) \\ (76) Munich \\ ich bin grad wieder am winterspeck bekämpfen (.) \\ (77) Munich \\ jetzt bist diese heizung am modernisieren \\ (78) Munich \\ is jetz immer am überlegen
}




\section{Privacy Verklaring Form ('Privacy Statement Form')}

\section{Regels Transcriberen Onderzoek 'Speaking Cité Duits in a coalminers' neighborhood', project aanbieder Nantke Pecht}

Om aan de Wet Bescherming Persoonsgegevens en aan de Gedragscode voor Gebruik van Persoonsgegevens in Wetenschappelijk Onderzoek gevolg te geven, zijn een aantal regels vastgelegd:

1. Onderzoekers dienen zich te onthouden van pogingen om individuele respondenten te identificeren;

2. Het is onderzoekers niet toegestaan om de persoonsgegevens die in de opnamen genoemd worden of te herleiden zijn (namen, adressen, werkplekken, e-mailadressen etc.) naar buiten te brengen in welke vorm dan ook (inclusief sociale media);

3. Bij gevoelige onderwerpen wordt terughoudendheid betracht bij het naar buiten brengen van informatie in het kader van bescherming van de privacy van de informanten en de onderzoeker nu en in de verre toekomst.

4. Alle opnamen en het daarin vertelde zijn het (intellectueel) eigendom van de onderzoekster/instituut. De opnames mogen niet bewaard, opgeslagen of verspreid worden in welke vorm dan ook.

5. $\mathrm{Na}$ afronding van het project dienen alle geluidsopnamen definitief verwijderd te worden.

Onderzoeker aan wie data uitgeleend wordt:

Datum:

Plaats:

Naam.

Nantke Pecht 


\section{Toestemmingsformulier ('Agreement Form')}

Titel project: 'The construction of social relationships through language practices in a coalminer's neighborhood: The use of Cité Duits'

[Het spreken van Cité-Duits in een mijnwerkersbuurt: de constructie en reproductie van sociale identiteiten door taalpraktijken]

Verantwoordelijke project: Nantke Pecht, Universiteit Maastricht

\section{In te vullen door de deelnemers}

Ik verklaar op een duidelijke wijze te zijn ingelicht ben over de aard, methode, doel en eventuele mate van risico's van het project. Ik weet dat mijn anonimiteit gewaarborgd zal worden door middel van pseudoniemen, tenzij ik dit zelf anders aangeef. Ik begrijp dat Nantke Pecht de gegevens en resultaten zal beheren en dat mijn gegevens alleen anoniem en vertrouwelijk bekend gemaakt zullen worden. Mijn vragen zijn naar tevredenheid beantwoord, voor verdere vragen weet ik dat ik bij Nantke Pecht terecht kan.

Ik begrijp dat foto en- audiomateriaal of bewerking daarvan uitsluitend voor analyse en/of wetenschappelijke publicaties/presentaties zal worden gebruikt.

Ik stem geheel vrijwillig in met deelname aan dit project. Ik weet dat ik zonder toelichting of enige gevolgen het recht heb om mijn medewerking aan dit project op elk moment te beëindigen.

Naam

deelnemer:

Datum:

Handtekening deelnemer:

In te vullen door Nantke Pecht

Ik heb een mondelinge en schriftelijke toelichting gegeven op het project. Ik zal resterende vragen van deelnemers over het project ten allen tijden naar vermogen beantwoorden. De deelnemer zal van een eventuele voortijdige beëindiging van deelname aan dit project geen nadelige gevolgen ondervinden.

Datum:

Handtekening Nantke Pecht:. 


\section{Overview of Audio Recordings}

The figure below gives an overview of the audio recordings that I carried out between August 2015 and July 2017. The names have been changed and often abbreviated to maintain the anonymity of the participants (see $\S 3$ ).

\begin{tabular}{|l|l|l|}
\hline PARTICIPANTS & DATE & $\begin{array}{l}\text { RECORDED } \\
\text { TIME }\end{array}$ \\
\hline Jan & 18.08 .2015 & 00.21 .13 \\
\hline Jan, Ingrid & 18.08 .2015 & 01.06 .03 \\
\hline Jan & 18.08 .2015 & 00.05 .54 \\
\hline Ingrid & 18.08 .2015 & 00.32 .38 \\
\hline Adriana & 21.08 .2015 & 00.37 .29 \\
\hline Adriana & 21.08 .2015 & 00.25 .50 \\
\hline Jan & 21.08 .2015 & 00.14 .33 \\
\hline F.P. & 25.08 .2015 & 00.57 .21 \\
\hline F.P. & 25.08 .2015 & 00.05 .33 \\
\hline Marina, Tiano & 25.08 .2015 & 01.12 .47 \\
\hline F.P. & 28.08 .2015 & 00.12 .18 \\
\hline F.P. & 28.08 .2015 & 00.08 .45 \\
\hline N.S., Anna & 28.08 .2015 & 00.19 .38 \\
\hline N.S., Anna & 28.08 .2015 & 00.21 .19 \\
\hline N.S., Anna & 28.08 .2015 & 00.10 .30 \\
\hline N.S., Anna & 28.08 .2015 & 00.05 .23 \\
\hline R.B. & 28.08 .2015 & 00.12 .21 \\
\hline R.B. & 28.08 .2015 & 00.26 .28 \\
\hline M.G. & 01.09 .2015 & 00.54 .15 \\
\hline J.L. & 01.09 .2015 & 00.34 .02 \\
\hline Anna & 08.09 .2015 & 00.50 .19 \\
\hline E.P., A.K. & 08.09 .2015 & 00.21 .46 \\
\hline Lena, Ingrid, Anna & 15.09 .2015 & 00.12 .59 \\
\hline Lena, Ingrid, Anna & 15.09 .2015 & 00.36 .38 \\
\hline & & \\
\hline
\end{tabular}




\begin{tabular}{|l|l|l|}
\hline Lena, Ingrid, Anna & 15.09 .2015 & 00.46 .05 \\
\hline Lena, Ingrid, Anna & 15.09 .2015 & 00.10 .03 \\
\hline Lena, Ingrid, Anna & 15.09 .2015 & 00.10 .25 \\
\hline M.J, MO.J. & 18.09 .2015 & 00.12 .57 \\
\hline M.J, MO.J. & 18.09 .2015 & 00.58 .34 \\
\hline L.Z. & 29.09 .2015 & 00.24 .56 \\
\hline Mi. R., J. BU., M.G., & 06.10 .2015 & 00.33 .04 \\
\hline K.D., Mi. R., J. BU., M.G. & 06.10 .2015 & 00.14 .41 \\
\hline K.D., Mi. R., J. BU., M.G. & 06.10 .2015 & 00.18 .32 \\
\hline K.D., Mi. R., J. BU., M.G. & 06.10 .2015 & 00.05 .36 \\
\hline R.C., M.D., F.B. & 08.10 .2015 & 00.31 .30 \\
\hline R.C., M.D., F.B. & 08.10 .2015 & 00.46 .40 \\
\hline R.C., M.D., F.B. & 08.10 .2015 & 00.02 .34 \\
\hline J.K.W. & 09.10 .2015 & 00.47 .58 \\
\hline J.K.W. & 09.10 .2015 & 00.01 .13 \\
\hline M.BU. & 09.10 .2015 & 00.19 .23 \\
\hline NL.S. & 09.10 .2015 & 00.33 .06 \\
\hline A.B., N.T. & 13.10 .2015 & 00.31 .18 \\
\hline A.B., N.T. & 13.10 .2015 & 00.31 .19 \\
\hline JE.S.H. & 28.10 .2015 & 00.40 .34 \\
\hline Vadik, I.P. & 28.10 .2015 & 00.23 .31 \\
\hline Vadik, I.P. & 28.10 .2015 & 00.31 .48 \\
\hline Vadik, I.P. & 28.10 .2015 & 00.06 .15 \\
\hline Vadik, I.P., Q.R. & $11.2015 *$ & 00.47 .57 \\
\hline $\begin{array}{l}\text { Ferenc, Raf, Yanis, Josef, Jan, Olaf, Tiano, } \\
\text { Theo }\end{array}$ & 17.11 .2015 & 00.08 .53 \\
\hline $\begin{array}{l}\text { Ferenc, Raf, Yanis, Josef, Jan, Olaf, Tiano, } \\
\text { Theo }\end{array}$ & 17.11 .2015 & 00.14 .44 \\
\hline $\begin{array}{l}\text { Ferenc, Raf, Yanis, Josef, Jan, Olaf, Tiano, } \\
\text { Theo }\end{array}$ & 17.11 .2015 & 00.24 .19 \\
\hline $\begin{array}{l}\text { Ferenc, Raf, Yanis, Josef, Jan, Olaf, Tiano, } \\
\text { Theo }\end{array}$ & 17.11 .2015 & 00.45 .58 \\
\hline & & \\
\hline
\end{tabular}




\begin{tabular}{|l|l|l|}
\hline $\begin{array}{l}\text { Ferenc, Raf, Yanis, Josef, Jan, Olaf, Tiano, } \\
\text { Theo }\end{array}$ & 17.11 .2015 & 00.04 .55 \\
\hline $\begin{array}{l}\text { Ferenc, Raf, Yanis, Josef, Jan, Olaf, Tiano, } \\
\text { Theo }\end{array}$ & 17.11 .2015 & 00.12 .04 \\
\hline $\begin{array}{l}\text { Vadik, Paolo, Ralf, Antonio, Olaf, Jan, Ferenc, } \\
\text { Raf, Yanis }\end{array}$ & 23.11 .2015 & 00.10 .05 \\
\hline $\begin{array}{l}\text { Vadik, Paolo, Ralf, Antonio, Olaf, Jan, Ferenc, } \\
\text { Raf, Yanis }\end{array}$ & 23.11 .2015 & 00.01 .15 \\
\hline $\begin{array}{l}\text { Vadik, Paolo, Ralf, Antonio, Olaf, Jan, Ferenc, } \\
\text { Raf, Yanis }\end{array}$ & 23.11 .2015 & 00.27 .54 \\
\hline $\begin{array}{l}\text { Vadik, Paolo, Ralf, Antonio, Olaf, Jan, Ferenc, } \\
\text { Raf, Yanis }\end{array}$ & 23.11 .2015 & 00.40 .43 \\
\hline $\begin{array}{l}\text { Vadik, Paolo, Ralf, Antonio, Olaf, Jan, Ferenc, } \\
\text { Raf, Yanis }\end{array}$ & 23.11 .2015 & 00.27 .52 \\
\hline Olaf & 04.12 .2015 & 00.25 .18 \\
\hline Olaf & 04.12 .2015 & 00.30 .50 \\
\hline Olaf, T.I., U.S. & 26.02 .2016 & 00.12 .09 \\
\hline ST.B., D. Ku & 26.02 .2016 & 00.19 .38 \\
\hline ST.B., D. Ku & 26.02 .2016 & 00.32 .01 \\
\hline Victor, Raf, Yanis, Josef, Jan, Olaf & 08.06 .2016 & 00.15 .22 \\
\hline Victor, Raf, Yanis, Josef, Jan, Olaf & 08.06 .2016 & 00.16 .57 \\
\hline Victor, Raf, Yanis, Josef, Jan, Olaf & 08.06 .2016 & 00.58 .26 \\
\hline Victor, Raf, Yanis, Josef, Jan, Olaf & 08.06 .2016 & 00.02 .09 \\
\hline Adriana & 30.09 .2016 & 00.07 .24 \\
\hline Adriana & 30.09 .2016 & 00.12 .20 \\
\hline Adriana & 30.09 .2016 & 00.22 .06 \\
\hline Adriana & 14.10 .2016 & 00.06 .28 \\
\hline Adriana & 14.10 .2016 & 00.04 .06 \\
\hline Adriana & 14.10 .2016 & 00.08 .51 \\
\hline Adriana & 14.10 .2016 & 00.06 .34 \\
\hline Adriana & 14.10 .2016 & 00.19 .57 \\
\hline Jan & 14.10 .2016 & 00.09 .34 \\
\hline Adriana & 13.11 .2016 & 00.13 .12 \\
\hline Adriana & 13.11 .2016 & 00.01 .13 \\
\hline
\end{tabular}




\begin{tabular}{|l|l|l|}
\hline Adriana, H.E., R.I. & 18.07 .2017 & 00.08 .05 \\
\hline Adriana, H.E., R.I. & 18.07 .2017 & 00.10 .52 \\
\hline Adriana, H.E., R.I. & 18.07 .2017 & 00.28 .43 \\
\hline
\end{tabular}

Figure 47: Overview of audio recordings (2015-2017) 


\section{Errinerunge wie ich noch klein wa... ('Memories of when I was little')}

The following text in Cite Duits was written by one of the speakers. To maintain the original character of the text, I did not make any orthographical changes (see $\S 3.5 .6$ ).

\section{ERRINERUNGE WIE ICH NOCH KLEIN WA ...}

Ich bin gebore auf dè Berkenlaan numma 3, aba da weis ich niks mehr von. Jets steht da gegenuba ein Moskee. In dè Oorloch sien ma verhaust nach dè Eindstrasse, neben dè Kasteel wo dè Direktor von Put hat gewohnt. Dat wa ein grosse Park, aba wie kontma da nich rein komme. Da wa erst ein Pikkelhecke, und dan ein Gang, und dan ein gewöne Hecke. In Herbs und in Winta, kontma durch die Hecke kucke nach die schöne Weibas die imma gans in weis gekleid ware. Da wa soms ein Gart dè is dan durch dè gang gewandelt und hat aufgepast wen keine Löchas ware in dè Pikkelhecke.

In de Oorloch hamma ein Schutskella gehat in Garten. Wie hamma abends gesehn wie die Deutschas gesucht habe mit grosse Lichtstrahle in dè Luft nach die Flukzeuge. Bei uns nich, aba in dè Gebure is ein Bombe runtagefalle.

Nach dè Oorloch stande bei uns in dè Strasse Tanks von Amerikénas oder Englendas. Da ware auch Soldate auf dè Ecke in ein Haus. Wir habe da Aias von unse Hühne gebracht, und dan hamma Tsjoekolade gekriegt. Die Englendas habe ein grosse weisse Hahn gehat, und dè is imma hinta mich gelaufe, dè hat mich einmal in mein Bein gepiekt. Morgens früh is ein Soldat durch dè Strasse marsjiert un hat auf ein Doedelsack gespielt um die Soldate wacka zu mache. Da wa auch ein Soldat dè hat mich mal lasse kucke durch ein Fernkucka.

Von ein andere Soldat hab ich ein Kombinatie von ein Gabel un Löffel gekriegt. Dat kontma zusammeklappe wen ma dat nich braucht, und dan offe klappe. Dan war an ein seite dè Gabel un an andere Seite dè Löffel. Ich hab dat noch imma un wen ich mit mein Kamerade auf Survival geh dan gebrauch ich dat fie zu esse.

Wie hamma auch in Busch hinta dè Kirche, an dè Sandberge viel Kugels gefunte. Die hamma na Hause gebracht, auf dè sjtoep gelegt, und mit ein dikke Hamma drauf geklopt. Dè Spitz von dè Kugel is in dè Hecke von Direktor reingefloge. Glücklich is kein Accident passiert.

Bei uns in dè Strasse hat nur ein Flamische Familie gewohnt, die andere ware allemaal Auslendas : Pollakken, Slovenas, ein Hollenda, mein Fatta un Mutta ware Ungarische Schwaben. 
Mein Fatta wa ein Schreinwerka. Die Plankskes hat dè auf dè Kiepe geholt. Dè hat sich ein kleine Kroekarre gemacht un festgemacht hinta sein Fiets. Ich bin vielmals mitgegange, hinta auf dè Sjtoelke hab ich gesesse. Ich muste unta an dè Kippe wachte bis mein Fatta mit sein Plankskes na unta gekomme is.

Auf dè Sjtoelke hab ich mich festgehalte an dè Sassel, aba unta dè Sassel ware zwei Fédas un da bin ich soms mit mein Fingas zwische gekomme. Dan hab ich geheult, dat hat weh gemacht.

Sjuins gegenüba in dè andere Garte habe Flammas gewohnt. Da bin ich viel gewese, dat wa ein grosse Familie, die habe ein Leuvense Sjtoof gehat. Da wa imma ein grosse schwarze Panne auf dè Sjtoof mit Speck. Wie kontma schwarz Brot neme, un in dè Panne soppe. Da hab ich fie erste Mahl schwarz Brot gegesse. Von unta an dè Sjtoof ware Löchas und da konte man seine Füsse reinstecke in Winta.

Wie hamma fiel auf Strasse gespielt, Toepie, Gläsels, Pienspiel, Stuckse un auch Fusbal. Damals ware noch nich viel Autos.

Toepie, dat wa in Flammisch "tol". Da hamma ein Kordel gehat, von ein seite wa dè schon ein bitske ausgerafelt. Mit Spuck hamma dè ausgerafelte Seite nas gemacht, von obe an dè dicke Seite met unse Daum festgehalte, un dan rund dè Toepie gedreht, beginnend unta an dè metale Piene. Auf Grund, in ein kleine Cirkel lage die andere Toepies von die Kamerade.

Dan muste man dè Toepie in dè Haufe schmeisse, gut an dè Kordel trekke, zodat dè Toepie ganz schnell bleibt drehe. Sommige von die andere Toepies sien dan schon aus dè Cirkel rausgefloge. Dè drehende Toepie hamma dan zwische Weisfinga un Ringfinga auf dè Palm von unse Hand genomme und dan mustma, so viel wie ma konnte andere Toepies aus dè Ring tschieke, solang dè Toepie drehe bleibt.

Stuckse dat ging mit ein grosse Rondelle. Kamerade die schon in Put gearbeit habe, oda dè Fatta bracht dat mit von Put. Ungefähr drei Meta vor uns war ein Linie getrokke auf Grund. Dè Rondelle mustma zo kurz wie ma konnte bei dè Linie schmeisse.

Pienspiel ging mit ein Piene gemacht von ein stuck Holz 3-4 cm dick un 10-15 cm lang. Mit ein Beile hamma an beide Kante ein Spitze gekapt. Da hamma auch ein Knuppel gehat, $4-5 \mathrm{~cm}$ dick un ungefähr $40 \mathrm{~cm}$ lang. Die gege uns gespielt habe, stande 20 meta weita hinta ein Linie, auf dè Strasse getrokke. Mit dè Knuppel in ein Hand, und dè Piene in dè andere Hand mustma ein Schlag gebe auf dè Piene um ihm so weit wiema konnte hinta dè Linie zu kriege.

Die andere konnte dè Piene aber auffange, und dan warst du aus. Wenn die dè Piene nich gefange habe, konte man doch drei mahl auf dè Spitze van dè Piene kloppe, dè Piene flog dan hoch, drehte sich, un da muste man probiere ihm weita zu schlage. Die andere konnte 
dè Piene aba fange un da wars du auch aus. Es kam drauf an dè Piene so weit wie man konnte hinta dè Linie zu kriege. Da ware noch viel andere Reglemente bei, aber zu viel um dat hier alles aus zu lege.

Gläsels, dat ware Kniekas (glazen knikkers) Da ware auch viel verschillige metodes um Kniekas zu spiele, auch zu viel um alles aus zu lege aba ein Sache will ich toch verzähle. Jeda hat ein Knieka gehat womit dè am liebste spielte. Dè Knieka hat ein speziale Name gehat : dat wa ein Pikeur, komische Name. Ein Pikeur hatma gebraucht in Put fie Kohle zu mache (afbouwhamer).

Aba da ware auch gefährliche Spiele bei. Da hamma Carbuur in ein Blechdose gemacht, Deksel zugemacht, ein loch gemacht un ein paar Druppels Wassa drauf getan. Von hinta durch ein Loch ein Stekske angemacht ... und Bum da ging dè Deksel. Soms ware die Fingas verbrant ...

Wie hamma auch Deutsche Helme gefunde un PilootMutze un dan hamma Oorloch gespielt.

Wie hamma Graszode ausgetrokke un dat ware Handgranate.

Von Handgranate gesproche ... Zwei von unse Kamerade habe in Busch ein echte Granate gefunde. Gege Abends sien die langs dè Walonische Schule gekomme un habe, ich weis nich wie lang, dè Granate gegen dè Maua geschmisse. Change dat die nich gewust habe dè Piene raus zu trekke. Sagt dè eine gege dè andere : " Lass ihm liege, dè plof toch nich. Nächste Tag wa ein Kordel rond dè Granate gespant un stande die Gendarme da.

Nach dè Oorloch hat dè Put neue Betonstrasse angelegt auf dè Cité. Zwischen die Betonne Plate wa schwarze Pek. Dat hamma mit ein Messa rausgepeutert, und dat wa dan unse Sjwing-gum (chewing gum). Wenn dè Pek in Mund warm is geworde, dan wa dè zjust goed weich un konte ma drauf kaue. Dè Sjpoek hat nich gepakt auf dè Pek. Wie hamma schöne weisse Zehne davon gekriegt.

Bei uns in dè Strasse hat ein Polnische Familie gewohnt, da ware viel Kindas, ich glaub Siebe oder Ach. Die Mutta war ein Slovenische und konnte gut HochDeutsch spreche. Die wa imma böse wen wie nich richtig Deutsch gesproche habe. Wenn wie sagten : " Dat weisma nich " (dat weten we niet) dan hat sie iema gerufe : "Weisse ... weisse ... ein Weises Hemd kanst du tragen aber sonst sollst du sagen : das wissen wir nicht ... “"

Bei sommige Familieën war das auch so, un so komt es das auf dè Citè nich uberal das cité-Deutsch datselbe war. Ich habe zu Hause Ungarisch-Schwäbisch gesprochen, dat war wieda wat andas.

Un mit mein Onkel un meine Cousinen in Deutschland musste ich Hoch Deutsch spreche. 
Wenn ich da auf Besuch bin, muss ich ganz gut aufpasse wie ich sprech. So is mich folgendes passiert :

Fragt mein Onkel : "Na Jozsi hast du gute Fahrt gehabt? “

Hab ich geantwort : "Ja Onkel, alles ist gut gegangen, manchmal war ein bischen Mist ... “

Sagt mein Onkel : "Na sowas, bist du in ein Bauernhof reingefahren ? ... "

So habe Polnische Leute, Ungarische odea Slovenische immer ein bitske andas gesproche.

In Ungarisch is dè Klemtoon imma auf dè erste Lettergreep (hier was geen echt cité-duits woord voor bekend, en dan werd gewoon het nederlands gebruikt) un dat klang imma komisch aber sehr gut zu erkennen. So kam soms ein Ungarische Frau bei mein Mutta. Ich hör sie noch verzehle :

"Na, Lissi Neni (hongaars voor mevrouw) mein Latsika war sehr braver Junge nichtwahr aber hat er gettroffen diese Schiekse, diese Niederträchtige wạs sie war ... der Taifel soll sie holen.

$\mathrm{Na}$ Lissi Neni und weist schon wie das geht nịchtwahr ... hatt sie gemacht Schweinerei mit ihm un schon war es passiert ... Haben sie dan miessen heiraten ... Was glaubst du Lissi Neni ... haben sie eine kleine Puppe bekommen ... hat die kleine ein Gesicht bekommen genau wie meine ... wa denkst du jetzt ?... “ 


\section{References}

Aalberse, Suzanne. 2009. Inflectional economy and politeness: morphology-internal and morphology-external factors in the loss of second person marking in Dutch. Utrecht: LOT.

Aarts, Flor. 2001. Mestreechs. Eus moojertaol. 'n Besjrijving vaan 't dialek vaan mestreech. Maastricht: Veldeke-Krink Mestreech.

-. 2005. Dictionairke vaan 't Mestreechs. Mie es doezend Mestreechse wäörd, oetdrökkinge en gezègkdes. Mestreech.

Aboh, Enoch Oladé. 2015. The Emergence of Hybrid Grammars. Cambridge: Cambridge University Press.

Abraham, Werner. 2004. The Grammaticalization of the Infinitival Preposition - Toward a Theory of 'Grammaticalizing Re-analysis'. The Journal of Comparative Germanic Linguistics 7. 111-70.

—. 2016. Was bedeutet Subordination mit V2 im Deutschen und Niederländischen: omdat und want ebenso wie weil und denn? . Leuvense Bijdragen 99-100. Sprache in Raum und Geschichte, System und Kultur. Festschrift für Luk Draye. 122-32.

Abraham, Werner \& Theo Janssen (eds) 1989. Tempus - Aspekt - Modus: Die lexikalischen und grammatischen Formen in den germanischen Sprachen. Tübingen: Max Niemeyer Verlag.

Abraham, Werner \& Anko Wiegel. 1993. Reduktionsformen und Kasussynkretismus bei deutschen und niederländischen Pronomina. Dialektsyntax, ed. by W. Abraham \& J. Bayer, 12-49. Opladen: Westdeutscher Verlag.

Adli, Aria, Marco García \& Göz Kaufmann. 2015. Variation in Language: System- and Usage-based Approaches. Berlin/Boston: Walter de Gruyter.

Ahrenholz, Bernt. 2012. Verweise mit Demonstrativa im gesprochenen Deutsch: Grammatik, Zweitspracherwerb und Deutsch als Fremdsprache: De Gruyter.

Alexiadou, Artemis \& Terje Lohndal. 2018. V3 in Germanic: A comparison of urban vernaculars and heritage Languages. Non-Canonical Verb Positioning in Main Clauses. Special Issue of Linguistische Berichte, ed. by M. Antomo \& S. Müller, 245-64.

Allen, Cynthia L. 1999. Case Marking and Reanalysis: Grammatical Relations from Old to Early Modern English. Oxford: Oxford University Press.

Álvarez López, Laura. 2019. The dialect of São João da Chapada: Possible remains of a mining language in Minas Gerais, Brazil. International Journal of the Sociology of Language (IJSL), ed. by L. Cornips \& P. Muysken, 143-70. New York: de Gruyter. 
Ammon, Ulrich. 2004. Standard Variety/Standardvarietät. Sociolinguistics: An International Handbook of the Science of Language and Society., ed. by U. Ammon, N. Dittmar, K.J. Mattheier \& P. Trudgill. Berlin/New York: de Gruyter

Andersson, Sven-Gunnar. 1989. On the Generalization of Progressive Constructions. "Ich bin (das Buch) am Lesen" - Status and Usage in Three Varieties of German. Proceedings of the Second Scandinavian Symposium on Aspectology, ed. by L.G. Larsson, 95-106. Uppsala: Almqvist \& Wiksell.

Anthonissen, Lynn, Astrid de Wit \& Tanja Mortelmans. 2016. Aspects meets modality: A semantic analysis of the German am-Progressive. Journal of Germanic Linguistics 28. 1-30.

—. 2019. (Inter)subjective uses of the Dutch progressive constructions. Linguistics 57. 1111-59.

Antonsich, Marco. 2010. Searching for Belonging - An Analytical Framework. Geography Compass 4/6. 644-59.

Assmann, Aleida 2010. Re-framing memory. Between individual and collective forms of constructing the past. Performing the Past. Memory, History, and Identity in Modern Europe, ed. by K. Tilmans, F. van Vree \& J. Winter, 35-50.

Athanasopoulos, Panos \& Daniel Albright. 2016. A Perceptual Learning Approach to the Whorfian Hypothesis: Supervised Classification of Motion. Language Learning 66. 666-89.

Atkinson, Paul \& Martyn Hammersley. 2007. Ethnography: Principles in Practice. London/New York: Routledge.

Audring, Jenny. 2006. Pronominal Gender in Spoken Dutch. Journal of Germanic Linguistics 18. 85-116.

-. 2009. Reinventing Pronoun Gender. Utrecht: LOT. $\begin{array}{cccc}2018 . & \text { Personal } & \text { pronouns. } & \text { Taalportaal. }\end{array}$ April 17, 2018.

2020. Demonstrative pronouns. Taalportaal. http://www.taalportaal.org/taalportaal/topic/pid/topic-13998813297389634.

March 24, 2020.

Auer, Peter. 1995. The pragmatics of code-switching: a sequential approach. One speaker, two languages: Cross-disciplinary perspectives on code-switching, ed. by L. Milroy \& P. Muysken. Cambridge: Cambridge University Press.

—. 1998a. From Code-switching via Language Mixing to Fused Lects: Toward a Dynamic Typology of Bilingual Speech. Interaction and Linguistic Structures 6. 1-30.

- 1998b. Introduction: Bilingual Conversation Revisited. Code-switching in Conversation: Language, Interaction and Identity, ed. by P. Auer, 1-24. London: Routledge.

—. 2000. Online Syntax - oder: Was es bedeuten könnte, die Zeitlichkeit der mündlichen Sprache ernst zu nehmen. Sprache und Literatur (Themenheft: Die Medialität der Gesprochenen Sprache). 43-56. 
- 2010. Zum Segmentierungsproblem in der Gesprochenen Sprache. Interaction and Linguistic Structures 49. 1-19.

- 2011. Dialect vs. standard: a typology of scenarios in Europe. The languages and linguistics of Europe. A comprehensive guide, ed. by B. Kortmann \& J.v.d. Auwera, 485-500. Berlin/New York: Mouton de Gruyter.

- . 2014. Language mixing and language fusion: when bilingual talk becomes monolingual. Congruence in Contact-Induced Language Change: Language Families, Typological Resemblance, and Perceived Similarity, ed. by J. BestersDilger, C. Dermarkar, S. Pfänder \& A. Rabus, 294-336. Berlin: De Gruyter.

Auer, Peter \& Leonie Cornips. 2018. Cité Duits - a polyethnic miners' variety. The Sociolinguistics of Place and Belonging. Perspectives from the Margins, ed. by L. Cornips \& V.d. Rooij, 55-88. Amsterdam: John Benjamins.

- forthcoming. Bare nouns in prepositional phrases in Cité Duits, a moribund miners' multi-ethnolect (and other varieties of Dutch and German).

Auer, Peter \& Susanne Günthner. 2003. Die Entstehung von Diskursmarkern im Deutschen - ein Fall von Grammatikalisierung? Interaction and Linguistic Structures 38. 1-25.

Auer, Peter \& Nikolay Hakimov. 2020. From language mixing to fused lects: The process and its outcomes (Introduction to Special Issue). International Journal of Bilingualism. 1-8.

Auer, Peter \& Frans Hinskens. 1996. The convergence and divergence of dialects in Europe. New and not so new developments in an old area. Sociolinguistica 10. $1-30$.

Auer, Peter \& Vanessa Siegel. 2016. Some features of multi-ethnic youth styles in Stuttgart. Paper presented to the Meertens Instituut/KNAW on March 14, 2016, Amsterdam 2016.

Backhaus, Peter. 2007. Linguistic Landscapes: A Comparative Study of Urban Multilingualism in Tokyo. Clevedon/Tonawanda N.Y./Ontario: Multilingual Matters Ltd.

Backus, Ad. 2000. Insertional codeswitching in an immigrant language: 'just' borrowing or lexical re-orientation? Bilingualism: Language and Cognition 3. 103-05.

- 2005. Codeswitching and language change: one thing leads to another? International Journal of Bilingualism 9. 307-41.

Bader, Markus \& Yvonne Portele. 2019. The interpretation of German personal pronouns and d-pronouns. Zeitschrift für Sprachwissenschaft 38. 155-90.

Bailey, Benjamin. 2007. Heterglossia and boundaries. Bilingualism: A Social Approach, ed. by M. Heller, 257-76. Basingstoke: Palgrave.

Bakker, Frans Theo Marie 2016. Waar scheiden de dialecten in Noord-Limburg? Een dialectometrisch onderzoek naar het gewicht van isoglossen. Utrecht: LOT.

Bakker, Frens. 1992. Wie me euver vrouwluuj sprik. Zeej of het, die of det. Veldeke 67. $1-15$. 
Bakker, Peter. 1994. Michif, the Cree-French mixed language of the Métis buffalo hunters in Canada. Mixed languages: 15 case studies in language intertwining, ed. by $\mathrm{P}$. Bakker \& M. Mous, 13-33. Amsterdam: IFOTT.

-. 1997. A Language of Our Own: The Genesis of Michif, the Mixed Cree-French Language of the Canadian Métis. Oxford: Oxford University Press.

Bakker, Peter \& Marteen Mous. 1994. Mixed languages: 15 case studies in language intertwining. Amsterdam: IFOTT.

Bakker, Peter \& Pieter Muysken. 1995. Mixed languages and language intertwining. Pidgins and Creoles: An Introduction, ed. by J. Arends, P. Muyken \& N. Smith, 41-52. Amsterdam Benjamins.

Bakkes, Pierre, Herman Crompvoets, Jan Notten \& Frans Walraven. 2003. Spelling 2003 voor de Limburgse dialecten. http://www.limburgsedialecten.nl/download/spelling2003.pdf.

Barbiers, Sjef. 2002. Microvariation in negation in varieties of Dutch. Syntactic Microvariation, ed. by S. Barbiers, L. Cornips \& S.v.d. Kleij. Meertens Institute Electronic Publications in Linguistics: 305-332.

- 2009. Verb clusters and the grammar of the right-periphery. [A Dutch version of this paper appeared in Nederlandse Taalkunde 13, 2008-2. 169-187].

Barbiers, Sjef \& et al. 2006. Dynamische Syntactische Atlas van de Nederlandse Dialecten (DynaSAND). Amsterdam: Meertens Instituut.

Barbiers, Sjef, Hans Bennis, Gunther De Vogelaer, Magda Devos \& Margreet van der Ham. 2005. Syntactic Atlas of Dutch Dialects. Volume I. Amsterdam: Amsterdam University Press.

Barbour, Stephen \& Patrick Stevenson. 1990. Variation in German: A Critical Approach to German Sociolinguistics. Cambridge: Cambridge University Press.

Bayer, Josef. 1984. COMP in Bavarian syntax. The Linguistic Review 3. 209-74.

Becker, Anne Katrin. 2003. „Ruhrdeutsch“ - Die Sprache des Ruhrgebiets in einer umfassenden Analyse. Cologne: University of Cologne.

Behrens, Bergljot, Monique Flecken \& Mary Carroll. 2013. Progressive Attraction: On the Use and Grammaticalization of Progressive Aspect in Dutch, Norwegian, and German. Journal of Germanic Linguistics 25. 95-136. 10.1017/S1470542713000020.

Belemans, Rob. 2007. Het Centraal-Limburgs. Riek van klank: inleiding in de Limburgse dialecten, ed. by R. Keulen, T. Van de Wijngaard, H. Crompvoets \& F. Walraven, 85-93. Sittard: Veldeke Limburg.

—. 2009. Taal of tongval?: de gespleten Limburgse kus, oraal erfgoed en taalpolitiek. Brussels: Pharo.

Belemans, Rob \& Ronny Keulen. 2004. Belgisch-Limburgs. Tielt: Lannoo.

Bell, Allan. 1984. Language style as audience design. Language in Society 13. 145-204.

Bell, Allan \& Andy Gibson. 2011. Staging language: An introduction to the sociolinguistics of performance. Journal of Sociolinguistics 15. 555-72. 
Ben-Rafael, Eliezer, Elana Shohamy, Muhammad Hasan Amara \& Nira Trumper-Hecht. 2006. Linguistic Landscape as Symbolic Construction of the Public Space: The Case of Israel. International Journal of Multilingualism 3. 7-30.

Benincà, Paola \& Cecilia Poletto. 2005. The third dimension of person features. Syntax and Variation: Reconciling the Biological and the Social, ed. by L. Cornips \& K.P. Corrigan, 265-99. Amsterdam: John Benjamins Publishing Company.

Bentahila, Abdelâli \& Eirlys Davies. 1995. Patterns of code-switching and patterns of language contact. Lingua 96. 75-93.

Berends, Sanne. 2019. Acquiring Dutch quantitative ER. Amsterdam: LOT.

Berends, Sanne, Jeannette Schaeffer \& Petra Sleeman. 2017. Cross-linguistic Influence in Adult Second Language Learners: Dutch Quantitative Pronoun Constructions. Proceedings of the 41st annual Boston University Conference on Language Development, ed. by M. LaMendola \& J. Scott, 74-87. Somerville, MA: Cascadilla Press.

Bergstra, Myrthe. 2019. Infinitival innovations A case study on Frisian-Dutch language contact. Amsterdam: LOT.

Bernard, Harvey Russell. 2000. Social Research Methods: Qualitative and Quantitative Approaches. Thousand Oaks, CA: Sage Publications.

Bertinetto, Pier Marco, Karen H. Ebert \& Casper de Groot. 2000. The progressive in Europe. Tense and Aspect in the Languages of Europe, ed. by Ö. Dahl, 517-653. Berlin: Mouton de Gruyter.

Beyers, Leen. 2006. Opgroeien in de schaduw van de mijn. Integratie en identiteit van jonge Polen in Belgisch-Limburg tussen 1925 en 1955. Studies over de Sociaaleconomische Geschiedenis van Limburg. Jaarboek van het Sociaal Historisch Centrum voor Limburg 51. 135-58.

-.2007. Iedereen zwart. Het samenleven van nieuwkomers en gevestigden in de mijncité Zwartberg, 1930-1990. Amsterdam: Aksant.

-. 2008. From Class to Culture: Immigration, Recession, and Daily Ethnic Boundaries in Belgium, 1940s-1990s. International Review of Social History 53. 37-61.

Bhat, D.N. Shankara. 2004. Pronouns. Oxford: Oxford University Press.

- 2013. Third Person Pronouns and Demonstratives. In The World Atlas of Language Structures Online (eds) M.S. Dryer \& M. Haspelmath. Leipzig: Max Planck Institute for Evolutionary Anthropology.

Bhatt, Christa. 1991. Die 'Rheinische Verlaufsform': Eine Bereicherung der deutschen Sprache. Cologne: University of Cologne.

Bhatt, Christa \& Claudia Maria Schmidt. 1993. Die am + Infinitiv-Konstruktion im Kölnischen und im umgangssprachlichen Standarddeutschen als AspektPhrasen. Dialektsyntax, ed. by W. Abraham \& J. Bayer, 71-98. Wiesbaden: VS Verlag für Sozialwissenschaften.

Bhatt, Rakesh M. \& Agnes Bolonyai. 2019. On the theoretical and empirical bases of translanguaging. Working Papers in Urban Language \& Literacies 254. 1-25. 
Binnick, Robert. 2001. Temporality and aspectuality. Language Typology and Language Universals. An International Handbook, ed. by M. Haspelmath, E. König, W. Oesterreicher \& W. Raible, 557-67. Berlin/New York: De Gruyter.

- 2012. The Oxford Handbook of Tense and Aspect. Oxford: Oxford University Press.

Blaxter, Tam \& Peter Trudgill. 2019. On case loss and svarabhakti vowels: the sociolinguistic typology and geolinguistics of simplification in North Germanic. Journal of Linguistic Geography 7. 1-13.

Blevins, Margaret. 2018. Towards a constructional analysis of the progressive aspect in Texas German. Constructions in Contact: Constructional perspectives on contact phenomena in Germanic languages, ed. by H.C. Boas \& S. Höder, 73114. Amsterdam: John Benjamins Publishing Company.

Bloem, Jelke, Arjen Versloot \& Fred Weerman. 2017. Verbal cluster order and processing complexity. Language Sciences 60. 94-119.

Blommaert, Jan. 2010. The Sociolinguistics of Globalization. Cambridge: Cambridge University Press.

Blommaert, Jan \& A. Backus. 2011. Repertoires revisited: 'Knowing language' in superdiversity. Working Papers in Urban Language \& Literacies 67. 1-26.

Blommaert, Jan, James Collins \& Sjef Slembrouck. 2005. Spaces of multilingualism. Language and Communication 25. 197-216.

Blommaert, Jan \& Ben Rampton. 2011. Language and superdiversity: A position paper. Working Papers in Urban Language \& Literacies.

Boas, Hans C. 2016. Variation im Texasdeutschen: Implikationen für eine vergleichende Sprachinselforschung. German Abroad. Perspektiven der Variationslinguistik, Sprachkontakt- und Mehrsprachigkeitsforschung, ed. by A. Lenz, 11-44. Vienna: Vienna University Press.

Boas, Hans C. \& Steffen Höder (eds) 2018. Constructions in Contact: Constructional perspectives on contact phenomena in Germanic languages. Amsterdam: John Benjamins Publishing Company.

Boef, Eefje. 2013. Doubling in relative clauses: Aspects of morphosyntactic microvariation in Dutch. Amsterdam: LOT.

Boogaart, Ronny. 1991. "Progressive Aspect" in Dutch. Linguistics in the Netherlands. 19. 10.1075/avt.8.03boo.

-. 1999. Aspect and Temporal Ordering: A Contrastive Analysis of Dutch and English. Amsterdam: Holland Academic Graphics.

Booij, Geert. 2008. Constructional idioms as products of language change: the aan het + infinitive construction in Dutch. Constructions and language change, ed. by A. Bergs \& G. Diewald, 81-106. Berlin: Mouton de Gruyter.

—. 2010. Construction Morphology. Oxford: Oxford University Press.

Borik, Olga \& Behrit Gehrke. 2019. Participles: Form, use and meaning. Glossa: A Journal of General Linguistics 4. 1-27. http://doi.org/10.5334/gjgl.1055.

Bosch, Peter, Graham Katz \& Carla Umbach. 2007. The Non-Subject Bias of German Demonstrative Pronouns. Anaphors in Text: Cognitive, formal and applied 
approaches to anaphoric reference, ed. by M. Schwarz-Friesel, M. Consten \& M. Knees, 145-64.

Bowern, Claire. 2013. Fieldwork in contact situations. The Handbook of Language Contact, ed. by R. Hickey, 340-58. Malden: Blackwell.

Braber, Natalie. 2019. Borers, chockers, and back rippers. The language and heritage of coal miners. Babel: The Language Magazine 44. 44-47.

Brandner, Ellen. 2012. Syntactic Microvariation. Language and Linguistics Compass 6. 113-30.

Braunmüller, Kurt. 2009. Converging genetically related languages. Convergence and Divergence in Language Contact Situations (Hamburg Studies on Multilingualism 8), ed. by K. Braunmüller \& J. House, 53-70. Amsterdam: John Benjamins.

Breed, Adri, Frank Brisard \& Ben Verhoeven. 2017. Periphrastic Progressive Constructions in Dutch and Afrikaans: A Contrastive Analysis. Journal of Germanic Linguistics 29. 305-78.

Bresnan, Joan. 2001. The emergence of the unmarked Pronoun. Optimality-theoretic Syntax, ed. by G. Legendre, J.B. Grimshaw \& S. Vikner, 113-43. Cambridge: MIT Press.

Briggs, Charles L. 1986. Learning how to ask: A sociolinguistic appraisal of the role of the interview in social science research. Cambridge: Cambridge University Press.

Broekhuis, H. \& L. Cornips. 2012. The verb krijgen 'to get' as an undative verb. Linguistics 50-6. $1205-49$.

Broekhuis, Hans. 2013a. Syntax of Dutch: Adjectives and Adjective Phrases. Amsterdam: Amsterdam University Press.

-. 2013b. Syntax of Dutch: Adpositions and Adpositional Phrases. Amsterdam: Amsterdam University Press.

Broekhuis, Hans \& Norbert Corver. 2015b. Syntax of Dutch: Verbs and Verb Phrases. Volume 2. Amsterdam: Amsterdam University Press.

- 2016. Syntax of Dutch: Verbs and Verb Phrases. Volume 3. Amsterdam: Amsterdam University Press.

- 2019. Narrative inversion. Taalportaal. http://www.taalportaal.org/taalportaal/topic/link/syntax Dutch_vp V11_W ord_order_Clause_initial_position_V11_Word_order_Clause_initial_position. 11.2.4.xml. February 3, 2019.

Broekhuis, Hans, Norbert Corver \& Riet Vos (eds) 2015a. Syntax of Dutch: Verbs and Verb Phrases. Volume 11). Amsterdam: Amsterdam University Press.

Broekhuis, Hans \& Marcel den Dikken. 2012b. Syntax of Dutch: Nouns and Noun phrases. Volume 2. Amsterdam: Amsterdam University Press.

Broekhuis, Hans \& Evelien Keizer. 2012a. Syntax of Dutch: Nouns and Noun phrases. Volume 1. Amsterdam: Amsterdam University Press. 
Broekhuis, Hans \& Henk J. Verkuyl. 2014. Binary tense and modality. Natural Language and Linguistic Theory 32. 973-1009. 10.1007/s11049-013-9213-9.

Broekx. 1939. Inleiding. Het Kempisch steenkolenbekken: een economische studie, ed. by K. Pinxten, i-ix.

Bucholtz, M. 1999. "Why Be Normal?": Language and Identity Practices in a Community of Nerd Girls. Language in Society 28. 203-23.

Bucholtz, M. \& K. Hall. 2005. Identity and interaction: a sociocultural linguistic approach. Discourse Studies 7. 585-614.

- 2008. All of the above: New coalitions in sociocultural linguistics. Journal of Sociolinguistics $12.401-31$.

Bucholtz, Mary. 2000. The politics of transcription. Journal of Pragmatics 32. 1439-65.

- 2003. Sociolinguistic nostalgia and the authentication of identity. Journal of Sociolinguistics 7. 398-416.

-. 2007. Variation in transcription. Discourse Studies 9. 784-808.

Bullock, Barbara E. \& Almeida Jacqueline Toribio. 2012. The Cambridge Handbook of Linguistic Code-switching. Cambridge: Cambridge University Press.

Bußmann, Hadumod (ed.) 2002. Lexikon der Sprachwissenschaft. Stuttgart: Alfred Kröner Verlag.

Bybee, Joan. 2007. Frequency of Use And the Organization of Language. Oxford: Oxford University Press.

-. 2013. Usage-based Theory and Exemplar Representations of Constructions. The Oxford Handbook of Construction Grammar, ed. by T. Hoffmann \& G. Trousdale. Oxford: Oxford University Press.

Bybee, Joan \& Östen Dahl. 1989. The creation of tense and aspect systems in the languages of the world. Studies in Language 13. 53-103.

Bybee, Joan, Revere Perkins \& William Pagliuca. 1994. The Evolution of Grammar: Tense, Aspect, and Modality in the Languages of the World. Chicago/London: University of Chicago Press.

Cacoullos, Rena Torres \& Catharine E. Travis. 2018. Bilingualism in the Community: Code-switching and Grammars in Contact. Cambridge: Cambridge University Press.

Caestecker, Frank. 2008. Arbeidsmarktstrategieën in de Belgische mijnindustrie tot 1940. Tijdschrift voor sociale en economische geschiedenis 5. 30-52.

Canagarajah, Suresh 2014. Theorizing a Competence for Translingual Practice at the Contact Zone. The multilingual turn: implications for SLA, TESOL and bilingual education, ed. by S. May, 78-102. New York, London: Taylor \& Francis.

Cardinaletti, Anna \& Michal Starke. 1996. Deficient pronouns: A view from Germanic. A study in the unified description of Germanic and Romance. Studies in Comparative Germanic Syntax, Volume 2, ed. by H. Thräinsson, S.D. Epstein \& S. Peter, 21-65. Dordrecht/Boston/London: Kluwer. 
- 1999. The Typology of Structural Deficiency: A Case Study of the Three Classes of Pronouns. Clitics in the Languages of Europe, ed. by H.C. van Riemsdijk, 145233. Berlin/New York: Mouton de Gruyter.

Cenoz, Jasone \& Durk Gorter. 2006. Linguistic landscape and minority languages. The International Journal of Multilingualism. 67-80.

Charmaz, Kathy. 2006. Constructing Grounded Theory: A Practical Guide Through Qualitative Analysis. London, Thousand Oaks, New Delhi: SAGE Publications.

Chun, Elaine. 2011. Reading race beyond black and white. Discourse \& Society 22. 40321.

Clyne, Michael. 1992. Pluricentric Languages: Differing Norms in Different Nations. Berlin: Walter de Gruyter.

-. 2003. Dynamics of Language Contact: English and Immigrant Languages. Cambridge: Cambridge University Press.

Comrie, Bernard. 1976. Aspect: An Introduction to the Study of Verbal Aspect and Related Problems. Cambridge: Cambridge University Press.

Comrie, Bernard, Martin Haspelmath \& Balthasar Bickel. 2015. The Leipzig Glossing Rules: Conventions for interlinear morpheme-by-morpheme glosses. https://www.eva.mpg.de/lingua/resources/glossing-rules.php.

Corbett, Greville G. 1979. The agreement hierarchy. Journal of Linguistics 15. 203-24.

Cornelis, Louise \& Arie Verhagen. 1995. Does Dutch really have a Passive? Linguistics in the Netherlands. 49-60.

Cornips, Leonie. 1994. Syntactische variatie in het Algemeen Nederlands van Heerlen. Amsterdam: IFOTT.

—. 1998. Habitual doen in Heerlen Dutch. 'Do' in English, Dutch and German. History and present-day variation, ed. by I.T.-B.v. Ostade, M.v.d. Wal \& Arjan van Leuvenstijn, 83-101. Münster: Nodus.

- 2002. Variation between the infinitival complementizers om/voor in spontaneous speech data compared to elicitation data. Syntactic Microvariation, ed. by S. Barbiers, L. Cornips \& S.v.d. Kleij, 75-96. Amsterdam: Electronic publication of the Meertens Instituut. http://www.meertens.knaw.nl/projecten/sand/synmic/.

—. 2013. Recent developments in the Limburg dialect region. Language and Space: An international handbook of Linguistic variation, ed. by F. Hinskens \& J. Taeldeman, 378-98. Berlin: Walter de Gruyter.

Cornips, Leonie \& Vincent De Rooij. 2019. Katanga Swahili and Heerlen Dutch: A sociohistorical and linguistic comparison of contact varieties in mining regions. International Journal of the Sociology of Language (IJSL), ed. by L. Cornips \& P. Muysken, 35-70. New York: de Gruyter.

Cornips, Leonie, Jürgen Jaspers \& Vincent De Rooij. 2014. The politics of labelling youth vernaculars in the Netherlands and Belgium. Language, youth and identity in the 21st century: linguistic practices across urban spaces, ed. by J. Nortier \& B.A. Svendsen, 45-68. Cambridge: Cambridge University Press. 
Cornips, Leonie \& Ad Knotter. 2016. De uitvinding van Limburg: De territorialisiering van geschiedenis, taal en identiteit. SHCL Jaarboek, 137-63.

Cornips, Leonie \& Pieter Muysken. 2019. Introduction: Language in the mines. International Journal of the Sociology of Language (IJSL), ed. by L. Cornips \& P. Muysken, 1-11. New York: de Gruyter.

Cornips, Leonie \& Cecilia Poletto. 2005. On standardising syntactic elicitation techniques (part 1). Lingua 115. 939-57.

Cornips, Leonie \& Vincent de Rooij. 2013. Selfing and othering through categories of race, place, and language among minority youths in Rotterdam, The Netherlands. Multilingualism and Language Diversity in Urban Areas. Acquisition, identities, space, education ed. by P. Siemund, I. Gogolin, M.E. Schulz \& J. Davydova, 129-64. Amsterdam: John Benjamins.

Corrigan, Karen P. 2010. Language Contact and Grammatical Theory. The Handbook of Language Contact, ed. by R. Hickey, 106-27. London: Blackwell Publishing.

Corver, Norbert \& Denis Delfitto. 1999. On the nature of pronoun movement. Clitics in the Languages of Europe, ed. by H.C. van Riemsdijk, 799-864. Berlin/New York: Mouton de Gruyter.

Costa, James. 2015. New speakers, new language: on being a legitimate speaker of a minority language in Provence. International journal of the sociology of language 2015. 127-45.

Coupland, Nikolas. 2003. Sociolinguistic authenticities. Journal of Sociolinguistics 7. 417-31.

Coupland, Nikolas \& Justine Coupland. 1995. Discourse, Identity, and Aging. Handbook of communication and aging research, ed. by J. Nussbaum \& J. Coupland. Mahwah, New Jersey/London: L. Erlbaum Associates.

Creese, Angela \& Adrian Blackledge. 2011. Separate and flexible bilingualism in complementary schools: Multiple language practices in interrelationship. Journal of Pragmatics 43. 1196-208.

Cresswell, Tim. 1996. In Place/out of Place: Geography, Ideology, and Transgression. Minnesota: University of Minnesota Press.

—. 2004. Place - a short introduction. Malden/Oxford/Carlton: Blackwell Publishing.

Cysouw, Michael. 2003. The Paradigmatic Structure of Person Marking. Oxford: OUP Oxford.

Dahl, Östen. 1985. Tense and aspect systems. Oxford: Basil Blackwell.

Davies, Charlotte Aull. 2002 [1998]. Reflexive Ethnography: A Guide to Researching Selves and Others. New York/London: Routledge.

De Caluwe, Johan. 2006. Tussentaal als natuurlijke omgangstaal in Vlaanderen. Structuren in talige variatie in Vlaanderen, ed. by J. De Caluwe \& M. Devos, 19-34. Gent: Academia Press.

De Fina, Anna. 2007. Code-switching and the construction of ethnic identity in a community of practice. Language in Society 36. 371-92. 
De Schutter, Georges \& Ben Hermans. 2013. The Limburg dialects: Grammatical properties. Language and Space: An international handbook of Linguistic variation, ed. by F. Hinskens \& J. Taeldeman, 356-77. Berlin: Walter de Gruyter.

De Sutter, Gert, Dirk Speelman \& Dirk Geeraerts. 2005. Regionale en stilistische effecten op de woordvolgorde in werkwoordelijke eindgroepen. Nederlandse Taalkunde 10. $97-128$.

De Sutter, Gert \& Marc Van de Velde. 2008. Do the mechanisms that govern syntactic choices differ between original and translated language? A corpus-based translation study of PP placement in Dutch and German. Paper presented to the Proceedings of the international symposium on using corpora in contrastive and translation studies (UCCTS 2008), 2008.

de Vogelaer, Gunther. 2007. De Nederlandse en Friese subjectsmarkeerders: geografie, typologie en diachronie. Gent: Koninklijke Academie voor Nederlandse Taal- en Letterkunde.

De Vogelaer, Gunther \& Magda Devos. 2008. On Geographical Adequacy, Or: How Many Types Of Subject Doubling In Dutch. Microvariation in Syntactic Doubling. 251-76. https://doi.org/10.1163/9781848550216 010.

De Vogelaer, Gunther \& Jan Klom. 2013. Mikrovariation beim Erwerb des niederländischen Genussystems. Dialektologie in neuem Gewand: Zu MikroNarietätenlinguistik, Sprachenvergleich und Universalgrammatik, ed. by W. Abraham \& E. Leiss, 141-70. Hamburg: Helmut Buske Verlag.

- 2017. Semantic agreement competing with syntactic agreement: the case of Dutch pronouns. Leuvense Bijdragen 106. 123-49.

de Vos, Magda. 2013. The grammar of the southwestern dialects. Language and Space. An International Handbook of Linguistic Variation. Volume 3: Dutch, ed. by F. Hinskens \& J. Taeldeman, 174-93. Berlin/Boston: de Gruyter Mouton.

de Wit, Astrid \& Frank Brisard. 2014. A Cognitive Grammar account of the semantics of the English present progressive. Journal of Linguistics 50. 49-90. $10.1017 /$ S0022226713000169.

De Wulf, Chris. 2003. Procope van de h-. Taal \& Tongval 55. 216-31.

de Zwart, Henriëtte. 2012. Verbal Aspect. The Oxford Handbook of Tense and Aspect, ed. by R. Binnick, 752-80. Oxford: Oxford University Press.

Defoin, G. 1962. Vocabulaire professionnel du houilleur belge. Liège: Université de Liège.

Degand, Liesbeth. 2016. Omdat ik heb tot half één tentamen. Nederlandse Taalkunde 21. 419-31.

Delbroek, Bart. 2008. Op zoek naar koolputters. Buitenlandse mijnwerkers in BelgischLimburg in de twintigste eeuw. Tijdschrift voor sociale en economische geschiedenis 5. 80-103.

-. 2009. Porions and Conducteurs: Supervisory Functions in the Belgian Limburg CoalMining Industry (1917-1939). Supervision and authority in industry. Western 
European experiences, 1830-1939., ed. by P. Van den Eeckhout, 191-216. New York: Berghahn Books.

—. 2016. In de put. De arbeidsmarkt voor mijnwerkers in Belgisch-Limburg, 1900-1966. Maastricht: Sociaal Historisch Centrum.

Denison, David. 2014. English Historical Syntax. Verbal constructions. Oxon/New York: Taylor \& Francis.

Deppermann, Arnulf \& Silke Reineke. 2018. Sprache im kommunikativen, interaktiven und kulturellen Kontext. Berlin/Boston: De Gruyter.

Desclés, Jean-Pierre \& Zlatka Guentchéva. 2012. Universals and Typology. The Oxford Handbook of Tense and Aspect, ed. by R. Binnick, 123-54. Oxford: Oxford University Press.

Deumert, Ana. 2003. Markedness and salience in language contact and second-language acquisition: evidence from a non-canonical contact language. Language Sciences 25. 561-613.

Devlin, Thomas, Peter French \& Carmen Llamas. 2019. Vowel change across time, space, and conversational topic: The use of localized features in former mining communities. Language Variation and Change 31. 303-28.

DeWalt, Kathleen Musante \& Billie R. DeWalt. 2002. Participant Observation: A Guide for Fieldworkers. Lanham/New York/Toronto/Oxford: Rowman \& Littlefield Pub Incorporated.

Di Sciullo, Anne-Marie, Pieter Muysken \& Rajendra Singh. 1986. Government and codemixing. Journal of Linguistics 22. 1-24.

Dickey, Stephen M. 2000. Parameters of Slavic Aspect: A Cognitive Approach. Cambridge: Cambridge University Press.

Dirix, Peter, Liesbeth Augustinus \& Frank Van Eynde. 2020. IPP in Afrikaans: a corpusbased investigation and a comparison with Dutch and German. German and Dutch in Contrast, ed. by G.D. Vogelaer, D. Koster \& T. Leuschner, 110-41. Berlin/Boston: De Gruyter.

Dörnyei, Zoltán. 2007. Research Methods in Applied Linguistics: Quantitative, Qualitative, and Mixed Methodologies. Oxford: Oxford University Press.

Dorren, Gabrielle (ed.) 2013. Met de minsten der Mijnen: Geschiedenis van de kleine zusters van de H. Joseph. Hilversum: Verloren.

Dowty, David R. 1979. Word Meaning and Montague Grammar. The Semantics of Verbs and Times in Generative Semantics and in Montague's PTQ. Dordrecht: Reidel.

Drach, Ernst. 1937. Grundgedanken der deutschen Satzlehre. Frankfurt am Main: Diesterweg.

Drossard, Werner. 2004. Aktionsarten in der Stadtkölner Mundart. Morphologie und Syntax deutscher Dialekte und Historische Dialektologie des Deutschen. Beiträge zum 1. Kongress der Internationalen Gesellschaft für Dialektologie des Deutschen, ed. by F. Patocka \& P. Wiesinger, 120-42. Wien: Edition Praesens.

Duden. 2009. Duden. Die Grammatik (Band 4). Mannheim: Duden Verlag. 
—. 2016. Die Grammatik: Unentbehrlich für richtiges Deutsch. Volume 4. 9th edition. Berlin: Bibliographisches Institut.

Duranti, Alessandro. 1997. Linguistic Anthropology. Cambridge: Cambridge University Press.

—. 2011. Linguistic anthropology: the study of language as a non-neutral medium. The Cambridge Handbook of Sociolinguistics, ed. by R. Mesthrie, 28-46. Cambridge: Cambridge University Press.

Ebert, Karen H. 1989. Aspektmarkierung im Fering (Nordfriesisch) und verwandten Sprachen. Tempus - Aspekt - Modus: Die lexikalischen und grammatischen Formen in den germanischen Sprachen, ed. by W. Abraham \& T. Janssen, 293322. Tübingen: Max Niemeyer Verlag.

- 1996. Progressive aspect in German and Dutch. Journal of Germanic Languages and Literature 1. 41-62.

- 2000. Progressive markers in Germanic languages. Tense and Aspect in the Languages of Europe, ed. by Ö. Dahl, 605-54. Berlin: Mouton de Gruyter.

Eckert, Penelope. 1990. The whole woman: Sex and gender differences in variation. Language Variation and Change 1. 245-67.

—. 2000. Language Variation as Social Practice: The Linguistic Construction of Identity in Belten High. Malden: Wiley.

—. 2003. Sociolinguistics and authenticity: An elephant in the room. Journal of Sociolinguistics 7. 392-97.

- 2006. Communities of Practice. In Encyclopedia of language and linguistics: Elsevier.

-. 2008. Variation and the indexical field. Journal of Sociolinguistics 12. 453-76.

- 2014. The Problem with Binaries: Coding for Gender and Sexuality. Language and Linguistics Compass 8. 529-35.

-. 2018. Meaning and Linguistic Variation: The Third Wave in Sociolinguistics. Cambridge: Cambridge University Press.

Eckert, Penelope \& Sally McConnell-Ginet. 1992. Think Practically and Look Locally: Language and Gender as Community-Based Practice. Annual Review of Anthropology 21. 461-88.

Ehlich, Konrad. 1982. Anaphora and Deixis: Same, Similar, or Different? Speech, Place and Action, ed. by R.J. Jarvella \& W. Klein, 315-38.

Ehlich, Konrad \& Jochen Rehbein. 1976. Halbinterpretative Arbeitstranskriptionen (HIAT). Linguistische Berichte 45. 21-41.

Ehrich, Veronika \& Heinz Vater. 1989. Das Perfekt im Dänischen und im Deutschen. Tempus - Aspekt - Modus. Die lexikalischen und grammatischen Formen in den germanischen Sprachen, ed. by W. Abraham \& T. Janssen, 103-32. Tübingen: Niemeyer.

Eichinger, Ludwig M. 2016. Konstanz, Wandel, Variation. Sprachkontakt in der Welt europäischer National- und Standardsprachen. Gegenwärtige Sprachkontakte im Kontext der Migration, ed. by S. Ptashnyk, R. Beckert, P. Wolf-Farré \& M. Wolny, 13-22. Heidelberg: Winter. 
Eisden. 2010. Eisden: Stichting Erfgoed Eisden.

—. 2013. Eisden: Stichting Erfgoed Eisden.

-. 2014. Eisden: Stichting Erfgoed Eisden.

—. 2018a. Eisden: Stichting Erfgoed Eisden.

—. 2018b. Eisden: Stichting Erfgoed Eisden.

Eisenberg, Peter. 2006. Der Satz. Grundriss der deutschen Grammatik. 3rd edition. Stuttgart/Weimar: Metzler Verlag.

—. 2013. Das Wort. Grundriss der deutschen Grammatik. 4th edition. Stuttgart/Weimar: Metzler Verlag.

—. 2016. Grundriss der deutschen Grammatik: Band 2: Der Satz. Stuttgart/Weimar: J.B. Metzler.

Elmentaler, Michael. 2019. Nordniederdeutsch, Ostfälisch, Westfälisch, Nordrheinmaasländisch. Deutsch: Sprache und Raum - Ein internationales Handbuch der Sprachvariation, ed. by J. Herrgen \& J.E. Schmidt, 550-90. Berlin/Boston: De Gruyter.

Elspaß, Stephan \& Robert Möller. 2011. Atlas zur deutschen Alltagssprache. http://www.atlas-alltagssprache.de/runde-2/f18a-b/.

Emmel, Ina. 2005. "Die kann nun nich', die is' beim treppenputzen!” O progressivo no alemão de Pomerode-Sc. Florianópolis: Universidade Federal de Santa Catarina.

Engelberg, Stefan, Stefanie Frink, Svenja König \& Agata Sokolowski. 2013. Kleines Wörterbuch der Verlaufsformen im Deutschen. 21-07-2016.

Erickson, Frederick \& Jeffrey Shultz. 1982. The Counselor As Gatekeeper: Social Interaction in Interviews. New York: Academic Press.

Eyskens, G. 1939. Voorwoord. Het Kempisch steenkolenbekken: Een economische studie, ed. by K. Pinxten, I-IX. Brussel/Anwerpen/Leuven/Gent: Naaml. Venn. Standaard-Boekhandel.

Fahrner, Annette. 2016. Der Erwerb von es-Konstruktionen durch spanischsprachige Deutschlernende. Inaugural Dissertation. Freiburg: Albert-Ludwigs-Universität Freiburg.

Ferguson, Charles A. 1959. Diglossia. Word 15. 325-40.

Fiehler, Reinhard, Birgit Barden, Mechthild Elstermann \& Barbara Kraft. 2004. Eigenschaften gesprochener Sprache. Tübingen: Gunter Narr Verlag Tübingen.

Filip, Hana. 2011. Aspectual class and Aktionsart. Semantics: An International Handbook of Natural Language Meaning, ed. by C. Maienborn, P. Portner \& K.v. Heusinger, 1186-217. Berlin/Boston: de Gruyter.

-. 2012. Lexical Aspect. The Oxford Handbook of Tense and Aspect, ed. by R.I. Binnick, 721-51. Oxford: Oxford University Press.

Finlay, Linda \& Brendan Gough. 2008. Reflexivity: A Practical Guide for Researchers in Health and Social Sciences. London/New York: Wiley Publishers.

Fischer, Hanna. 2016. Präteritumschwund im Deutschen: Dokumentation und Erklärung eines Verdrängungsprozesses. Marburg: De Gruyter. 
Flecken, Monique. 2010. Event conceptualization in language production of early bilinguals. Nijmegen: Radboud Universiteit Nijmegen.

—. 2011a. Event conceptualization by early Dutch-German bilinguals: Insights from linguistic and eye-tracking data. Bilingualism: Language and Cognition 14. 6177.

—. 2011b. What native speaker judgments tell us about the grammaticalization of a progressive aspectual marker in Dutch. Linguistics 49. 479-524.

Flecken, Monique \& Johannes Gerwien. 2013. Grammatical aspect influences event duration estimations: Evidence from Dutch. Paper presented to the Cooperative minds: Social interaction and group dynamics. Proceedings of the 35th Annual Meeting of the Cognitive Science Society, Austin, TX, 2013.

Fleischer, Jürg. 2006. Dative and indirect object in German dialects: evidence from relative clauses. Datives and Other Cases: between Argument Structure and Event Structure, ed. by D. Hole, A. Meinunger \& W. Abraham, 213-38. Amsterdam: Benjamins.

Flick, Johanna. 2016. Der am-Progressiv und parallele am V-en sein-Konstruktionen: Kompositionalität, Variabilität und Netzwerkbildung. Beiträge zur Geschichte der deutschen Sprache und Literatur (PBB) 138. 163-96.

Flick, Johanna \& Katrin Kuhmichel. 2013. Der am-Progressiv in Dialekt und Standardsprache. Jahrbuch für Germanistische Sprachgeschichte 4. 52-76. 10.1515/jbgsg-2013-0005. 8 Apr. 2019.

Forchheimer, Paul. 1953. The Category of Person in Language. Berlin: De Gruyter.

Franco, Karlien, Dirk Geeraerts, Dirk Speelman \& Roeland van Hout. 2019. Maps, meanings and loanwords: The interaction of geography and semantics in lexical borrowing. Journal of Linguistic Geography 7. 14-32.

Fraser, Katherine \& Cora Pots. in preparation. Progressive microvariation.

Fredsted, Elin. 2000. Hvordan gør sprogkontakt sig gældende i en sprogkontaktzone. Språkkontakt: Innverknaden frå nedertysk på andre nordeuropeiske språk, ed. by E. Håkon Jahr, 131-51. Copenhagen: Nordisk Ministerråd.

Freywald, Ulrike. 2013. Subjunktionen als parataktische Konnektoren. Hypothesen zur Herausbildung der heutigen Konjunktionspaare. Akten des XII. Internationalen Germanistenkongresses der IVG Warschau 2010. Vielheit und Einheit der Germanistik weltweit. Publikationen der Internationalen Vereinigung für Germanistik ed. by F. Grucza, 65-70. Frankfurt am Main: Lang.

Freywald, Ulrike, Leonie Cornips, Natalia Ganuza, Ingvild Nistov \& Toril Opsahl. 2015. Beyond verb second - a matter of novel information-structural effects? Evidence from Norwegian, Swedish, German and Dutch. Language Youth \& Identity in the 21 st Century, ed. by J. Nortier \& B.A. Svendsen, 73-92. Cambridge: Cambridge University Press.

Fuß, Eric. 2005. The rise of agreement. A formal approach to the syntax and grammaticalization of verbal inflection. Amsterdam: John Benjamins Publishing Company. 
Gallmann, Peter. 2006. Der Satz. Die Grammatik. Duden, ed. by Dudenredaktion. Mannheim, Leipzig, Wien, Zürich: Dudenverlag.

Ganuza, Natalia. 2010. Subject-Verb Order Variation in the Swedish of Young People in Multilingual Urban Areas. Multilingual Urban Scandinavia: New Linguistic Practices, ed. by P. Quist \& B.A. Svendsen, 31-48. Bristol: Short Run Press.

Ganzelewski, Michael \& Rainer Slotta. 1999. Die Denkmal-Landschaft „Zeche Zollverein". Eine Steinkohlezeche als Weltkulturerbe?! . Bochum: Deutsches Bergbau-Museum.

García, Ofelia \& Li Wei. 2014. Translanguaging: Language, Bilingualism and Education Basingstoke: Palgrave Macmillian.

Gardner-Chloros, Penelope. 1995. Code-switching in community, regional and national repertoires: The myth of the discreteness of linguistic systems. One speaker, two languages: Cross-disciplinary perspectives on code-switching, ed. by L. Milroy \& P. Muysken, 68-89. Cambridge: Cambridge University Press.

-. 2009. Contact and Code-switching. Code-switching, ed. by P. Gardner-Chloros, 188207. Cambridge: Cambridge University Press.

- 2010. Contact and Code-switching. The Handbook of Language Contact, ed. by R. Hickey, 188-207. London: Blackwell.

Garey, Howard B. 1957. Verbal Aspect in French Language 33. 91-110.

Gárgyán, Gabriella. 2010. Der am-Progressiv im heutigen Deutsch. Neue Erkenntnisse mit besonderer Hinsicht auf die Sprachgeschichte, die Aspektualität und den kontrastiven Vergleich mit dem Ungarischen: Szeged.

GDPR. General Data Protection Regulation. https://gdpr-info.eu/art-4-gdpr/.

Geeraerts, Dirk. 2001. Een zondagspak? Het Nederlands in Vlaanderen: gedrag, beleid, attitudes. Ons Erfdeel 44. 337-44.

- 2010. Schmidt redux: How systematic is the linguistic system if variation is rampant? Language Usage and Language Structure, ed. by K. Boye \& E. EngbergPedersen, 237-62. Berlin/New York: Walter de Gruyter.

Gehl, Hans. 2009. Das Bild der Deutschen bei Rumänen, Ungarn und Serben. Filologica Jassyensia 1. 103-29.

Ghyselen, Anne-Sophie. 2016. From diglossia to diaglossia: A West Flemish case-study. The future of dialects, ed. by M.-H. Côté, R. Knooihuizen \& J. Nerbonne, 35-63. Berlin: Language Science Press.

Ghyselen, Anne-Sophie \& Gunther De Vogelaer. 2018. Seeking Systematicity in Variation: Theoretical and Methodological Considerations on the "Variety" Concept. frontiers in Psychology 9. 1-19. 10.3389/fpsyg.2018.00385.

Ghyselen, Anne-Sophie \& Jacques Van Keymeulen. 2016. Implicational scales in colloquial Belgian Dutch. Dialectologia et Geolinguistica 24. 62-82. https://doi.org/10.1515/dialect-2016-0004.

Giles, Howard. 2016. Communication Accommodation Theory: Negotiating Personal Relationships and Social Identities Across Contexts. Cambridge: Cambridge University Press. 
Giles, Howard \& Tania Ogay. 2007. Communication Accomodation Theory. Explaining communication: Contemporary theories and exemplars, ed. by B.B. Whaley \& W. Samter, 293-310. Mahway, N.J.: Lawrence Erlbaum.

Glück, Helmut. 2001. Die Verlaufsform in den germanischen Sprachen, besonders im Deutschen. Valenztheorie: Einsichten und Ausblicke, ed. by W. Thielemann \& K. Welke, 81-96. Münster: Nodus Publikationen.

Goeman, Ton, J. Taeldeman \& P.Th. Van Reenen. 2014. MAND database. GoemanTaeldeman-Van Reenen-project. Amsterdam.

Gohl, Christine \& Susanne Günthner. 1999. Grammatikalisierung von weil als Diskursmarker in der gesprochenen Sprache. Zeitschrift für Sprachwissenschaft 18. 39-75.

Gooskens, Charlotte, Renée van Besooijen \& Sebastian Kürschner. 2010. The reflection of historical language contact in present-day Dutch and Swedish. Language Contact: New Perspectives, ed. by C. Hasselblatt, B.d. Jonge \& M. Norde, 10318. Amsterdam: John Benjamins Publishing.

Goossens, Jan. 1965. Die Gliederung des Südniederfränkischen. Rheinische Vierteljahrsblätter 30. 79-94.

—. 1988. Woeringen en de oriëntatie van het Maasland. Bijlagen van de Vereniging voor Limburgse Dialect- en Naamkunde 3.

—. 1994a. Sprachatlas des nördlichen Rheinlands und des südöstlichen Niederlands. Marburg: Fränkischer Sprachatlas. Zweite Lieferung.

—. 1994b. Zu den Personalpronomina im Rhein- und Maasland. Dialektologie des Deutschen. Forschungsstand und Entwicklungstendenzen, ed. by K. Mattheier \& P. Wiesinger, 45-48. Tübingen: Niemeyer.

—. 1996. Een geïsoleerd voornaamwoord: Limburgs doe, dich, dijn. Mededelingen van de Vereniging voor Limburgse Dialect- en Naamkunde, Nr. 88.

—. 2012 [1977]. Deutsche Dialektologie. Berlin/New York: Walter de Gruyter.

Greco, Ciro \& Liliane Haegeman. 2016. Frame setters and the microvariation of subjectinitial V2. Paper presented at the LAGB meeting, York.

Grijzenhout, Janet. 2000. Voicing and devoicing in English, German, and Dutch; evidence for domain-specific identity constraints. HHU Düsseldorf.

Grijzenhout, Janet \& Martin Krämer. 1998. Final Devoicing and Voicing Assimilation in Dutch Derivation and Cliticization. Theorie des Lexikons: Arbeiten des Sonderforschungsbereichs 282.

Grondelaers, Stefan. 2000. De distributie van niet-anaforisch er buiten de eerste zinsplaats. Sociolexicologische, functionele en psycholinguïstische aspecten van er's status als presentatief signaal. Leuven: KU Leuven.

Grondelaers, Stefan, Marc Brysbaert, Dirk Speelman \& Dirk Geeraerts. 2002. 'Er' als accessibility marker: on- en offline evidentie voor een procedurele interpretatie van presentatieve zinnen. Gramma/TTT $9 . \quad 1-22$. https://www.researchgate.net/publication/239543133_Er_als_accessibility_mar ker_on- 
_en_offline evidentie voor_een_procedurele_interpretatie van presentatieve zinnen. July 182018.

Grondelaers, Stefan \& Dirk Speelman. 2001. Regionale variatie in de postverbale distributie van presentatief er. Neerlandistik 1. 1-41.

Grondelaers, Stefan \& Roeland Van Hout. 2016. How (in)coherent can standard languages be? A perceptual perspective on co-variation. Lingua 172-173. 62-71.

Grondelaers, Stefan, Roeland van Hout \& Dirk Speelman. 2011. A perceptual typology of standard language situations in the Low Countries. Standard Languages and Language Standards in a Changing Europe, ed. by T. Kristiansen \& N. Coupland, 199-222. Oslo: Novus.

Grutman, Rainier. 2006. Refraction and Recognition: Literary multilingualism in translation. Target 18. 17-47.

Gudmestad, Aarnes \& Amanda Edmonds. 2018. Critical Reflections on Data in Second Language Acquisition. Amsterdam: John Benjamins Publishing Company.

Guentchéva, Zlatka. 2016. Aspectuality and Temporality: Descriptive and theoretical issues. Amsterdam/Philadelphia: John Benjamins Publishing Company.

Gumperz, John J. 1968. The speech community. International encyclopedia of the social sciences, ed. by D.L. Sills, 381-86. New York: Macmillan.

- 1976. The Sociolinguistic Significance of Conversational Code-Switching. Papers on Language and Context, ed. by C. Gumperz \& J.J. Gumperz. University of California: Working Paper no. 46. Berkeley: Language Behavior Research Laboratory.

Gumperz, John J. \& Dell Hymes. 1986 [1972]. Directions in Sociolinguistics: The Ethnography of Communication. New York: Wiley.

Gvozdanović, Jadranka. 2012. Perfective and Imperfective Aspect. The Oxford Handbook of Tense and Aspect, ed. by R. Binnick, 781-802. Oxford: OUP USA.

Haegeman, Liliane. 1992. Theory and description in generative syntax. A case study in West Flemish. Cambridge: Cambridge University Press.

Haegeman, Liliane \& Ciro Greco. 2018. West Flemish V3 and the interaction of syntax and discourse. Journal of Comparative Germanic Linguistics 21. 1-56.

Haegeman, Liliane \& Terje Lohndal. 2010. Negative concord and multiple agree: a case study of West Flemish. Linguistic Inquiry 41. 181-211.

Haegeman, Liliane \& Marjo Van Koppen. 2012. Complementizer Agreement and the Relation Between $\mathrm{C}^{\circ}$ and $\mathrm{T}^{\circ}$. Linguistic Inquiry 43. 441-54.

Haeseryn, Walter. 2013. Belgian Dutch. Language and Space. Volume 3. Dutch. An International Handbook of Linguistic Variation, ed. by F. Hinskens \& J. Taeldeman, 700-20. Berlin \& Boston: Mouton de Gruyter.

Haiman, John \& Paoloa Benincà. 1992. The Rhaeto-Romance Languages. London: Routledge.

Halliday, M. A. K. 1976. Anti-Languages. American Anthropologist 78. 570-84.

Halpern, Aaron. 1995. On the Placement and Morphology of Clitics. Cambridge: Cambridge University Press. 
Hartmann, Jutta M. 2008. Expletives in Existentials. English there and German da. Amsterdam: LOT.

Haslinger, Peter. 2008. Sprachenpolitik, Sprachendynamik und imperiale Herrschaft in der Habsburgermonarchie 1740-1914. Zeitschrift für OstmitteleuropaForschung 57. 81-111.

Haugen, Einar. 1950. The analysis of linguistic borrowing. Language 26. 210-31.

Heine, Bernd \& Tania Kuteva. 2008. Constraints on contact-induced linguistic change. Journal of Language Contact. 57 - 90.

- 2010. Contact and grammaticalization. The Handbook of Language Contact, ed. by R. Hickey, 86-105. London: Blackwell.

Heinold, Simone. 2015. Tempus, Modus und Aspekt im Deutschen: Ein Studienbuch. Tübingen: Narr Francke Attempto Verlag.

Helbig, Gerhard \& Joachim Buscha. 2001. Deutsche Grammatik. Ein Handbuch für den Ausländerunterricht. Berlin/München: Langenscheidt.

Heller, Monica. 2007. Bilingualism: A Social Approach. Hampshire: Palgrave Macmillan UK.

Henning, Mathilde. 2006. Grammatik der gesprochenen Sprache in Theorie und Praxis. Kassel: Kassel University Press.

Henriksson, Henrik. 2006. Aspektualität ohne Aspekt?: Progressivität und Imperfektität im Deutschen und Schwedischen. Stockholm: Almqvist \& Wiksell International.

Hermans, Ben. 2013. Phonological features of Limburgian dialects. Language and Space: An International Handbook of Linguistic Variation, ed. by F. Hinskens \& J. Taeldeman, 336-55. Berlin: Walter de Gruyter.

Heyl, Barbara Sherman. 2001. Ethnographic Interviewing. Handbook of Ethnography, ed. by P. Atkinson, S. Delamont, A. Coffey, J. Lofland \& L. Lofland, 369-83. London: SAGE Publications.

Hickey, Raymond. 2010. The Handbook of Language Contact. London: Blackwell Publishing.

- . 2013. The Handbook of Language Contact. Malden: Wiley-Blackwell.

Hilden, Patricia. 1993. Women, Work, and Politics: Belgium, 1830-1914. Oxford: Clarendon Press.

Hinskens, Frans. 1996. Dialect Levelling in Limburg: Structural and sociolinguistic aspects. Tübingen: Max Niemeyer Verlag.

Hoeksema, Jack. 2000. Ikke als default-nominatief [I as default case]. Tabu 30. 27-46.

Holmes, J. \& M. Meyerhoff. 1999. The Community of Practice: Theories and methodologies in language and gender research. Language in Society 28. 17383.

Howe, Stephen. 1996. The Personal Pronouns in the Germanic Languages. A study of personal pronoun morphology and change in the Germanic languages from the first records to the present day. Berlin \& New York: Walter de Gruyter.

Hua, Zhu. 2016. Research Methods in Intercultural Communication: A Practical Guide. Malden, Oxford, Chichester: Wiley. 
Imo, Wolfgang. 2008. Wenn mündliche Syntax zum schriftlichen Standard wird: Konsequenzen für den Normbegriff im Deutschunterricht. Frischwärts und unkaputtbar: Sprachverfall oder Sprachwandel im Deutschen, ed. by M. Denkler, S. Günthner, W. Imo, J. Macha, D. Meer, B. Stoltenburg \& E. Topalovic, 153 - 80. Münster: Aschendorff.

Inoue, Miyako. 2004. What Does Language Remember?: Indexical Inversion and the Naturalized History of Japanese Women. Journal of Linguistic Anthropology 14. $39-56$.

Jacquemet, Marco. 2005. Transidiomatic practices: Language and power in the age of globalization. Language \& Communication 25. 257-77.

Jaffe, Alexandra \& Shana Walton. 2000. The voices people read: Orthography and the representation of non-standard speech. Journal of Sociolinguistics 4. 561-87.

Jansen, Frank. 1981. Syntaktische konstrukties in gesproken taal. Amsterdam: Huis aan de Drie Grachten.

Jarva, Vesa. 2008. Old Helsinki Slang and language mixing. Journal of Language Contact 1. $52-80$.

Jaspers, Jürgen. 2001. Het Vlaamse stigma. Over tussentaal en normativiteit. Taal \& Tongval 53. 129-53.

Jaspers, Patrik. 2003. De Sint Barbarakerk van Eisden: Een Limburgse mijnkathedraal. Eisden: Stichting Erfgoed Eisden.

Jefferson, Gail. 2004. Glossary of transcript symbols with an introduction. Conversation analysis: Studies from the first generation, ed. by G.H. Lerner, 13-31. Philadelphia: John Benjamins.

Jenks, Christopher Joseph. 2013. Working with Transcripts: An Abridged Review of Issues in Transcription. Language and Linguistics Compass 7. 251-61.

Johnstone, Barbara. 2000. Qualitative Methods in Sociolinguistics. Oxford/New York: Oxford University Press.

—. 2006. Reflexivity in Sociolinguistics. In Encyclopedia of Language \& Linguistics (ed.) K. Brown. Oxford: Elsevier.

- 2010. Indexing the Local. The Handbook of Language and Globalization, ed. by N. Coupland, 386-405. Malden: Wiley-Blackwell.

- 2014. Ideology and discourse in the enregisterment of regional variation. Space in Language and Linguistics: Geographical, Interactional, and Cognitive Perspectives, ed. by P. Auer, M. Hilpert, A. Stukenbrock \& B. Szmrecsanyi. Berlin/Boston: De Gruyter.

Jørgensen, Normann. 1998. Children's acquisition of code-switching for power-wielding. Code-switching in Conversation: Language, Interaction and Identity, ed. by P. Auer, 237-58. London: Routledge.

Kaiser, Elsi \& John Trueswell. 2004. The referential properties of Dutch pronouns and demonstratives: Is salience enough? Paper presented to the Sinn und Bedeutung 8, Arbeitspapier Nr. 177, FB Sprachwissenschaft, Konstanz, 2004. 
Kapia, Enkeleida. 2014. Acquisition of dative and accusative clitic-doubling in Albanian: A syntactic-pragmatic approach. Developments in the Acquisition of Clitics, ed. by K.K. Grohmann \& T. Neokleous, 212-48. Cambridge: Cambridge Scholars Publisher.

Kaufmann, Göz. 2008. Where Syntax meets Morphology. Varianten des bestimmten Artikels und die Variation satzfinaler Verbcluster im Plattdeutschen texanischer Mennoniten. Paper presented to the Dialektale Morphologie, dialektale Syntax. Beiträge zum 2. Kongress der Internationalen Gesellschaft für Dialektologie des Deutschen, 20.-23. September 2006, Wien, 2008.

- 2016. The World Beyond Verb Clusters: Aspects of the Syntax of Mennonite Low German. Freiburg: Albert-Ludwigs-University of Freiburg.

Kayne, R.S. 1975. French Syntax. The Tranformational Cycle. Cambridge, MA: MIT Press.

Kayne, Richard S. 2000. Parameters and Universals. New York: Oxford University Press. Keel, William D. 2015. Noun Phrase Case Shift in Volga German Varieties on the Great Plains of Kansas. Moribund Germanic Heritage Languages in North America: Theoretical Perspectives and Empirical Findings, ed. by B.R. Page \& M.T. Putnam, 133-52. Leiden/Boston: Brill.

Kern, Friederike \& Margret Selting. 2006. Einheitenkonstruktion im Türkendeutschen: Grammatische und prosodische Aspekte. Zeitschrift für Sprachwissenschaft 25. 239-72.

Keunen, Paul. 2010. Mijn Cité: Met de mijncités naar de 21ste eeuw. Genk: Stebo.

Kiessling, Roland \& Maarten Mous. 2004. Urban Youth Languages in Africa. Anthropological Linguistics 46. 303-41.

Klein, Wolfgang. 2009. How Time is Encoded. The Expression of Time, ed. by W. Klein \& P. Li, 39-82. Berlin: De Gruyter.

Klessmann, Christoph. 1978. Polnische Bergarbeiter im Ruhrgebiet, 1870-1945: Soziale Integration und nationale Subkultur einer Minderheit in der deutschen Industriegesellschaft Göttingen: Vandenhoeck und Ruprecht.

- 1986. Comparative Immigrant History: Polish Workers in the Ruhr Area and the North of France Journal of Social History 20. 335-53.

Knops, Uus \& Roland van Hout. 1988. Language Attitudes in the Dutch Language Area: An Introduction. Language Attitudes in the Dutch Language Area, ed. by R. van Hout \& U. Knops, 1-24. Dordrecht: Foris Publications.

Knotter, Ad. 2008. Inleiding: Arbeidsmigranten en grensarbeiders. Vergelijkende perspectieven op de mijnarbeidsmarkten in het Belgisch-Duits-Nederlandse grensgebied in de twintigste eeuw. Tijdschrift voor sociale en economische geschiedenis 5. 2-29.

-. 2012a. Labour migrants and cross-border commuters. Comparative perspectives on mining labour markets in the Belgian-Dutch-German borderland in the twentieth century. Montanregion als Sozialregion: Zur gesellschaftlichen Dimension von 
Region in der Montanwirtschaft, ed. by A. Westermann, 125-50. Husum: Matthiesen.

—. 2012b. Mijnwerkers in Limburg: een sociale geschiedenis. Nijmegen: Vantilt Uitgeverij.

Koch, Peter \& Wulf Oesterreicher. 1985. Sprache der Nähe - Sprache der Distanz. Mündlichkeit und Schriftlichkeit im Spannungsfeld von Sprachtheorie und Sprachgeschichte. Romanistisches Jahrbuch, ed. by O. Deutschmann, H. Flasche, B. König, M. Kruse, W. Pabst \& W.-D. Stempel, 15-43. Berlin: Walter de Gruyter.

-. 1994. Schriftlichkeit und Sprache. Schrift und Schriftlichkeit, ed. by H. Günther \& L. Otto, 587-603. Berlin/New York: Walter de Gruyer.

Kohlbacher, Jan. 1986. 1910-1985. Lagere Scholen Eisden Tuinwijk. In Feestschrift.

-. 1995. Het jongenspatronaat van Eisden cité. Een case studie Ons Hem 49.

-. 1998. Het Russisch Kamp. De kampen bij de Limburgse mijnen, 1942-1965. . Eisden, Maasmechelen Stichting Erfgoed Eisden.

—. 2003. Das organisierte Leben in der Bergarbeitersiedlung Eisden. Tagungsband, 6. Int. Bergbau-Workshop 2003, 134-37. Rescheid.

—. 2016. Het Cité Duits: Een eiland in een zee van talen. Paper presented to the Symposium: Spoken Language in the Mines: Euregion and beyond, Maastricht University, Maastricht, 2016.

Kölligan, Daniel. 2004. Zur präteritalen "tun"-Periphrase im Ripuarischen. Morphologie und Syntax deutscher Dialekte und Historische Dialektologie des Deutschen. Beiträge zum 1. Kongress der Internationalen Gesellschaft für Dialektologie des Deutschen, ed. by F. Patocka \& P. Wiesinger, 429-52. Wien: Edition Praesens.

Kolmer, Agnes. 2010. Contact-induced changes in cliticization and word order: the Cimbrian dialect of Luserna as a case study. 63. 146-63.

-. 2012. Pronomen und Pronominalklitika im Cimbro : Untersuchungen zum grammatischen Wandel einer deutschen Minderheitensprache in romanischer Umgebung. Stuttgart: Steiner.

Kotsinas, Ulla-Britt. 1998. Language contact in Rinkeby, an immigrant suburb. Jugendsprache/langue des jeunes/youth language: Linguistische und soziolinguistische Perspektiven, ed. by J. Androutsopoulos \& A. Scholz, 125-47. Frankfurt am Main: Peter Lang.

Kouwenberg, Silvia \& John Victor Singler. 2011. Pidgins and creoles. The Cambridge Handbook of Sociolinguistics, ed. by R. Mesthrie, 283-300. Cambridge/New York: Cambridge University Press.

Kraft, Kamilla. 2019. Language policies and linguistic competence: new speakers in the Norwegian construction industry. Language Policy 18. 573-91.

Krause, Olaf. 1994. Progressiv-Konstruktionen im Deutschen im Vergleich mit dem Niederländischen, Englischen und Italienischen [*reduced version of Zur Typologie der Progressiv-Konstruktionen im Deutschen. Eine kontrastive Untersuchung]. Berlin: Freie Universität Berlin. 
—. 2002. Progressiv im Deutschen: Eine empirische Untersuchung im Kontrast mit Niederländisch und Englisch. Tübingen: Max Niemeyer Verlag.

Kristiansen, Tore. 2003. The youth and the gatekeepers. Discourse Constructions of Youth Identities, ed. by J. Androutsopoulos \& A. Georgakopoulou, 279-302. Amsterdam: John Benjamins.

Kuhmichel, Katrin. 2016. Zum Ausdruck von Progressivität in den Dialekten Hessens. Syntaktische Variation: Areallinguistische Perspektiven, ed. by A. Lenz \& F. Patocka, 67-88. Göttingen: Vienna University Press.

Kürschner, Sebastian. 2019. Personal communication on July 4, 2019 in Berlin. Berlin, Germany.

Kuteva, Tania. 1999. On 'sit'/'stand'/'lie' auxiliation. Linguistics 37. 191-213.

-.2001. Auxiliation: An Enquiry Into the Nature of Grammaticalization. Oxford: Oxford University Press.

Labov, William. 1966. When Intuitions Fail. Papers from the 32nd Regional Meeting of the Chicago Linguistics Society 32. 76-106.

- 1972. Sociolinguistic Patterns. Philadelphia: University of Pennsylvania Press.

- 1982. Objectivity and commitment in linguistic science: The case of the Black English trial in Ann Arbor. Language in Society 11.), 165-201.

—. 2001. Principles of Linguistic Change. Volume 2: Social Factors. Oxford: Blackwell Publishers.

Langeweg, Serge. 2012a. De bedrijfshiërarchie en de vakopleidingen. Mijnwerkers in Limburg. Een Sociale Geschiedenis, ed. by A. Knotter, 178-219. Nijmegen: Uitgeverij Vantilt.

—. 2012b. Werving, herkomst en binding van mijnwerkers. Mijnwerkers in Limburg: een sociale geschiedenis, ed. by A. Knotter, 54-99. Nijmegen: Vantilt Uitgeverij.

Lattewitz, Karen. 1997. Adjacency in Dutch and German. Groningen: Grodil.

Lave, Jean \& Etienne Wenger. 1991. Situated Learning: Legitimate Peripheral Participation. Cambridge: Cambridge University Press.

Lemmens, Maarten. 2002. Over de gemotiveerde alomtegenwoordigheid van liggen, zitten en staan: linguistische en didactische perpectieven. Le néerlandais en France et en Belgique francophone: approches scientifiques, approches didactiques, ed. by P. Hiligsmann, 91-114. Université Lille 3, France: Collection UL3 Travaux et recherches.

- 2005. Aspectual Posture Verb Constructions in Dutch. Journal of Germanic Linguistics 17. 183-217.

- 2012. Variatie en verankering bij progressiefconstructies in het Nederlands. Nederlandse Taalkunde 17. 284-91.

Lenerz, Jürgen. 1993. Zu Syntax und Semantik deutscher Personalpronomina. Wortstellung und Informationsstruktur, ed. by M. Reis, 117-54. Tübingen: Niemeyer. 
—. 1994. Pronomenprobleme. Was determiniert Wortstellungsvariation?: Studien zu einem Interaktionsfeld von Grammatik, Pragmatik und Sprachtypologie, ed. by B. Haftka, 161-74. Opladen: Westdeutscher Verlag.

Lenz, Alexandra. 2010. Emergence of varieties through restructuring and reevaluation. Language and Space: An International Handbook of Linguistic Variation, ed. by P. Auer \& J.E. Schmidt, 295-315. Berlin/New York: De Gruyter Mouton.

Lenz, Alexandra N. 2017. „Dativpassiv”. In SyHD-atlas (Syntax Hessischer DialekteAtlas). Developed by Ludwig M. Breuer. Marburg/Wien/Frankfurt am Main: Fleischer, Jürg; Lenz, Alexandra N.; Weiß, Helmut.

Lessiak, Primus. 1963. Die Mundart von Pernegg in Kärnten. Marburg: N.G. Elwert.

Lindner, Karl-Peter. 1987. Grammatische Untersuchungen zur Charakteristik des Räroromanischen in Graubünden. Tübingen: Gunter Narr.

Lindstedt, Jouko. 2001. Tense and aspect. Language Typology and Language Universals / Sprachtypologie und sprachliche Universalien / La typologie des langues et les universaux linguistiques, ed. by M. Haspelmath, E. König, W. Oesterreicher \& W. Raible, 768-83. Berlin/New York: De Gruyter.

Linke, Kathrin \& Anna Kirstein. 2018. Clitics. Taalportaal. http://www.taalportaal.org/taalportaal/topic/pid/topic-14020545821582167. July 19, 2018.

Lohnstein, Horst \& Antonios Tsiknakis. 2020. Verb Second. Berlin/Boston: De Gruyter.

Long, Daniel \& Dennis Richard Preston (eds) 2002. Handbook of Perceptual Dialectology. Amsterdam/Philadelphia: John Benjamins Publishing Company.

Lønsmann, Dorte, Hartmut Haberland \& Spencer Hazel. 2017. Introduction to Special Issue on Transience: Emerging Norms of Language Use. Journal of Linguistic Anthropology 27. 264-70.

Louden, Mark. 1992. German as an object-verb language: A unification of typological and generative approaches. On Germanic Linguistics: Issues and Methods, ed. by I. Rauch, G.F. Carr \& R.L. Kyes, 217-31 Berlin/New York: De Gruyter.

-. 1994. Syntactic Change in Multilingual Speech Islands. Sprachinselforschung: eine Gedenkschrift für Hugo Jedig, ed. by N. Berend \& K.J. Mattheier. Frankfurt am Main: P. Lang.

—. 2011. Synchrony and Diachrony of Verb Clusters in Pennsylvania Dutch. Studies on German-Language Islands, ed. by M.T. Putnam, 165-85. Amsterdam: John Benjamins Publishing Company.

Mæhlum, Brit Kirsten. 1996. Codeswitching in Hemnesberget - Myth or reality? Journal of Pragmatics 25. 749-61.

Mair, Christian. 2012. Progressive and Continuous Aspect. The Oxford Handbook of Tense and Aspect, ed. by R. Binnick, 803-27. Oxford/New York: Oxford University Press.

Maitz, Péter. 2017. Dekreolisierung und Variation in Unserdeutsch. Räume - Grenzen Übergänge. Akten des 5. Kongresses der Internationalen Gesellschaft für 
Dialektologie des Deutschen (IGDD), ed. by H. Christen, P. Gilles \& C. Purschke. Stuttgart: Steiner.

Maitz, Péter, Siegwalt Lindenfelser \& Craig A. Volker. forthcoming. Unserdeutsch (Rabaul Creole German), Papua New Guinea. Varieties of German worldwide, ed. by H.C. Boas, A. Deumert, M. Louden \& P. Maitz. Oxford: Oxford University Press.

Maitz, Péter \& Attila Németh. 2014. Language Contact and Morphosyntactic Complexity: Evidence from German. Journal of Germanic Linguistics 26. 1-19.

Maiwald, Cordula. 2004. Tempus und Aspekt im Bairischen. Morphologie und Syntax deutscher Dialekte und Historische Dialektologie des Deutschen. Beiträge zum 1. Kongress der Internationalen Gesellschaft für Dialektologie des Deutschen, ed. by F. Patocka \& P. Wiesinger, 227-43. Wien: Edition Praesens.

Marynissen, Ann \& Guy Janssen. 2013. A regional history of Dutch. Language and Space. Volume 3. Dutch. An International Handbook of Linguistic Variation, ed. by F. Hinskens \& J. Taeldeman, 81-100. Berlin \& Boston: Mouton de Gruyter.

Marzo, Stefania \& Evy Ceuleers. 2011. The use of Citétaal among adolescents in Limburg: the role of space appropriation in language variation and change. Journal of Multilingual and Multicultural Development 32. 451-64.

Massey, Doreen. 1994. Space, Place and Gender. Minneapolis: University of Minnesota Press.

Matras, Yaron. 2000. Mixed languages: a functional-communicative approach. Bilingualism: Language and Cognition 3. 79-99.

—. 2009. Language Contact. Cambridge: Cambridge University Press.

Mazzoli, Maria \& Eeva Sippola. forthcoming. New Perspectives on Mixed Languages. From Core to Fringe. Amsterdam: Mouton de Gruyter.

Mazzucato, Valentina, Rijk van Dijk, Cindy Horst \& Pieter de Vries. 2004. Transcending the nation. Explorations of transnationalism as a concept and phenomenon. Globalization and Development: Themes and Concepts in Current Research, ed. by D. Kalb, W. Pansters \& H. Siebers, 131-62. Dordrecht: Kluwer Academic Publishers.

Meakins, Felicity. 2011. Case-Marking in Contact: The development and function of case morphology in Gurindji Kriol. Amsterdam/Philadelphia: John Benjamins Publishing Company.

- 2018. Mixed languages. Oxford Research Encyclopedia of Linguistics, ed. by A. Mark, 1-29. Oxford: Oxford University Press.

Meillet, Antoine. 1912. L'évolution des formes grammaticales: Zanichelli.

Menge, Heinz H. 1985. Einflüsse aus dem Polnischen im Ruhrgebiet? Exemplarische Behandlung eines Kapitels aus der „Volkslinguistik“. Sprache an Rhein und Ruhr. Dialektologische und soziolinguistische Studien zur sprachlichen Situation im Rhein-Ruhr-Gebiet und ihrer Geschichte, ed. by A. Mihm, 223-44. Wiesbaden/Stuttgart: Franz Steiner Verlag. 
Mennen, Ineke, Clara Levelt \& Ellen Gerrits. 2007. Dutch Speech Acquisition. The International Guide to Speech Acquisition, ed. by S. McLeod, 405-19. Michigan: Thomson Delmar Learning.

Mesthrie, Rajend. 1989. The origins of Fanagalo. Journal of Pidgin \& Creole Languages 4. 211-40.

—. 2009. Regional Dialectology. Introducing Sociolinguistics, ed. by R. Mesthrie, J. Swann, A. Deumert \& W.L. Leap, 42-73. Edinburgh: Edinburgh University Press.

—. 2019. Fanakalo as a mining language in South Africa: A new overview. International Journal of the Sociology of Language (IJSL), ed. by L. Cornips \& P. Muysken, 13-34. New York: de Gruyter.

Meyer, Caitlin \& Fred Weerman. 2015. Language acquisition and language change: the case of verb clusters. Paper presented at the A Germanic Sandwich 2015, University of Nottingham.

Meyerhoff, Miriam, Chie Adachi, Golnaz Nanbakhsh \& Anna Strycharz. 2012. Sociolinguistic fieldwork. The Oxford Handbook of Linguistic Fieldwork, ed. by N. Thieberger, 121-45. Oxford: Oxford University Press.

Mieroop, Dorien van de, Eline Zenner \& Stefania Marzo. 2016. Standard and Colloquial Belgian Dutch pronouns of address: A variationist-interactional study of childdirected speech in dinner table interactions. Folia Linguistica 50. 31-64.

Mihm, Arend. 1985a. Prestige und Stigma des Substandards. Zur Bewertung des Ruhrdeutschen im Ruhrgebiet. Sprache an Rhein und Ruhr. Dialektologische und soziolinguistische Studien zur sprachlichen Situation im Rhein-Ruhr-Gebiet und ihrer Geschichte, ed. by A. Mihm, 163-93. Wiesbaden/Stuttgart: Franz Steiner Verlag.

—. 1985b. Zur Entstehung neuer Sprachvarietäten. Ruhrdeutscher Kasusgebrauch und seine Erklärung. Sprache an Rhein und Ruhr. Dialektologische und soziolinguistische Studien zur sprachlichen Situation im Rhein-Ruhr-Gebiet und ihrer Geschichte, ed. by A. Mihm, 245-76. Wiesbaden/Stuttgart: Franz Steiner Verlag.

—. 1995. Die Realität des Ruhrdeutschen - soziale Funktion und sozialer Ort einer Gebietssprache. Sprache und Literatur an der Ruhr, ed. by K. Ehlich, W. Elmer $\&$ R. Noltenius, 15-34. Essen: Klartext.

—. 2010. Mehrsprachigkeit und Sprachdynamik im Mittelalter und in der frühen Neuzeit. Sprache in der Stadt, ed. by C. Moulin, F. Ravida \& N. Ruge, 11-54. Heidelberg: Winter.

Miller, David, Vincent DeLuca, Denny Berndt, Michael Iverson \& Jason Rothman. 2017. Subtle aspectual differences in the L2 acquisition of German: The case of the present tense and pseudo-progressive am+infinitive and beim+infinitive constructions. Cross-linguistic Influence in Bilingualism: In honor of Aafke Hulk, ed. by E. Blom, L. Cornips \& J. Schaeffer, 207-30. Amsterdam: John Benjamins Publishing Company. 
Miller, Tina \& Mary Boulton. 2007. Changing constructions of informed consent: Qualitative research and complex social worlds. Social Science \& Medicine 65. 2199-211.

Milroy, Lesley \& Matthew Gordon. 2003. Sociolinguistics. Method and Interpretation. Oxford: Blackwell.

Milroy, Lesley \& Pieter Muysken. 1995. Introduction: Code-switching and bilingualism research. One speaker, two languages: Cross-disciplinary perspectives on codeswitching, ed. by L. Milroy \& P. Muysken, 1-14. Cambridge: Cambridge University Press.

Mitterer, Holger \& Anne Cutler. 2006. Speech Perception. Encyclopedia of Language and Linguistics, ed. by K. Brown, 770-82. Oxford: Elsevier.

Mitterer, Holger \& Annelie Tuinman. 2012. The role of native-language knowledge in the perception of casual speech in a second language. frontiers in Psychology 3. 10.3389/fpsyg.2012.00249.

Modan, Gabriella Gahlia. 2007. Turf Wars: Discourse, Diversity, and the Politics of Place. New York: Wiley.

Møller, Janus Spindler \& J. Normann Jørgensen. 2009. From language to languaging: changing relations between humans and linguistic features. Acta Linguistica Hafniensia 41. 143-66.

Mortensen, Janus. 2017. Transient Multilingual Communities as a Field of Investigation: Challenges and Opportunities. Linguistic Anthropology 27. 271-88.

Mous, Maarten. 2009. The development of Urban Youth Languages in Africa. Transferences: The Expression of Extra-Linguistic Processes in the World's Languages, ed. by M.C. Junyent, 215-32. Vic, Spain: Eumo Editorial.

Mous, Marteen. 2003. The linguistic properties of lexical manipulation and its relevance for Ma'a. The mixed language debate: Theoretical and Empirical Advances, ed. by Y. Matras \& P. Bakker, 209-35. Berlin \& New York: Mouton de Gruyter.

Müller, Gereon. 2002a. Harmonic alignment and the hierarchy of pronouns in German. Pronouns: Grammar and Representation, ed. by H.J. Simon \& H. Wiese, 20532. Amsterdam/Philadelphia: John Benjamins.

Müller, Sonja \& Mailin Antomo. 2018. Non-canonical verb positioning in main clauses: Phenomena and research questions. Non-Canonical Verb Positioning in Main Clauses. Special Issue of Linguistische Berichte, ed. by M. Antomo \& S. Müller, 5-20.

Müller, Stefan. 2002b. Complex Predicates: Verbal Complexes, Resultative Constructions, and Particle Verbs in German. Groningen: CSLI Publications: Unglue edition.

Muysken, Pieter. 1981. Halfway between Quechua and Spanish: the case for relexification. Historicity and variation in creole studies, ed. by A. Highfield \& A. Valdman, 52 - 78. Karoma: Ann Arbor.

—. 2000. Bilingual Speech: A Typology of Code-Mixing: Cambridge University Press. 
—. 2014. Déjà Voodoo or new trails ahead? Re-evaluating the mixing typology model. Linguistic Variation: Confronting Fact and Theory, ed. by R. Torres Cacoullos, N. Dion \& A. Lapierre, 243-62.

- 2019. Multilingualism and mixed language in the mines of Potosí (Bolivia). International Journal of the Sociology of Language (IJSL), ed. by L. Cornips \& P. Muysken, 121-43. New York: de Gruyter.

Myers-Scotton, Carol. 1988. Codeswitching as indexical of social negotiations. Codeswitching. Anthropological and Sociolinguistic Perspectives, ed. by M. Heller, 151-86. Berlin: Mouton de Gruyter.

-. 1993. Social Motivations for Codeswitching: Evidence from Africa. Oxford: Clarendon Press.

- 2003. What lies beneath: Split (mixed) languages as contact phenomena. The Mixed Language Debate, ed. by Y. Matras \& P. Bakker, 73-106. Berlin/New York: Mouton de Gruyter.

Nelde, Peter \& Jeroen Darquennes. 2002. German in Belgium: Linguistic Variation from a Contact Linguistic Point of View. Journal of Multilingual and Multicultural Development 23. 65-79.

Nelissen, Nico. 2006. Hart voor Architectuur in Europa. Een 'kleine tocht' door de geschiedenis. Nijmegen: Nelissen.

Nevis, Joel Ashmore. 1985. Finnish Particle Clitics and General Clitic Theory. Published as OSU WPL 33, 1986: Ohio State University.

Newman, John. 2002. A cross-linguistic overview of the posture verbs 'sit', 'stand' and 'lie'. The linguistics of sitting, standing, and lying, ed. by J. Newman, 1-24. Amsterdam: John Benjamins Publishing Company.

Newton, G. 2013. Central Franconian. The Dialects of Modern German: A Linguistic Survey, ed. by C.V.J. Russ, 136-209. Oxon: Taylor \& Francis.

Nicolay, Nathalie. 2007. Aktionsarten im Deutschen: Prozessualität und Stativität. Tübingen: Max Niemeyer.

Niedzielski, Nancy \& Dennis Richard Preston. 2000. Folk Linguistics. Berlin/New York: Mouton de Gruyter.

Nortier, Jacomine. 2018. Youth Languages. Jugendsprachen/Youth Languages: Aktuelle Perspektiven internationaler Forschung/Current Perspectives of International Research, ed. by A. Ziegler, 3-24. Berlin: De Gruyter.

Nortier, Jacomine \& Bente A. Svendsen (eds) 2015. Language, Youth and Identity in the 21 st Century. Cambridge: Cambridge University Press.

Nübling, Damaris. 1992. Klitika im Deutschen: Schriftsprache, Umgangssprache, alemannische Dialekte. Tübingen: Gunter Narr Verlag.

- 2015. Between feminine and neuter, between semantic and pragmatic gender: hybrid names in German dialects and in Luxembourgish. Agreement from a Diachronic Perspective, ed. by J. Fleischer, E. Rieken \& P. Widmer, 235-65. Berlin: Walter de Gruyter. 
Nützel, Daniel \& Joseph Salmons. 2011. Language Contact and New Dialect Formation: Evidence from German in North America. Language and Linguistics Compass 5. 705-17.

O'Rourke, Bernadette \& Joan Pujolar. 2013. From native speakers to "new speakers" problematizing nativeness in language revitalization contexts Histoire de Épistémologie Langage 35. 47-67.

-. 2015. New speakers and processes of new speakerness across time and space. Applied Linguistics Review 2015 6. 145-50.

Ochs, Elinor. 1979. Transcription as theory. Developmental pragmatics 10. 43-72.

Opsahl, Toril \& Ingvild Nistov. 2010. On some structural aspects of Norwegian spoken among adolescents in multilingual settings in Oslo. Multilingual Urban Scandinavia. New Linguistic Practices, ed. by P. Quist \& B.A. Svendsen, 49-63. Bristol: Multilingual Matters.

Otsuji, Emi \& Alastair Pennycook. 2010. Metrolingualism: fixity, fluidity and language in flux. International Journal of Multilingualism 7. 240-54.

Patrick, Peter 2008. The speech community. The Handbook of Language Variation and Change, ed. by J.K. Chambers \& N. Schilling, 573 - 97. Oxford: Blackwell.

Pecht, Nantke. 2013. "Siehs' du, du wars (...) besser wie du hast gedacht: Du has' Französisch gesprochen!" Taal en Tongval 65. 149-69.

—. 2014. Masterarbeit. Unpublished script. Department of German Linguistics, AlbertLudwigs-University of Freiburg.

- 2015. The postfield in Cité Duits: Syntactic variation in in-group speech. Paper presented at the Artikelen van de 8ste Anéla Conferentie Toegepaste Taalwetenschap 2015.

-. 2019. Grammatical features of a moribund coalminers' language in a Belgian cité. International Journal of the Sociology of Language (IJSL), ed. by L. Cornips \& P. Muysken, 71-98. New York: de Gruyter.

- forthcoming. Personal pronouns in Cité Duits. New Perspectives on Mixed Languages. From Core to Fringe, ed. by M. Mazzoli \& E. Sippola. Amsterdam: Mouton de Gruyter.

Peet, Jan. 2012. Mijnarbeid, veiligheid en gezondheid. Mijnwerkers in Limburg: een sociale geschiedenis, ed. by A. Knotter, 220-67. Nijmegen: Vantilt Uitgeverij.

Pennycook, Alastair \& Emi Otsuji. 2014. Metrolingual multitasking and spatial repertoires: 'Pizza mo two minutes coming'. Journal of Sociolinguistics 18. 16184.

Persoon, Ingrid, Ted Sanders, Hugo Quené \& Arie Verhagen. 2010. Een coördinerende omdat-constructie in gesproken Nederlands? - Tekstlinguïstische en prosodische aspecten. Nederlandse Taalkunde 15. 259-82.

Pichler, Heike, Suzanne Evans Wagner \& Ashley Hesson. 2018. Old-age language variation and change: Confronting variationist ageism. Language and Linguistics Compass. 1-21. 
Piepers, Joske \& Theresa Redl. 2018. Gender-mismatching pronouns in context: The interpretation of possessive pronouns in Dutch and Limburgian. Linguistics in the Netherlands 35. 97-110.

Pierrehumbert, Janet B. 1994. Knowledge of Variation. Paper presented at the Papers from 30th Regional Meeting of the Chicago Linguistic Society. The Parasession of Variation in Linguistic Theory, Chicago.

- 2001. Exemplar dynamics: Word frequency, lenition and contrast. Frequency and the Emergence of Linguistic Structure, ed. by J. Bybee \& P. Hopper, 137-58. Philadelphia: Johns Benjamins.

Pinxten, K. 1939. Het Kempisch steenkolenbekken: Een economische studie. Brussel/Anwerpen/Leuven/Gent: Naaml. Venn. Standaard-Boekhandel.

Plevoets, Koen. 2008. Tussen spreek- en standaardtaal. Een corpusgebaseerd onderzoek naar de situationele, regionale en sociale verspreiding van enkele morfosyntactische verschijnselen uit het gesproken Belgisch-Nederlands. Leuven: KU Leuven.

- 2013. De status van de Vlaamse tussentaal. Een analyse van enkele socio-economische determinanten. Tijdschrift voor Nederlandse Taal- en Letterkunde 129. 191-233. https://biblio.ugent.be/publication/4183608. March 17, 2020.

Plevoets, Koen, Dirk Speelman \& Dirk Geeraerts. 2008. The distribution of T/V pronouns in Netherlandic and Belgian Dutch. Variational pragmatics: a focus on regional varieties in pluricentric languages, ed. by K. Schneider \& A. Barron, 181-209. Amsterdam: John Benjamins.

Poletto, Cecilia. 2000. The Higher Functional Field. Evidence from Northern Italian dialects. Oxford: Oxford University Press.

Pollner, Melvin \& Robert M. Emerson. 2001. Ethnomethodology and Ethnography. Handbook of Ethnography, ed. by P. Atkinson, S. Delamont, A. Coffey, J. Lofland \& L. Lofland, 118-35. London: SAGE Publications.

Poplack, Shana. 1980. "Sometimes I'll start a sentence in Spanish y termino en Español": toward a typology of code-switching. Linguistics 18. 581-618.

Postma, Gertjan. 2018. Personal communication. Amsterdam, Meertens Instituut KNAW. November 2018.

Pots, Cora. 2018. How progressives progress. The case of Dutch and Afrikaans. Paper presented to the LingLunch, London, 2018.

Pratt, Marie Louise. 2014. Comparative Literature and Global Languascapes. A Companion to Comparative Literature, ed. by A. Behdad \& D. Thomas, 273-95. Malden/Oxford: Wiley.

Ptashnyk, Stefaniya. 2016a. Historische Sprachkontakte in einer multilingualen Stadt: Beschreibungsprobleme und Desiderate (am Beispiel Lembergs im 19. Jahrhundert). Historische Sprachkontaktforschung (Jahrbuch für germanistische Sprachgeschichte 7), ed. by C. Wich-Reif, 235-63. Berlin/Boston: de Gruyter. 
—. 2016b. Sprachkontakte gestern und heute: Forschungsfragen, methodische Zugänge und Desiderate. Gegenwärtige Sprachkontakte im Kontext der Migration, ed. by S. Ptashnyk, R. Beckert, P. Wolf-Farré \& M. Wolny, 61-76. Heidelberg: Winter.

Putnam, Michael T. 2011. Studies on German-language Islands. Amsterdam/Philadelphia: John Benjamins Publishing Company.

Quist, Pia. 2008. Sociolinguistic approaches to multiethnolect: Language variety and stylistic practice. International Journal of Bilingualism 12. 43-61.

Ramelli, Christian. 2015. Die Rheinische Verlaufsform im rheinfränkischen Dialekt. Potsdam: Universität Potsdam, Philosophische Fakultät.

Rampton, Ben. 2000. Speech community. Handbook of Pragmatics, ed. by J. Verschueren, J.-O. Östman, J. Blommaert \& C. Bulcaen, 1-34. Amsterdam/Philapdelphia: John Benjamins.

-. 2011a. From 'Multi-ethnic adolescent heteroglossia' to 'Contemporary urban vernaculars'. Language \& Communication 31. 276-94.

- 2011b. Style contrasts, migration and social class. Journal of Pragmatics 43. 1236-50.

-. 2014. Crossings: Language and Ethnicity Among Adolescents. London/New York: Taylor \& Francis.

RDM. 2016. Research Data Management Code of Conduct. 2016. http://library.maastrichtuniversity.nl/library-researchers/research-datamanagement/. May 6, 2016.

Reichenbach, Hans. 1947. Elements of Symbolic Logic. Berkeley: University of California Press.

Riehl, Claudia M. 2009. Sprachkontaktforschung. Eine Einführung. Tübingen: Gunther Narr.

Riionheimo, Helka \& Maria Frick. 2015. The emergence of Finnish-Estonian bilingual constructions in two contact settings. Sociolinguistic Studies 8.3. 409-77.

Rizzi, Luigi. 1986. On the status of subject clitics in Romance. Studies in Romance Linguistics, ed. by O. Jaeggli \& C. Silva-Corvalan, 391-419. Dordrecht: Foris.

Roberge, Paul. 2010. Contact and the History of Germanic Languages. The Handbook of Language Contact, ed. by R. Hickey. London: Blackwell.

Roberts, Ian \& Anna Roussou. 2003. Syntactic Change. A Minimalist Approach to Grammaticalization. Cambridge: Cambridge University Press.

Roels, Leen. 2008. "In Belgium, women do all the work". De arbeid van vrouwen in de Luikse mijnen, negentiende begin twintigste eeuw. Belgisch Tijdschrift voor Nieuwste Geschiedenis. 45-86.

—. 2014. Het tekort: Studies over de arbeidsmarkt voor mijnwerkers in het Luikse kolenbekken vanaf het einde van de negentiende eeuw tot 1974. Hilversum: Uitgeverij Verloren.

Roodenburg, Jasper \& Aafke Hulk. 2008. Puzzles on grammatical gender. Lingue e Linguaggio Vii 1. 67-91.

—. 2009. "Gender" puzzles. Taal \& Tongval 22. 143-64. 
Rothmayr, Antonia. 2013. And the beat goes on. Language Variation - European Perspectives IV: Selected papers from the Sixth International Conference on Language Variation in Europe (ICLaVE 6), ed. by P. Auer, J. Reina \& G. Kaufmann, 187-200. Amsterdam: John Benjamins Publishing Company.

Rothstein, Susan. 2008a. Verb Classes and Aspectual Classification. Structuring Events: A Study in the Semantics of Lexical Aspect, ed. by S. Rothstein, 1-35. London: Blackwell Publishing Ltd.

Rothstein, Susan Deborah (ed.) 2008b. Theoretical and Crosslinguistic Approaches to the Semantics of Aspect. Amsterdam: John Benjamins Publishing.

Rozendaal, Margaretha Isabella. 2008. The acquisition of reference: A cross-linguistic study. Utrecht: LOT.

Ruoff, Arno. 1990. Häufigkeitswörterbuch gesprochener Sprache. Second edition. Tübingen: Niemeyer.

Rutten, Gijsbert \& Rik Vosters. 2010. Chaos and Standards. Orthography in the Southern Netherlands (1720-1830). Multilingua 29. 417-38.

Rutten, Willibrord. 2012. Het thuisfront van de mijnwerker. Mijnwerkers in Limburg: een sociale geschiedenis, ed. by A. Knotter, 388-424. Nijmegen: Vantilt Uitgeverij.

Rutten, Willibrord \& Serge Langeweg. 2012. Verenigingsleven en vrijetijdsbesteding. Mijnwerkers in Limburg: een sociale geschiedenis, ed. by A. Knotter, 492-526. Nijmegen: Vantilt Uitgeverij.

Sacks, Harvey, Emanuel A. Schegloff \& Gail Jefferson. 1974. A simplest systematics for the organisation of turn-taking for conversation. Language 50. 696-735.

Salewski, K. 1998. Zur Homogenität des Substandards älterer Bergleute im Ruhrgebiet. Stuttgart: Franz Steiner Verlag.

Sankoff, Gillian. 2004. Linguistic Outcomes of Language Contact. The handbook of language variation and change, ed. by J.K. Chambers, P. Trudgill \& N. Schilling-Estes, 638-68. Malden/Oxford: Blackwell.

Saussure, Ferdinand de. 1968-1974 [1916]. Cours de linguistique générale. Edition critique par Rudolf Engler. Wiesbaden: Harrassowitz.

Schallert, Oliver. 2014. IPP-constructions in Alemannic and Bavarian in comparison. Bavarian Syntax: Contributions to the theory of syntax, ed. by G. Grewendorf \& H. Weiß, 247-304. Amsterdam: John Benjamins.

Schalowski, Sören (*posthum by Heike Wiese and Ulrike Freywald). 2015. Wortstellungsvariation aus informationsstruktureller Perspektive: Eine Untersuchung der linken Satzperipherie im gesprochenen Deutsch. Interdisciplinary Studies on Information Structure 18.

Scherpenisse, Wim. 1986. The connection between base structure and linearization restrictions in German and Dutch. Frankfurt am Main: Peter Lang.

Schiering, René. 2002. Klitisierung von Pronomina und Artikelformen. Eine empirische Untersuchung am Beispiel des Ruhrdeutschen. Arbeitspapier (Neue Folge) 44. $1-62$. 
Schlücker, Barbara. 2009. Passive in German and Dutch: The sein / zijn + past participle construction. Groninger Arbeiten zur Germanistischen Linguistik 49. 96-124. http://gagl.eldoc.ub.rug.nl. November 17, 2019.

Schmidt, Jürgen Erich \& Robert Möller. 2019. Historisches Westdeutsch/Rheinisch (Moselfränkisch, Ripuarisch, Südniederfränkisch). Deutsch: Sprache und Raum - Ein internationales Handbuch der Sprachvariation, ed. by J. Herrgen \& J.E. Schmidt, 515-50. Berlin/Boston: De Gruyter.

Schmuck, Miriam. 2020. The grammaticalisation of definite articles in German, Dutch, and English: a microtypological approach. German and Dutch in Contrast, ed. by G.D. Vogelaer, D. Koster \& T. Leuschner, 145-78. Berlin/Boston: De Gruyter.

Scholten, Beate. 1988. Standard und städtischer Substandard bei Heranwachsenden im Ruhrgebiet. Tübingen: Max Niemeyer Verlag.

Schönfeld, Helmut. 1990. East Low German. The Dialects of Modern German. A Linguistic Survey, ed. by C.V.J. Russ, 91-135. London: Routledge.

Schutter, Georges de. 1989. Pronominale clitica in de Nederlandse dialecten. Antwerp Papers in Linguistics 58. 1-18.

—. 2013. The dialects of the Brabant region: Phonological properties. Language and Space: An International Handbook of Linguistic Variation, ed. by F. Hinskens \& J. Taeldeman, 277-96. Berlin: Walter de Gruyter.

Scott-Jones, Julie \& Sal Watt. 2010. Ethnography in Social Science Practice. London: Routledge.

Seiler, Guido. 2004. On three types of dialect variation and their implications for linguistic theory. Evidence from verb clusters in Swiss German dialects. Dialectology Meets Typology: Dialect Grammar from a Cross-linguistic Perspective, ed. by B. Kortmann, 367-99. Berlin: Mouton de Gruyter.

Selting, Margret, Peter Auer, Dagmar Barth-Weingarten, Jörg Bergmann, Pia Bergmann, Karin Birkner, Elizabeth Couper-Kuhlen, Arnulf Deppermann, Peter Gilles, Susanne Günthner, Martin Hartung, Friederike Kern, Christine Mertzlufft, Christian Meyer, Miriam Morek, Frank Oberzaucher, Jörg Peters, Uta Quasthoff, Wilfried Schütte, Anja Stukenbrock \& Susanne Uhmann. 2009. Gesprächsanalytisches Transkriptionssystem 2 (GAT 2). Gesprächsforschung Online-Zeitschrift zur verbalen Interaktion 10. 353-402.

Shah, Sheena. 2007. German in a contact situation: The case of Namibian German. eDusa 2. 20-45.

Siegel, Vanessa. 2016. Multiethnolektale Syntax. Artikel, Präpositionen und Pronomen in der Jugendsprache. Inaugural-Dissertation. Freiburg: Albert-LudwigsUniversity Freiburg.

Siewierska, Anna. 1999. From anaphoric pronoun to grammatical agreement marker: why objects don't make it. Folia Linguistica $33 . \quad 225-52$. https://doi.org/10.1515/flin.1999.33.1-2.225. March 27, 2019. 
Silverstein, Michael. 1985. Language and the Culture of Gender: At the intersection of Structure, Usage, and Ideology. Semiotic Mediation: Sociocultural and Psychological Perspectives, ed. by E. Mertz \& R.J. Parmentier, 219-59. Orlando: Academic Press.

-. 1996. Encountering Language and Languages of Encounter in North American Ethnohistory. Journal of Linguistic Anthropology 6. 126-44.

Simon, Horst J. \& Heike Wiese. 2002. Grammatical properties of pronouns and their representation: An exposition. Pronouns: Grammar and Representation, ed. by H.J. Simon \& H. Wiese, 1-22. Amsterdam/Philadelphia: John Benjamins Publishing Company.

Slater, Ariane 2012. Grammatik im Wandel: Die Verlaufsform im Deutschen und Englischen. Entwickelt das Deutsche eine "progressive form"? [appeared earlier as Reimann, Ariane (1996)] München/Ravensburg: GRIN Verlag.

Smith, Carlotta S. 1991. The Parameter of Aspect. Dordrecht: Springer.

Smith, Vicki. 2001. Ethnographies of Work and the Work of Ethnographers. Handbook of Ethnography, ed. by P. Atkinson, S. Delamont, A. Coffey, J. Lofland \& L. Lofland, 220-32. London: SAGE Publications.

Statbel. 2019. Belgische statistiekbureau: Structuur van de bevolking. https://statbel.fgov.be/nl/themas/bevolking/structuur-van-de-bevolking. February 5, 2020.

Stell, Gerald \& Kofi Yakpo. 2015. Code-switching Between Structural and Sociolinguistic Perspectives. Berlin/Munich/Boston: De Gruyter.

Stevens, A. 1949/1985. Pronominale isomorfen in Belgisch-Limburg. (Mededelingen van de Vereniging voor Limburgse Dialect- en Naamkunde, Nr. 34). Hasselt 1985.

Stolt, Birgit. 1964. Die Sprachmischung in Luthers Tischreden. Studien zum Problem der Zweisprachigkeit. Stockholm: Almqvist \& Wiksell.

Strobel, Thomas. 2016. Die syntaktische Variable "pronominale Partitivität" in den deutschen Dialekten. Syntaktische Variation: Areallinguistische Perspektiven, ed. by A. Lenz \& F. Patocka, 151-98. Göttingen: V\&R Unipress.

—. 2017. Indefinit-partitive Pronomina. SyHD-atlas (Syntax Hessischer Dialekte-Atlas), ed. by J.r. Fleischer, A. Lenz \& H. Weiß. Marburg/Wien/Frankfurt am Main: Developed by Ludwig M. Breuer.

Stuyck, Karen, Sarah Luyten, Chris Kesteloot, Henk Meert \& Katleen Peleman. 2010. A geography of gender relations: Role patterns in the context of different regional industrial development. Regional Studies $42 . \quad 69-82$. https://doi.org/10.1080/00343400701291492. January 28, 2018.

Sudhoff, Stefan. 2010. Focus Particles in German: Syntax, prosody, and information structure. Amsterdam/Philadelphia: John Benjamins Publishing Company.

Taeldeman, Johan. 2008. Zich stabiliserende grammaticale kenmerken in Vlaamse tussentaal. Taal \& Tongval 60. 26-50. 
Taeldeman, Johan \& Frans Hinskens. 2013. The classification of the dialects of Dutch. Language and Space: An International Handbook of Linguistic Variation, ed. by F. Hinskens \& J. Taeldeman, 129-41. Berlin: Walter de Gruyter.

Tagliamonte, Sali A. 2006. Analysing Sociolinguistic Variation. Cambridge: Cambridge University Press.

Tannen, Deborah. 2005 [1984]. Conversational Style: Analyzing Talk among Friends. Oxford: Oxford University Press.

Taylor, Talbot J. 2000. Language constructing language: the implications of reflexivity for linguistic theory. Language Sciences 22. 483-99.

Temmerman, Martina. 2014. "Nail polish - We've chosen the nicest shades for you!" Editorial voice and 'we' in a Flemish women's magazine. Constructing Collectivity. 'We' across languages and contexts, ed. by T.-S. Pavlidou, 247-63. Amsterdam \& Philadelphia: John Benjamins Publishing Company.

Thelin, Nils B. (ed.) 1990. Verbal Aspect in Discourse: Contributions to the Semantics of Time and Temporal Perspective in Slavic and Non-slavic Languages. Amsterdam/Philadelphia: John Benjamins Publishing Company.

Thissen, Lotte. 2018. Talking in and out of place. Ethnographic reflections on language, place, and (un)belonging in Limburg, the Netherlands. Maastricht: Maastricht University.

Thomason, Sarah G. 2001. Language Contact: An Introduction. Edinburgh: Edinburgh University Press.

Thomason, Sarah G. \& Terrence Kaufman. 1988. Language Contact, Creolization, and Genetic Linguistics. Berkeley, Los Angeles, Oxford: University of California Press.

Thüne, Eva-Maria. 2007. Einleitung in die Beiträge der Arbeitsgruppe 'Gesprochene Sprache'. Gesprochene Sprache - Partikeln: Beiträge der Arbeitsgruppen der 2. Tagung Deutsche Sprachwissenschaft in Italien, Rom 2006, ed. by E.-M. Thüne \& F. Ortu, 11-20. Frankfurt am Main: Peter Lang.

Tomas, Adam. 2018. Der "am"-Progressiv im Pennsylvaniadeutschen: Grammatikalisierung in einer normfernen Varietät. Tübingen: Narr Francke Attempto Verlag.

Torres Cacoullos, Rena \& Catharine Travis. 2015. Gauging convergence on the ground: Code-switching in the community. International Journal of Bilingualism 19. 365-86.

Tortora, Christina. 2003. The Syntax of Italian Dialects. Oxford: Oxford University Press.

Treffers-Daller, Jeanine. 1994. Mixing Two Languages: French-Dutch Contact in a Comparative Perspective. Berlin/New York: De Gruyter.

—. 1998. Variability in code-switching styles: Turkish-German code-switching patterns. Codeswitching Worldwide, ed. by R. Jacobson. Berlin/New York: De Gruyter.

-. 2002. Language Use and Language Contact in Brussels. Journal of Multilingual and Multicultural Development 23. 50-64. 
Tsiplakou, Stavroula. 2014. How 'mixed' is a mixed system? The case of the Cypriot Greek koine. Linguistic Variation. Special Issue: Three Factors and Beyond. Socio-Syntax and Language Acquisition, ed. by K.K. Grohmann, 161-78. Amsterdam: John Benjamins.

Tsiplakou, Stavroula, Spyros Armostis \& Dimitris Evripidou. 2016. Coherence 'in the mix'? Coherence in the face of language shift in Cypriot Greek. Lingua 172-173. $10-25$.

van Avermaet, Piet. 2008. Taalverschuiving in de Italiaanse gemeenschap in Eisden, Maasmechelen. Leuven: Katholieke Universiteit Leuven.

van Bree, Cor. 1994. The development of so-called Town Frisian. Mixed languages: 15 case studies in language intertwining, ed. by P. Bakker \& M. Mous, 69-82. Amsterdam: IFOTT.

- 1996. Historische taalkunde. Leuven/Amersfoort: Acco. https://dbnl.org/tekst/bree001hist01 01/bree001hist01_01 0021.php.

- 2001. De morfologie van het Stadsfries Tijdschrift voor Nederlandse Taal-en Letterkunde 117. 41-58.

van Craenenbroeck, Jeroen \& Marjo van Koppen. 2002. Subject doubling in Dutch dialects. Proceedings ConSole 9. 55-67.

van de Velde, Hans. 1996. Variatie en verandering in het gesproken StandaardNederlands (1935-1993). Nijmegen: Katholieke Universiteit Nijmegen.

—. 2018. Personal e-mail communication. August 28, 2018.

van de Wijngaard, Ton \& Herman Crompvoets. 2006. Mijnwerkersterminologie in de beide Limburgen: meer verscheidenheid dan eenheid. Paper presented to the Mededelingen van de Vereniging voor Limburgse Dialect- en Naamkunde 51 (Hasselt 1989), 2006.

van de Wijngaard, Ton \& Ronny Keulen. 2007. De indeling van de Limburgse dialecten. Riek van klank: inleiding in de Limburgse dialecten, ed. by R. Keulen, T. Van de Wijngaard, H. Crompvoets \& F. Walraven, 15-23. Sittard: Veldeke Limburg.

van den Berg, Margot \& T. Oosting. 2017. Zitten is het nieuwe zijn. Variatie en verandering in het gebruik van positiewerkwoorden in het Nederlands. Paper presented to the Grote Taaldag Anela, Utrecht, The Netherlands, 2017.

van der Sijs, Nicoline. 2005. Groot leenwoordenboek. Utrecht: Van Dale Lexicografie.

van der Sijs, Nicoline, Henk van den Heuvel \& Roeland van Hout. 2017. Elektronisch Woordenboek van de Limburgse Dialecten (e-WLD). http://e-wld.nl/. May 18, 2018.

van Hout, Angeliek, Bart Hollebrandse \& Co Vet. 2005. Crosslinguistic Views on Tense, Aspect and Modality. Amsterdam/New York: Rodopi.

van Hout, Roeland \& Pieter Muysken. 1994. Modeling lexical borrowability. Language Variation and Change 6. 39-62.

van Hout, Roland. 2006. Limburgse voornaamwoorden. Een eeuw lang Limburgs. SGVenquête 
https://repository.ubn.ru.nl/bitstream/handle/2066/42983/266532.pdf?sequence $=1$. December 4, 2018.

Van Keymeulen, Jacques. 2018. Dialectzinnen. Databaseproject. http://www.dialectzinnen.ugent.be/dialectzinnen/\#Vlaams. November 30, 2018.

van Koppen, Marjo. 2017. Complementizer Agreement. The Wiley Blackwell Companion to Syntax, ed. by M. Everaert \& H. van Riemsdijk, 1-40: John Wiley \& Sons. 10.1002/9781118358733.wbsyncom061. September 12, 2019.

van Oostendorp, Marc. 2006. Topics in the phonology of Dutch. http://citeseerx.ist.psu.edu/viewdoc/download?doi=10.1.1.540.4166\&rep=rep1 \&type $=$ pdf. July 14, 2019.

van Pottelberge, Jeroen. 2004. Der am-Progressiv: Struktur und parallele Entwicklung in den kontinentalwestgermanischen Sprachen. Tübingen: Gunther Narr Verlag.

- 2007. Defining grammatical constructions as a linguistic sign: The case of periphrastic progressives in the Germanic languages. Folia Linguistica 41. 99-134.

van Riemsdijk, Henk C. 1999. Clitics: a state-of-the-art report. Clitics in the Languages of Europe, ed. by H.C. van Riemsdijk, 1-30. Berlin/New York: Mouton de Gruyter.

Vandekerckhove, Reinhild. 2004. Waar zijn je, jij en jou(w) gebleven? Pronominale aanspreekvormen in het gesproken Nederlands van Vlamingen. Taeldeman, Man Van De Taal, Schatbewaarder Van De Taal: Liber Amicorum Johan Taeldeman, ed. by J. De Caluwe, M. Devos, J. Van Keymeulen \& G. De Schutter, 981-94. Gent: Academia Press.

—. 2005. Belgian Dutch versus Netherlandic Dutch: New patterns of divergence? On pronouns of address and diminutives. Multilingua 24. 379-97.

-. 2009. Dialect loss and dialect vitality in Flanders International journal of the sociology of language 196-197. 73-97.

Vandenbussche, Wim. 2010. Standardisation through the media. The case of Dutch in Flanders. Variatio delectat: empirische Evidenzen und theoretische Passungen sprachlicher Variation, ed. by P. Gilles, J. Scharloth \& E. Ziegler. Frankfurt am Main: Lang.

Vanhinsberg, Fred. 1996. Waarom die Italianen? Berchem: EPO.

Velde, Hans van de \& Dirk Geeraerts. 2013. Supra-regional characteristics of colloquial Dutch. Language and Space. Volume 3. Dutch. An International Handbook of Linguistic Variation, ed. by F. Hinskens \& J. Taeldeman, 532-56. Berlin \& Boston: Mouton de Gruyter.

Vendler, Zeno. 1957. Verbs and Times. The Philosophical Review 66. 143-60.

—. 1967. Linguistics in philosophy. Cornell: Cornell University Press.

Verkuyl, Henk J. 1972. On the compositional nature of the aspects. Dordrecht: Reidel Publishing Company.

-. 1989. Aspectual Classes and Aspectual Composition. Linguistics and Philosophy 12. 39-94. 
—. 1996. A Theory of Aspectuality: The Interaction Between Temporal and Atemporal Structure. Cambridge: Cambridge University Press.

Verkuyl, Henk J., Henriette De Swart \& Angeliek Van Hout. 2006. Perspectives on Aspect. Amsterdam: Springer.

Versteegh, A. P. 1994. De onvermijdelijke afkomst? : de opname van Polen in het Duits, Belgisch en Nederlands mijnbedrijf in de periode 1920-1930. Hilversum: Verloren.

Vinckel-Roisin, Hélène. 2011. Wortstellungsvariation und Salienz von Diskursreferenten: Die Besetzung des Nachfeldes in deutschen Pressetexten als kohärenzstiftendes Mittel. Zeitschrift für germanistische Linguistik 39. 377-404.

Vinckel, Hélène. 2006. Die diskursstrategische Bedeutung des Nachfelds im Deutschen. Eine Untersuchung anhand politischer Reden der Gegenwartssprache. Wiesbaden: Springer Verlag.

von Heusinger, Klaus. 2002. Reference and representation of pronouns. Pronouns: Grammar and Representation, ed. by H.J. Simon \& H. Wiese, 109-36. Amsterdam/Philadelphia: John Benjamins.

Vosters, Rik. 2009. Integrationisten en particularisten? Taalstrijd in Vlaanderen tijdens het Verenigd Koninkrijk der Nederlanden (1815-1830). Handelingen van de Koninklijke Zuid-Nederlandse Maatschappij voor Taal-en Letterkunde en Geschiedenis LXII. 41-58.

Wagener, Peter \& Karl Heinz Bausch. 1997. Tonaufnahmen des gesprochenen Deutsch: Dokumentation der Bestände von sprachwissenschaftlichen Forschungsprojekten und Archiven. Tübingen: Niemeyer.

Wanat, Carolyn L. 2008. Getting Past the Gatekeepers: Differences Between Access and Cooperation in Public School Research. Field Methods 20. 191-208. 10.1177/1525822X07313811. September 2, 2019.

Wang, Xuan, M. Spotti, K. Jufermans, Leonie Cornips, S. Kroon \& Jan Blommaert. 2014. Globalization in the margins: toward a re-evalution of language and mobility. Applied Linguistics Review 5. 23-44.

Watanabe, Akira. 2004. The Genesis of Negative Concord: Syntax and Morphology of Negative Doubling. Linguistic Inquiry 35. 559-612.

Weber, Thilo. 2017. Die 'TUN'-Periphrase im Niederdeutschen. Funktionale und formale Aspekte. Tübingen: Staufenburg.

- 2018. An OT analysis of do-support across varieties of German. Journal of Comparative Germanic Linguistics 21. 75-129.

Weerd, Pomme van de. 2019. "Those foreigners ruin everything here": Interactional functions of ethnic labelling among pupils in the Netherlands. Journal of Sociolinguistics 23. 244-62.

Wegener, Heide. 1993. weil - das hat schon seinen Grund. Zur Verbstellung in Kausalsätzen mit weil im gegenwärtigen Deutsch. Deutsche Sprache 21. 289305. 
Wei, Li. 1998. The 'why' and 'how' questions in the analysis of conversational codeswitching. Code-switching in Conversation: Language, Interaction and Identity, ed. by P. Auer, 156-79. London: Routledge.

- 2011. Moment Analysis and translanguaging space: Discursive construction of identities by multilingual Chinese youth in Britain. Journal of Pragmatics 43. 1222-35.

Weijnen, Antonius Angelus. 2003 [1966]. Nederlandse dialectkunde. Assen: Van Gorcum \& - Dr. H.J. Prakke \& H.M.G. Prakke.

Weinert, Regina. 2007. Demonstrative and personal pronouns in formal and informal conversations. Spoken Language Pragmatics: Analysis of Form-Function Relations, ed. by R. Weinert, 1-28. London/New York: Bloomsbury Academic.

Weinreich, Uriel. 1953. Languages in Contact: Findings and Problems. The Hague/Paris/New York: De Gruyter.

Weinrich, Harald, Maria Thurmair, Eva Breindl \& Eva-Maria Willkop. 2003. Textgrammatik der deutschen Sprache. Hildesheim/Zürich/New York: Georg Olms.

Weise, Oskar. 1906. Der Teilungsgenetiv in den Mundarten. Zeitschrift für deutsche Mundarten. 289-305.

Weiß, Helmut. 1998. Syntax des Bairischen: Studien zur Grammatik einer natürlichen Sprache. Tübingen: Max Niemeyer Verlag.

- 2005. Inflected Complementizers in Continental West Germanic Dialects. Zeitschrift für Dialektologie und Linguistik 72. 148-66.

-. 2017. Doppelte Negation. In SyHD-atlas (Syntax Hessischer Dialekte-Atlas). Developed by Ludwig M. Breuer. Edited by Fleischer, Jürg; Lenz, Alexandra N. and Helmut Weiß. Marburg/Wien/Frankfurt am Main.

Weiß, Helmut 2002. Three Types of Negation: A Case Study in Bavarian. Syntactic Microvariation, ed. by S. Barbiers, L. Cornips \& S.v.d. Kleij.

Werth, Alexander. 2017. (Pro)Nominalsyntax. In SyHD-atlas (Syntax Hessischer Dialekte-Atlas). Developed by Ludwig M. Breuer. Edited by Fleischer, Jürg; Lenz, Alexandra N. and Helmut Weiß. Marburg/Wien/Frankfurt am Main.

Wesseling, Franca. 2018. There is more. Variation in expletive constructions in Dutch. Amsterdam: LOT.

Westpfahl, Svantje. 2020. POS-Tagging für Transkripte gesprochener Sprache: Entwicklung einer automatisierten Wortarten-Annotation am Beispiel des Forschungs- und Lehrkorpus Gesprochenes Deutsch (FOLK). Tübingen: Gunter Narr.

Wiese, Heike. 2013a. From feature pool to pond: The ecology of new urban vernaculars. Working Papers in Urban Language \& Literacies.

-. 2013b. What can new urban dialects tell us about internal language dynamics? The power of language diversity. Linguistische Berichte, Special Issue 19: Dialektologie in neuem Gewand. $\mathrm{Zu}$ Mikro-/Varietätenlinguistik, 
Sprachenvergleich und Universalgrammatik, ed. by W. Abraham \& E. Leiss, 207-45.

Wiese, Heike \& Hans G. Müller. 2018. The hidden Life of V3: An overlooked word-order variant on verb-second. Non-Canonical Verb Positioning in Main Clauses. Special Issue of Linguistische Berichte, ed. by M. Antomo \& S. Müller, 201-24.

Wiese, Heike, Mehmet Tanir Öncü \& Philip Bracker. 2017a. Verb-dritt-Stellung im türkisch-deutschen Sprachkontakt: Informationsstrukturelle Linearisierungen ein- und mehrsprachiger Sprecher/innen. Deutsche Sprache. 31-52.

Wiese, Heike \& Ines Rehbein. 2016. Coherence in new urban dialects: A case study. Lingua 172-173. 45-61.

Wiese, Heike, Horst J. Simon, Christian Zimmer \& Kathleen Schumann. 2017b. German in Namibia: A vital speech community and its multilingual dynamics. Language Contact in the German Colonies: Papua New Guinea and Beyond. Special issue Language and Linguistics in Melanesia, ed. by P. Maitz \& C.A. Volker, 221-45.

Wiesinger, Peter. 1989. Die Flexionsmorphologie des Verbums im Bairischen. Vienna: Verlag der Österreichischen Akademie der Wissenschaften.

Wijers, Carla. 1990. In de shaduw van het kruis. Vrouwenlevens in de Limburgse mijnstreek, 1910-1970. Vrouwen tussen grenzen. Limburgse vrouwen in de 19e en 20 e eeuw, ed. by H. Vossen, B. Kruijtzer \& Y.d. Vries, 44-64. Roermond: LVR/WEB Roermond; Van Spijk Venlo.

Willemyns, Roland. 2002. The Dutch-French Language Border in Belgium. Journal of Multilingual and Multicultural Development 23. 36-49.

—. 2013. Dutch: Biography of a Language. Oxford: Oxford University Press.

Winchatz, Michaela R. 2006. Fieldworker or Foreigner? Ethnographic Interviewing in Nonnative Languages. Field Methods 18. 83-97. 10.1177/1525822X05279902. May 14, 2015.

Winford, Donald. 2010. Contact and Borrowing. The Handbook of Language Contact, ed. by R. Hickey. London: Blackwell.

Winter, Jay. 2010. The performance of the past: Memory, history, identity. Performing the Past: Memory, History, and Identity in Modern Europe, ed. by K. Tilmans, F. van Vree \& J. Winter, 11-34. Amsterdam: Amsterdam University Press.

Witt, Arne. 2015. Deutsche Progressivkonstruktionen und ihre Verwendung. Dissertation. University of Hamburg: Hamburg.

Wolf, Michaela. 2015. The Habsburg Monarchy's Many-Languaged Soul. Translating and interpreting, 1848-1918. Amsterdam / Philadelphia: John Benjamins Publishing Company.

Wurmbrand, Susi. 2004. West Germanic verb clusters: The empirical domain. Verb Clusters: A study of Hungarian, German and Dutch, ed. by K.É. Kiss \& H. van Riemsdijk, 41-85. Amsterdam/Philadelphia: John Benjamins Publishing Company.

Yager, Lisa, Nora Hellmold, Hyoun-AJoo, Michael T. Putnam, Eleonora Rossi, Catherine Stafford \& Joseph Salmons. 2015. New Structural Patterns in Moribund 
Grammar: Case Marking in Heritage German. frontiers in Psychology 6. 1-9. 10.3389/fpsyg.2015.01716. January 17, 2020.

Yuval-Davis, Nira. 2006. Belonging and the politics of belonging. Patterns of Prejudice 40. $197-214$.

Zeijlstra, Hedde. 2004. Sentential Negation and Negative Concord, PhD dissertation. University of Amsterdam.

Ziegler, Arne (ed.) 2018. Jugendsprachen/Youth Languages: Aktuelle Perspektiven internationaler Forschung/Current Perspectives of International Research. Berlin: De Gruyter.

Zifonun, Gisela, Ludger Hoffmann \& Bruno Strecker. 1997. Grammatik der deutschen Sprache. Berlin: De Gruyter.

Zwart, Jan-Wouter. 1993. Notes on clitics in Dutch. Eurotyp Working Papers, Theme Group 8, Clitics: Clitics in Germanic and Slavic, ed. by L. Hellan, 119-55. Berlin: European Science Foundation.

- (ed.) 2006. Complementizer agreement and dependency marking typology (Special issue of Leiden Working Papers in Linguistics 3.2

Zwart, Jan Wouter. 2000. 'Ikke' en de default-naamval. Een reactie op Hoeksema. Tabu 30. $175-82$.

Zwicky, Arnold. 1977. On clitics. Paper presented at the Paper presented at the 3rd International Phonologie-Tagung at the University of Vienna, 1976, Bloomington.

-. 1985. Clitics and particles. Language 61.

-. 1994. What is a clitic? Clitics: A Comprehensive Bibliography 1892-1991, ed. by J. Nevis, B. Joseph, D. Wanner \& A. Zwicky, xii-xx. Amsterdam: Benjamins.

Zwicky, Arnold \& Geoffrey K. Pullum. 1983. Cliticization vs. Inflection: English N'T. Language 59. 502-13.

\section{Software programs and Corpora}

Audacity® software. https://www.audacityteam.org/

CGN 2014. Corpus Gesproken Nederlands.

https://ivdnt.org/downloads/taalmaterialen/tstc-corpus-gesproken-nederlands

ELAN. https://tla.mpi.nl/tools/tla-tools/elan/elan-description/

MOCA. http://www.hpsl.uni-freiburg.de 


\section{Impact Paragraph}

In a basic sense, this study provides an analysis of personal pronouns and progressive aspect in Cité Duits, thereby shedding light on the contact processes between colloquial spoken German, Belgian Dutch, and the Limburgish dialect Maaslands, three varieties that are structurally extremely similar. Yet in a broader sense, this study recognizes the various linguistic resources of the former mining community by showing that its language use is unique and worth investigating. While much research has focused on the language practices of immigrants as opposed to long-time residents, the speakers central to this study can be regarded as falling in between two 'categories': they are no migrants but were locally-born and have the Belgian nationality. At the same time, most of them do not feel completely Belgian (see also $\S$ 2.3.2). As one of the speakers put it, 'we are paperBelgians.' In this section, I will briefly highlight the relevance of my dissertation, how I reached out to different audiences, and consider the possible meanings of my research in the nearby future. ${ }^{1}$

First, this study enhances our knowledge of language contact processes between closely related varieties and Germanic in particular, as well as of informal spoken language. Working on this dissertation has made me aware of several important challenges that one encounters when analyzing data of informal spoken group-interactions. While the research was unfolding, it became evident that many previous studies draw conclusions based on 'conceptionally written' language. But informal and formal language may differ significantly. For this reason, I suggest that linguistics research ought to pay closer attention to informal speech data. Such data reveal how grammar is used in daily interactions, but they can also offer a window onto the dynamics of language change.

Second, I believe that my dissertation is relevant to the studied community, as well as to other communities marked by similar experiences. Most of my interviewees seemed to appreciate the opportunity to share their viewpoints and experiences of growing up in a mining family. That the university finally paid attention to their language and social practices actually meant a lot to them after decades of discrimination and stigmatization. For many decades, the community of Eisden-cité remained largely marginalized, and many of its members faced discrimination and hostility in childhood and their later life. The harsh work of being a coal miner was often undervalued, while belonging to a mining family and coming from the cité was highly stigmatized. Although perceptions of miners slowly grew more positive after the kolenslag, a postwar recruitment policy introduced by Minister Achille Van Acker to increase the production of coal, in-depth conversations

\footnotetext{
${ }^{1}$ While I strongly support efforts that encourage scholars and scientists to step down from the ivory tower of academic achievement and consider the wider world, I personally question whether it is beneficial to make it mandatory for scholars to evaluate their outcomes in terms of economic and social criteria.
} 
with numerous community members proved that such prejudices at least persisted up to the late 1970s.

Even though this dissertation took on a historical dimension in focusing on the 1930s, it should be stressed that newcomers continue to encounter problems of integration in present-day society. While schools tend to teach only those languages spoken in economically-prosperous countries, it would be highly beneficial to offer classes in regional (e.g. Limburgish) and minority (e.g. Turkish) languages. This would create more awareness for cultural, social, and linguistic diversity, and perhaps facilitate integration efforts in regions where the local variety plays a crucial role in social interaction. Similarly, if a particular region wants to attract employees from elsewhere and also keep them, integration measures for newcomers must be substantially improved. Language classes are quite expensive and therefore only accessible to those who can afford them, while such classes may also be incompatible with the schedule of many workers. For companies that (aim to) work with people from numerous linguistic backgrounds, tailormade language classes may help to sustain their ambitions, in particular in sectors that depend on attracting a large number of workers from abroad.

Finally, I shared the insights I acquired while conducting my research with various audiences at different events. I presented my work at seventeen conferences and workshops, and I published several peer-reviewed articles. Next to talks and presentations to a linguistic audience, I presented some preliminary findings at NWO Bessensap (June 10, 2016), attended by journalists, scholars from a wide range of disciplines, and the general public. I was also an invited speaker at the conference De dynamiek van het Limburgs (December 14, 2016) in Maastricht, directed to a large audience interested in particular in Limburgish. Likewise, I presented my work at Gruuts op mien moojertaol (February 21, 2018, Maastricht) and at the interdisciplinary symposium 'Multilingualism as Migration' in Luxemburg (July 3 and 4, 2017), attended by scholars from various disciplines. In addition, there was interest by the media in this research: A video clip ${ }^{2}$ made by Maastricht University features me during fieldwork, and NRC Handelsblad, one of the leading newspapers of the Netherlands, published an extensive article on this project, which can be assumed to have reached a large readership. ${ }^{3}$ Writing a dissertation, however, taught me much beyond linguistics. I believe that a large share of the knowledge one acquires during the $\mathrm{PhD}$ trajectory pertains to broader skills not directly related to the topic of the dissertation. The insights and capabilities I developed along the way will prove to be useful in the nearby future, as I will continue to share my knowledge with researchers, students, and lay audiences.

\footnotetext{
${ }^{2}$ Please see https://www.youtube.com/watch?v=DoJGWUzjtd4.

${ }^{3}$ See https://www.nrc.nl/nieuws/2017/02/17/hoe-net-over-de-grens-razendsnel-een-nieuwe-taalontstond-6727658-a1546528.
} 


\section{Summary in English}

Cité Duits (lit. 'mining district German') developed as a contact variety among second generation immigrants in the former coalmining district of Eisden (the cité) in the 1930s. The town of Eisden is part of a region where most people speak Belgian Dutch and the Limburgish dialect Maaslands, whereas the speakers, now all men in their eighties, grew up with different home languages, including Czech, Polish, and Italian. Until recently, the community of Eisden and their language use remained a blind spot in sociolinguistics research. This dissertation examines the linguistic character of Cite Duits with a focus on personal pronouns and progressive aspect. While the examination of personal pronouns involves both morphosyntax and phonology, progressive constructions reveal much about the syntactic and semantic characteristics of Cité Duits. Following a sociolinguistic and grammatical framework, this study sheds light in particular on the contact processes between colloquial spoken German, Belgian Dutch, and Maaslands, three varieties that are structurally extremely similar. The main goal of this dissertation is to unravel the language contact dynamics involved in Cité Duits. Through this analysis, I aim to provide more general insights into contact between closely related varieties, and enhance our understanding of variability and change in spoken language. The linguistic analysis of this work is largely based on an audio corpus of spontaneous-like group interactions of male speakers. In addition, I did group recordings with female speakers and engaged in participant observation, while I also collected written materials, took photographs, conducted semi-structured interviews and performed an oral translation task from Dutch to Maaslands.

My analysis reveals that Cité Duits cannot be easily characterized as a variety of German, or Dutch. Despite the speakers' label Duits, there is much evidence toward an amalgamation of features due to intensive language contact between Belgian Dutch, the Maaslands dialect and varieties of German. If the lexicon resembles colloquial German, next to words from the French-Walloon mining vocabulary, boundaries between the three varieties are generally blurred. While much of the syntax can be associated with Belgian Dutch and Maaslands, Cité Duits usually exhibits fewer constraints. Furthermore, it becomes clear that Cité Duits could only develop due to a combination of sociolinguistic conditions present in the cité of Eisden in the 1930s. It emerged in a setting of multilingualism where speakers already shared a common language (Belgian Dutch), and therefore it served to mark an in-group identity rather than facilitating communication. These findings will be elucidated below.

Due to its geographically isolated location, the mine of Eisden was heavily dependent on migrant workers in the late 1920s (Chapter 2). Most of them had some knowledge of German, which was widely spoken in the countries of the former Habsburg Empire. Because Eisden-cité pursued a specific housing policy of placing families of 
diverse ethnic backgrounds in the same street, its inhabitants had to find a way to communicate with each other. While the technical vocabulary underground became French-Walloon based, a variety of German turned into a lingua franca for the first generation of speakers. It can be assumed that this lingua franca consisted of a mixture of different dialects and non-standard varieties of German as spoken in Europe back then. The second generation - the speakers featured in this study - grew up with Belgian Dutch, the home language of their parents (e.g. Hungarian, Italian), and some French. In public, however, they heard their parents speaking 'German.' These varieties provided the input for what the speakers themselves would later label 'Cité Duits.'

As in most cités, the miners' children grew up with little contact to people from outside since schooling and leisure activities took place within the district. The social isolation of the mining community was further reinforced by the hostile attitudes of the local population. These circumstances likely contributed to a strong in-group feeling among the miners' children. Although I can only reconstruct the phases of its emergence, it seems that Cité Duits functioned for a long time as a vehicle for identifying with one particular group (coal miners and family members) and dis-identifying with others (local population). In a similar vein, it appears that speaking Cité Duits became associated with masculinity linked to the male underground miner. While there is evidence that girls with numerous brothers may have spoken Cité Duits, this seems to have been an exception. In addition, Cité Duits has not been transmitted to subsequent generations, which can be explained by socioeconomic transformations, as well as by the ambivalent attitude of many miners toward their work. The changing composition of the work force in the 1960s, followed by the closure of the mining industry in the early 1990s, led to the gradual disappearance of the social contexts necessary to speak and maintain Cité Duits. Today this 'mining language' is on the verge of disappearing, with fewer than a dozen speakers left.

My analysis of personal pronouns (Chapters 5 and 6) establishes that Cité Duits displays a quite coherent pattern of personal pronouns. By means of a frequency analysis, I show that speakers use these forms quite systematically. While there is some variation in the data, this type of variation often resembles spoken varieties of Dutch and German. Cité Duits shares a large part of the pronouns with colloquial standard German and to some degree with the Maaslands dialect. There are hardly any forms that correspond to Belgian Dutch alone. Similarly, reduced forms are usually enclitics and must attach to another element, in line with German. Furthermore, I identified three intermediate forms, namely ich 'I' [rç], wie [vi:] 'we,' and $d e(r)$ [de:] 'he.' Ich 'I' seems a Belgian DutchMaaslands-German form, whereas wie 'we' exhibits congruence with the German wir and the Belgian Dutch form we. In contrast, $d e(r)$ 'he' can be associated with the German der and the Maaslands de, but not with Belgian Dutch.

Unlike its contact varieties, Cité Duits does not distinguish grammatical gender. Biological gender, in turn, is specified. Yet Cité Duits differs in some pronouns from German. While German has the form ihr in subject position but euch in object position, 
Cité Duits uses euch as a joint subject-object pronoun for the second-person plural. Another feature that distinguishes Cité Duits from colloquial standard German is the fact that object pronouns do not display case distinctions.

Based on selected examples (Chapter 4), I furthermore demonstrate that Cité Duits has a number of lexical, syntactic and morphosyntactic features that distinguish it from colloquial standard German (and partly Dutch). For instance, Cité Duits does not mark case on possessive pronouns (un sacht de Conducteur zu sein Frau), determiners (de Conducteur), negative articles (kein Arbeit), and attributive adjectives (für warme Wasser). Moreover, the order of verbal elements (e.g. du wars besser wie du hast gedacht) follows the Belgian Dutch-Maaslands pattern and therefore differs from (dialects of) German (gedacht hast). Similarly, Cité Duits has verbal infinitives (Josef is nich komme esse) where German has a participle (gekommen). In addition, it allows the finite verb in third position in certain contexts (und ein Tag ich geh gucken), and it regularly extraposes elements (ich musste fahren mit de Fiets).

My examination of progressive aspect (Chapter 7) - i.e. constructions that express ongoingness such as de wart televisie an gucke 'he was watching television' shows that these constructions differ syntactically from colloquial standard German, and often resemble Dutch and Maaslands. To be precise, Cité Duits progressive combines with transitive and intransitive verbs and allows different types of complements. While some constructions can be associated with Ruhr-German, next to Dutch, Cité Duits exhibits fewer syntactic and semantic restrictions than colloquial standard German. Cité Duits mainly uses the an-progressive, whereas spoken varieties of Dutch and German have numerous means to express ongoingness. Yet the an-progressive has several characteristics that distinguish it from the latter. For instance, Cité Duits has a progressive marker that does not exist in the three contact varieties (an). In a similar vein, Cité Duits systematically expresses stative contexts by the an-construction, whereby it often has a posture verb such as 'to sit' in the respective construction (e.g. ich war drausse an sitze). Such examples make up 30 percent in the data, which confirms that they are used systematically.

Based on my findings, I argue that Cité Duits differs from most previously established categories identified in sociolinguistics research on language contact (Chapter 8). First, Cité Duits is not code-switching, whereby it is usually possible to distinguish stretches of speech from a language A, B and C. Rather, boundaries are often fluent and elements from Dutch or German cannot easily be delimited. Second, Cité Duits does not characterize as a 'fused lect' (Auer 1998a): There are elements of fusion and the speech exhibits a certain degree of sedimentation, shown by particular regularities. Because the contact varieties are so close, however, it sometimes remains impossible to determine whether a given feature should rather be associated with Belgian Dutch, Maaslands or German. In addition, dialectal and non-standard varieties of German and Dutch often display similar features. Third, Cité Duits clearly differs from 'mixed languages,' given that these usually derive from two unrelated languages whose speakers 
came in contact (e.g. Bakker \& Mous 1994). What is special about Cité Duits, then, is its sociolinguistic status and its history of emergence. In line with typical examples of mixed languages, Cité Duits arose in a setting of multilingualism where a shared language already existed. The type of linguistic fusion found in Cité Duits, then, often resembles those of contact settings involving one or more Germanic varieties, which suggests that the typological characteristics play a role.

Finally, this dissertation shows that the analysis of recordings resulting from interactions involving multiple speakers yields particular drawbacks, but also specific avenues for future research. Both the role of the researcher and the presence of the recording device influence the recordings (Chapter 3). Speakers are usually aware of being recorded, and this impacts the recorded material. Furthermore, Cité Duits has no spelling conventions, and the way in which the recorded data is rendered into text has an impact on the analysis. Moreover, data of spontaneous-like interactions are less comparable. For instance, the quantity of tokens in the corpus is not always sufficient to conduct a comprehensive analysis of a given feature, and the amount of speech differs per individual. Despite these caveats, I suggest that linguistics research should pay closer attention to informal speech data. Only this type of data allows us to study how grammatical constructions are produced in daily interaction and by different individuals, and thus make predictions on possible patterns of language change.

In the narrowest sense, this dissertation provides an analysis of personal pronouns and progressive aspect in Cité Duits. But in a broader sense, since both dialects and colloquial standard varieties are involved, it contributes to our general understanding of spoken and informal language. By highlighting the ways in which Cité Duits is unique and similar to spoken Belgian Dutch, Maaslands, and German, my analysis demonstrates that the grammatical structures that occur in language contact situations are not always new, but often reflect general patterns of language change. In addition, from a sociolinguistic perspective, this study illustrates that growing up with several language varieties does not impede learning the country's national languages. Rather, it can stimulate linguistic creativity and lifelong language awareness. 


\section{Nederlandse Samenvatting}

Cité Duits ontwikkelde zich in de jaren dertig van de vorige eeuw als contactvariëteit onder migranten van de tweede generatie in de voormalige mijnwerkersbuurt Eisden (de cité). Terwijl de stad Eisden bij een regio hoort waar de meeste mensen Belgisch Nederlands en het Limburgse dialect Maaslands spreken, zijn de sprekers, nu allemaal mannen van in de tachtig, opgegroeid met verschillende thuistalen, waaronder Tsjechisch, Pools en Italiaans. Tot voor kort bleef de gemeenschap van Eisden een blinde vlek in het sociolinguïstisch veld. Dit proefschrift onderzoekt het taalkundige karakter van Cité Duits aan de hand van persoonlijke voornaamwoorden en zogenoemde progressieve constructies. Terwijl het onderzoek van persoonlijke voornaamwoorden zowel morfosyntaxis als fonologie omvat, onthullen progressieve constructies veel over de syntactische en semantische kenmerken van het Cité Duits. Op basis van een sociolinguïstische en grammaticale benadering werpt deze studie met name licht op de contactprocessen tussen het gesproken Duits, Belgisch Nederlands en Maaslands, drie variëteiten die structureel sterk op elkaar lijken. Het belangrijkste doel van dit proefschrift is om de taalcontactdynamiek van het Cité Duits te ontrafelen. Bovendien wil ik met deze analyse meer algemene inzichten verschaffen in het contact tussen sprekers van nauw verwante variëteiten, en ons begrip van variabiliteit en verandering in gesproken taal vergroten. De taalkundige analyse van dit proefschrift is grotendeels gebaseerd op geluidsopnames van groepsinteracties tussen mannelijke sprekers. Daarnaast heb ik groepsopnames van vrouwelijke sprekers en participerende observatie uitgevoerd, terwijl ik ook schriftelijk materiaal verzamelde, foto's maakte, talrijke interviews deed en een mondelinge vertaling liet uitvoeren van het Nederlands naar het Maaslands.

Uit mijn analyse komt naar voren dat Cité Duits niet gemakkelijk te typeren is als een Duitse of Nederlandse variëteit. Ondanks dat de sprekers hun manier van spreken 'Duits' labelen is er veel bewijs voor een samensmelting van kenmerken door intensief taalcontact tussen het Belgisch Nederlands, het Maaslands dialect en varianten van het Duits. Hoewel de woordenschat op het eerste gezicht op de Duitse spreektaal lijkt, naast woorden uit de Frans-Waalse technische woordenschat, zijn de grenzen tussen deze drie variëteiten over het algemeen vervaagd. Terwijl de zinsstructuur vaak geassocieerd kan worden met Belgisch Nederlands en Maaslands, vertoont Cité Duits minder restricties in de syntaxis dan deze variëteiten. Bovendien stel ik dat Cité Duits zich alleen kon ontwikkelen door een combinatie van sociolinguïstische condities die aanwezig waren in Eisden-cité in de jaren dertig van de vorige eeuw: Cité Duits ontstond in een meertalige omgeving waar sprekers al een gemeenschappelijke taal deelden (Belgisch Nederlands) en diende eerder om een groepsidentiteit te markeren dan om communicatie te vergemakkelijken. In het vervolg zal ik deze bevindingen met een korte uitleg van de inhoud van ieder hoofdstuk toelichten. 
Vanwege de geografisch geïsoleerde ligging was de mijn van Eisden eind jaren twintig van de vorige eeuw sterk afhankelijk van arbeidsmigranten (Hoofdstuk 2). De meesten van hen hadden enige kennis van het Duits, dat veel werd gesproken in de landen van het voormalige Habsburgse rijk. Omdat Eisden-cité een specifiek huisvestingsbeleid voerde door gezinnen met verschillende etnische achtergronden in dezelfde straat te plaatsen, moesten de inwoners een manier vinden om met elkaar te communiceren. Terwijl de technische woordenschat ondergronds op het Frans-Waals gebaseerd was, werd het Duits een lingua franca voor de eerste generatie sprekers. Men kan aannemen dat deze lingua franca uit een mengeling van verschillende dialecten en niet-standaard variëteiten van het Duits bestond zoals toen gesproken in Europa. De tweede generatie - de sprekers die in deze studie aan bod komen - groeide op met Belgisch Nederlands, de thuistaal van hun ouders (bijv. Hongaars, Italiaans) en een beetje Frans. In het openbaar hoorden ze echter hun ouders 'Duits' spreken. Deze variëteiten vormden de input voor wat de sprekers zelf later 'Cité Duits' zouden noemen.

Zoals in de meeste Limburgse cités groeiden de mijnwerkerskinderen op met weinig contact met mensen van buitenaf, aangezien scholing en vrijetijdsbesteding in de wijk plaatsvonden. Het sociale isolement van de mijnwerkersgemeenschap werd nog verder versterkt door de xenofobe houding van de lokale bevolking. Deze omstandigheden hebben zeer waarschijnlijk bijgedragen aan een sterk groepsgevoel onder de kinderen van de mijnwerkers. Hoewel ik alleen de fases van het ontstaan ervan kan reconstrueren, lijkt het erop dat Cité Duits lange tijd gefunctioneerd heeft als een manier voor de sprekers om zich te identificeren met een bepaalde groep (mijnwerkers en familieleden) en zich te onderscheiden van anderen (lokale bevolking). Ook blijkt dat het spreken van Cité Duits geassocieerd werd met mannelijkheid van de mijnwerker. Hoewel er aanwijzingen zijn dat meisjes met talrijke broers Cité Duits hebben gesproken, lijkt dit een uitzondering te zijn geweest. Bovendien is Cité Duits niet overgedragen op volgende generaties, wat te verklaren valt door sociaaleconomische veranderingen, evenals door de ambivalente houding van veel mijnwerkers ten opzichte van hun werk. De veranderende samenstelling van het personeelsbestand in de jaren zestig van de vorige eeuw, gevolgd door de sluiting van de mijnindustrie in het begin van de jaren 1990, leidde tot het geleidelijk verdwijnen van de sociale contexten die nodig waren om Cité Duits te spreken en te behouden. Deze 'mijntaal' staat met minder dan een dozijn sprekers tegenwoordig op het punt van verdwijnen.

Mijn analyse van persoonlijke voornaamwoorden (Hoofdstukken 5 en 6) demonstreert dat Cité Duits een stabiel patroon van persoonlijke voornaamwoorden vertoont. Door frequentieanalyse laat ik zien dat sprekers deze vormen vrij systematisch gebruiken. Hoewel er enige variatie is in de vorm van de voornaamwoorden, lijkt deze variatie vaak op die die in de Nederlandse en Duitse spreektaal voorkomt. Cité Duits deelt een groot deel van de voornaamwoorden met het gesproken Standaard Duits en tot op zekere hoogte met het Maaslands, maar er zijn nauwelijks persoonlijke voornaamwoorden die alleen met het Belgisch Nederlands overeenkomen. Ook zijn gereduceerde vormen meestal enclitisch, in overeenstemming met het Duits. Verder identificeerde ik drie 
tussenvormen, namelijk ich [rç] 'ik', wie [vi:] 'wij' en $d e(r)$ [de:] 'hij'. Ich lijkt een Belgisch Nederlands-Maaslands-Duitse vorm, terwijl wie overeenkomst vertoont met de Duitse vorm wir en de Belgisch Nederlandse vorm wij. Daarentegen kan de(r) geassocieerd worden met Duits der en Maaslands de, maar niet met het Nederlands. In tegenstelling tot de contactvariëteiten maakt Cité Duits geen verschil tussen grammaticaal geslacht. Het biologische geslacht wordt op zijn beurt gespecificeerd. Toch verschilt Cité Duits op sommige voornaamwoorden van het Duits. Terwijl Duits de vorm ihr als onderwerpsvorm gebruikt en euch als objectsvorm, gebruikt Cité Duits euch als een gezamenlijk voornaamwoord voor de tweede persoon meervoud. Een ander kenmerk dat Cité Duits van het gesproken Standaard Duits onderscheidt is het feit dat de naamval bij voornaamwoorden niet gemarkeerd wordt.

Op basis van geselecteerde voorbeelden (Hoofdstuk 4), laat ik verder zien dat Cité Duits een aantal lexicale, syntactische en morfosyntactische kenmerken heeft die het onderscheiden van het informele standaard Duits (en deels Nederlands). Bijvoorbeeld markeert Cité Duits geen naamval op bezittelijke voornaamwoorden (un sacht de Conducteur zu sein Frau), lidwoorden (de Conducteur), negatieve kwantoren (kein Arbeit) en attributieve bijvoeglijke naamwoorden (für warme Wasser), in tegenstelling tot de Duitse spreektaal, maar overeenkomstig met het Nederlands. Verder lijkt de volgorde van verbale elementen (du wars besser wie du hast gedacht) op het Belgisch NederlandsMaaslands patroon en verschilt daarom van (dialecten van) het Duits (gedacht hast). Evenzo heeft Cité Duits infinitieven (Josef is nich komme esse) waar Duits een voltooid deelwoord heeft (gekommen). Ook lijkt Cité Duits minder beperkingen op het niveau van de zinsbouw te hebben: in bepaalde contexten is het mogelijk het finiete werkwoord op de derde positie te zetten (und ein Tag ich geh gucken). Verder heeft het de neiging om regelmatig elementen achter het werkwoord te plaatsen (ich musste fahren mit de Fiets).

Mijn analyse van progressiefconstructies (Hoofdstuk 7), d.w.z. constructies die continuïteit uitdrukken zoals 'hij was televisie aan het kijken,' laat zien dat deze constructies op zinsniveau van het gesproken Duits afwijken en vaak op Nederlands en Maaslands lijken. Om precies te zijn, het Cité Duits combineert progressieve met transitieve en intransitieve werkwoorden en laat verschillende soorten complementen toe. Hoewel sommige constructies geassocieerd kunnen worden met Ruhr-Duits en Nederlands, vertoont Cité Duits minder semantische en syntactische restricties dan informeel standaard Duits. Cité Duits gebruikt voornamelijk de an-progressief, terwijl gesproken Nederlands en Duits tal van middelen hebben om continuilteit uit te drukken. Toch heeft deze constructie verschillende kenmerken die te onderscheiden zijn van het Nederlands en Duits. Zo heeft Cité Duits een progressieve marker die niet voorkomt in de contactvariëteiten (an). Bovendien drukt Cité Duits systematisch statische contexten uit door middel van de an-constructie, waarbij er vaak een houdingswerkwoord zoals 'zitten' in de betreffende constructie verschijnt (bijv. ich war drausse an sitze). Dergelijke voorbeelden maken 30 procent uit van de gegevens, wat bevestigt dat ze systematisch worden gebruikt. 
Op basis van mijn bevindingen suggereer ik dat Cité Duits van de meeste eerder vastgestelde taalcontactfenomenen verschilt (Hoofdstuk 8). Ten eerste laat Cité Duits zich niet als een vorm van codewisseling definiëren, waarbij het meestal mogelijk is om talige vormen te onderscheiden uit een taal A, B en C. Taalgrenzen zijn eerder vloeiend en elementen uit het Nederlands of Duits zijn niet gemakkelijk te onderscheiden. Ten tweede vertoont het Cité Duits bepaalde regelmatigheden maar omdat de contactvariëteiten zo dicht bij elkaar liggen, is het soms onmogelijk om te bepalen of een talig kenmerk eerder geassocieerd moet worden met het Belgisch Nederlands, Maaslands of Duits. Bovendien vertonen dialecten en niet-standaard variëteiten van het Duits en het Nederlands vaak vergelijkbare kenmerken. Ten derde verschilt Cité Duits duidelijk van 'mengtalen', die meestal afkomstig zijn van twee niet-verwante talen waarvan de sprekers met elkaar in contact kwamen (Bakker \& Mous 1994). Het bijzondere aan Cité Duits is dan ook de sociolinguïstische status en de ontstaansgeschiedenis: Cité Duits is ontstaan in een meertalige omgeving waar al een gedeelde taal bestond, zoals vaak met mengtalen het geval is. Het type taalfusie dat in Cité Duits wordt aangetroffen lijkt op dat van het taalcontact met één of meer Germaanse variëteiten, wat suggereert dat de typologische kenmerken een rol spelen.

Ten slotte laat dit proefschrift zien dat de analyse van opnames van interacties tussen meerdere sprekers bepaalde nadelen oplevert, maar ook specifieke mogelijkheden voor toekomstig onderzoek. Zowel mijn rol als onderzoekster als de aanwezigheid van het opnameapparaat beïnvloeden de opnames (Hoofdstuk 3). Sprekers zijn zich er meestal van bewust dat ze worden opgenomen, en dit heeft invloed op hoe zij spreken. Bovendien heeft Cité Duits geen spellingsconventies, en de manier waarop de geluidsopnames in tekst worden omgezet heeft invloed op de analyse. Tot slot zijn gegevens van spontane interacties minder vergelijkbaar. Zo is het aantal tokens in het corpus niet altijd voldoende om een bepaald talig kenmerk uitgebreid te analyseren, en verschilt de hoeveelheid gesproken materiaal per individu. Ondanks deze uitdagingen, stel ik voor dat taalkundig onderzoek meer aandacht moet besteden aan informele spraakgegevens. Alleen met dit soort gegevens kunnen we bestuderen hoe grammaticale constructies worden geproduceerd in dagelijkse interactie en door verschillende individuen, en zo voorspellingen doen over mogelijke patronen van taalverandering.

Op het eerste gezicht geeft dit proefschrift een analyse van persoonlijke voornaamwoorden en progressiefconstructies in Cité Duits. Maar in bredere zin draagt deze studie bij tot een beter begrip van informele gesproken talen, aangezien zowel dialecten als informele standaardvariëteiten aan bod komen. Bovendien toont mijn analyse aan dat de grammaticale structuren in Cité Duits niet altijd nieuw zijn, maar vaak algemene taalpatronen weerspiegelen: Cité Duits is zowel uniek als vergelijkbaar met gesproken Belgisch Nederlands, Maaslands en Duits. Daarnaast laat ik vanuit sociolinguïstisch perspectief zien dat het opgroeien met verschillende talen en dialecten het leren van een nationale taal niet belemmert. Het kan eerder linguïstische creativiteit en levenslang taalbegrip stimuleren. 


\section{Curriculum Vitae}

After obtaining her BA in Spanish language, literature, and media with a minor in English and American Studies (2012) from the Albert-Ludwigs-Universität Freiburg, Nantke Pecht (1987, Wilhelmshaven) obtained a MA in European Linguistics (2014). During her bachelor years, Nantke studied two semesters at the Universidad de La Laguna, Spain. As a student, Nantke worked as academic assistant in the department for Romance Languages on the Spanish part of a multilingual database of spontaneous speech data (sgs corpus), and later in the department of German Linguistics, teaching introductory courses to students of German linguistics. During her PhD trajectory, Nantke taught courses in the BA European Studies at the University of Maastricht. In 2018, she spent three months as a short-term fellow at the SFB 1287 at the University of Potsdam, where she participated in the project 'Integration of linguistic resources in highly diverse urban settings: Stretching the limits of variability.' She was further enrolled in the Netherlands Graduate School of Linguistics (LOT), and she is a member of the Societas Linguistica Europaea (SLE), the Algemene Vereniging voor Taalwetenschap (AVT), and the Limburgishsection of Levende Talen. Nantke is currently employed as lecturer in the department of European Languages and Society at the University of Groningen. 